\title{
Catalogue of \\ Turkish Manuscripts in the \\ Library of Leiden University and Other Collections \\ in the Netherlands
}




\title{
Islamic Manuscripts and Books
}

\author{
Arnoud Vrolijk \\ Leiden University
}

VOLUME 3

The titles published in this series are listed at brill.nl/imb 


\title{
Catalogue of Turkish Manuscripts in the Library of Leiden University and Other Collections in the Netherlands
}

\author{
Minor Collections
}

By

Jan Schmidt

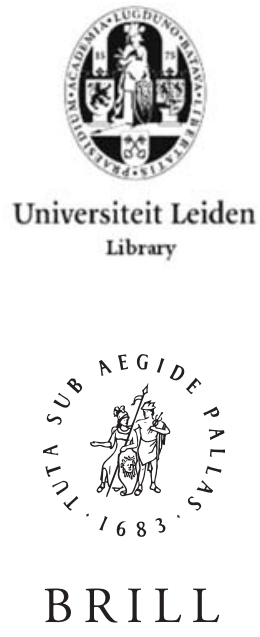

LEIDEN · BOSTON

2012 
The digital edition of this title is published in Open Access.

Cover illustration: Utrecht, UB Hs. 16 B 18, f. 28b. A page of a magnificently produced encyclopaedia of cosmic knowledge by İsmā'îl Ḥaḳkī Erżurumī (d. 1186/1772), copied and designed in Erzurum in $1241 / 1826$, with a schematic drawing of the universe centred on the Kaaba.

LC control no.: 2001372669

This title is co-published with the Leiden University Library as

\section{BIBLIOTHECA UNIVERSITATIS LEIDENSIS}

CODICES MANUSCRIPTI XLI

ISSN 0169-8672, Volume 41

It is also Volume Four in the series Catalogue of Turkish Manuscripts in the Library of Leiden University and Other Collections in the Netherlands.

This publication has been typeset in the multilingual "Brill" typeface. With over 5,100 characters covering Latin, IPA, Greek, and Cyrillic, this typeface is especially suitable for use in the humanities. For more information, please see www.brill.nl/brill-typeface.

ISSN 1877-9964

ISBN 9789004221901 (hardback)

ISBN 9789004221918 (e-book)

Copyright 2012 by Koninklijke Brill NV, Leiden, The Netherlands.

Koninklijke Brill NV incorporates the imprints Brill, Global Oriental, Hotei Publishing, IDC Publishers and Martinus Nijhoff Publishers.

All rights reserved. No part of this publication may be reproduced, translated, stored in a retrieval system, or transmitted in any form or by any means, electronic, mechanical, photocopying, recording or otherwise, without prior written permission from the publisher.

Authorization to photocopy items for internal or personal use is granted by Koninklijke Brill NV provided that the appropriate fees are paid directly to The Copyright Clearance Center, 222 Rosewood Drive, Suite 910, Danvers, MA 01923, USA.

Fees are subject to change.

This book is printed on acid-free paper. 


\section{CONTENTS}

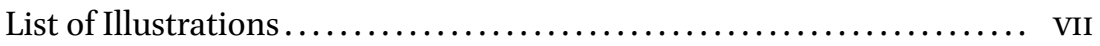

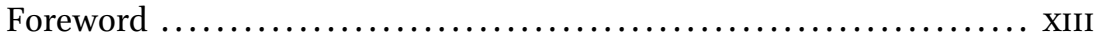

List of Abbreviations..................................... XV

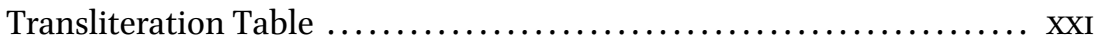

1. Amsterdam, Amsterdam Museum ....................... 1

2. Amsterdam, International Institute of Social History (IISH) ....... 3

3. Amsterdam, Nederlands Scheepvaartmuseum (Netherlands

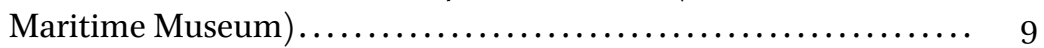

4. Amsterdam, Universiteitsbibliotheek (UB, University Library) ..... 11

5. Groningen, Universiteitsbibliotheek (UB, University Library) ...... $5^{8}$

6. The Hague, Koninklijke Bibliotheek (KB, Royal Library)........... 90

7. The Hague, Museum Meermanno-Westreenianum/Huis van het boek ........................................... 96

8. Leiden, Museum Volkenkunde (Museum of Ethnology, Leiden)..... 100

9. Leiden, Universiteitsbibliotheek (UB, University Library), Bibliotheek A. Hotz (The Hotz Library).................... 108

10. Leiden, Universiteitsbibliotheek (UB, University Library), Bibliotheca Publica Latina (BPL)...

11. Leiden, Universiteitsbibliotheek (University Library), Collection of the Royal Academy of Arts and Sciences (Koninklijke Akademie van Wetenschappen) ............................... 139

12. Leiden, Universiteitsbibliotheek (UB, University Library), Legatum Warnerianum, Addenda ................................ 215

13. Rotterdam, Maritiem Museum (Maritime Museum)............ 258

14. Rotterdam, Wereldmuseum (World Museum)................ 265

15. Utrecht, Universiteitsbibliotheek (University Library) ......... 273

Epilogue. Turkish Manuscripts in Public Collections in the Netherlands:

A Treasure Trove for the History of Turkish Literary Culture and a

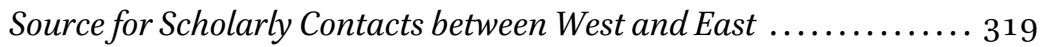

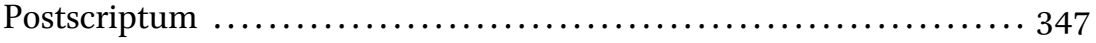

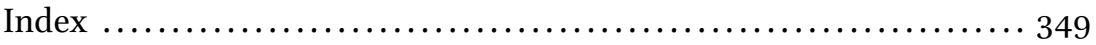

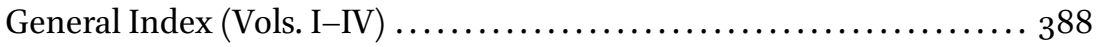


Jan Schmidt - 978-90-04-22191-8

Downloaded from Brill.com04/26/2023 07:45:40AM via free access 


\section{LIST OF ILLUSTRATIONS}

1. Amsterdam, IIHS, Vâ-Nû Archive 209. Two pages of a passport issued to the writer and journalist, Aḥmed Vâlâ b. Nürüddīn, who used the pen-name of Vâ-Nû, dated 1336 (1920), with photograph of the bearer. ............................... 6

2. Amsterdam, IIHS, Vâ-Nû Archive 179. Letter from Yahya Kemal (Beyatlı), at Warsaw, to Aḥmed Vâlâ b. Nūrüddīn, who used the pen-name of Vâ-Nû, dated 15 September 1928. Sender writes addressee how much he liked his stories; all good writers were always poets first. Nâzım Hikmet had returned from Moscow under arrest. He advises addressee to write to the latter to abandon politics, and live quietly in Istanbul, the most beautiful place on earth. He could become a very good poet if he would refrain from attending and speaking in Communist meetings......

3. Amsterdam, UB Hs. VI H 2, l. A slip of paper with notes on the translation- and copy-work by Shahin Kandi found in a translation by Bobovius of the Book of Isaiah between

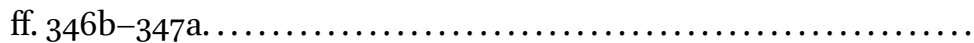

4. Amsterdam, UB Hs. VI H 2, m, f. 10oa. The final page of a translation of the Book of Jeremiah (f. 100a) with a colophon and copyist's verses by Bobovius, made in the 1660 s in Istanbul.

5. Amsterdam, UB Hs. VI H 2, o, f. 1 b. The first page of a neat draft of a translation by Bobovius of the Book of Daniel copied by Shahin Kandi, who was employed by the Leiden orientalist, Jacob Golius, in the 1660 s.

6. Amsterdam, UB Hs. VI H 2. A page of the translation of the Book of Psalms by Bobovius (f. 153a), with a note (in the upper margin) by the copyist Shahin Kandi stating that the passage, indicated by a red line in the left margin, had been corrected.

7. Amsterdam, UB Hs. Cn 12, 13-14a. Two pages from a miscellaneous work with divinatory diagrams, 17 th century....... 30

8. Amsterdam, UB Hs. Cq 48a. A quotation from Lamartine's Le Lac sent by Dāvud Paşa to Frederike Prokesch, née Gossmann, 1868. .. 34

9. Amsterdam, UB Hs. Cq 48a. A photograph of Dāvud Paşa, sent by him to Frederike Prokesch, née Gossmann, 1868............. 35 
10. Amsterdam, UB Hs. Cq 50. A note concerning the Wallachian tribute for the year $1231\left(1815^{-1816}\right)$ from Hālet Efendi to the

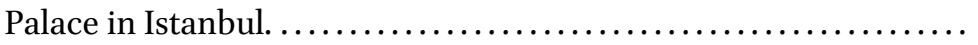

11. Amsterdam, UB Hs. Diederichs 136 G 2. A pass (fermān) issued to Countess Ida Hahn-Hahn for a journey from Istanbul to Izmir, Damascus, Jerusalem and Egypt, and back, dated 1259/1853 ......

12. Amsterdam, UB Hs. Diederichs $136 \mathrm{I}$. A passport issued to a French doctor and colonel called Ciax for a journey to Corfu and Naples, dated 1262/1846.

13. Amsterdam, UB Hs. Diederichs $136 \mathrm{~J}$. The last page of a letter from Tepedelenli 'Alī Paşa to Napoleon, dated 1807 .

14. Amsterdam, UB Hs. Diederichs $136 \mathrm{M}$. The last page of a letter of an Ottoman 'prince', Cigala Paşa, to a friend, written in Brussels, 10 March 1669.

15. Amsterdam, UB Hs. Diederichs 136 N. A letter in French and Turkish from 'Ömer Ag̀a of Lūbīn (Ljubinje) to General Gauthier, commander of the French Dalmatian Army, dated 1812

16. Amsterdam, UB Hs. Dortmond 56 (left) and 291 (right). The upper parts of two rüznämes in scroll-format, 19th-century.

17. Groningen, UB Hs. 471, ff. 147b-148a. Two pages from a collection of pious and magical texts, 18 th century or earlier.

18. Groningen, UB Hs. 474, f. 9a. A page from a miscellany dated 799 (1396-1397) in the second line. The erroneously spelt title of 'Atebetü l-hākāayık, a didactic poem in eastern Turkish by Edīb Ahmed of Yüknek (12th-13th century), is found in the third line. .. 64

19. Groningen, UB Hs. 479, ff. 146b-147a. Two pages from a copy of the Book of Psalms in Italian, Turkish and Dutch, first half of the 18th century or earlier.

20. Groningen, UB Hs. 485, ff. 11b-12a. Two pages from an exercise-book filled by Jacob Christmann; dated $989 / 1582$. On the left is the text of an anonymous treatise on religion, a draft translation into Latin is found in the margin; a transcription of the Turkish text is on the right.

21. Groningen, UB Hs. 487, middle section. Part of a scroll with calligraphic samples, with texts in Arabic, Persian and Turkish,

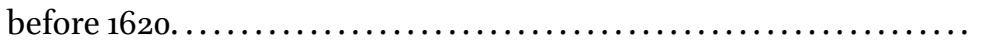

22. Groningen, UB Hs. 489, f. 2a. The 'title page' of a unique, autograph copy of Zihn̄̄ Efendi's Yūsuf $u$ Züleyhā, written in $1024 / 1615$ 
23. Groningen, UB Hs. 490, f. $69 \mathrm{~b}$. The last page of a copy of the Dìvān of Uṣūlì, with an author's inscription by Daniel Widmer of

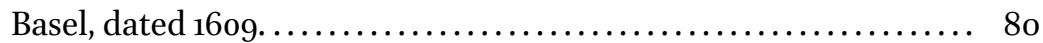

24. Groningen, UB Hs. 491, f. 28a. A ġurre-nāme for the years 1044-1051 (1634-1642) found in a miscellany............... 84

25. Groningen, UB Hs. 491, f. 18(bis)a. An inscription in German of a soldier declaring that he had found the manuscript on, apparently, a battlefield........................... 86

26. The Hague, KB Hs. 130 E 32, f. 68a. Inscription by the Leiden orientalist, Jacob Golius, dated 1639, in an album amicorum compiled by the classicist Gronovius $(1611-1671) \ldots \ldots \ldots \ldots \ldots . . . .291$

27. The Hague, KB Hs. 134 C 44, p. 188. Inscription, with a quotation of a verse by Hāfiz, made by the poet, Willem Bilderdijk, in an album amicorum compiled by the Dutch orientalist, Joannes

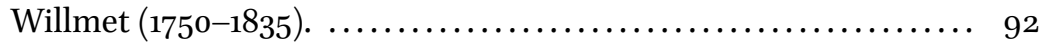

28. The Hague, KB Hs. 135 K 4, f. 11b. Signature and seal of the Ottoman Admiral, Kapudan, Halīl Pasa, dated 1023/1614, found in an album amicorum compiled by Ernst Brinck, secretary to the first Dutch ambassador to the Porte. ................... 93

29. The Hague, Museum Meermanno-Westreenianum Hs. 10 E 30, 1oth flyleaf, verso. Ornate inscription in German, stating that the manuscript had been obtained as war-booty in Hungary in 1687 . . 98

30. The Hague, Museum Meermanno-Westreenianum Hs. 10 E 30, last, recto. Three recipes in Turkish added to a copy of a part of the Koran, 17 th century of earlier.

31. Leiden, Museum Volkenkunde 2871-19. Miniature of 'Sultan Murād' by an anonymous artist, undated................. 101

32. Leiden, Museum Volkenkunde 360-7375. Coloured drawing, $165 \times 105 \mathrm{~mm}$, of a courtier, according to the Dutch caption: 'herald (roeper) of the Sultan', probably 19th-century. 102

33. Leiden, Museum Volkenkunde 360-7424. Coloured drawing, $165 \times 105 \mathrm{~mm}$, of, according to the Dutch caption: 'the Sultan in his former costume', probably 19th-century. ............... 103

34. Leiden, Museum Volkenkunde 36o-7425. Coloured drawing, $165 \times 105 \mathrm{~mm}$, of, according to the Dutch caption: 'the Sultan in his present costume', probably 19th-century. 104

35. Leiden, Museum Volkenkunde 36-9550. A copy of a letter from the Dutch consul at Izmir. Daniel Alexander de Hochepied, to the commander (kapudan) of the Ottoman Fleet, early 18th-century. 
36. Fritz Rudolf Kraus at the entrance of the Department of the Ancient Near East of the Archaeological Museum in Istanbul, with Hittite lion statues (undated photograph, NINO Archive) ... 115

37. Fritz Rudolf Kraus and Hariklia Anastasiadis in Istanbul

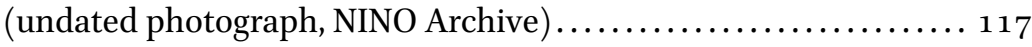

38. Fritz Rudolf Kraus on a ferry in the Bosphorus (undated

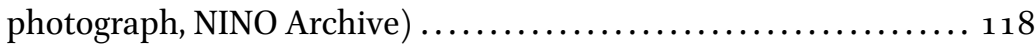

39. Leiden, UB Anhegger 7(11). Meldungsbuch (certificate of enrollment) issued by the University of Vienna in 1932, with photograph of Robert Anhegger. ..................... 253

40. Leiden, UB Anhegger 7(13). First page of a letter from Robert Anhegger to his mother, dated 5 April $1936 \ldots \ldots \ldots \ldots \ldots \ldots \ldots 254$

41a-e. Samples from the collection of late Ottoman cigarette paper booklets, depicting Nasruddin Hoca, a hare (Ch. Dragonis), 'brothers in arms' (silahdaşlar, Penso \& Varon), Hindenburg (Samir Sarrafoglu) and weightlifters. ................... 255

42. Rotterdam, Maritiem Museum H336(3). A visa with a stamp of the Ottoman Consulate in Amsterdam on a passport issued to a Dutch Navy officer, dated 4 June $1870 \ldots \ldots \ldots \ldots \ldots \ldots \ldots \ldots \ldots . \ldots 259$

43. Rotterdam, Maritiem Museum H639, p. 11. Flags depicted in an Ottoman signal book, early 19 th-century. ................. 261

44. Rotterdam, Maritiem Museum H639, p. 47. A page of an Ottoman signal book with explanations of number codes, early

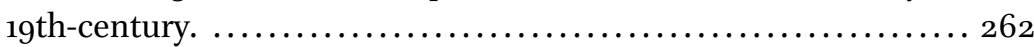

45. Rotterdam, Maritiem Museum H639, p. 338. Lighthouse codes with explanations found in an Ottoman signal book, early 19 th

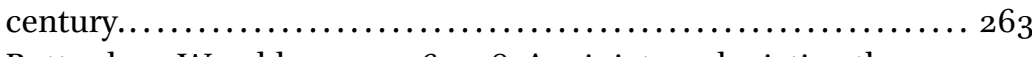

46. Rotterdam, Wereldmuseum 6o948. A miniature depicting the murder of 'Alī by Ibn Muljam, 16th century, taken from Fużūlī's

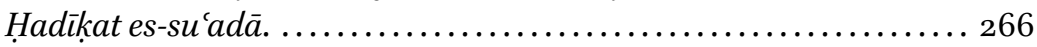

47. Rotterdam, Wereldmuseum 63215. The upper part of a copy of the 'ahdnāme of 1027/1618, granted to the Venetian Republic..... 268

48. Rotterdam, Wereldmuseum 70935. The first page of a magnificently illuminated copy of Fużūlī's Dìvān, undated. . 270

49. Utrecht, UB Hs. 1 B 8, f. 225b. The first page of a manuscript with a translation of al-Maqrīzì's Khitaț, with tailed signatures and an explanation by Christianus Ravius that he had borrowed the book from an owner in Istanbul for an edition in 1640 
50a-b. Utrecht, UB Hs. 1 B 8, ff. 24a-23b. Two pages from a translation of al-Maqrīzì's Khitat, showing the work of two different copyists; the catchword on the right suits the first word on the following page on the left............................ 276

51. Utrecht, UB Hs. 16 B 14, f. 7a. A page from a collection of religious parables, copied in $1222(1807-1808)$, with a heading of the parable of Kesik-baş ('severed head'). .................... 284

52. Utrecht, UB Hs. 16 B 18, f. 15b. The first page from a magnificently produced encyclopaedia of cosmic knowledge by İsmācîl Haḳḳ̄ Erżurumī (d. 1186/1772), copied and designed in Erzurum in

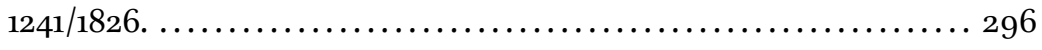

53. Utrecht, UB Hs. 16 B 18, f. 28b. A page from a magnificently produced encyclopaedia of cosmic knowledge by İsmācîl Haḳḳ̄ Erżurumī (d. 1186/1772), copied and designed in Erzurum in $1241 / 1826$, with a schematic drawing of the universe centred on the Kaaba.

54. Utrecht, UB Hs. 16 B 18, f. 317 b. A page from a magnificently produced encyclopaedia of cosmic knowledge by İsmāōil Haḳḳ̄ Erżurumī (d. 1186/1772), copied and designed in Erzurum in $1241 / 1826$, with a plan of the house of the author's shaykh, İsmāicl Tillovì. 298

55. Utrecht, UB Hs. 16 B 18, f. 349 b. The final page of a letter of advice to a 'bother' appended to a magnificently produced encyclopaedia of cosmic knowledge by İsmāōl Haḳḳ̄ Erżurumī (d. 1186/1772), copied and designed in Erzurum in 1241/1826..... 299

56. Utrecht, UB Hs. $16 \mathrm{C}$ 1, p. 51 . A page from a collection of original letters and documents, showing a report (by the ḳahvecibaşı of the Palace, Sa'dullāh) and a hüküm concerning the purchase of wheat and barley in Sīrūz (Serre), with bureaucratic annotations,

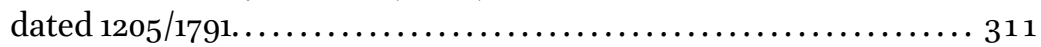

57. Utrecht, UB Hs. 16 C 1, p. 89. A page from a collection of original letters and documents, showing a petition and a legal report concerning a conflict about the repair of a building near the quay of Davudpaşa, Istanbul, preceded by bureaucratic annotations,

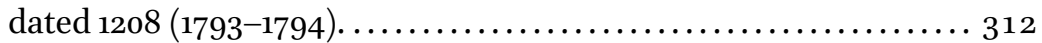

58. Utrecht, UB Hs. 16 C 1, p. 132. A page from a collection of original letters and documents, showing a statement of the Venetian ambassador, surrounded by bureaucratic annotations, on the shipwreck of a Venetian vessel off Limnos which had been on its way to Istanbul with grain, dated $1205 / 1791 . \ldots \ldots \ldots \ldots \ldots \ldots \ldots \ldots \ldots \ldots$ 
59. Utrecht, UB Hs. 16 C 1, p. 131. The verso side of the previous document, with a copy of a report of the gümrük emini of Istanbul on the same affair, dated 1205/1791.

6o. Utrecht, UB Hs. 16 C 2, p. 13. A page from a collection of original letters and documents, showing a copy of a private letter from the mother of the Ottoman rebel Țayyār Paşa to her brother,

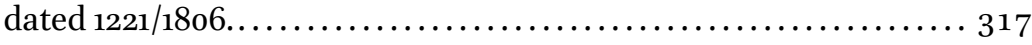

61. Utrecht, UB Hs. 16 C 2, p. 17. A page from a collection of original letters and documents, showing a report on the purchase, shipment and eventual loss of a load of grain sent from the Mora (Peloponnese) to Istanbul, preceded by bureaucratic annotations, dated 1204-1205 (1789-1791).................. 318 


\section{FOREWORD}

The present volume is the fourth and final in a series that describe the Turkish manuscripts kept in Dutch public collections with the exception of archives. The first three volumes were published by the Leiden University Library in the years 2000, 2002 and 2006. They describe the Turkish manuscripts kept in the main Oriental collection in the Leiden University Library, the so-called Legatum Warnerianum, which came, so to speak, to life in 1665 with the bequest of Levinus Warner (described in the first volume). The Legatum, although the most voluminous collection of handwritten Oriental and Turkish texts in the Netherlands, is not the only one. There is more. Smaller collections of between only one up to a few dozens of items are kept in both the Leiden library and libraries in Amsterdam, Groningen, The Hague, Leiden, Rotterdam and Utrecht. These smaller collections are described in this volume. Inevitably, mistakes have been made in the past. I took the opportunity to repair here one of them that concerns the oversight of some Turkish texts in the Legatum. These are described in chapter 9. This chapter also contains descriptions of items that came to light or were acquired after the publication of the first three volumes. The chapters on the various collections is concluded by an 'Epilogue' that presents an assessment of the Dutch Turkish collection as a whole. The book is concluded with a general index which covers all four volumes.

The manuscript of the book was completed in 2003, but for various reasons, its publication was postponed until now. I would also like to take here the opportunity to show my gratitude to the staff of the Leiden University Library, and in particular to the, by now retired, keeper of the Leiden Oriental collection, Jan Just Witkam, who took the initiative to organize the cataloguing project. Personnel of the other libraries in the Netherlands covered in this book were without exception extremely helpful in giving me access to their treasures. I also thank the Dutch Research Fund $(N W O)$ which financed the cataloguing project. A final word of thanks goes to my colleagues Hans Theunissen and Machiel van Crevel who gave the final push that made the publication of this book possible (and inspired me to return to my cataloguing work and resume the thread which I had left dangling about a decade ago) and to Ingrid Heijckers-Velt of Brill's who helped me in the last phase of this publication. 
Jan Schmidt - 978-90-04-22191-8

Downloaded from Brill.com04/26/2023 07:45:40AM via free access 


\section{LIST OF ABBREVIATIONS}

Van der Aa

Aumer

Ateş

b.

besmele

Blaškovičs

$B L K O$

$B N B$

$B N W$

Blochet

Brugmans, Catalogus

BSOAS

Catalogue 1696

$C C A$

$\mathrm{CCO}$

CCOBARS

Churchill

Cods.
A.J. van der Aa et al. Biographisch Woordenboek der Nederlanden. Revised ed. 21. Vols. Haarlem ?-1878. I. Aumer, Verzeichnis der orientalischen Handschriften der K. Hof-und Staatsbibliothek in München (Türkische Handschriften). Munich 1875.

Ahmed Ateş, Istanbul kütüphanelerinde Farsça manzum eserler I. Istanbul 1968.

ibn, bin (son of)

bismi llāhi r-rahmmāni rahīm

Jozef Blaškovičs, Arabische, türkische und persische

Handschriften der Universitäts-bibliothek in Bratislava.

Bratislava 1961.

Biographisches Lexicon des Kaiserthums Oesterreich. 59

Vols. Vienna 1856-189o.

Biographie Nationale publiée par l'Académie Royale de Belgique. $1866 \mathrm{ff}$.

Biografisch Woordenboek van Nederland. 4 Vols., The

Hague 1979-1994.

E. Blochet, Bibliothèque Nationale. Catalogue des manuscrits turcs. 2 Vols., Paris 1932-1933.

H. Brugmans, Catalogus Codicum Manu Scriptorum.

Groningen 1898 .

Bulletin of the School of Oriental and African Studies.

Catalogus Insignium in omni facultate linguisque,

Arabica, Persica, turcica, Chinense \&c. librorum M.SS. quos Doctissimus Clarissimus Vir D. Jacobus Golius ... collegit quorum auctio habebitur in Aedibus Johannis du Vivie ... Ad diem XVI Octobris ... Leiden 1696.

M.J. de Goeije \& M.Th. Houtsma, Catalogus Codicum Arabicorum Bibliothecae Academiae Lugduno-Bataviae. 2 Vols., Leiden 1888 \& 1907.

R. Dozy, P. de Jong et alii, Catalogus Codicum Orientalium Bibliothecae Lugduno-Batavae. 6 Vols., Leiden 1851-1877.

P. de Jong, Catalogus Codicum Orientalium Bibliothecae Academiae Regiae Scientiarum. Leiden 1862.

W.A. Churchill, Watermarks in Paper in Holland,

England, France etc., in the XVII and XVIII Centuries and their Interconnection. Amsterdam 1935.

Codices 
$\operatorname{col}(\mathrm{s})$

d.

Danişmend, Kronoloji

$D B F$

Divanlar

$D N B$

$E I^{1}$

$E I^{2}$

Ethé

Fihris

Fleischer

Flemming

Flügel

$G A L$

GOD

Gölpınarlı

GOR

Götz I, II

GOW

De Groot, Ottoman

Empire

Heawood column(s)

died

İsmail Hâmi Danişmend, İzahlı Osmanlı tarihi kronolojisi. 2nd ed. 5 Vols., Istanbul 1971-1972.

Dictionnaire de biographie française I ff. Paris $1933 \mathrm{ff}$. İstanbul kitaplıkları Türkçe yazma divanlar kataloğu. 3 Vols., Istanbul 1947, 1959 \& 1965.

Dictionary of National Biography. London $1885 \mathrm{ff}$.

Encyclopaedia of Islam. 1st ed. M.T. Houtsma, T.W.

Arnold et alii, eds. 4 Vols., Leiden \& London, 1912-1942.

Encyclopaedia of Islam. 2nd ed. H.A.R. Gibb, J.H.

Kramers et al. 8 Vols., Leiden \& London 1954-.

Hermann Ethé, Catalogue of the Persian, Turkish, Hindûstânî and Pushtû Manuscripts in the Bodleian Library II. Oxford 1930.

Fihris al-makhțūtāt al-Turkīya al-'Uthmānīya. 4 Vols., Cairo 1987-1992. (A Survey of the Ottoman and Turkish Manuscripts of the Dār al-Kutub al-Qawmīya at Cairo) Henricus Orthobius Fleischer, Catalogus Codicum Manuscriptorum Orientalium Bibliothecae Regiae Dresdensis. Leipzig 1831.

Barbara Flemming, Türkische Handschriften. Wiesbaden 1968. (Verzeichnis der orientalischen Handschriften in Deutschland, XIII, 1)

Gustav Flügel, Die arabischen, persischen und türkischen Handschriften der k.-k. Hofbibliothek zu Wien. 3 Vols., Vienna $1865^{-1867 .}$

Carl Brockelmann, Geschichte der arabischen Literatur. 2nd ed. 2 Vols. Leiden 1946-1949; Suppl. 3 Vols., Leiden 1937-1942.

Joseph von Hammer, Geschichte der osmanischen Dichtkunst. 4 Vols., Pest 1836-1838.

Abdülbâki Gölpınarlı, Mevlânâ Müzesi Yazmalar

Kataloğu. 2 Vols., Ankara 1967-1972.

Joseph von Hammer, Geschichte des osmanischen Reiches. 10 Vols., Pest 1827-1835.

Manfred Götz, Türkische Handschriften. 2 Vols.

Wiesbaden 1968 \& 1979. (Verzeichnis der orientalischen Handschriften in Deutschland, III, 2 \& XIII, 4)

Franz Babinger, Die Geschichtsschreiber der Osmanen und ihre Werke. Leipzig 1927.

A.H. de Groot, The Ottoman Empire and the Dutch Republic. A History of the Earliest Diplomatic Relations 1610-1630. Leiden 1978.

Edward Heawood, Monumentae Charta Papyraceae I, Watermarks. Hilversum 1950. 
Heeringa, Bronnen

HOP

Houtsma, Correspondentie

$\dot{I} A$

İnal

JNES

Juynboll, Beoefenaars

Karabulut

Karatay

Kashfaż-Żunūn

KIYK

Kut

Kut, Manisa

Levend

Majda

Medical Manuscripts

Minorsky

MS(S)

NA LH
K. Heeringa ed., Bronnen tot de geschiedenis van den Levantschen handel I (1590-1660) \& II (1661-1726). The Hague 1910 \& 1917.

E.J.W. Gibb, A History of Ottoman Poetry. 6 Vols., London 1900-1909.

M.Th. Houtsma, 'Uit de Oostersche correspondentie van Th. Erpenius, Jac. Golius en Lev. Warner. Eene bijdrage tot de geschiedenis van de beoefening der Oostersche letteren in Nederland'. Verhandelingen der Koninklijke Akademie van Wetenschappen, Afdeeling Letterkunde 17, 116 pp. Amsterdam 1887.

İslâm Anseklopedisi. 12 Vols., Istanbul 1940-1978.

İbnülemin Mahmud Kemal İnal, Son Asır Türk Şairleri. 2nd impr., 4 Vols. Istanbul 1969-1971.

Journal of Near Eastern Studies (Chicago)

Wilhelmina Cornelia Juynboll. Zeventiende-eewsche Beoefenaars van het Arabisch in Nederland. Utrecht 1931. Ali Rıza Karabulut, Kayseri Râşid Efendi Kütüphanesindeki Türkçe, Farsça, Arabça Yazmalar Kataloğu. Kayseri 1982.

Fehmi Edhem Karatay, Topkapı Sarayı Müzesi Küphanesi Türkçe Yazmalar Kataloğu. 2 Vols., Istanbul 1961.

Gustavus Fluegel, ed., Lexicon Bibliographicum et Encyclopaedicum a Mustafa ben Abdallah KatibJelebi dicto. 6 Vols., Leipzig \& London $1835^{-18} 5^{2}$.

Ramazan Şeşen, Mustafa Haşim et al., Kıbrıs İslâm Yazmaları Kataloğu. Istanbul 1995.

Günay Kut, Tercüman Gazetesi Kütüphanesi Türkçe Yazmalar Kataloğu I. Istanbul 1989.

Günay Kut Alpay, 'Bursa ve Manisa İl-Halk kütüphanelerindeki bazı Türkçe Yazmalar üzerine', in Journal of Turkish Studies I (1977), pp. 121-147.

Agâh Sırrı Levend, Türk Edebiyatı Tarihi I. Giriş. Ankara 1973.

T. Majda, Katalog Rekopisów Tureckich i Perskich. Warsaw 1968.

Ramazan Şeşen, Cemil Akpınar \& Cevad İzgi, Catalogue of Islamic Medical Manuscripts (in Arabic, Turkish \& Persian) in the Libraries of Turkey. Istanbul 1984 (text in Arabic).

V. Minorsky. The Chester Beatty Library. A Catalogue of the Turkish Mansucripts and Miniatures. Dublin 1958.

Manuscript(s)

Nationaal Archief (National Archives, The Hague), (first department) collection 'Directeuren der Levantsche Handel' 
NA LT

NA SG

Nallino

Nanninga, Bronnen

Nat, 'Studie'

$N N B W$

$O A$

$\ddot{O B} L$

$' O M$

Özege

Pertsch

Pertsch (Berlin)

PhTF

Représentants

Rieu

Rossi

Rypka

Sachau \& Ethé

Sarajevo

SBL
Nationaal Archief (National Archives, The Hague), (second department) collection 'Legatie Turkije en de Levant'

Nationaal Archief (National Archives, The Hague), (first department) collection 'Staten-Generaal'

Carlo Alfonso Nallino, I manoscritti Arabi, Persici, Siriaci e Turchi della Biblioteca Nazionale e della R. Accademia delle scienze di Torino. Turin 1900.

J.G. Nanninga, Bronnen tot de geschiedenis van den Levantschen handel III (1727-1764) \& IV (1765-1826). The Hague 1964, 1968.

Jan Nat, 'De studie van de oostersche talen in Nederland in de $18 \mathrm{e}$ en $19^{\mathrm{e}}$ eeuw'. Diss. Purmerend 1929.

P.C. Molhuysen, P.J. Blok et alii, Nieuw Nederlandsch Biografisch Woordenboek. 10 Vols., Leiden 1911-1937. Osmanlı Araştırmaları/The Journal of Ottoman Studies. Österreichisches Biographisches Lexicon 1815-1950. Graz \& Cologne $1957 \mathrm{ff}$.

Brusalı Mehmed Tahir, 'Oșmānlı mü'ellifleri. 3 Vols., Istanbul 1334-1343.

M. Seyfettin Özege, Eski harflerle basılmış Türkçe eserler kataloğu. 5 Vols., Istanbul 1971-1979.

W. Pertsch, Die orientalischen Handschriften der Herzoglichen Bibliothek zu Gotha II: Die Türkischen Handschriften. Vienna 1864.

W. Pertsch, Verzeichnis der türkischen Handschriften der Königlichen Bibliothek zu Berlin. Berlin 1889.

Philologiae Turcicae Fundamenta. 2 Vols. Wiesbaden 1959 \& 1964

Jean-Louis Bacqué-Grammont, Sinan Kuneralp et al., Représentants permanents de la France en Turquie (1536-1991) et de la Turquie en France (1797-1991). Paris \& Istanbul 1991.

Charles Rieu, Catalogue of the Turkish Manuscripts in the British Museum. London 1888.

E. Rossi, Elenco dei manuscritti turchi della Biblioteca Vaticana. Vatican City 1953.

Jan Rypka, History of Iranian Literature. Karl Jahn, ed. Dordrecht 1968.

Ed. Sachau \& Hermann Ethé, Catalogue of the Persian, Turkish, Hindûstânî and Pushtû Manuscripts in the Bodleian Library I. Oxford 1889.

Kasim Dobrača, Fehim Nametak et alii, Gazi Husrev-

Begova Biblioteka u Sarajevu; Katalog Arapskih,

Turskih i Perzijskih Rukopisa. 6 Vols. Sarajevo 19631999.

Svenskt Biografiskt Lexikon. I ff. Stockholm $1918 \mathrm{ff}$. 
Schmidt

Schmidt, 'Heyman Papers'

Schmidt, Legation Window

Schmidt, Opium Trade

Schmidt, Pure Water

Schmitz

Schutte, Repertorium

Schutte (1983)

Şeşen

$S^{\prime} O$

$S^{\prime} O^{2}$

Sohrweide I, II

Storey

$T A$

Taeschner, Geographische Literatur TDVIA

Tornberg

Tornberg (Lund)
Jan Schmidt, A Catalogue of the Turkish Manuscripts in the John Rylands University Library at Manchester. Leiden \& Boston 2011.

Jan Schmidt, 'An Ostrich Egg for Golius. The Heyman Papers preserved in the Leiden and Manchester University Libraries and Early-modern Contacts between the Netherlands and the Middle East', in Jan Schmidt, The Joys of Philology; Studies in Ottoman Literature, History and Orientalism (1500-1923) II, 8-74. Istanbul 2002.

Jan Schmidt, Through the Legation Window 1876-1926. Four Essays on Dutch, Dutch-Indian and Ottoman History. Istanbul 1992.

Jan Schmidt, From Anatolia to Indonesia. Opium Trade and the Dutch Community of Izmir, 1820-1940. Istanbul 1998.

Jan Schmidt. Pure Water for Thrsty Muslims; A Study of Muștafā 'Ālī of Gallipoli’s Künhül-ahbār. Leiden 1992. Barbara Schmitz, Islamic Manuscripts in the New York Public Library. New York \& Oxford 1992.

O. Schutte, Repertorium der Nederlandse vertegenwoordigers residerende in het buitenland 1584-1810. The Hague 1976.

O. Schutte, Repertorium der buitenlandse vertegenwoordigers residerende in Nederland 1584-1810. The Hague 1983.

Ramazan Şeşen, Cevat İlgi and Cemil Akpınar, Catalogue of Manuscripts in the Köprülü Library. 3 Vols., Istanbul 1986.

Mehmed Süreyyā, Sicill-i 'Oșmān̄̄ 4 Vols., Istanbul 1308-1315.

Mehmed Süreyya, Sicill-i osmanî. Osmanlı ünlüleri. Nuri Akbayar \& Seyit Ali Kahraman, ed. 6 Vols., Istanbul 1996. Hanna Sohrweide, Türkische Handschriften. Wiesbaden 1974 \& 1981. (Verzeichnis der orientalischen Handschriften in Deutschland, XIII, 3 \& XIII, 5)

C.A. Storey, Persian Literature: A Bio-bibliographical Survey. 7 Vols. London \& Leiden 1925-1992. Turkologischer Anzeiger I ff. Vienna $1975 \mathrm{ff}$. Franz Taeschner, 'Die geographische Literatur der Osmanen'. ZDMG 2/77 (1923), pp. 31-80. Türk Diyanet Vakfi İslam Ansiklopedisi I ff. $1988 \mathrm{ff}$. C.J. Tornberg, Codices Arabici, Persici et Turcici Bibliothecae Regiae Universitatis Upsaliensis. Upsala 1849 .

C.J. Tornberg, Codices Orientales Bibliothecae Regiae Universitatis Lundensis. Lund $185^{\circ}$. 
TTY

TYTK (Adana)

TYTK (Adıyaman)

TYTK (Ankara, Cumhurbaşkanlığı

TYTK (Antalya)

TYTK (Çankırı)
Istanbul Kütüphaneleri Tarih-Coğafya Yazmaları Kataloğları. I. Türkçe Tarih Yazmaları Istanbul 1943-1962.

Türkiye Yazmaları Toplu Kataloğu/ The Union Catalogue of Manuscripts in Turkey. Adana İl Halk Kütüphanesi ve Müzesi, o1. Ankara 1979.

Türkiye Yazmaları Toplu Kataloğu/ The Union Catalogue of Manuscripts in Turkey, 02. Ankara 1979. Türkiye Yazmaları Toplu Kataloğu/ The Union Catalogue of Manuscripts in Turkey, o6, pp. 13-25. Ankara 1979. Türkiye Yazmaları Toplu Kataloğu/ The Union Catalogue of Manuscripts in Turkey, 05. 5 Vols. Istanbul 1982-1984. Türkiye Yazmaları Toplu Kataloğu/ The Union Catalogue of Manuscripts in Turkey, Çankırı İl Halk Kütüphanesi Yamalar Karaloğu. Ankara 1998.

TYTK (Giresun, Rize, Ordu)

Türkiye Yazmaları Toplu Kataloğu/ The Union Catalogue of Manuscripts in Turkey, o6. Ankara 1980.

TYTK (Süleymaniye, Türkiye Yazmaları Toplu Kataloğu/The Union Catalogue Mustafa Âşir Efendi) of Manuscripts in Turkey, 34/iv. Ankara 1994.

TYTK (Süleymaniye, Ali Nihat Tarlan)

TYTK (Türkiye Büyük Millet Meclisi)

UB

Umur

Voorhoeve

Warner and his Legacy

Weijers, Orientalia

Yardım

Zambaur

$Z D M G$
Türkiye Yazmaları Toplu Kataloğu / The Union Catalogue of Manuscripts in Turkey, 34. Ankara 1981.

Türkiye Yazmaları Toplu Kataloğu / The Union Catalogue of Manuscripts in Turkey, 06, pp. 29-72. Ankara 1979. University Library

Süha Umur, Osmanlı Padişah Tuğraları. Istanbul 1980. P. Voorhoeve, Handlist of Arabic Manuscripts (Bibliothecae Universitatis Leidensis Codices Manuscripti VII). The Hague, Boston \& London 1980.

Levinus Warner and his Legacy. Three Centuries Legatum Warnerianum in the Leiden University Library. Catalogue of the Commemorative Exhibition in the Bibliotheca Thysiana from April 27th till May 15th 1970. Leiden 1970. Henricus Engelinus Weijers, 'Commentarii de Codicibus Manuscriptis Orientalibus Bobliothecae Leidensis'. T.G.J. Juynboll, T. Roorda \& H.E. Weijers, Orientalia I, pp. 297-504. Amsterdam 1840.

Ali Yardım, Izmir Millî Kütüphanesi Yazma Eserleri Kataloğu. 4 Vols. Izmir 1992-1997.

E. von Zambaur, Manuel de généalogie pour l'histoire de l'Islam. Hanover 1927.

Zeitschrift der Deutschen Morgendländischen Gesellschaft (Leipzig-Stuttgart). 
TRANSLITERATION TABLE

\begin{tabular}{|c|c|c|c|c|}
\hline letter & general & Arabic & Persian & Turkish \\
\hline i &, $\bar{a}$ & & & \\
\hline ب & $\mathrm{b}$ & & & \\
\hline 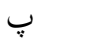 & $\mathrm{p}$ & & & \\
\hline ت & $\mathrm{t}$ & & & \\
\hline$\dot{ث}$ & th & th & th & $\underline{\mathbf{S}}$ \\
\hline ة & & $\mathrm{t}$ & & \\
\hline ج & & $\mathrm{j}$ & $\mathrm{j}$ & $\mathrm{c}$ \\
\hline ج & & & ch & ç \\
\hline 乙 & h & & & \\
\hline$\dot{\tau}$ & & kh & $\mathrm{kh}$ & $\mathrm{h}$ \\
\hline خوا & & & $\mathrm{kh}^{\mathrm{w}} \overline{\mathrm{a}}$ & hōo \\
\hline د & d & & & \\
\hline ذ & $\mathrm{dh}$ & $\mathrm{dh}$ & $\mathrm{dh}$ & $\underline{\mathrm{z}}$ \\
\hline ر & $\mathrm{r}$ & & & \\
\hline j & $\mathrm{z}$ & & & \\
\hline j & & & $\mathrm{zh}$ & $\mathrm{j}$ \\
\hline س & $\mathrm{s}$ & & & \\
\hline ش & & sh & sh & Ş \\
\hline ص & ș & & & \\
\hline ض ض & d & d & d & $\dot{\mathrm{z}}$ \\
\hline b & $\mathrm{t}$ & & & \\
\hline ظ & $\mathrm{z}$ & & & \\
\hline$\varepsilon$ & ' & & & \\
\hline$\dot{\varepsilon}$ & & gh & gh & $\dot{\mathrm{g}}$ \\
\hline ف & $\mathrm{f}$ & & & \\
\hline ق & & $\mathrm{q}$ & $\mathrm{q}$ & $\mathrm{k}$ \\
\hline ك) & & $\mathrm{k}$ & $\mathrm{k}, \mathrm{g}$ & $\mathrm{k}, \mathrm{g}$ \\
\hline 」 & l & & & \\
\hline b & $\mathrm{m}$ & & & \\
\hline ن & $\mathrm{n}$ & & & \\
\hline 9 & & $\overline{\mathrm{u}}, \mathrm{w}$ & $\overline{\mathrm{u}}, \mathrm{w}$ & $\mathrm{o}, \ddot{\mathrm{o}}, \mathrm{u}, \overline{\mathrm{u}}, \ddot{\mathrm{u}}, \mathrm{v}$ \\
\hline$ه$ & & $\mathrm{~h}$ & $\mathrm{~h}$ & $\mathrm{~h}, \mathrm{a}, \mathrm{e}$ \\
\hline ي & $\mathrm{y}, \overline{\mathrm{l}}$ & & & \\
\hline ⿶ & & $\overline{\mathbf{l}}, \overline{\mathrm{a}}$ & $\overline{\mathbf{1}}, \overline{\mathrm{a}}$ & $\overline{\mathbf{1}}, \mathrm{i}, \mathrm{l}, \overline{\mathrm{a}}$ \\
\hline
\end{tabular}


Jan Schmidt - 978-90-04-22191-8

Downloaded from Brill.com04/26/2023 07:45:40AM via free access 


\section{CHAPTER ONE}

AMSTERDAM, AMSTERDAM MUSEUM

Address: Kalverstraat 92, Nieuwezijdse Voorburgwal 357

The museum, formerly the Amsterdam Historical Museum, first opened its doors to the public in 1926. It houses the city's art collection brought together from the 17th century onward. The collection was later expanded with donations. Among the holdings of the museum is a part of the collection of fine and applied art of Abraham Willet (1825-1888), which includes a library comprizing some manuscripts, among them one Turkish item (described below), acquired though his widow, Louisa Willet-Holthuysen (1824-1895), who bequeathed her possessions to the city of Amsterdam. Two modern Turkish letters, composed for the museum for an exhibition in 1985 by two anonymous refugees describing their painful experiences in the Netherlands, are still kept in a file tentoonstellingsdocumentatie Allemaal Amsterdammer found in a box labelled $1985 / 5 b$.

Literature: Geert-Jan Koot \& Fransje Kuyvenhoven, "The 'Willet-Holthuysen' Collection of Books", in Art Libraries Journal 12/1 (1987), pp. 32-38.

Hs. LA 2047

Yūsufu Züleyhā

يوسف و زليخا

A 16th-century illustrated copy of a narrative poem in mesnevi rhyme on the story of Yūsuf and Züleyḩā by Meḥmed Ḥamdullāh, who used the pen-name of Hamdì (d. 909/1503). It was the first Ottoman version on this theme and was completed by the poet in 897 (1491-1492) according to the concluding chronogram: 'in exactly 897 the poor Hamdī finished this poem' (sekizyüzle toksan yedide temām / bu nazmı temām etdi Hamdī fakìir, f. 222a:2). The last word of the final chronogram (quoted below) results in the same number. The title is written in white in a gilt headpiece on $\mathrm{f} . \mathrm{b}$; the name of the author, Hamdì Çelebi b. eş-Şeyh, also in white occurs in another headpiece on $\mathrm{f}$. 2a. The last chronogram is followed by a riddle colophon (cf. below). A description on the author and contents in Dutch is found on the last flyleaf, recto; it states that the manuscript was completed in 1562 (but cf. below). The manuscript contains nine coloured miniatures (23a, 47b, 6ob, 
77b, 118b, 166a, 194b, 215b and 216a); six pages (89a-b, 153a-b, 154a-b) have, apart from the borders, remained blank but had obviously been destined for further pictures. One of these contains the year 1235 (1819-1820). (For another, incomplete, copy of the same work see Leiden, UB Cod.Or. 14.561.)

Bound in embossed dark brown leather, possibly of Western origin; cream glazed paper; $(1)+222+(1)$ folios; $177 \times 104 \mathrm{~mm}$ and $126 \times 65 \mathrm{~mm} ; 15$ lines or less on pages containing slanting lines; catchwords; small nesih of calligraphic quality; headings in gold and blue, occasionally in green; multiple borders in gold contained within double blue lines; rich floral illumination in gold, blue, red, pink and green on ff. $1 \mathrm{~b}-2 \mathrm{a}$; writing surface filled in with gold on ff. 2b-3a; completed by Meḥmed b. Ramażān in the early afternoon of Wednesday 24 Rebïü l-ăhir 969 (1 January 1562); an owner's inscription of Bursalı Șālị Ag a at the Körhane barracks and of 'Keyfli Ṭanacı' İbrāhīm Ag̀a, with a price of ' 54 ', is found on the first flyleaf, verso; a small circular bookplate of Abraham Willet (cf. the Introduction, above) is found on the inner back-board.

Begins (lb):

$$
\text { ذكر اولناسه اول اسم الله *هر نه بشلنسه آخر اوله تباه }
$$

The work proper ends (221b):

$$
\text { شكر و منت خداى سبحانه *كه بو نظى بتوردى پايانه }
$$

The concluding chronogram ends (222a):

$$
\text { قودى اهل درده بونى يادكار *مرادى اولاردن دعاى منير }
$$

The copyist's chronogram ends (ibidem):

$$
\text { هر كه اين را بخواند از كمش * ياد كردن بخير جرسندم }
$$

Colophon (ibidem):

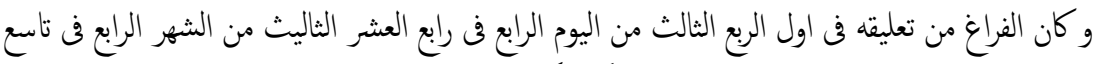

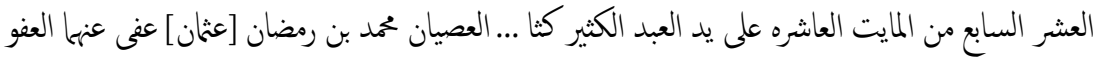

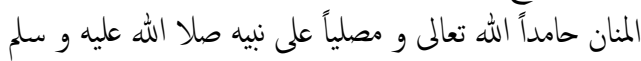

Catalogue entries: [Frans Coenen], Catalogus der Bibliotheek van het Museum Willet-Holthuysen (Amsterdam 1896), p. 208; Flemming $5^{1}$ and Sohrweide II, 246, where other MSS are mentioned; see also Fihris 5144-5153 (IV, pp. 278-279); Kut, Manisa, p. 131; Schmidt 15, 6o; TYTK (Süleymaniye, Ali Nihat Tarlan) 287-288.

Literature: cf. Flemming, pp. 37-38; M. Naci Onur, "Hamdullah Hamdi'nin Yûsuf ve Züleyhâ'sındaki bazı millî motifler", in Türk Dünya Araştırmaları 38 (1985), pp. 113-127. 


\section{CHAPTER TWO}

\section{AMSTERDAM, INTERNATIONAL INSTITUTE OF SOCIAL HISTORY}

(IISH)

\section{Address: Cruquiusweg 31}

The IISH was founded in 1935 on the initiative of N.W. Posthumus, professor of Economic History at Rotterdam and, later, Amsterdam; the project was supported by De Centrale (Central Workers' Insurance and Deposit Bank), and had as its central aim the gathering and preservation of source materials on social history, in particular those concerned with the history of trade unions and workers' organisations, which otherwise - the coming world war had already begun to cast its ominous shadows - might have gone lost. One of the most spectacular acquisitions of the pre-war period was the 'party archive' of the Sozial-demokratische Partei Deutschlands (SPD), containing the personal collections of outstanding German radicals and socialists, among whom Karl Marx and Friedrich Engels. After the difficult war years, when the holdings which had not been evacuated out of the country were confiscated and transported to Germany, the institute saw a new period of consolidation - the major part of the possessions returned safely to Amsterdam - and expansion. At present, the collection includes more than five miles of archival documents, and many more miles of books, periodicals, pamphlets, photographs, posters, audiovisual materials, and various objects. Turkey and the Ottoman Empire only became a special focus of interest in 1986 thanks to a growing interest in the area fostered by the presence of a large Turkish minority in the Netherlands, but was particularly triggered when a large collection of Turkish publications, photographs and posters, owned by Orhan Silier, became available for purchase. Henceforward the Turkish collection, consisting of books, periodicals, and private archives with materials of interest to the history of political movements but also of literature has been steadily increasing. Although the collections are easily accessible through the Internet-most recently the non-Dutch collections have also been described in Jaap Haag \& Atie van der Horst, eds., Guide to the International Archives and Collections at the IISH, Amsterdam (Amsterdam 1999) - I nevertheless take the opportunity here to give a succinct survey of the Ottoman/Turkish collections which contain manuscript materials, and to include some plates from one of the collections in order 
to give an idea of the many-faceted richness of the collections-for more details one should consult the on-line catalogue. I do not include here the archives of institutions such as political parties.

\section{Anhegger archive $(0,02 \mathrm{~m})$}

Robert Anhegger (1911-2001), Turkologist and teacher of German, born in Vienna, who lived most of his life in Turkey, particularly from 1940 onwards; from 1961 he was director of the Goethe Institut in Istanbul and Amsterdam. The IISH obtained two photocopies of typescripts in German describing his travels with Andreas Tietze in Anatolia in 1936 and 1937. (See for his manuscripts and papers, including copies of the same texts, acquired by Leiden University Library, the chapter on the 'Addenda', below.)

Literature: Erik-Jan Zürcher, "Two Young Ottomanists Discover Kemalist Turkey. The Travel Diaries of Robert Anhegger and Andreas Tietze", in Jan Schmidt, ed., Essays in Honour of Barbara Flemming II (Harvard University 2002), pp. 359-369.

\section{Arar archive (10.2 m)}

İsmail H. Arar (1909-1993), lawyer, parliamentarian and Minister of Justice, of Education and without portfolio (1971-1973), member of the advisory committee set up by the military after the 1980 coup; author of many books on Turkish modern history. The archive contains mostly printed materials documenting late-Ottoman and Turkish history.

\section{Bahadinli archive $(0.06 \mathrm{~m})$}

YusufZiya Bahadinli, born 1927, writer and educator; member of the Turkish National Assembly for the Turkish Labour Party,Türkiye İşci Partisi (TIP), 1965-1982. The archive contains documents concerning his activities on behalf of TIP, 1966-1977, and some letters, 1969-1982.

Fegan Archive ( $0.6 \mathrm{~m})$

Fuat Fegan (born 1937, disappeared 1983), leftwing political activist, friend of Hikmet Kıvilcıml (cf. below). The archive contains documentation on various political organisations, the Cyprus question and the Comintern, 1957-1982. 
Kivılcımlı archive $(4.12 \mathrm{~m})$

Dr. Hikmet Kıvılcımlı (1902-1971), prolific publicist, translator of, among other works, Marx's Das Kapital, and political activist. Member of the Türkiye Komünist Partisi (TPK), he later, in 1954, founded his own Vatan Partisi; he spent twenty years of his life in prison. He escaped Turkey by fishingboat after the military coup of 1971, and died in Belgrade, Yugoslavia, the same year. The collection contain his private papers, consisting of notebooks, manuscripts of his published and unpublished works, and various documents, some concerning his escape from Turkey, but mostly papers related to a number of organisations he had been involved with. The archive was saved by his friend, Fuat Fegan (cf. above), who fled to Sweden in 1971 and intended to write a biography of Kıvilcıml. It was acquired in 1992 and handed over to the IISH by Latife Fegan. The autograph materials are written in a tiny Arabic script, both in pencil and ink, which is difficult to read.

Küçük archive $(0.12 \mathrm{~m})$

Celâl Küçük (born 1933), trade unionist, mostly active in the rubber factory workers union, Lastik $\dot{I s}$, imprisoned 1980-1984. The archive contain his prison diaries and a memoir of his incarceration, 1981-1984.

\section{Pamukçu archive $(0.85 \mathrm{~m})$}

Sina Pamukçu (born 1927), political activist and trade unionist; finally assistant general secratary of Türkiye Devrimci İşçi Sendikaları Konfederasyonu (DISK) from 1967; he moved to Brussels after the military coup of 1980. The archive, acquired in 1991, contains correspondence, notes, circulars and various documents, 1980-1987.

\section{Sertel archive $(0.03 \mathrm{~m})$}

Zekeriya Sertel (1890-1980), writer and journalist; published, together with his wife, Sabiha Sertel, the monthly illustrated paper, Resimli Ay, from 1924, and founded the newspaper Tan, the offices of which were plundered by right-wing demonstrators in 1945. He lived in Azerbaijan and France between $195^{\circ}$ and 1977. The archive contains correspondence with his lawyer Etem Derviş, and some other documents, 1949-1954. 


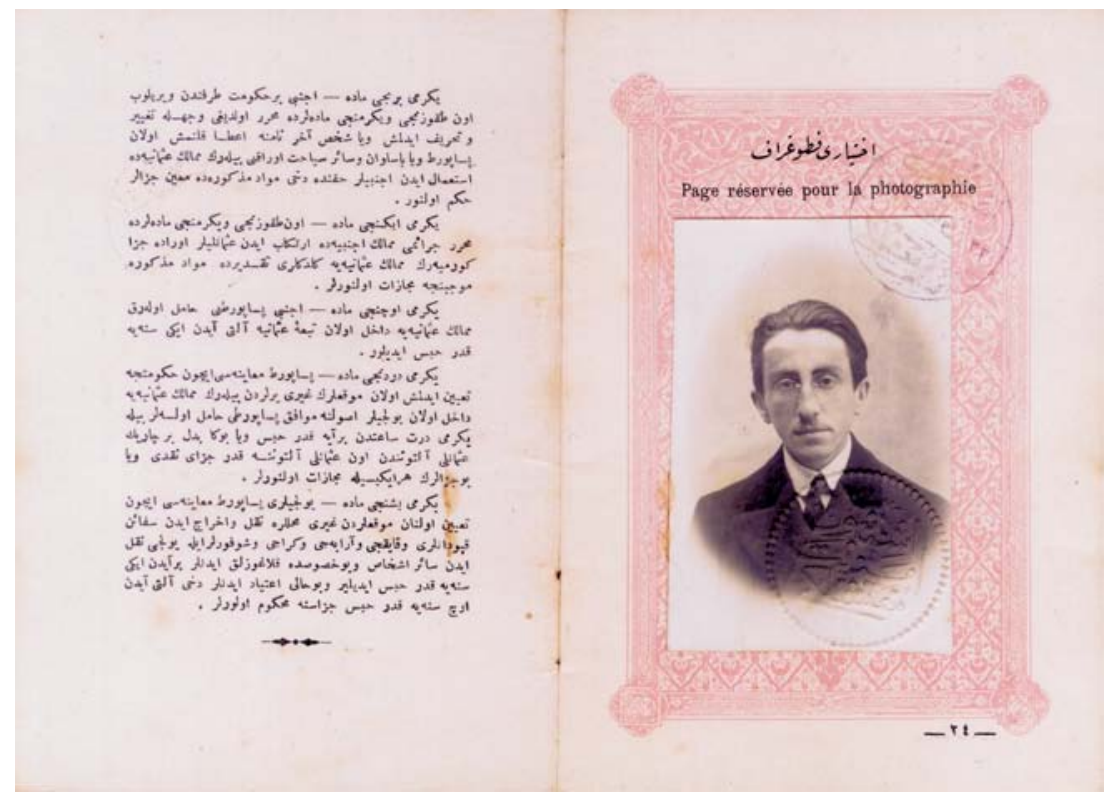

Figure 1. Amsterdam, IIHS, Vâ-Nû Archive 209. Two pages of a passport issued to the writer and journalist, Aḥmed Vâlâ b. Nürüddīn, who used the pen-name of Vâ-Nû, dated 1336 (1920), with photograph of the bearer.

\section{Sülker archive (12.1 m)}

Kemal Sülker (1919-1995), writer of novels and short stories, journalist and trade unionist. In the 1950s, he became active in the trade uninion organisation of Türk-Işs, in the 1960 s and helped to found Türkiye Devrimci İşçi Sendikaları Konfederasyonu (DISK), and became its first secretary. In the 1970s he was one of the organisers of the Authors Uninion of Turkey, Türkiye Yazarlar Sendikası. The large archive contains correspondence, manuscripts of articles and studies, and various documents, mostly related to his trade union work, 1919-1993.

\section{Vâ-Nû archive (1.4 m)}

Ahmed Vâlâ Nûruddin ('Vâ-Nû', 1901-1967), writer and journalist. After a brief stint as a teacher in Bolu, he moved together with the poet Nâzım Hikmet (Ran) to Moscow where he studied at the Communist University of the Workers of the East, and returned to Turkey in 1928. He was married to the prolix novelist and translator, Müzehher Vâ-Nû (born 1912). The archive contains materials originating from both husband and wife, and 


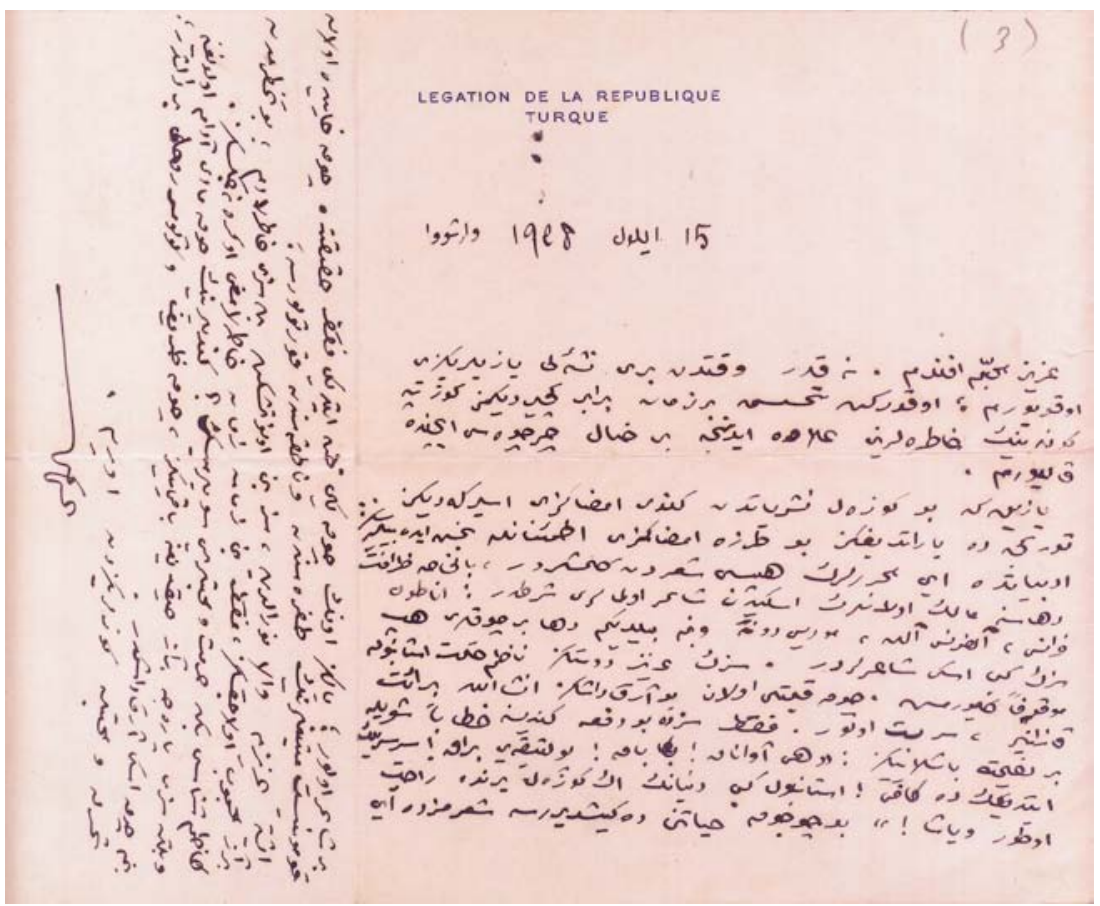

Figure 2. Amsterdam, IIHS, Vâ-Nû Archive 179. Letter from Yahya Kemal (Beyatlı), at Warsaw, to Ahmed Vâlâ b. Nūrüddīn, who used the pen-name of Vâ-Nû, dated 15 September 1928. Sender writes addressee how much he liked his stories; all good writers were always poets first. Nâzım Hikmet had returned from Moscow under arrest. He advises addressee to write to the latter to abandon politics, and live quietly in Istanbul, the most beautiful place on earth. He could become a very good poet if he would refrain from attending and speaking in Communist meetings.

comprises correspondence, notebooks, personal papers, manuscripts, also in typescript, of literary and other works, and various documents, 1919-1996.

Among the acquisitions made since the early 2000 se find:

\section{Dikerdem Papers $(0.5 \mathrm{~m})$}

Mahmut Dikerdem (1916-1993), diplomat and peace activist; ambassador to various countries; founding president of the Turkish Peace Association (Barış Derneği), 1977; imprisoned 1982-1985. His archive contains correspondence (1969-1992), typescripts and printed materials. 
Gül Papers (0.7 m)

Turan Gül (1940-1997), journalist; emigrated to the Netherlands in 1971. The papers contain correspondence, typescripts and other materials, mainly on Turkish migrant workers in Zaandam, the Netherlands.

İsmen Papers $(0.25 \mathrm{~m})$

Fatma Hikmet İsmen (1918-2006), plant pathologist; member of various left-wing Turkish parties; senator (1966-1975) for the TiP (Turkish Labour Party). The archive contains diaries, notebooks and correspondence.

Kramers archive $(0.12 \mathrm{~m})$

Jan Hendrik Kramers (1871-1951), Dutch Orientalist; dragoman at the Dutch Embassy in Istanbul (1915-1923); lecturer and professor at Leiden University (see also under Leiden UB, Or. 14.221-228). The archive comprises personal papers, including letters, a diary and photographs (1925, concerning a visit to Kurdistan) and printed materials. Donated in 1992 and 1993.

Olcay Papers $(0.87 \mathrm{~m})$

Osman Olcay (1924-2010), diplomat and ambassador to various countries; Minister of Foreign Affairs in 1971; Turkish representative to the UN and NATO (1992-1998). The archive contains a diary (1944), manuscripts and various other papers, including letters.

Literature: Jan Lucassen, Tracing the Past. Collections and Research in Social and Economic History: The International Institute of Social History, the Netherlands Economic History Archive and Related Institutions (Amsterdam 1989); The International Institute of Social History. The Department of Turkey (Amsterdam 1991); Sosyal Tarih: Ulusarası Sosyal Tarih Enstitüsü Türkiye Bülteni 2 (Amsterdam 2002). 


\section{AMSTERDAM, NEDERLANDS SCHEEPVAARTMUSEUM (NETHERLANDS MARITIME MUSEUM)}

\section{Address: Kattenburgerplein 1}

The museum had its origin in a grand exhibition of Dutch shipping, the Eerste Nederlandsche Tentoonstelling op Scheepvaartgebied, held in Amsterdam in 1913. Not long after, in 1916, on the instigation of Queen Wilhelmina, who visited the exhibition, the Vereeniging Historisch Scheepvaart Museum, an association which aimed at founding a maritime museum of a nationwide scope, the museum was founded in 1921. In 1973 the expanded collection was tranferred to the monumental 17th-century Navy Arsenal, 's Lands Zeemagazijn, in the eastern docks, which was completely restored and refurbished in 1981. The collection comprises some materials of interest for the maritime relations between the Low Countries and the Ottoman Empire, among them three fermāns, A.4898(14-16), which had been acquired from the collection of Jacob Baart de la Faille (1795-1867), professor of Medicine in Groningen (1832-1865, cf. NNBW IV, cols. 597-598), and sold at public auction in 1868; they had formerly belonged to his grand-father, Ambroise Veijdt of the Antwerp firm of De Heijder Veijdt \& Co.

Literature: Sjoerd de Meer, 's Lands Zeemagazijn (Zutphen 1994), esp. pp. $71-86$.

\section{A.4898(14) \\ A passport}

An original copy of a fermān issued on request of the Austrian internuntius (orta elçisi) to the Porte, Baron de Herbert Rathkeal [Peter Philipp Herbert Freiherr von Rathkeal, 1733-1802, in function 1780-1789, cf. BLKO VI, pp. 352-357], to grant safe conduct to the ship de Stad Lier under Captain Dirick Lauerman [sailing for the Antwerp firm of De Heijder Veijdt \& Co.] in the Mediterranean Sea, dated at the beginning of Rebïü l-ähir 1197 (6-15 March 1783). The text is headed by a tugra in gold-dusted black ink of Sultan 'Abulhamīd I (see Umur, pp. 270-277). A brief description in French is found on the back (4 lines).

Glazed white paper; $760 \times 530 \mathrm{~mm} ; 14$ lines; dìvāni. 


\section{A.4898(15)}

A passport

An original copy of a fermān issued on requeste of the Austrian internuntius (orta elçisi) to the Porte, Baron de Herbert Rathkeal (cf. above), to grant safe conduct to the ship la Dame Catherine under Captain Hans Hoier [sailing for the Antwerp firm of De Heijder Veijdt \& Co.] in the Mediterranean Sea, dated at the end of Şevvāl 1196 (28 September-7 October 1782). The text is headed by a tugra in gold-dusted black ink of Sultan 'Abulhamīd I (see Umur, pp. 270-277). A brief description in French is found on the back (4 lines).

Glazed white paper; $760 \times 530 \mathrm{~mm} ; 13$ lines; dìvānī.

\section{A.4898(16)}

A passport

An original copy of an official document, addressing $k \bar{a} \dot{z} \bar{\imath}$ s and other authorities on the way between Izmir and Istanbul, on behalf of two Dutch gentlemen (Felemenk begzādeler), [Lieutenant B.G.] Escher and [aspirant de ${ }^{\text {ire }}$ classe, J.A.K] van Hasselt, instructing them to let the men pass along unhindered, and see to their comfort as regards lodging and horses; the document was handed over to the [Dutch] consul in Izmir. It is signed by 'Ömer Luṭ̂i, nāzir-i ihtisāb (d. 1252/1836-1837, cf. SO IV, p. 1322; see also Schmidt, Opium Trade, p. 49, passim) - the calligraphed signature is adorned with two tugs —and dated 29 Rebǐü l-evvel [12]46 (17 September 1830). A signature and a seal are found on the back. (The journey of the two officers is documented in consular correspondence: the consul in Izmir, Jacob van Lennep, informed the envoy in Istanbul, Caspard Testa, on the 17th that the men had arrived on the 16th-they were crew members of the Dutch Navy brig Kemphaan - and would travel to Istanbul over land in the company of the cavass 'Alī. Testa informed Van Lennep on the 28th that the men had savely arrived, and had been introduced to the kapudan paşa and the ser'asker. They had left the city on the previous day. See NA, file Nederlands Gezantschap in Turkije 1814-1872, 164 \& 165.)

Glazed white paper; $540 \times 300 \mathrm{~mm}$; irregular dìvānī; 9 lines. 


\section{CHAPTER FOUR}

\section{AMSTERDAM, UNIVERSITEITSBIBLIOTHEEK \\ (UB, UNIVERSITY LIBRARY) \\ Address: Oude Turfmarkt 129 \\ (Bijzondere Collecties/Special Collections)}

The Library of the University of Amsterdam, not to be confused with the Vrije Universiteit van Amsterdam (Free University of Amsterdam), was established in 1877, when the existing Athenaeum Illustre was turned into a regular university. The library had formerly been a municipal library which had been founded in 1578 and housed in the New Church. It later served as library for the Athenaeum upon its foundation in 1632 when the manuscripts and printed books were moved from the church to the loft over its teaching rooms. Oriental languages, in particular Hebrew, were taught at the Athenaeum between 1686-1877, and among the professors was Joannes Willmet (1804-1835), whose manuscript collection is described below (as part of the Academy of Arts and Sciences collection, kept in the Leiden University Library). Christianus Ravius, some of whose manuscripts were acquired by the University Library of Utrecht (described below), vainly tried to get appointed professor in Hebrew in 1646-1647. The library only occasionally purchased or was donated Oriental manuscripts. The first Turkish manuscripts, parts of a 17th-century Bible translation, were acquired in 1783 from the library of a pastor of Amsterdam, Thomas Vieroot (1698-1780). In 1875 a large collection of, mostly, letters, kept in twenty boxes was offered to the municipality of Amsterdam by W.G.A. Diederichs; the texts had been gathered in the Netherlands, Germany, England, France, Italy and elsewhere, by his father, Pieter Arnold Diederichs (1804-1874), bookseller and publisher in Amsterdam. The collection, comprising c. 35,000 items, came into the possession of the library in 1892. With the exeption of the German

and Swiss items, the collection was described in printed catalogues during the years 1893-1917. A few letters, among them official documents issued by the Porte, contain texts in Turkish or are closely related to the history of the Ottoman Empire. They are all unique, and some of the documents are of an unusual format and content. In later years, the library acquired more items in the genre, in particular a small collection of letters mostly addressed to the traveller, writer and envoy to the Porte (internuntius), Anton Graf 
Prokesch von Osten (1795-1876, cf. ÖBL VIII, pp. 301-302; Georg Pfligersdorffer, Aus den griechischen Reise- und Zeitbildern des Grafen Prokesch von Osten, Graz 1978, pp. 15-65), compiled by his son or one of his daughters, and purchased in the 1920s. These are described under rubric Cq, below. (I am indebted to Daniel Koster, Amsterdam, for drawing my attention to these mostly uncatalogued items.) A miscellaneous manuscipt with, mostly, Turkish texts on divination and poems, was purchased in 1923 after it had been refused by the Leiden University Library (Hs. Cn 12). A major collection containing a few Turkish texts which came in to the possession of the library was the Collection Dortmond. It comprises materials, among them texts, related to the history of writing and scripts, and was compiled during extensive travel by J.A. Dortmond (1912-1988), wholesale dealer in stationary and office materials. The collection was purchased by the library in 1975 and a selection of the materials is on permanent exhibition in the library premises. This collection comprises two Ottoman rüznāmes, in the form of splendidly designed and calligraphed scrolls.

Literature: C.P. Burger \& J.S. Theissen, "De stedelijke bibliotheek", in $G e$ denkboekvan het Athenaeum en de Universiteit van Amsterdam (Amsterdam 1932), pp. 369-391; Carla M. Faas, "Enkele opmerkelijke collecties handschriften in de Universiteitsbibliotheek van Amsterdam", in: De Arte et Libris. Festschrift Erasmus 1934-1984 (Amsterdam 1984), pp. 93-117; Herman de la Fontaine Verwey, "The City Library in the Nieuwe Kerk 1578-1632", in: Quaerendo 14 (1984), pp. 163-206; E.O.G. Haitsma Mulier, C.L. Heesakkers et alii (eds.), Athenaeum Illustre. Elf studies over de Amsterdamse Doorluchtige School 1632-1877 (Amsterdam 1997), pp. 27-28; J. Hellendoorn, SchenkingDiederichs. Nederlandsche Afdeeling (Bibliotheek der Universiteit van Amsterdam. Catalogus der handschriften I, Amsterdam 1899), pp. i-iv; Universiteitsbibliotheek Amsterdam. Schriftmuseum J.A. Dortmond (brochure published by the University of Amsterdam, without date).

\section{Hs. VI H 2}

\section{Translation of the Bible}

The translation consists of a collection of unbound quires, measuring $210 \times$ $165 \mathrm{~mm}$, with a translation by 'Alī Ufkī, also known as Wojcieh Bobowski or Albertus Bobovius (d. c. 1675), who was a court musician and First Dragoman to Sultan Mehmed IV. His handwriting, a small, often vowelled nesih, found in some of the quires, is similar to that in the facsimile edition (by Şükrü Elçin) of his, Ufkī’s, Mecmū'a-i sāz u söz (Istanbul 1976). The text 
was written in 1662-1664 (cf. Neudecker, Bible Translation, pp. 371-372; for data on the author, see ibidem, p. 365n, and Hannah Neudecker, 'Wojcieh Bobowski and his Turkish Grammar (1666); a Dragoman and Musician at the Court of Sultan Mehmed IV', in Dutch Studies on Near Eastern Languages and Literatures 2/2 (Leiden 1996), pp. 169-192. Bobovius was charged with the translation work by Lieven Warner (Warnerus, 1619-1665), a student of the Leiden orientalist, Jacob Gool (Golius, 1596-1667), and a resident of Istanbul from 1644. In other quires, the elegant neshi hand of Shahin Kandi, a copyist employed by Golius in Leiden from 1656 onwards (cf. Juynboll, Beoefenaars, pp. 167-168), is recognisable. Golius was involved as a supervisor in the translation project and had Shahin Kandi apparently correct Bobovius's work - the latter's texts show a great many corrections and emendations by the copyist (see also below). The quires are preserved in an old wooden box. Other remains of the project are kept in the Leiden University Library, see under Codices Or. 386, 390, 391, 1101, 1117a and 3100 (described in the first and second volumes of this catalogue). A revised version was eventually printed as Biblia Turcica in Paris in 1827-1828. The box with manuscripts and additional papers was acquired by the library from the pastor Thomas Vieroot in 1783 .

As is clear from the catalogue of $185^{8}$ (mentioned below), the MS included four letters related to the translation project; these had been removed by 1902, when Mendes da Costa published his new catalogue (cf. below). In one letter addressed to the merchant Laurens de Geer (16141666), financier of the project, Golius criticizes Bobovius's translation work, and recommends the services of 'a learned Armenian [this obviously was Shahin Kandi], who lives in Leiden' and should be charged with improving the text while making use of the existing Arabic translation (quoted in the catalogue of $185^{8}$, pp. $\left.712-713\right)$. In one letter, kept in the Leiden University Library, Cod.Or. 1228, No. 72, Shahin Kandi himself refers to his work on the Bible (mașlahat al-Bībìya) for which he was paid by 'Monsieur Geer' 'مسور كير' (printed in Houtsma, Correspondentie, pp. 69-70). What has remained in the box is two folded leaves with notes in Dutch in pencil and ink, kept in a cardboard cover. One leaf contains a list of the books of the Old testament, from Joshua onwards, with numbers of quires (vellen) received and handed over to Golius; the second contains lists of Bible books in two columns, with additional notes related to shipping; one lot, sent with the commander, Jan Gidionsz, was received in October 1663, a second, carried by the ship de Son (cf. Heeringa, Bronnen, II, p. 113) in June 1664. In both lists books are mentioned which are not found in this collection. 
If we turn to the extant parts (quires) - they only cover the books of the Old Testament, with the exception of the first five-we find the following:

\section{Hs. VI H 2, a}

The Book of Joshua. The work occurs twice, first $(1 a-44 b)$ in the hand of Bobovius, second (45b-95a) in that of Shahin Kandi; corrections in red by Shahin Kandi in the first part; $11+13$ quires, with original numbers $2-13$, of two folded leaves (4 folios); (1-44) white paper; text surface $170 \times 115 \mathrm{~mm}$, varying; 15 lines; catchwords; (from f. 45) glazed cream paper; text surface $155 \times 105 \mathrm{~mm}$, varying; 13 lines; catchwords; titles, rubrics and dots in red; undated. The quires are wrapped in a folded leaf with the inscription Josua.

Heading (1a):

$$
\text { يو شع اولكى باب }
$$

Begins (ibidem):

ا و اولديكه تكرى قولى موسى نك وفاتند نصكره الله تعالى موسينك خدمتكارى نون اوغلى يوشعه :

سويليوب دديكه

Ends (95a):

بَ اندن هارون اوغلى العازار دخى وفات ايتدى ... دفن ايتديلر تم

\section{Hs. VI H 2, b}

Ruth, Esther, the Song of Songs \& Lamentations, in the handwriting of Bobovius; one quire of 3 folded leaves ( 6 folios) + one quire of 4 leaves ( 8 folios $)+$ one quire of 3 folded leaves $(6$ folios $)+2$ quires of 4 folded leaves ( 8 folios); white glazed paper; text surface $165 \times 125 \mathrm{~mm}$, varying; 15 lines; catchwords; undated. A folded sheet wrapped around the quires contains the inscription Canticū Canticor. Salom. Ruth Ester, Nehemia. Lamentationes Jeremiae.

Heading (1a):

$$
\text { روت اولكى باب }
$$

Begins (ibidem):

$$
\text { ا اولديكه حاكملر حكم اتدكلرى كونلرده يرده قط اولايده ... }
$$


Ends (35b):

$$
\text { r rكه بزى همان كليت ايله رد ايدرمسين بزوم اوزريزه قانى يك غضوب اولورمى سن }
$$

Colophon (ibidem):

نياحات تمام اولدى م

\section{Hs. VI H 2, c}

The First and Second Book of Samuel, Ecclesiastes \& Proverbs, in the handwriting of Bobovius; 26 quires of 2 folded leaves ( 4 folios) $+2+5$ quires of 4 folded leaves ( 8 folios); (1-104) white paper, (from f. 105) white glazed paper; text surface $165 \times 125 \mathrm{~mm}$, varying; $15^{-16}$ lines; catchwords; undated. Extensive red lines, corrections and additions by Shahin Kandi in the first book.

Heading (1a):

$$
\text { شموال ا اولكى باب }
$$

Begins (ibidem):

$$
\text { ا راماتايم صوفيمدن افرايم طاغندن بر آدم وار ايدى }
$$

Ends (159a):

$$
\text { اب اكاكندو اللرينك يمشندن ويرك آنوك عملرى آنى قبولرده مدح ايلسونلر }
$$

Colophon (ibidem):

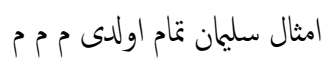

Hs. VI H 2, d

The First and Second Book of Samuel, copied by Shahin Kandi, with marginal corrections and additions in black and red by the same, particularly in the second book; 16 quires of two folded leaves (4 folios) + one quire of one folded leaf ( 2 folios) +16 quires of two folded leaves ( 4 folios); the quires bear original numbers: $2-17$ and 2-16; glazed white paper; text surface $155 \times 105 \mathrm{~mm}$, varying; 13 lines; catchwords; titles, rubrics and dots in red; undated. The remnant of an envelope with traces of red wax and the inscription IISamuel is wrapped around the quires.

Title (1a):

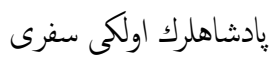


Heading ( $(\mathrm{b})$ :

$$
\text { شموال بيغمبرك سفرى اولكى فصل }
$$

Begins (ibidem):

$$
\text { ا راماتايم صوفيمدن افرايم طاغندن بر آدم وار ايدى }
$$

Ends (126b):

$$
\text { هr و اوراده الله تعالى يه بر مذبحه يا يدى ... اسرائيل اوزرندن طاعون منع اولدى }
$$

Colophon (ibidem):

$$
\text { اسفار ملوكك ايكنجيسى اولدى تمام م }
$$

\section{Hs. VI H 2, e}

The Second Book of Kings (1a-43b), followed by the First Book of Kings (45a-67a), incomplete at the beginning, and unconnected parts of, at least partly, the same book (69a-92b), in the handwriting of Bobovius, with corrections in red by Shahin Kandi; 5 quires of 4 folded leaves ( 8 folios) and $1+7+6$ quires of two folded leaves ( 4 folios); glazed white to cream paper; text surface $180 \times 125 \mathrm{~mm}$, varying; 15 lines; catchwords; lines and marginal corrections in red; undated. A folded sheet wrapped around the quires contains the heading ' 2 Regum', and, on the backside, two notes in, clearly, 17th-century Dutch.

Heading (1a):

$$
\text { ملوك ب اولكى باب }
$$

Begins (ibidem):

$$
\text { او اخاب اولدكدن صكره موآب اسرائيل عاصى اولدى }
$$

Ends (1Kings 2:9, 92b):

$$
9 \text { يُ شمدى اكا صوجنى باغشلمه ... انوك آق صاهلو غنى مزاده قانيله اندره سن[يس] }
$$

Hs. VI H 2, f

The First and Second Book of Kings, copied by Shahin Kandi, with marginal corrections and additions in red by the same; 35 quires of two folded leaves ( 4 folios) with original numbers $2-18$ and 2-17; glazed white to cream paper; text surface $155 \times 105 \mathrm{~mm}$, varying; 13 lines; catchwords; titles, rubrics, dots and the colophon in red; undated. Two leaves are wrapped 
around the quires. The outer leaf contains the title: II Boeken der Koningen; the second, inner leaf contains, on the inside, four lines in the handwriting of Bobovius; on the outside we find the inscriptions 'ملوك ب' and '2. Reg.'.

Title (1a):

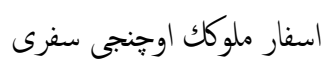

Begins ( $(\mathrm{lb})$ :

$$
\text { ا اند نصكره داود يادشاه يُك قوجيوب ياشلو يِير اومشيدى }
$$

Ends (139b):

$$
\text { . بو انوك وظيفه سى هر دايم معين ايدى ... عمرك جمله اياملرنده ويرلور ايدى. }
$$

Colophon (ibidem):

$$
\text { بادشاهلرك اسفاركتابى اولدى تمام }
$$

Hs. VI H 2, g

The First and Second Book of the Chronicles. They occur twice, first (1a$135 \mathrm{~b}$ ) in the hand of Bobovius, second (137a-247a) in that of Shahin Kandi; corrections and additions in red by Shahin Kandi; the word mukāaele, indicating a collation, is found below the first colophon on f. 135b; 8 quires of 4 folded leaves ( 8 folios $)+18$ quires of 2 folded leaves $(4$ folios $)+28$ quires, idem; (1-64) white glazed paper, $\left(65^{-136)}\right.$ white paper; text surface $160 \times 115 \mathrm{~mm}$, varying; 15 lines; catchwords; (from f. 137) glazed cream paper; text surface $155 \times 105 \mathrm{~mm}$, varying; 13 lines; catchwords; titles, rubrics, dots and a colophon in red; undated. The quires are wrapped in a folded leaf with the inscription II Boeken der Chroniken.

Heading (1a):

$$
\text { تواريخك قسم اولى اولكى باب }
$$

Begins (ibidem):

$$
\text { ا ادم ست [شيث] آنوس }
$$

Ends (247a):

$$
\text { ب ب فارس קيادشاهى كورش بويله دديكه ... تكريسى الله تعالى انوكله اولسون و تجقسون }
$$

Colophon (ibidem):

$$
\text { تواريخك قسم ثانيسى اولدى تمام م }
$$




\section{Hs. VI H 2, h}

The Book of Ezra, in the handwriting of Bobovius; 5 quires of 2 folded leaves ( 4 folios); white paper; text surface $165 \times 125 \mathrm{~mm}$, varying; 15 lines; catchwords; undated; kept in an envelope with the inscription Ezra and containing the remains of a red wax seal.

Heading (1a):

$$
\text { كناب عزرا اولكى باب }
$$

Begins (ibidem):

إيارس هادشاهى كورشك اولكى سنه سنده يرميا آغندن اولان الله تعلى نك ساوزى تمام اولماسى ايهون ... Ends (19a):

$$
\text { عـ جمله بونلر اجنى عورتلرى آلديلر و اونلردن عورتلر وار ايدى كه اوغللر ايدنديلر تم عزرا }
$$

Hs. VI H 2, i

The Book of Nehemiah, in the handwriting of Bobovius, with one marginal correction by the same on f. 12a; 7 quires of 2 folded leaves ( 4 folios); white paper; text surface $165 \times 125 \mathrm{~mm}$, varying; 15 lines; catchwords; undated. A folded sheet wrapped around the quires contains the inscription Nehemia.

Heading (1a):

$$
\text { كناب نحميا اولكى باب }
$$

Begins (ibidem):

$$
\text { ا خاخاليا اوغلى نحميانك كسلو آينده يكرمنجى ييلده اولان سوزلرى بن سوسان سراينده ايكن }
$$

Ends $(27 \mathrm{~b})$ :

$$
\text { آس و معين وقتلرده اوطون يشكشلرينى و ترفنده لرينى يا اللهم بنى ايلكه ذكر ايله }
$$

Colophon (ibidem):

$$
\text { تمام شد كتاب نحميا }
$$

Hs. VI H 2, j

The Book of Job, in the handwriting of Bobovius, with red lines and marginal corrections in red by Shahin Kandi; 6 quires of 4 folded leaves ( 8 folios); white glazed paper; text surface $165 \times 115 \mathrm{~mm}$, varying; 15 lines; catchwords; undated. A folded sheet wrapped around the quires contains the inscription Job. 
Heading (1a):

$$
\text { ايوب اولى باب }
$$

Begins (ibidem):

$$
\text { عوص ولايتده بر آدم وار ايدى آنك آدى ايوب ايدى }
$$

Ends (47b):

$$
\text { l l l اندن ايوب قوجه و سال خورده اولوب وفات ايلدى }
$$

Colophon (ibidem):

$$
\text { ايوب تمام اولدى }
$$

\section{Hs. VI H 2, k}

The Book of Job, copied by Shahin Kandi, with corrections and additions in black and red by the same; 14 quires of two folded leaves ( 4 folios), with the original numbers 2-14; white to light brown paper; text surface $155 \times 105 \mathrm{~mm}$, varying; 13 lines; catchwords; titles, rubrics, dots and the colophon in red; undated. A leaf with the inscription Liber Job is wrapped around the quires.

Title (1a):

$$
\text { كتاب ايوب الصابر }
$$

Heading (1b):

$$
\text { ايوب الصديقك كتابى اولى فصل }
$$

Begins (ibidem):

$$
\text { اعوص ولايتنده بر آدم وار ايدى آنوك آدى ايوب ايدى }
$$

Ends (55a):

$$
\text { VI اندن ايوب قوجه و سال خورده اولوب وفات ايلدى }
$$

Colophon (ibidem):

$$
\text { صديق صابر ايوبك سفرى تمام اولدى }
$$

Marginal note (ibidem):

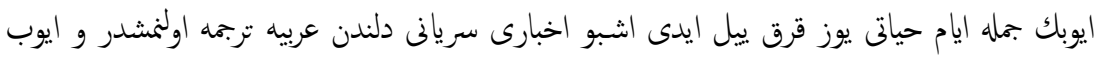

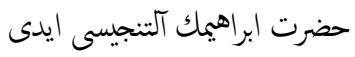




\section{Hs. VI H 2, 1}

Psalms, Isaiah \& the Book of Judges. The books occur twice, both in the hands of Bobovius and Shahin Kandi. The Book of Psalms occurs in a draft copy, incomplete at the end (it breaks off in the 118th Psalm, verse 168), of Shahin Kandi, with extensive corrections and additions in red by the same (1b-109a), followed by that in Bobovius's handwriting (113a-23ob) with lines and additions in red by Shahin Kandi as well as marginal notes (in Persian) in red by the same indicating faults and corrected parts; 28 quires, with original numbers $2-28$, of two folded leaves ( 4 folios) +9 quires of 2 folded leaves ( 4 folios $)+$ one half leaf ( 1 folio $)+$ one folded leaf, holding half a leaf ( 3 folios) +11 quires of 2 folded leaves ( 4 folios) +4 quires of 4 folded leaves ( 8 folios $)+$ one folded leaf ( 2 folios). The Psalms are followed by a copy of the Book of Isaiah by Shahin Kandi (231a-336a), with a few marginal corrections in black and red by the same, and a copy of the same book in Bobovius's handwriting, with lines and corrections in red by Shahin Kandi, particularly at the beginning $(337 \mathrm{a}-424 \mathrm{~b})$ - a slip of paper with a note on the translation- and copy-work by Shahin Kandi is found between ff. 346b-347a; 25 quires, with original numbers $2-25$, of 2 folded leaves ( 4 folios $)+3$ quires of one folded leaf $(2$ folios $)+3$ quires of 2 folded leaves ( 4 folios $)+$ one quire of one folded leaf $(2$ folios $)+3$ quires of 2 folded leaves ( 4 folios $)+$ one quire of one folded leaf $(2$ folios $)+15$ quires of 2 folded leaves ( 4 folios). Finally, there is the Book of Judges, both in a neat copy by Shahin Kandi $(425 \mathrm{~b}-472 \mathrm{~b})$ and by Bobovius with the usual emendations by Shahin Kandi ( $\left.473^{a}-516 b\right) ; 12+11$ quires of 2 folded leaves ( 4 folios). White to light brown paper; glazed white paper in ff. 113-230.

Title (1a):

$$
\text { اسرائيل پادشاهى عليه السلام داود ييغمبرك مزاميرى }
$$

Heading ( $(\mathrm{b})$ :

$$
\text { داود ييغمبرك اولكى مزمورى }
$$

Begins (ibidem):

$$
\text { انه موتلو اول آدمه كه يرامزلرك مشامره سنده كزمدى }
$$

Ends (516b):

$$
\text { ه ا ول كونلرده اسرآئيلده يادشاه يوق ايدى هر آدم كند و كزينه ايو كورينى ايشلردى }
$$

Colophon (ibidem):

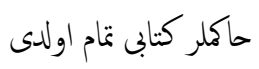




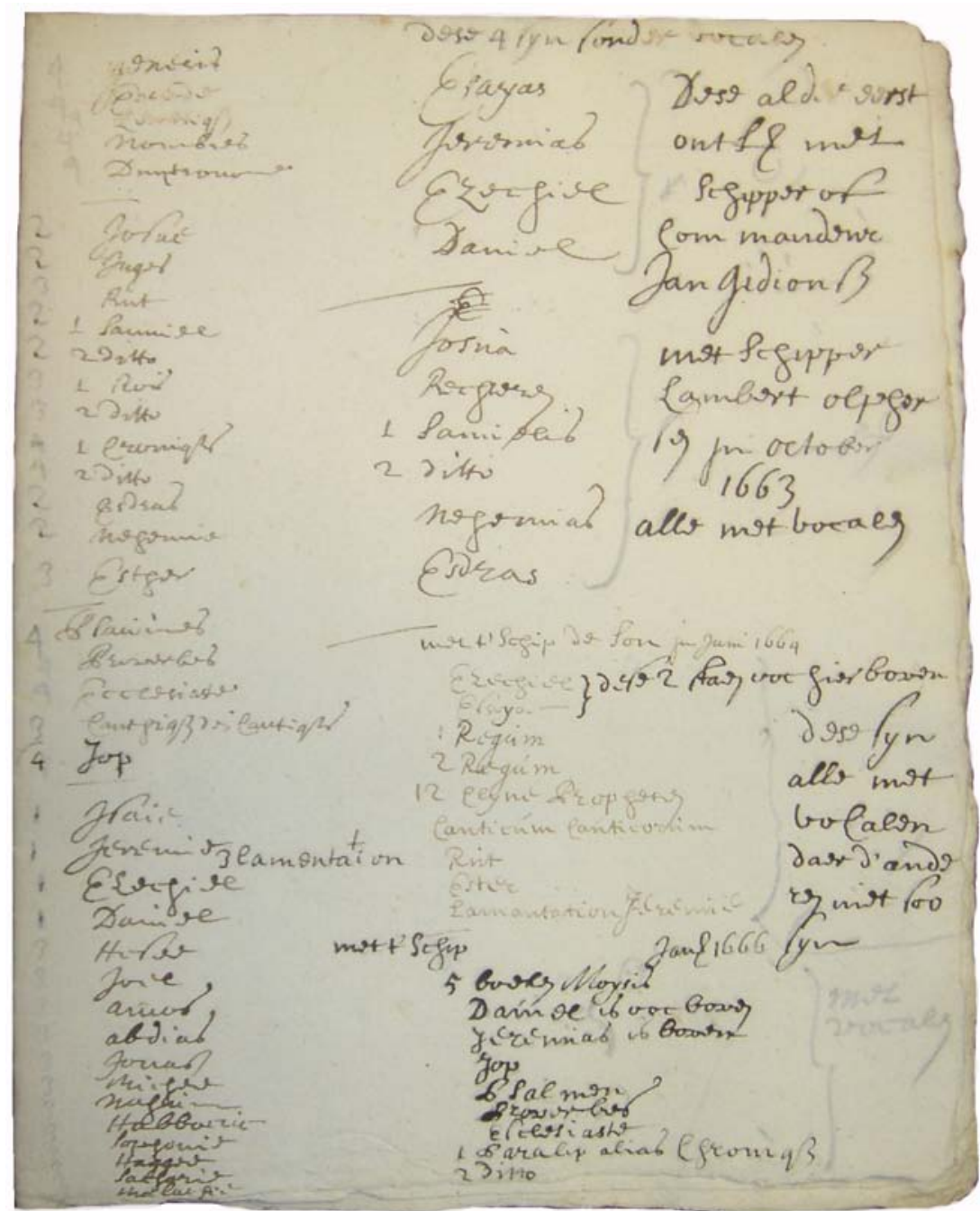

Figure 3. Amsterdam, UB Hs. VI H 2, l. A slip of paper with notes on the translationand copy-work by Shahin Kandi found in a translation by Bobovius of the Book of Isaiah between ff. 346b-347a. 


\section{Hs. VI H 2, m}

The Book of Jeremiah. The work occurs twice, first (1a-100a) in the hand of Bobovius, second (101b-223a) in that of Shahin Kandi; corrections by Bobovus and Shahin Kandi (in red) in the first part; 12 quires of two folded sheets ( 4 folios), wrapped by one folded sheet + one folded sheet ( 2 folios) +12 quires of the same type +31 quires, idem, with original numbers 2-30 (7 occurs twice); (1-100) white paper; text surface $160 \times 110 \mathrm{~mm}$, varying; 15 lines; catchwords; (from f. 101) glazed cream paper; text surface $155 \times 105 \mathrm{~mm}$, varying; 13 lines; catchwords; titles, rubrics, dots and a colophon in red; undated.

Heading (1a):

$$
\text { كناب يرميا اولكى باب }
$$

Begins (ibidem):

$$
\text { ا بنيامين ولايتنده عناتوتده كى اماملردن اولان خلقيا اوغلى يرمييانك سوزلريدر }
$$

Ends (223a):

$$
\text { عَr و بابل يادشاهندن اكا معين اولمنش ... جمله عرنك كونلرنده تا اولدوكى كنه دك }
$$

First colophon, with verses (by Bobovius, 100a):

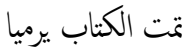

$$
\begin{aligned}
& \text { يرميا كنابى اولمشدر تمام *جو لطف اتدى خدا و مرد هام } \\
& \text { بيك اوجيوز التمش درت در آياتى *رب الحى يتشدر سون حياتى } \\
& \text { يخرقل كنابينه بانشليالم *مبهم رموزاتنى آكليالم }
\end{aligned}
$$

Second colophon, with a note (by Shahin Kandi, 223a):

$$
\text { ارميا شد تمام }
$$

اشبو ارميا و اشعياء و دانيال جمله سى بصمه كتاب اولمسى رواكور نور اما خرقيال روا كورنز زيرا بعضى ونى خبطى وار تصحيحه محتاج 


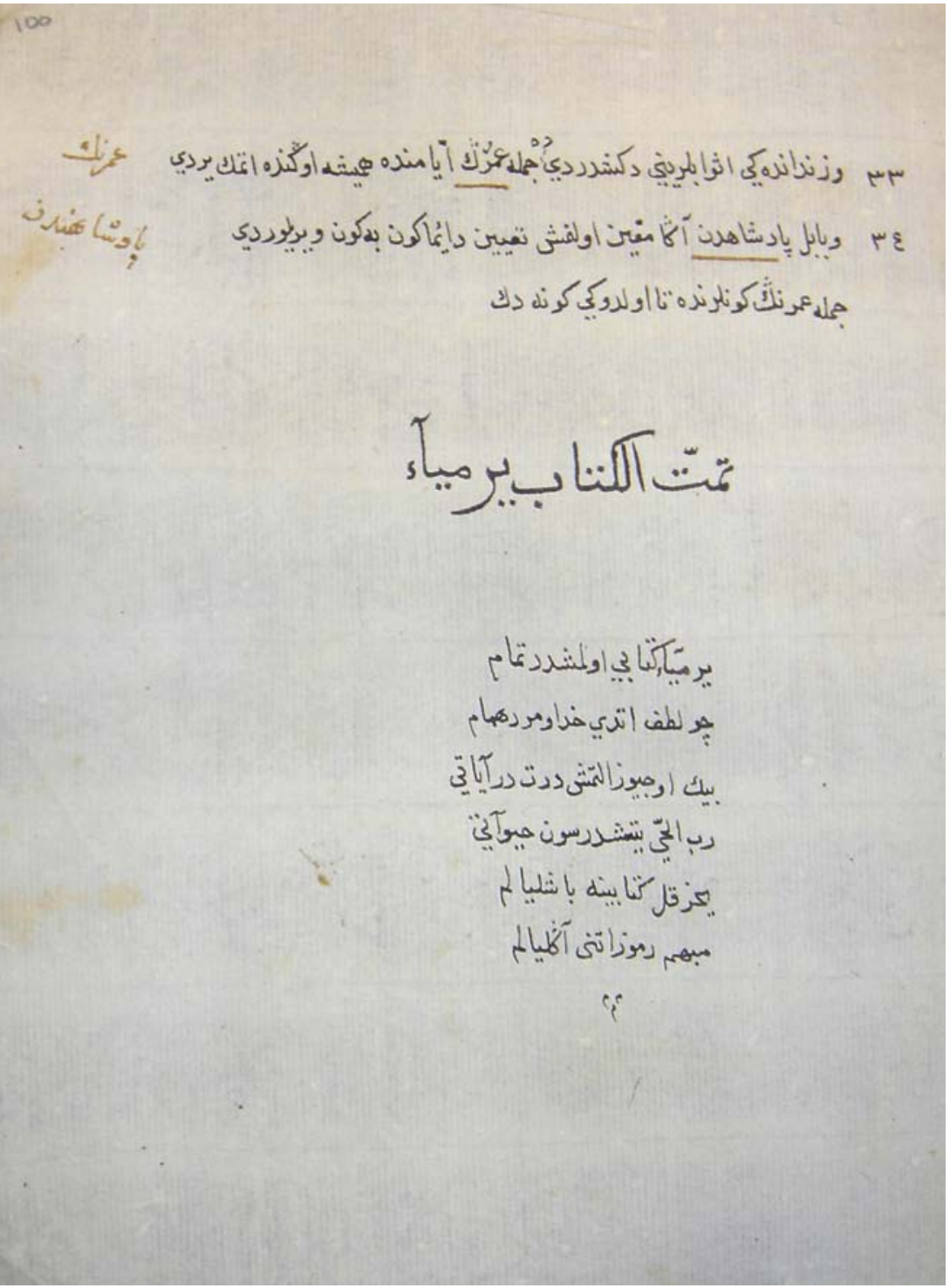

Figure 4. Amsterdam, UB Hs. VI H 2, m, f. 100a. The final page of a translation of the Book of Jeremiah (f. 10oa) with a colophon and copyist's verses by Bobovius, made in the 1660 in Istanbul. 


\section{Hs. VI H 2, n}

The Book of Ezekiel. The work occurs twice, first (1a-92b) in the hand of Bobovius, second (93b-196a) in that of Shahin Kandi, and is followed $(197 b-204 b)$ by the beginning of the same book, also in the hand of Shahin Kandi; a few corrections and additions in black and red by the same; $23+26+2$ quires of two folded leaves (4 folios) - the second series show original numbers $2-26$; $(1-92)$ white paper; text surface $165 \times 120 \mathrm{~mm}$, varying; 15 lines; catchwords; (from f. 93) glazed cream paper; text surface $155 \times 105 \mathrm{~mm}$, varying; 13 lines; catchwords; titles, rubrics and dots in red; undated.

Heading (1a):

$$
\text { كتاب يخرقل اولكى باب }
$$

Begins (ibidem):

$$
\begin{aligned}
& \text { ا و اولديكه اوتوزنجى ييلده دوردنجى آيك بشنجى كونده بن كبار ايرماغك } \\
& \text { ياننده اسيرلك جاعتى آراسنده ايكن ... }
\end{aligned}
$$

Ends (Ezekiel 2:3, 204b):

$$
\begin{aligned}
& \text { ז و بكا ددى اي آدم اوغلى بن سنى اسرائيل اولادينه كوندررم ... و با بالرى بكا كناهكار تا بو كندو كونه } \\
& \text { دكين [و : يك] }
\end{aligned}
$$

\section{Hs. VI H 2, o}

The Book of Daniel. The work occurs twice, first $(1 \mathrm{a}-33 \mathrm{~b})$ in the hand of Shahin Kandi, second (35a-63a) in that of Bobovius; a few marginal corrections in black and red in the hand of Shahin Kandi; 2 quires of one folded leaf ( 2 folios $)+7$ quires of 2 folded leaves ( 4 folios) + one quire of one folded leaf ( 2 folios $)+7$ quires of 2 folded leaves ( 4 folios $)+$ one quire of one folded leaf ( 2 folios); quires in the first part bear the original numbers 2-9; (1-34) white glazed paper; text surface $155 \times 105 \mathrm{~mm}$, varying; 13 lines; catchwords; titles, rubrics, dots and a colophon in red; (from f. 35) white paper; text surface $165 \times 120 \mathrm{~mm}$, varying; 15 lines; catchwords; undated. The quires are wrapped in a folded leaf with the inscription Daniel. 


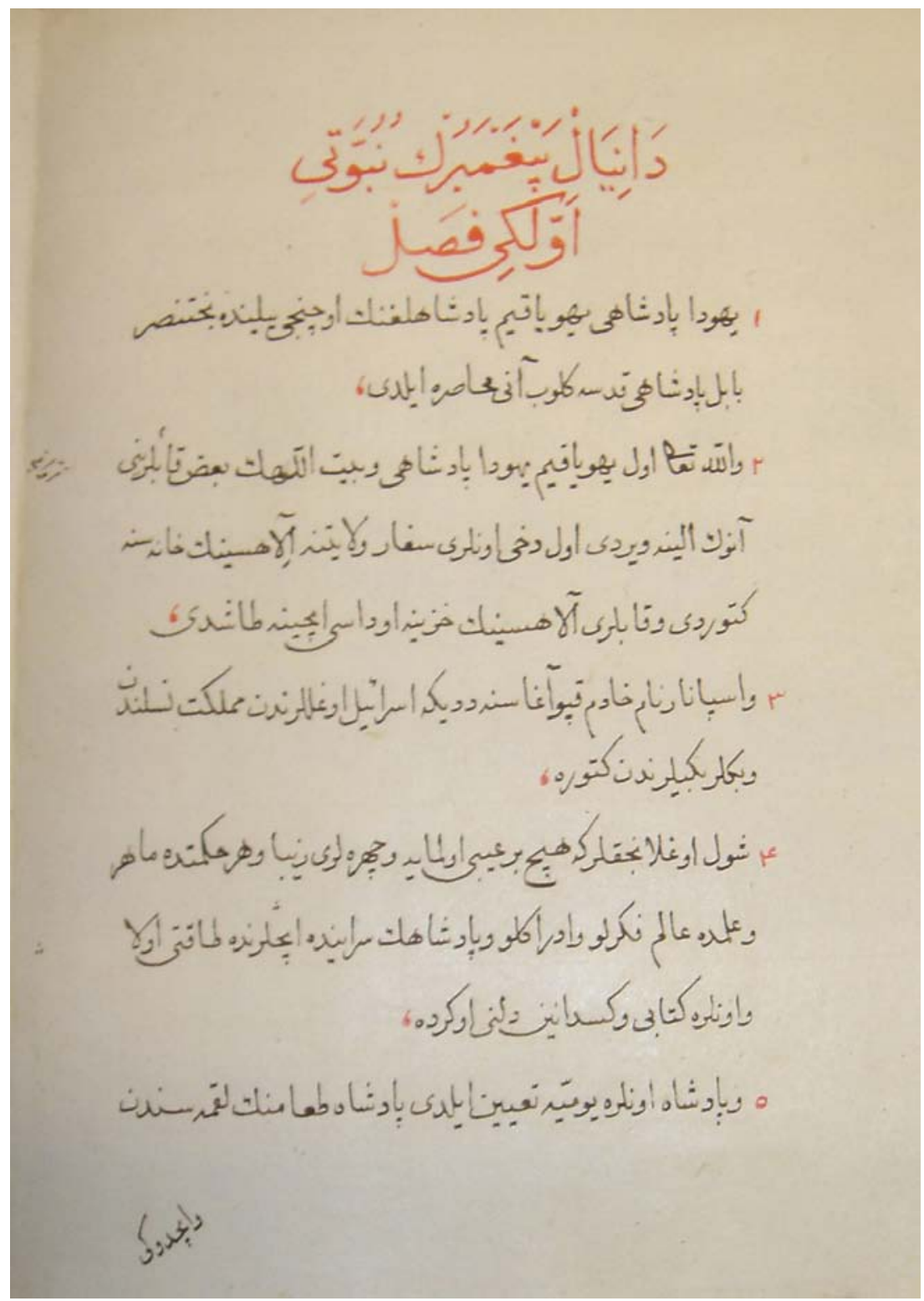

Figure 5. Amsterdam, UB Hs. VI H 2, o, f. 1b. The first page of a neat draft of a translation by Bobovius of the Book of Daniel copied by Shahin Kandi, who was employed by the Leiden orientalist, Jacob Golius, in the 166os. 
Heading ( $(\mathrm{b})$ :

$$
\text { دانيال ييغمبرك نبوتى اولكى فصل }
$$

Begins (ibidem):

إهودا يادشاهى مهوياقيم هادشاهلغنك اوحنجى يلينده نبختصر بابل هادشاهى قدسه كلوب آنى محاصره

Ends (63a):

$$
\text { rا سن آرتوق صوكيكه وار و راحة ايله صوك كونلره دك نصيكده طوره سن }
$$

Colophon (ibidem):

$$
\text { تمت كتاب دانيال و الله اعلم بالصواب }
$$

\section{Hs. VI H 2, p}

Hosea, Joel, Micah, Amos, Jonah, Obadiah, Habakkuk, Zechariah, Zephaniah, Nahum, Haggai \& Malachi, in the handwriting of Bobovius; 3 quires of 5 folded leaves (10 folios) + one quire of 4 folded leaves ( 8 folios $)+9$ quires of 2 folded leaves ( 4 folios), the last two groups being wrapped in a folded leaf; white glazed paper; text surface $165 \times 115 \mathrm{~mm}$, varying; 16 lines; catchwords; undated. A folded sheet wrapped around the quires contains the inscription XII. kleine Propheeten.

Heading (1a):

Begins (ibidem):

$$
\text { هوشع اولكى باب }
$$

$$
\text { ا عزيا يوتام اخاز يخزقيا بهودا پادشاهلرينك ايامنده ... }
$$

Ends $\left(75^{b}\right)$ :

$$
\text { آو با بالرن قلبى اوغللره هم اوغللرك قلبى با بالرينه توجه ايليه تاكه بن كلوب يرى احترام اتيم }
$$

Colophon (ibidem):

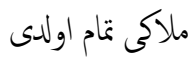

\section{Hs. VI H 2, q}

Three folded leaves of coarse white paper with titles of Bible books which had been wrapped around some of the quires of c, described above. The titles in Dutch: De Psalmen, Prediker and Spreuken van Salomo, did not match the contents of the relevant quires and were removed in December 2002 in order to avoid confusion. 


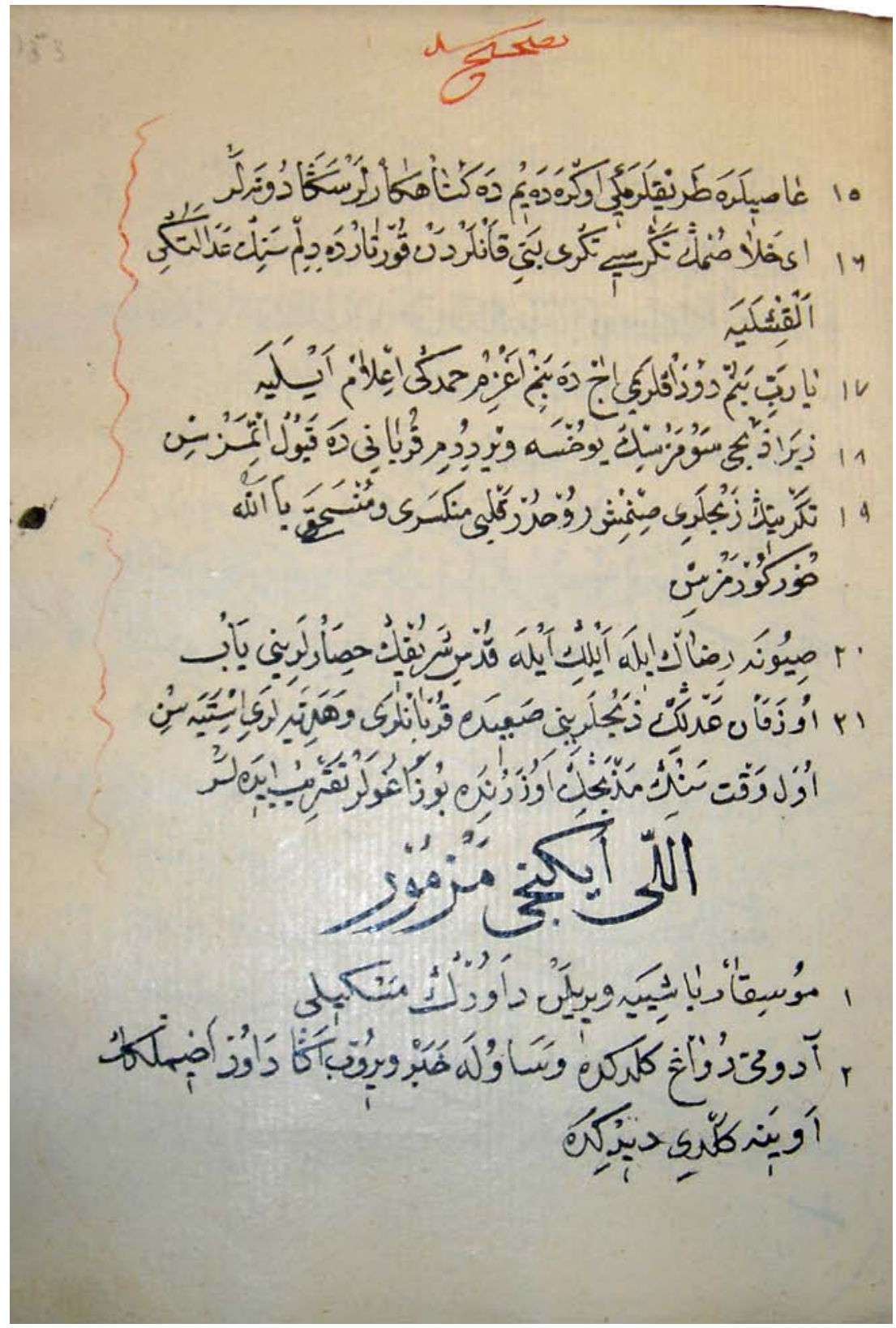

Figure 6. Amsterdam, UB Hs. VI H 2. A page of the translation of the Book of Psalms by Bobovius (f. 153a), with a note (in the upper margin) by the copyist Shahin Kandi stating that the passage, indicated by a red line in the left margin, had been corrected. 
Catalogue entries: Catalogusvan de bibliotheek der stad Amsterdam IV (Amsterdam 1858), pp. 711-713; M.B. Mendes da Costa, De handschriften der Stedelijke Bibliotheek met de latere aanwinsten (Bibliotheek der Universiteit van Amsterdam. Catalogus der handschriften II, Amsterdam 1902), 49 (p. 9).

Literature: B. Flemming, "Zwei türkische Bibelhandschriften in Leiden als mittelosmanische Sprachdenkmäler", in WZKM 76 (1986), pp. 111-118; Hannah Neudecker, The Turkish Bible Translation by Yahya bin Tshak, also called Haki (Leiden 1994).

\section{Hs. Cn 12}

A miscellany

The mansucript consists of three unbound quires with texts, mostly copied by one scribe. The outer and inner front-covers are filled with lengthy quotations in Arabic. The manuscript is accompanied by a description of the contents in Dutch by Dr Büchner on headed notepaper of the Leiden Unversity Library; a hand-witten letter in Dutch from L.A. de Vries (in Dresden) to Burger, librarian of the Amsterdam University Library, dated 28 September 1923, offering the manuscript (a Turksch tooverboek) for sale-an added note by the librarian suggests sending the manuscript to Leiden; a typed letter in Dutch from the librarian of the Leiden University Library to Burger, dated 27 October 1923, declaring that the manuscript was returned after it had appeared that the 'gentlemen of the Oriental department' had sent it back 'being of insufficient importance for the Leiden collection'. The valutation ranged between one and two and a half guilders. We find the following items:

\section{(1) ff. la-8b}

An incomplete, late 17th-century copy of a work, not identified, on cosmology and calendar science which is given the form of a colloquy between İskender (zzu $l-k$ karneyn $)$ and his teacher, Arisțus (Aristotle). The beginning is lacking, as do at least two central leaves (four folios) of the (first) quire: the catchwords on ff. $3 \mathrm{~b}, 4 \mathrm{~b}$ and $5 \mathrm{~b}$ do not match the first words on the following pages. The work ends (from f. $4 \mathrm{a}$ ) with a discussion of the astrological characteristics of the consecutive days of the week, followed by a prayer in Arabic. The discourse is punctated with anecdotes (hikäye). Marginal 
corrections and additions. Two distichs by $\operatorname{Nev}^{c} \overline{1}$ are added in the right margin of f. 8b. The colophon (ibidem) is followed by Arabic verses, among them by Fużūì.

Begins (1a):

انجويه قدرت قطريه نظر ايتدى اول طاقت كتورميوب صو اولدى بر زمان [؟] موجه اوروب خالقندى نيجهه مدة كجدى اول صويه نظر ايلدى

Ends (5b):

... بو دعاء يازوب ... بعون الله الهادى اسماء شريف بودر ... ولا حول و لا قوة الح بالله العلى العظيم Colophon (ibidem):

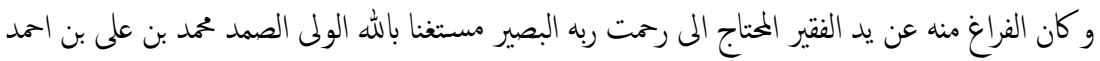

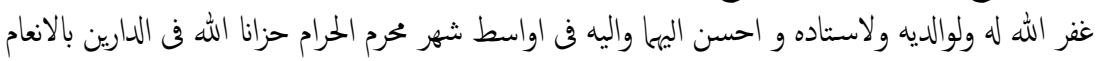

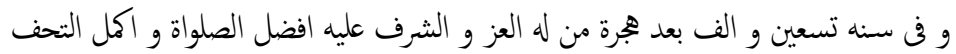

(2) ff. 9a-16b

A collection of tables, diagrams and poetry

The first three tables/diagrams (9a-10a) are of an astrological nature: the first two list ten and twelve characteristics respectively of the twelve signs of the Zodiac. The margins of f. $g \mathrm{~b}$ also contain two tables indicating the numerical value of the letters of the alphabet according to two different methods of reckoning, cümel-i kebir and cümel-i șagìr (cf. İsmail Yakıt, Türk-Issmâm Kültüründe Ebced Hesabı ve Tarih Düşürme (Istanbul 1992), pp. 36-39). A third diagram describes the influence on earth, for example on the weather, of the various mansions of the moon (menzil). The tables/diagrams are followed, on f. 1ob, by an abbreviated Cefr-i Hażret Imām 'Alī, a treatise on onomancy (1o lines), ascribed to the Caliph 'Alī; it begins:

هذا جفر مختصر يوز اوتوز ايكى حرفدر شرطى اولدركه بر فاتحت الكتاب و بركزه بو ايت كيمه اوقويه ...

It is followed on the same page by three distichs in Arabic. The final pages of this (second) quire are filled with brief quotations in Arabic, Persian and Turkish, mostly verses. Among the Turkish texts are: müfreds by Nev'ì Efendi (11a); a distich by the copyist (müharrirühü), who used the pen-name of Fedāyī (12a); and chronograms on the death of Monlā Husrev (dated 885/1451, 12a), of Sultan Mehmed (idem), on the accession to the throne of Sultan Selìm (dated 918/1512-1513, ibidem), on the death of shaykh Sünbül 'Alī (dated 936/1529-1530, ibidem), of Kemāl Paşazāde (12b), by Hāşimī 


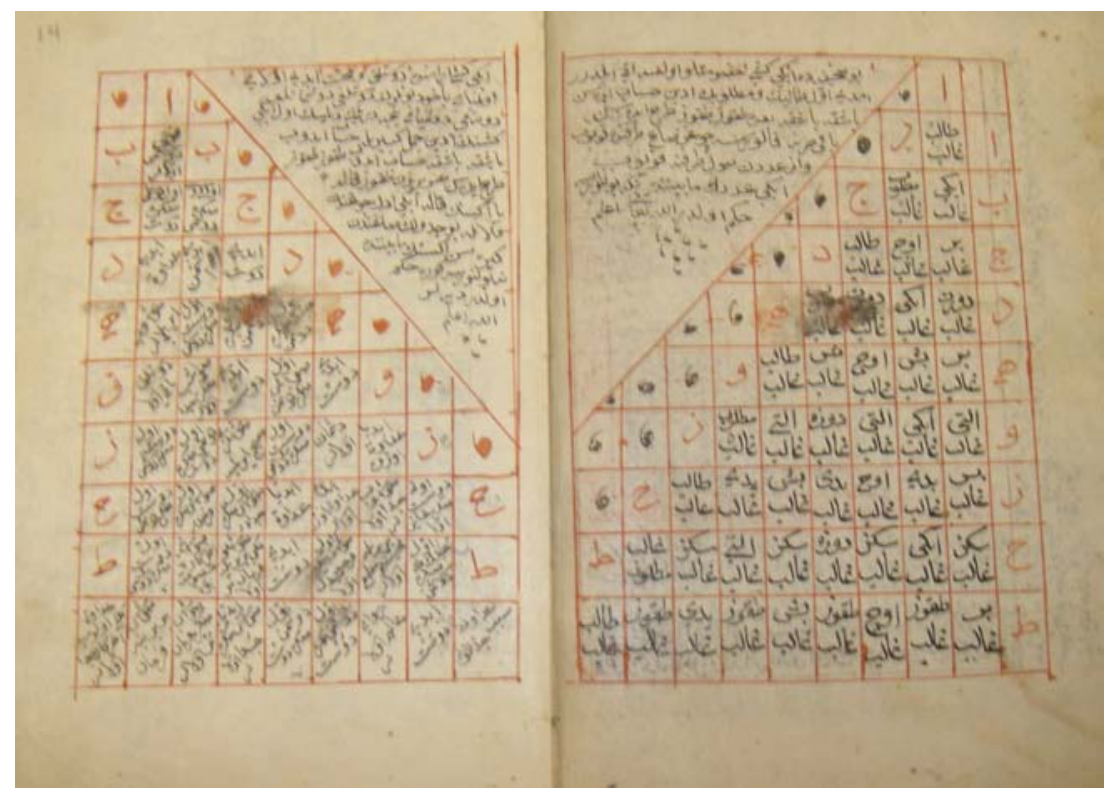

Figure 7. Amsterdam, UB Hs. Cn 12, 13-14a. Two pages from a miscellaneous work with divinatory diagrams, 17 th century.

Efendi on [the death of] Ahızāde Efendi (ibidem) —in a Persian heading it is explained that each hemistich [of the total of twelve] contains a date-and on the death of Ebūssu'ūd (ibidem).

The last quire contains a diagram (13a) indicating the auspicious moments and ways for approaching the sultan, followed by a brief explanation (her kim bir pādişāh ḥużūrına varmaḳ dileyse anuñ meclisini şöyle ki żikr olunur ...); a double table with two explanations (13b-14a) for detecting the amiable or hostile disposition of a loved one by way of the numerical characteristics of that person's name; a double astrological table showing the signs of the Zodiac for each hour of each day of the week as well as the inauspicious hours $\left(s \bar{a}^{\complement} \bar{a} t-i s ̧ \bar{\imath} b\right)$. The last pages are again filled with Arabic, Persian and Turkish quotations. The Turkish items are: poetical fragments by Nevīi (15a, 15b, 16a), Niksārīzāde Efendi (16a), Yahyā Efendi b. Zekeriyā Efendi (16a), by the copyist (16b), and chronograms on the death of the müftī, 'Alì Çelebi (dated 932/1525-1526, 16b), of Șun'ullāh Efendi by Fāyı̇̇i Efendi (ibidem), and of Bostānzāde Efendi (dated 1000/1591-1592, ibidem). 
Four unbound quires, kept in a folded cover of orange cardboard; glazed paper of varying colours: cream, orange, yellow and pink; 16 folios; $202 \times$ $141 \mathrm{~mm}$ and (1) $155 \times 100 \mathrm{~mm}$; (1) 23 lines; nesihn, dìvāni (2a-8b), and talīk. (first 9 lines on f. 1a); tables/diagrams in black and red, or in blue, red and green (10a); (1) rubrics in red and green (from f. 4a); occasional lines and dots in green and white; (1) was completed by Meḥmed b. 'Alī b. Aḥmed in the middle of Muharrem 1090 (22 February-3 March 1679). Acquired from L.A. de Vries in 1923 (cf. above).

Hs. Cq 42a-f

\section{Letters}

Five brief letters in French of varying format, from 'Aali Pascha' to Anton Graf Prokesch von Osten (see the introduction to this chapter). The latter was internuntius, later ambassador to the Porte, from 1855 onwards. 'Ālì Meḥmed Emīn Paşa (d. 1288/1871), diplomat and statesman, was many times grand vizier and minister of foreign affairs (cf. $\left.S O^{2} \mathrm{I}, \mathrm{pp}, 269-270\right)$. The letters are of little historical importance, and mostly concern the banalities of diplomatic life such as the exchange of presents and visits- $f$ proposes an audience with the Sultan in the company of Von Prokesch's son [Anton, 1837-1919] and a travel companion. They are dated 26 June 1862 (a); 4 November 1862 (b); and 29 June 1871 (d) — 'Álī Paşa died on 8 Augustundated are $\mathrm{c}$ and $\mathrm{f}$. There is one note (e) in Turkish in pencil: bir kıt t'a mektūb Avusturya sefāreti țarafindan gelüb vāṣıl oldı, signed Muștafā and dated 4 Şevvāl 1280 (3 March 1864). Three envelopes have been preserved in the file.

Hs. Cq 43

\section{A letter}

A note in French, $220 \times 180 \mathrm{~mm}$, from 'Aarifi Pascha' to Anton Graf Prokesch von Osten (see the introduction to this chapter), dated 14 January 1859. 'Ārifī Aḥmed Paşa (d. 1313/1895), was a translator and diplomat, later also minister of foreign affairs; between 1274/1858 and 1286/1869 he was translator for the Dìvān (Dìvān-i hümāyūn tercümānı), cf. $S O^{2} \mathrm{I}$, pp. 321-322. The text reads: Mon Cher Baron, J'ai l'honneur de vous informer que l'IradeImp: de l'investiture du Prince Miloch vient de sortire [sic]. Je profite de cette occasion pour vous offrir l'assurance de ma très haute consideration. A Aarifi. 


\section{Hs. Cq 44}

\section{A letter}

A letter in French, $271 \times 210 \mathrm{~mm}$, two pages of text, from 'Méhéméd Ali [Pascha]', ministre de la Marine, Grand Amiral de l'Empire, to Anton Graf Prokesch von Osten (see the introduction to this chapter), dated 16 August 1858. In the letter the pasha thanks Von Prokesch for the 'compliments' received through Mr. le Bidard, and expresses his joy that his addressee had had good journey and had arrived safe and sound [in Vienna]. (Vizier Meḥmed 'Alī Paşa, d. 1285/1868, statesman and navy officer, was many times kapudan-i deryā, for the fourth time between 1271/1855 and 8 Muharrem 1275/18 August 1858, cf. $S O^{2}$ III, pp. 956-957.)

\section{Hs. Cq $45 a-c$}

Letters

Three brief letters in various formats in French from Boghos Yūsuf Beg to Anton Graf Prokesch von Osten (see the introduction to this chapter). Boghos Yūsuf Beg (d. 1844) was secretary and, from 1826, minister for trade and foreign affairs, to Muhammad 'Alī Pasha, semi-independent governor and vice-roy of Egypt between 1220/1805 and 1264/1848 (cf. Arthur Goldtschmidt Jr., Biographical Dictionary of Modern Egypt, Boulder, Colorado \& London 2000, p. 40). Prokesch von Osten was officer with the General Staff of the Austrian Mediterranean Fleet between 1827 and 1848 . In 1833 he was sent to Muhammad 'Alī as an intermediary between the latter and Sultan Mahmūd II-war, developing desastrously for the Ottomans, had been raging since 1831, and peace was only restored in June 1833; from 1834 Prokesch was also envoy to the new court of King Otto of Greece. The letters are (a) a note informing Prokesch that he would be received by Muhammad 'Alī on the next day, at Alexandria, dated 3 April 1833 (cf. Prokesch's Diary, p. 179:4 April. Übergebe Boghos-Jussuf-Beymein Kreditiv ...); (b) a note thanking Prokesch for a letter addressed to the vice-roy, congratulating him with the cease-fire reached [at Kütahya, cf. Diary, p. 180], at Alexandria, 16 April 1833; and (c) a note thanking Prokesch for his letters of 24 and 27 February, and regretting he had not responded to one written on 14 February 1835, at Alexandria, dated 13 March 1836.

Literature: Aus den Tagebüchern des Grafen Prokesch von Osten k. u. k. österr-ungarn. Botschafters und Feldzeugmeisters 1830-1834 (Vienna 1909). 


\title{
Hs. Cq 46
}

\begin{abstract}
A letter
A letter in French, $223 \times 170 \mathrm{~mm}$, three pages of text, from 'Cabouly Pacha' to Anton Graf Prokesch von Osten (see the introduction to this chapter), at Istanbul, dated 29 November 1871. Kabūlī Meḥmed Paşa (d. 1294/1877), statesman and diplomat, was dismissed as minister of trade in Cemāzīl-āhir 1288/August-September 1871 (cf. $S O^{2}$ III, pp. 854-855). The pasha thanks Prokesch von Osten for his letter; he was not depressed because of his dismissal - that had happened before-but regretted the loss of a friend, and hoped to see Prokesch before his departure [to Austria]; finally he discusses his coin collection, a part of which he was going to sell to make some money. (See also under Hs. Diederichs $136 \mathrm{~K}$, below).
\end{abstract}

\section{Hs. Cq 48a-d}

A miscellany

Four sheets of paper in varying format with copies of French poems, among these Le Lac by Alphonse de Lamartine (1790-1869). These were sent by 'Davoud Pacha', minister of Public Works, to Frederike Gossmann (18381906), actress, who married Anton Graf Prokesch von Osten (1837-1919), see ÖBL II, p. 35. Dāvud Paşa, a Catholic Armenian, was the first non-Muslim to become Ottoman minister; he was in function between 1868 and 1871 (cf. Yllmaz Öztuna, Devletler ve Hânedanlar. Türkiye (1074-199o) II (Ankara 1989), p. 1061). The first item (a), is dated 15 August 1868. Added is a photograph of the pasha by Maison Levitsky, 22 rue de Choiseul, Paris.

\section{Hs. Cq $49 \mathrm{a}-\mathrm{d}$}

\section{Letters}

Four brief letters in various formats in French from 'Fuad Méhémed Pascha' to Anton Graf Prokesch von Osten (see the introduction to this chapter). (Keçecizāde) Fu'ād Meḥmed Paşa (d. 1285/1869), diplomat and statesman (cf. SO $\mathrm{II}^{2}$ pp. 539-540), was many times minister of foreign affairs and grand vizier. The letters, on day-to-day affairs, were written from the Sublime Porte or Camlica, and only two are dated:(a) 1 May 1867, and (b) 24June 1862. Of some interest is c, undated, which is concerned with 'measures' regarding the embouchure du Danube and the Île des serpents. 
34

CHAPTER FOUR

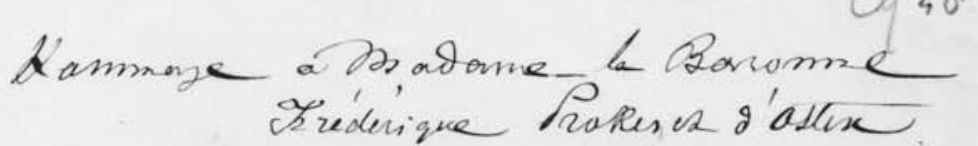
le 15 aon- 1868 .

Le Lac.

Comair-tes ce bean lae du nome de femunien

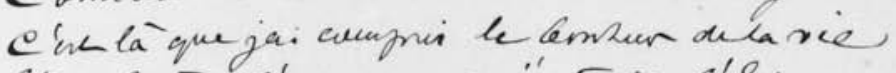

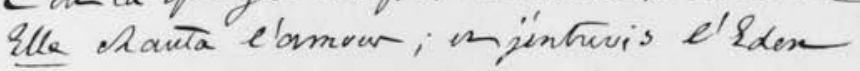
Sam mox ame savee.

Qlee Romta c'omour exlut true de da voip Tivits omomen de Conkeen à havers le eaupp uppes répüterise Lone nom pormice un mile fo is Same louter ta montagnes

-

La Iuesse du naiss, ex athe carefs an Argenta don minosis pun coutueupler les Larmes moir jalvare aupitol de ton ail languissone Bacelé unsa da larmue.

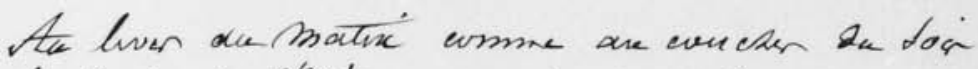

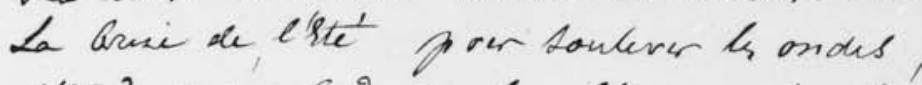

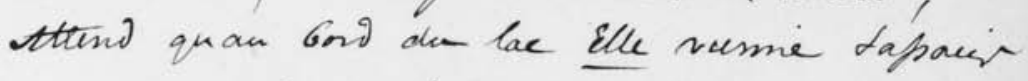
in Martipe du modes.

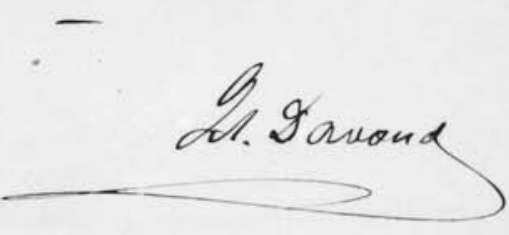

Figure 8. Amsterdam, UB Hs. Cq 48a. A quotation from Lamartine's Le Lac sent by Dāvud Paşa to Frederike Prokesch, née Gossmann, 1868.

Jan Schmidt - 978-90-04-22191-8

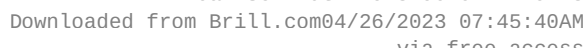

via free access 


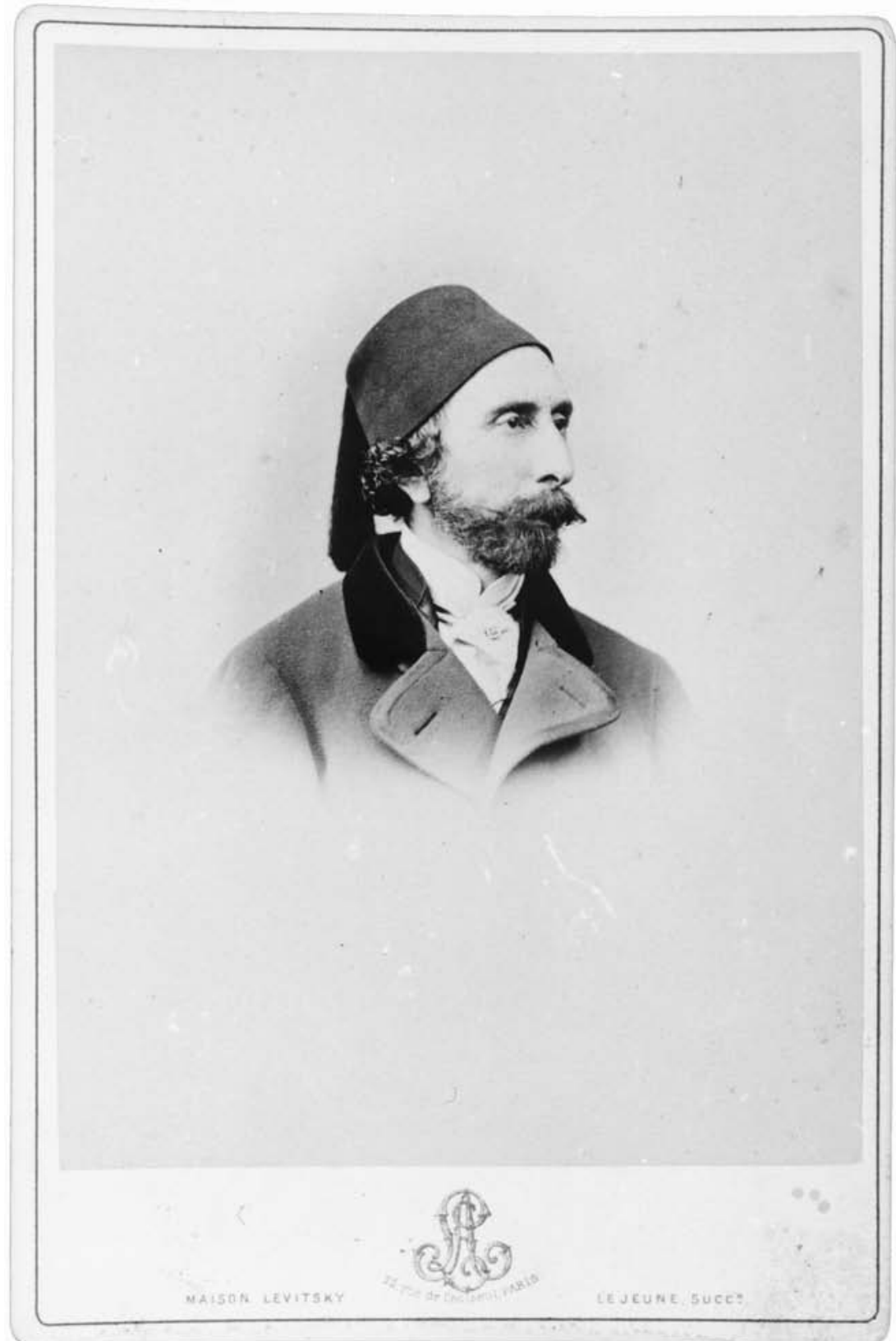

Figure 9. Amsterdam, UB Hs. Cq 48a. A photograph of Dāvud Paşa, sent by him to Frederike Prokesch, née Gossmann, 1868. 


\section{Hs. Cq 50}

A letter with translation

The Turkish letter, glazed white paper, $255 \times 155 \mathrm{~mm}$, from Mehmed Hālet Efendi to a veli n-ni'met (according to the French translation the 'Bassi Zochadar', the çohadār of the Palace), informs the functionary that the fourth instalment of the tribute owed by the voyvoda of Wallachia over the year ' 31 [1231/1815-1816], 1200 kese akçe, had been sent to him, signed bende Mehmed Ḥālet. A note on top instructs an unnamed official to inform Ḥālet Efendi that the money had been received (meblag-i mezbūr vāșıl olmuşdur Hālet Efendi'ye tahrīrve ifāde eyleyesin). Mehmed Ḥālet Efendi was probably Ḥālet Meḥmed Sa'īd Efendi (d. after 1238/1822), diplomat and statesman, nişānçı between 1230 (1815) and 1238 (1822).

\section{Hs. Cq 53a-e}

\section{Letters}

Five letters and brief notes in various formats in French from 'Musurus Pacha' to Anton Graf Prokesch von Osten (see the introduction to this chapter) and his wife, Irene Prokesch, née Kiesewetter von Wiesenbrunn (1881-1872), cf. ÖBL III, p. 327. Kostaki Musurus Paşa (d. 1309/1891-1892), diplomat and statesman, was Ottoman envoy to Athens, Vienna (from 1264/1848), and London (1267/1851-1303/1885), cf. $S O^{2} \mathrm{VI}$, p. 1819. The more substantial letters discuss (a) the birth of a daughter and sender's departure for Samos, where he would visit his father-in law [Stefanaki Vogoridis Bey], and Izmir - he had been appointed ministre résident in Greece—at Istanbul, 29 March 1840 (4 pages of text), and (e), suffering from a severe cold, sender informs addressee about his journey from Vienna to Triestewhere he had found a letter from Prokesch [who was in Italy at that time], and later to Navplio and Istanbul; he expresses his hope that the events in Greece will develop as he and Prokesch wish they would, at Trieste, 24 July 1831 (to Irene Prokesch, 4 pages of text). Shorter notes were written in the 186os: (b) is dated 14 September 1868 (at Arnavutköy), (c) 15 September 1869 (at London). 


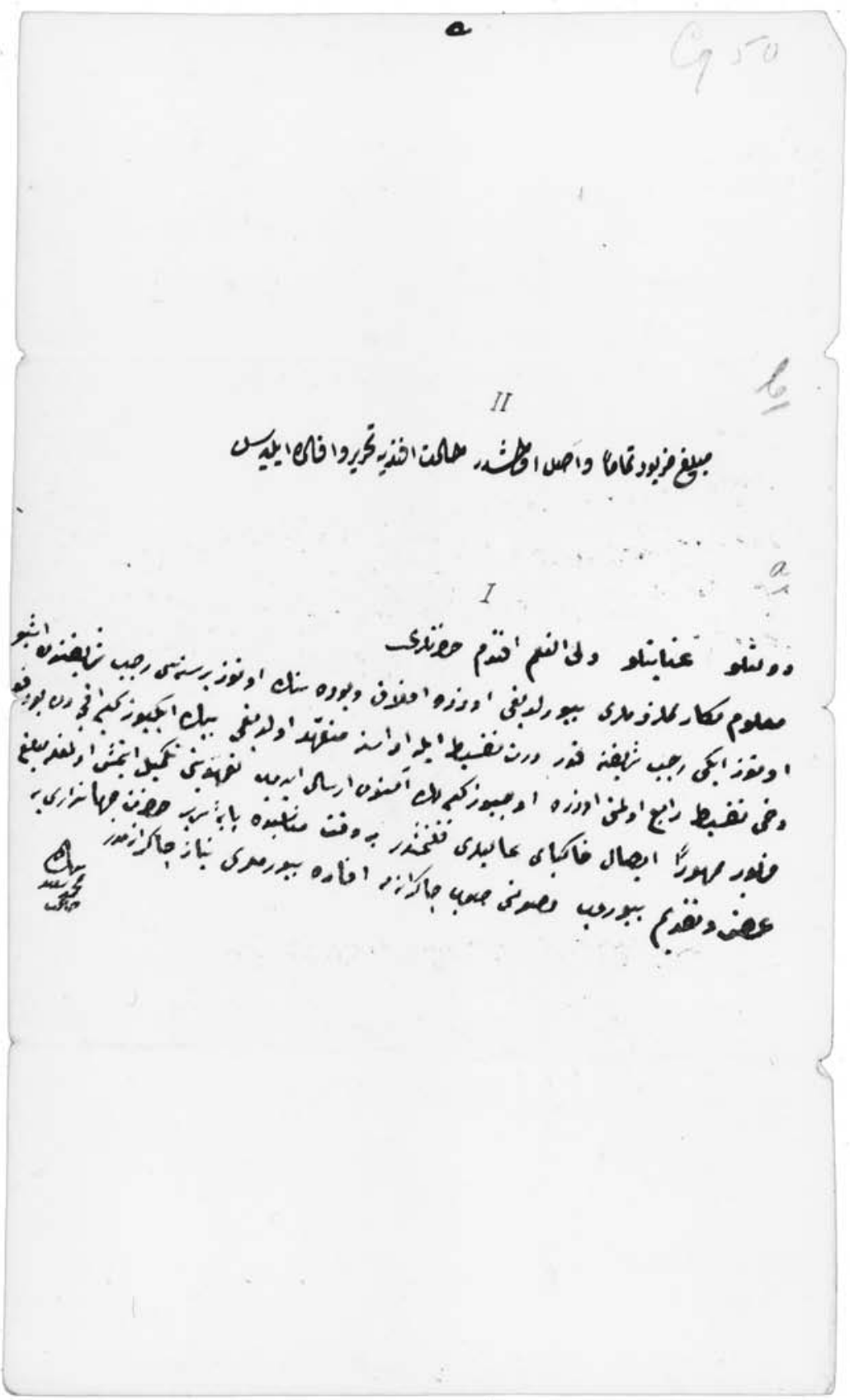

Figure 10. Amsterdam, UB Hs. Cq 50. A note concerning the Wallachian tribute for the year 1231 (1815-1816) from Hạlet Efendi to the Palace in Istanbul. 
Hs. Cq 54

A letter

A letter in French from 'Réchid Pacha' to 'Baron de Stürmer' at Istanbul, dated 23 September 1839. Reşīd Paşa was probably Muștafā Reşīd Paşa, not the (former and later) grand vizier, as is mentioned on the cover-this was either Ra'uf Paşa and Husrev Paşa later in that year-but the minister of foreign affairs and envoy to London, cf. $S O^{2} \mathrm{VI}$, p. 1756. Bartholomäus Graf von Stürmer (1787-1863), was internuntius in Istanbul from 1834 to $185^{\circ}$, cf. $B L K O, 175^{-178}$. The Ottoman informs the Austrian diplomat that the Sultan had decided to honour Mr. de Hussar with a box embellished with diamonds. Valentin von Huszár $\left(1788-c .185^{\circ}\right)$ was orientalist and Austrian state official, cf. $B L K O$ 9, pp. 448-449.

\section{Hs. Cq. 55a-c}

\section{Letters}

Three letters and notes in various formats in French from 'Mirza Housein Chan' to Anton Graf Prokesch von Osten (see the introduction to this chapter). Mīrzā Husayn Khān was Persian envoy to the Porte. The most substantial letter, a, two pages of text, dated 25 January 1867, informs Prokesch of a financial conflict between Dr. Charles Rossi, inspecteur sanitaire at Erzurum, and a Persian trader, Mollā Ṣādiq, and sends him instructions for the Persian consul-general, Mahdī Khān; he requests addressee to recommend the Persians to Rossi in order to avoid their being locked up in quarantine on any futile pretext.

\section{Hs. Diederichs 9 U}

\section{A letter}

An original copy of a letter, four pages, in Dutch from Cornelis Haga (15871654), envoy for the Dutch Republic at the Porte (1612-1639), to an unknown addressee, at Istanbul, dated 27 January 1616. The letter, sent with his attaché, Cornelis Sijms (cf. p. 4), who returned to the Netherlands in February 1616, gives a detailed survey of political events, in particular on the conflicts on the north-eastern border of the Ottoman Empire. Haga first mentions the truce between the Habsburgs and the grand vizier, Nașuh Paşa, executed the previous year (1023/1614), over Hungary, where Bethlen Gabor was confirmed as prince of Transylvania (1023/1614); the raiding by Tatars of Polish territory-according to Haga the raid was instigated by 
the $k \bar{a}$ 'immakām, in revenge of the raids by Cossacks into Ottoman territory (whereby the port towns of Trabzon and Sinop had been ravaged). The same official had appointed Stefanus Tomsza as governor of Moldavia, upon which the exiled Constantinus (Mohila) had gathered a group of Polish magnates and attacked Moldavia. The attack was countered by a military expedition led by İskender Pasa and supported by Tatar raidsthey captured Constantinus who later escaped but drowned; the outcome of the conflict, which was only to be solved in 1617 , was still uncertain when Haga was writing. Haga finally mentions the further preparations at Aleppo by the vizier (Kara Mehmed Paşa) of a new military expedition against Persia, and the exile and reinstatement of the emir of Sayda (Sidon).

Mijn Heere. Doorlaeche dat uwe ed: so selden met mijne brieven/ van hier besouche ende het offitie van schrijven niet na behooren ende/ gelijck mijn oblige tot uwe ed: wel verwijst tot noch toe voldaen heb/ is geweest, eensdeels de continuele occupatije, daer mede is dese/ eerste sware ende moijelijcke beginselen gestadelijck altijt ben/ getravaglieert geweest, eensdeels oock d'ongesegentheijt, diemen/ hier heeft omde brieven seeckerlijck te lande te bestellen, te meer/ overmits door de continuele remonstratijen, die successivelijck van/ alle voorvallende swaricheden, soo aen mijne heeren de Staeten Generael/ als andre heeren int particulier genootsaeckt ben geweest te/ doen, de plijchen altijt seer groot gevallen sijn, daer door perijchel/ loopen dat geen goet recapito becomen, doch bij dese goede occasije/ ende sicure gesegentheijt, heb niet konnen nalaten mijne dienstelijcke/ gebiedenisse aen uwe ed: mitsgaders detoestant vanden tegewoordige/ staet deser landen sommierlijck over te schrijven. De troubles/ ende motijen in Ungaria tentijden vanden voorgaende opperste Vijsijr/ Nassuff Passa (die voor een jaer van sijn Mat: gestranguleertis ge-/ worden) tuschen de Duijtsche Keijs: Mat: ende de Turcken ontstaen;/ sijn voorleden soomer ten overstaen vanden gouverneur van Buda, met/ een minnelijck accoort geaccommodeert, tot welcke sijne men/ dagelijx een Ambass: vanden Duijts: Keijs: alhier is verwachtende,/ omde vrede te renoveren, ende de Capitulatien voor achtjaren/ gemaeckt op nieus te confirmeeren. De saecken in Transilvania/ sijn noch in incertis terminis. De overlevering vande twe fortressen/ Lippoa ende Genoa bijden jegenwoordige Prins Betlem Gabor aen/ den Turcksen Keijs: belooft (also op die conditie van sijn Mat: armata/ manu in die landen is ingestelt) is alsnog niet geschiet, door dien/ de steeden sulcks geensins willen toelaeten. In Poolen is alles in/ weijnich tijts herwarts so getroubleert ende in alarm gestelt, dat de/ vrundtschap met de Turcken die over de hondert jaeren oudt is, niet/ alleen wel gefinieert, maer oock is aen openbaer ende bloedich oorlog/ verandert mocht worden, sijnde den Gov: van Tartarijen ontrent vijff/ 
maenden geleeden, heeft in persoon met tsestich Duijsent mannen hier/ onversients inde landen van Podolia ende Russia, sijnde onder het gebiet/

[2] aende subjectije vande Gov: van Poolen, vijantlijch ingevallen, het/ gantsche teenemael geruineert, ende over de hondertduijsent slaven/ gevanchelijck wechgevoert, behalven het vee ende alderleij andre/ meubelen, sijnde een ruine so terribel ende de schaede soo enorm, dat/ diergelijcks noijt te vooren ande rijchen van Poolen is geschiet./ Dit feijt is quaeluijs [?] bijde Tartars begaen, ende voorgeeft, sonder/ weeten oft consent, veelmin eenige last vanhier daer toe te hebben/ daer nochtans heimelijck genouch is, dat over sulx Turcx is/ sinu gaudeant, ende met conniventije ja na apparentie door last/ ende ordervan sijn Mat: geschiet is, als tot vindicte vanden aftbreuch/ ende schaede bijde Chazacken het jaer voorleden in Asia ande/ Turcken gedaen, alles door Instigatije vanden Cahimacham dat is/ Luogo tenente vande Vijsijr Azem, de welcks een obstinaet gesworen/ vijandt vande Poolen is. Dese vijantschap heeft sijn oorspronck ... / die als gedachten Cahimacham ontrent vijffjaren geleden den Prins/ van Moldavia genaemt Constantinus zijnde de oudste soon van/ Jeremias Vaivoda met gewelt heeft verdreven, ende daer in=/ gestelt, een Grieck sijnde een van sijn Vx: creaturen genaemt/ Stefanus Tomse, tot groot nadeel ende prejuditie vande croone/ van Poolen, waer over de Poolen haer ten hoochsten geoffenseert/ houdende, als sijnde een daet haere capitulatije met den Turckschen/ Keijs: gemaeckt contrarierende, hebben de clachten daer van/ door haer Ambass: alhier aende porta meenichmael ter ernstige/ gedaen, doch siende dat daer bij niet en avanceerden, heeft de/ voorgedachten verdreven Prins Constantinius in Poolen gevlucht/ sijnde voor drij jaren gearresteert met eenige voornemen Poolsche/ Vaivodes, gehuwelijckt met sijn susters van Constantinius, met/ comminuentije van den Con:van Poolen hem met twintich duijsent/ mannen heeft opgemaeckt, ende een aenslach op Moldavia gehadt/ met meeninge omden voorgen: Stefanus wederom te verdrijven,/ twelck seer ongeluckelijck heeft gesuccideert, sijnde vande Turcken/ ende Tartars onversients, in een haer ongelegen plaets so overompelt/ dat niets heeft kennen schamheeren [?] die de tijdinge vandese nederlage/ in Poolen brochte, alle gader verslagen ofte gevangen sijnde,/

[3] Constantinius selfs in handen vande Tartars gevallen, is daerna ontvlucht, ende/

bij nacht willende een riviere passeerde verdroncken, waer over dito/ Stefanus Tomse hem altijt seer vijandtlijck jegens de poolen heeft/ gedraeghen, alle dispect ende hostiliteijt jegens haer plegende, alle/ haere actien ten quaesten aende porta alhier overdragende, ende calum=/ nieerende, daer door het herte vande Cahimacham heer vande poolen/ heeft geabalieneert ende geinimiceert. Men seijt oock dat den selven/ Tomse de principaelste oorsaeck ende instigatiee soude geweest/ sijn, vande laeste voorverhaelde invasijen bijde Tartars begaen, door/ alle welcks hostiliteijten, ende vijantlijcke actijen de Poolen gerri.../ 
sijnde, hebben twe maenden geleden met twintich duijsent mannen/ een inval op nieus in Moldavia gedaen, dito Stefanus vuijt den lande/ verdreven ende met bewilliginge van de lantsheeren ende tgenen/ volck vande welcke Stefanus aen sijn groote Tijrannije seer gehaet/ was, voor prins vande landen gedechareert ende aengenomen de/ broeder van de voorgedachte Constantinius. Dit feijt heeft sijn Mat:/ alhier ende int particulier de Cahimacham ten alderhoochste warnt [?]/ eerhalven men incontinentij Giausen met ernstige bevelen van sijn/ Mat: anden Tartar Chan, princen van Transilvania ende Valachia ende/ voort aen alle Turckse Governeurs alomme op de frontieren geex=/ pedieert heeft, ten eijnd haer met gesae..r macht soude opmaecken/ ende de Poolen wederom uijt Moldavia verdrijven: het sulckx sall/ ons den tijt leeren: het is een saech van groote consideratije ende/ mocht wel eenige notabile veranderinge causeeren. Den Vijsijr/ onthout hem alsnoch tot Aleppo met meeninge na alle uijterlijck/ apparentijen en de aengevangene oorloge jegens deCon:van/ Persia ernstelijck voorte vaeren, daerter den Aras ende hem seer/ genegen toone: Den Persijaensen Ambass: die nu over de vijff/ maenden hier is, wert alsnoch sonder audientije opgesonden -/ hier is oock seecher tijdinge dat de Emijre van Saita, die van Nassuff/ Passa uijt sijn landt verdreven ende is Italijen bij den groot Hartooch/ van Fijorenzen gevlucht was, in Cijprus gearriveert is, ende werdt/ van sijn Mat: wederom is sijn voorige stadt gerestitueert -/

[4] Den brenger deses is de soon van Mijn Heer Claes Jacob Sijmisz:/ saliger gedachtenisse, die nu over de vier jaeren lanch mijn voor/ page ende camerlingh seer naerstich ende getrouwelijck heeft/ gedient, ende hem altijt door sijne volcomene gehoorsaemheijt/ stilheijt ende modestije, sulcks jegens mijn gecomforteert dat ten/ hoochsten genegen ben hem in alle occurentijen behulpichkende vordelijck/ te sijn. Doch also bemercke ende considerere, dat alhier indese lande/ weijnich gelegentheijt hebbe om hem tot eenich avancement te/ brengen, na dat mijn hart wel soude wenschen ende gij wel neriteert/ so ist dat ick gesien hebbende sijn ernstich versouch ende begeerte om/ wederom in sijn vaderlandt te reijsen, hem daer toe niet alleen mijn/ consent heb willen geven, maer ooch aen uw eed: met desen seer/ verdienstelijck raccomandeeren, versouchende dat de selven believe/ voor gerecommandeertte houden. Ten deele aen sijne getrouwe/ dienste aen mijn alhier so langen tijt gedaen. Ten deele oock om/ de merijte ende diensten, die sijn heer vader saliger so getrouwelijck/ ande landen heeft beweesen, twelck ick voor een sonderlinge/ gunst ende aen mijn eijgen persoon gedaen sal aennemen ende altijt/ na vermogen dienstelijck erkennen

Hier Meede

Edele, eerentheste, voorneme Achtbaere Heer, Ende Godt/ Almachtich voor uwe ed: gesontheijt ende lange leven mijn dienstelijck/ aen uwe ed: gebiedende. In Constant. den 27 en Januarij 1616 
uwe Ed.

Ende dienstwillige

Haga

Catalogue entry: J. Hellendoorn, Schenking-Diederichs. Nederlandsche Afdeeling (Bibliotheek der Universiteit van Amsterdam. Catalogus der Handschriften I, Amsterdam 1899), p. 83.

Literature: Danişmend, Kronoloji III, pp. 257-264; De Groot, Ottoman Empire, esp. pp. 190, 192; W.F. Reddaway, J.H. Penson, et alii (eds.), The Cambridge History of Poland (Cambridge 1950), pp. 468-469.

\section{Hs. Diederichs 136 Bp}

\section{A letter}

A letter in French from Saïd Bey to 'Monsieur le Vice-Amiral Bisson Bey Majar-Général [sic] de la flotte Egyptienne' concerning the gift of a drum, dated 22 June 1836. Pencil notes in German. The text reads: Mon Général, J'ai reçu avec plaisir la timbale que vous m'avez eu la bonté de m'envoyer par M. Gautié [? cf. also under Hs. 136 N, below], et je vouz en remercie. Je vous prie de donner vos ordres au menuisier pour qu'il lui destine une place dans mon nécessaire. Saïd Bey. White paper, $227 \times 221 \mathrm{~mm}$, additional pencil notes in German. (According to the notes, Saïd Bey was a governor of Egypt and admiral, and may be identified with Sa'id Muhammad Beg (d. 1863/1270, cf. $S O^{2} \mathrm{~V}$, p. 1456) son of the then governor Muhammad 'Ali Pasha. Bisson Bey is not identified.)

Catalogue entry: Bertha M. v.d. Stempel, Schenking-Diederichs. Kleinere afdeelingen (Bibliotheek der Universiteit van Amsterdam. Catalogus der Handschriften VI, Amsterdam 1917), p. 73.

\section{Hs. Diederichs 136 F 1, 2}

\section{Two letters}

The letters are written on folded leaves of the same format and in the same handwriting. Both are petitions in Latin (and probably translations from the Turkish) — the first also contains a final paragraph in German-from 'Arslann Chann' [Arslan Süleymān Paşa], 'governor of Bosnia', to Sultan 'Abdulmecīd [I, ruled 1255/1839-1277/1861], written at Leutschau (Levoča), Hungary, and dated 6 December 1839. The, obviously, exiled prince begs the 
sultan, recently succeeded to the throne, to allow him to return to Istanbul. Particularly in the second letter, he lectures the sultan on recent European history, the integrity of the Ottoman territory, the interference of foreign powers, and the newly established 'system of peace', and warns him, pointing to the example of the rebellious Muhammad 'Alì of Egypt-he also mentions the latter's son, Ibrāhīm Pasha-against too great an independence of provincial governors. The first letter contains a list of 'families', mainly of Bosnian extraction, who support him. Who this Arslan Paşa was, is unknown. He may have been a son, or otherwise related to, Arslan Mehmed Paşa, who had been a governor of Bosnia in 1203 (1789-1790, cf. SO I, pp. 323-324).

Brownish paper of poor quality, approximately $405 \times 247 \mathrm{~mm}$ per page, text in a large, spidery and irregular script. A few notes in pencil in German. The curious text of the letters merits quotation in full (the reading of names is uncertain is some places):

1. Magnus Sultanus Mahmud Ali Mehmed Aegipti Provincia sui Rebellionis adactus pro tempore debuerat cedere. Sic Potentiis est reponendum. Non gratis faedus est initum Cum Russico Reginine adeo quam primum aliquis Pascha independenticum affectaverit petitis Copiis Potentiarum emmen ... os statim dignetur curare agredi. Familiae quae me agnoverunt ac agnoscunt Muselmanicae Principum sunt sequentes Familia Arslann Kreo M. Ducatus Hercegovinae Ducis Pricipiis ac Arriorum Praevecti Familia Vesirii Suleimanu Pascha Commendantis de Klissa Familia Assan Pascha Srebrenicae de Srebrenik Familia Smail Pascha Familia Assan Pascha Cum Familia Ferdus Begi de Livno Commendantis Kapidschy Pascha Familia Miraly Regni Bosniae ac Principis de Inferior Vacuf. Cum Familia Assan Begi Abbadelodricsje Familia Omnium Principum Phillippovich, Familia Omnium Principum Durattieg de Batuteha et Do lach. Cum Familia Agae Manovich et Agae Granich Cum Familia Principum Dugalich de Varvara. Familia Principum Kovetich de Rumpochi et Jaklischcsi, Familia Omnium Principum Teskeredschy de Travnik et Vilicsia Pole. Familia Principis Sali Aga Commendantis de Tepen et Vranduk. His Familiis Omnes Spahi Seu Domini Terrestres acceperunt. Adeo Vestra Majestas dignetur me evocare Constantinopolim. Ego ab his Omnibus Familiis Nobilitatem Principum retinuo Cum perpetua Excellentia in statu civi et militari aeque Nobilitatem Regni Bosnia ac perpetuam Excellentiam retineo. Sed succesionis Dominia nulla habebo nisi mihi Familiae libere obtulerint. Ego ad Hungarian contra meam vultatem veneram In Hungaria nihil comisseram, nec comittarum Vestra Majestatis Infimus Cliens die 6 sex Decembris 1839. Signatum Leutschoviae Arslann Chann Dux Princeps Berglerbegis de KaraEnidler [?] 
Diese mei $[$ ne $]$ bitte soll expediert werden nach Constantinopol an den Meinen Monarchen ... Sultann Abdulmeschid durch Johann Maurojeny [Ioanni Mavrogeni] Deutscher ... Ratherr und Otthomanischen Agenten ... Leutschau In Hungarn am 6ten December Durch Arslann Chann Prinzen Reichs Bosnien. [A red was seal is added to the text; it shows escutcheon with crown and circular text: Pr. Arslan Suleiman Afron [in Greek capitals] Pascha. An address in French and in the same handwriting, addressing the Sultan, is found on the backside.]

2. Tam multis Literis Vestrae Majestati directis, sum testatus intimum dolorem ob mortem sua majestatis Magni Sultani Olim Mahmud. Testatus pariter sum mecum gaudium ob vestra majestatis consecutionem Throni Otthomanici. Deum Omnipotem praecor ut Vestra Majestatis Thronus in sempiter conservetur. Persuasus sum, quod Vestra majestas velit vestigia sequi. Vestris majestatis Potentissimi Parentis dignetur igitur Vestra Majestas illam culturam conservare ac promovere quam culturam annuentibus Exteris Magnis Potentiis Vester Pater incoaverat promovendam data libertate cui libet in quantum Politicum et necessitas status Europae deposuit quia si Vestra Majestas praefatam culturam non promoverit volerit magna Potentias offendere alias Cultura scientifica civili ac militari conservatur Majestas Islamismi Majestas conservatur Otthomani Throni In primis dignetur Vestra Majestas Gubernatores singulae Provinciae habere, sed non Regentes quia hii gratia abuti poterunt, et tunc sapius Turcarum sunt actore S.Tu Imperio. Gubernatores dignitur denominari propria potentia Medio Fulgidae Portae. Sive ista gratiosa denominatia eveniat gratia sive meritis nullus in ista denominatione influxsus Exceterarum Potentiarum admitti debet. Non scio qua ratione Gallicum Regimen palavi dicit Ibrahim Pascham legitime independer posse in Aegipto, in Siria, Arabia, et Candia posse succedere suisso Imperio Otthomanico. Alias scimus quod Ali Mehmed, qua Rebellis profatas Provincias possederit adeos qualitatis rebellis non haereditatem Aegipti meritus fuerat et mortem meritas fuerat ude potuerat possionem Aegipti sibi praetendere numquid Aegiptum a suo Patre obtinuerat. Ergo quomodo Gallicum Regimen potest latis rebellis partes fovere. Ecce Gallicum Regimen post introductum Sistema Pacis Europae occupationes facit in provinciis Otthomanicae Coronae pertinendis, et has Provincias non permittit Regimen Gallicum suis Belli ducibus haereditarias fieri. Ecce Napoleon Bonaparte votis totius Gentis Gallicae fuerat Galliarum Imperator Elecitus ipsius fratres in multis Regius Reges sunt facti. et Nunc Napoleonis posteritas nec unicam possesionem missiodendam habet in Galliarum Provinciis imo nec habitationem, sed hic inde per Orbem migrare debet. quia illegitine fuerat factum. Adeaque si potentiae aliquae foverint 
partes alicuius Rebellantis Paschae. Tunc statim Vestra majestas dignetur a Potentiis quaerere, an Potentiae suis Gubernatoribus admittant sciscionem ud monare hice facere repositum fuerit non permittere tunc dignetur licere nec se posse permittere quia Omne Regnum in se divisum desolabilitur. Ibrahim Pascha meretur ut per Vestram Majestatem alicujus Provinciae Gubernator denominetur sed omni dispositioni et ordinationi Vestrae Majestatis sit obnoxius hoc poterat illi exoperari Gallicum Regimen. Dignetur Vestra Majestas considerare Regimen Austriacum et Borussicum jam postquam introductum fuerat Sistema Pacis Europae, necunicam orgiam alieni Territorii occupaverat. Non pridem Anglica Pacis Bellica cum Pacis Bellica Gallica in Dardanellis jucta haerebat in Conspectu Constantinopolim. nihil dignetur timere Vestra Majestas, etiam Omnes Potentiae cum tota Armada in Conspectum Constantinopolim venerint. quam primum illis pacem obferret tunc nec unan Orgian Territorii Otthomanici ocupabunt. quia foret contra Sistema Europae Signatum Leutschovice In Hungaria die 6. Decembris 1839. Arslan Chann Dux Princeps. [The text is followed by the same red wax seal. An address in Latin and in the same handwriting, addressing the Sultan, is found on the backside.]

Catalogue entry: Bertha M. v.d. Stempel, Schenking-Diederichs. Kleinere afdeelingen (Bibliotheek der Universiteit van Amsterdam. Catalogus der Handschriften VI, Amsterdam 1917), p. 5 .

\section{Hs. Diederichs 136 G 1-4}

Two fermāns with translations

The documents once belonged to the, once, popular writer, Countess Ida Hahn-Hahn (1805-1880). She travelled in the company of her lover, Baron Adolf von Bystram, from Vienna to Istanbul in August 1843; from there they moved on to Rhodes, Cyprus, Damascus, Beirut, Jerusalem and Cairo-in February 1844 she cruised down the Nile to Wādī Khalfa. Returning by way of Athens, they arrived in Trieste on 13 April 1844. The writer described her experiences in twelve 'Orientalische Briefe', printed in three volumes in Berlin in 1844; in them she boasts to be the first woman ever who had requested - and obtained - a passport for travel in the Orient, cf. I, p. 301: Es hat aber Mühe gemacht ihn zu bekommen und der Secretär, dem die Ausfertigung eines solches Firmans zukommt, hat nicht gewagt die verantwortung allein über sich zu nehmen und ihn auszustellen; höhere Beamten sind 
im Rath gezogen worden. Und nun rathe weshalb!-Weil noch nie eine Frau einen Reisefirman begehrt hat. Es war mir vorbehalten diesen in den Annalen des osmanischen Reiches unerhörten Fall herbeizuführen und ich werde nicht ermangeln dies ausserordentliche Document mit mir nach Europa zurückzubringen, weil es vielleicht einzig seiner Art aufder Welt ist. Übrigens sieht es ganz gemein aus und, wenn phoenixselten, ist es doch nichten phönixschön. (see also Van Munster, Die junge Ida, pp. 149-155). The documents contain pencil notes in German.

1. A hükm-i şerīf issued on behalf of a Prussian Mademoiselle Conto [the name has remained a blank], ordering $k \bar{a} \dot{\bar{c}} \bar{\imath} \mathrm{s}, n \bar{a} \dot{i} b s$ and muftis on the route between Izmir and 'Anatolia and surroundings' to adhere to the rules established by the tanzi mät-i hayrìye, regarding the protection of travellers, in particular the proper functioning of posting houses (menzilhāne) on the roads between Üsküdar and Izmir, and between Istanbul and Edirne- the lady is to be given six horses in every post against a rent of 40 para-dated at the beginning of Şa $\bar{c} \bar{a} n 1259$ (27 August-4 September 1843).

The text is headed by a tuggra in black of Sultan 'Abdulmecīd (cf. Umur, pp. 296-301). Two signatures on the back. Glazed white paper, 13 lines, $720 \times 244 \mathrm{~mm}$, dìvānī.

2. A fermān (passport) issued on request of the Prussian envoy at the Porte, Chevalier de Lecoy, to the Prussian Contessa [Gräfin] Ida Hahn-Hahn and two servants who are to travel from Istanbul to Izmir, and from there to Jerusalem, Damascus and Egypt, and back again, ordering k $k \bar{a} \bar{z} \bar{\imath}$ s, $n \bar{a} i b s$ and muftis along the route to take care that the travellers be not demanded unlawful taxes and granted a safe passage, dated at the end of Şa $b \bar{a} n 1259$ (15-24 September 1843).

The text is headed by a tugira in black of Sultan 'Abdulmecīd (cf. Umur, pp. 296-301). Administrative notes and signatures on the back. Glazed white paper, $800 \times 540 \mathrm{~mm}$, 9 lines, bold dìvānì.

3. A German translation of 3 in small, neat Kurrentschrift.

4. A German translation of 2 in neat Kurrentschrift. 


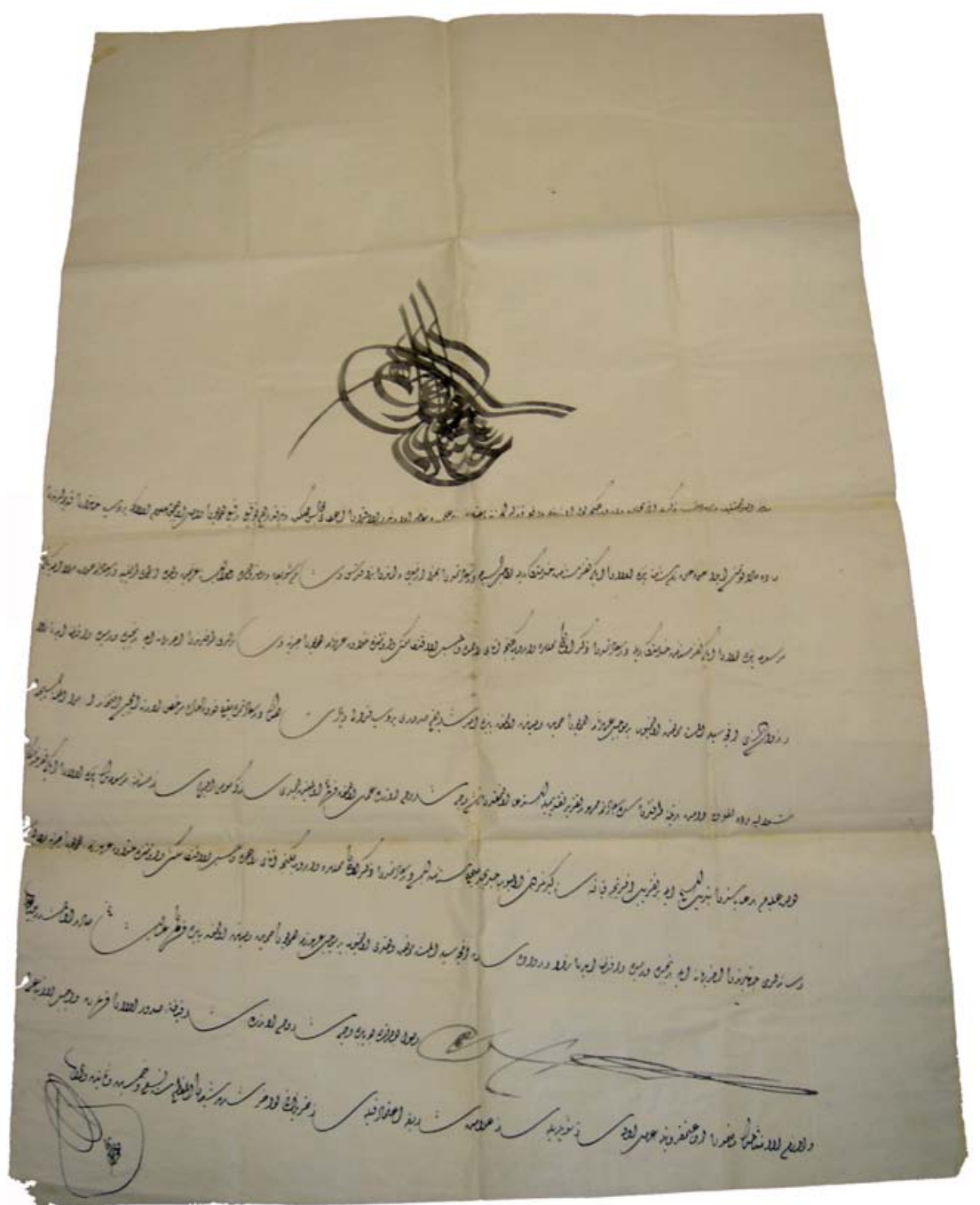

Figure 11. Amsterdam, UB Hs. Diederichs $136 \mathrm{G} 2$. A pass (fermān) issued to Countess Ida Hahn-Hahn for a journey from Istanbul to Izmir, Damascus, Jerusalem and Egypt, and back, dated 1259/1853. 
Catalogue entry: Bertha M. v.d. Stempel, Schenking-Diederichs. Kleinere afdeelingen (Bibliotheek der Universiteit van Amsterdam. Catalogus der Handschriften VI, Amsterdam 1917), p. 1.

Literature: Katrien van Munster, Die junge Ida Gräfin Hahn-Hahn (Graz 1929); Gert Oberemt, Ida Gräfin Hahn-Hahn. Weltschmerz und Ultramontismus. Sudien zum Unterhaltungsroman im 19. Jahrhundert (Bonn 1980).

\section{Hs. Diederichs 136 H 1, 2}

A fermān with a translation

1. A hükm-işerîf(yol emri, passport) issued on request of the Austrian envoy [murahhas] at the Porte, Baron von Ottenfeld, to Francesco Lubīn [Franz Lubin], Austrian merchant, and his servant who are to travel from Istanbul to Bucharest, ordering $k \bar{a} \dot{z} \bar{i}$ along the route to take care that the travellers be not demanded unlawful taxes and granted a safe passage, dated at the end of Ramażān 1242 (18-27 April 1827). A plate is found in D. Koster's monograph, mentioned below.

The text is headed by a tugira in black of Sultan Mahmūd II (cf. Umur, pp. 291-295). Glazed cream paper, $785 \times 530 \mathrm{~mm}$; 8 lines, dīvāní.

2. A German translation of $\mathbf{1}$ in neat Kurrentschrift.

Catalogue entry: Bertha M. v.d. Stempel, Schenking-Diederichs. Kleinere afdeelingen (Bibliotheek der Universiteit van Amsterdam. Catalogus der Handschriften VI, Amsterdam 1917), p. 7; D. Koster, "Naar't heerlijk Griekenland, Verbeelding! voer mij heen". Reizen naar Griekenland 1488-1843 (Groningen 1993), No. 121 (p. 145).

\section{Hs. Diederichs 136 I}

\section{A fermān}

A pre-printed copy of a passport, partly filled in with black ink, in French issued to 'Mr. le docteur Ciax, Colonel et Chevalier' for a journey to Corfu, and from there onwards to Naples, dated ${ }_{15}$ Cemāzí l-evvel 1262/ 10 May 1846. Signed by the Minister of Foreign Affairs, Aali. A seal with the legend nizāret-i ümūr-i häricīye-i devlet-i 'alīye and the year [1]253 (1837-1838) is printed left of the signature. The text is headed by a tü $\dot{g} r a$ of Sultan 'Abdulmecìd and (twice, in Latin and Arabic script) the number 1442. Visas of the British and Sicilian embassies, with signatures and a seal, are found on the back. Pencil notes in German. 


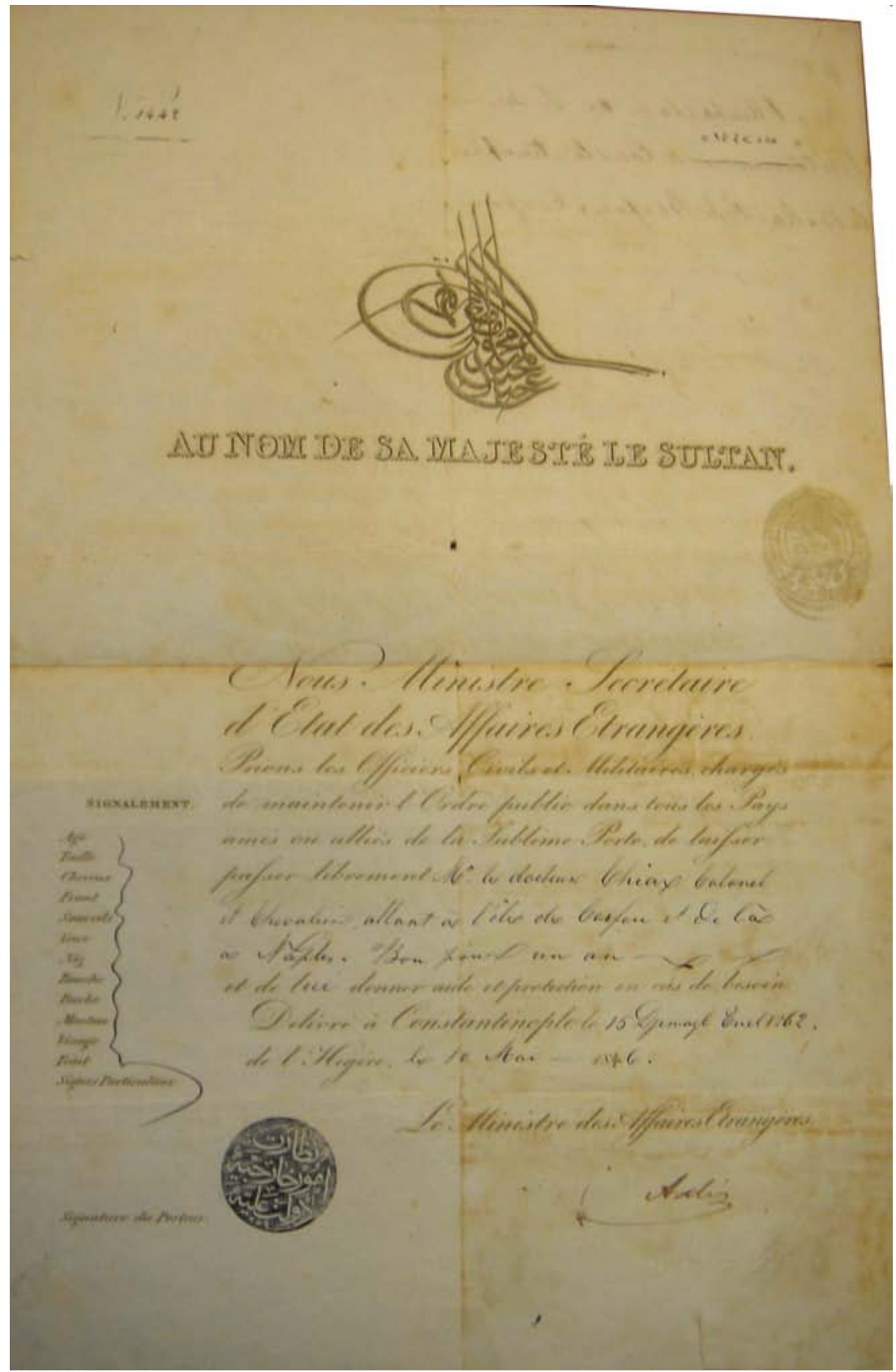

Figure 12. Amsterdam, UB Hs. Diederichs 136 I. A passport issued to a French doctor and colonel called Ciax for a journey to Corfu and Naples, dated 1262/1846. 
White paper of poor quality, $420 \times 270 \mathrm{~mm}, 11$ lines.

Catalogue entry: Bertha M. v.d. Stempel, Schenking-Diederichs. Kleinere afdeelingen (Bibliotheek der Universiteit van Amsterdam. Catalogus der Handschriften VI, Amsterdam 1917), p. 1.

\section{Hs. Diederichs 136 J}

\section{A letter}

The letter, with a text in Italian, is addressed to the French Emperor Napoleon I in Venice, and signed and sealed by Ali Pacha [Tepedelenli 'Alì Paşa, semi-independent ruler of Albania and what is today north-west Greece] at Janina [Ioannina], dated 15/27 December 1807. In the letter, 'Alī Paşa begs the Emperor to reinstate the coastal town of Parga, occupied by the French General César Berthier, to his authority. He also asks him to exile the local rebellious refugees [the population favoured the French occupation] to France, at the same time promising military assitance to Berthier. It is questionable whether the letter ever reached Napoleon; only in 1819 was 'Alī Paşa able to purchase Parga from the British for $£ 156,000$. (For the historical background, see the introduction to Koster's edition, mentioned below.)

A folded leaf of white paper, two folios $245 \times 241 \mathrm{~mm}$, three pages with text.

Catalogue entry: Bertha M. v.d. Stempel, Schenking-Diederichs. Kleinere afdeelingen (Bibliotheek der Universiteit van Amsterdam. Catalogus der Handschriften VI, Amsterdam 1917), p. 3.

Edition: Daniel Koster, "An Unpublished Letter from Ali Pasha to the Emperor Napoleon", in Ipirotiko Imerologio T. ID \& T. IE-IST (Ioannina, 1992 \& 1993-1994), pp. 83-94 (with facsimile) \& 319-324 (with footnotes).

\section{Hs. Diederichs $136 \mathrm{~K}$}

A note

The note, with a brief text in French, was addressed by a certain 'Cabouly' to a friend, undated. The upper margin mentions the address: ' 1 Bryanstone Square'. The text reads as follows: Mon cher ami, Mon cocher étant allé ordonné des chevaux, je suis faché de ne pas pouvoir envoyer la voiture pour vous chercher chez vous. Je vous prierai de vouloir bien monter un 'cab', et de 


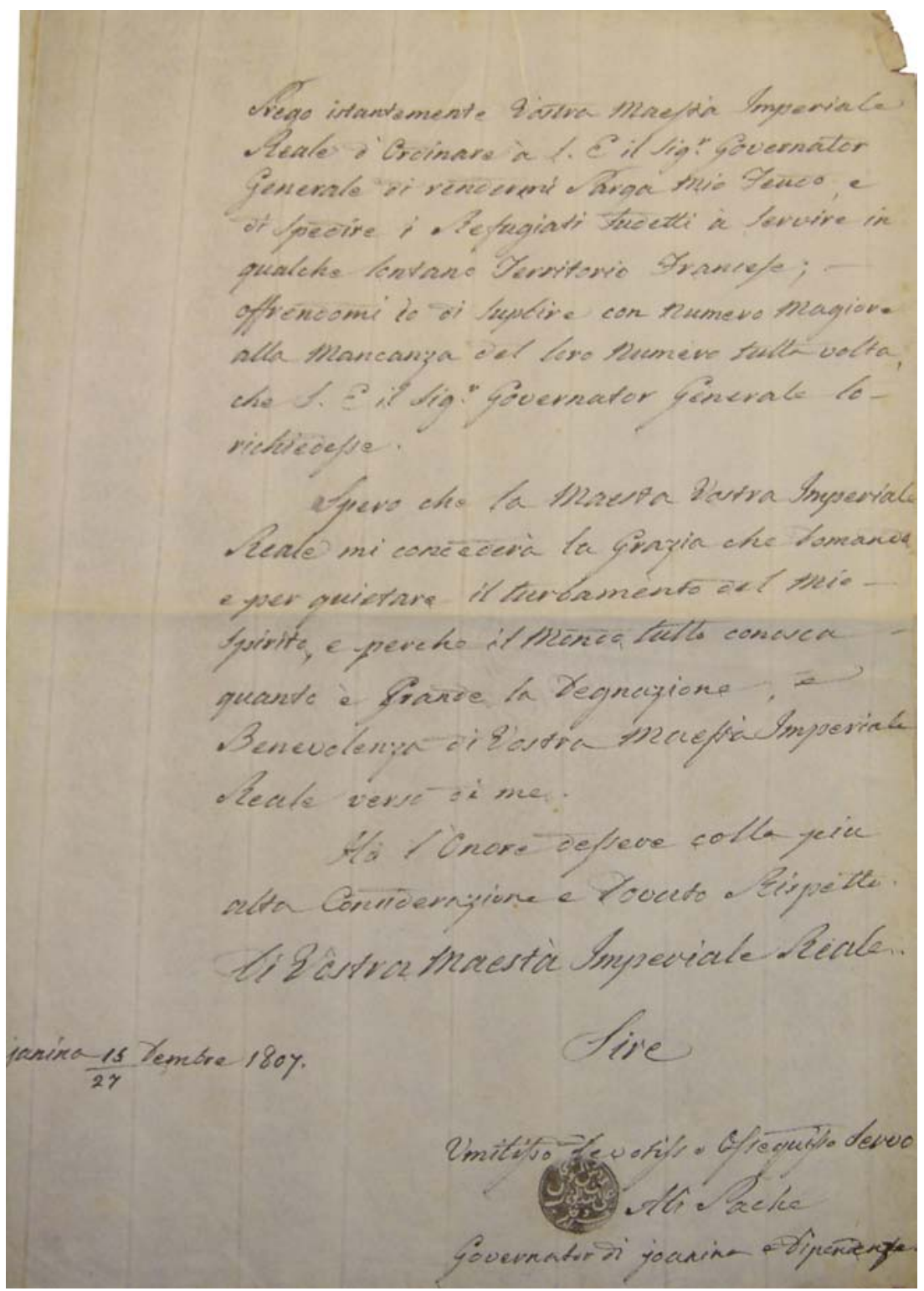

Figure 13. Amsterdam, UB Hs. Diederichs $136 \mathrm{~J}$. The last page of a letter from Tepedelenli 'Alī Paşa to Napoleon, dated 1807. 
venir à l'Ambassade vers une heure de l'après-midi d'où nous partions ensemble. Toutavous - Ce Mardi. 'Cabouly' almost certainly is Kabūlī Meḥmed Paşa (d. 1294/1877), translator, official, ambassador and minister. He served at the Ottoman Embassy in London as secretary (başkātibi) and chargé d'affaires between 1265 (1849) and 1268 (1852), upon which he was promoted to ambassador in Athens (cf. $S O^{2}$ III, pp. 854-855) - see also under Hs. Cq 46 , above. White paper, $185 \times 113 \mathrm{~mm}$, 10 lines.

Catalogue entry: Bertha M. v.d. Stempel, Schenking-Diederichs. Kleinere afdeelingen (Bibliotheek der Universiteit van Amsterdam. Catalogus der Handschriften VI, Amsterdam 1917), p. 15.

\section{Hs. Diederichs 136 M}

\section{A letter}

A letter in French addressed to an unspecified 'Monsieur', signed by 'Bassa Cigala Prince Ottomano', at Brussels, 10 March 1669. The text is as follows: Monsieur, J'ai receu lav [ost]re du $22^{e}$ fevrier, ie suis fort ayse de seauvoir l'Estat de $v[$ ost]re santé et ie vous remercie de la memoire que vous me conferue, et des civilites que J'ay receu de vous et de Mad. ${ }^{\text {elle }} v[$ ost] re Compaigne sans que nous nous cognoissions l'un lautre. J'éspere aussi que le bon Dieu quelque temps me fera la grace de trouuer l'occasion de Vous temoigner l'affection que ie Vous porte et a tous ceux de $v[$ ost]re maison, mes affaires sont Icy faict sy ce n'est que J'attend Encore une Lettre de Change de l'Empereur, J'espere de retourner bien tost a Amsterdam, ie vous prie d'aller a la maison de Mons. ${ }^{r}$ Le Bourgemestre et lui faire mes baisemains et a Mad. ${ }^{e}$ Sa Compaigne et Mess. ${ }^{\text {rs }}$ Ses Enfans aueq tout ceux de Sa Maison, et aussy a Madmoiselle Emmerentia Mons. ${ }^{r}$ Son frere et Pere et touts ceux de Leur maison, et aussy Particulierement a Mad. ${ }^{e}$ marie vostre Compaigne, Mad. elle Anne, et Mons. ${ }^{r}$ Son Mary Mad. ${ }^{\text {elle }}$ Cornelia, Mons. ${ }^{r}$ Gaspar Monsieur Abraham Mad. ${ }^{\text {elle }}$ Marie $v[$ ost]re fille, Jan et Jacob vos fils et a touts autres de La maison, ie suis, Monsieur $V^{t}$ re tres humble tres affect. Serviteur ... (margin: La Medaille que le Magistrat de Boldue m'auoit promis m'ont Envoyé J'cij a Brux.es) The identity of the sender does not seem to be documented. The name 'Cigala', points to the Çiğalazāde family, whose most famous scion was the Grand Vizier Sinān Yūsuf Paşa (d. 1013/1605), originally called Scipione Cicala. Father and son, the father a corsair operating from Messina, were captured by the Ottomans in 967/1561 off Jerba. Sinān Paşa's only son, Mạ̣mūd, died in 1052/1643.

A folded leaf of white paper, 2 folios, $215 \times 156 \mathrm{~mm}$; a remnant of red wax is found on the of the last folio. 


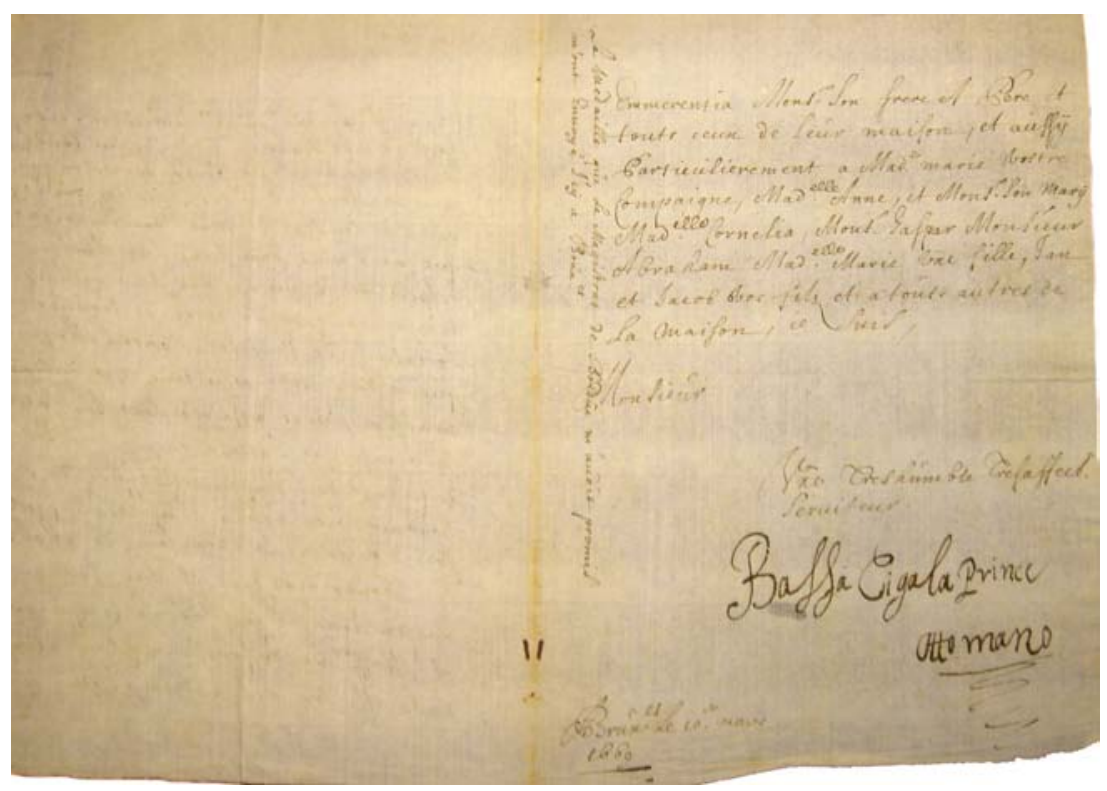

Figure 14. Amsterdam, UB Hs. Diederichs $136 \mathrm{M}$. The last page of a letter of an Ottoman 'prince', Cigala Paşa, to a friend, written in Brussels, 1o March 1669.

Catalogue entry: Bertha M. v.d. Stempel, Schenking-Diederichs. Kleinere afdeelingen (Bibliotheek der Universiteit van Amsterdam. Catalogus der Handschriften VI, Amsterdam 1917), p. 22.

\section{Hs. Diederichs $136 \mathrm{~N}$}

\section{A letter with translation}

The letter consists of a folded leaf; the original Turkish text occurs on the lower half, the French translation on the upper half. It is a complaint (siyāḳat) from the ayān of Lūbīn [Ljubinje], 'Ömer Ag̀a, to General [JeanJoseph] Gauthier [1765-1815], commander [of the French Dalmatian Army] at Ragusa (Dubrovnik) [cf. DBF XV, p. 802]. Sender, for the sake of good neighbourship, requests military assistance against 'Alī Ag of Mostar and İsmā'īl Kapudān of Buhtal [Počitelj] who are conspiring against him and have gathered a bunch of local 'insects' to attack him and plunder his subjects, and asks in particular for the mobilisation of a thousand men from the town of Metkovik [Metković] for its defense and that of Dračevo as well as the lodging of an official complaint with the governor of Bosnia in Travnik. An address to Gauthier, 'commander of Dobre [Dubrovnik] and Albania', in 
Turkish, and a note in French with the date of arrival, 25 February 1812, and the remnant of a red wax seal, are found on the back.

Glazed white paper, $465 \times 330 \mathrm{~mm}$, French and Turkish texts, 18 and 12 lines, Turkish text in $r k^{c} a$.

Catalogue entry: Bertha M. v.d. Stempel, Schenking-Diederichs. Kleinere afdeelingen (Bibliotheek der Universiteit van Amsterdam. Catalogus der Handschriften VI, Amsterdam 1917), p. 59.

\section{Hs. Diederichs 136 O}

A note

The note contains a brief note on the exchange of gifts of tobacco in French, reading: Son Excellence Monsieur l'ambassadeur de Turquie, presente ses compliment $[s]$ à Monsieur le Baron de Schachten, Elle le remercie infiniment d'avoir eu l'obligeance de lui envoyer du Tabac à priser. Elle le prie aussi de vouloir bien accepter le Tabac Turc qu'elle a promis de lui envoyer. Paris le 30 Janvier 1848. The text is followed by a German annotation, stating that the note was written by Rechid Pascha, [Ottoman] ambassador at Paris. This is unlikely in view of the date: Muștafā Reşīd Paşa (1800-1858) was envoy in Paris in 1835-1836, 1841-1843, and 1844-1845, and returned to Istanbul in the year last mentioned. In January 1848, Süleymān Paşa was the Ottoman ambassador in Paris, and he may have been the author of the note (cf. Représentants, pp. 120-124).

White paper, $205 \times 132 \mathrm{~mm}, 11$ lines.

Catalogue entry: Bertha M. v.d. Stempel, Schenking-Diederichs. Kleinere afdeelingen (Bibliotheek der Universiteit van Amsterdam. Catalogus der Handschriften VI, Amsterdam 1917), p. 69.

\section{Hs. Dortmond 56}

\section{A rūznāme}

A vellum scroll, wrapped around a small wooden wand, with a calendar/almanac in tabular form. The twelve tables found on the scroll are surrounded by marginal notes and explanations and provide, mostly, astronomical data and cover the years 1289-1359 (1872-1940). The first table indicates correlations between musical modes (makāms), their use and social setting, and the signs of the Zodiac dominating the subsequent hours of the day. The rüznāme was particularly meant to establish the kıble for each hour 


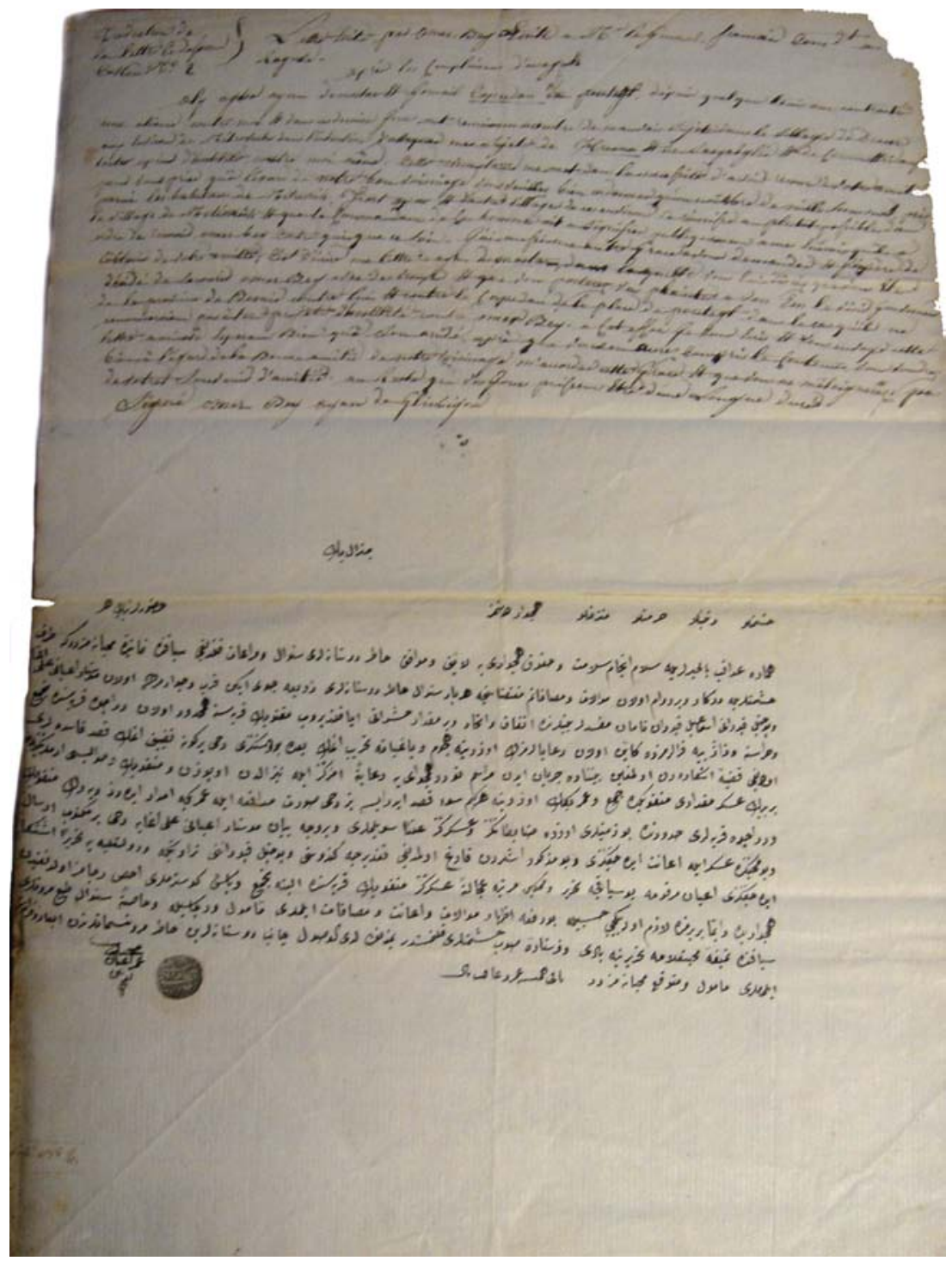

Figure 15. Amsterdam, UB Hs. Diederichs 136 N. A letter in French and Turkish from 'Ömer Ag̀a of Lūbīn (Ljubinje) to General Gauthier, commander of the French Dalmatian Army, dated 1812. 
in the Istanbul region, as is explaned in an appendix below the colophon: $b u$

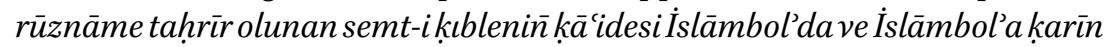
olan mekānlerde șahịh sā'atler bu cedveldeki mikdārda geldikde bir kimse güneşe ḳarşu dursa tamām-i kıbleye teveccüh etmişler olur ... The tables were designed, as is mentioned in the undated colophon, by Mehmed, known as Nā'ilī:

$$
\text { كتبه محمد المعروف بنائلى }
$$

The scroll measures $1080 \times 100 \mathrm{~mm}$; the tables are preceded by a fine headpiece in gold, green, black, pink, red and blue; texts in small nesih; multiple gold borders.

\section{Hs. Dortmond 291}

\section{A rūznāme}

A scroll in leather and glazed white paper, without a colophon, comprising a calendar/almanac in tabular form for the years 1239-1240 (1823-1825). The scroll contains two double and a further eight single tables for the lunar months of the year, with multiple rubrics, among them, on the left, indication of the intiyārāt, the inauspicious days and hours for doing certain things, and comparison to the solar calendar. The scroll measures $1000 \times 110 \mathrm{~mm}$; nesih in black, gold, red, orange and green; multiple gold borders. 


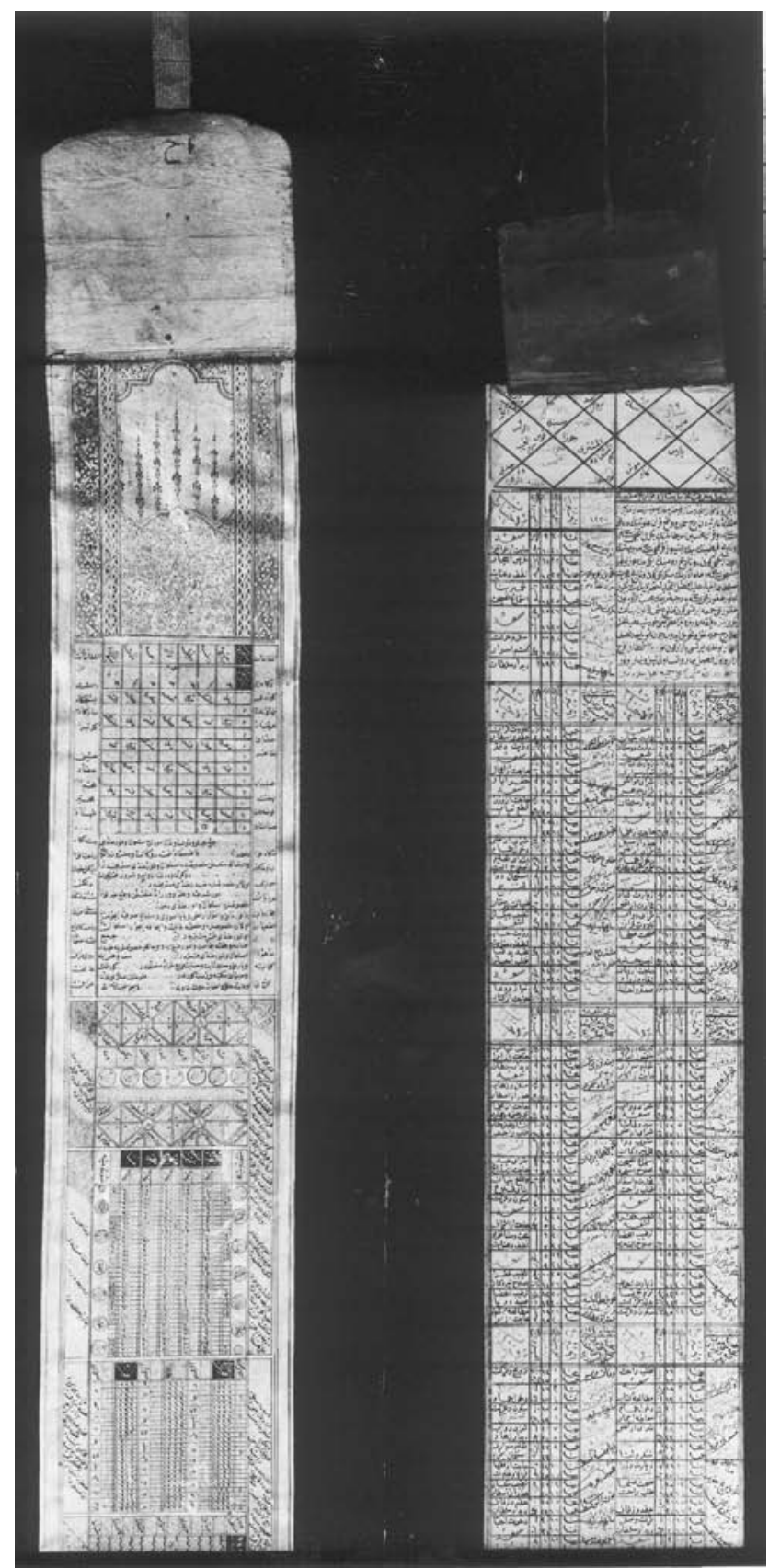

Figure 16. Amsterdam, UB Hs. Dortmond 56 (left) and 291 (right). The upper parts of two rüznāmes in scroll-format, 19th-century. 


\section{CHAPTER FIVE}

\section{GRONINGEN, UNIVERSITEITSBIBLIOTHEEK (UB, UNIVERSITY LIBRARY)}

\section{Address: Oude Kijk in 't Jatstraat 26 (Bibliotheek der Letteren)}

In 1615, a year after the University of Groningen, originally named Provinciale Hogeschool van Stad en Lande, had been formed, the Provincial States decided to found an academic library as well. A chair of Oriental Languages came into existence in 1641-Hebrew had been taught since 1618 . The small Oriental collection in the library had its origin in 1620 when the director of the local grammar-school, Joachim Borgesius, purchased a collection of eighteen Arabic and Turkish manuscripts for his library; Turkish texts are found in Hss. 465, 482, 485, 486, 487, 492, and 493. They had belonged to the German scholar Jakob Christmann (1554-1613) who had been professor of Hebrew and Logic in Heidelberg and had studied Arabic and Turkish. He published a grammar of Arabic in 1584, and was able to teach the language from 16og. At least one of the manuscripts had been given to him by a certain Isaacus Badouacius in 1590 (Hs. 493).

In the 18 th and early 19 th centuries, the library was enriched with some manuscripts which had belonged to scholars connected to Groningen University, among them Leonard Offerhaus (1699-1779), professor of History and Latin (from 1728), later also keeper of the academic library (from 1744, cf. NNBW V, col. 383; Hs. 489); Nicolaus Wilhelm Schroeder [Steinmetz] (1721-1798), professor in Marburg, and from 1747, in Groningen, where he taught Greek, later Hebrew, and Oriental Languages (Hss. 473, 483, 484, 490, 491; cf. Nat, 'Studie', pp. 74-79); his student Everard Scheidius (1742-1794), professor of Oriental Languages, Theology and Greek in Harderwijk and Leiden (Hs. 462, cf. Nat, 'Studie', pp. 83-87); and Gerardus Kuijpers (1722-1798), professor of Theology in Groningen from 1765 (Hs. 479, cf. Nat, 'Studie', p. 65). Two of the manuscripts, Hss. 484 and 488, which had belonged to Schroeder, had earlier been in the possession of the orientalist, Johann Heinrich Hottinger (1647-1692), professor at the University of Zurich and son of the better known theologian and orientalist, Johann Heinrich Hottinger (1620-1667), who had been a student of Golius in Leiden and later taught at the universities of Zurich and Heidelberg (cf. NDB 6, pp. 656-657). Another one, Hs. 490, had been acquired by a certain Daniel Widmer of Basel in 1609. 
Some manuscripts had been war trophees, originally acquired on the battle fields of south-eastern Europe: Hs. 486 (? possibly from the Buda area, late 16th century or later); Hs. 489 (obtained from the Ottoman troops withdrawing from Hungary, late 17th century); and Hs. 491 (contains an soldier's inscription in German, stating that he had found the manuscript which had belonged to 'my enemy', early 17 th century).

The collection has been described in $\mathrm{CCO}$ and H. Brugmans, Catalogus Codicum Manu Scriptorum (Groningen 1898); the data in the latter are mostly, apart from some additional facts (and conjections) about provenance, derived from the former - the numbers of the manuscripts, at present in use, are based on Brugmans's catalogue. To the more interesting items of the collection belong a miscellany dating, it seems, from the late 14th century, with texts in Arabic and eastern Turkish (Hs. 474); a draft copy of a poem in mesnevī rhyme by a horseman (deli) named Cān Beg, dated 985/1587, and further undocumented (Hs. 486); and a unique copy of the mešnevī, Yūsuf u Züleyhāā, by Zihnī (Hs. 489).

Literature: W.H.R. Koops, J. Kingma \& G.C. Huisman (eds.), Universiteitsbibliotheek Groningen 1615-1990. Korte geschiedenis van een academische bibliotheek (Groningen 1990); Jos M.M. Hermans \& Gerda C. Huisman (eds.), Aan de Ketting. Boek en bibliotheek in Groningen voor 1669 (Groningen 1996), pp. $76-80$.

Hs. 462(2)

A copyist's verse in Turkish

The manuscript contains a copy of a second volume, consisting of somewhat disorderly bound parts in various hands, of an Arabic dictionary, aș-Ṣahạh , by Ismācil b. H.ammād al-Jawharī (d. 393/1003), cf. GAL I, p. 128. The final colophon on f. $444 \mathrm{~b}$ mentions the name of a copyist, 'Alī b. Yūsuf b. Mü'min, but no date. (The first volume, Hs. 462(1), contains the date 839/1435-1436.) The colophon is followed by a copyist's verse in Turkish in a different hand: Hakk-i Çelābuñ rahmetiolsun aña *bunıyazanı du'ā-yile aña, and an illegible seal. The manuscript had belonged to Everard Scheidius (see the introduction to this chapter), who used it for his edition of the dictionary (... Thesaurus vulgo dictus liber Sehah ...), published in Harderwijk in 1774-1776 (cf. Nat, 'Studie', p. 85) - the two volumes of the manuscript are mentioned in the preface to the edition ( $3 \mathrm{a})$. He in turn had acquired the manuscript 'from the Orient' in 1769 . 
Catalogue entries: $C C O 2712$ (V, pp. 280-281); Voorhoeve, p. 323; Brugmans, Catalogus, p. 250.

Hs. 465

Turkish text fragments

The manuscript contains an old copy in Kufic script of a work on medicine, at-Tadhkira, by Abū l-Muțarrif 'Abd ar-Raḥmān Ibn Wāfid (d. after 46o/ 1068), cf. GAL I, p. 485. Various Turkish text fragments are found on the

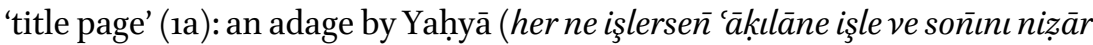
eyle); a gazel by the same; a preamble to a letter addressing a pasha (one line, dīvānì); and an owner's inscription of Hyalil b. 'Abdī. Acquired from the library of Jakob Christmann in 1620 (see the introduction to this chapter).

Catalogue entries: $C C O 2723$ (V, pp. 285); Voorhoeve, p. 351; Brugmans, Catalogus, p. 251.

Hs. 471

A miscellany

An undated collection of pious and magical texts, mostly prayers in Arabic with Turkish commentary and Turkish prayer prescriptions. A brief description of the contents in Latin in Schroeder's handwriting (cf. below) is found on the penultimate flyleaf, recto. The volume begins with the süra Yã Sin, followed by three Arabic commentaries ( $1 b-9 b)$. Arabic Prayers, preceded by Turkish commentaries are found on ff. 16a-101a; headings contain the following titles: Mübārek-i nūr (16a), Mübārek-i cemül (23b), Mübārek-i șalāt (28a), Mubārek-i ḳadeh (39a), Du'ā-i devlet (59a), Hı̇̇ır İlyās du'āsı (64b), İmām du'āsı (78b), Yetmiş iki nesniye kefāret (74a) Kenzü l-'arş (75b), Du'ā-i mi'rāc (92b), Du'ā-i ism-i 'azm (95b), Ḳāż̀ du'āsı (99a), and Du'á-i maḳbūl (100a). A series of short prayers followed with Turkish instructions for their (multiple) use, partly accompanied with talismanic formulae, are found on ff. 101a-132a, 133b-162a, 173a-20ob, 201b-202b. One of the prayers only consists of 1138 هو's (148a-151a), another of 889 الها الأ (151a-153a) - the numbers are noted in a Western hand in the margins. Drawings of 'seals' (mühür), attributed to the prophets Yūsuf (162a, 171b), Muhammad (163a), 'Alī (167a), Süleymān (168b), Hıżır-İlyās (17ob) with explanations of their magical use in Turkish are found on ff. 162a. A prayer with further fragments occur on ff. 203b, 204b and 205a. The volume also contains some divinatory texts involving the text of the Koran: a Şerh-ifäl-i Kur'ān (9b-13b) It begins: 


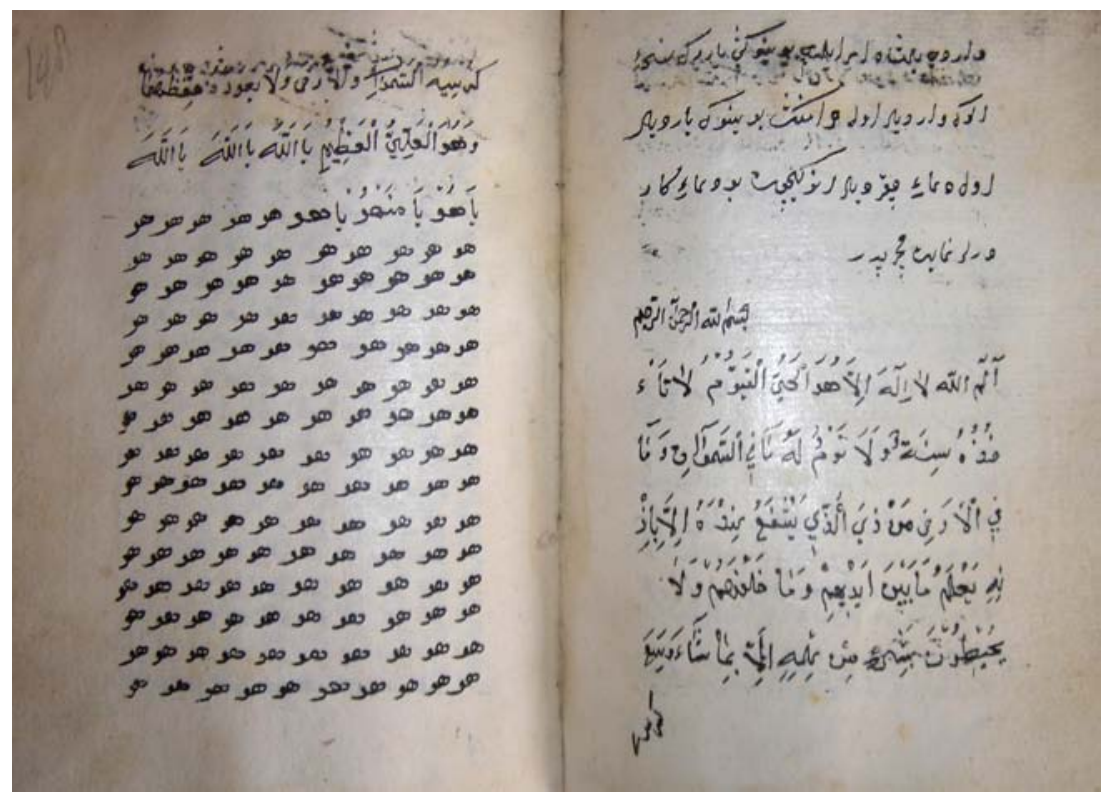

Figure 17. Groningen, UB Hs. 471, ff. 147b-148a. Two pages from a collection of pious and magical texts, 18 th century or earlier.

وقتكه فال اتمك دلسك مصحف كيمدن بر نيت اوزره درست اعتقاديله ابدست اله اند نصكره اوج كه سوره: فاتحه اوقيه

Ends (13a):

$$
\text { حرف كى كلسه لقوله تعالى يس و القرآن الحكيم تأويل خير و سونكدر و سفر مباركدر }
$$

It is followed by two brief texts of a similar type: a Şerḥ-i tekrār-nāme, discussing the letters appearing repeatedly in a chosen Koran passage $(13 \mathrm{~b}-$ 15a); it begins:

ا تكرار كلسه امكدر نسنه حاصل اوملاز بيك جالشسك ب تكرار كلسه كثى معاونت قيلورسه مراد حاصل اولور

Ends (15a):

$$
\text { كى تكرار كلسه ... مكر تهلب حضرتنزه عذركز دليه سين و الله اعلم بالصواب }
$$

A Şerh-i sefer-näme follows on ff. $15 \mathrm{a}-16 \mathrm{a}$, with predictions related to military action; it begins:

قهان سفره كتمك ايهون نيت ايلسك مصحف اجدقده اقلكى حرفنه نظر ايليه قاجان مال تحصل اتك ايهون نيت ايلسك 
It ends (16a):

$$
\text { اكر بواو سلوٍ اوزره دوترلرسه هر كيز فالكدر كزب بولونميا و الله اعلم بالصواب }
$$

Finally we find a list of auspicious days, preceded by an explanation (132b133a), and a gurre-nāme with two tables (205b-206a). An invocation of 'Alī is written on f. 1a. The volume also contains a folded piece of worn paper, approximately $210 \times 170 \mathrm{~mm}$, with a (Christian) prayer text, 23 lines, in an unidentified language in Latin script and in Schoeder's handwriting (begins: Toma io mabolido la Jehova ta mau numma ta jehova tamau.).

Rebound in embossed brown leather with blind tooled insets and ornaments in quasi-oriental style; glazed white to cream paper; an illegible text is written on the fore-edge; $(2)+206+(2)$ folios; $150 \times 102 \mathrm{~mm}$ and $112 \times 68 \mathrm{~mm}$, varying from f. 132a onwards; 10 lines, varying form f. 14ob onwards; small nesih, vowelled in the Arabic texts, and decaying to şikeste in various hands towards the end; red headings, rubrics and lines up to f. $129 \mathrm{~b}$ and on ff. 162a-172b; double red borders on ff. $1 \mathrm{~b}-134 \mathrm{~b}$; circular drawings in black and red on ff. 162b, 163b, 165b, 167a, 168a, 169a, 169b, 170a, and 171b; without a date and the name of a copyist. Probably acquired in 1776 through Nicolaus Wilhelm Schroeder (cf. Brugmans, Catalogus, p. 252).

Catalogue entries: $\mathrm{CCO} 2729$ (V, pp. 288); Voorhoeve, p. 278; Brugmans, Catalogus, p. 252.

Hs. 472

\section{A miscellany}

The undated volume, incomplete at the end, contains a collection of pious texts in Arabic and Turkish. A description of the contents in Latin in the hand of Nicolaus Wilhelm Schroeder (cf. the Introduction to this chapter) is found on the 'title page' (1a). The texts mostly consist of chapters from the Koran $(1 b-23 b)$, which are followed by prayers in Arabic preceded by Turkish com-mentaries. Titles mentioned in headings are Du'ä-i on iki imām (sic, 23b) and Du'a-i Hiżrr-ilyās (25b). The collection breaks off after the first line of the Arabic prayer text (29b). Notes in Latin and German are found on ff. $1 \mathrm{a}$ and in the margin of f. 14b with the names Anna and D. Feyrerin and the years 1614 and 1619 .

Rebound in boards covered in pink and black marbled paper; white glazed paper; $(1)+29+(1)$ folios; $146 \times 97 \mathrm{~mm}$ and $100 \times 50 \mathrm{~mm}$, varying; 11 lines; 
catchwords; calligraphic nesih, vowelled in the Arabic texts; headings and dots in red; without a date and the name of a copyist. Acquired in 1776 (cf. Brugmans, Catalogus, p. 253).

Catalogue entries: $C C O 2730$ (V, p. 288); Voorhoeve, p. 278; Brugmans, Catalogus, p. 253 .

Hs. 473

A miscellany

An undated collection of pious and magical texts, incomplete at the end, which commences with two chapters from the Koran: süras 36 (1b-10a) and 67 (10b-14a), followed by prayers in Arabic, preceded by prescriptions in Turkish, for various purposes; magical formulae are found on $\mathrm{ff} .17 \mathrm{a}, 33^{\text {bis }} \mathrm{a}-\mathrm{b}$, 34b, 54b and 66b.

Latin inscriptions are found on f. 1a: Accepi ex Burgundia á fr. Sebastiano Ranspek [?] d. 15 Feb 1651 per iuvenem Neclementem, and on f. $69 \mathrm{~b}$ in the hand of Nicolaus Wilhelm Schroeder (see the introduction to this chapter), Continet hic Codex Duo Corani capita sci xxxvi et lxvii additis pro more precum formulis Arabicis et Turcicis, with the number XVIII.

Bound in dark brown leather with flap and blind tooled insets in Oriental style; glazed paper without watermarks; 69 folios (33 counted twice); $103 \times 71 \mathrm{~mm}$ and $60 \times 50 \mathrm{~mm}$, varying; 7 lines; catchwords; small vowelled nesih; without a date and the name of a copyist.

Catalogue entries: CCO 2731 (V, p. 288); Brugmans, Catalogus, p. 253.

Hs. 474

A miscellany

The, possibly late 14th-century (cf. under (1) below), volume in oblong format with texts in Arabic and eastern Turkish, written by the same copyist, is incomplete at both the beginning and the end. The penultimate flyleaf, recto, contains a brief description of the contents in Latin in Schoeder's handwriting (cf. below). 


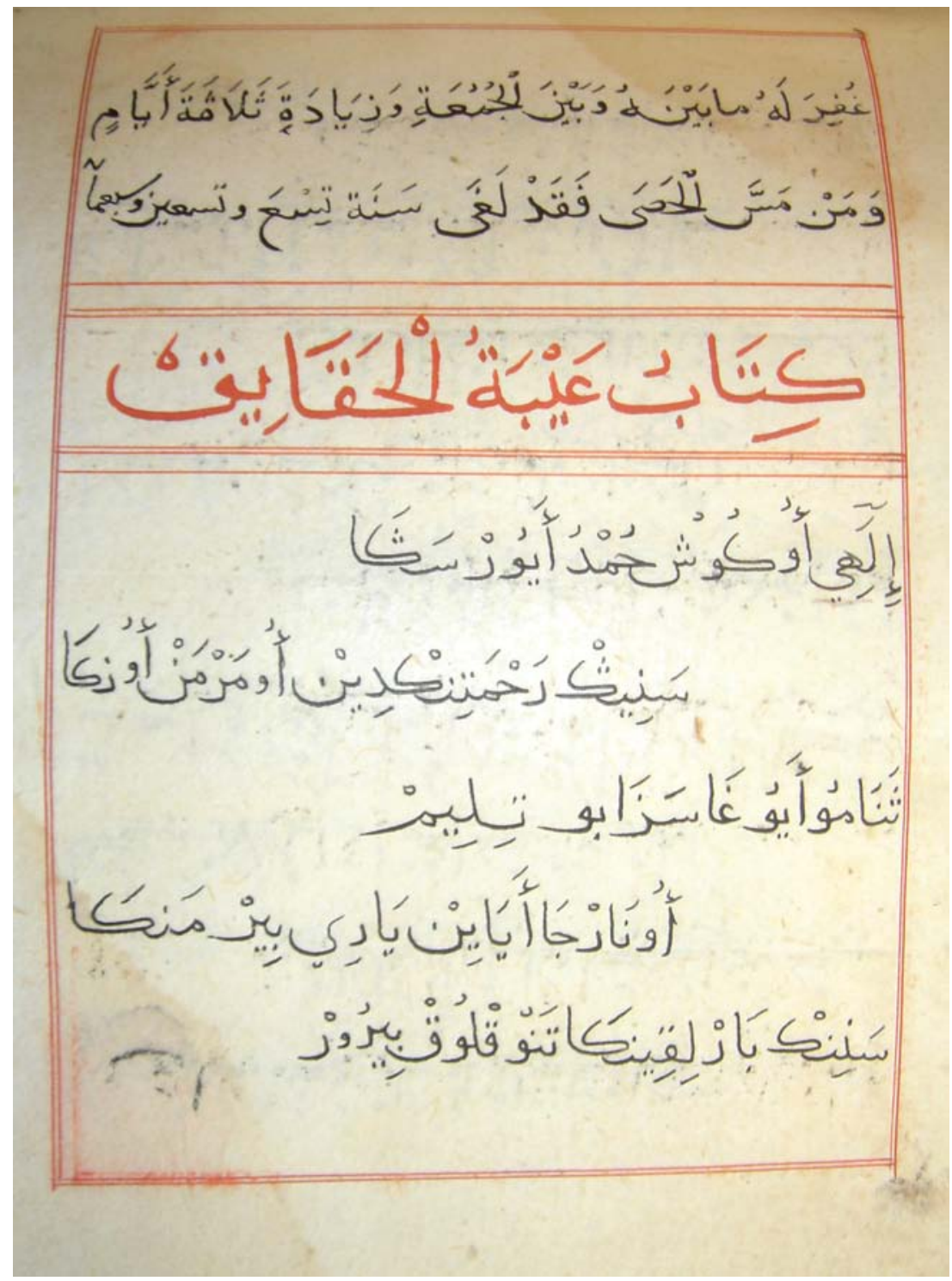

Figure 18. Groningen, UB Hs. 474, f. 9a. A page from a miscellany dated 799 (13961397) in the second line. The erroneously spelt title of 'Atebetü l-hâakāyık, a didactic poem in eastern Turkish by Edīb Ahmed of Yüknek (12th-13th century), is found in the third line. 
(1) ff. la-9a.

A collection of traditions (hadith) in Arabic, probably part of a series of the usual forty, from the final part of the fifth to the thirty-third. The text ends in the year 799 (1396-1397).

(2) ff. 9a-32b

\section{'Atebetü l-hāạkāylk}

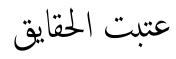

An incomplete copy of a poem, consisting of a series of quatrains, on ethics in eastern Turkish by Edīb Aḥmed b. Maḥmūd of Yüknek, a village near Samarkand, who flourished at the end of the 12th to the early 13th century. The work belongs to the oldest literary works known in any Turkish language. It was dedicated to Dād Sipehsālār Beg, mentioned in some manuscripts and praised on ff. 11b-12b. The title, with the word 'aybe instead of the correct 'atebe, is found in a heading preceding the text on f. ga. The name of the author is mentioned in f. $32 \mathrm{~b}$ :1. The work consists of an introduction ( $9 \mathrm{~b}-12 \mathrm{~b})$, and, in this copy, eight numbered chapters $(b \bar{a} b)$ with headings in Arabic (rendered in Turkish in Rahmeti Arat's edition) - the heading of the first chapter is missing. The work breaks off towards the end of the concluding section (which begins in f. 32:6). Catchwords on ff. 12b and $15 \mathrm{~b}$ do not suit the text following on the next page.

Begins (9a, as in Rahmeti Arat's edition, p. 41:1-2):

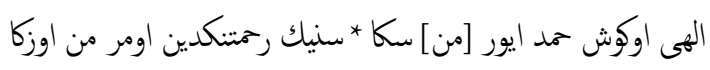

Ends (32b, as in Rahmeti Arat's edition, p. 78:479/477):

$$
\text { قلى بارسا اوزوب سوزوم قالسو تيب * انين از ايرور بو كناب دا سوزنك [تلو] }
$$

Catalogue entries: Karatay 3077; six MSS, among which the Topkapı Sarayı Library MS mentioned by Karatay, are described in the introductory part of Rahmeti Arat's edition, pp. 20-39.

Edition: by Reşid Rahmeti Arat (Istanbul 1951).

Literature: Ahmed Caferoğlu, "La littérature turque de l'époque des Karakhanides", in PhTF, pp. 267-275, esp. 270-271. 
(3) ff. $33 a-57 b$.

A collection of about 72 quatrains in eastern Turkish, incomplete at both

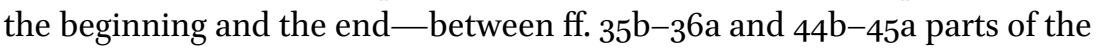
text seem also to be missing - each headed with the word 'by someone else' (li-gayrihī) in bold red script. No mahlaṣ or title is mentioned.

Begins (33a):

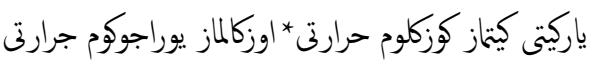

Ends (57b):

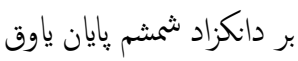

Rebound in embossed brown leather with blind tooled insets and ornaments in quasi-oriental style; glazed white paper, slight moisture damage; pieces are torn or cut from $\mathrm{ff} .26$ and 55 , with loss of text; f. 1 has been worn to partial illegibility; $2+57+2$ folios; $137 \times 182 \mathrm{~mm}$ and $98 \times 145 \mathrm{~mm} ; 9$ lines; occasional catchwords; vowelled nesih; headings, rubrics, Arabic quotations and double borders in red; dated 799 (1396-1397) on f. 9a; without the name of a copyist. Probably acquired in 1776 through Nicolaus Wilhelm Schroeder (cf. Brugmans, Catalogus, p. 253).

Catalogue entries: $\mathrm{CCO} 2732$ (V, pp. 288-289); Voorhoeve, p. 22; Brugmans, Catalogus, p. 253.

Hs. 479

The Book of Psalms

An incomplete, undated copy of the Book of Psalms, 1-48, in Italian, Dutch and Turkish. No name of a translator is mentioned. The Italian together with the Dutch and the Turkish versions are found on separate, alternating folios. The title page (1a) shows the inscription: Versio haec Psalmonim est Persica. quid, quantum e quidem scio, nulli si extat in bibliis Polijglottis. The Psalms are preceded by an introduction (dībāce) in Turkish and Italian (1b-10b). The first part of the Turkish version of the first Psalm is missing; the last lines of it and the beginning of the second Psalm are found on $\mathrm{f}$. 12a. The Turkish text breaks off in an introduction to the 48th Psalm. 


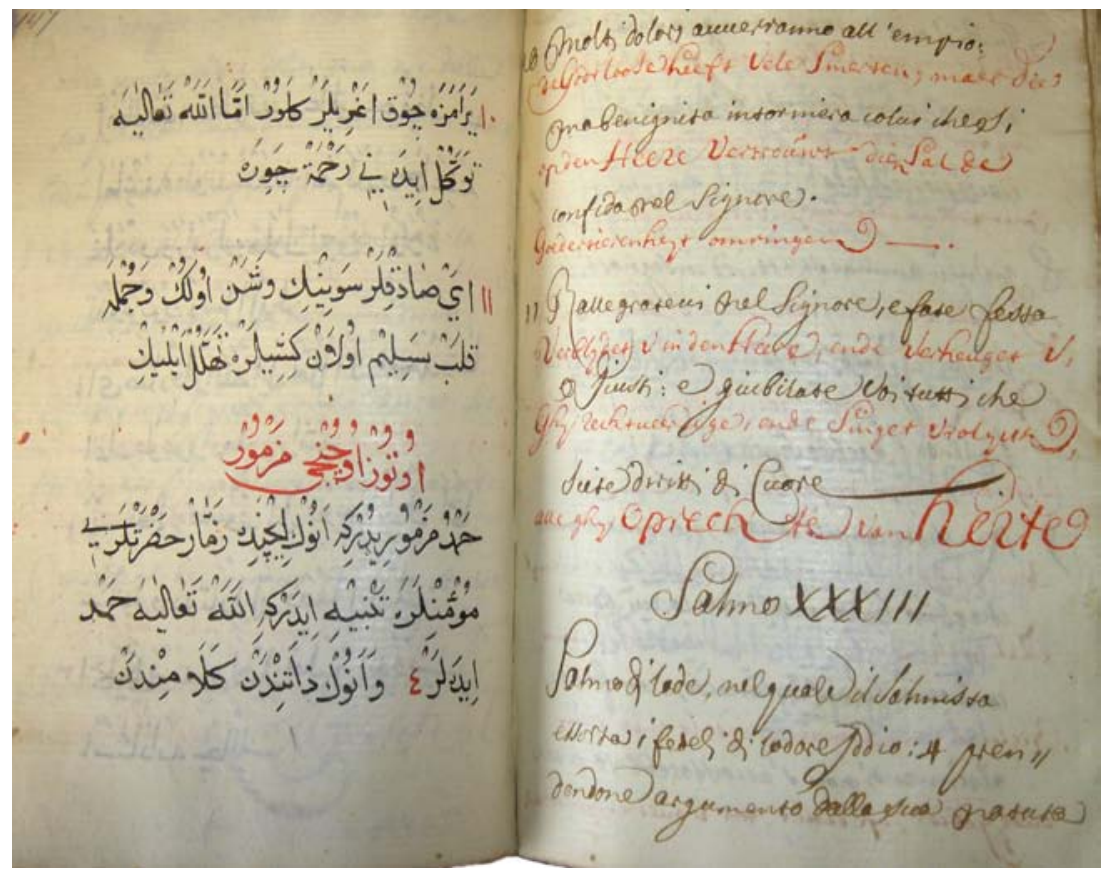

Figure 19. Groningen, UB Hs. 479, ff. 146b-147a. Two pages from a copy of the Book of Psalms in Italian, Turkish and Dutch, first half of the 18th century or earlier.

The first flyleaf, verso, contains a note in Latin on the contents of the manuscript, headed by 'G: Kuijpers 1747’. (Gerardus Kuijpers was professor of Theology at Groningen University from 1765 , see the introduction to this chapter, above.) Two separate leaves have been bound with the volume between $\mathrm{f} .187$ and the last flyleaf; a a folded leaf of red paper with a Chinese text; and a small leaf of white glazed paper $(112 \times 80 \mathrm{~mm})$ with administrative notes in Turkish - the two entries found at the top are dated 1127/1715, they concern a female slave (mollada), whose features are described in the last three lines, with a signature and two seals containing the name Süleymān.

Bound in brown leather with gold ornamentation in Western style; a lable in red and gold with the title PSALMI ET PRECES AR. M:S: is found on the back; glazed white paper; (1) $+187+(2)$ folios; $153 \times 105 \mathrm{~mm}$ and (Turkish text) $110 \times 70 \mathrm{~mm}$, varying; (Turkish text) 10 lines; without catchwords; vowelled nesih; headings, rubrics and, mostly, the Dutch version in red; without a date and the name of a copyist. An inscription, twice in Latin and once in Arabic script, of Hendrick (Henrico) Danti is found on f. 1 . 
Turkish title $(\mathrm{lb})$ :

$$
\text { حضرت داوود ييغمبرك ع م زبورى }
$$

The Turkish introduction begins ( $1 \mathrm{~b} / 3 \mathrm{a}$, after a besmele):

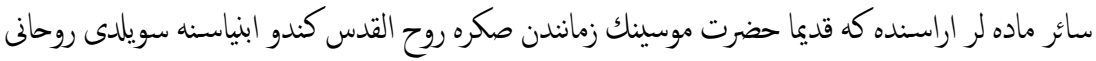

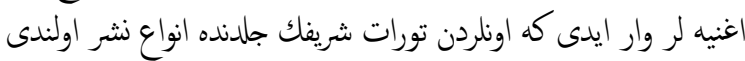

Ends (187b):

$$
\text { اوتوزسكزينجى مزبور ... r ا دوستلردن و دشمنلردن شكايت ايدر ع الكن اونلرك جفالرينه }
$$

Catalogue entry: Brugmans, Catalogus, p. 254.

Hs. 482

Turkish glosses and text fragments

An incomplete, undated copy of an anonymous Arabic treatise without title on grammar with paradigms accompanied by interlinear Turkish explanations in a smaller script. A title in Latin: Literae Turcicae, various notes, the name Maria ... and a series of letters in a Western hand occur on the inside of the front cover. A plethora of text fragments, among which the opening lines of two petitions in Turkish, later erased - the first concerns a posting at the fortress of İstolni Belgirad (Székesferhérvár) — as well notes and jottings in Arabic, Persian and Turkish are found on f. 1 .

Bound in glazed white paper; glazed white paper; 12 folios; $161 \times 110 \mathrm{~mm}$ and $125 \times 75 \mathrm{~mm}$, varying; $6-11$ lines; şikeste; without a date and the name of a copyist. Acquired from the library of Jakob Christmann in 1620 (see the introduction to this chapter).

Begins ( $1 \mathrm{~b}$, after a besmele):

$$
\text { مشرب [اى شرب ايتمك] عذب [اى دنلو اولماق] مركب [اى بنكك] ... }
$$

Ends (12b):

$$
\text { اكتساب اقتصاص امتزاج [اظفار امله] }
$$

Catalogue entries: $C C O 2709$ (V, p. 279); Voorhoeve, p. 415; Brugmans, Catalogus, p. 255 . 
Hs. 483

A miscellany

An undated collection of Koran chapters and, in Turkish, prayer prescriptions, with stories based on hadith; it commences with a series of prayers to be said on the subsequent days and nights of the week ( $1 \mathrm{~b}-10 \mathrm{~b})$. The texts were copied in different hands, and separate parts of the volume only contain Arabic texts: ff. 31b-59b and 6ob-97b. A talisman prescription with a magical formula is found on f. 99a, the first page of a fälnāme on f. $99 \mathrm{~b}$. A description in Latin of the contents in Schroeder's handwriting (cf. below) is found on 100a: Libellus precum partim Turcica, partim Arabica lingua, pro singulis diei cuiusque statis temporibus. subiiciuntur Corani Capita LI-LVII et LXXVIII-CXIV, followed by the number XIII.

Rebound in embossed brown leather with blind tooled insets and ornaments in quasi-oriental style; glazed cream paper; $(2)+99+(2)$ folios; $153 \times$ $100 \mathrm{~mm}$ and $115 \times 70 \mathrm{~mm}$, varying; 7-11 lines; cachwords; vowelled nesih of various formats and in various hands; occasional headings, rubrics, dots and lines in red; without a date and the name of a copyist. Probably acquired in 1776 through Nicolaus Wilhelm Schroeder (cf. Brugmans, Catalogus, p. 255).

Catalogue entries: $\mathrm{CCO}_{2734}$ (V, p. 289); Voorhoeve, pp. 67, 278; Brugmans, p. 255 .

\section{Hs. 484}

\section{A miscellany}

An undated collection of pious and magical texts, mostly prayers in Arabic and Turkish prayer prescriptions, some of them comprising stories based on hadīth; magical formulae and diagrams (in black and red) are found on ff. 22a-23a, 28a, 29b. The 'title page' (6a) contains a title in Latin in Schroeder's (cf. introduction to this chapter) handwriting: Libellus Precum Turcice et Arabice, followed by the number 17. The names of Fātima and the Twelve Imāms are indicated in red on ff. 6oa-66b. The texts are interrupted by blank pages ( $69 a-71 a)$, followed by prayers with preceding Turkish commentary, the names of these indicated in red headings: Du' $\bar{a}-i$ cemill (73a, $79 \mathrm{~b}$ ) and Du'ä-itesbīh (82a). Two further prayer prescriptions (83b-84b), are followed by a Seyir-nāme $\left(84 \mathrm{~b}-10 \mathrm{~b}^{\mathrm{bis}}\right)$, an anonymous treatise on the interpretation of nervous twitches in humans; it begins ( $84 \mathrm{~b}$, after a besmele): 


$$
\text { جدول اختلاج اعضا على اختلاف الاقويل دانيال ذو القرنين سليمان باشك اورتاسى سكرسه شرف و }
$$

The treatise in turn is followed by a few brief texts recounting traditions and prayers $\left(100^{\text {bis }}-104 \mathrm{~b}\right)$. Jottings and text fragments, mostly prayers, occur on the inner boards and endpapers.

Bound in embossed dark brown leather with blind tooled insets in Oriental style on the outer covers; glazed white paper; $105+26$ folios $(100$ numbered twice); $104 \times 77 \mathrm{~mm}$ and $70 \times 45 \mathrm{~mm}$, varying; 7 lines; catchwords; vowelled nesih; occasional headings, rubrics and dots in red; without date and the name of a copyist. The inscription H.R.W. 1625 occurs on f. $105 \mathrm{~b}$; a Latin owner's inscription of Joh. Henr. Hottingerus with the date 5 December 1677 is found on f. 6a (see also the introduction to this chapter). Probably acquired in 1776 through Nicolaus Wilhelm Schroeder (cf. Brugmans, Catalogus, p. 257).

Catalogue entries: $\mathrm{CCO} 2736$ (V, p. 290); Voorhoeve, p. 67; Brugmans, Catalogus, p. 255 .

\section{Hs. 485}

\section{Exercitationes linguae Turcicae}

Autograph 'Exercises in Turkish' by Jacob Christmann (see the introduction to this chapter)-his name is mentioned on the same page (1a) as the title given above - consisting mostly of a (part of) an anonymous treatise on the Islamic religion with Latin transcription (on separate pages), Latin translation (in the margins) and various linguistic annotations (on pages preceding and following the main text). Many pages have remained blank, in particular ff. 35b-49b. A colophon with the date mid-Zí l-hicce 989 (5-14 January 1582) and the the placename of Istanbul is found on f. 5 oa (cf. quotation below).

The Turkish text begins (4a):

$$
\text { اولكى باب كه ايمان بلدرر بلكلكي عالملر ايمان نه ايله تمام اولدغن بيان اتمكده جوق اختلاف ادبدررلر }
$$

The transcription begins $(3 \mathrm{~b})$ :

Evvelkhibaab khiyman bildurur/bilgilkim aalimleryman neylé tamam oldugin bean itmekde tschok ichtilaf idubdururler 


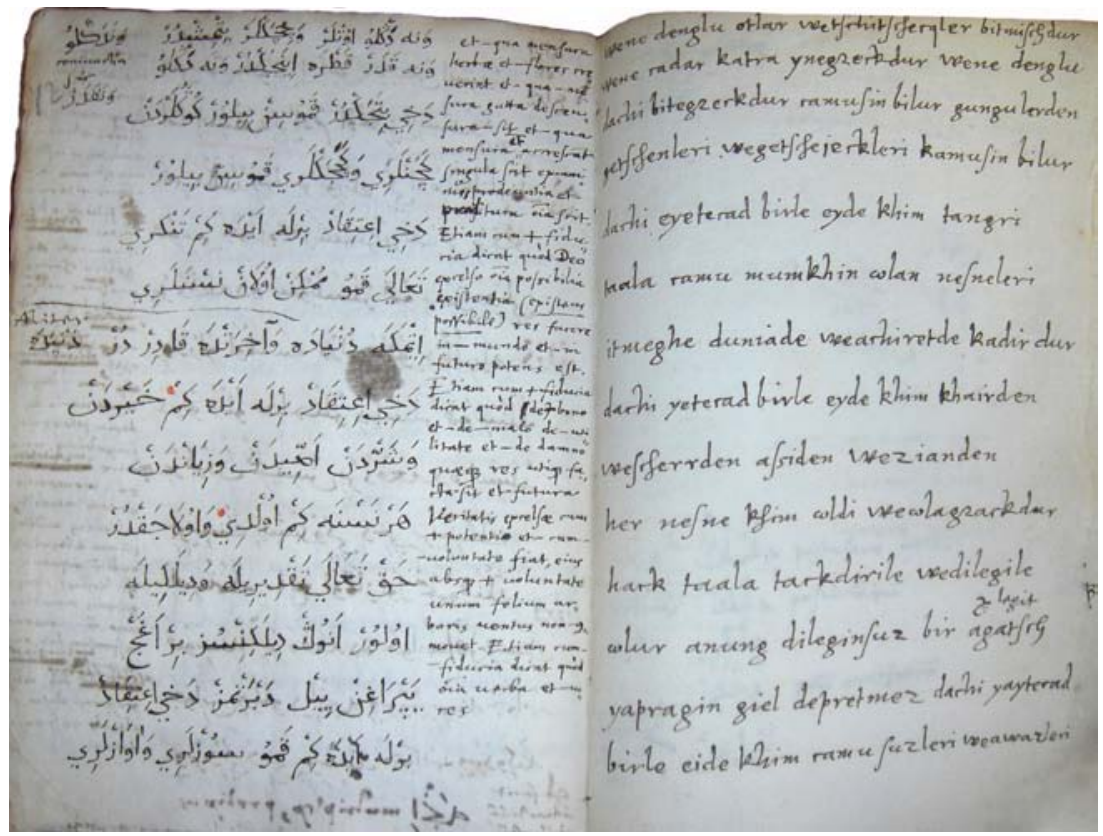

Figure 20. Groningen, UB Hs. 485, ff. 11b-12a. Two pages from an exercise-book filled by Jacob Christmann; dated $989 / 1582$. On the left is the text of an anonymous treatise on religion, a draft translation into Latin is found in the margin; a transcription of the Turkish text is on the right.

Ends (33a):

نيجه مؤمنلره دخى ايدجكدر كم اى مؤمن تيز كهكيل كه سنك ايمانك نورى بنم اودومى سويندرمسون ديجكدر

And (32b):

nitsche muuminlere dachi eidegzekdur khim y mumin tez getschgil khi senung imanung nuri benum odumi suyundurmesun digzeckdur

Colophon (50a):

$$
\text { في اوسط ذى الحجه سنه تسع و تاميه و تسع مايه ...بمقام قوسطنطينى }
$$

With the transcription:

fi eywasitti silhiddgze sene tisza wesemaniije wetisza meja

Bound in a leaf of paper, containing on both sides a varicoloured, probably late-mediaeval Latin text in Gothic script with staffs of musical notes 
(cf. Hs. 493); white paper; 50 folios; $173 \times 120 \mathrm{~mm}$; no regular written surface; elegant vowelled nesih; autograph by Johann Christmann, dated 989/1582, see also above.

Catalogue entries: CCO 2711 (V, p. 28o); Brugmans, Catalogus, pp. 255-256.

Hs. 486

A poem

A draft copy, with erasures and additions, of an anonymous poem of 33 beyts in mesnevi rhyme. The poem describes a battle against 'Frankish' infidels under the command of Ferenc Nádasdy (1555-1603, cf. BLKO 19, pp. 20-21), who were crushingly defeated in the plain of Budin (Buda, cf. the seventh line); the work is dated 5 Receb 995 (11 June 1587 , cf. the penultimate line, quoted below). Which battle is meant, is not clear-the last major Hungarian campaign undertaken by the Ottomans dated from 973-974 (1566). The names of Sinān Paşa and Cān Beg, an irregular horseman (deli) who was also the author and participant of the battle are mentioned in the penultimate line and elsewhere. The poem was probably meant to be offered to the pasha, possibly identical with Frenk Sinān Paşa (governor of Buda from March 1587 to November 1588, cf. Fekete Lajos, Budapest a Törökkorban (Budapest 1944), p. 216), and was, it seems from the last line, a request to grant him, now horseless, a new riding animal. Verse fragments are also scribbled on the back.

Begins:

$$
\text { حدايه شكر فروار بحمد الله سزه قلدى بو احسانى *او كافرلر كه سندردك زبون اتمشلر جهانى }
$$

Ends:

$$
\text { بورتك طقوز يوز طقسان بش رجب ايكده تمام * يورد طابور جان بك التنده سنان یاشا يتحام }
$$

Coarse brownish paper, somewhat worn at the edges; approximately $720 \times$ $240 \mathrm{~mm}$; irregular şikeste. The MS is kept between boards on which a label with the text Diploma Turcicum, charactere diwani exaratum has been pasted. Acquired from the library of Jakob Christmann in 1620 (see the introduction to this chapter).

Catalogue entries: CCO 2714 (V, p. 281); Brugmans, Catalogus, p. 256. 
Edition \& Translation: Edith Gülçin Ambros \& Jan Schmidt, "A Rhymed Petition of 1587 by a Deli: A Unique Document Kept in the Groningen University Library (Hs. 486)", Şinasi Tekin'in Anısına Uygurlardan Osmanlıya (Istanbul 2005), pp. 112-121.

Hs. 487

\section{Calligraphic samples}

A scroll with (combinations of) letters and text fragments, including verses by the scribe, in Arabic, Persian and Turkish, serving as samples for various

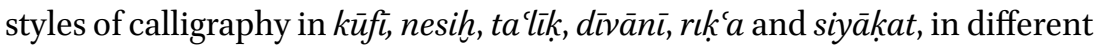
variations and formats-most names of the scripts are mentioned in the left margin. At the bottom there is an undated colophon with the name of İsmā'ìl, a scribe in the service of the $D \bar{v} v \bar{a} n$. The Turkish samples comprise three opening lines of a letter (in $d \bar{\imath} v \bar{a} n \bar{\imath})$; two opening lines of a petition for a posting - salary 30 a ķçe - at the Selimìye Mosque in Istanbul (in siyāḳat); two opening lines of a letter to the Sultan (in $r \iota k^{c} a$ ); various administrative entries, among them five signatures (in defter kırması); and a preamble with a honorific title addressing an Emīr (one line, small dīvānī), followed by a verse: gözüm yaşı gibi her yaña aḳma * gözüm nūrı beni gözden bıraḳma (vowelled ta'like).

Glazed white paper, worn at the bottom; $980 \times 253 \mathrm{~mm}$; designed by İsmā̄ôl; without a date. Acquired from the library of Jakob Christmann in 1620 (see the introduction to this chapter).

Catalogue entries: $\mathrm{CCO} 2714$ (V, p. 281); Brugmans, Catalogus, p. 256.

\section{Hs. 488}

\section{A miscellany}

The undated volume contains two works, both written by the same copyist. A description of the contents in Latin in Schroeder's handwriting (cf. below) is found on the 'title page' (79b): Est narratio casuum singularium Nasroddini Chovagiae. Turcice. Accedit narratiuncularum lepidarum. Turcice., followed by the number XIV. On the last flyleaf, verso, there are notes in a less litterate hand on the contents in Latin and the number 4. 


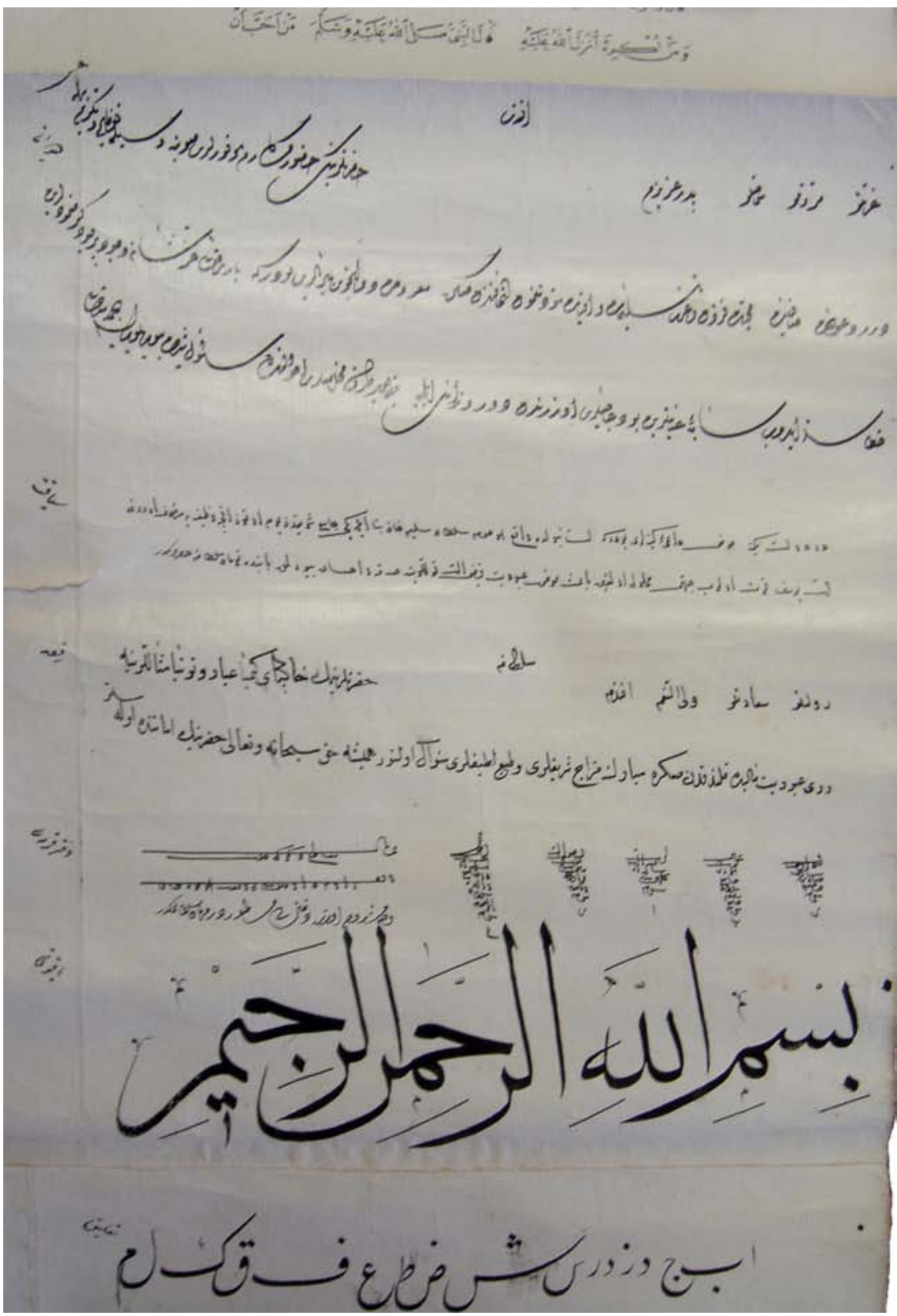

Figure 21. Groningen, UB Hs. 487, middle section. Part of a scroll with calligraphic samples, with texts in Arabic, Persian and Turkish, before 1620. 
(1) ff. $79 a-62 b$

Menāḳıb-ı Nașruddīn Hōōca

مناقب نصر الدين خواجه

A collection of stories/anecdotes in which the traditional Turkish 'wise fool' figure of Nașruddīn Hōca is the protagonist. The title is found in a heading preceding the text on $\mathrm{f}$. 79 a. The 76 stories in simple Turkish, numbered in the margin, have always enjoyed a large readership (audience). Many collections exist in manuscript and have been printed, often with illustrations, in numerous editions ever since the 19th century; there are also translations into many languages. The present collection contains, as is explained in the introduction, four chapters $(b \bar{a} b)$ devoted to, respectively, stories about the hōca himself, women (6gb), his son and a person indicated as 'imād (66a). The fourth chapter is not indicated separately in the text. Most of the anecdotes here collected are not more than coarse, facetious jokes. (For copies of similar collections, see Leiden, UB Codices Or. 1132 and 2067.)

Begins (79a):

راويان اخبار و ناقلان اثار روايت اتديلر كه نصر الدين خوجه درلر سوزى حصارده بر عزيز واردى انوك أك

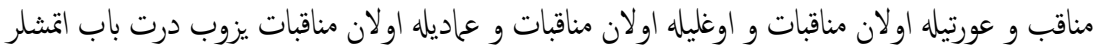
Ends $(63 a-62 b)$ :

$$
\text { بصر الدين خواجه اشكك قاضى اومش دمشلر ... بر سيدى قازى اشغى درر تعجب ايليوب فكر ادركى }
$$

Catalogue entries: Ethé 2092-2098; Majda 9; Rieu, p. 224; Schmidt 5-7; TYTK (Antalya) 2055.

Editions (selective): K.R.F. Burrill, "The Nasreddin Hoca Stories. An Early Ottoman Manuscript at the University of Groningen", in Archivum Ottomanum II (1970), pp. 7-114, with a facsimile of the text; Būlāq 1257; Istanbul 1303,1325 .

Translations (selective): into English, see Burrill's edition, pp. 32-48; into French (from 1847 at Izmir); Arabic (Būlāq 1260); German (from 1911); Persian (Tehran 1315); Hungarian (Budapest 1899); Russian (from 1970); Bulgarian (Sofia 1975).

Literature (selective): the Introduction to Burrill's edition; Ahmed Kudsi Tecer, "Nasreddīn Hoca", in $\dot{I} A$; U. Marzolph, "Nașr ad-Dīn Khodja", in $E I^{2}$; Şükrü Kurgan, Nasrettin Hoca (Ankara 1986); Mustafa Duman, "En eski 
kaynaklarda Nasreddin Hoca", in Tarih ve Toplum 1484 (1990), pp. 381-384; Saim Sakaoğlu, Türk fikralarıve Nasrettin Hoca (Konya 1992).

(2) ff. 57a-la

Dāfíu l-ġumūm ve rāfíu l-hümüm

دافع الغموم و رافع المموم

A treatise on the practice of sex in its various forms, illustrated with poems and erotic anecdotes, by Meḥmed, who used the pen-name of Gazālī and was nicknamed 'Deli Birāder' (d. 941/1534-1535). The title is mentioned in f. 55a:1. The heading Lațîfe-i Dìvāne Birāder is found in a heading preceding the text on f. 57a. The book was written in commission of a certain Piyāle Beg (cf. f. 56a:2) for the author's patron Prince Korkud (mentioned in f. $56 \mathrm{~b}: 11$ ). The latter seems to have been displeased with the work and dismissed the author from his court at Amasya. It consists of an introduction (57a-55a), which mentions five sources (55b), and, according to the introduction, seven chapters $(b \bar{a} b)$ by which the stories were grouped according to themes, ranging from 'the benefits of marriage and adultery', to masturbation, bestiality, catamites and pimps - the titles are printed in Flügel I, p. 427; these are not found in the text itself. The work seems to be incomplete at the end.

Begins (57a):

ناقلان اخبار ظرافت شعار و راويان روايت مودت آميز و حاكيان حكايت محبت انكيز ... شيله نقل انديلر

Ends (1a):

لطيفه بر عورته صورمشلر سيك نه اصل اولنجق ايودر ديو ... بوندن اكسك اوليجق * ديش فور دليجق ديرلر

Catalogue entries: Blochet A.F. 394, S. 441, 653; Kut 346; Flügel 442-443; Pertsch (Berlin) 460.

Literature: 'OM II, pp. 48-49; HOP III, pp. 36-40; G. Alpay, "Ghazālī", in $E I^{2}$, Selim Kuru, "Sex in the Text: Deli Birader's Dâfiül 'l-gumûm ve Râfiülhumûm and the Ottoman literary Canon", in: Middle Eastern Literature 10/2 (2007), pp. 157-174.

Bound in embossed brown leather with gold-cum-red tooled insets in Oriental style; two red ribbons each attached to the front- and back-covers; 
glazed white paper; $11+79+1$ folios, numbered in Western style; $155 \times 105 \mathrm{~mm}$ and $105 \times 70 \mathrm{~mm}$, varying; 13 lines; catchwords; small nesih; headings, rubrics and dots in red; without a date and the name of a copyist. The inscription H.R.W. 1625 occurs on the flyleaf opposte f. 1a; a Latin owner's inscription of Joh. Henr. Hottingerus with the date 5 December 1677 is found on $\mathrm{f} .79 \mathrm{~b}$ (see also the introduction to this chapter). Probably acquired in 1776 through Nicolaus Wilhelm Schroeder (cf. Brugmans, Catalogus, p. 256).

Catalogue entries: $C C O 2715$ (V, pp. 281-282); Brugmans, Catalogus, p. 256.

Hs. 489

Yūsufu Züleyhā

يوسف و زليخا

An autograph copy of a long poem in mesnevi rhyme, recounting the story of Yūsuf and Züleyhāā, by Zihnī Efendi who is probably identical with Zihnī 'Abdüldelil of Baghdad. According to a colophon on f. 146a, the work was completed in the first part of Cemāzi l-ähir 1024 (28 June-7 July 1615, cf. the article by Türledoğan, mentioned below, p. 77). No other copy of the work has hitherto been found. The title and the name of the author are mentioned twice on the 'title page', f. 2a. (The name of the author is also mentioned on f. 1a.) A note on the same page, f. $2 a$, indicates that the text was written by the author himself (cf. quotation below). The work does not seem to be documented and the identity of the author cannot be established with any certainty. The work is preceded by five introductory sections $(2 b-8 b)$, the last of which $(7 \mathrm{~b}-8 \mathrm{~b})$ is a personal prayer by the author, who, however, does not reveal his name. A few marginal additions.

A description in Latin, possibly by Schroeder, of the contents and authorship (ascribed to Dhahni Efendifilius Karfes Zanis - the last part of the name probably did not belong to the author but to a later owner, cf. below) is found on the second flyleaf, recto, with the addition that the manuscript was a gift of the Professor of History, Leonard Offerhaus [1699-1779, see also the introduction to this chapter]. According to an inscription, also in Latin, on the next page (second flyleaf, verso), the manuscript had been obtained at the conquest of Buda by Johann Schmitz, governor of 'Lipp. Swalenburgensis' [= Lipova], and given to Henricus [Heinrich] Mische in 1695 (quoted in $\mathrm{CCO}$ and Brugmans, Catalogus). The inscription is followed by the number XII. A prescription for a medicine ( 5 lines) is found on $\mathrm{f} . \mathrm{lb}$. 


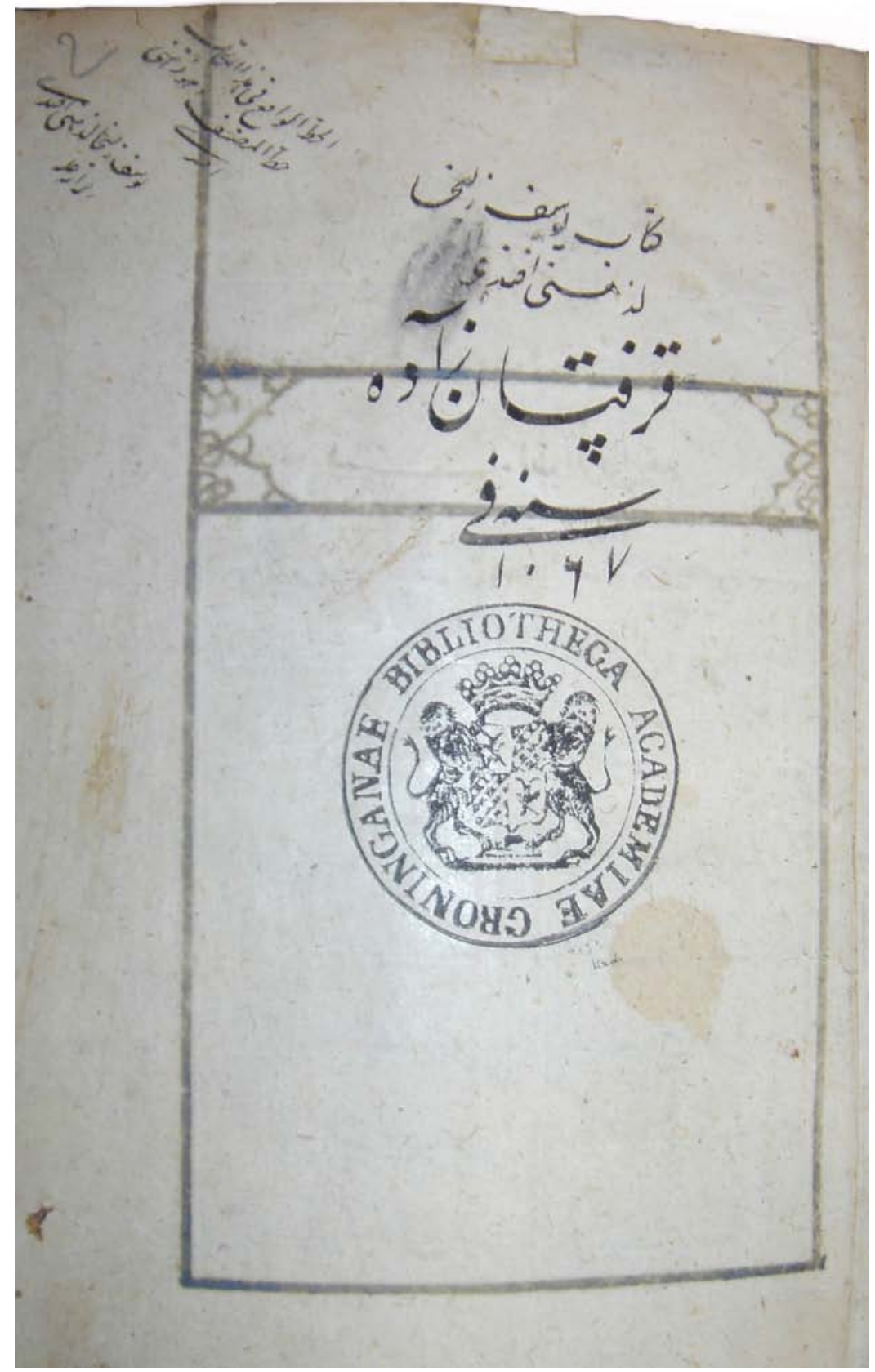

Figure 22. Groningen, UB Hs. 489, f. 2a. The 'title page' of a unique, autograph copy of Zihnī Efendi's Yūsufu Züleyhā, written in 1024/1615. 
Note on the autograph status of the MS (2a):

$$
\text { الخط الواقع فى هذا الكتاب خط المصنف و هو ذهنى افندى }
$$

Begins (2b, after a besmele):

$$
\text { آلهى باغ طبعم قيل كلستان * اميدم غنجه سنى ايله خندان }
$$

Ends (146a):

$$
\text { حمد الله كه بو نظم بحانسوز *اولبدر هم دلارا هم دلفروز }
$$$$
\text { و الله اعلم }
$$

Colophon (ibidem):

$$
\text { تخريراً فى اوايل جماذى الاخره سنه اربع و عشرين و الف تح }
$$

Bound in embossed light and dark brown leather with flap and blind tooled insets in Oriental style; glazed cream paper; $2+146+13$ folios; $180 \times 110 \mathrm{~mm}$ and $120 \times 75 \mathrm{~mm}$, varying; 11 lines; catchwords; calligraphic talïk; initial besmele and headings, omitted from f. 126a, in red; (oxidised) gold borders within black lines on ff. $2 \mathrm{~b}-3 \mathrm{~b}$; a simple headpiece in gold and red stippling on f. 2b; an owner's inscription of Karfetānzāde [?] with the year 1067 $\left(165^{6-1657)}\right.$ is found on $\mathrm{f} .2 \mathrm{a}$.

Catalogue entries: CCO 2719 (V, p. 283); Brugmans, Catalogus, p. 256.

Literature: Melike Gökcan Türkdoğan, "Klâsik Edebiyatında Kur’an kıssalarını konu alan mesnevileri", in: The Journal of International Social Research 3/15 (2010), pp. 77 .

Hs. 490

Dīvān

ديوان

An undated copy of the collected poems of Ușūlī (d. 945/1538-1539), in parts erroneously bound and incomplete at the beginnning - the first ten distichs of the mirāciye with which the work commences are missing. A description in Latin of the contents, but without the name of the author, possibly by Schoeder, is found on f. 70a. The work proper is preceded $(1 \mathrm{a}-2 \mathrm{~b})$ by an incomplete series of quatrains elaborating Arabic quotations from hadith which occur in some copies of the Divan at the end, and comprise, in their fullest extent, 80 items (cf. İsen's edition, pp. 19-20). The mirācīye is followed by some mesnevīs: Münācāt-i bār-i ta'älā (6b);

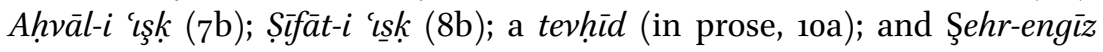




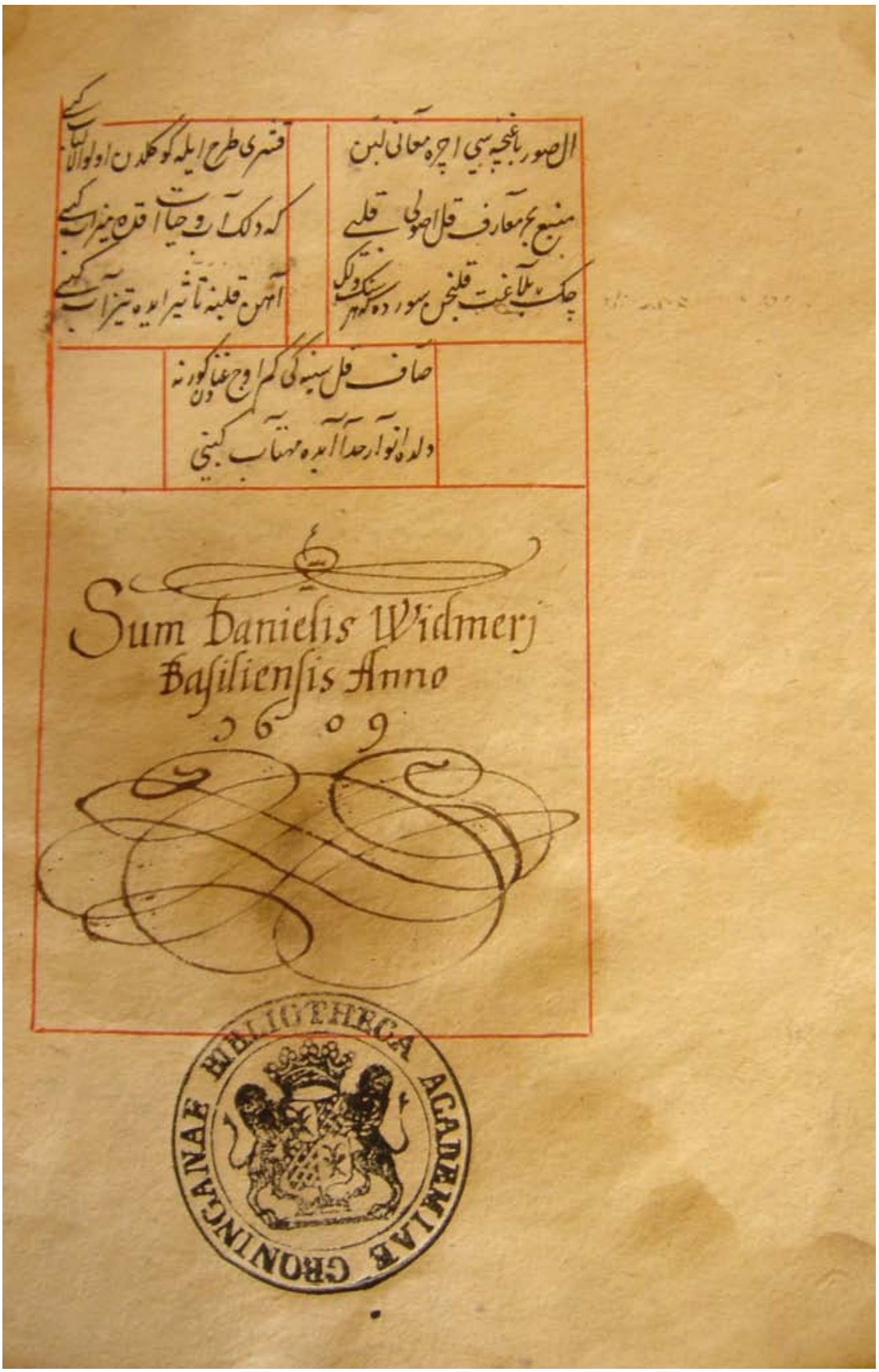

Figure 23. Groningen, UB Hs. 490, f. 6gb. The last page of a copy of the Dìvān of Ușulì, with an author's inscription by Daniel Widmer of Basel, dated 1609 . 
der Yeñiçe (10b), followed by 5 ḳașides (18a); a merșiye on the death of Shaykh Gülşenī (25a); a müseddes in praise of the shah of Khurāsān [the Imām Mūsā er-Rıżā] (26a); a muhammes der tevḥīd [on a gazel by Seyyid] (27a); a muhammes [on a ġazel by Nesīmī] (28a); a mu'aşşer in praise of the Prophet (29a); 3 mürabba's (30a); 4 kıt 'as (32a); and $114 \dot{g} a z e l$ in

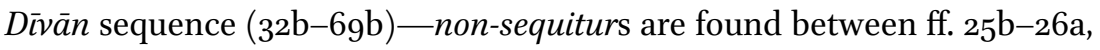
32b-33a, 4ob-41a, 46b-47a and 67b-68a.

A few marginal additions. Remnants of a Persian distich in bold ta'īk and some illegible jottings are found on the inner front-boards; a series of Persian verses in the shape of a tree, and all rhymed in -im, the final words being Şāh Selim, are found on f. $72 \mathrm{a}$ - these are surrounded by Turkish beyts in a smaller script; a plethora of verses (kıț as), some attributed to Ahmed Paşa and in the same hand, but partly erased by blotting, occur on the next page, f. $72 b$.

Bound dark brown leather with flap and blind tooled insets in Oriental style; glazed cream and pale yellow paper, partly stained by moisture; 72 folios; $212 \times 130 \mathrm{~mm}$ and $139 \times 73 \mathrm{~mm} ; 13$ lines; catch words, occasionally omitted or erased; calligraphic ta līk; headings in gold up to f. $32 \mathrm{a}$; multiple borders in red and blue; gold borders within black lines on ff. $32 \mathrm{~b}-33^{2}$; an owner's seal of Hōoca Üftāde is found on f. 1ob; an author's inscription in calligraphic Latin of Daniel Widmer of Basel, with the year 16o9, is found on f. 6gb. Probably acquired in 1776 through Nicolaus Wilhelm Schroeder (cf. Brugmans, Catalogus, p. 257).

Begins (1a):

$$
\text { حن عقدى تلى ليا فقد آذبته بالحرب حضرت يِيغمبره وردى خبر *بر لكمييله بنم بز كسه كم قلسه جدال }
$$

The mírācīye begins (3a, as in İsen's edition, p. 29:21-22):

$$
\text { اون سكز بيك عالمى جرخى هم * شش جهت شش روزده قلدى رقز }
$$

Ends (69b, as in İsen's edition, p. 239, penultimate distich):

$$
\text { صآف قل سينه كى كई اوج غنادن كورنه * دلده انوآر خدآ آبده محتآب كى : }
$$

Catalogue entries: CCO 2720 (V, pp. 283-284); Brugmans, Catalogus, p. 257; Blochet A.F. 284; Divanlar I, pp. 112-113; Karatay 2317; Rieu, pp. 175-176, 208; see also İsen's edition, p. 25. 
Edition: Mustafa İsen, Usûlî Divanı (Ankara 199o), with a facsimile of MS Feyzi Paşa 2209 (kept in the Çorum İl Halk Library).

Literature: 'OM II, p. 76; HOP III, pp. 45-46.

Hs. 491

\section{A miscellany}

The manuscript contains texts which originally seem to have been part of more than one volume. It dates from the first half of the 17 th century (see under 3), but some parts may be older. Inscriptions in a somewhat enigmatic German by a soldier who had found the manuscript, written up-side down, are found on $\mathrm{ff} .18^{\text {bis }}$ a:Dass buch hob ich gefunden in na bei vor meinen Feind wüh den sondmock gediet hob under den sodowüchichsen regemend gedient hab, and 19b-20a (largely faded to illegibility). These make it likely that at least a part of the manuscript was acquired as war booty. The last (relatively new) flyleaf, recto, contains an inscription by, it seems, Nicolaus Wilhelm Schroeder (cf. the introduction to this chapter): Carmina Turcica in laudem Muhammedis et alia. Liber ab initio et fine mutilus.; the number 35 is added in different ink. Various annotations are found on the inner frontboard: a prescription for a prayer for the death (3 lines) and two fragments of prayers in Arabic. A list of saints and the number of times a vow should be devoted to them in case of dire need, and a prayer prescription are found on the 'title page' (1a). A few text fragments are also found on the following two pages: a g gazel by Kadirī (1b); a beyt (2a); a gazel (ibidem); and a prayer prescription (5 lines, ibidem).

(1) ff. 2b-4a.

A kașide warning the population of Istanbul for the wrath of God and rhymed in -āh, by Fakīīi. The last part, from f. 3 b:11, is partly autobiographical, and mentions his place of birth as Konya (3b:14); the pen-name of the poet is found in f. 4a:5 (cf. quotation below).

Begins (2b):

$$
\text { ايام قوم اسلامبول بيلك تحقيق اولوك آكهاه بايرور ناكهان بركون سيزه قهريه حشم الله }
$$

Final lines (4a):

$$
\text { فقيرى لطف ايدوب اكك دعا و حير همتله *كوكل برلو كين ايلك بزومله اي رجال الله }
$$


(2) ff. $4 \mathrm{~b}-18 \mathrm{~b}$

Vesīletün-necāt fì mevlūdi n-nebì 'aleyhī șș̣alāt

$$
\text { وسيلة النجات فى مولود النبى عليه الصلاة }
$$

A copy, incomplete at the end, of the popular poem in mesnevi rhyme in praise of the Prophet by Muhammad by Süleymān Çelebi (d. 826/1422), Imam at the Great Mosque of Bursa. The work is also simply known as Mevlid or Mevlüd. From the 16th century onward, the poem has been recited as part of the celebration of Muhammad's birth (on 12 Rebïül-evvel). The main subjects of the work are a discourse on the Light of Muhammad, his birth, the wonders preceding it, his virtues, the miracles attributed to him, the mirāc (his journey to heaven), and his last illness and death. (For other copies, complete and fragmentary, of the same work, see Leiden, UB Codices Or. 1205(4), 12.395(1), $12.397(1,2,3), 12.441(1), 14.555(5)$, and 25.769.) Headings are omitted on ff. $4 \mathrm{~b}-8 \mathrm{~b}$ and $18 \mathrm{a}-\mathrm{b}$. Verses, invoking the Prophet and written up-side down, are found in the margin of f. $6 \mathrm{~b}$.

Begins (4b, after a besmele, as in Ateş's edition, p. 92:1):

$$
\text { الله آدين ذكر ايده لم اولا *واجب اولدر جمله اشده هر قولا }
$$

Ends (18a, as in Ateş's edition, p. 139:17):

$$
\text { اى دده سزسز بز اوش قلدق يتيم * فرقتك اودى بيزى يقدى عظيم [فاطميله] }
$$

Catalogue entries: Götz II, 501, where other MSS are mentioned; see also Fihris 5077-5084 (IV, pp. 260-261); Yardım 3507.

Editions: by Ahmed Ateş (Ankara 1954) in Latin script with facsimile plates; among the more popular versions in Latin script are those by Tahir Alangu (Istanbul 1958) and Ahmet Kahraman (Istanbul 1972).

Translations: into many languages, see the articles by Burrill and Pekolcay; an English translation was made by F. Lyman MacCallum, The Mevlidi Sherif by Süleyman Chelebi (London 1943).

Literature: Kathleen R.F. Burrill, "Süleymān Çelebi, Dede" in $E I^{2}$; Neclâ Pekolcay, "Süleyman Çelebî" in İA; by the same: Mevlid (Ankara 1993); see also the introductory parts to Ateş's edition. 


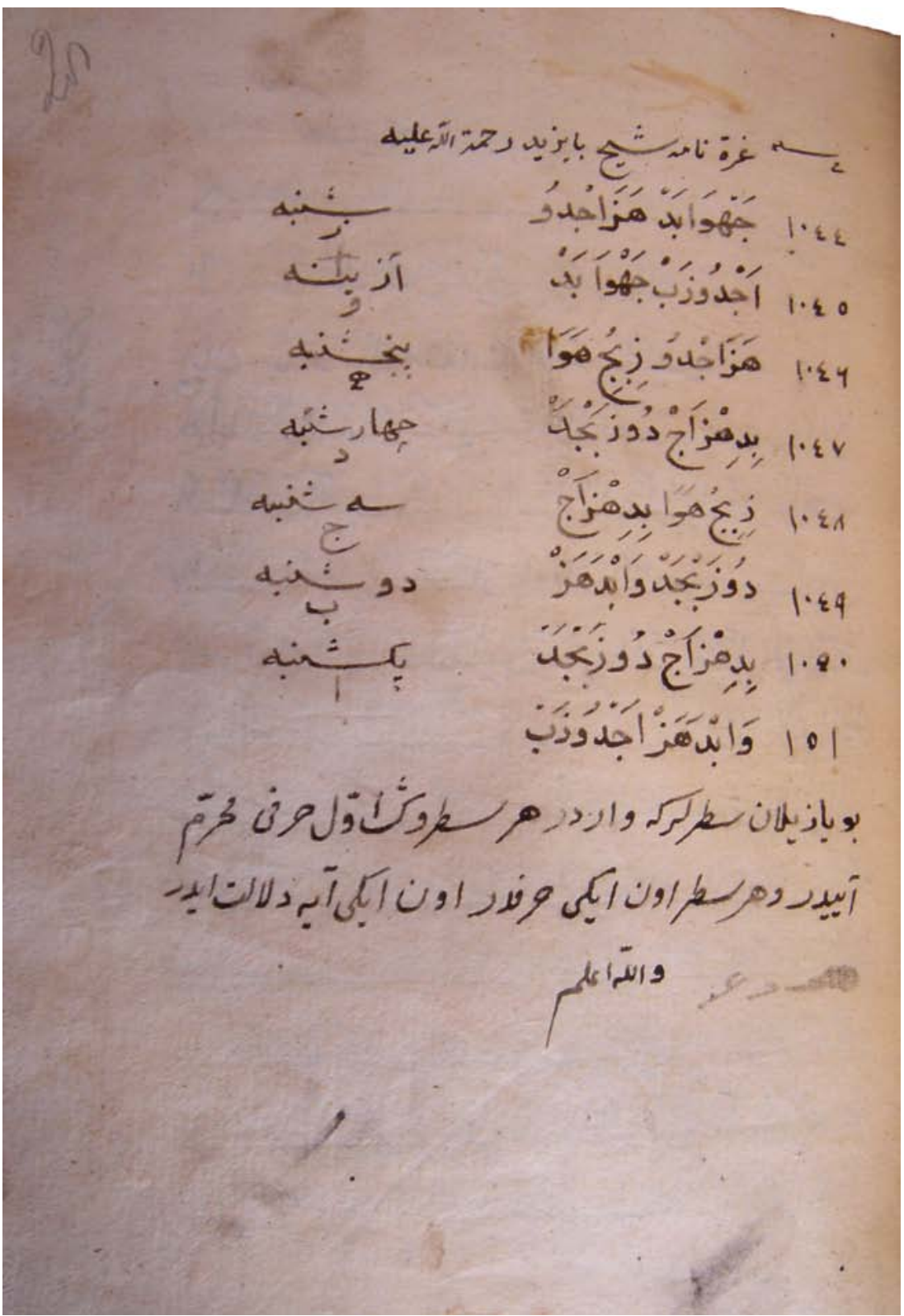

Figure 24. Groningen, UB Hs. 491, f. 28a. A gंurre-nāme for the years 1044-1051 (1634-1642) found in a miscellany. 
(3) ff. 28b-39a

Pious texts in Arabic, Persian and Turkish

These consists of a Wird-i sharif (in Arabic, 28b-3ob); an anonymous tract, beginning with a brief introduction (3ob-31a), on the seven stages ('circles', $d \bar{a}^{\prime}$ ire $)$ of the path towards the truth (tarik-i haḳikat, 3ob-35b), begins (3ob, after a besmele):

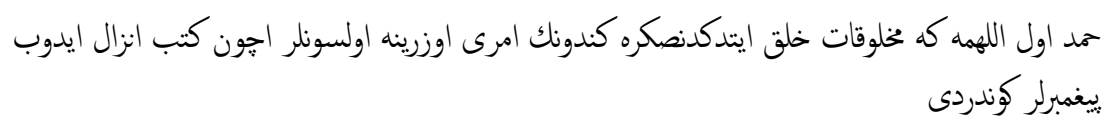

a prayer in Arabic (35b-37a); an Āyat Abū Bakr aṣ-Ṣiddīq (in Arabic, 37a); a prayer prescription (37b); a colloquy between the Prophet İsāand some boys (in Persian, 38a); a prayer prescription to be said on entering a privy, followed by a magical diagram (ibidem); an Āyat 'Umar al-Fārūq (in Arabic, $38 \mathrm{~b})$; and a prayer prescription for avoiding a vision of Hell when visiting the graves of one's parents (39a). The texts are preceded by a gurre-nāme attributed to Shaykh Bāyezīd and covering the years 1044-1051 (1634-1642).

(4) ff. $40 a-45 b$

Beyān-i su'āl-i cevāb ve cevāb be-su'āl

$$
\text { بيان سؤال جواب و جواب بسؤال }
$$

A copy of an anonymous tract which consists of a series of questions and answers regarding the tenets of the Islamic faith. The title is found in a heading preceding the text on $\mathrm{f}$. 40a.

Begins (40a):

$$
\text { آكر صورسلر مسلمان مسين جواب ويرك المّد قله مونداش هر بر مسلمان بو سؤاللرى بلمك فرض عيندر سؤال }
$$

Ends (45bo):

$$
\text { دحى لعين [?] ديدوكوك اولومدر دحى صرب ديدوكك عملسز قبر دكيرمكر و السلام }
$$




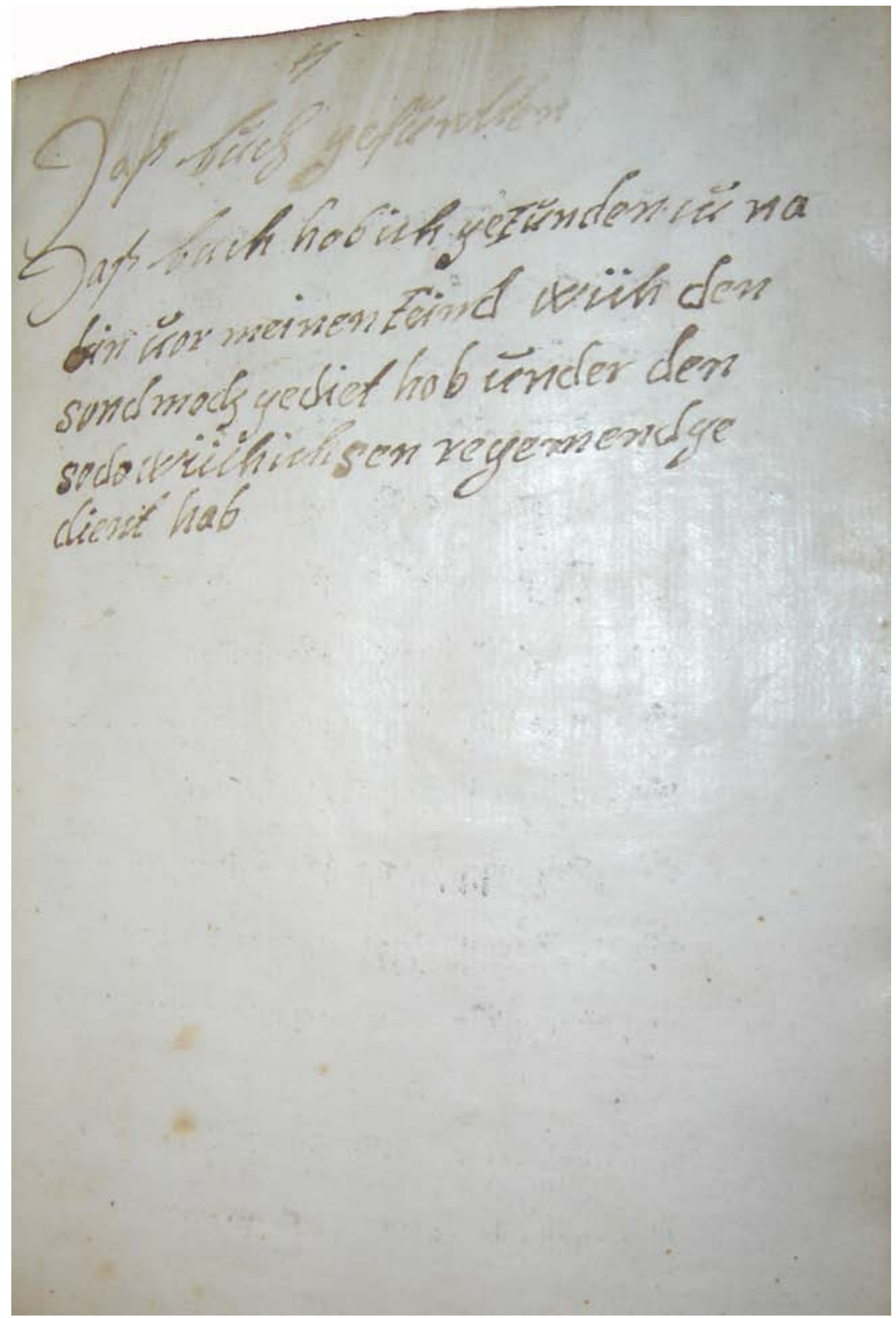

Figure 25. Groningen, UB Hs. 491, f. 18(bis)a. An inscription in German of a soldier declaring that he had found the manuscript on, apparently, a battlefield. 
(5) ff. $48 \mathrm{a}-\mathrm{b}$

Two pious prescriptions

A prescription for a prayer and Koran reading, to be preceded by an ablution with April rain kept in a bucket not made of copper and attributed to the Prophet (19 lines) and a prescription for a prayer to be performed on a Wednesday by readers who have neither son nor servant (7 lines).

(6) ff. $51 \mathrm{a}-97 \mathrm{~b}$

Dīvān

ديوان

An undated copy, incomplete both at the beginning and the end, of a collection of poems by İsmāīl of Karaman, who wrote under the pen-names of Kemāl Ümmī and Ümmī Kemāl (d. 88o/1475-1477); the mahlaṣ of the author is found in either form in most poems. The collection contains one ilāhi in mesnevi rhyme, incomplete at the beginning, followed by 66 poems of the kașide/gazel format, but not in the usual dìvān sequence, and four quatrains.

Begins (51a):

$$
\text { كر ايده سن بو جرمه عدل دادى *بل اخى زهر اولا بو دينه دادى }
$$

Ends:

$$
\text { وقلم بلم واردركن دنيه بِرسن * عاقل كثى طاش استنه طير ق سوادر }
$$

Catalogue entries: Divanlar I, pp. 28-31; Rossi Vat. Turco 206(ii); TYTK (Çankırı) 639.

Literature: Divanlar, p. 28; 'OM I, p. $15^{2}$.

Bound in dark brown leather with flap and blind tooled insets in Oriental style; glazed white to light brown paper; $(1)+97+(1)$ folios (18 is counted twice); $200 \times 140 \mathrm{~mm}$ and $150 \times 95 \mathrm{~mm}$, varying; $15^{-16}$ lines; catchwords, occasionally missing; nesih and ta lïk in various hands; headings and rubrics in red on ff. 11b-15a, 52a-97b; without dates and the name of a copyist. Probably acquired in 1776 through Nicolaus Wilhelm Schroeder (cf. Brugmans, Catalogus, p. 257).

Catalogue entries: CCO 2721 (V, p. 284); Brugmans, Catalogus, p. 257. 
Hs. 492

Prayers and prayer prescriptions

An undated scroll, incomplete at both the beginning and the end, with, mostly, prayers in Arabic accompanied by prescriptions for their use in Turkish. A heading preceding the main prayer, following on a lengthy Turkish prescription, is entitled $D u^{\prime} \bar{a}-i$ şerîf and had, according to the same heading, its origin with the scribe 'Alī who had served as treasurer to İbrāhīm Paşa. The prayer takes most space of the scroll. It is followed at the bottom by a brief prayer prescription in Turkish and a prescription, also in Turkish, for a talisman (headed $b \bar{a} b e l-h u b b$ ) and is meant to attract the attention of a beloved.

White paper, worn and torn in some places; $3400 \times 80 \mathrm{~mm}$; irregular, vowelled nesih; double black borders; headings and some text passages in red. Acquired from the library of Jakob Christmann in 1620 (see the introduction to this chapter).

Catalogue entries: CCO 2733 (V, p. 289); Brugmans, Catalogus, p. 257.

Hs. 493

A treatise on religion

A quire of five folded leaves, undated, with a copy, incomplete at both the beginning and the end, of an unidentified treatise on the tenets of the Islamic religion, with references to hadis and tefsis. The original leaves of glazed paper have been rebound with leaves of unglazed western paper, alternating with the original folios, which have remained blank. A marginal addition is found on $\mathrm{f}$. $6 \mathrm{a}$; red numbers $1-5$ have been aded in red and in a Western hand on ff. 2a, 4a, $4 \mathrm{~b}$ and $5 \mathrm{a}$.

A Latin inscription occurs at the bottom of the first page (1a): Ego Isaacus Badouacius Hunc Quinternionem Turcicum Amicitiae causa dono dedi D. Jacobo Christmanno Professori Hebraicae Linguae, Heidelbergae $8^{\circ}$ Octobris 1590 . The number 22 is found on the third flyleaf, verso. (See also the introduction to this chapter, above)

Bound in a leaf of vellum, containing on both sides a varicoloured, illuminated, probably late-mediaeval Latin text in Gothic script (cf. Hs. 485); glazed (without watermarks) and unglazed paper, the original text comprising 10 folios; $213 \times 160 \mathrm{~mm}$ and $140 \times 90 \mathrm{~mm}$, varying; 15 lines; catchwords; vowelled nesih; without a date and the name of a copyist. 
Begins (1a):

كوكل فاسد اولدوغيجون هم اخرتده دخى اول يراماز صفتك عذابنه اوغرار نتكم تفسيرده و حديثده معلوم و مقدر اولمشدر

Ends (10b):

$$
\text { اول فرض علمى ييرينه كتورميه او دمسه طاموده ابداً قالور جقماز بو اولو قورقو دكمدر [اخرته] }
$$

Catalogue entries: CCO 2739 (V, 290-291); Brugmans, Catalogus, p. 257. 


\section{THE HAGUE, KONINKLIJKE BIBLIOTHEEK (KB, ROYAL LIBRARY)}

\section{Address: Prins Willem-Alexanderhof 5}

The Royal Library had its origin in the collection of the two last Stadtholders of the Dutch Republic, Willem IV and Willem V. The latter fled to England in 1795 , and three years later, in 1798 , the Parliament of the newly founded Batavian Republic decided to turn the collection, comprising about 5000 books and manuscripts, into a National Library. In 1806, during the reign of the French King Louis Napoleon, the term 'National' was changed to 'Royal'. Since then the holdings have expanded continually, and at present the collection boasts about 2.2 million volumes.

The library's acquisition policy does not encompass materials of nonWestern origin, and in the 19th century some Oriental manuscripts in its possession were transferred to the Leiden University Library (see Vol. II, Chapter 10). Nevertheless, the rich manuscript collection does contain some Oriental items besides texts in Western languages which have a documentary value for the history of the Ottoman Empire. Apart from travelogues, these include interesting items such as a survey in Dutch of the salaries paid by the Ottoman Sultan to his officials, early 18 th century (Hs. $71 \mathrm{~J} 38,20 \mathrm{ff}$.), entitled De beschrijvinge vande salarissen, soldien, en vande incoemen, die den Turcxschen keijser geeft aen sijne slaven soo vande Militie ende aen allen anderen officieren, die in sijn dienst sijn; the MS had originally been bought for Prince Willem IV in 1749, cf. A.D. Renting \& J.T.C. Renting-Kuijpers, The Seventeenth-Century Orange-Nassau Library, Uterecht 1993, No. 2145; a Mémoire sur les turcs by François Emmanuel Guignard, comte de St. Priest, French envoy to the Porte, late 18th century (Hs. 129 B 9, 20 pp.); and a typescript journal in Dutch of a mission to Istanbul in 1915 by C.L. Torley Duwel (Hs. $134 \mathrm{C}_{15}, 34 \mathrm{pp}$, donated to the library by the author in 1952; see for details, Schmidt, Legation Window, pp. 36-41).

Some Oriental texts, mostly in Hebrew, and brief aphorisms or other quotations in, mostly, Arabic by scholars and students, are found in scrapbooks with dedications, sometimes illustrated or illuminated, by friends and acquaintances of the owners (album amicorum) - the genre was particularly popular in the $17^{\text {th }}$ and 18th century - a large collection of which is 


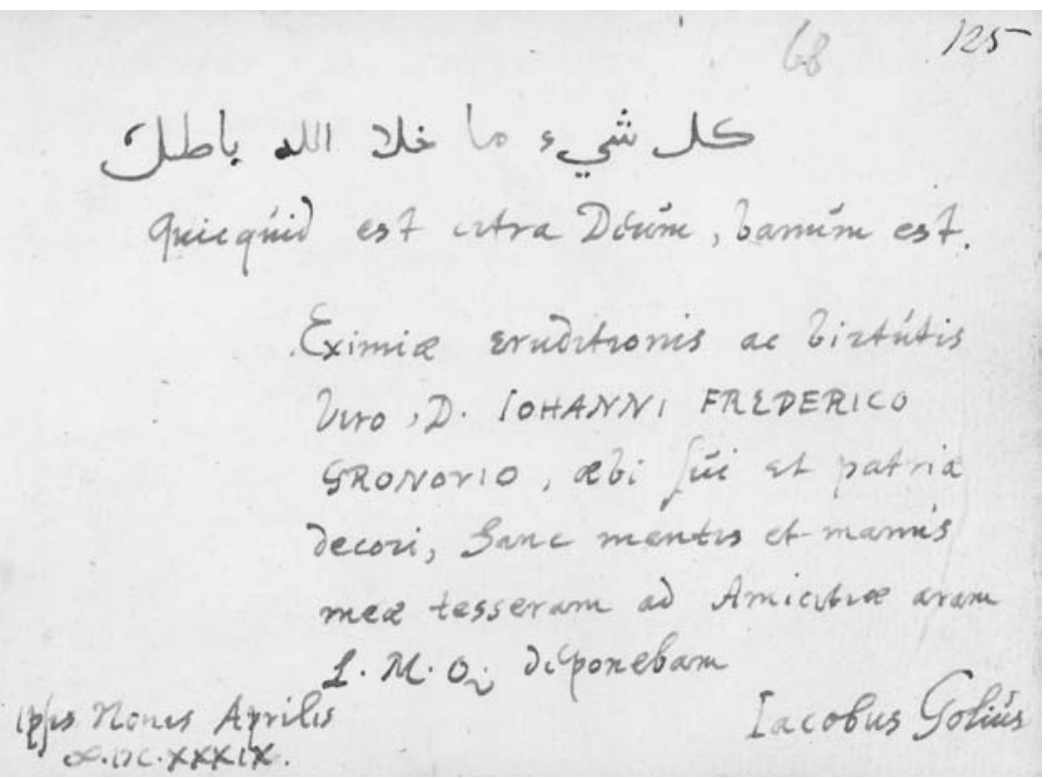

Figure 26. The Hague, KB Hs. 130 E 32, f. 68a. Inscription by the Leiden orientalist, Jacob Golius, dated 1639, in an album amicorum compiled by the classicist Gronovius (1611-1671).

being preserved in the library (and still being expanded). Only one item, Ms. $135 \mathrm{~K} \mathrm{4}$, separately described below, contains Turkish texts. Some of the Dutch alba in the collection contain inscriptions with Arabic phrases by Orientalists already encountered on these pages: Jacob Golius (twice: at Leiden, 1639, in Hs. 130 E 32, f. 68a, album compiled by the classicist, Johannes Fredericus Gronovius, 1611-1671, and at Leiden, 1644, in Hs. 129 F 6, f. 138a, album compiled by Johan Philip Mulhausen or Mulheuser, an officer serving in Brasil and the Dutch Republic) and Jan Jacob Schultens (at Leiden, 1766, in Hs. $133 \mathrm{H} \mathrm{28}$, f. 93a, album compiled by the Leiden philologist Laurentius van Santen, $1746-1798)$. There is one album compiled by an Orientalist, Joannes Willmet (1750-1835; see for his manuscripts, Leiden, UB, Academy of Arts and Sciences, below): Hs. $134 \mathrm{C} 44$, acquired from the antiquarian bookshop of Nijhoff in The Hague in 1956. It contains contributions by, among others, his colleagues Hendrik Albert Schultens (at Leiden, 1773, p. 145) and Hendrik Arent Hamaker (at Leiden, 1820, p. 215), and, curiously, by the famous Dutch poet and amateur-Orientalist, Willem Bilderdijk (1756-1831), who contributed, apart from a distich of Haăfiz in Persian, the lines En, moet de val der taal ons beider zang vernielen/ Uw uitspraak en uw naam verduren lot en tijds (at Amsterdam, 8 Oogstmaand 1812, p. 188). 


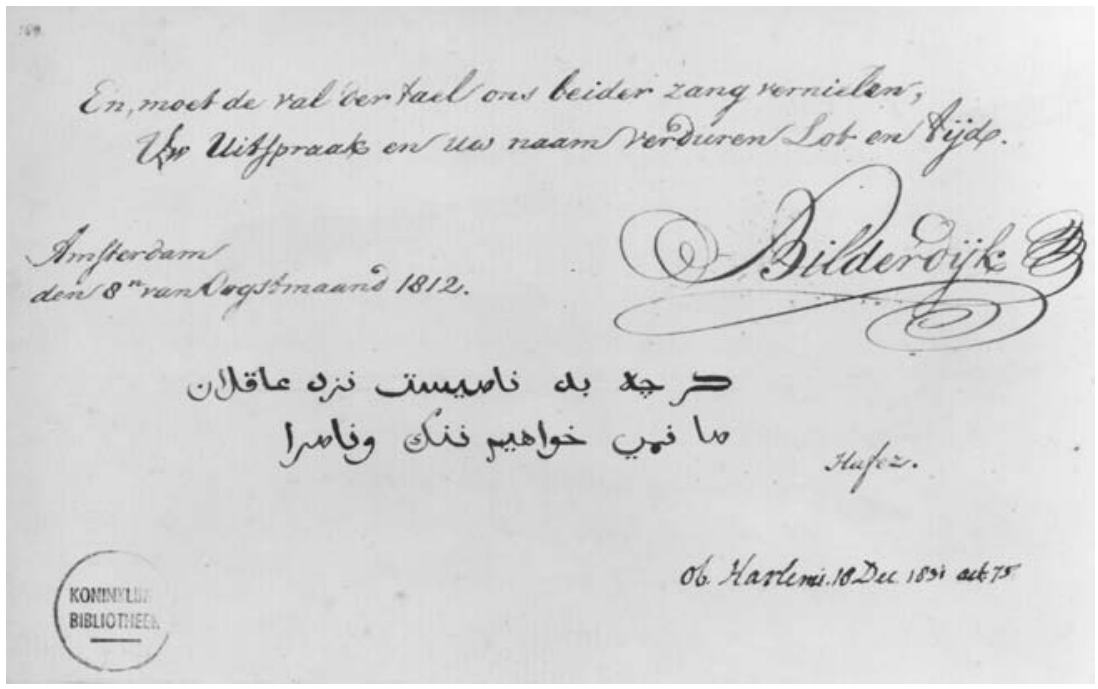

Figure 27. The Hague, KB Hs. 134 C 44, p. 188. Inscription, with a quotation of a verse by Hāfiz, made by the poet, Willem Bilderdijk, in an album amicorum compiled by the Dutch orientalist, Joannes Willmet (1750-1835).

Literature: Verzamelaars en verzamelingen. Koninklijke Bibliotheek $1798-1998$ (Zwolle 1998); K. Thomassen, ed., Alba Amicorum. Vijf eeuwen vriendschap op papier gezet: Het Album Amicorum en de poëziealbum in de Nederlanden (The Hague 1990).

\section{Hs. $135 \mathrm{~K} 4$}

\section{Turkish text fragments}

A second volume (out of three) of an album amicorum compiled by Ernst Brinck (c. 1582-1649), secretary to the first Dutch ambassador at the Porte, Cornelis Haga, between 1612 and 1615. It contains about 180 contributions in more than 200 languages during the years $1612-1635$, among them by Ottomans and Istanbul ambassadors; 188 folios, $155 \times 105 \mathrm{~mm}$. Three poems in Arabic and Persian by Bahā̄̄î, Jāmī and 'Urfì, and copied in calligraphic ta līk by the cubicularis of the Sultan, Aḥmed, also known as Tịrmānī (probably the mirāhnōr, Aḥmed Agia, in function 1020/1611-1023/1614, cf. $S O^{2} \mathrm{VI}$, p. 1736), are found on ff. gb-10a (see also the plate in Zeki Çelikkol, Alexander de Groot \& Ben J. Slot, "... It began with the tulip". The History of Four Centuries of Relationship between Turkey and the Netherlands in Pictures (Ankara 200o), p. 34). The volume had belonged to the Orientalist Joannes Willmet 


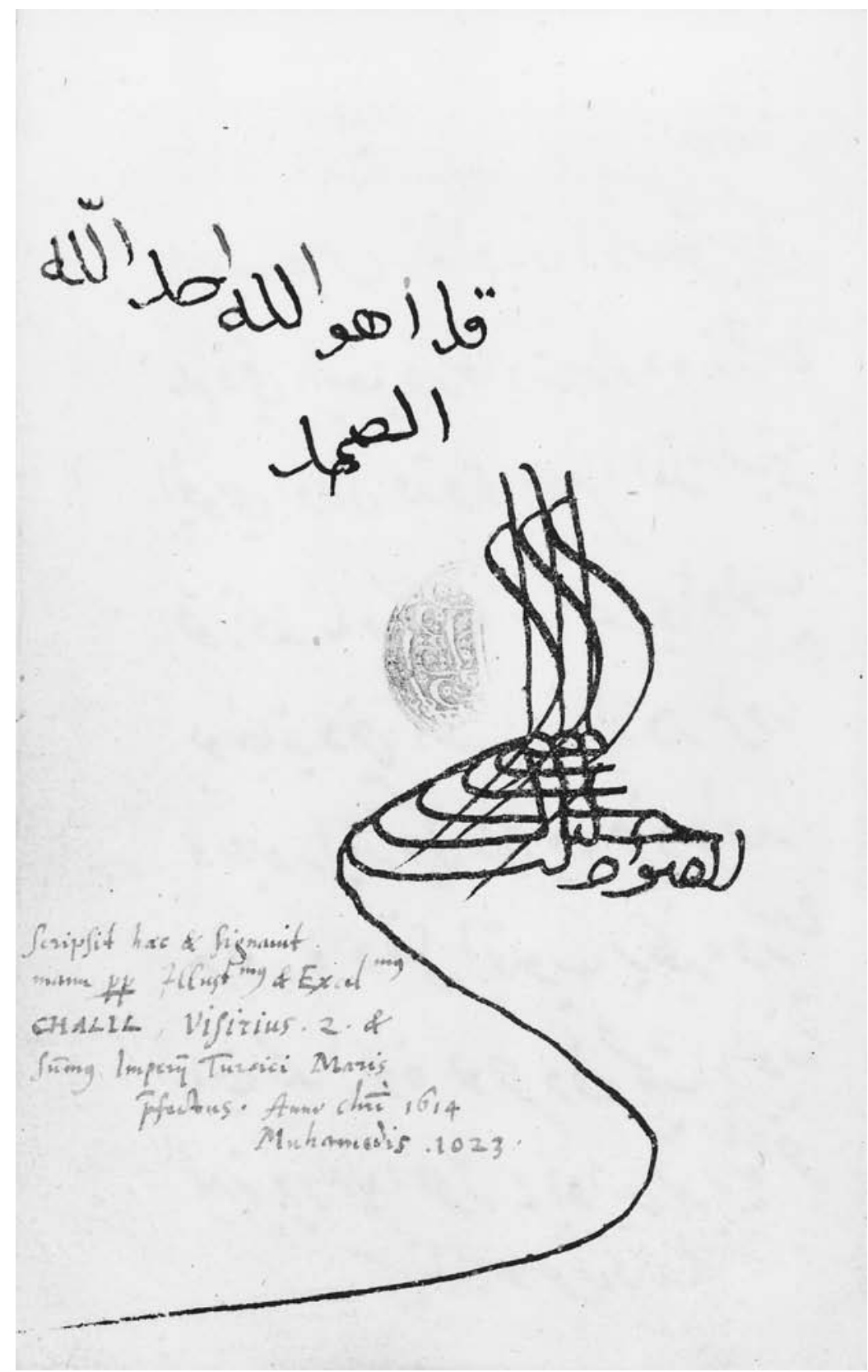

Figure 28. The Hague, KB Hs. 135 K 4, f. 11b. Signature and seal of the Ottoman Admiral, Kapudan, Halil Pasa, dated 1023/1614, found in an album amicorum compiled by Ernst Brinck, secretary to the first Dutch ambassador to the Porte. 
(1750-1835; see for his manuscripts, Leiden, UB, Academy of Arts and Sciences, below), and later to the collector of rare books and coins (and biographer of the compiler), Frans Alexander van Rappard (1793-1867); it was finally acquired by the library at an auction in Munich in 1973. The Turkish fragments are the following:

(1) ff. 10a-11b.

A copy of a letter of safe-conduct, issued by the kapudān, Halī Pasa, to Ernst Brinck, with explanations in Latin (these are printed in Van Rappard, Ernst Brinck, p. 40). It is dated Rebīü l-ähir 1023 (May-June 1614). The brief text reads as follows (10a): işbu hāamil-i rıḳ'a olan Ernesto Brinḳ-nām zimmī bi'l-fil Der-i sa 'ādet-medārda Nederland elçisi olan ḳudvetü l-ümerā l-milletü l-mesịhìye Kornelhaga-nām [Cornelis Haga] begzādenün kethüdası olub bu cānibe dahı intisābı vardur mürūr ü 'ubūr etdügi mahallerde ferd-i vāhid-i mezbūrı dahl etmeyüb rencìde vü remìde etmemek içün bu hurüf ketb olunub yedine verildi hurrire evāyil-i şehr Rebïü l-ähir sene sü̈s ve 'aşerīn ve elf. The following page (11b), contains, after a pious formula in Arabic, the signature, with three tuggs, of Halīl Paşa. See on Hualil Paşa's role as supporter of Ottoman-Dutch relations: De Groot, Ottoman Empire, pp. 106-181, passim.

\section{(2) ff. $13 b$}

A distich in calligraphic nesih against a background of gold stippling: gözlerüm ḳanlu yaşın der bu serāser cānānumdur [?]/ gül-i handeler üzere düşer sen anı șanma şebnemdür. Below the line is an inscription in Italian of And[rea] Negroni (d. 1615), ambassador of the [Habsburg] Emperor at the Porte, dated June 1613 (cf. De Groot, Ottoman Empire, pp. 306-307).

$$
\text { (3) ff. 100b-10la. }
$$

Samples of Ottoman calligaphy, with inscriptions in neshi, div $\bar{a} n \bar{\imath}$, and siy $\bar{a}-$ kat script. These were made by 'Abdullāh Çelebi in Istanbul in [10]22 (16131614), according to a colophon in the margin of f. 10ob:

$$
\text { كتبه عبد الله هلبى فى قسطنطنيه المحروسه سنه Tri the }
$$

An explanation in Latin, octo varii modi Turcicae scripturae, is found in the margin of f. 101a. 
Catalogue entry: Alba Amicorum 38.

Literature: F.A. Ridder van Rappard, Ernst Brinck (Utrecht 1868); De Groot, Ottoman Empire, pp. 307-308. 


\author{
CHAPTER SEVEN \\ THE HAGUE, MUSEUM \\ MEERMANNO-WESTREENIANUM/HUIS VAN HET BOEK
}

Address: Prinsessegracht 30

The museum, particularly devoted to preservation and exhibition of books and manuscripts, was founded in 1848 and comprised the estate of the collector W.H.J. baron van Westreenen van Tiellandt (1783-1848). A substantial part of the collection had belonged to a distant relative, Johan Meerman (1753-1815), whose library was sold in auction in 1824. Only a few items have been acquired since 1935 .

The museum's collection comprises about 20,00o books and 339 manuscripts, among these a few in Arabic, described in Boeren's Catalogue, pp. 146-147 and 197-198. Two of them, copies of Korans, had their origin in the Ottoman Empire: Hs. 10 E 29, an undated copy, made part of a vakf, founded by the kapudan, İbrāhīm Paşa, in 1118/1706-1707 (see the inscription on f. 1a, where an impression of his seal is also found) - already in 1711 the manuscript was offered by the missionary among Armenians, Jaques Villotte, to Charles Dauchez, rector of the Collège de Clermont in Paris (and purchased by Meerman in 1764) — and Hs. 10 E 30, described below.

Literature: P.C. Boeren, Catalogus van de handschriften van het Rijksmuseum Meermanno-Westreenianum (The Hague 1979); W.A. Laseur \& Jos van Heel, Het Museum Meermanno-Westreenianum 1848-196o. Een bijdrage tot de geschiedenis en zijn bewoners (The Hague 1998).

\title{
Hs. 10 E 30
}

Three Turkish recipes

The manuscript contains an undated and incomplete copy of the Koran. A description of the contents in German is found on the first flyleaf, recto. An ornate inscription, equally in German and in green ink, informs us that the manuscript (dieses Türchische Buch) had been captured from a Turkish tentby an officer named Fuchshofer, in the service of the Bayreuth regiment of the Count (Markgraf) Karl August of Brandenburg, at the fortress of Arsca in the aftermath of the Battle of Siclos (Siklós) on 12 August 1687, but 
had later donated it to Johan Rossmann, the author of the inscription, on 20 November 1687 (1oth flyleaf, verso). Baron van Westreenen bought the manuscript from the bookseller Friedrich Augus Helm in Halberstadt on 1 August 1836 (e-mail from Jos van Heel, 21 February 2009).

The last flyleaf, recto, contains three recipes, with lists of ingredients, for two ointments to allay fever in horses and a medical powder to relieve melancholy (sevdā); three headings, followed by, each, 5 lines.

Catalogue entries: $\mathrm{CCO}_{2797}$ (V, p. 311); Voorhoeve, p. 278; Boeren, Catalogus, p. 147 . 


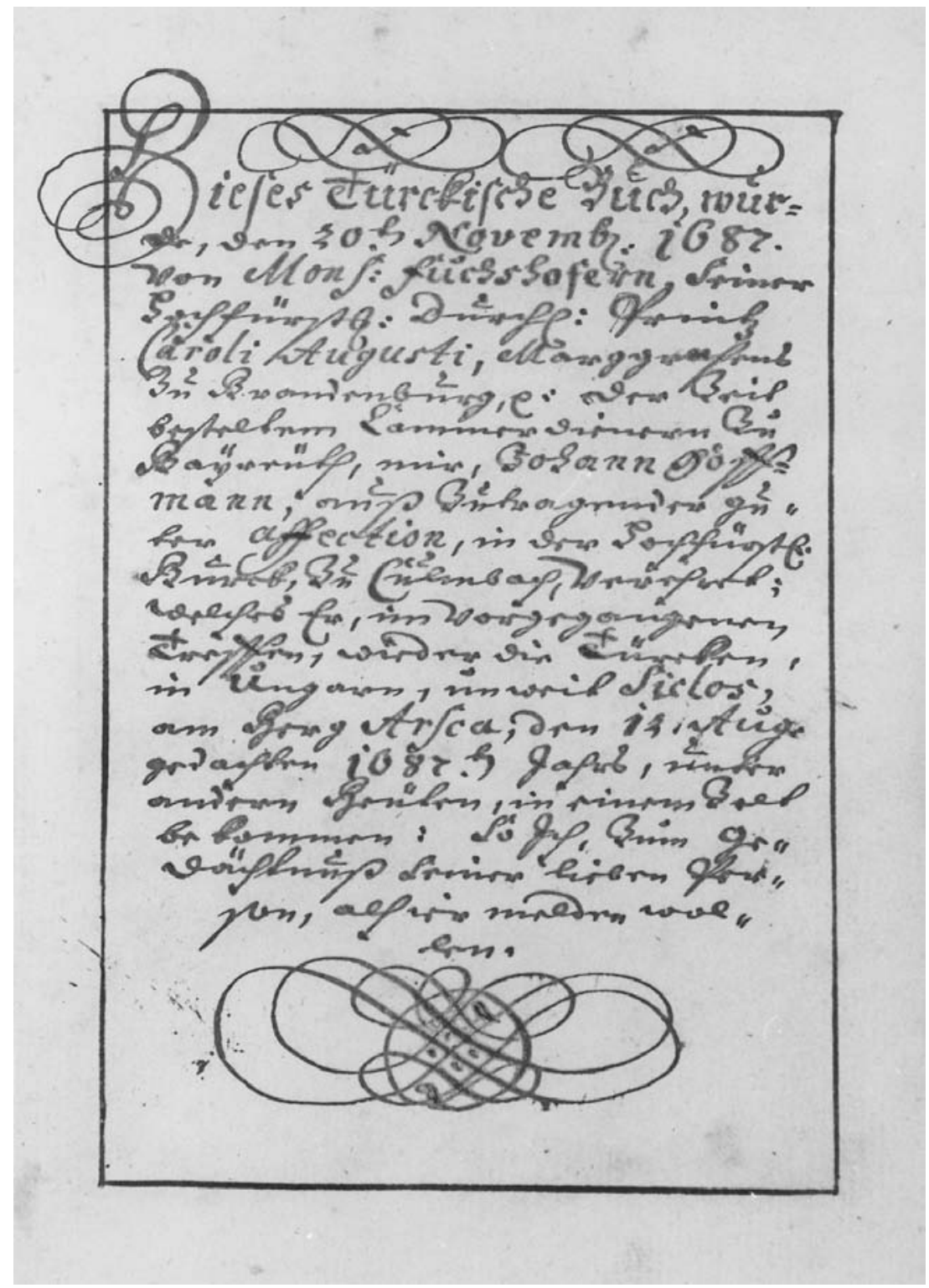

Figure 29. The Hague, Museum Meermanno-Westreenianum Hs. 10 E 30, 1oth flyleaf, verso. Ornate inscription in German, stating that the manuscript had been obtained as war-booty in Hungary in 1687 . 


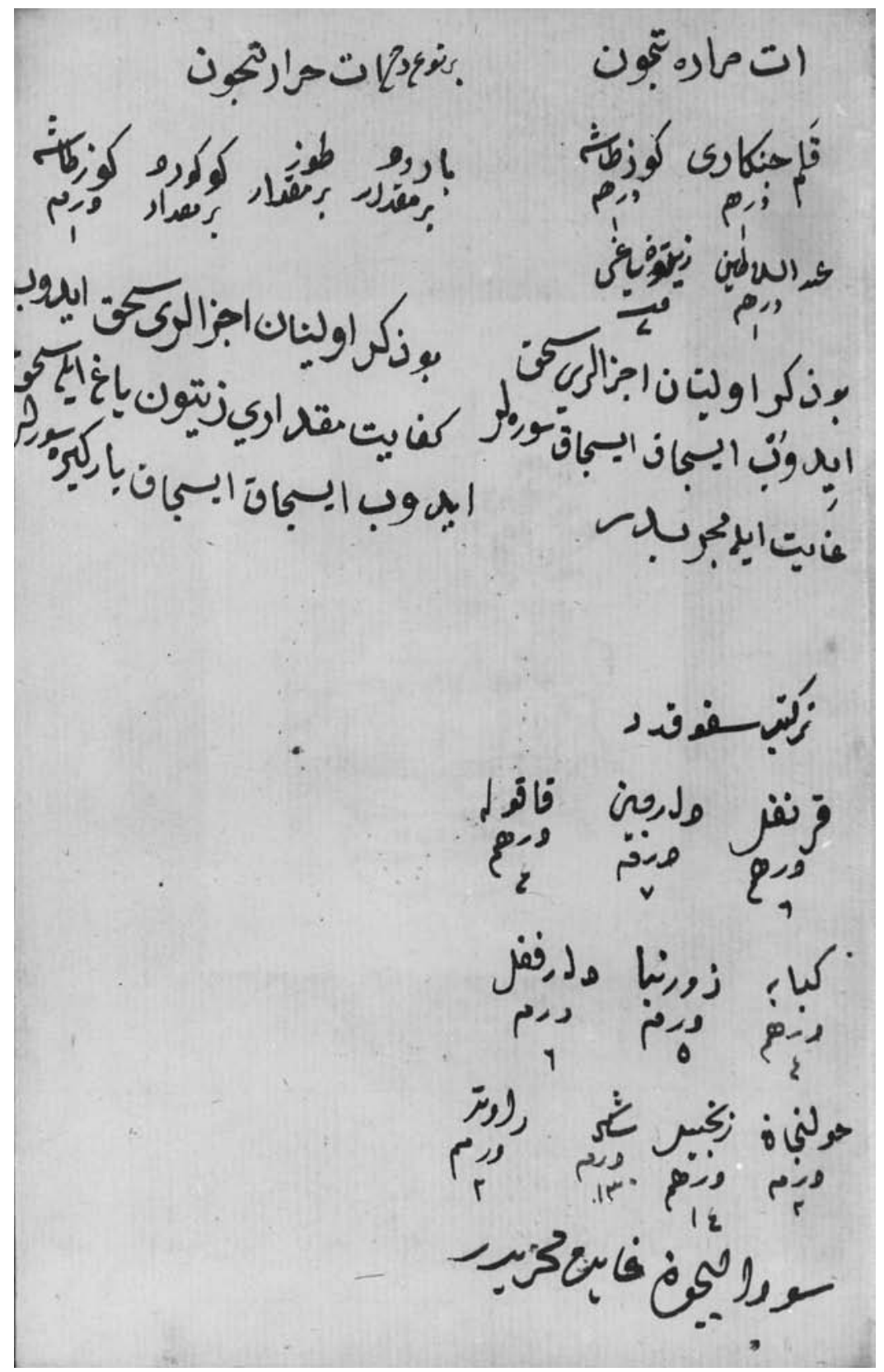

Figure 30. The Hague, Museum Meermanno-Westreenianum Hs. 10 E 30, last, recto. Three recipes in Turkish added to a copy of a part of the Koran, 17th century of earlier. 


\section{CHAPTER EIGHT}

\section{LEIDEN, MUSEUM VOLKENKUNDE (MUSEUM OF ETHNOLOGY)}

\section{Address: Steenstraat 1}

The museum was founded in 1859 , and is considered to be among the earliest public collections of the ethnographic type (see also under Leiden, UB Cod.Or. 1686). The extensive holdings of the museum contain a small collection of objects originating from the Middle East, among them prints, drawings, textiles, musical instruments and various utensils. A few objects had their origin in the Ottoman Empire, outstanding among these a series of coloured drawings: two miniatures with varicoloured paintings on paper, $152 \times 110 \mathrm{~mm}$, depicting, as is indicated in headings in Arabic script, a Sulțān Murād (No. 2871-19) and an Aġa coḳdārī [çuhadār] (No. 2871-20) - these were acquired from the antiquarian E. von Scherling in 1950 - and a series of, seemingly, 19th-century coloured drawings $\left(198 \times 13^{2} \mathrm{~mm}\right)$ of Ottoman functionaries and other 'types' with captions in, mostly, Dutch (Nos. $360-7364$ to 7429 ), originally part of the Royal 'Collection of Rarities' kept in the Mauritshuis in The Hague, abolished in 1883 and transferred to the museum in the same year. This latter series of drawings may in part have been inspired by the coloured etchings published in Paris in 1714 and done in a similar style (see the coloured plates in Şevket Rado, ed., On sekizinciyüzyılın başında Osmanlı kıyafetleri Fransız Büyükelçisi Marquis de Ferriol'un Hollandalı ressam Van Mour'a yaptırdıgı 100 resim ile Türklere ait bazı tören ve açılkmalar, Istanbul 1980). Objects with Turkish texts comprise a letter and two scrolls, described below. Another item, described as a Turkish passport (No. 1210-1211), donated to the museum by W.J. Spruyt in 1899, seems to have been lost. 


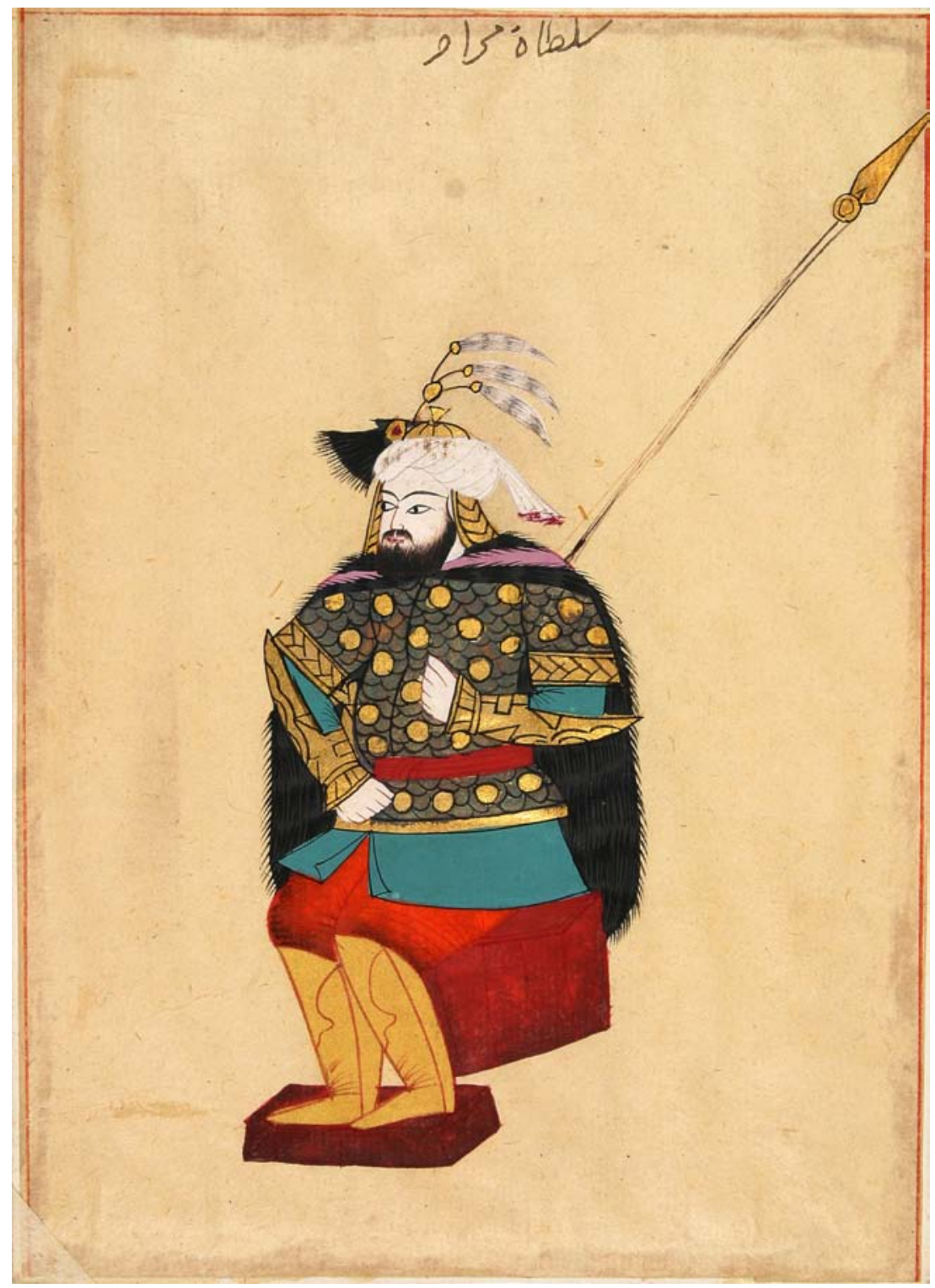

Figure 31. Leiden, Museum Volkenkunde 2871-19. Miniature of 'Sultan Murād' by an anonymous artist, undated. 


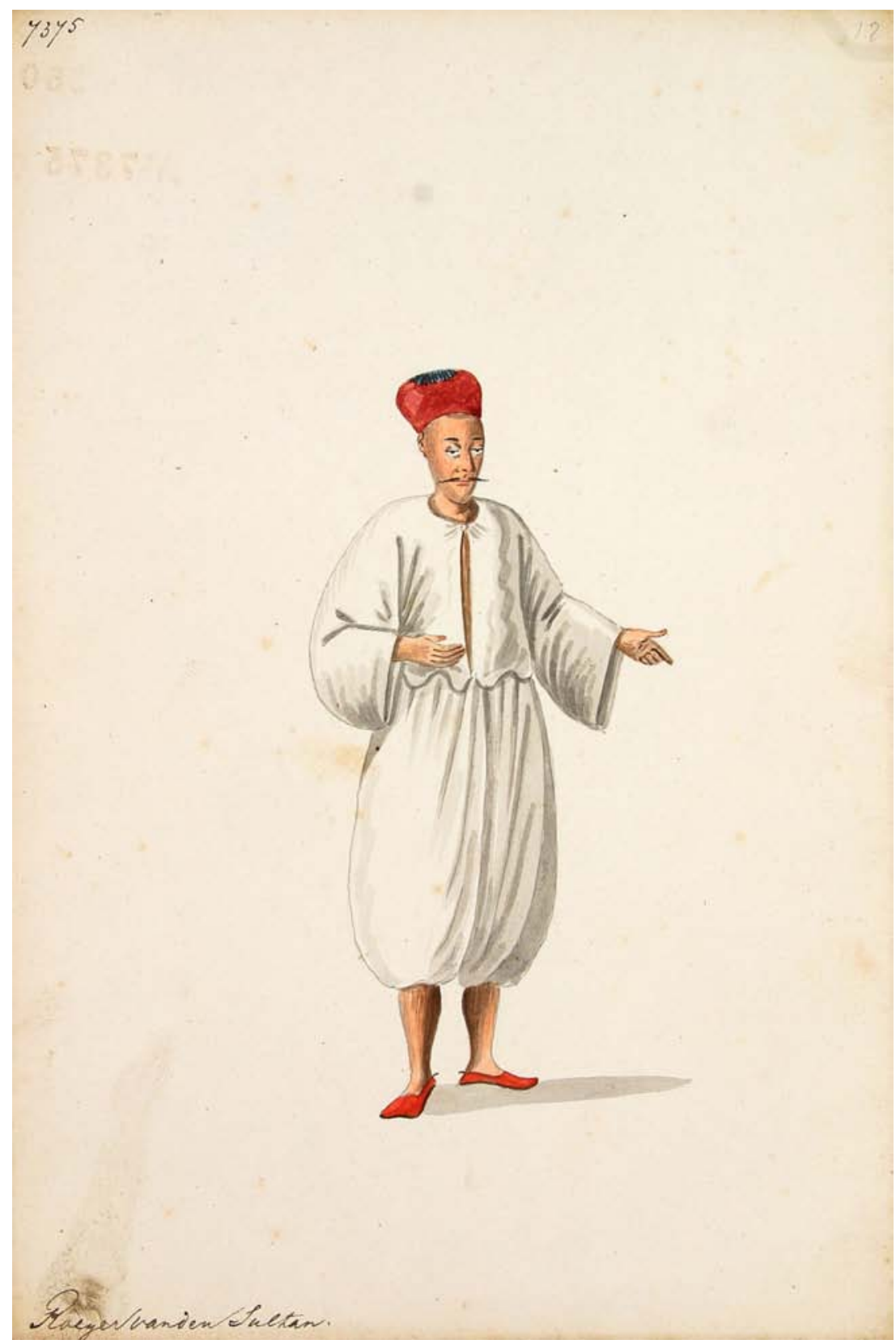

Figure 32 . Leiden, Museum Volkenkunde 360-7375. Coloured drawing, $165 \times 105$ $\mathrm{mm}$, of a courtier, according to the Dutch caption: 'herald (roeper) of the Sultan', probably 19 th-century. 


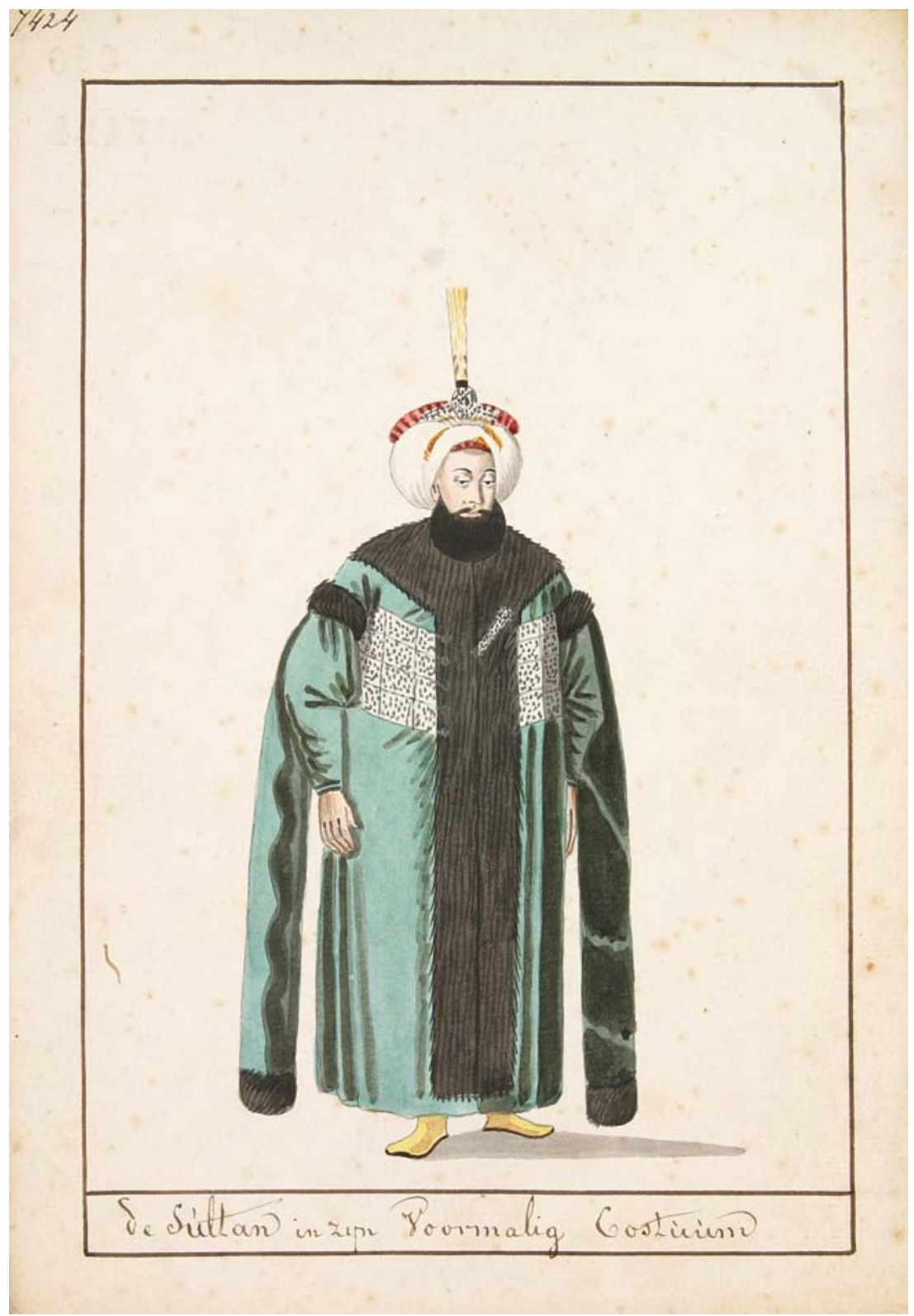

Figure 33. Leiden, Museum Volkenkunde 36o-7424. Coloured drawing, $165 \times 105$ $\mathrm{mm}$, of, according to the Dutch caption: 'the Sultan in his former costume', probably 19th-century. 


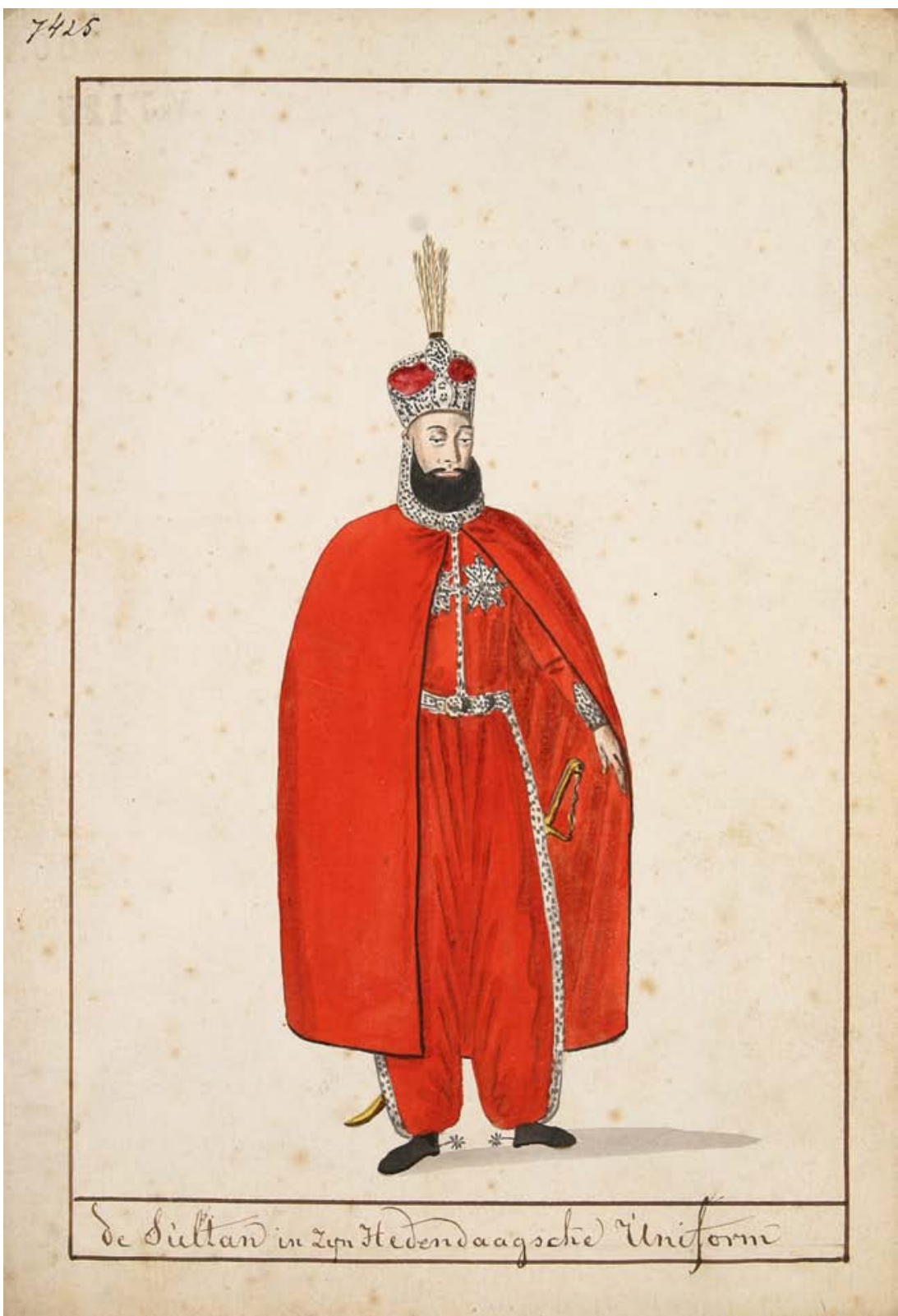

Figure 34. Leiden, Museum Volkenkunde 360-7425. Coloured drawing, $165 \times 105$ $\mathrm{mm}$, of, according to the Dutch caption: 'the Sultan in his present costume', probably 19th-century. 


\section{$36-9550$}

\section{A letter}

An original copy of an undated letter from Daniel Alexander baron de Hochepied [1686-1759], Dutch consul [in Izmir, from 1720, cf. Schutte, p. 335], to the, unnamed, commander (Kapudan) of the Ottoman Fleet (donanma-ı hümāyūn). In the letter the consul complains about the obstruction of Dutch ships carrying grain in Ottoman waters. Recently, the Dutch vessel Eendragt with captain William Eschenhuize [اشنحوزه], transporting $2800 \mathrm{kil}$ of wheat as well as cotton for Ottomans, had been forced to unload the wheat, this contrary to the existing treaty with the Dutch Republic. A request (Du'ānāme) to stop this practice had meanwhile been sent to the Porte.

Folded, thick glazed white paper, $420 \times 290 \mathrm{~mm}, 17$ lines, dìvānī, probably by a dragoman of the consulate, also found in Leiden, UB Cod.Or. 1380(1"). A label with printed text Een Turksche Paspoort in d'Arabische taal geschreven is found on the back. Donated by the Royal Collection of Curiosities, The Hague, in 1883.

\section{0-9545}

\section{A rūznāme}

A scroll of vellum, with red leather on the back, comprising a calendar/almanac consisting eleven tables and diagrams, designed by Ḥasan es-Sürūrī, undated. The richly illuminated borders on the left and right contain information of various type in Turkish. The tables and diagrams are preceded by a magnificent, varicoloured headpiece with floral motifs. They are separated by headings with texts in gold against a dark red background. The scroll ends in a colophon in gold:

$$
\text { كتبه المعروف بحسن السرورى }
$$

followed by the prescription bu rūznàmede tahrìr olunan imsāk-i temkin-i șavm içün murād eden kimesne on beş dakịka mukaddem etmek gerek. 950× $92 \mathrm{~mm}$, calligraphic nesih in black and red, gold borders. Donated by the Royal Collection of Curiosities, The Hague, in 1883. 


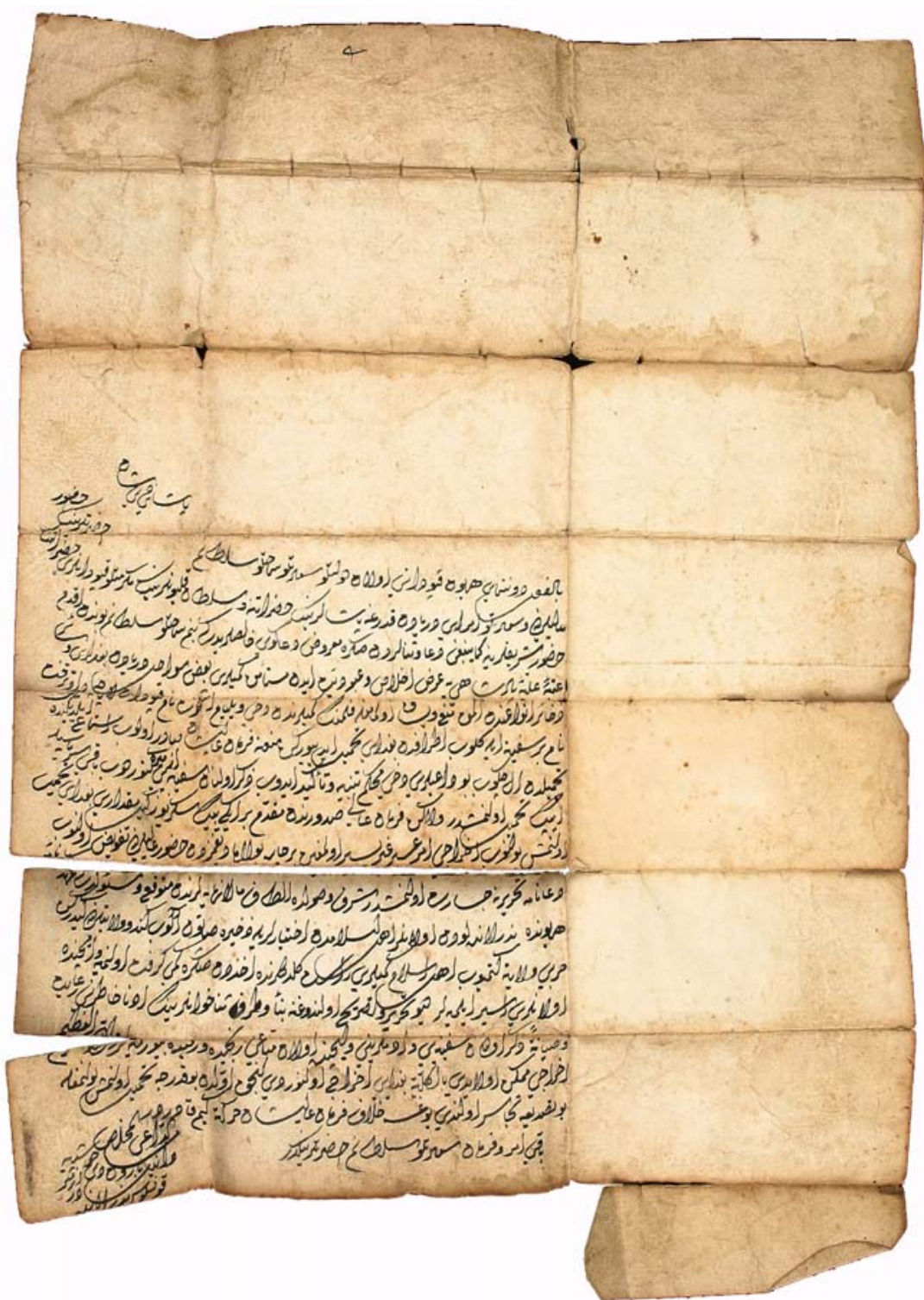

Figure 35. Leiden, Museum Volkenkunde 36-9550. A copy of a letter from the Dutch consul at Izmir, Daniel Alexander de Hochepied, to the commander (kapudan) of the Ottoman Fleet, early 18 th-century. 
360-9546

\section{A rūznāme}

A scroll of vellum, with red leather on the back, comprising a calendar/almanac consisting of eleven tables and diagrams, designed by Mehmed Emīn Hilmī, undated. The name of the designer occurs at the top of the scroll, written on white against a golden background within a gold crescent, and in a colophon in gold and blue at the bottom. The borders on the left and right contain information of various type in Turkish. The tables and diagrams are preceded by a varicoloured headpiece with floral motifs. They are separated by headings with texts in gold against a blue background. The colophon is followed by the prescription bu rūznāmede yazılan imsāk-i temkin-i șavm içün murādeden kimesne on beş daḳiḳa muḳaddem etmek gerek. $950 \times 86 \mathrm{~mm}$, calligraphic nesih in black and red, gold borders. Donated by the Royal Collection of Curiosities, The Hague, in 1883. 


\section{CHAPTER NINE}

\section{LEIDEN, UNIVERSITEITSBIBLIOTHEEK \\ (UNIVERSITY LIBRARY), BIBLIOTHEEK A. HOTZ}

\section{Address: Witte Singel 23}

A.P.H. (Albert) Hotz $\left(1855^{-1930}\right)$ was a merchant active in various cities in Persia from 1874-his father founded the Perzische Handelsvereeniging J.C.P. Hotz \& Zoon - and, after the firm had collapsed in 1895, consul in Beirut (1909-1921). His library, which contained about 15,000 volumes, mostly printed books on Oriental subjects, was donated to the Leiden University Library by his widow, L. Hotz-Woods, in 1935.

Literature: Bibliotheca Academiae Lugduno-Batavae Catalogus, Deel XXVII. Bibliotheek A. Hotz. Uitheemsche landen, in het bijzonder Perzië en het Oosten (Leiden 1935); Corien Vuurmans \& Theo Martens, Perzië en Hotz. Beelden uit de fotocollectie-Hotz in de Leidse Universiteitsbibliotheek (Leiden 1995) - a biography of Hotz is found on pp. 24-30. Schmidt, Opium Trade, pp. 137, 148.

Hotz 2289 (Ar. 3008)

Tuhfe-i Şāhidī

تحفة شاهدى

An undated, illustrated copy of a rhymed Persian-Turkish dictionary by İbrāhīm Şāhidī, a Mevlevī dervish and poet (d. 957/1550). The name of the author and the title of the work occur in f. 4a:5-8. Many copies of this work have survived. (For a description of the contents and further data, see Leiden, UB Acad. 77, below.)

A clipping from the printed catalogue and an ex-libris bookplate designed by A.P.H. Hotz (cf. Perzië en Hotz, p. 92) are pasted on the inner front-board.

Rebound in gold-embossed, dark brown leather with flap and red-cum-gold tooled insets in Oriental style; glazed white paper without watermarks; $32+1$ folios; $177 \times 120 \mathrm{~mm}$ and $137 \times 77 \mathrm{~mm}$; 15 lines in 3 or 4 columns; catchwords; vowelled nesih; headings, rubrics, numbers and dots in red; multiple gold borders within black lines; a crude headpiece in gold, orange, red and blue on f. $1 \mathrm{~b}$; multicoloured miniatures occur on ff. $7 \mathrm{~b}$ (two Oriental figures against a starry sky), 10a (tiny portraits of twelve men wearing turbans), 
$11 \mathrm{~b}$ (a king, a devil and three Oriental figures in a boat), 14a (the sign of saggitarius), 16a (a joker surrounded by animals, moons and a star), 20a (a naked man eaten by a fish and three Oriental figures in a boat), 22b (Oriental figures, of whom one is sitting on a throne carried by two men) and 32a (two Oriental figures and a box with snakes); without a date and the name of a copyist.

Begins ( $2 \mathrm{~b}$, as in the printed edition of 1275$)$ :

$$
\text { بنام خالق و حى توانا * قديم و قادر و بينا و دآنا }
$$

Author and title are found on f. 4a (as in the printed edition of 1275, p. 7):

$$
\begin{aligned}
& \text { جو الطاف خدا وكستردى اتمام *ديدم بنداخى تحفه شاهدى نام } \\
& \text { كدايم شاهدى مولوى يم *ديار منتشاده مغلوى يم }
\end{aligned}
$$

Ends (33b):

$$
\text { فاعلاتن فاعلاتن فاعلات * بو كتابى اوكرن آج آب حيات }
$$

Catalogue entry: Catalogus, Deel XXVII, Bibliotheek A. Hotz, p. 146. 


\section{LEIDEN, UNIVERSITEITSBIBLIOTHEEK \\ (UNIVERSITY LIBRARY), BIBLIOTHECA PUBLICA LATINA}

The collection contains Westerns manuscripts with texts in various languages. Although the occurence of Turkish texts in it is rare, there are a few items which document aspects of the history of the Ottoman Empire and the Turkish Republic. Among them, notably, is BPL 238 I-II, which contains autograph manuscripts in Dutch by Herman van der Horst, Protestant minister of the Dutch community of Izmir between 1718 and 1727; I, contains a diary of his boat journey between Amsterdam (Texel) and Izmir of $1717-1718$, a description of a journey in the surroundings of Izmir in 1719 and notes on a trip to Ephesus in 1720 (123 folios); II has fragments describing boat journeys between Izmir and Istanbul in 1726 and 1727 (6 folios). The contents are described in Jan Schmidt, "The Travel Notes of a Dutch Pastor in Anatolia 1717-1727", in: Çiğdem Balım-Harding \& Colin Imber, eds., The Balance of Truth. Essays in Honour of Professor Geoffrey Lewis (Istanbul 1999), pp. 309-330. The collection also comprises a large collection of letters, among them from and to Dutch orientalists like Jacob Golius, Jan Jacob Schultens and Joannes Willmet, manuscript collectors mentioned in other chapters. There is also one letter (in French), BPL $2211 \mathrm{c} \mathrm{f}$, from the first Dutch envoy to the Porte, Cornelis Haga (1587-1654, cf. Amsterdam, UB Hs. Diederichs 9 U, above) to the Protestant minister, André Rivet (dated 1634), and one (in Italian) addressed to him (BPL 1886) by the Patriarch

of Constantinople, Cyrillus Lucaris (dated 1617). A remarkable item is also BPL 3273, described below.

BPL 3273

The Kraus archive

The archive is of some importance for the history of Turkey during the 1930 and 1940s, even more so for that of scholarship related to the ancient Middle East, and the exile of German academics in Turkey-they found a welcome in Turkey thanks to a reform programme of Turkish higher education implemented in the early 1930 shich cost the job to 240 staff members of Istanbul University alone. The archive mostly consists of letters 
written and received by Fritz Rudolf Kraus (1910-1991) in German, Turkish, and some other languages. The archive is accessible through the website of the University library.

Born in Spremberg (Brandenburg, Prussia) — his father, Siegfried Kraus (1870-1937), was a textile manufacturer of Viennese-Jewish origin - Kraus studied Semitic and Oriental languages at the Universities of Munich and Leipzig (1928-1935) much against the wish of his father; among the languages he learnt was also Turkish. Impossible to find an academic job in Nazi Germany as a 'half Jew', he decided to migrate to Turkey in June 1937. Thanks to the mediation of one of his former teachers in Leipzig, Professor Benno Landsberger (1890-1968), who, being of Jewish origin, had preceded Kraus to Turkey in 1935, Kraus was appointed conservator (tablet mütehassisi) at the Department of the Ancient East (Eski Şark) of the Archeological Museum in Istanbul. His main task was cataloguing its enormous collection of over 70,00o clay tablets, found in Mesopotamia and Anatolia. From 1940 onwards, he had two assistants, Muazzez 'ilmiye İtil (later, after marriage, Çı̆̆) and Hatice Kızılyay, who were students of Landsberger in Ankara and with whom he later corresponded (see below). In 1942, Kraus was also appointed assistant lecturer (ilmîyardımı) in Ancient Mesopotamic History and Assyriology at Istanbul University. In 1946, he married a local Greek woman, Chariklia Anastasiadis-she died in 1988. In 1949 Kraus moved to Vienna, where he was appointed 'extraordinary' professor of Ancient Semitic Philology and Oriental Archeology; at the same time he obtained Austrian citizenship. In 1953 he was appointed professor of Languages and History of Babylonia and Assyria at Leiden University. He retired in 1980. The University Library acquired his archive in parts between 1990 and 1994.

Outstanding in the archive, both in quantity - there are about 6 oo letters-and from a literary point of view, is Kraus' correspondence with his younger brother Werner, an entrepreneur who remained in Germany all his life. The letters of the 1930s and 1940s (Nos. 1-154) in this file (sub 3) document in an impressive way the daily life of an academic exile in Turkey during the eventful and tragic 1930s and 1940s. I will give an impression of their contents in what follows below. The letters written by his brother Werner (sub 4) covering the same period (Nos. 1-209) should, for a better understanding, be read alongside them. I also describe their contents briefly below. Their historical value lies in the detailed documentation they provide on day-to-day life in Nazi Germany and, later, in the occupied Soviet zone and the German Democratic Republic. Additional details on Kraus' life in Istanbul are found in the correspondence in sub-files 1 (letters addressed to Kraus) and 2 (letters from Kraus), but they primar- 
ily document Kraus' work, academic activities, scholarly interests, and the exchange of ideas. Important for the period under discussion is the correspondence with teachers and colleagues Benno Landsberger, Hans Gustav Güterbock (1908-2000), Theo Bauer (1896-1957), Martin David (1898-1986), Hans Ehelolf, (1891-1939), Johannes Friedrich (1893-1972), Paul Koschaker (1879-1951), and Johann Jakob Stamm (1910-1993). Of primary scholarly interest are letters exchanged with many other colleagues, not further referred to here. The letters under discussion here are all in German, but with a few correspondents, whom Kraus came to know in Istanbul, letters in Turkish were exchanged: Muazzez Çığ and Hatice Kızllyay (44 typed letters to Kraus and 38 carbon copies of letters from Kraus, dated 1950-1967); Kemal Balkan (a former student and later lecturer in Ankara, 35 and 22 handwritten and typed items, dated 1949-1951); Emin Bilgiç (a former student, 4 and 2 items, dated 1943-1949); Kadriye Tanzuğ (a former student, 2 handwritten letters to Kraus, dated 1949); Mebrure Tosun (a former student, one handwritten letter to Kraus, dated 1975); Mustafa Kalaç (a former student, a handwritten postcard to Kraus, dated 1954); and Bahadur Alkım (a student, one typed letter to Kraus, dated 1975). Copies of three petitions in Turkish, concerning emoluments for a book published in commission of the Ministry of Education in Ankara, from Kraus to Dr Hamid Zübeyr Koşay (cf. below), are found under 'Ankara' (in sub-file 2). The quality of the paper and carbon copies of the letters is unequal. The carbon copies of Kraus' letters produced during the war are of poor quality, and the text partly illegible because they were, clearly in order to save paper, used on both sides. The content of the letters was influenced by the existence of censorship in Nazi Germany, eastern Germany under the Soviets and in (occupied) Austria before 1953.

\section{Fritz Rudolf Kraus in Istanbul}

Kraus' life in exile is best and most entertainingly described in his letters to his younger brother Werner, occasionally also his mother Ilse Kraus-Karge (1886-1945) — numbers within brackets used below refer to the sequential numbers in pencil found on them. The letters to Werner and his mother were primarily meant to entertain. Kraus compared himself in this respect to the 19th-century author of a description of Turkey, Helmuth von Moltke [1800-1891] (66). Kraus' literary talent—clearly much greater than any of his correspondents with the exception of Landsberger - and his keen eye for bizarre details, ranging from descriptions of Turkish cuisine to the curious behaviour of himself and the people he met, with, often ironic, comments - there are also lengthy but lively descriptions of Istanbul and 
Ankara-make all his more personal letters immensely readible. Thus he described the ancient monuments of the Turkish capital to Stamm on 4 December 1937: Man muß allerdings alle deutsche Begriffe von Altertümern hinter sich lassen, wenn man die reste früherer Zeiten hier genießen will. Ruinen werden hier nicht zärtlich gepflegt wie bei uns, sondern zeigen sich in trostloser Verwüstung. In den verfallenen Medressen, deren einzelne Zellen, den Karthäuserklöstern nicht unähnlich, um einen Brunnengeschmückten Hof liegen, siedelt elendes Volk barfuß und in Lumpen; die Vorhöfe auch der großen, viel besuchten Moscheen sind verwahrlost, die Friedhöfe verfallen. Müllabladeplätze dehnen sich an der Stadtmauer, die im übrigen ein durchaus ländliches, mit Gärten und einzelnen Häusern bedecktes gebiet umzirken ... (3). But by early 1944, Kraus had to confess that he had become tired of this type of correspondence, and particularly of the fact that he could only produce 'sketches' to his brother and could not say what was on his mind (105): Schon seitJahren verfasse ich im Schweiße meines Angesichtes (dies allerdings in etwa die Hälfte der Fälle wegen der Sommerhitze) so eine Art Feuilletons und Ihr habt sogar die Güte, diese Art von Hervorbringungen amüsant zu finden... Aber richtige Briefe sind es doch nicht. Was ich gern wollte, mich einmal richtig auszusprechen über das, was einen wirklich angeht und bewegt, das kann man ja im Briefe schon längst nicht mehr ... Na, und bei dem schrecklichen Ernst der Zeit hatte ich nun einfach von dieser Art Schriftstellerei die Nase voll ...

This is not to say that the letters completely lack references to actual events; thus Kraus mentioned the decline and death of Atatürk (without mentioning his name however) in $1938(18,19,20)$. On 11 October 1938, he wrote: ... heute morgen ist der Staatspräsident gestorben. Es wurde mittags mit einem Schlage bekannt gegeben und in einer halben Stunde war die Stadt ganz halbmast beflaggt ... Abends sind alle Kaffees, Bars, Kinos geschlossen, alle Schaufenster dunkel odermeistens mit eisernen Vorhängen bedeckt, sogar alle Kinoreklamen abgenommen ... Some time later, Kraus tried to pay his respects to the bier on which the mortal remains were lying in state in the Dolmabahçe Palace, but this turned out to be practically impossible; great crowds fought their way through the gates, whereby, it later turned out, eleven persons were trampled to death (20). Atatürk, as a staunch nationalist, had been an important supporter of the study of ancient history, particularly that of Anatolia, and on the occasion of the official change of the placename Diyarbekir into, more Turkish, 'Diyarbakır', Kraus was instructed to investigate whether the town had perhaps already been known as 'Copper Town' in ancient times. It had not (letters to Landsberger, 9, 10). Kraus also refers to the murder of the German Embassy Secretary [Ernst-Eduard vom Rath] in Paris (which led to the 'Crystal Night' in Germany) in the 
same year (19) - the following antisemitische Welle and the burning of synagogues made him extremely worried about his family both in Spremberg and Vienna (letters to Landsberger, 11, 32, 38). In other letters Kraus mentioned the occupation of Albania in 1939 and the threat of Turkey becoming involved in the following [as it turned out Second World] war (24); the outbreak of that war (on 10 October 1939 he wrote: Hier verfolgt man mit Spannung die Weltlage, wie sie sich in den Zeitungs- und Radioberichten spiegelt ... Bei Kriegsausbruch hat man schon im Museum Luftschutzmaßnahmen getroffen, die weiter durchgeführt werden ...); the military campaign in France (35); the continuous uncertainty of the political situation in the Balkans in the Summer of 1940 (37), followed by the first serious war measures taken in Turkey like a (temporary) general black-out and the ban on the private use of cars (42); and military exercises (Luftschutzübungen erinnern uns dann rechtzeitig sowohl an den Krieg als auch zum Glück daran, daß dieses schöne Land noch von ihm verschont ist ... 46). To Landberger Kraus reported: "Als die Nachricht vom Kriegsausbruch eintraf, dachte ich natürlich auch zunächst sehnsüchtig an Ankara. Einzelne Juden unter meinen Bekannten, die sich kein Nest in Ankara wissen, dachten an Konzentrationslager und packten sich neugekaufte Rucksäcke mit Wollsachen, Verbandzeug und ich weiß nicht was. Ich tue das nicht ... (80). He also referred, albeit surreptitiously, to the distortionate 'capital tax' (varlık vergisi), $55 \%$ of which had to be paid by the small minorities who still inhabited Turkey-Kraus' friend and later spouse of Greek origin, Chariklia, a simple ex-office-worker, had to cough up the equivalent of 1000 Marks, which would ruin her (and him), but fortunately, after nine months of 'trembling', she was exempted in September 1943 (100). Bitterly commenting on Werner's protest against the destruction of cultural monuments by bombing, Kraus replied that it had been Ludendorf himself who had proposed the indiscriminate use of bombs in his book Der totale Krieg, and continued: Manchmal werde ich ja traurig, wenn ich denke, daß der Mensch alle wilden Tiere und fast alle Naturgewalten zweckdienlich bezwungen und sich unterworfen hat, um sich dann höchstselbst mit größtem Raffinement auszurotten. Wozu dann erst die ganze schmerzliche Entwickelung vom Höhlen-menschen bis zumLuftschutzkellergast 1943? (24 August 1943, 99). On 13 February 1944, desparing of the future, he wrote: [Wir] ... starren bange und mit dem Gefuihl der Lahmung in den trüben, blutigen Nebel, der uns die Zukunft verhüllt ... (105). Beside man-made disasters, there were also natural ones like the regularly returning phenomena of earthquakes and tremors (reported in 33, 78, 105) and a typhus epidemic (in the Summer of 1943, 95, 97). One of the recurring themes ( $36 \mathrm{ff}$.), directly related to the war situation, was the continual 


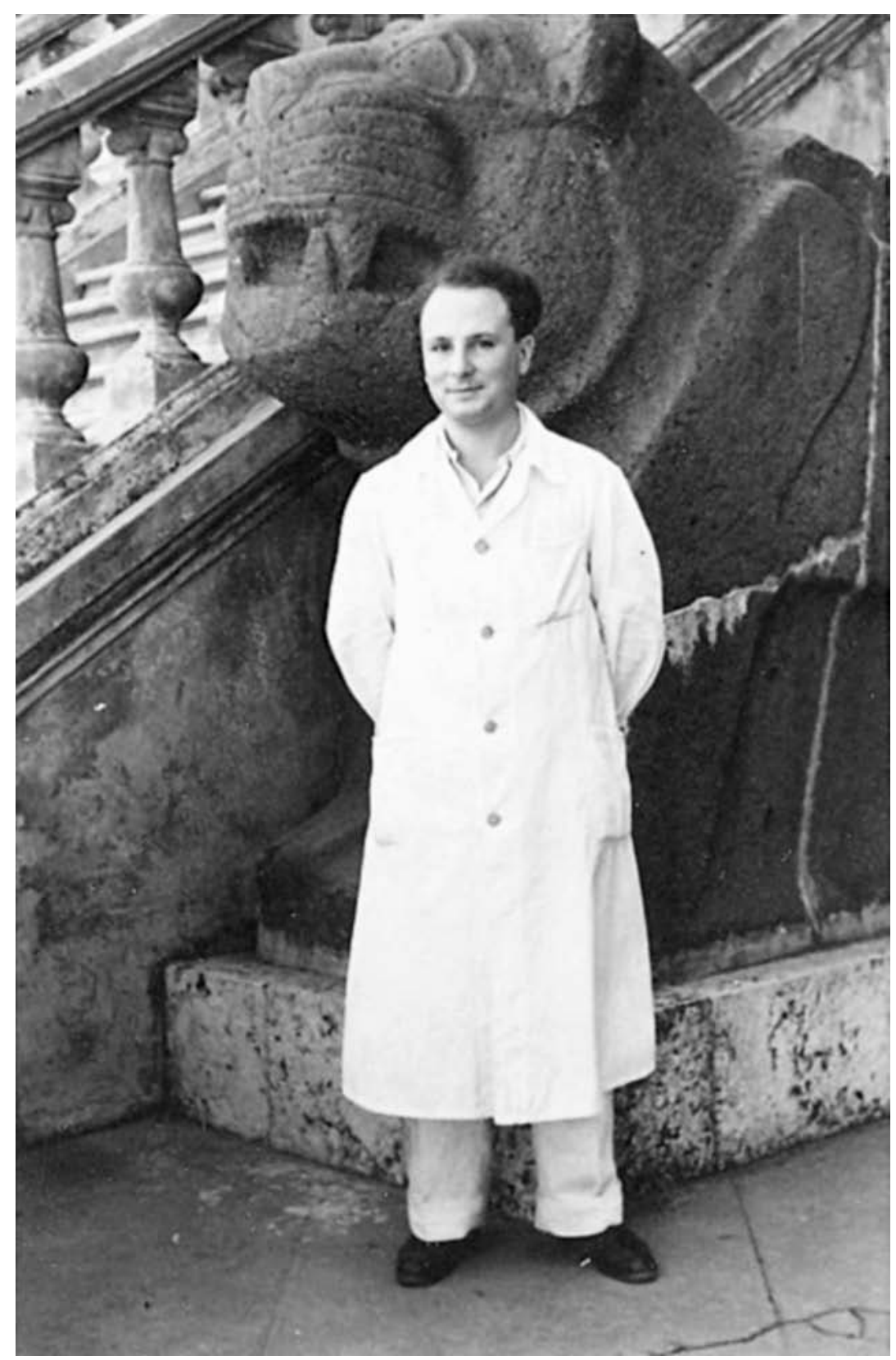

Figure 36. Fritz Rudolf Kraus at the entrance of the Department of the Ancient Near East of the Archaeological Museum in Istanbul, with Hittite lion statues (undated photograph, NINO Archive) 
rise of prices, hardly compensated by small and rare salary rises. This soon reduced Kraus to the status of Kleinbürger mit proletarischem Lebensstandar" (109). By the end of the war, almost all he earned was spent on primary necessities like food, firewood and coal—if available at all (cf. 71, 73) - gas and electricity, and housing, clothes and shoes, and he could hardly afford the purchase of furniture or other luxuries. Cigarettes remained relatively cheap and Kraus soon came into the habit of smoking some twenty per day. On 1 May 1943, he wrote: Für Gas und Elektrizität habe ich im April 38.24 RM bezahlt und dabei sitzen wir abends bei einer einzigen vierkerzigen Birne alle zusammen ... Würde ich ein Hiesiger, so würde ich sagen "Gott ist gross", Allah büyük. Damit können sich die Leutchen irgendwie trösten. Wohl ihnen. (93) In the harsh winter of 1941-1942, Kraus was forced to spend his evenings in coffee houses. All along during Kraus' stay in Turkey, he had to be content with the clothes, shoes and hats, time and again repaired by Chariklia, which he had brought from Germany. The impossibility to import foreign goods even forced the cable tram in Galata (Tünel) temporarily out of service in 1941 $(61,68)$, but also the normal tram services often broke down owing to a lack of spare parts and horse-drawn coaches appeared on the streets because of a lack of petrol (63). Bread was rationed from January 1942 (71); the daily ration was 300 grammes for an adult, and the quality was often dubious $(58$, 65, 74). Food prices soared and by April 1942 Kraus reported home: Ich habe eine neue Krankheit ... beim Essen beginne ich unwillkürlich auszurechnen, für wieviel Piaster Essen ich eben im Munde habe ... (76) Razor-blades, matches, rubber shoes, coffee and pastry disappeared all together $(61,67,71,73,92$, 95).

The letters indeed make it perfectly clear that Kraus' life in Istanbul was difficult and a painful experience throughout; dominant themes are those of financial insecurity and poverty made worse by his low and uncertain status as a foreign employee (who could not be promoted or publish any work without the express permission of the state). Despite repeated attempts by Werner and his lawyer in Spremberg, it also proved impossible to transfer money from Germany - Kraus' share of the family capital (of 165,366 Marks, cf. 81) remained frozen on a bank account (Sperrkonto) of the Dresdner Bank. The insecurity became worse with the outbreak of the war and Turkey's challenged neutrality: once the country would become involved in it on the side of the Allies, Kraus was surely to be dismissed and imprisoned. This threat was never completely absent, and almost became a fact in 1944.

After the rupture of diplomatic ties with Germany in the Summer of that year, a policeman presented himself at Kraus' door - this was at the end of August-informing him that he had to move to Anatolia. At Haydarpaşa 


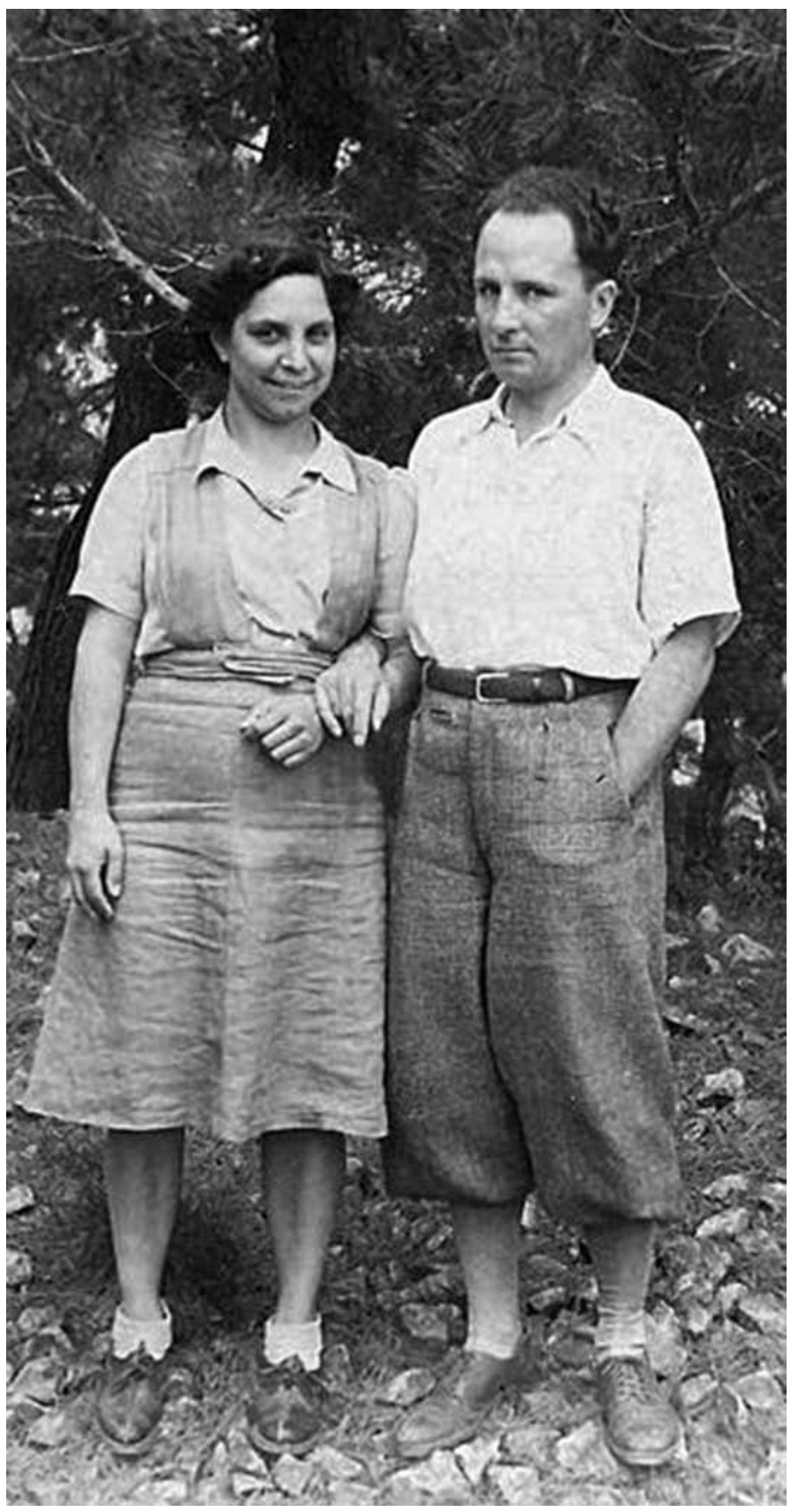

Figure 37. Fritz Rudolf Kraus and Hariklia Anastasiadis in Istanbul (undated photograph, NINO Archive) 


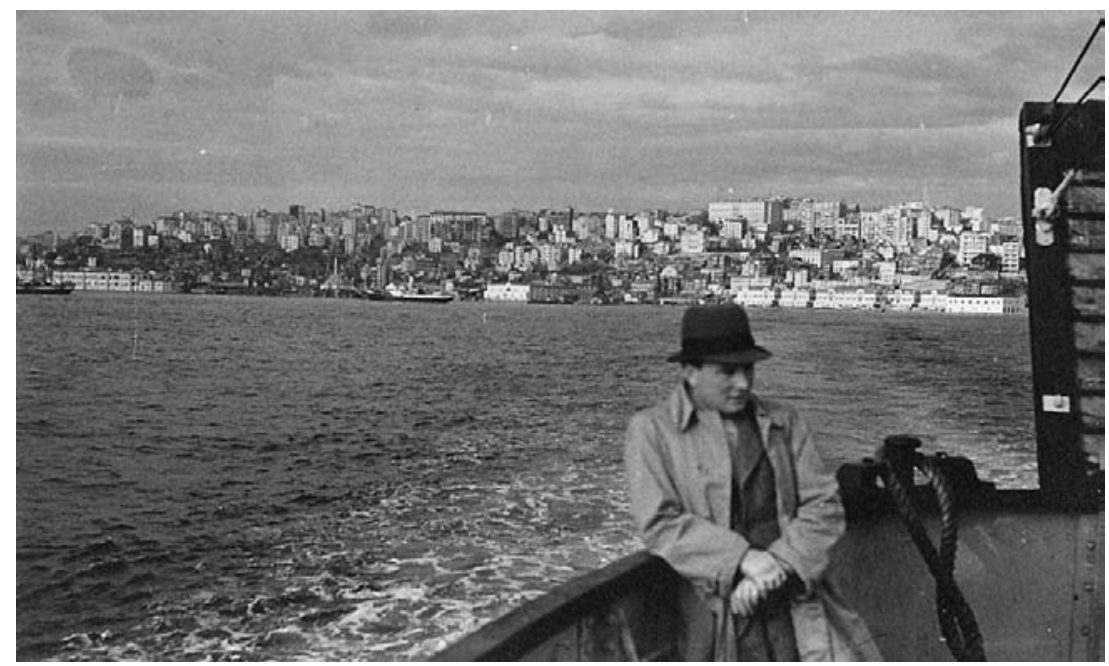

Figure 38. Fritz Rudolf Kraus on a ferry in the Bosphorus (undated photograph, NINO Archive)

Station, where he was to board a special train, he soon heard that he was exempted from internment on orders of the provincial governor and was allowed, thanks to pressure exerted by the Dean of the Literary Faculty, to return home (109). Most other compatriots were not so lucky: die Abtransportierten, wahllos Nazis, Nichtnazis und Zufallsdeutsche fremder Zungen durcheinander, blieben $1^{1 / 2} \mathrm{Jahr}$ im Landesinnern (letter to Bauer, 4). Then there was the continual worry, made worse by the irregular and often severed mail connections, about his brother and widowed mother in Spremberg (his father had died soon after he had departed for Turkey), particularly after war had broken out - connections were completely cut off between August 1944 and April 1946. Her health declined steadily, as was clear from Werner's letters, until she died soon after hostilities had ended in 1945 as Kraus only learned in the early summer of 1946.

Kraus often suffered from homesickness-it soon became clear to him that travel to Germany was impossible for both bureaucratic-passes of 'non-Aryans' reportedly were confiscated on crossing the German borderand financial reasons (a ticket of the Orient Express cost more than a month's salary) — which became particularly felt during the period of Pentecost, when he reminisced the wonderful trips he used to make in Germany prior to his exile (cf. 15, 77). He in fact never disengaged himself from his fatherland, and remained a German at heart, albeit not of the Hurrah, Wellfleischessen und Antisemitismus type (111). Neither did Germany forget 
him completely. Ironically he noted how he was called up for a medical examination in the German Hospital in March 1942 (75); in September he was informed that he was fit for military service and incorporated into the Second Ersatz-Reserve (83).

One of the problems encountered by Kraus-it was directly related to his poverty - was housing. When he arrived in Istanbul, he first rented rooms in an (expensive) German pension, 'Hella', in Taksim (eine Oase der Sauberkeit und bescheiden Europäiziteit inmitten der sonstigen Stadt [letter to Landsberger, 1] but Essen in der Pension besteht hauptsächlich aus Huhn und Apfelkompott, 5), but later he moved in with a German family in Beyoğlu: Ich binjetztwieder "möblierter Herr" bei einer anständigen kleinen deutschen Familie, mit zwei grossen, nicht sehr hellen und fast kahlen Zimmern in einem Einfamilienhause inmitten der alten Botschaftsgebäude und nahe dem Zentrum der Stadt ... (October 1938, 18). A year later he moved to rooms in Cihangir (29) — where one day he found his landlady dead in the bathtub (40) - and had to move to a hotel, soon afterwards to a room in Çarşıkapı (42), back to Beyoğlu (48), back again to Çarşıkapı (so eine Art Zeltlager aus Beton; the landlord was a Czech Jew from Egypt, called Hersch, married to a Viennese woman) (48; letters to Landsberger, 80, 92) —and again back to Beyoğlu (61) and Galata (64). There he was thrown out of his rooms after the government had forbidden non-Turks to let appartments (September 1942). After a tiring six-week search, Kraus, Chariklia and her mother were able to rent a flat on the third floor of a newly built housing estate in Feriköy opposite an Armenian church. Among the neighbours were Armenians, Greeks, Germans and a Turk (82). Apart from the inconvenience caused by noise (yelling children and radio music-einheimische sogenannte Musik, markerschütternder Zeuge einer gottverlassenen völligen künstlerischen Unfähigkeit, die die Leutchen aber nicht müde werden täglich in die Welt zu schreien ..., 96), particularly in summer-how did he long for the quiet garden in Spremgberg where he had written his thesis in the Summer of 1933! (126) — there was the increased distance from work: it took a 70-minute walk to reach the old town-centre and the tram-journey was a harrowing experience, due to constant over-crowding.

Apart from occasional German lessons he gave to private persons, Kraus was employed by the Archeological Museum; his appointment had been arranged at the Turkish Embassy in Berlin. Upon arrival from Germany, he was introduced to the staff (as he wrote Ehelolf on 12 August 1937): Dorthin ging ich gleich mit Landsberger und ließ mich Haydar, meinem unmittelbaren Chef, und [Ahmed] Aziz [Ogan] vorstellen. Alles war eitel Freude, 
nur erklärte man, gar nichts von mir zu wissen. Man müsse erst nach Ankara telegraphieren und fragen, was mit mir geschehen solle; dieses Telegramm ist angeblich am 29.VII. an Hamit [the Director of Antiquities and Museums at the Ministry of Education in Ankara, Dr Hamit Zübeyr Koşay] abgegangen, dann hat Landsb. selbst geschrieben und dann ich noch an Hamit nach Alaca Hüyük. Bis jetzt ist die Antwort noch nicht da, Geld auch nicht, ich lebe von Geborgtem und von Schulden. Man sagte so allgemein, es würde drei Monate dauern ... Man ist eben hier Ankara-feindlich und reaktionär, wie Sie mir ja auch schon sagten, außerdem will man hier nicht aus seiner Ruhe aufgestört werden durch einen, der immerfort arbeitet und vor dem man sich dazu blamiert, weil er Sachen versteht, von denen man keine Ahnung hat, obgleich sie einem in sein Ressort gehören. Aber man hat noch mehr gegen mich:man hält mich für Landsbergers "jungen Mann", der hier für Landsb. das wissenschaftliche Fett abschöpfen soll, was man selbst aber von den Türken gemacht haben möchte, welche aus Ankara und aus Europa als gelehrte junge Männer hervorgehen werden ... This uneasiness and uncertainty was never to go away. Kraus' task was to look through the enormous, but still largely unexplored, collection of cuneiform tablets. After the initial bureaucratic problems had been solved, Kraus was employed by the Museum, but only on and off because appointments had to be renewed every year-sometimes for even shorter periods - because tenure was not given to foreigners. Every appointment required confirmation from the government in Ankara, and this often took some weeks, sometimes even months. Thereupon Kraus had to sign contracts at a notary's office (for which he had to pay a stiff fee). The same problems were encountered after he had been appointed lecturer at the university. While renewal was still unconfirmed, Kraus did not receive any pay and often had to borrow money to breach the void. Once Kraus was unemployed for fourteen months (June 1940-August 1941). This, according to Kraus, was a consequence of a temporary anti-German policy following the Spring Campaign of 1940 (letter to Stamm, 9) and cost him savings worth 6000 Marks (75). His uncertain status led to endless worries about money and his residence permit, and obliged him to repeated, fortnightly, visits to police stations - on one occasion Kraus had to repeat the visit when it appeared that his file had been lost (letters to Landsberger, 64, 72). Only after thirteen weeks did he receive a permanent residence permit. Problems had been caused by the fact that Kraus was not able to produce evidence of his status as 'Aryan'; ich hatte keine geringe Mühe, nachdem ich als "Deutscher" entlassen worden war, als "Nichtarier" privatim bleiben zu durfen (Letter to Stamm, 9). During his enforced idleness, he tried to get support from the Notgemeinschaft Deutscher Wissenschaftler im Ausland, which sup- 
ported the emigration of many German academics to Turkey since 1933, and spoke to the pathologist Philipp Schwartz, an exile himself and one of its leading figures. The latter offered him a job as porter at his Institute for Pathological Anatomy. Kraus declined (letter to Landsberger, 67). Kraus also approached the Romanist Erich Auerbach, formerly professor in Marburg, author of the famous study on realism in Western literature, Mimesis, and head of the School of Foreign Languages of Istanbul University, but he was not able to help him to a job (letter to Landsberger, 70). The school did employ a few orientalists, among whom the turcologists Andreas Tietze, only superficially known by Kraus, and Robert Anhegger; both taught German (letters to Landsberger, 134, 137). Desperate, Kraus mused that he could always try to become German broadcaster of Radio Istanbul (letter to Landsberger 72). To market himself as a teacher of German or Latin proved to be impossible by that time-for this he needed a permit issued by the state. Kraus characterized his plight to Landsberger on 29 November 1940 thus: So spiele ich hier möglichst leger die Rolle des nicht pressanten Bittstellers, obgleich ich auf meiner ofenlose Bude jämmerlich friere und mich unregelmäßig und unzweckmäßig ernähre ... (82). The latter, with whom he finally went to live in the summer of 1941 in order to cut costs supported him during the crisis, as he had done before and was to do again in the future; he was in fact the most important patron throughout his, Kraus', career, lending him money when necessary, and solving bureaucratic problems in Ankara. He also arranged Kraus' final escape from Turkey by sponsoring his appointment at Vienna University in 1949.

The work in the museum was often tedious-also because there was no good reference library available (he had to look up things at home in the few books he had brought with him from Germany or could occasionally be sent from there by Werner). Kraus had, a fifteen-day holiday excepted, to be in the museum every working-day during office hours, including Saturday morning. The work was quite a change from what he had experienced in Germany so far: Es ist eine große Veränderung zu konstatieren zwischen dem Schreibtischdasein im Leipziger Institut und dem hiesigen Kampf mit den Originalen ... (letter to Bauer, 1). The museum management was, apart from bureaucratic, often, as was the case with the technical staff who had to take care of the cleaning and conservation of the clay tablets, clearly incompetent, and Kraus repeatedly complained about this in his letters $(15,16)$. Landsberger did his utmost to hold Kraus' irascible temperament in check; on the very first day Kraus came into conflict, later regretted as a Fehler [meines] Preußentums, with the director, Aziz Bey, who told him, clearly contrary to the contract, that the cataloguing job should be finished within 
five months (letters to Landsberger, 1, 65). A recurring irritant was in particular the, in Kraus' eyes, laziness and incompetence of the chemist Nurettin [Akbulut], who had to prepare the tablets prior to labelling and cataloguing, and about whom he endlessly complained in letters to Landsberger. To Koschaker, Kraus sketched the situation: Mein augenblickliches Arbeitsfeld ist die Nippursammlung, welcher hier an Große nur die aus Lagaš vielleicht gleichkommt; genaue Daten über den Umfang der Sammlungen fehlen allerdings ganz. Nippur ist nun ein reiches Feld für den Juristen, wir schwimmen in Texten der dritten Dynastie von Ur, und zwar die kleinen ... aus Kontrakten der Larsa- und Babylon-Dynastie, gar nicht zu sprechen von den Kassitentexten privatwirtschaftlicher und administrativer Natur. Dazu kommen dann noch die neubabylonischen Texte und die aus der Perserzeit ... Auch unter den 500 Assurtexten, die ich anfangs durchgesehen habe, war der überwiegende Teil juristisch ... Was das reguläre Arbeiten hier angeht, so muß man ein viel großerer Diplomat sein, als ich es leider bin, um hier etwas zu leisten ohne anzustoßen. Man muß sich zunächst an Mentalität und Tempo gewöhnen. Es geht verzweiflungsvoll langsam, von Ankara kommt kein Geld, wenn es da ist, bleibt es lange liegen, dann hat man weiter auf die Fertigstellung der in Auftrag gegebenen Sachen (wie Kartothekszettel, Kästchen für die Tontafel, Schränke etc. etc.) zu warten. Das Laboratorium arbeitet mit einem einzigen Mann, der sich ein Universalgenie dünkt, und mit ungenügender Apparatur, hat aber neben der Tontafelbrennerei noch die Konservierung sämtlicher in den Ausgrabungen gemachten Funde zu erledigen mit dem Erfolg, daß so gut wie nichtsfertig wird ... (1). In other letters, Kraus described in detail the clash of cultures which made his life and that of Germans in general often a trial: Die deutsche Zucht, welche bei mir als einem Zögling des ehemals Königlich preussischen Joachimstalschen Gymnasiums eine speziell preussische Ausprägung hat, ist für die Deutschen warscheinlich das größte Hindernis, wenn sie im Ausland etwas leisten wollen ... Dinge wie Pflichtgefühl, kategorischer Imperativ und dergleichen Hochbegriffe tut man gut, hiernur für den Privatgebrauch zu reservieren und nicht hervorzukehren wie ich es leider getan habe. Zur Erläuterung darf ich ein aktuelles Beispiel anführen: wir haben heute den 14. Tag des Ramazan [20 November 1937], der in dem altmodischen Istanbul noch weitgehend als Fastenmonat eingehalten wird. Die Leute essen also von früh um 6 bis nachmittags um 5 etwa nichts und müssen morgens schon vor 5 aufstehen, um ihr nächtliches Frühstück zu nehmen. Da der Islam nich mehr Staatsreligion ist und aufdie Fastenden offiziell keine Rücksicht mehr genommen wird, sie also arbeiten müssen, sind sie nicht nur verhungert, sondern auch müde. Der Anblick der Essenden, welche es auch unter den Muslimen zahlreich gibt heutzutage, macht sie noch nervöser: sie werden von Tag zu Tag 
ungenießbarer. Der regelrechte Streik eines Dieners im Museum veranlasste mich zu einer Nachforschung, welche ergab, daß das gesamte Museum sich in heller Entrüstung gegen mich befindet. Mein alter Diener (der mich nebenbei überwachen soll) wohnt mindestens eine halbe Stunde zu Fuß vom Museum und muß laufen, da er kein Geld für die Trambahn hat. Da die offizielle Arbeitszeit bis 5 ist, kommt er fast eine Stunde nach Ende der Fastenzeit nach Hause und muß auf diese Weise eine Stunde länger fasten, was dem älteren Manne beschwerlich fällt. Man erwartet nun von mir, daß ich das Museum so zeitlich verlasse, daß er beim Kanonschuß, welcher das Ende des Tagfastens bezeichnet, mit speisen beginnen [kann] ... Ich fragte nun einen der deutschsprechenden türkischen Herren: wie kann ich denn um 4 Uhr weggehen, wo mir der Direktor doch gesagt hat am Anfang, mein Dienst dauerte bis 5 Uhr? Antwort: das macht nichts, da findet niemand was dabei. Nun gut, sagte ich, warum hat mir kein Mensch gesagt, ich solle vorher weggehen? Antwort: so etwas verbietet die türkische Höflichkeit (welche aber nicht verbietet den ahnungsloser Ausländer unschuldig Fehler begehen zu lassen und dann dafür zu hassen). Ich: dann werde ich also sofort den Direktor Erlaubnis bitten, früher gehen zu dürfen. Antwort: wenn Sie das tun, muß er Ihnen laut Gesetz sagen, daß Sie bis 5 Uhr zu bleiben haben. Dann ist eben außer der Dienerschaft und den unteren Beambten, auch der Dir. wütend, daß sie ihnen so verfängliche Fragen stellen. Also ist es hier wieder die Frage der Verantwortlichkeit welche keiner hier haben will: ich soll sie auf mich nehmen, indem ich nach dem Wunsch der Diener gegen die amtliche Verfügung früher schließe. (letter to Friedrich, 2). To his mother he wrote on 9 October 1937 that he was sitting während des ganzen lieben Tages in meinem Depôt und lasse mich von den Mücken auffressen. Am immer offenen Fenster tront der alte Diener auf einer Kiste, welche mit jahrtausendealten Gegenständen gefüllt ist-man hat seit 5o Jahren noch nicht die Zeit gefunden sie auszupacken-und liest solange halblaut in seinem Koran, bis ihn die Müdigkeit überwältigt; dann rückt er seinen Stuhl in einen Winkel und nickt eine halbe Stunde. Ich habe es nicht so gut, obgleich ich auch oft schwer gegen das Einschlafen kämpfen muß. Meine Arbeit könnte interessant sein, aber da die Bücherei weit entfernt ist und auch wenige Bücher enthält, kann ich aus meinen Tontafeln nicht das herholen was ich gern möchte ... (4) His cataloguing work made him so eine Art Trüffelhund, der die herrlichen Pilze zwar aufspüren muß, aber nicht frißt ... (65) This was not completely true, eventually, but only after 1945 Kraus was able to publish on the collection and some of its items. Nor was he always alone at his job; sometimes he taught students - in June 1938, four students, Kemal [Balkan], Emin [Bilgiç], Osman and Neriman (she died early in December 1939), arrived from Ankara $(15,17)$ — showed visitors around - as he did the 
German Ambassador Franz von Papen in December 1941 (67) — and during the final years he was assisted by two female students, the aforementioned Muazzez Çı̆̆ and Hatice Kızılyay (73). As seen above, Kraus remained in contact with his former students even after he had left Istanbul. Sometimes colleagues came and stayed to work for some weeks, among them particularly Güterbock and Landsberger from Ankara. In the end Kraus realized that he had contributed little to the cataloguing, and that it would have been a much better idea to photograph the whole collection - there was already a collection of photographs in the museum-instead of laboriously copy every single item by hand - as was mostly done by the two assistants-so that international scholarship could use the collection (cf. letter to Landsberger, 148).

From January 1941, Kraus was also lecturer at Istanbul University and was allowed by the museum to teach a few hours every week during term-time and assist at the examinations in June. At first Kraus spoke in German, as he reported to Werner in February: die Vorlesungen halte ich auf deutsch mit Dometscher, denn türkisch zu lesen getraue ich mich noch nicht, obgleich ich seit meiner Rückkehr [aus Ankara] nach Istanbul ziemliche Fortschritte gemacht habe und jetzt schon ganz munter plaudern kann ... (73), but in later years he did without an interpreter-from the beginning of his sojourn in Turkey, he had done his best to increase his fluency in Turkish (3) and had taken lessons from one of Landsberger's students, Mustafa Kalaç (letter to Landsberger, 2) - but progress was slow. In December 1938 he wrote to Theo Bauer:... mein Türkisch ist fast noch ebenso primitiv wie am ersten Tage, da man es in dieser polyglotten Stadt tatsächlich nur mit den Primitiven zu sprechen braucht, können doch sogar alle Straßenbahnschaffner wenigstens deutsch oder französisch zählen ... (2). He certainly did not attempt to use the difficult literary Turkish, which he used to read in newspapers (84) but which, to make things even more complicated, was being in a process of reform. Although he sometimes read the (official) Ulus, he mostly restricted himself to the lecture of a local French paper (Wurstblättchen), that is, if he could afford the price. Solange ich meine Sätze hübsch zu Ende haspele, geht alles gut, nur wenn ich etwa mitten im Satze stecken bleibe, dann liegen sie auch ratlos auf der Strecke und können aus Eigenem den Satz in ihren Heften nicht zu Ende bringen. Aber letztlich verstehen wir uns doch immer, glaube ich ..., he wrote to Werner on 27 November 1942. Classes-mostly history courses and only occasionally philological exercises-were held in the Dolmabahçe Palace-wenig Dekane der Welt werden ein so fürstliches Arbeitzimmer haben ... mit einem so schönen Blick ... - (until the autumn of 1943) after a fire had destroyed the faculty buildings in the old town. 
Ich hatte etwas dreißig Hörer, Kraus wrote to Werner on 12 March 1942, wenn ich recht gezählt habe, eine ganz stattliche Anzahl, die Mehrzahl weiblich. Ich sage einen Satz, der Übersetzer, ein junger Türke, der in Leipzig in Geschichte doktoriert hat, den ich aber dort nicht kennen gelernt habe, übersetzt und alle Federn rascheln über das Papier. Die jüngeren schreiben Lateinschrift, die älteren arabisch, aber sie schreiben jedes Wort des Übersetzers. Das ist alte Sitte hier, die Studenten haben ja keine Bücher ... Die arabische Schrift ist übrigens fast wie Stenographie, mann kann sie erstaunlich schnell schreiben ... (74) Sometimes there occurred hilarious misunderstandings; Manchmal laufen mir unfreiwillige Witze im türkischen unter, so endlich, als ich, indem ich in einem Worte ein g ausließ, statt "zahllose [sayısı] Ruinenhügel"- "respektlose [saygısı]" Ruinenhügel sagte, was die Studenten höchlichst erheiterte ... (it was rather the other way round: he erroneously added a ' $\mathrm{g}$ ' instead of omitting one.)

Kraus had only a few close friends in Istanbul, and soon upon his arrival in Istanbul he realized that relations with the opposite sex were not easy: ... die Hoffnung hier ein Mädchen zu finden habe ich vorsichtshalber schon aufgegeben ... alle sind hier eisern keusch, he reported home on 24 August 1937 (2). He also quickly discovered that visiting night-clubs was an expensive hobby, which he soon had to give up $(7,26)$. Occasionally, but not often, he visited a cinema (cf. 88, 105). After a brief engagement with an Italian Jewess and daughter of a Levantine merchant called Elsa Franco in $1938(9,16)$ he wrote in despair to Werner: Auf dem erotischen Kriegsschauplatz nichts neues, ich werde täglich immer elender und verzweifelter ... (17). He made the acquaintance of his future wife, Chariklia, with whom he was able to communicate in a mixture of French (das mehr oder weniger scheußliche Levantefranzösisch, cf. letter to Stamm, 10) and Turkish, in August 1940 (37). This provided him with homely pleasures, particularly after their move to Feriköy, if not, for the coming years, healthy sex - although he married her civilly in April 1946 - it was impossible to do this earlier because the Nuremberg Laws, which forbade sexual relations between 'Aryans' and Jews, had been recognized by Turkey (cf. letter to Bauer, 4) —Chariklia did not regard herself really married until the bond had been consecrated by a pope-but a church wedding was an expensive affair and was postponed until shortly before their departure from Turkey in 1949. By then they had begun sleeping in the same room (from November 1946, 114).

Kraus' work at the museum and for the university did not alter much in his relative social isolation; although there was a substantial community of German academics, mostly political refugees and Jews, with only a few of them he became intimate; he particularly missed friends of his own age 
(cf. letter to Bauer, 2). Landsberger, although he was in Ankara most of the time, was perhaps his most important contact during these years. The latter suffered even more from his forced exile than Kraus himself: [er ist] tief verdrossen, müde und sorgengequält; es ist traurig zu sehen, wie diese Exilsjahre an ihm zehren, der für Leipzig und für den Leipzig geschaffen schien. Wenn man sich so fünf Tage lang Stunden und Stunden lang mit ihm über Gott und die Welt unterhält, fühlt man wieder den Reiz und die tiefe Wirkung seiner ungewöhnlichen Persönlichkeit. Ich neige jetzt [December 1939] zur Skepsis gegen unsere (vorhitlerische) Kultur, aber ein Mann wie Landsberger zeigt durch seine Werke und seine Person, daß diese Skepsis doch nur teilweise berechtigt ist. (letter to Stamm, 8). In the museum there was, furthermore, the numismatician Clemens (Emin) Bosch; in 1938 he was appointed professor at the university. Another German colleague was the archeologist Hellmuth Bossert, famous for his later finds at Karatepe, who taught at the university between 1933-1934 and 1961, but whom Kraus unreservedly loathed as a Gewissenloser Opportunist, particularly after Kraus realized that he, Bossert, did his utmost to block his appointment at the university (letters to Landsberger, 64, 68; letter to Bauer, 17). (He was characterized as der Nazi by Schwartz; according to Kraus, hat er hier ... systematisch alle Emigranten und auch andere Deutschen beim Nazikonsulat denunziert, letter to Bauer 17; to Kemal Balkan Kraus characterized him (in Turkish) as: şu no (Ingilizce) boss ne de sert olan Bossert herif, 11) Kraus was also acquainted with the Iranist Hellmut Ritter, a strange fellow known for his homosexuality, but the latter made it clear that he did not wish to continue the contact (letter to Bauer, 19). In 1944, the Arabist Oskar Rescher became librarian at the museum; he had been teacher of German at the Military Academy in Istanbul from 1925 (letters to Landsberger, 105; letter to David, 1). He was not, as Kraus remarked, the conventional Schreibtischarabist, but had for years been reading texts with local scholars, and was busy translating Arabic poetry (letter to Bauer, 19). A central figure for the German emigrants was the astronomer Professor Hans Rosenberg, formerly professor in Kiel; but the man, who was like a father to Kraus, died already in July 1940 (cf. letter to Landsberger, 70, to whom he wrote Für mich ist die aus der Weltlage und meiner Situation sich ergebende Beklemmung erschwert durch den plötzlichen Tod von Professor Rosenberg, den ich hoch schätzte und dessen Haus mein geometrischer Ort in der hiesigen "Gesellschaft" und eine nie versagte und nie versagende Zuflucht für mich war). A few times Kraus was invited to visit his direct chief, the Second Director (not mentioned by name, but probably identical with Aziz Bey's secretary, Selim Bey), who owned a magnificent yalı on the Asiatic shore of the Bosphorus 
$(38,76,100)$. On 24 September 1943, he wrote to Werner: Dank dem Professor [Landsberger] partizipierte ich am letzten Samstag an der Essenseinladung zu unserem zweiten Direktor, welcher sich bisher mir gegenüber hochst zurückhaltend gezeig thatte. Dieser Mann, fünfJahre älter als ich, ist als Enkel eines Paschas und Sohn eines vermögenden Mannes deutsch erzogen worden, hat in Berlin studiert und spricht fließend deutsch. Als Erbe besitzt er ein altmodisches Haus in einem nahen Vorort und eine Besitzung am Bosporus, auf seinem asiatischen Ufer, wo er mit Mutter und Schwester, welche Witwe oder wenigstens dauernde Strohwitwe zu sein scheint, nebst seinem kleinen Neffen im Sommer wohnt. Man fährt mit dem Dampfer hinaus. Der einst ruhige Ort hat jetzt, wie zwei Flügelmänner zu beiden Seiten, rechts eine Alkoholfabrik der Monopolverwaltung, links eine Flaschenfabrik des Staates, ist aber im Innern wenig verändert. Das besondere an der Besetzung [?] ist ihr parkähnlicher großer Garten zwischen Straße und Wasser, an den sich, jenseits der Straße, ein großer Wein- und Baumgarten anschließt. Das einfache, etwas ungepflegte Haus steht ganz nahe dem Wasser auf einer sandigen Terrasse über eine Steinkai nahe bei einem kleinen ummauerten Bootshafen mit Bootshaus ... Tritt man ins Haus, so befindet man sich in der hier üblichen riesigen Halle. Das Eßzimmer typisch altmodischer, europäisierender türkischer Stil, sehr komisch die seinerzeit sicher sensationellen beiden Marmorwaschbecken mit fließendem Wasser an der Wand. Man wäscht sich hiernach dem Essendie Zeiten sind wohl noch nicht lange vorbei, wo man mit den Händern aß. Als Zeichen der modernisierung ein Eisschrank an der Wand. Wir speisen zu vier, der Gastgeber und sein schweigsamer kleiner Neffe, der Professor und ich, höchst aufmerksam bedient von einer alten Dienerin und in keiner vornehmen Familie fehlenden freundlichen Negerin. Die Schwester des Direktors, als Hausfrau, saß zwar bei Tisch, aß aberwegen des Fastenmonats nichts. Auch hier sind die Frauen noch frommer im Allgemeinen als die Männer. Das türkisch-europäische, etwas schablonmäßige, aber sehr gute Essen bestand aus Fisch am Grill, eine zarteste Bosporusspezialität, welche ich deutsch nicht zu benennen weiß, dann Lammbraten (aus dem Backofen) mit Röstkartoffeln, Auberginen gefüllt, Pilav, die nationale Mehlspeise Muhallebi aus Milch, Reismehl und Zucker und herrliche eisgekühlte Birnen nebst Feigen, und dazu Tomatensalat mit eingelegten Oliven und Flaschenbier. Der Kaffee wird im Salon genommen, dessen altmodische Ungeschicklichkeit durch gerahmte, kunstvoll aus Bein gearbeitete Koransprüche etwas ins Orientalische gewandelt ist. Unter den Manifestationen der sprichwörtlichen türkischen Gastfreundlichkeit, die sich hier über den, dem sie zuteil wird, reichlich ergießt, aber nicht so leicht angeboten wird, verbrachten wir wirklich sehr angenehmen Stunden reinsten Friedens und vollen Wohlseins. Once Kraus attended a 
tea party (Tanztee) organized by students, during which rather bombastic nationalistic poems were recited and folkdances, among them a sworddance, were performed (106).

Most of the time Kraus stayed at home, and during the summer he used to spend Saturday afternoons and Sundays walking or visiting Büyük Ada in order to swim. Travel in Istanbul and surroundings was restrictedMan ist hier gefangen, überall verbotene Zonen für die Ausländer, und Geld und Zeit habe ich auch nicht, he reported home (15), and when one abandoned the usual foot-paths, one was arrested (73); the reportedly fabulous Black Sea beaches were also military territory and out of bounds (102). The Yıldız Park was opened to the public in September 1943, offering an alternative outing for the wary city-wellers (... vor einem renovierten schlichten Pavillon (türkisch Köşk ...), in dem das städtische Kasino eine Filiale eröffnet hat, sitzt man auf einer Terrasse und blickt über eine Art Wiese ... auf den Bosporus hinab und auf Skutari, während eine rumänische Zigeunerkapelle hinter einem lärmt und man Mittelfinger-große belegte Brötchen ißt, eine langentbehrter Genuß. Preis pro Stück RM 1.-. So leben wir, so leben wir-aber durchaus nicht alle Tage, 101). On a few occasions Kraus travelled in Anatolia: in September 1938 he made a thirteen-day (first-class) train journey-30oo kms, of which 1000 in the Taurus Express, for 170 Marks-visiting Konya, Sivas, Adana, Malatya, and Bursa (18, 23; letter to Bauer, 2; most details are found in a letter to Friedrich, 3 ), which quite impressed him: die Berührung mit den ersten Vorposten des immernoch leidlich erhaltenen Orients ist für einen Orientalisten schlechterdings ein großes Erlebnis (letter to Bauer, 2). To Stamm he wrote: Mitte September war ich dann 13 Tage in Anatolien ... Ich kam bis nach Malatya, in Sicht des Eufrat ... überschreiten darf ihn ein Ausländer nicht, nur mit spezieller Genehmigung, die einzuholen ich nicht erst versucht hatte. Ich bin geneigt, diese kurze Reise auf einigen der Haupteisenbahnlinien des Landes für die schönste meines Lebens zu halten. Landschaft, Antiken, Berührung mit dem Orient waren die drei aufregenden Elemente einer teilweise märchenhaften Fahrt. Da sehen sie die Patriarchen auf ihren Eselhengsten reiten, da hocken die Kurdenfrauen vor dem Balkenzaun des Gefängnishofes und schreien zu ihren eingesperrten Männern hinüber, da schlafen die Menschen in Teppiche gewickelt auf den flächen Dächern der Häuser aus Lehm und Häcksel ... Würde dieses Land einmal turistisch ausgeschlachtet, etwa von Cook nach Muster Ägypten—und die Regierung will mit Gewalt den Turismus—, dann muß ich stark für die Schweiz fürchten: was für grandiose Gebirge gibt es hier! (5).

Kraus also visited Ankara several times; he sojourned there for a long period in 1941 during his forced idleness $(30,31,53)$. In June 1941, he joined 
Güterbock and a group of students on a trip by kaptıkaçtı to Kızılcahamam (55); afterwards the party drank beer on a terrace on the Gazi Boulevard. Another week was spent in the capital on the occasion of the Third History Congress organised by the Türk Tarih Kurumu in November 1943 (103). He was invited by Landsberger, and was lodged in the luxurious Anatolia Club. All costs were met by the Foundation, and participants were even given pocket money (from which Kraus was able to save 50 Marks, most welcome to the restricted household budget). Most time was spent translating his German paper on the museum collection, to be presented on the last day, into Turkish - no other language was permitted-with the help of the daughter of the museum director.

The letters of the post-war period covering the years 1946 to 1950, show much the same themes as those of the previous period. Apart from occasional comments on the depressing and continuing war-mongering and spreading of propagandistic lies which accompanied the emerging Cold War (125), Kraus time and again reported on his financial insecurity caused by repeated waiting mit Heulen und Zähneklappern (116) for contracts to be renewed, and his relentlessly increasing poverty (which contrasted sharply with the few, black-market tycoons and others, who profited from the economic situation). To Theo Bauer he wrote in 1948: Neulich hatte ich plötzlich das Gefühl, wenn ich in Chiton oder Toga mit Sandalen herumliefe, würde ich mich kaum weniger deplaciert finden als mit meinem 515 Lira Monatsgehalt zwischen den Luxusautomobilen, goldbeladenen Weibern und geldtrotzenden Kerlen unserer Hauptstrasse ... (11). The continuing economic difficulties in Turkey led to a marked increase in xenophobia, Kraus noted in the Summer of 1948 (139). Half a year later he remarked: Hier wird es an den Universitäten immer unangenehmer. Ein wüster nationalistischer Rummel hat eingesetzt, dem sich kein Türke zu widersetzen wagt ... (146). Despite his poor circumstances, Kraus, alarmed by Werner's letters from occupied Germany, decided to send packets with food and other necessities to Spremberg. They included lots of cigarettes, as long as those were allowed (until December 1947, 130), and, surprisingly, also bacon and pork fat, obtained, mostly, from Polonezköy (cf. 132)—only indigenous products except textile could be sent. This became impossible in October 1948, after prices had dramatically risen - bread, sugar and fuel even by 50\% - and Kraus could no longer postpone buying new shoes (141). The situation in eastern Germany did not look too bright, Kraus noted to his dismay, particularly after his brother's firm in Spremberg [Pagel \& Kraus] was expropriated at the end of 1948; Wir gehen weiter herrlichen Zeiten entgegen. Und zwar sind sie so beglückend, daß die Menschheit jedes Jahr noch um 15 oder 20 Millionen Personen 
wächst, welche offenbar so begierig sind, an unseren Massenstaat- und Atomglück teilzuhaben ... (145). Living conditions in Germany were not dissimilar from those in Turkey, Kraus noted, but one could at least do without the state in many spheres of life and always try to bribe officials (149). Another $20 \%$ rise in food prices followed in April 1949; in the same month Kraus received his first money since four months, of which, after deduction of his debts, only 11 Lira remained (148).

The end of the war had also brought the first re-emigrations: by June 1946 most exiled Jews had already left to the USA, a minority to Palestine (110). Kraus registered as a candidate for repatriation at the US Consulate (and had to fill in a form with ' 200 questions' which drove him mad, 110). A return to Germany was, for the time being, impossible because of the ruinous state of the country and the formerly magnificent network of universities and academic institutes; the occupation-Kraus hated uniforms-lack of vacancies - chairs in the West were still occupied by former Nazis — and the unimpressive number of his publications (111). In the USA, where the postwar period saw a flourishing of the more materialistic studies, the situation was also difficult. After another interruption of his income in early 1948, he mused: Das Leben wird immer teurer und man wäre gern anderswo-aber wo? Es ist überall mies, nur Australien soll in Aufschwung begriffen sein. Aber dort ist für Assyriologen nichts zu machen. (132) Güterbock and Landsberger, after they had been forced to resign from their Ankara posts, left Turkey in September 1948, the first to Uppsala, the latter to Chicago (141). Kraus by then desperately wanted to leave too, particularly after it had become clear that the Tarih Kurumu kept postponing publication of his work on the museum collection which was already for years gathering dust in some office drawer.

The post-war period finally did offer, however, possibilites to boost his academic reputation and to publish articles; although, thanks to Hitler, there was no embassy to support him (Was hier imponiert ist Macht, 116), but pressure of Landsberger on the Turkish authorities helped (110). To his satisfaction, Kraus also noted the re-emergence and development of his academic contacts through a rising number of academics visiting the museum and a, consequently, flourishing correspondence (112). An impressive occasion was his meeting with the famous British archeologist [Charles Leonard] Woolley [1880-1960] in June 1947: Er kam hierher, um nach gewissen Antiken zu sehen, welche er 1914 in Karkemiš ausgegraben hatte (damals zusammen mit dem berühmten nachmaligen Lawrence of Arabia). Als ich hörte er sei in Begleitung unseres Direktors in unserem Museum, sturmte ich los, um den berühmten Mann wenigstens mit Augen zu sehen. Ich wurde ihm vorgestellt, 
konnte einige Auskünfte über die gesuchten Antiken geben (deren größten Teil während des ersten Weltkrieges verloren gegangen zu sein scheint) und wurde vom Direktor beauftragt, Woolley unser Museumslaboratorium zu zeigen. The next day he came again, and after five o'clock, Kraus accompanied him to his hotel. Woolley invited Kraus to drink coffee with him. The latter only left at eleven nach fast 8-stundiger ununterbrochener Unterhaltung, die mir wie ein Märchen vorkam, um mich des alten, aber treffenden Ausdrucks zu bedienen. Beim Abendessen sprachen wir von Kriegszerstörungen in England, Deutschland, Italien, die er als Denkmalsschutzkommandant hinter der englischen Armee her bereist hatte, von der englischen Moral während des Krieges, der Laborparty, dem Königshause und anderem. W. ist nach seiner eigenen Angabe 67 Jahre alt und will künftig nicht mehr graben, man hält ihn aber für viel junger ... Man merkt ihm seine große Energie an, so hat er heuer die Ausgrabung von 250 Arbeitern vollkommen allein begleitet ... Als ungewöhnlichen Charakterzug, der ihn besonders sympatisch macht, habe ich seine Art empfunden, Fragen zu beantworten und aufden Gedankengang des Anderen einzugehen ... (letter to Stamm, 11).

Thanks to the exertions of, again, Landsberger, it appeared in July 1949 that there was a way out of his misery after all. Befriended with his, Kraus', former teacher of Turkish in Vienna and Dean of the Oriental Institute, the turkologist Herbert Wilhelm Duda, Landsberger had suggested to him when the latter visited the USA to ask Kraus to fill a vacancy at the Institute (after an Assyriologist and SS-officer, Viktor Christian, had been forced to resign). After some writing to and fro, Kraus was appointed extraordinary professor at Vienna in October $1949(152,153)$. Among the formalities to comply with he had to fill in all kinds of forms, one of which, Kraus noted ironically, asked him to declare whether he had been member of the Nazi Party, NSDAP (letter to Landsberger, 144; letter from Duda, 1; letter to Duda, 3). The advantages of the Viennese appointment were: escape from Turkey and Austrian citizenship_Kraus had lost his German passport, if not his German citizenship, during the war (cf. letter to Bauer, 4). Disadvantages were the extremely low salary (150): only 1314.50 Shilling (219 DM) per month, and the difficult housing situation. After endless bureaucratic complications (and wahnsinnige Laufereien), and scraping together just enough money for the journey (partly from Kemal Balkan whose thesis he agreed to translate into German for $35^{\circ}$ Turkish Lira, and partly from the royalties, te'lif hakkı, amounting to 600 lira of his book entitled Nippur ve Isin, Eski Babil vesikalarına göre, based on transcriptions made by his two assistants (cf. letter to Bauer, 12), which the Türk Tarih Kurumu had agreed to publish; the remaining part, 270 Lira, was with some difficulty cashed by Emin Bilgiç 
from Hamit Bey in December 1949, see the correspondence with him, letters to Kemal Balkan, 3, 5-8, and under 'Ankara'), Kraus, together with his wife, boarded a Swedish aeroplane on 5 January 1950 destined for Rome, where, before settling in their furnished room on Rudolf von Altplatz 7 (and worrying about how to survive there), they had a pleasant holiday, enjoying the sun, the low prices, richly furnished shops, busy traffic, and local wines (154).

\section{Werner Kraus writing from Germany}

The letters sent by Werner to his elder brother discuss a wide range of subjects, but are particularly informative about family affairs-a dominant theme is the declining health of their mother who, suffering from an incurable desease of the nervous system (pobably Multiple Sclerosis), spent long periods in sanatoriums and hospitals-financial matters, the development of the family business, and the family home in Spremberg (situated on Drebkauerstrasse). Whereas, owing to the strict censorship - traces of the censors are visible in the form of stamps and pencil lines after 1939 - the letters are rather short and superficial up to the end of the war, they became much more detailed and longer after April 1946 when the postal connection with Istanbul had been restored; the first letters sent after this date also give an abundance of lively details of events which took place before May 1945, the description of which had been distorted or suppressed in the earlier letters. (Kraus wrote Landsberger in 1940 that the letters he received from home occasionally contained nationalsozialistische Reflexionen über die militärische und politische Lage gespickt, krampfhaft den Ton schönsten Optimismus und schildern eitel Friedensidyll, 72.)

The first letter, sent on 10 August 1937, informed Kraus of the demise of his father, who died of the consequences of a stroke in a hospital in Cottbus. He had been born in Vienna, and had been proud of the fact; the family had lived in the Taborstrasse, in the second Bezirk, as Kraus would write to Landsberger (137). This left his mother and Werner with a capital of RM 320,000, invested in the textile factory of Michelsohn \& Ascher, where Werner worked as technician and sales manager-the firm had agents in Berlin, Munich and other German towns (29) - other associates in the firm were Mr Bernfeld, and father and son Max and Kurt Michelsohn, all Jews. Kraus inherited a further RM 255,000, frozen, however, in an account of the Dresdner Bank (cf. above- - he was never to see a penny of it). The family also owned two cars.

The year 1938 saw increased measures by the Nazi regime against the Jewish population. Werner reported in January that a boycott against Jew- 
ish businesses had been announced by the Association on German-Aryan Manufacturers (Arbeitsgemeinschaft Deutsch-Arischer Fabrikanten), which would bring a $40 \%$ loss in production and income (14). Later, after the 'Crystal Night' (9 November 1938), it appeared that the factory was to be forcibly liquidated and taken over by non-Jewish owners ('aryanized', $17 \mathrm{ff}$.). (As Werner explained after the war, the liquidation was primarily inspired by two local competitors who maintained good relations with the Cottbus Handels- und Industriekammer. After Crystal Night, Werner was refused further entrance to the factory, and the black-guard Treuhänder, Rudolf Bär, forced the owners to pay him a fee of RM 40,00o for his unwanted services. The owners received only a third of the real value of the property, cf. 158.) The spinning-mill was to be turned into a workshop for educational purposes (Lehrwerkstatt, 31). The take-over was completed in May 1939 (40). This left mother and Werner with a somewhat reduced capital, which was partly reinvested in other companies. It also left Werner without a job, and it soon appeared that he, being classified as a 'half Jew', and therefore discriminated against by the German Labour Front (Deutsche Arbeitsfront) of which he was forced to be a member (although it tried to oust him because of his criminal association with [full] Jews), could not get another job, despite the upswing of the economy caused by a booming rearmament industry. Owing to his poor health, the threat of having to serve in the army proved unfounded (48). In May 1940, finally and after about thirty vain attempts, Werned was accepted in the badly paid, lowly and exhausting job of warehouse assistant (Lagerist) in a textile trading firm in Cottbus (58). Almost his whole income was spent on travel: a complicated and long journey by bus and train, and on foot. Only in May 1942, Werner was able to quit and accept a job as accountant and salesman in a small metal factory in Spremberg (99). In February 1943 he succeeded in buying an engine factory with foundry at Schlottwitz in the Erz Mountains south of Dresden, which was renamed Kraus \& Co., but nominally under the direction of a Mr. Schreiber $(117,125)$, an entrepreneur working for the war industry (but at the same time involved in active sabotage of the production), whom Werner had met by chance and whom he had helped out with loans. Werned acted as sales manager and spent lengthy periods travelling in Germany-which by that time meant sitting or standing in overcrowded trains and waiting for long hours, sometimes days, at railway stations (or in anti-aircraft shelters, cf. 130) for erratic connections. Production increased rapidly towards the end of the war, when the work-force was increased to 65 persons and night-shifts were introduced (134). By then the factory mainly produced condensing engines used in the building of tunnels and roads (154). 
Details about daily life and historical events are scattered throughout Werner's letters. He referred to the breathtaking events leading up to the Second World War, like the annexation of Austria (March 1938, 18) and the occupation of Czechoslovakia a year later. When that happened he was spending a skiing holiday in Spindelmühle, Bohemia. On 15 and 16 March (1939) telephones fell dead and when am Donnerstag früh der Brünner und der Prager Sender mit "Heil Hitler" grüßten und sich großdeutsche Rundfunk nannten, wußten wir Bescheid. Es gab erst eine Weile großes Gelächter. Einige Stunden später flogen auch die ersten Flugzeug-geschwader über uns hinweg nach Richtung Prag. The border at Hohenelbe was closed und die tschechischen Grenzbeamten liefen schon ohne Waffen herum ... (37). The military campaign in the west is mentioned-nephew Horst died at Sedan in June 1940 (59) — and added triumphantly — this was clearly meant for the eyes of the censor, and did not fail to irritate Kraus - that nach unseren großartigen Erfolgen müssten die Engländer und Franzosen doch bald die Nase vollhaben ... die eingeschlossene Truppe in Flandern [ist] ja so gut wie erledigt. In den letzten Tagen sind weit über 6o Truppentransportschiffe, die die englischen Armee aus Flandern nach England zurückschaffen wollten, versenkt worden ... (59). At the end of the same month, he added in the same vein: Wir leben wohl doch eine der größten geschichtlichen Umwälzungen, die es in Europa je gegeben hat. Aufdie entgültige Landkarte bin ich ja gespannt! Life continued as usual, except for the rationing of food and clothes, and a general blackout. There were also many soldiers and prisoners of war about: Was ich so jeden Tag auf der Bahn an Gefangenen sehe, ist kaum zu beschreiben. Alle Hautfarben sind vertreten, von weißen Engländern, Franzosen und natürlich auch Polen an über Inder, Mohammedaner, Neger und sonstige Mischungen aller Schattierungen. Die Franzosen haben wohl restlos ihre Kolonien ausgemistet, um in Berlin einmarschieren zu können. Na, das tun sie ja nun zum Teil auch, aber etwas anders, als sie dachten ... (61). Further topics were the occupation of Belgrade (April 1941, 78); Allied bombs (in August 1943 he wrote: Wir haben 2 Bombengeschädigte zur Aufnahme bei uns zugeteilt gekommen ... So etwas von Zerstörungswut ist eine solche Kultur schande, daß man es überhaupt nicht verstehen kann ..., 129-it led to the angry reaction by Kraus quoted above). Werner agreed with his brother's opinion that war is always useless, but added that once one was involved, one should do one's duty and finish the job as soon as possible (131).

Occasionally Werner mentions the impact of the war on the economy. Thus he notes the almost complete disappearance of coffee $(78,126)$; the use of wood for shoe soles (78); the lack of wine, spirits-Betrunkene sind ja hier verschwunden, nachdem es Schnaps, und Wein nicht mehr gibt, und das 
Bier ist der Gesundheit sehr förderlich, aber nicht geeignet sich zu besaufen ... (131) — and cigarettes - a Raucherkarte was introduced in February 1942 (93); exorbitant black market prices (99); the rationing of potatoes (May 1942, 99); the special allowances necessary for petrol and train journeys (102); the appearance of foreign labourers and domestic servants (104, 113, 118)-Werner himself employed (forced) Polish and other east-European workers in Schlottwitz from February 1943-a barrack was built near the factory to house them $(118,126)$ - first came nine Polish ladies, but diese mussten wir allerdings selbst entlausen! Aber da ist so eine alte Aufwartefrau, die greift sich die Maruschkas jeden Sonnabend, und dann werden sie unter lautem Protest ihrerseits abgeschrubbt ... (118). At the same time all female citizens under 45 years of age and men without a 'useful' occupation were obliged to work (from March 1943) and shops selling luxury goods such as radios, grammaphones, pianos and cars, were closed down, as were restaurants and bars (119).

The correspondence petered down in 1944-by then it consisted only of postcards with a few lines - and stopped completely in August of that year. Apart from two Red Cross messages sent in December 1944 and May 1945, it was resumed in April 1946. The first letter (of 11 April, 154, with supplementary data in $157,158,160$ ) - the first in which Werner could freely speak his mind in nine years - contains the hair-rasing tale of what happened to him and his mother after August 1944. After the attempt to murder Hitler on 20 July 1944, Himmler ordered that 'half Jews' had to be moved to special camps in order to be kept ready for construction work under the Organisation Todt. Werner decided to escape and travelled to Strasbourg, officially as a commissoner for the Rüstungskommando, charged with rescuing machinery from capture by the approaching Allies, but was arrested by the police after thre weeks. Soon afterwards he was able to flee to Prague where he, provided with a false pass, could stay with Czech acquaintances of his friend Uhrig. Worrying about his mother, he went to Spremberg after another three weeks, but was soon arrested. In December, despite the fact that he was declared medically unfit, he was sent to Suhl, Thüringen, by the local Kreisleiter who thought it a bloody shame that Werner, a dreckiger Judenlummel, was still living in a villa with telephone, and that he was still around in the first place. In Suhl Werner was lodged in barracks behind barbed wire with sixty other Mischlinge and had to work in a tunnel, unprotected by any safety measures (and saw a number of his fellow-prisoners fall victim to dynamite explosions). Thanks to his poor health, he was reluctantly released in January 1945, and put at the disposal of the Gestapo in Spremberg (who wished to charge him with 
the collection of rubbish in the town). With the help of Schreiber, he could semi-clandestinely work as a metal worker in the latter's workshop; during weekends he secretly travelled to Schlottwitz to see to his factory. In February 1945, while the Soviet troops were approaching, Spremberg was turned into a reinforced bastion and the remaining men forcibly enrolled in the militia (Volkssturm). Bombing and shooting planes flew over the town and Werner decided to evacuate his mother, accompanied by a nurse, to Schlottwitz. Papers, jewelry and other important belongings were also moved there. Chaos reigned, worsened by a stream of refugees from the east. The populace lived off dead horses and army supplies. The battle of the Oder-Neisse began on 16 April and the Russians attacked in the early morning. A heavy bombardment burst forth at ten o'clock. Werner fled to the cellar when the first window panes broke. In the evening the town was burning and on the 17th Werner and his former camp companion, Pagel, fled with a wheel-barrow loaded with some essential necessities to the nearby Teschnitzer Forest. Most inhabitants and soldiers had left the town and were fleeing towards the west. Pagel had heard that the SS had decided to kill off the remaining 'half Jews' in a Wehrwolf action and they decided to try to move to Schlottwitz. At 3 o'clock in the morning of 18 April they departed and after an exhausting and difficult journey on foot, in cars and by train, sleeping rough every night, and on one occasion almost overtaken by the Russians near Klettwitz, arrived on the 24th. Production in the factory came to a halt, also because of a lack of electricity. The authorities had fled and by 7 May the Soviet troops had reached Dresden. Meanwhile the last demoralised German soldiers passed through (Bei uns kam ab und zu noch ein volkommen besoffener SS-Hengst und wollte verteidigen und kämpfen, bis man ihm die Jacke vollhaute ...) After the capitulation, in the night of 8 to 9 May, the first Soviet Panzer appeared in Schlottwitz. At the end of the month production in the factory started again on a small scale, but soon, on 4 August, the Red Army removed all machinery destined for war reparations, as it did in all factories in the occupied Soviet zone. Mother died on 12 June.

Later that month, Werner returned to Spremberg which looked desolate - the central (Wilhelm) square and main streets had been destroyed by fire - and was populated by thousands of displaced Italians and Poles but largely abandoned by its former inhabitants. The house in Drebkauerstrasse had been turned into a field hospital by the Soviet Army, as were the other houses in the street. (It was later used by the police, and definetely confiscated by the Soviet Army to house the local Ortskommandantur in June 1948, after Werner had lived there only for a short while again from 1947, cf. 188; 
he moved to another house in Berlinerstrasse.) The former Michelsohn \& Ascher factory was in ruins. Werner was registered as inhabitant No. 1234, obtained a ration of bread and carrots, and found lodgings with his old associate Bernfeld who had also survived the camp at Suhl. Not only did the family lose one factory and the working contents of another, it also lost its capital: all bank deposits and outstanding loans (but not the debts!) existing on 8 May 1945 in the eastern Zone were frozen. Werner was thus left with RM 1,500 in cash which he had by chance in his pocket and a few pieces of furniture, paintings and porcelain not yet robbed from the house. He also regained ownership of - the ruin of-Michelsohn \& Ascher (soon to be let) and was entitled to rent from the family home on Drebkauerstrasse. (He estimated his capital to be worth again RM 82,000 in April 1947, cf. 186.) In order to survive, Werner and Pagel, who had become friends, decided to start a repair shop and after many troubles - there was a lack of everything, particularly raw materials and electricity - they were able to make ends meet from the proceeds. By July the shop had grown into a factory, Pagel \& Kraus Giesserei und Gerätebau, which employed 40 workmen (158). Kraus \& Co. in Schlottwitz started again on 6 November 1945, but under difficult circumstances, particularly the energy problem halted productivity (162). Nevertheless life adopted more regular patterns, albeit on quite a reduced scale and with far less comfort. Werner went to parties, visited the cinema now and then - they only showed German and Soviet films (162) - and became befriended with a young lady called Charlotte who worked on a farm near Schlottwitz (163-she later became his wife). Food was scarce and the daily ration had a nutritional value of not more than 1200 calories, although Werner was privileged as an officially recognized 'victim of Fascism' (which meant paying less tax, cf. 186). Werner was able to increase the meager rations with vegetables, tobacco (cigarettes were hard to find) and fruit which he had begun to grow in the garden during the war. Transport largly depended on an old, highly untrustworthy, motorcycle; lorries were patched together from odds and ends out of the wreckage of military vehicles lying around everywhere. Petrol, however, was rare, new tires nonexistant (171).

After the harsh winter of 1946-1947, when the populace had to subside on a diet of potatoes, bread and cabbage (165-166), coal was scarse (168), and much time was spent on endless journeys in unheated trains (165), things began to look better although life for independent entrepreneurs was made extremely difficult. Not long after the war land, big firms, Nazi businesses and utility enterprises, like gas and electricity works, were confiscated by the state (171), and there was an appalling expansion of red tape, which 
forced the still active private entrepreneurs to keep up a minimum standard of production (174), write monthly reports, ask permission for every transaction and so forth $(161,202)$ — to bribe officials was hardly an option —as well as continual tax increases (167). Imports from the west became scarse (187), and later almost impossible, particularly after the currency reform of July 1948 which saw the introduction of a separate, worthless, new Mark in the eastern Zone $(189,190,191,192)$. In January Pagel \& Kraus was turned into 'people's property' (Volkseigentum) with a loss of at least DM 20,000, but the measure was soon again suspended $(196,198)$; Werner commented that the Planungswirtschaft had clearly become a Planungschaos (198). By then Werner had withdrawn from the firm and started (in December 1948) a cylinder grindery (Zylinderschleiferei) for cars (195), but permission to make it operative only came in August 1949 (203). In October 1949, Werner noted that the eastern Zone had obtained its own government - this in fact referred to the founding of the German Democratic Republic $(D D R)$ - and expressed his hope that economic life would become better once regular trade agreements had been concluded with the western zones of the country (205).

Literature: M. Stol, "In Memoriam F.R. Kraus", in Bibliotheca Orientalis XLVIII (1991); F.R. Kraus, "Die Istanbuler Tontafelsammlung”, in: Journal of Cuneiform Studies I (1947), pp. 93-119; Horst Widmann, Exil und Bildungshilfe. Die deutschsprachige akademische Emigration in die Türkei nach 1933 (Frankfurt/Main 1973); Haymatloz. Exil in der Türkei 1933-1945 (Schriftenreihe des Vereins Aktives Museum 8, Berlin 200o); Ludmile Hanisch, Ausgegrenzte Kompetenz. Porträts vertriebener Orientalisten und Orientalistinnen 1933-1945. Eine Hommage anläßlich des XXVIII. Deutschen Orientalistentags Bamberg 26.-30. März 2001 (Halle/Saale 2001), pp. 46-47; Jan Schmidt, "Fritz Rudolf Kraus in Istanbul (1937-1949) and the Development of Ancient Near Eastern Studies in Turkey", in Bibliotheca Orientalis LVII (2010), cols. 6-22. For the Istanbul cataloguing project, see Muazzez Çı̆̆, "Atatürk and the Beginnings of Cuneiform Studies in Turkey", in Journal of Cuneiform Studies 40/2 (1988), pp. 211-216. For Kraus' publications, see: G. van Driel, Th.J.H. Krispijn et alii, eds., Zikir Šumim. Assyriological Studies Presented to F.R. Kraus on the Occasion of his Seventieth Birthday (Leiden 1982), pp. 485491. On the historical background, see Erik J. Zürcher, Turkey. A Modern History (London \& New York 1993), pp. 184-227. 


\title{
CHAPTER ELEVEN
}

\author{
LEIDEN, UNIVERSITEITSBIBLIOTHEEK, \\ COLLECTION OF THE ROYAL ACADEMY \\ OF ARTS AND SCIENCES \\ (KONINKLIJKE AKADEMIE VAN WETENSCHAPPEN)
}

The greater part of the manuscripts with texts in various Oriental languages, including Hebrew, Arabic, Persian, Turkish, Malay and Chinese, MSS Acad. 1 to 257, had belonged to the library of the orientalist Joannes Willmet (1750-1835). After studies at the University of Harderwijk and in Leiden, he was appointed Protestant minister at Loenen in 1785 . He became professor of Oriental Languages, later also of Hebrew Antiquities, at Harderwijk in 1793, and later, in 1804, at the Athenaeum Illustre in Amsterdam. Like his teacher Everard Scheidius (1742-1794), Willmet was an avid collector of books and manuscripts. He was also himself the first to describe his manuscripts (in Latin); a manuscript catalogue in his hand is found in MS Acad. 264. The manuscripts seem to have been acquired in the Netherlands, and a considerable number of them had previously belonged to other Dutch scholars, among them Jacob Golius (1596-1667), Jacques Bernard (1658-1718), Adrianus Reland (1676-1718), Johannes Heyman (1667-1737), Jacob Meier (1679-1741), Jan Jacob Schultens (1716-1778), Jacob Willemsen (1698-1780), Didericus Adrianus Walraven (1732-1804), and others, and sometimes to more than one in succession. A substantial number of manuscripts, among them autographs and personal papers, had belonged to the German missionaries Stephan Schultz (1714-1776) and Albert Friedrich Woltersdorf (d. 1755, at Acre), who had travelled in the Middle East in 1752-1756 (see in particular under MS Acad. 97, below). Schultz was Oberdiacon of the Ulrichskirche at Halle, travelled for the Jewish Institute (Institutum Judaicum, meant to convert Jews and Muslims to Chris-

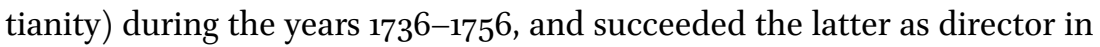
176o (see Friedrich Carl Gottlob Hirsching, Historisch-litterarisches Handbuch berühmter und denkwürdiger Personen welche in dem 18. Jahrhundert gelebt haben (17 Vols. Leipzig, 1794-1815), Vol. 11 (1808), p. 337.) A part of his autograph diary, covering the period May to September 1753 , is found in MS Acad. 196. An account of all his travels was printed in Der Leitungen des Höchsten nach seinem Rath auf den Reisen durch Europa, Asia und 
Africa (4 Vols. Halle 1771-1775); a selection is found in Editha Wolf-Crome, ed., Stephanus Schultz, Aus den Lebenserinnerungen (Hamburg 1977). The Jewish Institute was founded by Johann Heinrich Callenberg (1694-176o), professor of Oriental languages and theology at Halle University in 1728 ; it published books in various languages, among them Turkish (cf. NDB III, p. 96). The Schultz \& Woltersdorf collection was acquired by Willmet in 1773. Willmet's collection as a whole was eventually sold in auction in 1837 and bought by the then King, Willem I, who in turn donated the collection to the Academy, then called 'Royal Dutch Institute' (Koninklijk-Nederlandsche Instituut - stamps with this name are found in the manuscripts). On the covers, often light yellow boards with calf or light brown paper back and edges, of most manuscripts, clippings from the auction catalogue of 1837 are pasted. The collection is kept on permanent loan in the Leiden University Library.

Literature: Bibliotheca Willmetiana. Catalogus Bibliothecae Instructissimae, quam in suos usus comparavit vir clarissimus Joannes Willmet ... (Amsterdam 1837); Nat, 'Studie', pp. 81, 83-88, 102-103; NNBWX, col. 1222.

Acad. 1

The Four Gospels

An undated copy of a translation of the first four books of the New Testament. No translator is mentioned. The work is preceded by a brief introduction (p.1), and consists of the Gospels according to Matthew (pp.1-128); Mark (pp. 129-211); Luke (pp. 213-350); and John (pp. 351-403). Each chapter is preceded by a heading (in black) with the words 'In the name of the Father, the Son and the Holy Spirit who are One God' in slightly different Turkish versions. Numbered chapters are indicated in red by the word 'ishāḥ'. The translation does not seem to have been printed.

A few marginal additions and indications of content (in red), including occasional verse numbering. The title Quatuor Evangeliorum Versio Turcica and the inscription 'J. Willmet 1773' with the number 23 occur on the second flyleaf, recto.

Rebound in boards with flap; white glazed paper without watermarks; $5+453+5$ pages, with original numbers in red; $228 \times 175 \mathrm{~mm}$ and $171 \times 90 \mathrm{~mm}$; 15 lines; without catchwords; vowelled nesih; headings, rubrics, double borders, and dots in red; without a date and the name of a copyist. 
Begins (p. 1):

انجيل مقدس دورت مزدى لردن بتون عالمده مزده ايتديلر يازلمسنه بشلرز اولكى مزده متانك مزده سيدر ...

Ends (p. 403):

ويسوع حضرتلرى اوزكا ايتلر دخى جوق ايتمشدر كه ضن ايده رمكى برر برر يازيلورسه و ناجمله عالمك يازمش كتنابلر صغرلرجك امين تمرتك

Catalogue entry: CCOBARS 211 (p. 268).

Acad. 8

A miscellany

The collection which comprises treatises on religious matters as well as prayer prescriptions was written by one copyist who mentions himself in a colophon on p. 282 as Emīr b. Mehmed; it is dated the final days of $\underline{Z} \bar{\imath}$ l-ka'de 1003 (27 July-6 August 1595). The inscription 'J. Willmet 1773' with the number 37 occurs on the first original flyleaf, recto.

(1) pp. 1-282

Rāhat el-ḳulūb

راحت القلوب

An anonymous treatise on religious dogma and wisdom, further undocumented. The title is mentioned in a heading preceding the text on p. 1 and in p. 5:2-3. The work is preceded by an introduction (pp. 1-6) and divided into two parts ( faṣl) entitled, respectively, Ușül-i kelām (pp. 6-175) and İlm-i meşāyih (pp. 175-282), subdivided into, respectively, four and eight chapters $(b \bar{a} b)$ - the chapter headings are printed in CCOBARS. A few marginal additions.

Begins (p. 1, after a besmele):

$$
\begin{aligned}
& \text { الحمد الله رب العالمين و صلى ... شكر اول يادشاهه كم بزى ايمان اهل يرتدى هيج شكمز يوق انك وحدانيته } \\
& \text { سياس اول هلابه كم بزى امت محمد صلى }
\end{aligned}
$$

Ends (pp. 281-282):

$$
\text { جواب بز ايدرز يكم بزم سوزمز شول مشايخده در كيم اول تقوى اهل اوله مكارم اخلاق اوله }
$$

Colophon (p. 282):

تمت هذه الرسالة الشريفة بعون الله الملك المنان فى وقت الظهر فى آوآخر ذى العقده [= القعده] كتبه اضعف

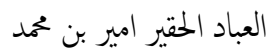


Catalogue entry: CCOBARS 214 (pp. 260-261).

(2) pp. 282-329

Vașīyetnāme-i resūl Allāh

وصيت نامهُ رسول الله

An anonymous tract on religious morals, which mostly consists of a colloquy between the Prophet Muhammad and the Devil, based on various traditions (hadīth) attributed to Abūlḥasan Bakrī Mūḥammad b. İsḥāq (cf. p. 283:3) and others. The title occurs in a heading preceding the text on p. 282. The alternative, more general, title Nașinatnāme is mentioned in the colophon (p. 329). A few marginal additions.

Begins (p. 282, after a besmele):

$$
\text { نصيحت اتدكن بيان ايدر لمليه نييه اما بعد بلكه بو رساله حضرت رسوله شيطان لعين حق تعالينك امرياله كلب }
$$

Ends (pp. 328-329):

رسول حضرت صحابلرى برله قالدى سنداخى اشت اى ياك دين ... دوت عصيانكى عقلكى در فكر كيله يارقيل ديله توفيق اللهكدن ذار قيل برن ليل

Colophon (p. 329):

$$
\text { تمت هذه الرسالة المسماة نصيحت نامه }
$$

Catalogue entries: CCOBARS 214 (pp. 261-262), where other MSS are mentioned; see also Sohrweide II, 20.

(3) pp. 329-341

A collection of Arabic prayer prescriptions with indications of their origin in hadīth literature and explanations in Turkish. Marginal additions. Begins:

$$
\text { و فى تفسير النبى فى فضل فضل [sic] الفاتحة و ثوابها عن آث ابن مالك ... }
$$

Rebound in boards with flap; white to cream glazed paper; $(2)+3+341+(2)$ pages; $205 \times 143 \mathrm{~mm}$ and $160 \times 85 \mathrm{~mm}$, varying; 11 lines; catchwords; vowelled nesih; headings, rubrics and lines in red. See also above. 
Acad. 22

A commentary on the thirty-sixth chapter of the Koran

The commentary on sūra Yāsin is both anonymous and undated. It is preceded by an introduction (pp. 1-4), in which, among other things, the benificent effects of the lecture of the chapter are enumerated, and consists of a verse-by-verse quotation of the original text in red, followed by an extensive commentary in Turkish. The text is interrupted at various points by Persian verses and 'stories' (hikāyet) based on hadìth. A few marginal additions by the copyist as well as pencil numbers indicating the subsequent ayets; interlinear and marginal remarks in Latin, equally in pencil, but in a different hand, possibly by Golius (cf. below), are found on pp. 54-55. The work was clearly written in the characteristic and elegant hand of Shahin Kandi who worked as a copyist for Jacob Golius in the middle of the 17th century (see on him, the introduction to Chapter 1 in Volume I, and index). A description of the contents in Latin, with the indication that the work was acquired at the auction of the library of [Jacques] Bernard [1658-1718], is found on the inner front-board; the legend 'J. Willmet' with the year 1804 and the number 184, is also found there. (Jacques Bernard was appointed pastor to the église Walonne in Leiden in 1705, and later, in 1712, became professor of Philosophy and Mathematics at the Leiden University, cf. NNBW III, cols. 101-102.) Willmet bought the manuscript when the library of D.A. Walraven (1779-1804), professor of Oriental languages in Amsterdam, was put up for sale.

Bound in soft cardboard covered in varicoloured marbled paper; glazed cream paper without watermarks; $1+59$ pages; $200 \times 160 \mathrm{~mm}$ and $145 \times 100$ mm, varying; catchwords; vowelled nesih; Arabic quotations, rubrics and lines in red; without a date (see also above).

Begins (p. 1, after a besmele):

$$
\begin{aligned}
& \text { الممد الله الذى انزل على عبده الكناب الكريم الحكيم و شرفه باعطاء الرسالة ... شكر و سياس و حمد بن }
\end{aligned}
$$

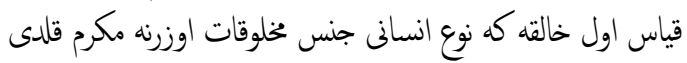

Ends (p. 59):

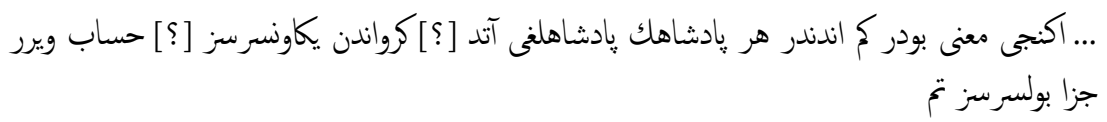

Catalogue entry: CCOBARS 212 (p. 259). 
Acad. 27

Vașīyet[-nāme]

وصلت [نامd

An undated copy of a treatise on the principles of the Muslim faith by Meḥmed b. Pīr 'Alī Birgivī (Birgili Meḥmed Efendi, d. 981/1573). Many manuscript copies have survived. The title and the name of the author are mentioned in p. 1:6-8; the legend haz̄ā kitāb Birgili Mehmed Efendi is found in a heading preceding the text on p. 1. After a short introduction (pp.1-2), the work consists of a great number of short chapters, discussing topics ranging from 'the negative attributes of God' (aș-șifāt es-selbìye, p. 2) and the miracles of the Prophet, to Koran recitation and 'atonement through fasting and oaths' (keffāretü ș-șavm ve l-yemīn, p. 9o). In an appendix (žeyl, p. 94), not rubricated in this copy, there are further chapters on canonical ablutions (istincā), prayer, and menstruation (hayż). A few marginal additions. (For other copies of the same work, see Leiden, UB Codices Or. 960, 1288, 1562, $11.042,14.264(2), 17.123,17.127$, and 23.650(2).).

A brief prayer formula, based on a text in el-Keşşâf, is added below the colophon on p. 118. Owner's inscriptions of 'Abdullāh Halīfe and Hüseyn are found on the (unnumbered) 'title page'. The legend 'J. Willmet' with the year 1800 and the number 121 occurs on the second flyleaf, verso. The manuscript was bought by Willmet at a public auction in Middelburg and had belonged to the library of J.J. de Bruin, and before him, to that of Jacob Willemsen, professor of Theology at Amsterdam (1698-1780), whose manuscripts had been sold at a public auction in Leiden in 1781 (cf. CCO$B A R S$, p. xi).

Rebound in boards covered in varicoloured marbled paper with goldembossed brown leather cover in Western style; a green ribbon is attached to the spine; glazed white paper without watermarks; $(4)+1+118+1+(2)$ pages; $146 \times 97 \mathrm{~mm}$ and $110 \times 65 \mathrm{~mm}$, varying; 11 lines; catchwords; vowelled nesih; headings in red; without a date and the name of a copyist.

Begins (p. 1, after a besmele):

$$
\text { الممد الله الذى هدانا للاسلام و جعلنا من امة محد عليه الصلوة و السلام }
$$

From the introduction (pp. 1-2):

اما بعد فهذه وصية الفقير الحقير المعترف بالعجز والتقصير محد بن يير على عفا عنها العفو العلى لنفسه ...

Ends (p. 118):

$$
\text { ... نمازن قله اوروجن دوته اريله ياته غسل دخى لازم دكلدر و الله اعلم بالصواب }
$$


Colophon (ibidem):

$$
\text { تمت الكتاب بعون الله الوهاب }
$$

Catalogue entries: CCOBARS 213 (p. 260); Sohrweide I, 29, where other MSS are mentioned; see also Fihris 5090-5107 (IV, pp. 263-265); Schmidt 126, G 1515(1); TYTK (Antalya) 207, 1170, 1553, 2915-2916; TIYK29; Yardım32923298.

Editions: Istanbul 1218, 1220 and 1249.

Translations: into French (from 1704) and Norwegian (1829), see Sohrweide I, p. 24 .

Literature: cf. Sohrweide I, p. 24.

Acad. 30

Turkish recipes

The manuscript contains an undated copy of an Arabic work on praying, Ghunyat al-mutamallī, by Ibrāhīm b. Muhammad al-Ḥalabī (d. 956/1549), cf. GAL I, p. 383 , followed by supplements (tatimmät), incomplete at the end; cf. CCOBARS 135 (pp. 173-174), Voorhoeve, p. 236. The legend 'J. Willmet' with the year 1800 and the number 91 occurs on the inner front-board. The manuscript was bought by Willmet at a public auction in Middelburg and had belonged to the library of J.J. de Bruin, and before him, to that of Jacob Willemsen, professor of Theology at Amsterdam (1698-1780), whose manuscripts had been sold at a public auction in Leiden in 1781 (cf. CCO$B A R S$, p. xi). An owner's inscription in Latin of [the orientalist] Jacob Meier [1679-1741] with the date 6 April 1705 is found on the second flyleaf, recto.

Various Turkish recipes for curing diarrhoea and other ailments are found on the second flyleaf, verso (3 lines), and the third flyleaf, recto (11 lines).

Acad. 34

\section{A miscellany}

The undated volume contains various prayers and an essay on praying. The unused pages contain various text fragments, partly illegible by fading and stains: two $\dot{g} a z e l s$ by Kara Ogilan (first original flyleaf, verso); a recipe (p. 18, 3 lines); a prayer prescription for attracting a beloved one (p. 19); a 
question ('if they ask you since when have you been a Muslim?') followed by an answer (p. 20, 6 lines); a prayer for allaying heart pain (ibidem, 4 lines written upside down); and an almost illegible text in which the Tevrät (Pentateuch), İsā and Muhammad are mentioned, followed by a prayer prescription (p. 125). The volume had belonged to the library of J.J. de Bruin, and possibly also to Jacob Willemsen, cf. under MS Acad. 30, above. The legend 'J. Willmet' with the year 1800 and the number 120 occurs on the second flyleaf, verso.

\section{(1) pp. 1-16}

A copy of an anonymous treatise without title on praying and the way how certain prayers should be performed. The work ends in a poem (nazm, p. 15), followed by a series of comparisons the type: 'the body of the imamm is the mihrāab; the soul of the imām is the Koran ...' and five types of kıble: 'the kıble of the body is Ka'ba; the kıble of the soul is the beytülma'mür' and so forth; these are ascribed to the authority of Abū Hinīfa.

Begins (p. 1, after a besmele):

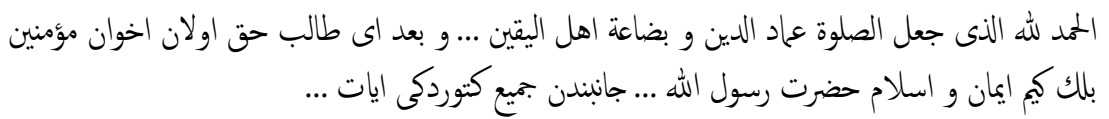

Ends (pp. 15-16):

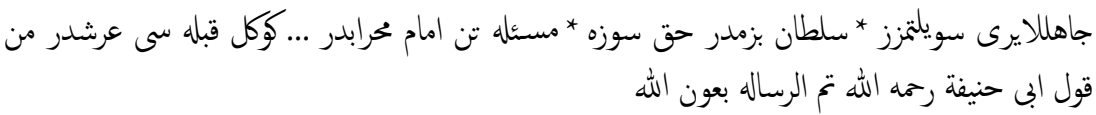

(2) pp. 21-124

A collection of (Arabic) prayers, preceded by Turkish commentaries. The name of the prayers is found in headings: Du'a $-i$ kadeh (p. 21); Du' $\bar{a}$ ș-șalāt (p. 37); Du'ā-i ism-i azam (p. 52); Du'ā-i nūr (p. 6o); Du'âa-i Hï̀rr-i İlyās

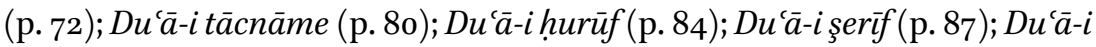
Muștafā (p. 99);Du'ā-i helāk-i düşmān (p. 107). Poems in a different hand are found on pp. 26 and 28 . The work ends with a series of prayer prescriptions and talisman texts with drawings (from p. 118); a final Arabic prayer is found on pp. 123-124.

Begins (p. 21):

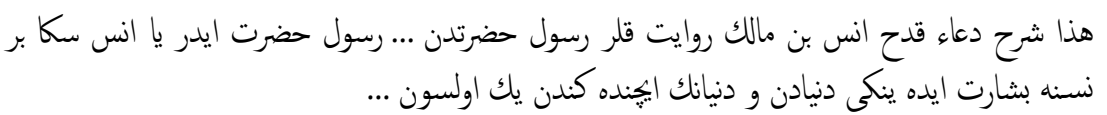


Rebound in boards with flap and brown leather back and edges; cream to pale yellow and dark green glazed paper, moisture stains; occasional stenciled patterns; (4)+3+125+(4) pages; $147 \times 100 \mathrm{~mm}$; irregular margins; nesih, vowelled in (2); (1) crudely illuminated borders in red, yellow and (oxidized) gold with tree and flower patterns; (2) headings, rubrics and dots in red; gold borders within black lines and a simple headpiece, equally in gold, on p. 21; without a date and the name of a copyist.

Catalogue entry: CCOBARS 220 (pp. 267-268).

\section{Leiden, Acad. 35}

\section{A miscellany}

The undated volume contains four main parts, possibly gathered from different manuscripts and rebound later, among them (2), pp. 10-35, an incomplete collection of Arabic prayers, and (3), pp. $3^{6-52}$, a collection of forty traditions with interlinear Persian commentary, both of great artistic and calligraphic excellence. An owner's inscription of Ahmed Beg b. Dāvud Paşa of Rumelia and calculations occurs on p. 7 ; the formula la hawl wa lā quwwa illā bi'Allāh in bold calligraphic sülüs is found on p. 9. The volume had belonged to the library of J.J. de Bruin, and possibly also to Jacob Willemsen, cf. under MS Acad. 30, above. The legend 'J. Willmet' with the number 115 occurs on the inner front-board. There are two parts with Turkish texts:

\section{(1) pp. 1-6}

A collection of drawings and brief texts in Arabic, Persian and Turkish: a circular drawing for locating 'the men of the absent world' which represent the main directions of the surface of the earth with numbers and explanations in Turkish, and preceded by a mnemotechnical poem (in Persian)-headed dāire-i ricāl-i ġayb (p. 1; see also under MS Acad. 45(2), below); a $D u^{\prime} \bar{a}-i$ ricāl-i gayb (in Arabic, p. 2); a Du'ā' hijābi quwwa (in Arabic, pp. 2-3); a prayer in Arabic headed fi muqābilat a'd $\bar{a}^{\prime}$ (p. 3 ); a prayer in Arabic with the heading yemekden șoñra oḳunacak du'adur (p. 3); a brief essay in Turkish on the star called Seküs (p. 4); a circular drawing with the main directions and numbers indicating the orbit of the same star, headed dã ire-inecm-i Seküs (p. 5); a Turkish poem (3 distich) with advice of 
Abū 'Alī [Ibn] Sīnā (Avicenna) about which directions to avoid on which days of the week (p. 6).

(4) pp. 55-67

An almanac (rūznāme) for the year 1054 (1644-1645), containing tables for each lunar month with indications of periods auspicious for certain activities and other data; these are preceded by an explanatory texts, headed ahkām-i şehr (pp. 57-66). The tables are preceded by introductory parts (pp.55-56), among them a digression on the astrologically blessed character of the year, being known as a 'year of the monkey' (sāl-i hamdūne / meymūn $y \iota l$, both terms being mentioned in blue in the heading preceding the text) among the Tatars and Turks and which results in particular in the increased valour of the ruling sultan in fighting the infidels. The margins contain additions in şikeste, partly lost by trimming, with notes on events, in particular the appointment of $k \hat{a} \bar{z} \dot{\imath} \bar{s}$ and other Ottoman officials taking place during the relevant month. The last table (p. 67) contains general characterists of the living conditions for certain parts of the population and of the weather, and is headed bakinye-iahkām-i şehr. A Turkish distich occurs on p. 54 .

Rebound in richly gold-embossed red leather in Western style; both front and back covers contain a title in gold capitals against a black background: Arabicae et Turcicae preces eleganter scriptae; white to cream glazed paper; pages in (1) enlarged by added strokes of paper; gold edges; $(10)+1+67+(12)$ pages; $177 \times 110 \mathrm{~mm} ;(\mathbf{1}, 4)$ calligraphic, partly vowelled nesih; (1) headings, rubrics and drawings (partly) in red; (4) headings in blue and green, diagrams in black, red, blue, and green; without a date and a name of a copyist/draftsman (see also above).

Catalogue entry: CCOBARS 223 (p. 269).

Acad. 38

A miscellany

The small, undated volume, containing pious and magical texts, has a part, pp. 114-135, which is written on different paper in the hand of a different scribe; it clearly had its origin in a different manuscript. An inscription in 
Latin A. 1680 Emptus Leidae 8 Aprilis is found on the third flyleaf, recto. It resembles one found in Acad. 218, where the name of Cornelis Uythage is mentioned. He studied theology in Leiden, and published some books, among which a tract entitled Antichristus Mahometes ... (Leiden 1666), which offended some local pastors and involved him in a lawsuit (cf. Van der Aa XVIII, p. 43; Willem Otterspeer, Groepsportret met Dame II. De vesting van de macht. De Leidse universiteit, 1673-1775 (Leiden 2002), p. 97). The legend 'J. Willmet' with the year 1804 and the number 115 occurs on the third flyleaf, verso. Willmet bought the manuscript when the library of D.A. Walraven (1779-1804), professor of Oriental languages in Amsterdam, was put up for sale.

The contents are the following: a series of Arabic prayers accompanied by Turkish interpretations, often instructions for the use of the prayers as talismans. Headings indicate the name of the prayers: Du' $\bar{a}-i m \ddot{u} h r-i$ Süleymān (p. 1);Du'ā-inūr (p. 21);Du'ā-i 'arş-i 'ażìm (p. 208);Du'ā-i ìmān (p. 228);Du'ā-i fáżं $i l$ (p. 235); a series of prescriptions for talismans (pp. 77-103); a series of Arabic prayers (pp. 104-135); an 'ahdnāme ascribed to the Prophet, preceded by a description of its magic quality (pp. 136-179); an enumeration in Arabic of the beautiful names of God, preceded by an explanation in Turkish headed Şerh esmā'i l-hüsnā (pp. 179-204); a description of the magic quality of two of the beautiful names (pp. 204-208); and prescriptions for talismans (pp. 244-257).

Rebound in vellum; glazed white to cream paper without watermarks; $(6)+1+257+(2)$ pages; $97 \times 70 \mathrm{~mm}$ and $50 \times 40 \mathrm{~mm}$, varying; 5 lines (pp. 104135: writing surface $80 \times 55 \mathrm{~mm}$, varying; 7 lines); catchwords; irregular vowelled nesih in two hands; headings and magic formulae in red; a circular drawing in black and red on p. 20; red dots on pp. 104-135; discoloured gold borders on pp. 1-20; a crude headpiece in black and gold on p. 1; without date and the name of a copyist.

Catalogue entry: CCOBARS 219 (pp. 266-267).

Acad. 42

A miscellany

The volume contains two main works copied by one copyist; a colophon with the name of Adamcıl 'Alī Hōoca Edirnevī and the date last days of Şa'bān 1062 (28 July-5 August 1652) occurs on p. 314. Brief texts in different hands are found on the first two flyleaves: two Arabic prayers (first flyleaf, recto 
and verso), the first preceded by an Turkish introduction; a Turkish text on faith (imānn, first flyleaf, recto, margin); two lines of a letter mentioning 'Alī Hōoca (possibly the copyist), a list of various ingredients (6 lines), and a pious phrase in Arabic (3 lines) (second flyleaf, recto). The legend 'J. Willmet' with the year 1821 and the number 249 occurs on the inner front-board. The manuscript had previously belonged to the Reverend V.D.M. Timmermans Hubert.

\section{(1) pp. 1-262}

An anonymous work on scholarship and scholars, probably incomplete at the beginning. It mostly consists of Arabic quotations from the Koran and hadith with explanations in Turkish. There are two parts $($ fașl) on, repectively, 'ilm (pp. 1-222) and on 'ulemā and fukahā (pp. 222-262). A few marginal corrections. The work is followed (pp. 262-263) by two quotations in Arabic from the Masnad by al-Bukhārī and Ihyā ulūm ad-dīn by al-Ghazalī.

Begins (p. 1, after a besmele):

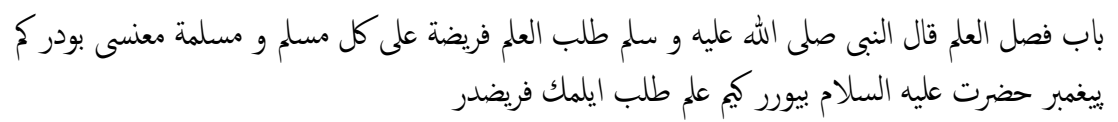

Ends (p. 262):

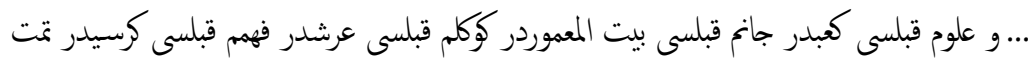

(2) pp. 263-314

\section{Daḳāyiḳül-ahbār}

$$
\text { دقايق الاخبار }
$$

A copy of a collection of traditions (hadith), incomplete at the end, by Kāżī 'Abdurrahīm b. Aḥmed or Ebū 'Abdullāḥ Meḥmed b. Selāmetülḳuẓāī. Neither title nor author is mentioned. The work, completed in $965 / 155^{8}$ (cf. Leiden, UB Cod.Or. 12.386, f. 99a), consists, after a brief introduction (p. 263) of traditions loosely arranged in chapters (bāb or haber) according to subject; these are the creation, the angels (p. 272), death (p. 275), the Devil (p. 289), and angelic wailing upon the departure of a soul from a body and other traditions related to death and resurrection (p. 292); the last chapter heading refers to the two recording angels which accompany man (kätibeyn, p. 306; cf. Leiden, UB Cod.Or. 12.386, f. 33a). (For other copies of the text see Leiden, UB Cod.Or. 12.386 and MS Acad. 178(1), below.) 
Begins (p. 263, after a besmele):

المحد لله رب العالمين و العاقبة للمتقين و لا عدوان الم على الظالمين اما [بعد] خبرده شويله كلمشدر كيم الله

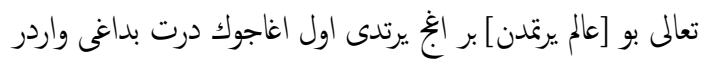

Ends (p. 314):

و دخى رسول ايدر بركثى علم اوكرنه ... آك بركثى علم اوكرنه ترك صلوة اولمق تون اولسه منافق

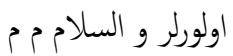

Colophon, including a verse (ibidem):

و تحرير فى اواخر شعبان مبارك سنه rآ • ا بونى يازدم يادكار اوملماغيون اوقينلر بر دعا قلماغيون كتبه

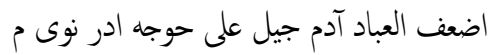

Catalogue entries: Götz II, 23, where other MSS are mentioned; see also Fihris 1662-1665 (II, p. 42); TYTK (Antalya) 999, 1472, 2733.

Bound in boards covered in varicloloured marbled paper with dark brown leather back and edges; glazed white paper; $5+314+5$ pages; $238 \times 170 \mathrm{~mm}$ and $180 \times 110 \mathrm{~mm}$, varying; 17 lines; catchwords; partly vowelled nesih; Arabic quotations, headins, rubrics and dots in red (see also above).

Catalogue entry: CCOBARS 216 (pp. 263-264).

Acad. 45

A miscellany

The volume is an almanac for prognostic purposes with texts and tables. A colophon of the copyist Bayrām er-Rūmī with the date 1 Șafer 993 (2 February 1585) is found on p. 51. The inscription 'J. Willmet' with the year 1779 occurs on the first flyleaf, recto-titles in Latin and Arabic script in his handwriting are found on the same page; the number $5^{6}$ is found on the inner front-board. The manuscript had previously belonged to the Abbot [and historian Joseph-Hippolyte] Ghesquière [1731-1802, cf. BNB VII (1880-1883), cols. 719-726] who had found them dans la casette d'un des grands Viziers. 
(1) pp. 1-51

Risāle-i Fāl-i Caffer Şādık.

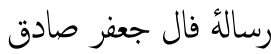

A copy of a manual with instructions on how to draw omens (fälnāme), attributed, as was traditionally done (cf. Rieu, p. 134), to the Imam Ja'far aș-Saadiq (d. 148/765). The title is found in the heading preceding the text on p. 1 and on the 'title page' (first flyleaf recto, with the Latin addition Diatribe de divinatione ope Corani auctore celeberrimo Imamo Giafar Sadik). The work is preceded by an introduction (pp. 1-4), mostly consisting of a poem in mesnevi rhyme, and consists of a series of alphabetically ordered sections with prayers to be said on reaching a subsequent sequence of three letters, from elif elif elif to dāl elif dāl, on the pages of, probably, the Koran, and the augury implied. Marginal additions, in particular the repeated word mübärek. (For copies of the same work, see Leiden, UB Codices Or. 1205(3) and 1259(3).) A prayer prescription in crude script is added on the last page (51).

Begins (p. 1, after a besmele):

الم ذلك الكناب لاريب فيه هدى للمتقين ... بيت هلب آدينى اول يآد ايدالم *جانى حق رحمته شاد ايدالم....

The treatise proper begins (p. 4):

الا قوله تعالى و جعلنا له مالآمدودا و بين شهودا اى فال اسى بو فال ك كلدى بشارت اولسون سكاك الله تبارك و تعالى سنك يار نكهداركدر ايكى جمانك عزتى ارزانى قلا ئ...

Ends (p. 51):

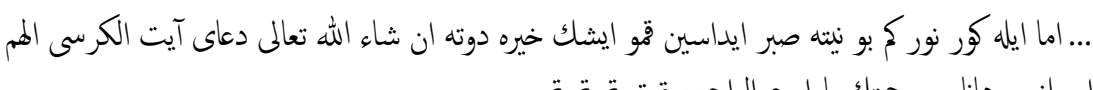

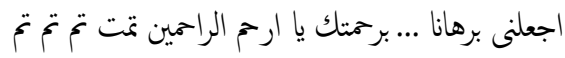

Colophon (ibidem):

$$
\text { كتبه مشتاق الرحةة بيرام الرومى سنه سو9 في غرة: صفر }
$$

(2) pp. 52-71

A collection of drawings and tables. We find the following items: (1) an astrological table indicating the influence of the sun, moon and planets on the various parts of each week-day (p. 52); (2) a circular drawing for locating 'the men of the absent world' which represent the main directions with numbers, and is headed $h \bar{a} z \bar{a} d \bar{a}$ 'ire-i ricāl-i $\dot{g} a y b$... (p. $5^{6}$; it is also found on the 'title page', with the Latin inscription Calendarium Astronomicum; see also MSS Acad. 35(1), above, and 46, f. 19a, below); (3) a table resembling 
(1), but of a more refined draughtmanship (p. 57); a circular diagram for calculating leap years (p. 58, cf. Leiden, UB Cod.Or. 1259, f. 56 b; and MS Acad. 45, f. 6a, below); a series of twelve tables for each of the solar months of a cycle of 19 years, showing the days of the week on which each of the lunar months begin, with additional information on astrological phenomena, feast days, the weather and so forth (cf. Leiden, UB Cod.Or. 1259(6)) - a note (Tärīh) on İskender Zülkarneyn with the number 1900 and the year $996\left(15^{8} 7-1588\right)$ is found on p. 66; and a circular drawing not yet filled in (p. 71). Additional texts in a crude hand are found on p. $5^{2}$ (margin, on the seven days of each month that bring misfortune, partly lost by trimming); p. 53 (two Arabic prayers); p. 54 (a sentence, commencing ey cum'a ...); p. 74 (an Arabic prayer); and p. 75 (a list of the lunar months).

Rebound in embossed dark red leather; blind tooled insets in Oriental style occur on the outer front- and back-covers; glazed cream paper; $3+75$ pages; $204 \times 135 \mathrm{~mm}$ and (1) $145 \times 75 \mathrm{~mm}$, varying; (1) 13 lines; (1) catchwords, partly lost by trimming; (1) vowelled nesih; (1) headings, rubrics, dots, lines and colophon in red, red borders on p. 43; (2) tables and diagrams in gold, black, red and blue; see also above.

Catalogue entry: CCOBARS 211 (pp. 258-259).

Acad. 46

A miscellany

This volume is an almanac for prognostic purposes with texts and tables. The inscription 'J. Willmet' with the year 1779 occurs on f. 1a-titles in Latin and Arabic script in his handwriting are found on the same page; the number 57 is found on the inner front-board. The manuscript had previously belonged to the Abbot [and historian Joseph-Hippolyte] Ghesquière [1731-1802, cf. BNB VII (1880-1883), cols. 719-726] who had found them dans la casette d'un des grands Viziers.

\section{(1) ff. 4b-2la}

A collection of tables with explanations: for establishing the first ( $\dot{g} u r r e)$ of each lunar month (gurre - $i$ 'Arabiye, 4b); a lunar calendar for the years 1061 $\left(165^{0-1651)}\right.$ to $1067\left(165^{6-1657)}\right.$ (5a); a circular diagram for calculating the 
feast day of nevrüz-Turkish and Persian mnemotechnic verses are added in the margins; a circular diagram for calculating leap years (6a, cf. Leiden, UB Cod.Or. 1259, f. 56b, and MS Acad. 45, p. 58, above) - a lengthy explanation in which the year $1047(1637-1638)$ occurs is found in the left margin; a mnemotechnic poem and a Persian chronogram by Ahmed Paşa on the death of Shaykh Vefā, dated 896 (1490-1491), are found in the lower margin; an astronomical almanac with detailed marginal explanations and additional historical and other references for the solar year in twelve double tables covering the months March to February (6b-18a); a gurre-nāme for the years 1063-1101/1652-1690 (18b); circular drawings for locating 'the men of the absent world' (see also MSS Acad. 35(1) and 45, p. 56, above) accompanied by an Arabic prayer, Du'â-i ricāl el-g̈ayb, and extensive marginal notes on astrological questions, including a Persian poem (19a); a gंurre-nāme ascribed to Birgili Çelebi [Meḥmed Efendi] (19b) and another ġurre-nāme, both preceded by brief introductions - a mnemotechnic quatrain occurs in the lower margin of f. 20a; a digression on the seven planets and their astrological characteristics, followed by a table headed Beyān-i sā $\bar{a} t(2 \mathrm{ob}-21 \mathrm{a})$.

(2) ff. 2lb-27a

Rūznāme-i nev

روزنامهُ نو

An undated copy of an almanac, which, according to the introduction (21b-22a), consists of an abbreviated selection from the works of the great calendar scholars of the past, among them Shaykh Vefā, and is meant to be of practical use for $\dot{g} \bar{a} z \bar{\imath} \mathrm{s}$, merchants, and travellers. The title is mentioned in the heading preceding the text on f. 21b. It is also known as Rüznāme-i istihrāc-i şemsīye. The work discusses, respectively, the solar (Rūmī) months and their letters (i.e. the weekdays of the first days of these months) (22a-b); separate paragraphs, then, are dedicated to the months January to December, with simple tables presenting a survey of feasts, auspicious and dangerous days, meteorological and astrological characteristics and so on; tables with the most important facts (icmäl-iahkām ...) for each month follow from f. 26a onwards. (For another copy of a similar, partly identical, work, see leiden, UB Cod.Or. 1259(7).)

Begins (21b):

الممد الله رب العالمين و الصلوة والسلام على سيدنا [محمد سيد] المرسلين و خاتم النبين و شفيع المذنبين ...

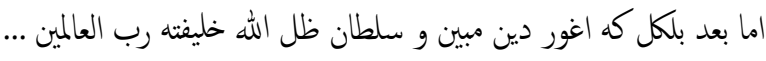


(3) ff. 29b-30a

\begin{abstract}
A letter
A copy of a warrant (berāt) by Sultan Murād I to Gāzī Evrenos Beg [d. 82o/ 1417], at Bursa, dated first days of Şevvāl 780 (21-30 January 1379), declaring that the warrior had been appointed fief-holder of a large sancak in Rumelia, stretching from Gümülcine (Komotini) westwards to Manastir (Bitola), with an income of ten times 100,000 [akçe]; he is also encouraged to conquer Salonica and found as many vakf s as he sees fit.
\end{abstract}

Edition: Feridūn Beg, Mecmū'a-i münşe’āt I (Istanbul 1274), pp. 87-89.

Literature: I. Mélikoff, "Ewrenos”, in $E I^{2}$.

$* * *$

Bound in gold-embossed, dark red leather with black and gold tooled insets in Oriental style; glazed white paper; $30+6$ folios; $243 \times 150 \mathrm{~mm}$; varying written surfaces; catchwords; small, calligraphic nesih; (3) slanting ta'lik; tables in black, gold and red; $(\mathbf{2}, 3)$ headings and rubrics in red; $(\mathbf{1}, \mathbf{2})$ multiple gold borders within black lines; (3) red borders; see also above.

\title{
Acad. 49
}

A collection of two treatises on the use of the astrolabe for time-reckoning. They were copied, according to colophons on p. $5^{\circ}$ and p. 47 (second series), by one copyist, 'Abduleșìm Aḳ 'Abalī b. Hüseyn, in 1137 (1724-1725). The second treatise was completed in the middle of Şa'bān (30 April). The flyleaves preceding (1) contain: a note on the times of the five daily prayers (begins: fașl fı evḳāti ș-șalāti l-hams, 12 lines, third flyleaf, recto, followed by a drawing showing a pattern of leaves); and a note with a drawing on the establishing of the kıble ( 15 lines, with a marginal addition in Arabic) - both are written in the hand of the copyist. The inscription 'J. Willmet' with the year 1773 and the number 54 occurs on $\mathrm{f}$. 1a- a title in Latin (Duo Tractatus Astronomici Turcici, uterque, ut videtur sub titulo ...) and the Arabic one of (1) in his handwriting are found on the same page. 
(1) pp. 1-50

Risāle-i muḳanțarāt

رسالله مقنطرات

A copy of an anonymous treatise on the use of the instrument which measures the circles of altitude parallel to the horizon (mukantarāt). The title is found in p. 1:2 and on the 'title page'. Its author most probably was Mușțafā b. 'Alī, timekeeper (muvaḳḳt) at the Selīmīye Mosque in Istanbul, who used the pen-name of Selīmì (d. 96o/1553, cf. 'OM III, p. 301, No. 10). It consists of a brief introduction, a preface (mukaddime), and thirteen chapters $(b \bar{a} b)$. Extensive marginal additions. (For another copy, see Leiden, UB Cod.Or. 20.400(2).)

Begins (p. 1, after a besmele):

$$
\begin{aligned}
& \text { المحد لله رب العالمين و صلى الله على سيدنا محد ... بو رسالة مقنطرات ديمكله متعارف اولدى آلت كه ربع } \\
& \text { دائره اقسامى ندن [در] علملرينى بيان ايدر }
\end{aligned}
$$

Ends (p. 50):

... اول قيونك اغزندن صوينه وارنجه در كلكى سكز زراع اولدى تمت الرسالة المقنطرات بعون الله خالق السموات

Colophon (ibidem):

قد و قع الفراغ من هذه الرسالة المرغوبه على يد عبد الاثيم اق عبالى بن حسين الى ححتاج [sic] رحت ربه

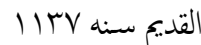

Catalogue entries: Flügel 1432; Karatay 1746IV; TYTK (Balıkesir) 1108; TYTK (Antalya) 3827 .

Literature: 'OM III, pp. 300-301.

(2) pp. 1-47 (second series)

Kifāyetü l-vaḳt li-ma 'rifeti d-dā'ire ve fașluh ve s-semt

كفايت الوقت لمعرفة الدائرة و فضله و السمت

An undated copy of a treatise on the use of the instrument which measures the circles of altitude parallel to the horizon (mukantarāt) in order to establish the hours of prayer by Mușțafā b. 'Alī Selīmī (see under 1, above). The title occurs in p. 2:10-11; the name of the author is mentioned in p. 2:3. The work consists of a brief introduction, a preface (mukaddime), and twelve chapters $(b \bar{a} b)$. The text is different from that found in other copies of a work with the same title and by the same author. The work is preceded 
(on p. 1) by a listing of, mostly, technical terms, headed rüsūm- mukanțarāt bildürür. A few marginal additions. (For other copies of a similar work, see Leiden, UB Codices Or. 12.058(4), 17.167, and 20.400(1).)

Begins (p. 2):

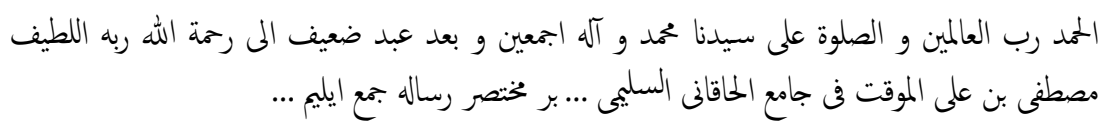

Ends (p. 47):

$$
\text { .... قبله دخى قوس ارتفاعك طرفنه واقع اولدى تمت الرسالة المتنطرات بعون الله خالق السوات }
$$

Colophon (ibidem):

قد و قع الفراغ من هذه الرسالة المرغوبه على يد عبد الاثيم اق عبالى بن حسين المى محتاج [sic] رمت ربه

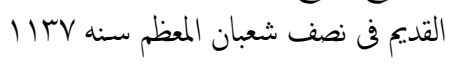

Catalogue entries: Götz II, 359-361, where other MSS are mentioned; see also Fihris 4052-4053 (III, p. 304); Kut 373; TYTK (Süleymaniye, Mustafa Âşir Efendi) 931; Yardım 3740.

Literature: 'OM III, pp. 300-301.

Bound in boards with a flap; glazed cream paper; $9+50+4+47+(2)$ pages; $136 \times 102 \mathrm{~mm}$ and $100 \times 70 \mathrm{~mm}$, varying; 13 lines; catchwords; nesih; rubrics and lines in red; see also above.

Catalogue entry: CCOBARS 209 (pp. 256-257).

Acad. 58

Turkish annotations and glosses

The undated manuscript contains a collection of works in Arabic on, mostly, grammar. The last, (5), pp. 173-202, is a paradigm showing the conjugation and derived nouns of the Arabic verb nașara with Turkish explanations and translations in smaller script, headed al-amthila al-mukhtalifa on p. 173 (for other copies of this work, see Leiden, UB Codices Or. 254(1), 950(5) and 12.005, p. 161). Various Turkish text fragments are found on pp. 84-85, 118 (a fetva concerning the legitimity of the $z i k r$ performed by dervishes, written upside down), 152 (a note on prosody), and 153. 
The inscription 'J. Willmet' with the year 1780 and the number 14 occurs on the 'title page'. The manuscript had earlier belonged to the Leiden Orientalist Jan Jacob Schultens (1716-1778), whose library was sold at a public auction in 1780 (see the introduction to Chapter 5 in the first volume.)

Catalogue entry: CCOBARS 16 (pp. 28-30).

Acad. 59

A grammar of the Turkish language

An undated copy of a simple Arabic grammar of the Turkish language with - they occupy almost all space-Arabic-Turkish word lists, entitled ash-Shudhür adh-dhahabìya wa l-qița' al-Ahmadīya fí l-lughat at-Turkìya by Ibn Muhammad Șâliḥ, composed in Cairo in 1029/1619. The work, mostly based on Ottoman sources, was written for Ahmad, the son of a local $k \bar{a} \bar{z} \dot{z}$ (hence the 'Ahmadiye of the title). The work was obviously used for teaching beginners, possibly school children or army recruits. It consists of an introduction (pp. 1-9) and four parts (rükn) further subdivided into chapters $(b \bar{a} b)$. The last part contains a number of Arabic sentences translated into Turkish (indicated by 'Ayn and $t \bar{a}$ in the margins). A few marginal additions, among which part/chapter numbers in Latin. Extensive disconnected marginal notes, partly in bold crude script and again crossed out, are found on p. 67 . Among them there is a vakfinscription dated ${ }_{5}$ Cemázi l-evvel $[1]_{120}$ (23 July 1708). (For other copies of the text, see Leiden, UB Cod.Or. 3087 and MS Acad. 6o, below.)

The inscription 'J. Willmet' with the year 1773 and the number 27 occurs on the 'title page'; there is also the title Grammatica Arabica Linguae Turcicae auctore Zeid Ibn Thabet in Willmet's handwriting. The first page of the original manuscript is missing and has been replaced by a copy in a different hand, possibly Willmet's.

Rebound in boards with flap; glazed white paper without watermarks; $(2)+3+67+(2)$ pages; $205 \times 150 \mathrm{~mm}$, varying, and $150 \times 90 \mathrm{~mm}$, varying; 20 lines; catchwords; partly vowelled nesih; headings, rubrics, Turkish examples and dots in red; headings and example phrases partly in green towards the end; without a date and the name of a copyist.

Catalogue entries: CCOBARS 23 (pp. 45-46); Voorhoeve, p. 345; see Ermers's monograph, p. 33 . 
Translation: (into Turkish) Besim Atalay, Eş-Şüzūr-üz-Zehebiyye vel-Kıtai 'l-Ahmediyye fil-Lügat-it-Türkiyye (Istanbul, without date).

Literature: Robert Ermers, Arabic Grammars of Turkic (Leiden, Boston, Cologne 1999), pp. 33-39.

Acad. 60

A grammar of the Turkish language.

An undated copy of the same work as decribed under MS Acad. 59, above. Marginal aditions. A detailed description with lengthy quotations from the text is found in CCOBARS. The inscription 'J. Willmet' with the year 1780 and the number 28 occurs on the 'title page'; there is also the title Grammatica Arabica Linguae Turcicae auctore ... Zeid Ibn Thabet in Willmet's handwriting. The manuscript had earlier belonged to the Leiden Orientalist Jan Jacob Schultens (1716-1778), whose library was sold at a public auction in 1780 (see the introduction to Chapter 5 in the first volume.)

Rebound in boards with flap; glazed white paper without watermarks; 36 folios; $200 \times 147 \mathrm{~mm}$, varying, and $150 \times 90 \mathrm{~mm}$, varying; 15 lines; catchwords; partly vowelled nesih; headings, rubrics, Turkish examples in red; some headings and Arabic sample texts in blue; without a date and the name of a copyist.

Catalogue entry: CCOBARS 22 (pp. 40-45); see also under MS Acad. 59, above.

Acad. 63

A Turkish distich and aphorisms

The manuscript contains a collection of Arabic treatises on grammar written by one copyist, called el-Ḥācc İbrāhīm b. Meḥmed b. Ḥasan, between Cemāż̄ l-evvel 1025 (May-June 1616) and Muhārrem 1026 (January-February 1617) (see colophons on pp. 32, 164 and 298). A seal of el-Ḥācc İbrāhīm, probably the copyist, is found on p. 38 . The inscription 'J. Willmet' with the year 1804 and the number 191 occurs on the 'title page'. Willmet bought the manuscript when the library of D.A. Walraven (1779-1804), professor of Oriental languages in Amsterdam, was put up for sale. A Turkish distich is found on the 'title page': hidmetin ed 'ārifün ile keşf-i ma'rifet/ cāhile yār 
olmag் ınādān olasın 'ạkıbet. Three Turkish aphorisms are found on the last flyleaf, recto.

Catalogue entry: CCOBARS 19 (pp. 33-36).

Acad. 64

A miscellany

The undated volume contains three main works written by one copyist: (1), pp. 1-44, an Arabic treatise on grammatical regents, Awāmil al-mi'a, by Abū Bakr 'Abd al-Qāhir b. 'Abd ar-Raḥmān al-Jurjānī (d. 471/1078, cf. GAL I, p. 287), with marginal additions and glosses, occasionally in Turkish, on pp. 1-2 and 5-6; (2), pp. 47-48, an Arabic prayer entitled Du'ä-i 'ahdnāme, and

(3) pp. 61-62

[Kitāb-i] 'Avāmil-i Türkìye

$$
\text { [كناب ] عوامل تركيه }
$$

An anonymous poem in mesnevi rhyme on grammatical regents, probably incomplete at the end. The title is found in a heading preceding the text on p. 61. The work was based on (1), above, as the name "Abd al-Qāhir' is mentioned in the first distich (see quotation, below). The poem was clearly meant as a mnemotechnic aid for students. (For a similar work, see Leiden, UB Cod.Or. 11.538(8).) A brief Arabic prayer, preceded by a Turkish heading with an instruction, is found on p. 60.

Begins (p. 61, after a besmele):

$$
\text { بل عوامل يوز درر في الظاهر * شونك اوزره دوزدى عبد القاهر }
$$

Ends (p. 62):

$$
\text { اون يد يدر حرف بر بر سكا *عد ايد اين مستع اولغل بكا }
$$

Various additional texts in Arabic and Turkish, often fragmentary, are found on the inner boards, endpapers and on p. 56 , among them a lengthy note in Turkish on Arabic grammar ('title page') and a Turkish distich (final flyleaf, verso). The inscription 'J. Willmet' with the year 1780 and the number 65 occurs on the 'title page'; there are also titles in Arabic script and in Latin (Liber Awamel, sive de vocibus regentibus auctore AbdalKaher Ibn Abdalrahman Georgiani) in Willmet's handwriting. The manuscript had earlier belonged to the Leiden Orientalist Jan Jacob Schultens (1716-1778), whose 
library was sold at a public auction in 1780 (see the introduction to Chapter 5 in the first volume.)

Bound in boards with flap; glazed white, occasionally pink and yellow paper; $1+62+35$ pages; $152 \times 108 \mathrm{~mm}$ and $(3) 110 \times 60 \mathrm{~mm}$, varying; 9 lines; catchwords; irregular, partly vowelled nesih; headings and borders in red and green; red rubrics, lines and dots; crude headpieces on pp. 1, 47, 6o, 61; yellow borders within green lines and a varicoloured endpiece on pp. 47-48; without a date and the name of a copyist.

Catalogue entry: CCOBARS 10 (pp. 18-19).

Acad. 74

A collection of vocabularies

The works, of different formats and written by different scribes, have clearly been compiled from different manuscripts. The flyleaves and $\mathrm{f}$. 1a contain a great number of notes in different hands, mostly in Arabic; lists of the Turkish words for the fingers occur on the first and second flyleaves; a talismanic square is found on the second flyleaf, verso; a fälnāme ascribed to Ja'far Șādiq preceded by an Arabic introduction occurs on the second flyleaf, verso (see also MS Acad. 45(1), above). Multiple owner's inscriptions of Seyyid Mușțafā Babazāde Diyārbekrī, with the date 25 Șafer 1053 (15 May 1643), are found on the second flyleaf, verso, and f. 1a; two inscriptions with seals of the copyist (of 2 and 7), Mollā Ḥasan b. Bayrām, occur on the same page, f. 1a. The inscription 'J. Willmet' with the year 1780 and the number 15 occurs on the inner front-board and on $\mathrm{f}$. 1 a. The title of (1) with an explanation in Latin (Encyclopaedia Phililogica continent Lex. Arabico Turc. et 5 alia opuscula ad Grammaticam et Prosodiam spectantia) by him is found on the same page (1a). The manuscript had earlier belonged to the Leiden Orientalist Jan Jacob Schultens (1716-1778), whose library was sold at a public auction in 1780 (see the introduction to Chapter 5 in the first volume.)

(1) ff. lb-18la

Müntehab fì ilmi l-lugiat

منتخب في علم اللغة

A mid 16th-century copy of an anonymous Arabic-Turkish vocabulary. The title occurs on the lower edge. It is also known as Cāmi ü l-lugat (cf. Leiden, 
UB Cod.Or. 2745). The work consists of an Arabic introduction ( $1 \mathrm{~b}-2 \mathrm{~b})$ and a list of alphabetically ordered Arabic words, divided into chapters and sections $(b \bar{a} b, f a s ̦ l)$ according to the subsequent letters, with interlinear and marginal Turkish equivalents and, mostly, brief grammatical explanations. (For other copies of the text, see Leiden, UB Cod.Or. 2745, and MS Acad. 75(1), below.)

Begins ( $1 \mathrm{~b}$, after a besmele):

الحمد لله حق حمده على كل نعم مسبوقة لعباده ... و بعده فاعلم ان اللغة العربية كثيرة الحاجة اليها لانه انزل

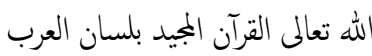

The vocabulary begins $(2 b)$ :

$$
\text { باب الالف آذان [ جمع اذان ] آن [ عالم و بلحي و زمان ] آل محمد [ محدك آلى و اهل بيتى ] }
$$

Ends (181a):

$$
\text { مهودى [ جهود ] يهود [ مثله ] هيد بهوت مهمود [ يدى كتورن بالق ] }
$$

Colophon (ibidem):

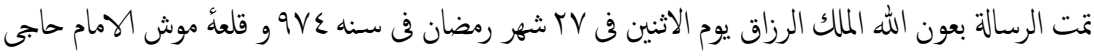

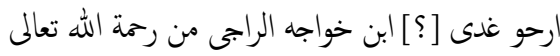

Catalogue entries: Voorhoeve, p. 416, where other MSS are mentioned; see also Blochet A.F. 211, 212; Fihris 4675-4676 (IV, p. 155); Karatay 2032; TYTK (Antalya) 1621; TYTK (Balıkesir) 901; TYTK (Burdur) 1616; TYTK (Çankırı) 488; TYTK (Isparta) 1059.

(2) ff. 182b-218a

[Kitāb-i] Maḥmūì̄ye

$$
\text { [كتاب ] محوديه }
$$

A mid 17th-century copy of an anonymous versified Arabic-Turkish dictionary by a scholar whose personal name was probably Mahmūd (cf. Sohrweide I, p. 185). The work is an elaborated-improved, according to the introduction-version of the equally versified Lugat-i Firişteog $l$, an ArabicTurkish dictionary of certain words found in the Koran, by 'Izzüddin 'Abdullațif b. Melek, known as Firişteoğl (flourished in the 8th/14th century, cf. Ömer Faruk Akün in $\left.E I^{2}\right)$. The work was written in 961/1553-1554 according to a chronogram (3b-4a) represented by the words خوش كله manuscripts have خوش كلا, cf. Sohrweide I, 185, which results in the year 957/1550; cf. also Kut 353). The title is found in the heading preceding the text on f. 182b and on f. 183a:6. The work consists of an introduction in 
mesnevī rhyme (182b-183a) and 23 chapters (kıt t'as) of the kașide/gizel format, the penultimate hemistich of each of which demonstrates the metre used by way of derivations of the verb فعل (For another copy of the same text, see Leiden, UB Cod.Or. 857.)

Begins (182b, after a besmele):

$$
\text { بنام خالق و فناح و واحد * بيمن هادى و وهاب و واحد }
$$

From the introduction:

$$
\begin{aligned}
& \text { (182b) نظر قلدم فرشته اوغلى سوزنه *كزل كورنش انسانك كزينه } \\
& \text { (183a) كه محوديه اولا اسمى بونكده *آلهى رحت و عفو ايله صوكده }
\end{aligned}
$$

Ends (218a):

$$
\text { مفتعلن فاعلن مفتعلن فاعلن * اوقيوب اوقيده نك يوزنى آغ ايده حق }
$$

Colophon (ibidem):

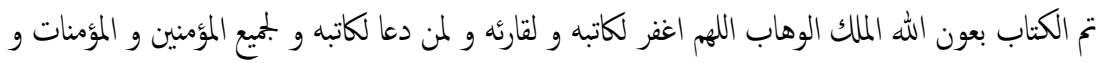

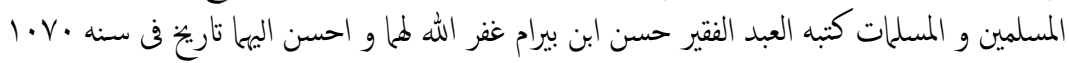

Catalogue entries: Voorhoeve, p. 170; Sohrweide I, 218, where (two) other MSS are mentioned; see also Götz II, 468; Kut 353. (In Fihris 2833-2835 it is erroneously suggested that the Mahmūdiye is identical with a dictionary entitled Subha-i șlbyān, an anonymous work composed in 1033/1623-1624, cf., e.g., Flügel I, pp. 120-121; see also J. Eckmann, "Kāmūs" (3) in $E I^{2}$ ).

(3) ff. 218b-226b

al-Lugha aṣ-șaghïra

$$
\text { اللغة الصغيرة }
$$

An undated, anonymous Arabic vocabulary with interlinear Turkish translations divided into alphabetically ordered chapters $(b \bar{a} b)$. The title is mentioned in the colophon on f. $226 \mathrm{~b}$ (quoted below).

Begins (218b, after a besmele):

$$
\text { باب الممزة اجلوز [ردده يور غلدى] اسلقى [ققس ؟ اوستنه يتدى ] اقشعر [ بر آرايه دير لدى ] }
$$

Ends (226b):

$$
\text { يقنمق [ جون سويلدى ] يتصابى [نه الصبى ] يرعوى [ اى رجع ] }
$$

Catalogue entry: Voorhoeve, p. 170. 
(4) ff. 229b-232b

Müşkilāt-i inşā

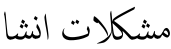

An undated, anonymous Arabic vocabulary of epistolary terms with interlinear Turkish translations, incomplete at the end, without any conspicuous order. (For a comparable text, see MS Acad. 87(2), below).

Begins (229b):

$$
\text { عنوان [ بر كاغد نشانى ] تسليمات [ بيو ... قومقله و سلام ويرمك ] نصاب [اغرى د ... ] }
$$

Ends (232b):

$$
\text { مطايبه [ لطيفه ] معلوك [ حرامى ] كج [كج] ] [ مرددى ] }
$$

Catalogue entry: Voorhoeve, p. 170.

(5) ff. $233 a-254 b$

An undated, anonymous Arabic vocabulary with interlinear Turkish translations divided into alphabetically ordered chapters $(b \bar{a} b)$. It breaks off in the chapter on the letter $w \bar{a} w$. A part is missing between ff. $25^{0}$ and 251. Marginal additions, partly quotations from the Tercümān-i Sahḥāh

Begins (233a):

$$
\text { اقتدى [ اولجق ] آستار [ الى بجوق در هم ] اجتاز [ تجاوز اتمك ] }
$$

Ends (254b):

$$
\text { وحيم [ قتى كون ] و بر [ اوجق و نجادى ] ورى [ سندن قورجقق ] }
$$

(6) ff. $255 \mathrm{a}-273 \mathrm{~b}$

Tuḥfat al-Hādīya

$$
\text { تحفة الهادية }
$$

An undated copy of a Persian-Turkish glossary by Muhammad b. Hājjī Ilyās who completed his work in or before 791/1389. The name of the author is mentioned in f. 255a:3. The glossary is also known as [Risāle-i] Dānisten from the first item mentioned (cf. f. 255b:1). Neither title is found in this copy. The work consists of a succinct introduction in Persian (255a), and, as mentioned here but only found in fuller versions, ten parts (qism) which treat the various verbal forms, from verbal nouns (mașdar) to passive participles $\left(m a f^{\prime} \bar{u} l\right)$, and four sections (fașl) which discuss common substantives. The brief introduction is followed by a first section (fașl) on verbs in the past and other tenses $\left(255^{\mathrm{b}}\right)$, a second on words referring to heaven and 
earth (267a), a third on body parts (269a), a fourth on contraptions (27ob), and a fifth on animals (272a). The work ends in two lists with the names of months and days $(273 \mathrm{~b})$. The lexical items are accompanied by interlinear Turkish translations in smaller script, which, however, are mostly lacking on ff. 258b-267a. (For different versions of the same work, see Leiden, UB Codices Or. 167, 1028 and 18.694; see also MS Acad. 79(1), below.)

Begins (255a, after a besmele):

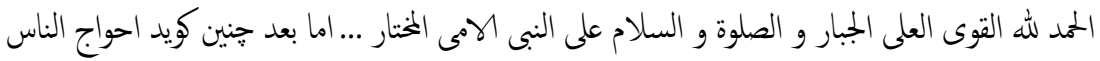

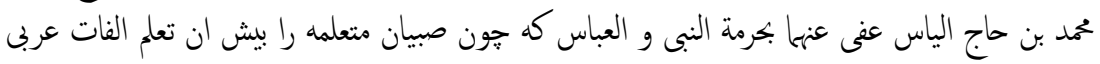

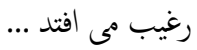

The glossary begins $(255 \mathrm{~b})$ :

$$
\text { فصل اول ماضى دانست [ بلدى ] شناخت [ اكلدى ] آموخت [ اوكندى ] }
$$

Ends (273b):

$$
\text { جهارشنبه ينج شنبه بمعه تمت م }
$$

Colophon (ibidem):

$$
\text { تمت الكتاب بعون الله الملك الوهاب }
$$

Catalogue entries and literature: Storey III/1, p. 65 .

(7) ff. 274a-284b

Nıșāb-i şıbyān-i 'Arabì ma'e Fārsī ma'e Türkī نصاب صبيان عربى مع فارسى مع تركى A mid 17th-century copy of an Arabic glossary with interlinear translations in Persian and Turkish written in smaller script. The title is found in a heading preceding the text on f. 274a. The work contains verbs in various forms and five sections ( $f a s+l)$ with substantives $(278 \mathrm{a})$ referring to five separate categories (as in 6 above); it ends with brief lists of specific verb forms, adverbs, the names of the days and numerals (from f. $283 \mathrm{~b}$ ).

Begins (274a, after a besmele):

$$
\text { العلم [ دانستن بلمك ] المعرفة [ شناختن اكلمك ] التعلم [ آموختن اوكمكك ] }
$$

Ends (284b):

ثمانين الف [ هشتاد هزار سكسن بيك ] تسعين الف [ نود هزار طقز بيك ] مائية الف [ صد هزار يوز 
Colophon (ibidem):

$$
\text { تمت الكناب بعون الله الملك الملاف كتبه الفقير حسن عفى عنه سنه •V· 1 م }
$$

Catalogue entry: Voorhoeve, p. 254.

(8) ff. $285^{a-29 o b}$

An undated copy of a Persian list of words and concise phrases, without title, alphabetically arranged and divided into chapters $(b \bar{a} b)$ according to the subsequent letters, with interlinear Turkish equivalents. The work is followed by six items of the same type and in the same handwriting.

Begins (285a):

$$
\text { آنتاب بلند آمده [ا]ست [كون يوخارو كهيدر] ابر است [ بولت در] آورده است [كتر یدر] }
$$

Ends (29ob):

$$
\text { هر كه من نواند بردر [ هر كई وايلور وارسون ] هر هنين كه [ هر نسنه ؟ تمت }
$$

Rebound in light and dark brown leather with flap; the title of (1) is written on the back and the bottom edge; glazed (except for 8) white to cream paper, extended in $(2-8)$ to suit the size of the pages of $(\mathbf{1}) ; 2+290$ folios, partly with original numbers; $215 \times 158 \mathrm{~mm}$; greatly varying written surfaces and numbers of lines; catchwords, except in (8); nesih, mostly vowelled, in various hands; (1) completed by the Imam Ḥāccī ارحوغدى [? = Erçog̉dı?] b. Hōca on the fortress of Muş on 27 Ramażān 974 (7 April 1567); (2,7) by Ḥasan b. Bayrām in 1070 (1659-1660). See also above.

Catalogue entry: CCOBARS 35 (pp. 80-84).

Acad. 75

A miscellany

The volume contains (1) a dictionary, described below, and (2) a poem in Arabic, both written by the same copyist. Various text fragments in Arabic, Persian and Turkish are found on the endpapers and the inner boards, among the Turkish texts we find: a letter from shaykh 'Abdulkādir el-Mollā concerning the promotion of Mevlānā 'Ubeydullāh, dated last days of Şa $\bar{b} \bar{a} n$ 991 (8-17 September 1583, 4 lines, inner front-board); a prescription against 
diarroeah $(3+4$ lines, first flyleaf, recto); a prayer prescription (5 lines, ibidem); a prescription for a talisman (6 lines, first flyleaf, verso); a preamble to a letter (1 line, vertically written, 'title page'); a fetvā concerning a heritage, signed by Mușțafā b. Dervīş Meḥmed (6 lines, idem); the price [of the MS] of '115' written by the owner Mehmed b. 'Alī at the każa of Çeşme (ibidem); three müfreds (inner back-board). The inscription 'J. Willmet' with the year 1773 and the number 29 occurs on the 'title page'; there is also the title Lexicon Arabicum Selectum, cum brevi explicatione vocum Turcica et Arabica in Willmet's handwriting.

(1) pp. 1-322

[Kitāb-i] Müntehab

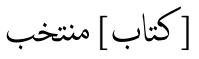

A mid 16th-century copy of an anonymous Arabic-Turkish vocabulary. The title occurs on the inner front-board and the 'title page'. It resembles the work described under MS Acad. 74(1) above, although it lacks the introductory part. Marginal additions, among them quotations from dictionaries, in various hands. (See for further references under Acad. 74(1), above.)

Begins (p. 1, after a besmele):

....آذآن [ جمع اذن ] آن [ بلجى و عالم [آل محمد [ محمدك اهل بيت و خصمى و قومى و كوك كنارنده اغرنى(؟)]

Ends (322):

$$
\text { مهودى [ جهود ] يهمو بوح بهمود [ ير كتورن بالق ] يوعد يوحو نام }
$$

Colophon, with a copyist's verse (ibidem):

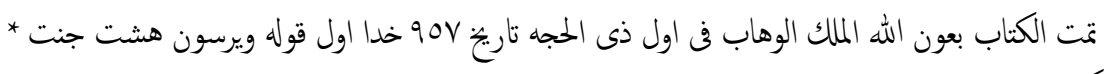
كه ديا يازنك جانبينه رحت الكتاب بعن المت المت

$* * *$

Bound in boards with flap; glazed cream paper; $3+331$ pages; $215 \times 155 \mathrm{~mm}$ and (1) $150 \times 95 \mathrm{~mm}$; (1) 7 lines (Arabic words); catchwords; (1) completed on 1 Zi l-hicce 957 (11 December 1550); without the name of a copyist.

Catalogue entry: CCOBARS 36 (pp. 84-85). 
Acad. 76

Müfı̈ül-müstefidīn

مفيد المستفدين

A late 17 th-century copy of an anonymous, rhymed Arabic-Turkish dictionary in 500 beyts on the example of the Tuhfe-i Şähidi (cf. pp. 4-5; for this work, see under MS Acad. 77, below). It was completed in 1053 (1643-1644). It consists of 32 , unnumbered sections $\left(k \iota t^{\prime} a\right)$, each exemplifying one of the metres indicated by فعل patterns in red. The final section functions as an epilogue and contains the title (p. 150:3), the number of beyts (p. 150:5), and the year of completion (p. 151:6). The work is rare.

A Latin title in capitals (Arabice Turcice Rythmice Rudimenta) and in the hand of Johannes Heyman (1667-1737), Protestant minister of the Dutch community at Izmir and later professor of Oriental languages at Leiden University (cf. Volume II, Introduction to Chapter 1), is found on the (unnumbered) 'title page'; it is followed by the explanation Est Vocabularium Rhythmicum, Arabico-Turcicum; inscriptions on the next two pages have been crossed out. The manuscript is of the same format as Leiden, UB Codices Or. 1289, 1591 and 14.456, all from Heyman's library and copied by, probably, the same copyist at Izmir. (See also MSS Acad. 80 and 96, below.) The inscription 'J. Willmet' with the year 1780 and the number 68 occurs on the inner front-board. Before him, the manuscript had belonged to the Leiden Orientalist Jan Jacob Schultens (1716-1778), whose library was sold at a public auction in 1780 (cf. Volume I, Introduction to Chapter 5.)

Bound in boards; glazed white, yellow, grey and pink paper; $2+15^{2}+4$ pages; $145 \times 103 \mathrm{~mm}$ and $105 \times 70 \mathrm{~mm}$, varying; 7 lines; catchwords; vowelled ta $\mathrm{l} i \bar{k}$; headings and scansion patterns in red; completed at Izmir on a Sunday in Muharrem1104 (September-October 1692); without the name of a copyist.

Begins (p. 2, after a besmele):

$$
\text { آله الخلق علام الخفايا * مفيض الخير قسام العطايا }
$$

Ends (p. 152):

$$
\text { خيرله كم ياد اده قيله دعا *خير حاجاتن روا قيلا خدا }
$$

Colophon (ibidem):

$$
\text { تمت بفضل الله تعالى و تقدس في يوم الاحد من شهر محرم الحرام لسنه اربع و مئة و الف حميت عن التدمير }
$$

Catalogue entries: CCOBARS 188 (p. 242); Fihris 4556 (IV, pp. 120-121). 
Acad. 77

Tuhfe-i Şāhidī

تحفَّ شاهدى

A late 17th-century copy of a rhymed Persian-Turkish dictionary by İbrāhīm Şāhidì, a Mevlevī dervish and poet (d. 957/1550). The name of the author and the title of the work occur in pp. 10:10-11:1. The title Kitāb-i Şāhidī is found on the 'title page' (and there accompanied by the Latin Lexicon Rythmicum Turcico-Persicum ...) and on p. 1. Many copies of this work have survived. It commences with an introductory mesnevi of 61 beyts in which, among other things, the author explains his life-long fascination for dictionaries and his decision to write a rhymed one as a nazìre to the Tuhfe-i Husāmi (of 802/1399). He also expresses his hope that the work will be helpful to children in learning Persian and scanning verses. It is followed by 27 kıt' $a$ s which discuss a vocabulary ranging from words for God to that for napkin. In the last section the author explains the numerical value of Arabic letters. The first four distichs are found both on p. 1 and p. 3. (For other copies, see Leiden, UB Codices Or. 148, 1582, 1583, 5808, 6965, 6967, 8330, 11.117(2), 11.575(1), 12.428 and 25.760(3); see also Leiden, UB MS Hotz 2289, above) The inscription ' $\mathrm{J}$. Willmet' with the year 1773 and the number 41 occurs on the 'title page'.

Bound in boards with flap; white paper; $2+93+3$ pages; $210 \times 150 \mathrm{~mm}$, varying, and $115 \times 70 \mathrm{~mm}$, varying; 10 lines; catchwords; inexpert nesih; copied by the German orientalist and traveller Stephan Schultz (whose manuscripts were acquired by J. Willmet in 1773) from an original copied by Hüseyn b. 'Abdulkerīm el-İskilibī in 1153 (1740-1741).

Begins (pp. 1 and 3 , as in the printed edition of 1275):

$$
\text { بنام خالق وحى و توانا * قديم و قادر و بينا و دانا }
$$

Ends (p. 93, as in the printed edition of 1275, p. 23:4-5):

$$
\text { شاهدى يه هر كم ايلرسه دعا * ايده محشرده شفاعت مصطفى }
$$

Original colophon (ibidem):

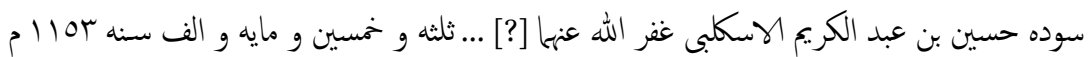

Catalogue entries: CCOBARS 186 (p. 239); Sohrweide II 199, where other references are fond; see also Fihris 518-532 (I, pp. 133-136); Schmidt 34, 115, G 1500(1); Şeşen III 694/3; TIYK 55; TYTK (Antalya) 1633-1635; TYTK(Türkiye Büyük Millet Meclisi) 105 . 
Editions: Istanbul 1275; Antoinette C. Verburg, "The Tufe-i Şāhidì: a Sixteenth Century Persian-Ottoman Dictionary in Rhyme", in Archivum Ottomanicum 15 (1997), pp. 5-87 (in transcription, with translation and glossary).

Literature: Janos Eckmann, "Kāmūs" in $E I^{2}$; Storey III, pp. 66-67; see also the introduction to Verburg's edition.

Acad. 78

\section{Tuhfe-i Şāhidī}

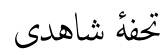

A late 17th-century copy of the rhymed Persian-Turkish dictionary by İbrāhīm Şāhidī, described under MS Acad. 77, above. The name of the author and the title of the work occur in p. 3:9-10. The title Kitāb-i Şāhidī is found on the 'title page' (and there accompanied by the Latin Lexicon dictum Sjahidi) and in a heading on p. 1. The inscription 'J. Willmet' with the year 1773 and the number 48 occurs on the inner front-board. Extensive marginal additions: distichs by various poets, among them Hayālī, Nesīmī and 'Ömer, with added distichs with scansion patterns and mention of the name of the metre, as well as a plethora of lexical glosses.

Rough drafts of two tugras (of Ahmed III, cf. Umur, pp. 241-245) and two tailed signatures with the year $1116(1704-1705)$ are found on the inner frontboard. A line in Arabic (نظر فيه قاسم قباطى بك) and the date 1 Șafer 50 occurs on the 'title page'. The last flyleaf (verso) and the inner back-board contain various administrative notes with the years $1125 / 1713$ and 1126/1714, epistolary fragments, verses and calculations as well as an owner's inscription with three seal impressions of a certain İbrāhīm. The inscription 'J. Willmet' with the year 1773 and the number 48 occurs on the inner front-board.

Bound in boards; glazed white paper; $3+39+2$ pages; $202 \times 132 \mathrm{~mm}$ and $152 \times 78 \mathrm{~mm}$; 17 lines; catchwords; vowelled nesih; headings, interlinear numbers, lines and marginal additions (the verses and some of the glosses) in red; multiple red borders; completed by Mușțafā Kātibzāde in Muharrem 1110 (July-August 1698).

Begins (p. 1, after a besmele, as in the printed edition of 1275):

$$
\text { بنام خالق وحى و توآنا * قديم و قادر و ببنا دانا }
$$

Ends (p. 39, as in the printed edition of 1275, p. 23:4-5):

شاهدى يه هر § ايلرسه دعآ * ايده محشرده شفاعت مصطفآ حق تعآلى رحمت ايليه آكا * بو كتآنى يازنه قيله 
Colophon (ibidem):

$$
\text { حرره الحقير مصطفى كاتبزاده تح شهر محرم الحرام سنه • • } 111 \text { مائه عشر و الف }
$$

Catalogue entry: CCOBARS 185 (p. 239); for further details, see under MS Acad. 77, above.

\section{Acad. 79}

A collection of glossaries

The undated volume contains two word-lists in double columns written by the same scribe, possible the German orientalist Albert Friedrich Woltersdorf (cf. the script in MS Acad. 83). The inscription 'J. Willmet' with the year 1804 and the number 178 occurs on the 'title page'. Willmet bought the manuscript when the library of D.A. Walraven (1779-1804), professor of Oriental languages in Amsterdam, was put up for sale.

(1) pp. 1-143

Tuhfat al-Hādìya

تحفة الهادية

A Persian-Turkish glossary by Muhammad b. Ḥājji İlyās who completed his work in or before 791/1389. The author or the title are not mentioned in the copy - the Persian introduction as well as the formal divisions of the text are also lacking - but the lexical items are those of MS Acad. 74(6), above. The glossary is also known as [Risāle-i] Dānisten from the first item mentioned.

Begins (p. 1):
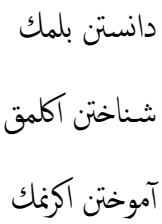

Ends (p. 143):

صد هزار يوز بيك

(2) pp. 145-475

An anonymous, alphabetically arranged Arabic-Turkish vocabulary, incomplete at the end-it breaks off in the chapter on the letter $q \bar{a} f$. 
Begins (p. 145):

$$
\begin{aligned}
& \text { حرف الهف } \\
& \text { ابتدا اول } \\
& \text { اب بابا يدر والد }
\end{aligned}
$$

Ends (p. 475):

$$
\text { قراع جاو ايتمك [قرعت] }
$$

Catalogue entry: Voorhoeve, p. 416.

Rebound in boards with flap and brown leather back and edges; glazed cream paper without watermarks; $(2)+1+475+(2)$ pages; $220 \times 150 \mathrm{~mm} ; 12$ lines; catchwords; vowelled nesih; a red heading on p. 145; without a date and the name of a copyist.

Catalogue entry: $C C O B A R S 37$ (pp. 85-86).

Acad. 80

A linguistic manual

The early 18th-century volume contains a word-list and phrases written by the same scribe. Latin and Italian titles (Vocabulario de' motti Turcheschi Secondo alfabeto/ Vocabularium Turcicum ordine alphabetico cum Interpretatione Italica) at least partly in the hand of Johannes Heyman (1667-1737), Protestant minister of the Dutch community at Izmir and later professor of Oriental languages at Leiden University (cf. Volume II, Introduction to Chapter 1), is found on the 'title page'. The verso-side of the same page contains the inscription Vocabulario Turcico. Sm [irna] 10/1 [17] o2. The manuscript is of the same format as MS Acad. 76 and Leidenm, UB Codices Or. 1289, 1591 and 14.456, all from Heyman's library and copied by, probably, the same copyist at Izmir. (See also MSS Acad. 87 and 96, below.) The inscription 'J. Willmet' with the year 1780 occurs on the same page; the number 66 is found on the inner front-board. Before him, the manuscript had belonged to the Leiden Orientalist Jan Jacob Schultens (1716-1778), whose library was sold at a public auction in 1780 (cf. Volume I, Introduction to Chapter 5). 
(1) pp. 1-192

Kelimāt-i Türkīye

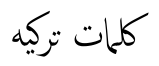

An alphabetically arranged Turkish vocabulary accompanied by glosses (but mostly lacking towards the end): transcriptions and Italian translations, in a smaller script by Heyman (cf. above). The title is found in a heading preceding the text.

Begins (p. 1):

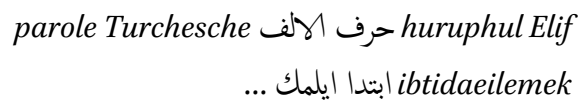

Ends (p. 192):

$$
\text { ياريم ياض ياب يا يجيه يإِجه }
$$

(2) pp. 192-207

A chapter on conversation, headed Bābü l-mușāhebe, consisting of brief colloquial phrases accompanied by glosses as in (1).

Begins (p. 192):

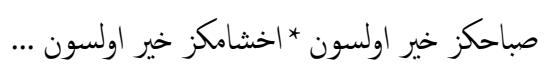

Ends (p. 207):

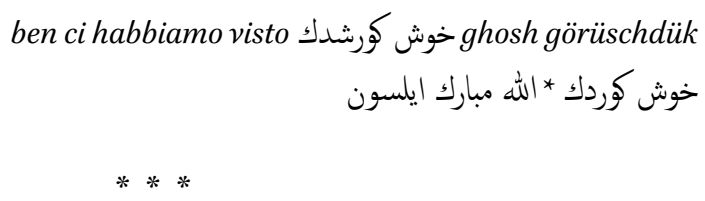

Bound in boards; white, pink, yellow, and grey paper; $3+207+2$ pages; $144 \times 98 \mathrm{~mm}$; 5 lines; without catchwords; bold vowelled nesih; headings, rubrics and (2) double disks in red; copied in Izmir in 1702 (cf. above); without the name of a copyist.

Acad. 82

A Turkish-French vocabulary and phrasebook.

The mid-18th-century anonymous copy was made by Stephan Schultz (see under MS Acad. 77, above) of Grammaire turque, ou méthode courte \& 
facile pour apprendre la langue turque etc. by Father Jean-Baptiste Holdermann S.J., published by İbrāhīm Müteferriḳa in Istanbul in 1730. It covers pp. 68-126 (Recueil des noms, pp. 1-122) and pp. 127-149 (Des manières de parler, pp. 123-146) of that edition. The transcriptions in Latin script of the Turkish found in the printed edition were omitted. An additional phrase with a German translation is found on p. 146. The 'title page' contains the inscriptions of A.F. Woltersdorf, a companion of Schultz, with the Latin title Nomenclator Turcico Gallicus, and of J. Willmet, with the year 1773 and the number 36. (See also under MS Acad. 92, below.)

Bound in boards with flap; white paper folded in four columns; $4+146+2$ pages; $210 \times 150 \mathrm{~mm}$; 10-14 lines; catchwords; inexpert nesih; without date and the name of a copyist.

$\operatorname{Begins~(p.1):~}$

Dieu createur de l'univers

Ends (pp. 145-146):

Il n'est pas riche

Wenn 2 Esel schreyn gibt es eine angenehmen Klang ايلى [ =ايكى ] اشك برابر هاغرر ايسه طراب اولور

Catalogue entry: CCOBARS 147 (p. 187).

Literature: Güney Alpay Kut, "Mațbaca” (2), in $E I^{2}$.

Acad. 84

\section{Kitāb-i İnşa $\bar{a}$}

An undated, anonymous collection of (model) letters. The title is found in a heading preceding the text on p. 1 and on the first unnumbered page, where the title Formulae Epistolarum. Turcice. charactere Diwani is added. The years 1134 (1721-1722) and $1133(1720-1721)$ are found on, respectively, the original 'title page' and p. 5 1. Headings, some of which have been omitted, vaguely indicate genre (mektūb, 'ariz-i hăl, temessük) or sender/addressee (sultans, beglerbegis, $k \bar{a} \bar{z} \dot{\imath} s$, 'from an inferior to a superior' etc.). Some letters, written in complex rhymed prose, contain Arabic quotations and Persian verses. The last item, a temessük concerning a loan, ends in a colophon, in which the month and year have been replaced by fulän, with the name of Aḥmed b. Meḥmed b. İbrāhīm, who may have been the copyist/compiler 
of the work. The letters are followed by a table explaining the siya kat figures by regular numbers in red (pp. 51-53). A few marginal additions. Text fragments, mostly epistolary phrases, calculations, illegible jottings in various hands, and a drawing are added on the 'title page' and p. 53.

The inscription 'J. Willmet' with the year 1773 and the number 7 occurs on the first unnumbered page.

Rebound in boards; glazed cream paper, stained in many places; the first and last original pages are tattered and partly mended with strips of paper; $(2)+1+51+2+(2)$ pages; $290 \times 205 \mathrm{~mm}$ and $250 \times 135 \mathrm{~mm}$, varying; 11 lines; catchwords; divānī; Arabic quotations in nesih; headings and lines in red; without date and the name of a copyist; inscriptions of Yūsuf, possibly an owner, are found on the 'title page' and in the margin of p. 8.

Begins (p. 1, after a besmele):

$$
\text { الممد لله الملك الجبار الواحد القهار ... و رازق جميع غخلوقات كفار اول پيادشاه يروردكار ... }
$$

Catalogue entry: CCOBARS 197 (p. 248).

Acad. 85

Kitāb-i İnşa

كناب انشاء

An undated, anonymous collection of (model) letters. The title is found on the 'title page', where the title Formulae Epistolarum. Charactere Diwani. As indicated in headings, the letters are mostly letters of friendship (muhabbetnāme) or epistles (mektūb) exchanched between friends (akrāndan akrānda). A few petitions ( $a r \dot{z}-i$ h $\bar{a} l)$ are found on pp. 17-25. A tezkire concerning a loan and dated Muharrem 980 (May-June 1572) occurs on p. 27.

The inscription 'J. Willmet' with the year 1773 and the number 26 occurs on the 'title page'.

Rebound in boards with flap; glazed white paper; $2+1+53+4$ pages; $230 \times 165$ $\mathrm{mm}$ and $170 \times 105 \mathrm{~mm}$, varying; 13 lines; without catchwords; talïk with divāni elements; headings in red; without date and the name of a copyist.

Begins (p. 1):

$$
\text { كرى قلوب اقرانه يازمشدر الوف تحيات صافيات مستجاب ايله و صنوف تسليمات وافيات مستطاب ثنيت }
$$

Catalogue entry: CCOBARS 199 (p. 249). 
Acad. 86

Kằide-i İnşā

قاعدة انشا

An undated, anonymous collection of (model) letters, mostly on commercial transactions and trade. The title is found in a heading preceding the text on p. 1 and on the first unnumbered page, where the title Fundamenta Compositionis sive Stili. Turcice is added. The years $1044(1634-1635)$ and 1008 (1599-160o) are found on, respectively, p. 64 and p. 65. The text is identical with that found in Leiden, UB Cod.Or. 1268, although headings indicating genre (mektüb, temessük) are added to all items in this manuscript and the two aforementioned years do not occur in, what is probably, the original text. (For a detailed description of the contents, see Volume I, pp. 562-565). The letters are followed (on p. 72) by a list of numbers in six groups: $1-9$, 10-90, 100-900, 1000-9000, 10000-90000, 100000-900000. A few marginal additions, mostly numbers in a Western hand.

The inscription 'J. Willmet' with the year 1780 and the number 16 occurs on the 'title page'. Before him, the manuscript had belonged to the Leiden orientalist Jan Jacob Schultens (1716-1778), whose library was sold at a public auction in 1780 (cf. Volume I, Introduction to Chapter 5 ), and Herman van der Horst (1692-1765), whose name also occurs on the 'title page'. The latter was minister of the Dutch Protestant community at Izmir between 1718 and 1727 (see NNBW VIII, cols. 851-852).

Rebound in boards with a flap; glazed white paper; $(2)+1+72+6$ pages; $215 \times 155 \mathrm{~mm}$ and $155 \times 80 \mathrm{~mm}$, varying; 11 lines; catchwords; vowelled nesih of calligraphic quality; headings and dots in red; without date or the name of a copyist.

Begins (p. 1):

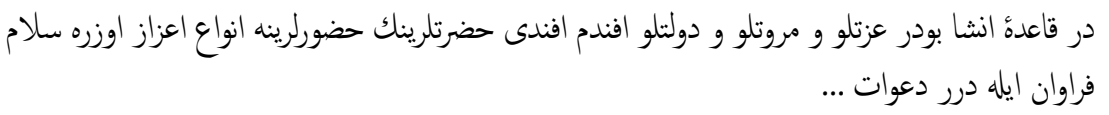

Catalogue entry: CCOBARS 197 (p. 248).

Acad. 87

\section{A miscellany}

The manuscript is of the same format as MSS Acad. 76 and 8o, above, and Leiden, UB Codices Or. 1289, 1591 and 14.456, all from the pastor and orientalist, Johannes Heyman's library and copied by, clearly, the same 
copyist. (See also MS Acad. 96, below.) A colophon on p. 132 mentions the town of Izmir and the year 1102 (1690-1691). The first part, up to p. 131, and the last pages (4), are accompanied by a plethora of glosses in tiny Latin script, mostly transcribed Turkish and Dutch. The manuscript also contains some slips of paper with notes in the same hand. The inscription 'J. Willmet' with the year 1780 occurs on the same page; the number 66 is found on the inner front-board. Before him, the manuscript had belonged to the Leiden orientalist Jan Jacob Schultens (1716-1778), whose library was sold at a public auction in 1780 (cf. Volume I, Introduction to Chapter 5).

(1) pp. 1-74.

Kitāb-i İnşā

كناب انشاء

An undated, anonymous collection of (model) letters, some of which contain Turkish or Persian verses. The title is found in the first line of the introduction (pp.1-2). The letters, as indicated in headings, cover the usual genres: letters exchanged between an inferior and a superior, between friends, between a father and a son, or letters addressed to the Porte (p. 28) or Ottoman officials (such as an agha of Janissaries, p. 34); there are also letters from the muhașșl of Aydın to the Molla of Izmir (p. 65), and from a secretary to an agha (p.67).

Heading (p. 1):

في زماننا مستعمل انشا مفيد و مختصردر

Begins (ibidem):

باعث تسطير كتاب انشاى بلاغت فزون و موجب تقرير خطاب املاى فصاحت نمون كه منشيان روزكار

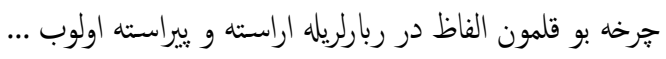

Ends (p. 74):

و سائر جميع احباب و خلانه و دوستان و صداقت عنوانه فدا فردا اكرام و اشتياق اوزره سلاملر اهدا اولنور تبلينى مرجودر و السلام و اللابر

(2) pp. $78-132$

İş̧ā-i pür-belāgat u fașāḥat

انشاء بر بلاغت و فصاحت

An anonymous, undated collection of (parts of) (model) letters, some of which contain Arabic, Persian and Turkish verses. The title is found in a heading preceding the text. Headings vaguely indicate genres, but mostly rhetorical excellence and stylistic elegance. 
Begins (p. 78):

$$
\text { سعادتلو ساحتلو افندم سلطانم حضرتلرينك نادى دليزير و محفل ارم نظيرلرى صوبنه ... }
$$

Ends (p. 132):

$$
\text { بودركه المى آخره تمت و عادتلو عدالتلو و عامة فقرايه مرحمنلو سلطانم ... مدينهُ ازمير اهاليسنك عرض و مخرلرى : }
$$

Colophon (p. 132):

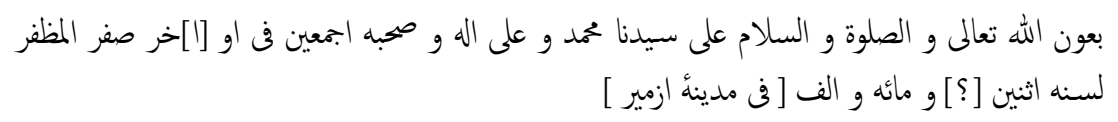

(3) pp. 141-261

An anonymous collection of copies of official letters addressed to, primarily, the $k \bar{a} \bar{z} \bar{\imath}$ of Izmir, on request of the Dutch envoy to the Porte, Giacomo [Jacob graaf] Colyer [in office 1682-1725, cf. Schutte, Repertorium, pp. 308-309], concerning trade and other matters of interest to the Dutch community of Izmir. The names of most Ottoman officials have been left out. (Additional data on some cases are found in the files of the Archives of the Directors of Levantine Trade (LH) and the States-General (SG) in the National Archive in The Hague, see in particular LH 125-126 and SG 6915-6917.)

pp. 141-146. A hü̈km-i hümāyūn addressing the ḳapudan Mușțafā Paşa and the $k \bar{a} \dot{z} \bar{\imath}$ and emin of Izmir on request of Giacomo Colyer; six Dutch ships had been asked, contrary to the 'ahdnāme, to pay 110 guruş each; ships entering Ottoman waters with friendly intentions should pay only 300 a kçe at the customs for selāmetlik resmi and be given their izin tezkiresi. Dated mid-Şąbān 1095 (24 July-1 August 1684).

pp. 146-150. A hükm-i hümāyūn addressing the kapudan İbrāhīm Paşa and the kạaż of Izmir on request of Giacomo Colyer; a slave of Șāgīir Ahmed, a levend of Algiers, had fled; in 1101 (1689-169o) the latter raided the house of the Dutch merchant Markīz [Willem Marcquis] at Izmir and abducted two men by force, and only freed them after he had received 500 guruss, all this contrary to the law; it orders that the case be brought to justice and that the sum be restituted (see also below), dated mid-Zī l-ḳa'de 1101 (16-25 August 1690), at Niş.

pp. 150-154. A hükkm-i şerîf addressing the kāàż of Izmir on the request of Giacomo Colyer, confirming that Dutchmen are allowed to buy and press 
grapes and make wine in their houses for their own consumption according to the 'ahdnāme, and that Janissaries, the hamr emini and other officers should not hinder them or forcibly levy tax on that activity; dated the beginning of Zi l-hicce 1100 (16-25 September 1689), at Sofia.

pp. 155-157. A hü̈km-i şerīf addressing the kiāzì of Izmir on request of Giacomo Colyer, forbids the levying of cizye from five men in the service of the Dutch Consul Daniel d'Hochepied, holder of a berāt appointing him Dutch consul at Izmir, dated the last days of Cemāzzi l-evvel 1100 (13-22 March 1689).

pp. 158-163. A hükm-i şerīf addressing the kạàż of Izmir on request of Giacomo Colyer; the houses of the Dutch merchants have all been destroyed in an earthquake in Izmir; they should not be harrassed as long as these houses are not rebuilt and should not be hindered to find lodgings or to trade (as had happened to five Dutch merchants), dated mid-Z il-hicce 1099 (6-15 October 1688).

pp. 163-166. A hü̈km-i hümāyūn addressing the kạ̄ìz of Izmir on request of Giacomo Colyer, ordering to the restitution of the rent to Dutch merchants paid in advance over houses since destroyed by the recent earthquake and for the period after the event, dated early $Z \bar{\imath} l$ - hicce 1099 (27 September -5 October 1688).

pp. 166-169. An emr-i şerīf addressing the keāzì of Izmir on request of Giacomo Colyer, forbidding the customs officers to levy import duties on wares Dutch merchants want to keep on board (as had been done by one officer), dated end-Zī l-hicce 1099 (16-25 October 1688).

pp. 169-174. A hü̈km-i şerîf addressing the kā̇ż of Izmir and local officials on request of the Dutch envoy, and ordering them to protect the rights of the Dutch merchants after Algerian pirates had killed a Dutch merchant [Daniël Cosson] of Izmir in the same year and had shown hostility to others, contary to the text of the 'ahdnāme; dated mid-Zī l-hicce 1100 (26 September-4 October 1689), at Sofia.

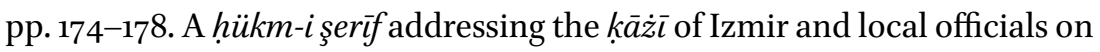
request of Giacomo Colyer, forbidding the opening of taverns (meyhāne) in the quarter inhabited by müste'min after the earthquake; some bandits had erected such places there and done great mischief, dated beginning of $\underline{Z} \bar{\imath}$ l-ka'de 1101 (6-15 August 169o). 
pp. 178-182. A hükm-i şerîf addressing the kāài of Izmir on request of the Dutch envoy, forbidding to levy more than three percent on the value of exported goods from Dutch merchants, after it had appeared that the customs officer, the warden and the caravansaray-keeper had demanded more money in cash before a freight of cloth could be transported, dated end of Rebï̌̈̈ l-evvel 1097 (15-24 February 1686).

pp. 182-186. A hä̈km-i hümāyūn addressing the ḳā̇ì of Izmir on request of Giacomo Colyer, forbidding local kiāzìs and kâassāms to levy death duty on property belonging to deceased men under the jurisdiction of the Dutch consul, dated mid-Z̄i l-hicce 1099 (7-16 September 1688).

pp. 186-191. A hükm-i şerîf addressing the kâà̇i and the gümrük emini of Izmir on request of Giacomo Colyer, forbidding the obstruction of trade in goods and cash transported by Dutch merchants on French ships, dated mid-Rebīü l-ähir 1101 (22 January-1 February 169o).

pp. 191-195. An unsigned and undated letter to Ahmed Aġa, probably a customs official, warning him not to obstruct the flow of goods passing through customs; if problems should arise, contact should be sought with the Porte first.

pp. 195-199. A hükm-i hümāyūn addressing the $n \bar{a} i b$ and the gümrük emini of Izmir on request of Giacomo Colyer, forbidding to obstruct the Dutch recuperating their possessions from the debris of their houses and warehouses destroyed by the great earthquake, dated end of Ramażān 1099 (20-29 July 1688).

pp. 199-203. A hä̈km-i şerîf addressing the $n \bar{a} i b$ of Izmir on request of Giacomo Colyer, repeating the message of the previous order, after some persons had robbed the Dutch of some of their recuperated possessions and urging the addressee to bring the guilty to justice, dated mid-Şevvāl 1099 (8-17 August 1688).

pp. 203-206. A hükkm-i hümāyūn addressing the nā'ib of Izmir on request of Giacomo Colyer, forbidding to levy export duty for a second time on goods, recuperated by the Dutch from the rubble of the great earthquake and brought to safety on French and English ships, dated mid-Şevvāl 1099 (8-17 August 1688). 
pp. 206-209. A hükm-i şerīf addressing the kā̄̇̀ of Izmir and local officials on request of Giacomo Colyer, forbidding to erect taverns (meyhăne) amidst the dwellings inhabitated by the Dutch consul and Dutch merchants, dated end of Cemāza l-ähir 1100 (11-20 April 1689).

pp. 210-213. A hü̈km-i şerīf addressing the kiāzì of Izmir on request of Giacomo Colyer, forbidding military personnel to harrass yasakçılar (guards) in the service of the Dutch consul proposing them to join a military expedition, dated mid-Receb 1100 (1-10 May 1689).

pp. 213-216. An unsigned and undated petition to the Porte requesting safe passage to Izmir of a Dutch merchantman which had fled to Midilli (Mytilene) harbour to escape from a French ship (see also below).

pp. 216-220. An emr-i şerîf addressing the kā̇zì of Izmir on request of Giacomo Colyer, forbidding the levy of a yasakçı akçesi or other taxes not specified in the 'ahdnāme from Dutch merchants, dated end of Rebï̈ l-evvel 1099 (25 January-3 February 1688).

pp. 220-224. A hä̈km-i şerīf addressing the kāàz of Izmir on request of Giacomo Colyer, forbidding to levy duties on cash, clothes, food and drink imported on Dutch ships and destined for the use and consumption by the Dutch themselves, dated early Şevvāl 1100 (19-28 July 1689).

pp. 224-230. A hükm-i şerîf addressing the Kapudan İbrāhīm Paşa and the $k \bar{a} \dot{z} \bar{\imath}$ of Izmir on request of Giacomo Colyer ordering the protection of the Dutch merchants trading with the Ottoman Empire and the punishment of Algerian pirates and brigands who harrass them, even wound and kill them (as happened at Foça recently), dated end of Ramażān 1101 (28 June-7 July 169o), at Edirne.

pp. 230-232. A hüccet issued by Ahmed, kā̇̇i of Izmir, to the Dutch balyoz and merchants, stating that an Algerian levend called Ṣāgir Ahmed had abducted two Dutch protégés from the house of a Dutch merchant in Izmir, reportedly in the possession of one of his slaves, threatening to keep them imprisoned as long as the slave was not handed over; they also demanded that the Porte be informed of the case (see also the next item, and below), dated 21 Ramażān 1101 (28 June 1690). 
pp. 232-234. A letter of complaint from Ahmed, kị̄ī of Izmir, to the Porte: while some Algerian levends were strolling through the Frankish quarter, a Frenchman attacked them, wounding one of them and killing another; the $k \bar{a} \dot{z} \bar{\imath}$ was informed by three Muslims who brought the corpse to the courtroom and demanded a hüccet, and also wished to inform the Porte about the slave in the possession of the Dutchman and the two kidnapped müste'min (see previous entry, and above; see also below), undated.

pp. 235-238. A hä̈km-i şerîf addressing the kāài of Izmir on request of Giacomo Colyer, forbidding the levying of taxes from the dragoman, his sons and servants in the service of the Dutch consul which are not specified in the berāt issued to the consul, dated end of Cemāzi l-evvel 1101 (2-11 March 1690).

pp. 238-242. A hü̈km-i şerîf addressing the ķā̇i of Izmir on request of Giacomo Colyer, forbidding the tamga emini to levy duties twice on wool and cotton purchased and shipped by Dutch merchants, dated mid-Receb 1101 (20-29 April 1690), at Edirne.

pp. 242-245. A hü̈km-i şerîf addressing the kā̇̇i and gümrükçi of Izmir on request of Giacomo Colyer, forbidding the kanțārçı to demand 70 akçe (in excess of the legal 120 akçe) for every guruş levied from goods imported and exported by Dutch merchants, dated mid-Rebïü l-ähir 1101 (22-31 January 1690, see also below).

pp. 245-249. A hä̈km-i şerîf addressing the kāà̇i, the gümrük emini and other officials in Izmir on request of Giacomo Colyer, forbidding the interference by the French in the affairs of the Dutch who have their own treaty with the Porte and pay their own custom duties and consular rights, dated early Cemāzī l-evvel 1101 (10-19 February 1690), at Edirne.

pp. 249-251. An unsigned and undated letter addressed to a begzāde, requesting him to send to the sender in Istanbul a good hound (zagar) and some cloth with 'Alī Beg, and also return the rifle after it had been repaired; sender had recommended addressee to Mehmed Pasa.

pp. 251-253. A petition to the Porte from the Dutch balyoz at Izmir, demanding the protection of the Dutch community after the murder of a Maghribian and the raid of the house of a Dutchman by five levends in order to free a slave (see above), undated. 
pp. 253-255. An unsigned and undated letter, by, probably, the Dutch consul at Izmir to a pasha (probably the kapudan paşa), requesting safe passage to Izmir of a Dutch ship which had taken refuge in the harbour of Midillü (Mytilene) after a conflict with the French (see also above).

pp. 255-258. A Du'annāme addressed to the Porte concerning the same case, and requesting the protection of Dutch ships against threats of the French, Algerians and Tunisians, undated.

pp. 258-262. A hükm-işerîf addressing the kāàż, the gümrük emini and other officials in Izmir on request of Giacomo Colyer, forbidding to obstruct Dutch merchants, who every year come with two ships loaded with akçes to buy figs and grapes, after they have paid the legal three percent custom duties, dated mid-Rebīü l-ähir 1101 (22-31 January 1690).

pp. 262-265. A hükm-i şerîf addressing the kāàz Giacomo Colyer, forbidding the kanțārçı to demand 70 akçe (in excess of the legal 120) for every riyāl or guruş levied from goods imported and exported by Dutch merchants, dated mid-Şacbān 1101 (20-29 May 169o, see also above).

Literature: Jan Schmidt, "Johannes Heyman (1667-1737). His Manuscript Collection and the Dutch community of Izmir", in: Colin Imber, Keiko Kiyotaki \& Rhoads Murphy (eds.), Frontier of Ottoman Studies: State, Province, and the West. Volume II (London \& New York 2005), pp. 75-89.

(4) pp. 265-284

\section{Luġat-i müşkilāt-i inşā}

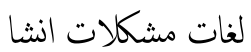

An undated, anonymous Arabic-Persian vocabulary of epistolary terms, arranged in alphabetical order, with interlinear Turkish translations. The last section contains words beginning with $\operatorname{mim}$. The title is found in a heading preceding the text. (For a copy of a comparable text, see MS Acad. 74(4), above).

Begins (p. 262):

$$
\text { اخلاص [رياسزلك و خالصلك و هاككلك] اختصاص [تخصوص اولوب غيرنى ترك اتكك }
$$

Ends (p. 280):

$$
\text { معتبر [اعتبار اولنمش و باقلمش و مقبول] ماهله [ غافل اولمق و ترك ايلمك شهوله }
$$


Bound in brown leather; glazed white and beige paper; $1+284+11$ pages; $198 \times 143 \mathrm{~mm}$ and $160 \times 100 \mathrm{~mm}$, varying; 9 lines; catchwords; div āni ; headings and rubrics in red up to p. 129; copied around 1102 (1690-1691, cf. above); without the name of a copyist.

Catalogue entry CCOBARS 196 (p. 247).

Acad. 92

Turkish dialogues with French translations.

The mid-18th-century anonymous copy was made by Stephan Schultz (see under MS Acad. 77, above) of Grammaire turque, ou méthode courte \& facile pour apprendre la langue turque etc. by Father Jean-Baptiste Holdermann S.J., published by İbrāhīm Müteferriḳa in Istanbul in 1730. It covers Septiéme Parti des Dialogues, pp. 144-194, of that edition. The transcriptions in Latin script of the Turkish found in the printed edition were omitted. The 'title page' contains the Latin title Viginti Dialogi Turcice et Gallice, and the inscription of J. Willmet, with the year 1773 and the number 36 . (See also under MS Acad. 82, above.)

Bound in boards with flap; white paper folded in four columns; $2+78+2$ pages; $208 \times 150 \mathrm{~mm} ; 14$ lines; catchwords; inexpert nesih; without date and the name of a copyist.

Begins (p. 1):

Dialogues

اولكى oكا

صباح وقتنده زيارت ايتمك ايهون

Ends (p. 78):

Que vous êtes heureux de vous bien porter Catalogue entry: CCOBARS 193 (p. 245). 
Acad. 95

\section{Turkish Dialogues}

A collection of dialogues copied by Stephan Schultz (see under MS Acad. 77, above) and based on the transcribed texts found in Johannes Christianus Clodius, Grammatica Turcica ... difficultates illustrans, ac aliquot colloquiis et sententiis Turcicis aucta (Leipzig 1729), pp. 107-167. The dialogues were written by Jacob Nagy de Harsani (Harsányi Nagy Jakab, 1615 - after 1677, Hungarian orientalist and diplomat), as is mentioned in the Praefatio and on the 'title page' of the manuscript. According to information on the same page, where also the title Dialogi quatuor Turcici, longiores occurs, Schultz made the work in Cairo in 1753. The text in Arabic script contains occasional notes in Greek and Latin script. The Latin translations of the original were omitted.

The inscription of J. Willmet, with the year 1773 and the number 42 is found on the 'title page'.

Bound in boards with flap; white paper folded in two columns; $4+73+5$ pages; $218 \times 150 \mathrm{~mm}$ and $180 \times 70 \mathrm{~mm}$, varying; text in the left column only; 14 lines; catchwords; inexpert nesih (see also above).

Begins (p. 1):

$$
\text { صباحكز خير اولسون يا صباح الخير V. }
$$

Ends (p. 73):

سيلردن وقوف حظ ايدرم مايفه نك ملتك خوينى طبعتلرنى بعض عادتلرنى و اعتقاد نه اوزره در كوره لوم بويله

Catalogue entry: CCOBARS 192 (pp. 244-245).

Acad. 96

Türkçe tekellümāt

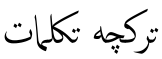

The early 18 th-century volume contains two copies of an anonymous collection of dialogues, the first (pp. 1-64) in neshi script, the second (pp. 68-125) in divanni. Both texts contain three sections. The title is found in headings preceding the texts on pp. 1 and 68. A table with letters and lettercombinations in divān $\bar{\imath}$ script is found on pp. $65^{-67}$. Glosses in, mostly, transcribed Turkish and Italian are found in the margins of pp. 2-9. Calculations in Western numbers are found on the first 'title page'. 
A Latin title in capitals (Dialogi Turcici) and in the hand of Johannes Heyman (1667-1737), Protestant minister of the Dutch community at Izmir and later professor of Oriental languages at Leiden University (cf. Volume II, Introduction to Chapter 1), is found on the (unnumbered) first 'title page'. The verso-side of the same page contains the inscription Dialoghi Turcheschi. Sm[irna $1 / 2$ [17]02. The inscriptions Dialogi Turcici Longiores and Geminum Exemplar; alterum, pagg. 64 literis Turcicis vulgaribus, alterum scribendi charactere Diwanico exaratum. The manuscript is of the same format as Leiden, UB Codices Or. 1289, 1591 and 14.456, all from Heyman's library and copied by, probably, the same copyist at Izmir. (See also MSS Acad. 76 and 80 , above.) The inscription 'J. Willmet' with the year 1780 and the number 67 occurs on the inner front-board. Before him the manuscript had belonged to the Leiden Orientalist Jan Jacob Schultens (1716-1778), whose library was sold at a public auction in 1780 (cf. Volume I, Introduction to Chapter 5.)

Bound in boards; glazed white, beige and pale green paper; $2+125+1$ folios; $136 \times 92 \mathrm{~mm}$ and $105 \times 70 \mathrm{~mm}$, varying; 5 lines; without catchwords; vowelled nesih (pp. 1-64) and dìvānī (pp. 65-125); headings, rubrics and circles in red; copied in Izmir in 1702 (cf. above); without the name of a copyist.

Begins (pp. 1, 68):

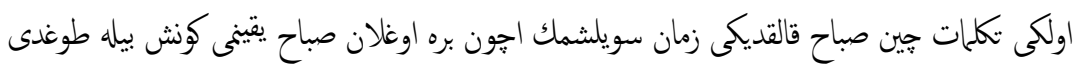

Ends (pp. 63-64, 125):

$$
\text { ـ.... و تلفظله ياردم اولور هان يك جالشوب تقيد اتمك كركدر }
$$

Catalogue entry: CCOBARS 191 (pp. 244).

Acad. 97

A miscellany

A collection of papers which had belonged to Stephan Schultz and Abert Friedrich Woltersdorf (see the Introduction to this chapter). It was acquired by Joannes Willmet in 1773 .

(1) A quire (four folded sheets) containing a copy of a letter of appointment (berāt) copied by Schultz (for another copy see MS Acad. 205, pp. 2-5, below). It concerned the renewed appointment of Mehmed Mehmed Kāàìzâde to a position accompanied by an income of 15 akçe daily from the 
gümrük mukătáa'ası at Istanbul after the accession of Sultan [Ahmed III], dated 22 Cemāzī l-āhir 1115 (2 November 1703). Lines in imitation of dìvānì are alternated by those in nesih. (For another copy, see Acad. 205, pp. 8, 10-14, below.)

(2) A folded sheet of glazed white paper containing a letter from a father 'Alī Başe to his son, Meḥmed Çelebi, mütevellì at Mağnisa (Manisa); mention is made of a trial by which he had been led before a judge with five to ten witnesses; he urges his son to write him, dated 16 Şa $b a \bar{n} n 1165$ (29 June 1752). The addressee is mentioned on the verso-side. Divanni with golddust. (For another copy of the text, see MS Acad. 205, pp. 47-48).

(3) A quire (6 folded sheets), containing a fragment from a book of wonders describing strange birds of Africa (ff. $1 \mathrm{a}-\mathrm{b}$ ), with marginal glosses in German, followed (ff. $1 \mathrm{~b}-3 \mathrm{~b}$ ) by a copy of a fermān issued on request of the Swedish envoy and addressed to the $k \bar{a} \dot{z} \bar{i} s$ and other dignitaries of Izmir, Aleppo, Jerusalem, Sidon, Jaffa, Alexandria, Cairo, Tripoli (Syria) and, Nicosia, urging them to grant a free passage to Schultz and Woltersdorf and their two servants, dated the middle of Rebïü l-evvel 1166 (16-25 January 1753), in the handwriting of Woltersdorf; it is followed by two aphorisms with Latin translations (4a). Two folded sheets with a copy of the aforementioned fermān, in the handwriting of Schultz. Two sheets of paper with a Latin translation of the same document, in the handwriting of Woltersdorf.

(4) A folded sheet containing a draft letter (one page) in Turkish from Woltersdorf informing an unknown addressee that they ('we', meant are Schultz and Woltersdorf) had arrived in Izmir safe and sound after a journey of eight days. The ship had been stopped by the customs officer at Bogazhị̦ārı for a full day. He thanked the addressee for his hospitality in Istanbul. They had given the letters to Rydelius Agha (the Swedish consul Rydel) and informed Palm Çelebi about what he had told them.

(5) A sheet of paper with a copy of a Turkish letter in the handwriting of Woltersdorf from Sellem, ser-kātib of the Swedish legation at Istanbul, to a friend (dostum), clearly Woltersdorf himself at Izmir (his name and the town are mentioned on the verso side), thanking him for his letter informing him that he had arrived safe and sound in Izmir, and expresses his warm feelings of friendship for him. He begs him to convey many greetings to Schultz and other friends, dated first days of Şa ${ }^{c} b \bar{a} n$ (3-12 June) 1753. 
(6) A folded sheet with a German letter from Petrus Nensén, pastor of the Swedish legation at Istanbul, to Woltersdorf Candidat Theologie at Izmir, dated 9 June 1753, received in Aleppo on 10 December and answered on the 16th. Nensén is glad to hear that the Candidate (Woltersdorf) has safely arrived in Izmir "and that our co-religionists show you love and friendship". Nensén expects that other Christians, too, for whom Woltersdorf has letters of recommendation, will do the same. May God give him strength so that he may reap the fruit of his work in this country (Turkey) as well as in Christendom ... A folded sheet containing a French letter from Sellém, at Istanbul, to Woltersdorf; sender is happy to know that he was in Aleppo and staying with the Dutch consul, and conveys greetings to Schultz; Nensén had been appointed pastor at the French church in Stockholm, dated 20 December 1753 (received 4 January 1754, replied on the 16th) - the letter also contains a note by Nensén, reminding Wolterdorf that Schultz was to send him attar of roses (oleum rosarum), with greetings for the consul Hahnwinkel (Hendrik Haanwinckel, Dutch consul at Aleppo, 1752-1753).

(7) A sheet containing a Latin letter, discussing common relations, from T.H. Callenberg - his father had been too busy-at Halle to Woltersdorf, dated 24 May 1753, received 11 November; the letter is followed by a postscript with a quotation from the Bible by his father (J.H. Callenberg, 16941760 , see the introduction to this chapter). A folded sheet with a draft response in Latin from Woltersdorf with pious advice to Callenberg junior; he also informs him that he and his companion were on the point of travelling from Aleppo through Syria.

(8) A folded sheet, containing a German letter from Gröning, Swedish consul at Alexandria, to Woltersdorf at Cairo, dated 12 August 1753; addressee thanks sender for his letter of the 31st and is glad that he had arrived safely in Cairo. The Count is still there; the reason cannot be guessed. Apparently Mr. Curet must be pressed to act as travelling companion ...

(9) A folded sheet containing an Italian letter from Francis Brown, viceconsul at Alexandria, to Woltersdorf at Cairo, dated 5 August 1753 (received 10/11 August), in response to his letter of the 31st.

(10) A folded sheet containg draft letters in Italian and French from Wolterdorf, dated, respectively, 31 July and 3 August 1753 . The first reported on his (their) departure from Alexandria and safe arrival (by boat) in Rosetta (Rāshid), where they had been received by Messrs. Eraud and Matthieu. 
A few days later they moved in the company of Mr. de Croix to Cairo, where they stayed with Mr. Hocker (an English physician), and later with the addressee who had made their journey possible. The second, addressed to Eraud, reported on their arrival in Cairo, thanks to Mr. de Croix, because their accompanying Janissary had not been able to understand a word of Italian or Turkish. He also thanked him for his hospitality. A folded sheet with a letter in French from Eraud, at Rosetta, to Woltersdorf, dated 7 September 1753 , in response to a letter of the 3 rd. The letter includes a copy of a bill of lading for a cargo of black linen and a coach for Mr. Francis Browne at Alexandria.

(11) A sheet containing a draft letter in Italian from Woltersdorf, undated, in request of a letter of recommendation and ${ }_{125}$ Piastres for his journey to Rhodes and Stanchio (Kos); he hopes to see addressee again in Seydiköy (the verso-side contains drawings and copies of Latin and Greek inscriptions.) A sheet with another draft letter in Italian from Woltersdorf, undated, informing the same addressee that he had arrived after a journey from Cairo, and thanks him for his recommendation to Mr. Coccolini; the money was not enough to pay for the journey to Alexandretta (İskenderun), but he (they) had received 50 Piastres from Coccolini. A sheet with two draft letters in French, the first informing Eraud that the cargo of linen had arrived and that he had paid Mr. Didier 408 medins for it, thanking him for the commission; they would return by way of Damietta; the second, dated 18 July 1753, informing an addressee that they had arrived in Alexandria on 18 June, but had been unable to leave the ship because of plague; they thank him for his recommendation for [Captain] Vougasso. A folded sheet with, on the outside a draft letter in Italian, on the inside another draft in German, both by Woltersdorf; the first informs the addressee that he had caught a cold on returning from the pyramids, thanking him for making the journey possible, and asking him for money in Jerusalem, to be made available through the Jesuit fathers. In the German draft, addressed to his friend and esteemed patron, Woltersdorf reports that after having left addressee, he had gone from Venice to Izmir and Istanbul, and from there via Izmir to Alexandria and Cairo, where he is now but intends to go to Aleppo; he thanks him for his hospitality shown in Trieste. On the right page, there is a list with questions, later crossed out, regarding the quarantine in Trieste, the passage of persons and goods there, especially of some Arabic and Greek books for personal use, and freight waggons from Trieste to Nuremberg or Augsburg. A smaller folded sheet with a German draft is included; it reponds to the aforementioned questions; it informs Woltersdorf that passengers' 
effects can pass freely through the quarantine in Trieste and advises to write to [Johann Frederik] Mann, Dutch consul at Izmir (Mann, in fact, was chancellor at the Dutch Consulate in Izmir betwen $175^{2}$ and 1774 -a letter (in German) from Schultz (in Halle) to him, dated 22 January 1766, is found in NA, Consulaat Smyrna 1685-1811, No. 518). A sheet with a draft letter in German by Woltersdorf at Aleppo, dated 28 December 1753, addressed at a friend and patron. Sender heard that he had not received his letters from Egypt. In case they still have not arrived, he reports that they cashed 100 piastres in Cairo from Mr. Larkiani, drawing on Messrs. Cohen \& Fratelli, and that they cashed $5^{o}$ Piastres in Cairo, drawing on Mr. Ferro, Venetian consul, for which they issued receipts.

(12) A folded sheet with two draft letters of thanks by Woltersdorf, dated, respectively, 6 December and 6 June 1753; the first informing addressee that they had arrived in Aleppo. A folded sheet with a letter in French from Louis Longy, consul at İskenderun, to Wolterdorf, dated 4 January 1754, in response to his letter of 6 December.

(13) A small collection of Greek, Arabic and Turkish letters and notes addressed to, one sent by, Louis Longy (Hōca Louis). Among the papers with a Turkish text, we find (a) a note from el-Hāāccī Yūsuf to Longy with a request to send him white stationary; (b) a piece of paper with an inscription and seal impression of Hayrullāh b. 'Alī, with the year 1151/1738-1739; (c) a note from el-Hâcc Yūsuf to Longy at İskenderun with a request to send him 29 guruş and a watch (address and seal, with the name Yūsuf 'Ārifi, occur on the verso-side); (d) another note from the same to the same concerning a mission of his servant Muștafā Beg to Longy (address and seal on the back-side); (e) a note from el-Ḥācc İbrāhīm to 'Oșmān Ag̉a concerning a shipment of rice (address, a seal, and an adminstrative note occur on the verso-side); and a note from Mehmed 'Abbās to Longy, informing him that the ordered goods have been bought and dispatched; costs were five giruş minus a quarter (a seal impression and calculations in Western script occur on the back).

Catalogue entry: CCOBARS 255 (pp. 293-296). 
Acad. 140

A miscellany

The undated volume contains two texts, copied by one copyist. The inscription 'J. Willmet' with the year 1780 and the number 22 occurs on p. 1. Before him, the manuscript had belonged to the Leiden Orientalist Jan Jacob Schultens (1716-1778), whose library was sold at a public auction in 1780 (cf. Volume I, Introduction to Chapter 5.) A list of the prophets and their life-time, with an additional note on the appearances of Jabrā'ill before the Prophet, is found on p. 141.

(1) pp. 2-126

\section{Şerḥ-i dībāce-i Gülistān}

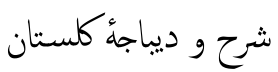

An incomplete copy of a commentary on the introduction to Sa'dì's Gulistān by Maḥmūd b. 'Oșmān, who wrote under the pen-name of Lāmi'î̀ (d. 938/ 1532). The work was completed in 910/1504. It is preceded by a lengthy introduction (pp. 2-12). The introduction to the Gulistān is mentioned on p. 6:11, the commentator in p. 8:4. A part of the introduction seems to be missing: the catchword on p. 8 does not suit the following text (on the Persian language) on p. 9. The commentary proper begins on p. 12 after a besmele. Interlinear and marginal additions.

Begins (p. 2, after a besmele):

$$
\text { يا من تعالى عن ثناء الخلاق جناب قدسك لا احصى ثناء عليك ... }
$$

Ends (p. 126);

دباب هشتم در اداب صحبت يعنى سكزنجى باب ... حوالت با خدا كرديم و رفنيم سنى خدايله اصمرلدق

Catalogue entries: see Alpay's article, p. 80; see also Götz I, 620; TYTK (Ali Nihat Tarlan) 385 .

Literature: Günay Kut Alpay, "Lāmi'ī Chelebi and his Works", in JNES 35/2 (1976), pp. 73-93; B.H. Flemming, "Lāmi'î", in $E I^{2}$.

(2) pp. 126-141

An anonymous treatise on Persian grammar, without title. It is preceded by a brief intoroduction, and consists of a prologue (mukaddime) and two 
chapters $(b \bar{a} b)$. Rubrics are omitted from p. 127 onwards. A few marginal additions.

Begins (p. 126):

$$
\begin{aligned}
& \text { ايا محبوب القلوب يسر الله لك المطلوب بو كتاب بر مقدمه و ايكى باب اوزرينه مرتبدر اما مقدمه لغت }
\end{aligned}
$$

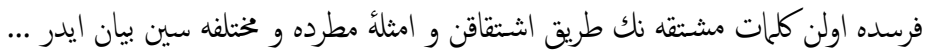

Ends (141):

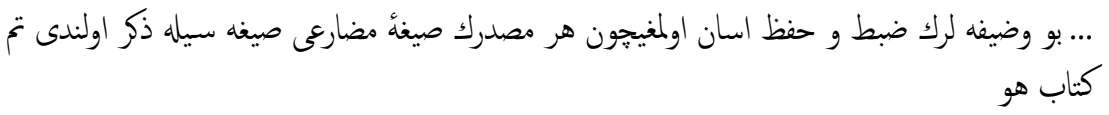

Bound in embossed dark brown leather with blind tooled insets on the outer covers; glazed white paper with watermarks (anchor); 142 pages; $210 \times 155 \mathrm{~mm}$ and $145 \times 95 \mathrm{~mm}$, varying; 13 lines; catchwords; nesih; red lines marking quotations; without a date and the name of a copyist; an owner's inscription of Mehmed b. 'Alī is found on p. 1.

Catalogue entries: CCOBARS 203 (pp. 251-252).

Acad. 142

Turkish annotations

The manuscript contains a copy of Sa'dì's Bustān. According to the colophon on f. 171b, the copy was completed by Ahmmad b. Muștafā b. Yūsuf on a Monday in the middle of Şevvāl 950 (6-15 January 1544). The inscription 'J. Willmet' with the year 1780 and the number 62 occurs on the first flyleaf, verso. Before him, the manuscript had belonged to the Leiden Orientalist Jan Jacob Schultens (1716-1778), whose library was sold at a public auction in 1780 (cf. Volume I, Introduction to Chapter 5.)

The endpapers contain annotations in various hands in Arabic, Persian and Turkish. Among the latter, we find lexical glosses, verse fragments attributed to Meḥmed Paşa (1a), a g azel by Ḥamdī (1b), a prose fragment (partly illegible) and seal impressions (2a), a series of fifteen numbered amorous quatrains devoted to boys; a list of the names precedes the poems (173a).

Catalogue entry: CCOBARS 168 (p. 220). 
Acad. 147

\section{Turkish glosses}

The manuscript contains an undated copy of the famous Pand-nāma attributed to Farīd ad-Dīn 'Ațțār (d. after 586/109o, cf. B. Reinert in Encyclopaedia Iranica). Numerous marginal and interlinear glosses, partly in Turkish and occasionally attributed to Şem 'i 1 (d. after 1012/1603-1604), in the early part of the work. Owner's inscriptions, partly torn off, of Mușțafā b. Aḥmed, dated 1058 (1648), and lost one with the year 1093 (1682), occur on f. 1a; a quotation in siyâkat script with the signature of Hüseyn and containing the years 1115 (1703-1704) and $1116(1704-1705)$ is found on the same page. The inscription J. Willmet with the year 1773 and the number 49 occur on the first flyleaf, recto.

Catalogue entry: CCOBARS 167 (pp. 219-220).

Acad. 149

Turkish verses

The manuscript contains a copy of the Persian Dīwān of Ṭālib Âmulī (d. 1036/1626-1627), cf. Munibur Rahman, in $E I^{2}$. According to a colophon on f. 165, the copy was completed by al-Hājj Mușțafā b. Mollā Riḍ̂ān alBaghdādī, a resident of Aleppo, on 13 Şevvāl 1070 (22 June 166o). The endpapers contain some Turkish verses: a gazel and four fragments (1a), two fragments (165a), a gazel, a quatrain and five fragments $(165 \mathrm{~b})$, all 'by the writer' (li-muharririh $\vec{\imath})$. The inscription J. Willmet with the year 1773 occurs on $\mathrm{f}$. 1a; the number 56 is found on the inner front-board.

Catalogue entry: CCOBARS 175 (pp. 224-225).

Acad. 151

An administrative note and a distich in Turkish.

The manuscript contains a copy of the Persian Dīwān of Saqqā (d. 962/15541555). According to the colophon on f. 92a, the copy was completed by Hajji Muhammad Samarqandī at Damascus in 979 (1571-1572). The inscription 'J. Willmet' with the year 1780 occurs on the first flyleaf, verso. The number 64 is found on the inner front-board. Before him, the manuscript had belonged to the Leiden orientalist Jan Jacob Schultens (1716-1778), whose library was sold at a public auction in 1780 (cf. Volume I, Introduction to Chapter 5.) 
A partly erased fragment of an adminisrative note and a distich, both in Turkish, are found on f. 1 .

Catalogue entry: CCOBARS 173 (p. 223).

Acad. 152

\section{Bahrel-ma'ārif}

A mid 17th-century copy of a compendium of prosody written in Șafer $95^{6}$ (March 1549, cf. p. 287:11) by Muṣlihüddīn Mușțafā b. Şacbān who used the pen-name of Sürūrī (d. 969/1562, cf. Ömer Faruk Akün in İA, Edith G. Ambros, "Surūrī", in $E I^{2}$ ). The title is mentioned in p. 2:14 and on the 'title page'. The work is preceded by an introduction (pp. 1-2) - the author introduces himself in p. 1:10-and explains that it was written for Prince Muștafā, son of Sultan Süleymān the Magnificent (mentioned in p. 2:2), whose teacher ( $h \bar{o} c a$ ) he was between $955 / 1548$ and $960 / 1553$. It is followed by a preface (mukaddime), three treatises (makāle), and a conclusion (hätime, p. 276), which contain an exhaustive treatment of Ottoman prosody ('arüi) , rhyme, and rhetoric elements, illustrated, sometimes in the form of diagrams, with quotations from Arabic, Persian and Turkish poetry, among them verses composed by the author. A few marginal additions in the hand of the copyist. (For other copies see Leiden, UB Codices Or. 451(1) and 2082(1).)

The endpapers contain various notes and text fragments in various hands, mostly in Turkish: chronograms by Mevlānā İsḥak with the year 933 (1526-1527), two gazel, and a müfred (first flyleaf, verso); a price of 250 and a $k \iota t^{\prime} a$ in praise of the main work, preceded by an introduction (second flyleaf, recto); various aphorisms, an ebced table, and a talismanic diagram (p. 298); a gurrenāme preceded by a brief introduction, and followed by a list of week-days in a Slavic language. The legend 'J. Willmet' with the year 1800 and the number 96 occurs on the first flyleaf, recto. The manuscript was bought by Willmet at a public auction in Middelburg and had belonged to the library of J.J. de Bruin, and before him, to that of Jacob Willemsen, professor of Theology at Amsterdam (1698-1780), whose manuscripts had been sold at a public auction in Leiden in 1781 (cf. CCOBARS, p. xi). Willemsen had bought the manuscript from the orientalist Adrianus Reland (1676-1718), who, in turn, had acquired it from the private collection of Jacob Golius (1596-1667, cf. Catalogue 1696, 54, p. 19)-an inscription of the former with an indication of the provenance (ex Bibliotheca J. Golii) is found on the same page. It is accompanied by 
an extensive description of the contents of the main work in Latin (9 lines).

Bound in embossed, dark brown leather with blind tooled insets in Oriental style; glazed white paper; $3+289$ pages; $203 \times 142 \mathrm{~mm}$ and $150 \times 85 \mathrm{~mm}$, varying; 19 lines; catchwords; calligraphic ta līk; rubrics, lines and dots in red; completed by 'Abdulkerīm b. Nu'mān on a Monday in early Ṣafer 1053 (21-30 April 1643).

Begins (pp. 1, 2, after a besmele):

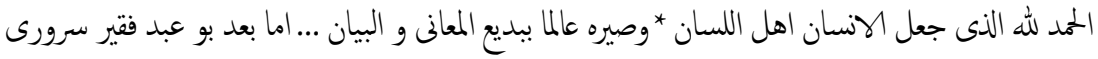

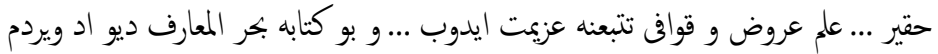

Ends (p. 287):

$$
\text { بو دعايه هر كه آمين ديرسه صدق قلب ايله * جاننه اولسون سلامتلر محصل والسلام }
$$

Author's colophon (ibidem):

$$
\text { تم تأليف الكناب فى اليوم الحادى عشر من صفر المظفر سنة ست و خمسين و تسعائه : }
$$

Colophon (ibidem):

$$
\begin{aligned}
& \text { قد وقع الفراغ من تخرير هذه النسخة الشريفة و المجموعة اللطيفة فى اليوم الاثنين من شهر اوائل صفر المظفر }
\end{aligned}
$$

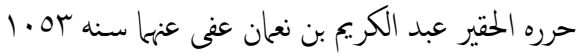

$$
\begin{aligned}
& \text { يازان كشى نه كونده و نه ايده و نه يلده يازرسه اكاكوره تاريخن ياز يه }
\end{aligned}
$$

Catalogue entries: CCOBARS 194 (pp. 245-246); see also Götz I, 284-286, where other MSS are mentioned, and Fihris 257-263; TYTK (Süleymaniye, Ali Nihat Tarlan) 170; TYTK (Süleymaniye, Mustafa Âşir Efendi), 969.

Literature: cf. Götz I, p. 193.

Acad. 153

Tuhfe-i Fedāȳ

تحفة فدايى

An undated copy of a rare rhymed Arabic-Turkish dictionary by Mehmed Fedāyī. The title is found in a heading preceding the text on p. 1 and in p. 5:6. The name of the author occurs in p. 2:5. The colophon (p. 37), dated 1044 (1634-1635), suggests that the copy was made by the author himself, but the 'title page' mentions the name of a copyist (cf. below). According to the introduction (pp. 1-5), the work was written in imitation of the popular 
Tuhfe-i Şāhidī. Here the author also explains that he was born in 'Ayntab (Gaziantep) but later settled in Tripoli (Ṭrablūs) where he was a teacher. The work consists of fifteen sections $\left(k \iota t^{\prime} a\right)$, a conclusion (hätime), and a final section explaining the numerical value of the letters of the alphabet (hisāa-i ebced); it ends in a chronogram (ḳoduñ dehre Fedāyì Tuhfe a la $\bar{a}=$ 1044). Pious sentences in Arabic and various jottings occur on the 'title page'. The inscription J. Willmet with the year 1773 and the number 18 is found on the inner front-board.

Bound on boards with dark brown leather backing; glazed white paper; 1+ 37 pages; $207 \times 155 \mathrm{~mm}$ and $160 \times 95 \mathrm{~mm}$, varying; 9-18 lines; catchwords; irregular nesih; headings, author's colophon, فعل patterns, scansion marks and triple dots in red; copied by Ḥasan Çelebi b. el-Hāàcc Ḥüseyn b. el-Ḥācc 'Abdulḳādir el-Çelebi; without a date (see also above); illegible owner's seals are found in the margin of p. 9; an owner's inscription of Abū Mikhāyīl b. Balāzmūz b. Jurjī Kharrāj [?] occurs on the inner back-board.

Begins (pp. 1, 2, after a besmele):

$$
\begin{aligned}
& \text { حمد اول الله كم يرتدى جهان * ادمى قلدى آكرمى اعيان } \\
& \text { [ ... ] } \\
& \text { بعده بن فقير و بيجاره *مبتلا غريب و آواره }
\end{aligned}
$$

Ends (p. 37):

$$
\text { بو مصراعك حروفك صاى سرابا * قودك دهره فدايى تحفه اعلا }
$$

Author's colophon (ibidem):

$$
\text { في سنه الف اربعه و اربعين *كان اختتام على يد الفدايى }
$$

Copyist's addition (ibidem):

$$
\begin{aligned}
& \text { وصلى الله على سيدنا محمد و على اله و صحبه و سلم تسليا كثيرا امين } \\
& \text { بونى يازدم يادكار اولماغيون *اوقيانلر بر دعا قل ماغيون } \\
& \text { ججله اوزره يزلمشدر قصورينه *نظر بيورلميه و المحد لله وحد [؟] }
\end{aligned}
$$

Catalogue entries: CCOBARS 187 (pp. 240-241); Pertsch (Berlin) 72. 
Acad. 154

Hā̄yrīye

خيريه

A mid 18th-century copy of popular didactic poem in mesnevī rhyme by Yūsuf Nābī (d. 1124/1712), addressed to his son Ebūlhayr. The title and the name of the author appear on the 'title page'. The work consists of an introduction (pp. 1-6) and a number of chapters, 'each devoted to the inculcation of some virtue or the reprehension of some vice or folly' (HOP III, p. 333). For a detailed description of the contents, see, ibidem, pp. 332-335. (For other copies of the same text, see Leiden, UB Codices Or. 25.724 and 25.758(1).) The inscription J. Willmet with the year 1773 is found on the 'title page'; the number 17 occurs on the inner front-board.

Bound in boards covered in pink paper with flap, with brown leather back and edges; glazed white paper; $1+119+2$ pages; $220 \times 160 \mathrm{~mm}$ and $175 \times 110$ mm, varying; 13 lines; catchwords; irregular nesih ; completed on 28 Zīl-hicce 1154 (6 March 1742).

Begins (p. 1, after a besmele):

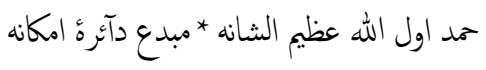

Ends (p. 119):

$$
\text { جون ابو الخير قونلدى نامك * خير ايده حضرة حق انجامك }
$$

Colophon (ibidem):

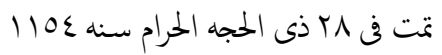

Catalogue entries: CCOBARS 206 (pp. 253-254); see also Götz I, 195-198, and Sohrweide I, 294-296, where other MSS are mentioned; see also Fihris 1046-1055 (II, 18-20); KIYK 77; Schmidt G 1757, P 895(2); Şeşen II 263-264; Kut 249-252; Sarajevo 2637, 2722, 2724-2726, 2897; TYTK (Antalya) 2040; TYTK (Süleymaniye, Mustafa Âşir Efendi) 1025; Yardım3544-3545.

Editions: Istanbul 1307; Mahmut Kaplan, Hayriyye-i Nâbî. Inceleme, metin (Diss. Ankara 1990)

Translation: into French, by M. Pavet de Corteille (Paris 1857).

Literature: cf. Götz I, p. 133; Mine Mengi, “Osmanlı imperatoluğu'nun gerileme devrini belgeleyen bir edebi eser: Nabi’nin Hariyye'si”, in 1o. Türk Tarih 
Kongresi (Ankara 1986), p. 182; Abdülkadir Karahan, Nâbî (Ankara 1987); E.G. Ambros in $E I^{2}$.

Acad. 156

Şāh u ged̄a

شاه وكدا

An undated copy of a popular narrative poem in mesnevı̄ rhyme by Yahyā Beg Dukakinzāde (d. after 982/1574-1575). Headings have been omitted; the poet's name is found in some gazel which punctuate the work. The poem is the first part of a quintet (Hāmse) dedicated to Sultan Süleymān the Magnificent. The story of 'the King and the Beggar' is preceded by lengthy introductory sections, among them in praise of the early Caliphs (in tercī-i bend form), Sultan Süleyman, Istanbul, the Aya Sofya Mosque, the Hippodrome (At meydānı) and the city's beloved ones (maḩbūblar). A detailed description of the contents is found in HOP III, pp. 112-115 and 368-370. (For other copies, see Leiden, UB Codices Or. 3047 and 10.851.) The endpapers contain a great number of additional texts in various hands: songs by, among others, Hālim amd Muhibbī (first three flyleaves); gazels by Bāḳi and Muhibbi are found on the third flyleaf, recto; a gazel and fragments by Siyāhī (margins of pp. 119-120, partly lost by trimming); a gazel by Meşāmī; distichs attributed to İbn-i Kemāl, Ḳyāsī, Șun'ī, Siyāhī and Emrī (p. 121); fragments by Șun'ī, Emrī (with a nażire by Hayālī) and Tācirī (p. 122); fragments by Fiḡānī, Himmetī and Siyāhī, and perhaps others (p. 123); a song (?) by ḥüsnā(p. 124); and a song by Yahyā (inner back-board). The heading 10 Poëta Turcicus Anonymus e Biblioth. Letteana is found on p. 135. (see for the Dutch pastor Gerardus Johannes Lette (1724-1760), a student of Albert Schultens, NNWB X, col. 515); the inscription J. Willmet with the year 1804 and the number 196 is found on the inner front-board. The manuscript had earlier belonged to the private library of Jacob Golius (1596-1667).

Bound in embosed dark brown leather with blind tooled insets in Oriental style; glazed cream paper with only partly visible watermarks; $5+135$ pages; $172 \times 105 \mathrm{~mm}$ and $122 \times 58 \mathrm{~mm} ; 17$ lines; catchwords; small ta'lik ; double red borders, within black lines on pp. 1-2; without a date and the name of a copyist.

Begins (p. 1):

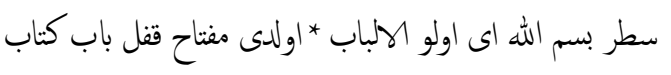


Ends (p. 120):

$$
\text { عين عفو كله اول بزه ناظر * سوزيمز بودر اول و آخر }
$$

Catalogue entries: CCOBARS 205 (p. 153); see also Flemming 426 and Sohrweide II, 252, where other MSS are mentioned; Fihris 2927-2930 (IV, pp.1-2); Sarajevo 2861(5); Schmidt 92; Şeşen II, 279/1; TYTK (Adana), 2530; TYTK (Süleymaniye, Ali Nihad Tarlan), 279, 301; Yardım 3537.

Edition: Istanbul 1284 .

Literature: Mehmed Çavuşoğlu in $\dot{I} A$.

Acad. 178

A miscellany

A collection of texts in Arabic and Turkish copied by one copyist in, here and there, most careless nesih. The copyist İlyās b. Hüseyn who worked in Algiers in 1017/1608 is mentioned in a colophon on p. 266. An incomplete fragment, later crossed out, describing a colloquy between the Prophet and Fātima is found on the first seven unnumbered pages (cf. Leiden, UB Codices Or. 14.556(8) and 17.133(3).) The inscription 'J. Willmet' with the year 1780 and the number 44, together with the title of (1), occurs on the first flyleaf, recto. Before him, the manuscript had belonged to the Leiden Orientalist Jan Jacob Schultens (1716-1778), whose library was sold at a public auction in 1780 (cf. Volume I, Introduction to Chapter 5.)

(1) pp. 1-266

\section{Daḳāyiḳül-ahbār}

دقايق الهخبار

A copy of a collection of traditions (hadìth) by Kạàzì 'Abdurrahīm b. Aḥmed or Ebū 'Abdullāh Meḥmed b. Selāmetülḳużā'ì. The title is mentioned in the heading preceding the text on p. 1. The last chapter, from p. 26o, is devoted to the dwellers of Paradise (ehlü l-cenne). A few marginal corrections and additions. See for a description and further data under MS Acad. 42(2), above.

Begins (p. 1, after a besmele):

$$
\text { الله تعالى [بو عالم يرتمدن] بر العالمين و العاقبة للمتقين و لا عدوان اله على الهى الظالمين اما [بعد] خبرده شويله كلمشدر كه }
$$


Ends (p. 266):

حضرت عليه السلام ايتدى جنت اهلى يدوكلرى و ايهدوكلرى مسك فقوسندن يكرك اوله صدق رسول الله

Colophon (ibidem):

قد وقع الفراغى من تمى [؟] هذا الكتاب الشريفه امدى عزز من بو قدالرى يزدقكه اول آكى جهان سرورى

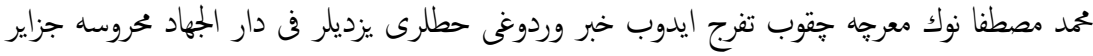

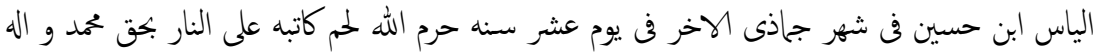

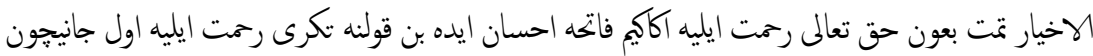
فاتحه احسان ايده يازانيجون بون تئن

(2) pp. 267-340

An anonymous treatise without title on the principles of the Islamic faith in the form of a series of questions and answers, and (from p. 281 onwards) on prayers and praying. A few marginal corrections and additions.

Begins (p. 267, after a besmele):

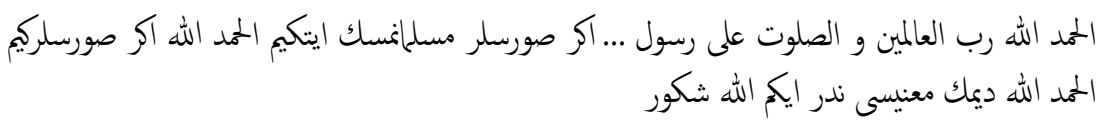

Ends (p. 340):

اول تسبيح بودر استغفرالله العظيم الذى لا اله الا هو ... اغفرلى و لوالدى ... و المسلمين و المسلمات

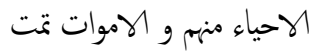

(3) pp. 341-359

An incomplete copy of an Arabic collection of, by intention, forty statements by the Prophet (hadìth), each section of which commences qäla $n$ nabì.

(4) pp. 360-370

A copy of an anonymous treatise without title on praying; it ends with a separate section on a statement (hadith) on praying attributed to Uns b. Mālik (from p. 368). 
Begins (p. 360):

باب صلوت قضاء القوة ييغمبر حضرت ع ايتدى هر كيم نمازى قضايه قلمش اولسه نه دكلو ايدوكين بلمسه : جمعه نامزندن صكره درت ركقت نامز قلسه فئ...

Ends (370):

$$
\text { اول آيت بودر قل انما اذا بشر مثلكم ... فليعمل عملا صالحا و لا يشرك بعبادت ربه احدا }
$$

Rebound in boards with a flap; partly glazed white paper; $(2)+7+371+(2)$ pages; $197 \times 145 \mathrm{~mm}$ and $140 \times 115 \mathrm{~mm}$, varying; 12 ; catchwords, omitted in some parts; irregular vowelled nesih; headings, rubrics, dots and lines occasionally in red; (1) completed by İlyās b. Hüseyn in Algiers on 20 Cemāz̄ l-ähir 1017 (1 October 16o8); illegible owner's seals are found on pp. 370-371.

Catalogue entry: CCOBARS 215 (pp. 262-263).

Acad. 179

Tuhfetül-'`āşıkīn

تحفة العاشقين

An undated copy of a work on the qualities and pilgimage ceremonies of Mecca, Medina, Jerusalem and Hebron by shaykh Meḥmed el-Yemenī. The title is found in p. 4:6; the name of the author is mentioned in p. 1:12. The more general title Feżäill-i Mekke ve l-Medine ve l-Kuds ve l-Halïl, also found in the introdution (cf. quotation, below), precedes the text on p. 1 and is copied on the 'title page' with the Latin explanation Descriptio Meccae, Medinae, Hierosolymorum et Hebronis et virorum illustrium qui in illis in. claruerunt auctore Scheich Mohammed Jemanensi. The inscription J. Willmet with the year 1773 is found on the same page; the number 20 occurs on the inner front-board. The work consists of an introduction in Arabic and Turkish, and fifteen chapters $(b \bar{a} b)$; p. 89 has mostly remained blank. (For another copy of this work, see Leiden, UB Cod.Or. 23.654.)

Various notes in Arabic are found on the inner front-board and the 'title page', among them by a reader called İbrāhīm, who wrote in 975 (1567-1568), and another reader called Süleymān el-'Ārif (p. 159); an incomplete prayer text in Arabic is found on p. 160.

Bound in boards with a flap; white paper without watermarks; $1+161$ pages; $212 \times 155 \mathrm{~mm}$ and $190 \times 125 \mathrm{~mm}$, varying; 16 lines; catchwords; irregular vowelled nesih; rubrics in red; copied by 'Alī in Jerusalem (according to his 
owner's inscriptions on the inner front-board and the 'title page'); other inscriptions of Ahmed and 'Alī Cān are found on, respectively, the 'title page' and p. 159; the latter's seal impressions occur on the same page and p. 161 as well as, occasionally, in the margins of the text.

Begins (p. 1, after a besmele):

الممد لله الى جعل الكعبة البيت الحرام قياما للناس ... و بعد هذا فضائل مكة و المدينة و القدس و الخليل

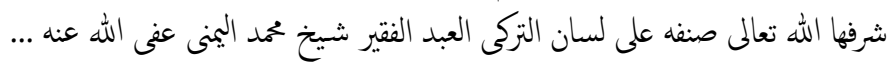

Ends (p. 159):

اول بيغمبرلر روحيجون اللرى و اهل بيتلرى روحيجون و بوكتابك مصنف روحيجون مراد حاصل

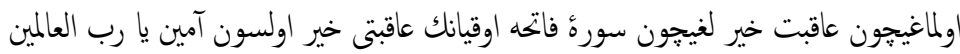

Colophon (ibidem):

$$
\text { تمت بعون الله كتبه الفقير على سلمه الله تعلى }
$$

Catalogue entries: CCOBARS 207 (p. 254); Blochet A.F. 133-134, S. 51; Fihris 3695-3696 (III, pp. 198-199); Rossi Borg. Turco 22; TYTK (Çankırı) 455; see also $G O W$, p. $121 n$.

Literature: 'OM III, pp. 172-173; GOW, p. 120 .

Acad. 182

\section{Subhatu l-ahbār}

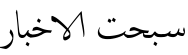

An undated copy of a historical pedigree, originally designed by Yusuf $b$. 'Abdullațîf for Sultan Süleymān the Magnificent who flourished during the first half of the 16th century. It was updated afterwards. The title is found in p. 1:18; the author is mentioned in p. 1:10-11. The pedigree is preceded by an introduction $(1 \mathrm{~b}-2 \mathrm{a})$ and a survey of the dynasties which had ruled, or still were ruling, the world, arranged according to tabaka, from the (preIslamic) Dādīyān to the 'Oșmānīyān (2a-3a). In the following pedigree, the historical personalities, ranging from Adam to Sultan Murād [III, ruled 982/1574-1003/1595] (34b), with an addition in a different hand to Ahmed [III, ruled 1115/1703-1143/1730], are figuring in coloured circles and connected with red, and in the end, black lines. The pedigree is accompanied by brief introductions to each tabaka and commentaries in Turkish and, occasionally, Latin. Annotations in Latin, Greek and in Arabic script on the pre-Islamic Persian dynasties occur on the inner front-board. (For a draft translation into Latin by Golius, see Leiden, UB Cod.Or. 3080.) 
The work was copied and designed by Shahin Kandi, an Armenian copyist who worked for the University Library and Jacob Golius in Leiden between 1656 and 1668 (see under Amsterdam, UB Hs. VI H 2, above). The manuscript was later bought by Adrianus Reland (1676-1718) who added a long Latin title on f. 1a (GENEALOGIA ab Adamo usque ad sultan Morad ab Josepho Ibn Abdollatif ex Persico in Turcicum sermonem translata ...) in which he also declares to have bought the manuscript at the auction at Leiden in 1696, when Golius's private manuscripts were put up for sale (cf. Catalogue 1696, 8, p. 24; a second copy, possibly the original, is described under 9). A catalogue clipping (but not from the 1696 sale) is pasted onto the same page. Reland is probably also responsible for the Latin glosses and the last updating of the pedigree (34b-36a). The legend 'J. Willmet' with the year 1800 and the number 95 occurs on the third flyleaf, verso. The manuscript was bought by Willmet at a public auction in Middelburg and had belonged to the library ofJ.J. de Bruin, and before him, to that of Jacob Willemsen, professor of Theology at Amsterdam (1698-1780), whose manuscripts had been sold at a public auction in Leiden in 1781 (cf. CCOBARS, p. xi). Willemsen, in turn, had acquired the manuscript from Reland.

Bound in vellum; the back is decorated with flower motifs in Western style; white paper; $3+36+1$ folios; $232 \times 175 \mathrm{~mm}$; calligraphic nesih; red lines; varicoloured and, often, multiple circles in red and varying shades of yellow; without a date and the name of a copyist (but cf. above).

Begins (p. 1):

$$
\begin{aligned}
& \text { حمد بيحد و ثناء بـ عد اول حكيم قديم و عليم كريمه كه بموجب خمرت طينت آدم بيدى ... اما بعد بو }
\end{aligned}
$$

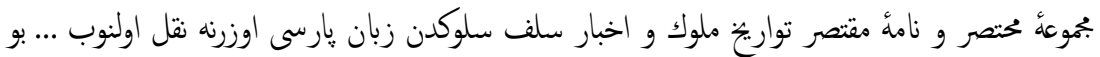

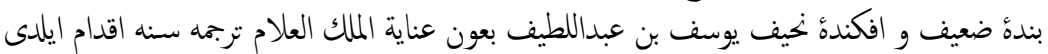

Catalogue entries: CCOBARS 208 (pp. 254-256); Flemming 14-15, where other MSS are mentioned; see also Fihris $2824-2825$ (II, pp. 318-319); Schmidt 140.

Literature: cf. Flemming pp. 11-12; see also Jan Schmidt, review of Kurt Holter, ed., Rosenkranz der Weltgeschichte Subhat al-Ahbār; Volständige Wiedergabe im Originalformat von Codex Vindobonensis A.F. 50 (Vienna 1981), in Manuscripts of the Middle East 2 (1987), pp. 152-154. 
Acad. 183

Kırān el-Habeşī [ḥikāyeti]

$$
\text { قران الحبشى [حكايتى] }
$$

An undated copy of the second volume of an anonymous translation of the (Persian) romance of Ḳrān el-Habeşī, slave of the Persian ruler Kubād, in prose and verse by Abū Ṭāhir Mūsā Ṭarțūsī, made for the Akkoyunly prince, Uzun Hasan (ruled 857/1453-882/1478). The title is found in a heading preceding the text on p. 2; the name of the author is found in the introductory remarks to most chapters. Chapter headings, which are omitted in some parts, are in Persian. The last chapter heading reads (p. 461):

$$
\text { خود عروسى كردن شاه قباد از براى فرزندان }
$$

Some blanks in the text have been filled in by a different copyist writing in an irregular şikeste. For a detailed description of the contents, see Rieu, pp. 219-222.

Jottings in Arabic, Turkish and Latin in various hands occur on the first flyleaf, recto. The inscription 'J. Willmet' with the year 1780 is found on the same page; the number 30 on the inner front-board. Before him, the manuscript had belonged to the Leiden orientalist Jan Jacob Schultens (1716-1778), whose library was sold at a public auction in 1780 (cf. Volume I, Introduction to Chapter 5), and to Jacob Golius (1596-1667), cf. Catalogue 1696, 64 (p. 14, where the word hikāyet is added to the title).

Bound in embossed black leather; partly glazed cream to white paper of varying quality, partly worn and mended afterwards; the title is written on the bottom edge; $3+464$ pages; $241 \times 160 \mathrm{~mm}$ and $200 \times 120 \mathrm{~mm}$, varying; 15-20 lines; catchwords, partly lost by trimming; vowelled nesih, of, mostly, calligrafic quality; headings, rubrics, lines and dots in red; without a date or the name of a copyist; an owner's inscription of Harşdār [?] Hüseyn occurs on the firts flyleaf, recto.

Heading (p. 2):

$$
\text { المجلد الثانى من كتاب المرسوم بقران الحبشى تجاوز عنه }
$$

Begins (ibidem):

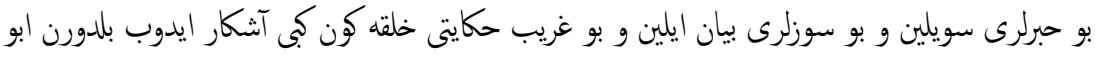

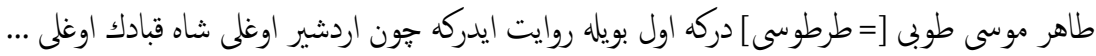
Ends (p. 464):

$$
\text { يكى جون رود ديكر آيد بجاى * بجانرا نماند بى كد خذاى }
$$


Catalogue entries: CCOBARS 204 (p. 252); Blochet A.F. 335-337, S. 447; Karatay 2819-2821; Rieu, pp. 219-222; Tornberg 117.

Acad. 197

\section{'Ahdnāme-i hümāyūn}

عهلنامة هـايون

An original copy of the renewed capitulations granted by Sultan Murād IV (ruled 1032/1623-1049/1640) to the Dutch Republic in 1634. The document, which misses the opening sentences and a tugra, is dated the first days of Rebïü l-ähir 1043 (14-23 October 1634), at Istanbul. The copy is authenticated by the $k \bar{a} \bar{z} \bar{\imath}$ of Istanbul, Bālī b. 'Alì, in the top right margin (with two seals). The original copy is found in the National Archive (SG 12593-47). (For a copy in the handwriting of Shahin Kandi, an Armenian copyist who worked for the University Library and Jacob Golius in Leiden between ${ }_{1656}$ and 1668 (see under Amsterdam, UB Hs. VI H 2, above), is found in Leiden, UB Cod.Or. 3083.)

J. Willmet, to whom the document belonged, bought the manuscript when the library of D.A. Walraven (1779-1804), professor of Oriental languages in Amsterdam, was put up for sale. He, in turned, had acquired it from Jacob Willemsen, professor of Theology at Amsterdam (1698-1780). Before him, the document had belonged to the orientalist Adrianus Reland (1676-1718).

Glazed cream paper; $1300 \times 500 \mathrm{~mm}$ and $1120 \times 380 \mathrm{~mm} ; 105$ lines; calligraphic nesih.

Catalogue entry: CCOBARS 195 (pp. 246-247).

Edition and translation (of the original capitulations of 1612): De Groot's study, pp. 231-26o.

Literature: A.H. de Groot, The Ottoman Empire and the Dutch Republic; A History of the Earliest Diplomatic Relations 1610-1630 (leiden 1978), pp. 206, 329.

Acad. 204

A collection of papers with annotations on (folded) sheets of glazed and unglazed white paper in various formats by Albert Friedrich Woltersdorf (see the introduction to this chapter). These include calligraphic exercises 
of various types of script, including dìvānì. Text fragments in German, Italian, Armenian, (transcribed) Turkish (including a complete letter) and Arabic; draft glossaries, mostly Arabic-Italian/German. Notes on Arabic grammer in a different hand. Probably acquired by Joannes Willmet in 1773.

Catalogue entry: CCOBARS 222 (pp. 268-269).

Acad. 205

\section{A collection of letters}

The collection was compiled and copied by Albert Friedrich Woltersdorf (see the Introduction to this chapter). The inscription Turcica Varia sive Miscellanea collecta ab Alberto Friderico Woltersdorffio/Istanbul 1753 is found on the 'title page'. That of J. Willmet, with the year 1773 and the number $40^{* * * *}$, is found on the same page.

pp. 1-5. A copy of a letter of appointment (berāt), dated 1115/1703. (For another copy and a description of the contents, see MS Acad. 97(1), above). The right pages contain the text in neshi script with an interlinear translation in Latin, the left pages a version in inexpert dìvānì.

pp. 6-9. Two copies of the same letter with some variations in the text, of the same format. (Another copy is found on p. 40, below)

pp. 8, 10-14. A berāt, confirming the renewed appointment of Mehmed Meḥmed Ḳāżizāde to a position accompanied by an income of ${ }_{15}$ akçe daily from the gümrük mukāta'ası at Istanbul after, mistakenly, the income had been suspended and given to others: Ḥasan İbrāhīm, Ken'ān 'Abdullāh and (1 a kç̧e) to the treasury, on the grounds that he had died, dated 18 Cemāzi $\bar{\imath}$ l-ähir 1107 (24 January 1696). Text in nesih with interlinear Latin translation; left pages have been left blank. (For another copy, see Acad. 97(1), above.)

pp. 14-22. A declaration from the sultan ('ilämet-i şeriffe) in response to a complaint from the inhabitants of a village, dated mid-Muharrem1126 (27 January-5 February 1714). Text in nesih, left pages have been left blank.

pp. 22-26. A letter from Ḥāccī Beşīr Ag̉a at Istanbul to an unnamed efendi, probably a local $k \bar{a} \bar{z} \dot{\imath}$, concerning the appointment of Hüseyn Ag̀a as mütevellī of the evkāa of the late Karamānogilı İbrāhīm at Konya from 1 March 1129 (1717). Text in nesih, left pages have been left blank. 
pp. 26-32. A fermān (berāt) addressed to Mehmed, formerly ḳāż̀ of Kütahya, appointing him to the każās of Sofia and Lefkoşa (Nicosia), dated midCemāż̃ l-evvel 1125 (5-14 June 1713) at Edirne. Text in nesih; pages 27, 29 and 31 have been left blank.

pp. 32-34. A letter of recommendation on behalf of Shaykh Muștafā Efendi, from the muteșarrıf el-Hāācc Süleymān, undated.

pp. 34-37. A letter from Muștafā, ser-țopçı of the Palace, to Mehmed Ag̉a who is with the army commander (serdār) at Bender [Tighina, in Moldavia], concerning the despatch of salaries worth 8,970.5 guruş and 18 para, dated 27 Muharrem $115^{2}$ (6 May 1739).

pp. 37-38. An informal note, inquiring after the health of an unnamed addressee and his brother, undated.

p. 39. An anecdote figuring Nāṣruddīn Hōoca. Begins:

$$
\text { ناصره دين خواجه نك بر كون دعواسى دو شر محكم دن بر ججت المق اقتضا ايدر }
$$

p. 40. A letter of appointment, similar to pp. 6-9, above.

pp. 40-41. A letter of appointment, assigning an income of 15 a kçe from the mukāța'a of Şema'hāne in Istanbul to Mehmed upon the death of his father Mevlānā Mehmed, formerly ḳăż̀ of Begpazarı (Beypazarı), dated 14 Muharrem 1060 (17 January 1650).

pp. 41-42. A letter of appointment, transferring the source of income of 15 akçe from the aforementioned fief to that of the mukāta $a$ of the customs at Istanbul, dated 20 Ramażān 1093 (22 September 1682).

pp. 42-43. A letter of appointment, confirming that of pp. 40-41, above, dated $21 \underline{Z i}$ l-ḳa'de 1087 (25 January 1677).

p. 43. A preamble to a letter.

pp. 43-44. A temessük (Eine Quittung) concerning a debt of 100 ġuruş owed to Ḥasan Ag̀a, followed by a Latin translation.

pp. 44-45. A letter conveying greetings for the gümrük eminni İsḥak Ag̀a, undated. 
pp. 45-46. A petition requesting the Porte to take measures to enforce the payment of a debt of 800 guruş owed by the Greek dragoman Yanaki, undated, followed by a partial Latin translation.

pp. 47-48. A letter from a father 'Alī Başeto his son, Meḥmed Çelebi, mütevelli at Maginisa(Manisa); for the original, see Acad. 97(2), above, followed by a Latin translation.

Bound in boards with flap; white paper; $207 \times 150 \mathrm{~mm}$. See also above.

Catalogue entry: CCOBARS 201 (p. 250).

Acad. 209

A collection of calligraphic exercises

The volume contains specimens in bold dīvānì script, clearly phrases from a letter, repeated two to eight times per page by, probably, Albert Friedrich Woltersdorf (see the Introduction to this chapter). The manuscript had belonged to Stephan Schultz and Albert Friedrich Woltersdorf and was acquired by Joannes Willmet in 1773. The inscription 'J. Willmet' with this year and the number $40^{\circ}$ is found on the first flyleaf, recto. The exercises are preceded om p. 1 by a recipe for lustrous black ink in Arabic.

Bound on boards with flap; glazed white paper; $2+1+25$ pages; $227 \times 165 \mathrm{~mm}$; $n e s i h$ (p. 1) and bold dìvānì (see also above).

Acad. 210

A collection of (fragments of) (model) letters

The collection was compiled and copied by Albert Friedrich Woltersdorf (see the Introduction to this chapter) in, alternating per line, dìvāni and neshi scripts. The manuscript had belonged to Stephan Schultz and Albert Friedrich Woltersdorf and was acquired by Joannes Willmet in 1773. The inscription 'J. Willmet' with this year and the number $40^{* * *}$ is found on the first flyleaf, recto. The collection contains the following items:

pp. 1-4. A series of preliminary phrases found in, mostly, petitions. 
pp. 4-7. A letter from the voyvoda Süleymān to a 'brother' concerning the delivery of a set of copper vessels and a stirrup for $120 \dot{g} u r u s ̧$, with a signature of the sender.

pp. 7-10. A letter from the same to a cizyedār, confirming the receipt of certain sums of money, with a signature of the sender.

pp. 10-13. A model petition from 'Ālī, by origin an Abessynian slave, to a pasha with three tuggs sent through a Janissary officer, İbrāhīm Ag̀a, at Tokat, with a signature.

pp. 13-17. A model letter from an inferior to a superior.

pp. 18-21. A model letter from a friend to a friend, with the year 1161 (1748) and the signature of Süleymān Agga.

pp. 22-25. A model petition from a servant at Tokat addressed to a grand vizier.

pp. $25^{-28}$. A letter fom 'Ālī to a comrade, also conveying greetings from his mother, with a signature and dated 1161 (1748).

pp. 29-30. A model petition from an inhabitant of Tokat, complaining about the non-payment of a debt of 1500 guruş owed to him, addressed to a pasha.

pp. 30-31. A promissory note (temessük) concerning a debt of 1114 guruş, dated 1161 (1748) and signed by 'Alī.

pp. 31-33. A promissory note (temessük) concerning a debt of 1500 guruş, incurred by way of a bill of exchange (poliçe) at the Vezīr Hān in Istanbul, dated 1161 (1748) and signed by Mușțafā.

pp. 33-34. A tesmessük documenting the contribution of 1500 guruş each by two business partners to their joint capital, dated 1161 (1748) and signed by 'Alī.

pp. 34-35. A model statement (temessük) by which business partners declare each other free from debt $(i b r \bar{a})$, signed by 'Ālī. 
pp. 35-36. A receipt (temessük) for 100 gurus in taxes received by the mutașarriffrom an agent who had levied the money from his ze'ämet, dated 1161 (1748) and signed by 'Âlì.

pp. 37-38. A title-deed (temessük) by which land, part of a timār held by the mutașarrıf 'A $\bar{l} \overline{1}$, was transferred to another villager, with signature, dated 1161 (1748).

pp. 38-39. A model letter of manumission ('itıknāme), signed by 'Ālì.

pp. 39-40. A title-deed (temessük) documenting the tranfer of the lease of a property, part of the evkāaf of Ahı Paşa at Tokat, dated 1161 (1748).

Bound in boards with a flap; glazed white paper; $3+40+1$ pages; $227 \times 165$ $\mathrm{mm} ; 8$ vertical lines per page; dìvānī and nesih; red headings from p. 25 (cf. also above).

Acad. 211

A miscellany

The undated, incomplete volume contains a number of texts on various subjects, all related to the Islamic religion, copied by one copyist. The manuscript was bought by Willmet—his inscription with the year 1800 and the number 104 occurs on the first flyleaf, verso - at a public auction in Middelburg and had belonged to the library of J.J. de Bruin, and before him, to that of Jacob Willemsen, professor of Theology at Amsterdam (1698-1780), whose manuscripts had been sold at a public auction in Leiden in 1781 (cf. CCOBARS, p. xi). Willemsen had bought the manuscript from the orientalist Adrianus Reland (1676-1718), who, in turn, had bought it in The Hague in 1700, as is clear from a Latin inscription on the same page. A Latin (Liber Turcicus manuscriptus) and Greek title are also found there.

$$
\text { (1) ff. la-88b }
$$

A copy of a treatise, incomplete at the beginning, on the tenets of the Islamic religion, with lengthy references to hadith and anecdotes. The work is, at least partly, divided into chapters (meclis) — the third begins on $\mathrm{f}$. $34 \mathrm{~b}$. Some passages have been crossed out; marginal additions, partly in Latin. 
Begins (1a):

ضعيف لغوك و سمكين لكله بكا درلوا درلوا عبادت لر قلورسين قيامدن و ركوع سجوددن بن قدرتله بايلغمله

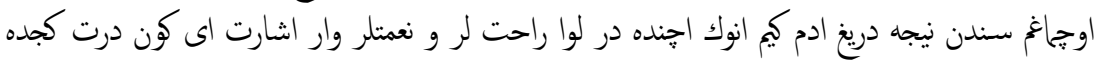
روشن اولر ....

Ends (p. 88b):

و دتى دكلمزوك كوكلنده و دلنده لا اله اله الله كلمه سن ثابت ايليه ان شاء الله تعالى امين يا رب العالمين

(2) ff. 88b-92a

A brief account and assessment of the religious meaning of the story of the Prophet Idrīs (cf. G. Vajda, in $E I^{2}$ ).

Begins (88b):

$$
\text { اندن صكره سى ادريس ييغامبر عليه السلام قصه سن بيان ادر }
$$

Ends (92a):

$$
\text { قلدم يكم ادريس دكلى خلقدن اكدن اوجياغه كره نتكم بيان قلدق و الله اعلم بالصواب و به نستعين. }
$$

(3) ff. 92b-100b

A brief account and assessment of the religious meaning of the story of 'the Prophet' Circīs (St. George, cf. B. Carra de Vaux in EI).

Begins (92b):

$$
\text { بوندن صكره جرجيس بيغامبر عليه السلام قضيه سن بيان ادر }
$$

Ends (100b):

اول كافرلر دكلى هلاك اولدلر مؤمنلر دكلى قرتلدى سكا كركم يونسلردن عبرت الاسن و الله اعلم بالصواب

(4) ff. 10la-124b

Hikāyāt min 'Acāyibi l-mahlūḳāt

حكايات من جعايب المخلوقات

A fragment from (a Turkish version of), allegedly, the popular cosmography by al-Qazwīnī (d. 682/1283, cf. GAL I, p. 481). It contains accounts about the prophets Adam, Dāvud and, most extensively, Mūsā, through whom God explains the principles of the Islamic religion. Some passages have been crossed out, particularly on f. 10gb. 
Begins (101a):

$$
\text { عجايب المخلوقات كتابنده كتركيم ادم ييغامبر عليه السلام تربسى سرنديل طاغنده در }
$$

Ends (124b):

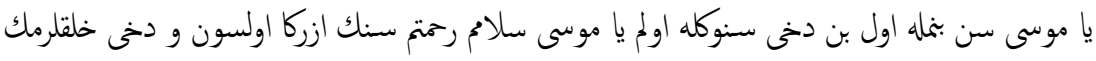

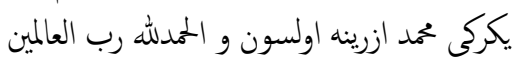

(5) ff. 124b-14la

A series of pious anecdotes (lațîfe), partly on the life of Yūsuf, and concerning matters of faith. A work entitled Sab'iya $\bar{a} t$ is mentioned as a source in the first line.

Begins (124b):

$$
\text { لطيفه سبعيات كتابنده كتزمش كيم مؤمنلر يارن قيامت امنا و صدقنا اوهاقيوست كلالر }
$$

Ends (141a):

$$
\text { سن سك زوال يوق بتون سكا جلب كيم بكا هر كيز مثال يوق و الله اعلم بالصواب و اليه المآب }
$$

Copyist's addition (ibidem):

يا الهى يازنى دكلاينى اقويانى سن ارر مقصودنه اى حق غنى هر كه ديلر رحت حق قازنه بر فاتحه اده

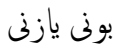

(6) ff. 14la-142b

An account, based on the authority of Ka $\mathrm{b}$ al-Ahbār, of a colloquy between the Prophet Sulaymān, the crane and other birds, incomplete at the end.

Begins (141a, after a besmele):

كب الاخبار ايدر سليمان بيغامبر قتنده عليه السلام طرناوتدى اى خلق هى بلورمسز بو طرنه اوتيجك نه در

Ends (142b):

طوطى ايدركه بنم ربم جميعى عيبلردن منزهدر بتموز ايدركه اللهى اكك اى غافللر [قرينا]

Rebound in boards with flap; glazed cream paper without watermarks; $(1)+142+(1)$ folios; $207 \times 145 \mathrm{~mm}$ and $160 \times 100 \mathrm{~mm}$, varying; 13 lines; catchwords; vowelled nesih; headings, rubrics and, occasioanlly, quotations in red; without a date and the name of a copyist. 
Catalogue entry: CCOBARS 217 (pp. 264-265).

Acad. 212

A treatise on religion and mysticism

The treatise found in the undated copy was written by, probably, Ālihì (آلكى), whose mahlas occurs in a number of poems in the text (e.g. pp. 3:1 and 96:2). No title is mentioned in the manuscript. The treatise lacks a formal structure, commences with an introductory part which changes, in one and the same poem, to Turkish (2:2), and contains a great number of verses of the mesnevi and $\dot{g} a z e l$ format as well as quotations in Arabic and Persian with additional Turkish commentary. Among the more unusual themes found in the work, there is a lengthy diatribe, mostly in the form of a mesnevi, against the use of tobacco (cf. pp. 94-96). The last pages, 122-123, contain a great number of jottings in Arabic in various hands. A few marginal and interlinear additions.

The inscription J. Willmet with the year 1804 and the number 183 occurs on the 'title page'. Willmet bought the manuscript when the library of D.A. Walraven (1779-1804), professor of Oriental languages in Amsterdam, was put up for sale.

Rebound in boards with flap; glazed cream paper without watermarks; $(2)+1+123+(2)$ pages; $198 \times 145 \mathrm{~mm}$ and $170 \times 105 \mathrm{~mm}$, varying; 13 lines; catchwords; partly vowelled nesih; rubrics, lines and triple dots in red; red borders on pp. 19-48; without a date and the name of a copyist.

Begins (pp. 1, 2, after a besmele):

$$
\begin{aligned}
& \text { الممد الله رب العالمين الرحن الرحيم مالك يوم الدين ... آلم ذلك الكناب لا ريب فيه هدى للمتقين الذين يؤمنون } \\
& \text { بالغيب و يقيمون ... ياز ددى يزدى قلم اسرارنى *اندى روح اشباحه كور آثارنى مابن }
\end{aligned}
$$

Ends (p. 121):

$$
\begin{aligned}
& \text { عدل و دادن هب كورر انس و يرى *طراق اولمق استر اول كافر جرى* } \\
& \text { عرش و رضوان استين دين سرورى * بونده هم انده اوله غمدن برى * } \\
& \text { فرقانده يوم نحشر المثقين الى الرحمن و فد وارد اولدى }
\end{aligned}
$$

Catalogue entry: CCOBARS 218 (p. 266). 
Acad. 222

Two vocabularies

The, seemingly, original text of the manuscript consists of a Persian-TurkishArabic-Aramaic vocabulary, possibly in the handwriting of Albert Friedrich Woltersdorf (see the Introduction to this chapter), in four columns on adjacent (verso-recto) pages. The Aramaic is written in Mandaic script (cf. for the alphabet and further data: Peter T. Daniels \& William Bright eds., The World's Writing Systems (New York \& Oxford 1996), pp. 511-514). Most of the Arabic words are preceded by an Italian equivalent in a different handwriting and written in German cursive script. There is no conspicuous order.

Begins (1b-2a):

$$
\text { كرفت دوتردى [accipere] اخذ }
$$

It ends (182b-183a):

$$
\text { بسيار بار جوق كزز [=كه؟؟ ... دفعات كثيره ... }
$$

An Italian-Turkish glossary in two columns and in a smaller script was added between the original columns of Turkish and Arabic, and (from 178b) Persian and Turkish words on each verso-page from ff. $182 \mathrm{~b}$ to $5^{2} \mathrm{~b}$. The Italian is again written in German cursive script. The glossary is arranged according to the alphabetical order of the Italian words, beginning (182b): abachista حسابح, and ending (52b): zuppa تريد,

The inscription J. Willmet with the year 1804 and the number 182 occurs on the 'title page' (1a). Willmet bought the manuscript when the library of D.A. Walraven (1779-1804), professor of Oriental languages in Amsterdam, was put up for sale. The MS at some time seems to have been lent to Prof. [H.C.] Millies [1810-1868] in Utrecht (see also Leiden, UB Or. 1940); a note added to the MS states that the Glossarium Sabicum-Arabicum was sent to Prof. P. de Jong in Leiden by the widow of Millies in December 1868. Included is also an envelope with small file cards containing lexical items transcribed from the text, probably made by Millies.

Rebound dark brown embossed leather with flap and insets in Oriental style; glazed cream paper with only partially visible watermarks; half of f. 2 has been cut off; moisture damage towards the end; $(1)+183$ folios; $210 \times 155 \mathrm{~mm}$; 16 lines (original text); without catchwords; partly vowelled nesih in two different hands; without a date and name of a copyist.

Catalogue entries: CCOBARS 44 (pp. 91-92); Voorhoeve, p. $5^{8}$ (No. 31). 


\section{LEIDEN, UNIVERSITEITSBIBLIOTHEEK \\ (UNIVERSITY LIBRARY), LEGATUM WARNERIANUM: ADDENDA}

During the years of cataloguing for the present publication, some Turkish texts, found in manuscripts preserved in the core collection of the Leiden University Library, the Legatum Warnerianum, named after the bequest made by Levinus Warner in 1665 (see Vol. I, Chapter 3) and described in the first three volumes of this catalogue, were overlooked and have only subsequently come to light thanks to the tireless industry of Jan Just Witkam and Hans van de Velde. They are described in this chapter. It may well be that more Turkish text fragments will be discovered in the future when more time will have been dedicated to further cataloguing of the Arabic and Persian manuscripts of the collection.

This chapter also contains descriptions of two collections acquired after Volume 3 of this catalogue had been concluded. These comprise, firstly, a collection of nine manuscripts, Codices Or. 26.264-272, donated by Barbara Flemming, professor of Turkish at Leiden University between 1976 and 1997, on 11 April 2003. (For a biography, see Jan Schmidt, ed., Essays in Honour of Barbara Flemming I (Journal of Turkish Studies 26/I, 2002), pp. xi-xiii). The manuscripts had their origin in Istanbul and Damascus. Another small collection of manuscripts which had formerly belonged to Robert Anhegger (1911-2001) as well as his scholarly archive came to the library later in the same year. A second and third installment of the archive followed in 2003 and 2008. Anhegger was a (self-taught) Turkologist and teacher of German, born in Vienna, who lived most of his life in Turkey, particularly from 1940 onwards-after various studies at universities in Zurich, Vienna and Berlin, he first travelled there in the autumn of 1935; he taught German at the School for Foreign Languages of Istanbul University between 1945 and 1957, and was director of the German Institute for Culture from 1957. In 1968 he was appointed director of the Goethe Institut in Istanbul and Amsterdam. He returned to Istanbul in 1973. (For a succinct biography, see Haymatloz. Exil un der Türkei 1933-1945 (Schriftenreie des Vereins Aktives Museum 8), Berlin 2000, pp. 52-53. A more detailed account of Anhegger's life and legacy is Jan Schmidt, 'Robert Anhegger and his Bequest in the Leiden University Library', forthcoming.) 
Cod.Or. 211

\section{Turkish text fragments}

The manuscript contains a copy of an Arabic work on rhetoric, Talkhīs al-Miftāh. by 'Abd ar-Raḥmān al-Qazwīnī Khațīb Dimashq (d. 739/1338), an abridgement of the third book of the Miftăh al-ulūm by Yūsuf b. Abū Bakr as-Saḳāḳ̄ (d. 626/1229), cf. GAL I, p. 294; Voorhoeve, pp. 210-211. The manuscript was copied by Muhammad b. Mas'ūd b. Aḥmad in 762 (136o-1361), see colophon on f. 88b. Some notes in Turkish are found on the endpapers: a note: Șarıķ̧ı der maḳām-i İbrāhìm is found on the first flyleaf, recto; four Turkish lines, perhaps part of a poem or a recipe, and partly lost, occur on f. 1a. The MS is part of the Golius collection, described in Vol. 1, Chapter 1.

\section{Cod.Or. 836}

\section{Turkish interlinear glosses}

This manuscript contains an undated copy of an anonymous Arabic-Persian dictionary without title, arranged in alphabetical order, cf. CCO 161 (I, pp. 90-91). The dictionary proper is preceded by an introduction in Persian $(1 \mathrm{~b}-2 \mathrm{a})$. The first two pages $(2 \mathrm{~b}-3 \mathrm{a})$ of the first chapter $(b \bar{a} b$ al-alif almaftūha) contain a few interlinear glosses in Turkish in smaller script. The MS is part of the Warner collection, described in Vol. 1, Chapter 3.

\section{Cod.Or. 854}

\section{Turkish recipes and notes}

This manuscript contains an undated copy of a Persian work on China and Central Asia, Tārīkh-i Khițāy u Khuțan, by 'Alī Akbar Khițāīì, written in 922/1516, and dedicated to Sultan Selīm I (cf. Storey I, p. 431; CCO 919, II, p. 9-for a Turkish translation, see Cod.Or. 12.365[1]). Owner's seals, with the legend Shaykh Muștafā, are found on f. 94a. A series of recipes in Turkish are found on f. 94 b, with additional notes in different hands on the same page and on the inner back-board. The MS is part of the Warner collection, described in Vol. 1, Chapter 3. 


\section{Cod.Or. 858}

Turkish notes and a Turkish aphorism

This manuscript contains two Arabic works, (1) a commentary by Mas'ūd b. 'Umar at-Taftāzānī (d. 792/1390) on a collection of proverbs, Nawābigh al-kalim, by Mahmūd b. 'Umar az-Zamakhsharī (d. 538/1144, cf. Voorhoeve, p. 251) and (2) another one by Dāvud b. Maḥmūd el-Kayserī (d. 751/1350) on the qașidat al-Khamrīya by Ibn Fāriḍ (632/1235, cf. Voorhoeve, p. 213), copied by two different copyists. Colophons with the dates Tuesday 24 Rebíul-evvel 1046 (26 August 1636) and Rebīu l-ähir 1036 (December 1626-January 1627) are found on pp. 128 and 169 respectively. The name of the copyist, Receb Müsteidd, occurs in the second colophon. Turkish annotations are added on p. 132: three notes on the contents and the author of $(2)$ as well as a note, followed by the number 100, on a number of books (manuscripts) committed to safety in a chest at the covered market (bezistān); and on p. 170: a rhymed aphorism on two cosmic phenomena: ḳubbe-i çarh-i lāciverd ūzere bildünüz minedür budur ḳamer/ pīr-i dehrün iki ġıdāsıdur birin ahşam yudur birini seher. The MS is part of the Warner collection, described in Vol. 1, Chapter 3 .

\section{Cod.Or. 878}

\section{A Turkish prescription}

This manuscript contains an undated, anonymous, Arabic commentary on a treatise which seeks to demonstrate the necessary existence of God, Risāla fi ithbāt al-wājib, by Muḥammad b. As'ad ad-Dawwānī (d. 907/1501), cf. GAL II, p. 217; Voorhoeve, p. 298. The work was written in Baghdad and dedicated to both Sultan Murād III (ruled 982/1574-1003/1595) and the grand vizier, [Koca] Sinān Paşa (three times in office from 988/158o, cf. $S O^{2}$ $\mathrm{V}$, p. 1512). A prescription in Turkish (6 lines) against impotence, including a talismanic formula, is found on $\mathrm{f}$. 39a. The MS is part of the Warner collection, described in Vol. 1, Chapter 3.

\section{Cod.Or. 896}

\section{A Persian-Turkish glossary}

This manuscript contains a copy of the famous Persian mesnevī, Bustān, by Sa'dī (d. 692/1292, cf. R. Davis, "Sa'dī" in $E I^{2}$ ). It was copied by Mușțafā in on 25 Rebïü l-ähir 957 (13 May 1550), cf. the colophon on f. 137b. Annotations by Levinus Warner are found in the margins (cf. the introduction to this 
chapter; $C C O 645$ [II, p. 113]). The text is followed, on f. 137b, by a brief glossary of 42 elementary Persian words, headed Kitāb-i Dānistan, with interlinear Turkish translations in red. Begins:

$$
\text { افتاب [كنش] ماه [اى] آب [صو] }
$$

The MS is part of the Warner collection, described in Vol. 1, Chapter 3.

Cod.Or. 919

Turkish verses

The manuscript contains an undated copy of an Arabic commentary, Kashf al-Wāridāt li-țālib al-kamālāt, by 'Abdullāh eș-Ṣimavī (d. 896/1490), on a work of jurisprudence, al-Wāridāt, by İbn Kaaż̇ìi Șimavna (d. 819/1416), cf. GAL S II, p. 315; Voorhoeve, p. 398. Among a number of text fragments by an owner, possibly identical with the copyist, Fażullāh b. Muștafā, whose name is mentioned on $\mathrm{f}$. 1a, there are two Turkish poems (quatrains), rhymed in gönül and '-â', repectively, both headed li-muharririh (ff. 147b and the final flyleaf, verso), and two distichs headed sirr-i cānān (last flyleaf, verso). The MS is part of the Warner collection, described in Vol. 1, Chapter 3.

\section{Cod.Or. 933}

\section{Turkish text fragments}

The manuscript contains an undated copy of an Arabic commentary, Mațāli' al-anzāar, by Maḥmūd b. 'Abd ar-Raḥmān al-Iṣfahānī (d. 749/1348), on a textbook on metaphysics, Tawāli' al-anwār min mațāli' al-anzāar, by 'Abd Allāh b. 'Umar al-Bayḍawī (d. 716/1316?), cf. GAL I, p. 418; Voorhoeve, p. 376. Turkish text fragments are found on the endpapers: a prayer prescription (13 lines, 209b), followed by a note that the text found its origin with Ḥiżīr Şāh Efendi and was related through Zahrī and and Ḥusāmzāde, and prescriptions for prayers to be said on the 1oth, 11th and 12th night of Ramażān (a heading and three brief lists, 211b). The MS is part of the Warner collection, described in Vol. 1, Chapter 3.

\section{Cod.Or. 942}

\section{Turkish texts}

The manuscript contains a collection of works by, or connected to, treatises by İsmāêl Anḳaravī (d. 1041/1631-1632), see my description in Vol. I, pp. $342-350$. It contains another three pages with Turkish texts, hitherto 
overlooked, primarily a survey of prayers to be said on the consecutive days

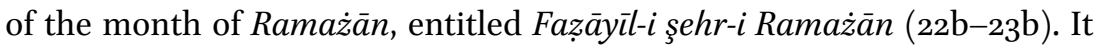
begins $(22 b)$ :

$$
\begin{aligned}
& \text { فضايل شهر رمضان اخبارده وارد اولمش و اثارده شويله كلمش دركه بر مؤمن موحد مبارك شهر رمضانك }
\end{aligned}
$$

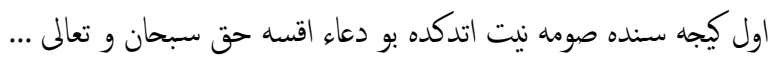

The digression is followed (on f. 23b) by a prayer (in Arabic) once said by the Prophet (4 lines); a prescription for a Friday prayer (2 lines); a prescription for curing cramp (one line); and recipes for remedies against colds and deafness ( $4 \& 2$ lines). The MS is part of the Warner collection, described in Vol. 1, Chapter 3.

\section{Cod.Or. 947}

A verse and a note in Turkish

The manuscript contains an undated copy of an Arabic encyclopaedia of sciences, Fawāìh al-miskīya fíl-fawātị̣ al-Makkīya, by 'Abdurraḥmān b. Meḥmed el-Bisțāmī of Antakya and Bursa (d. 858/1454), cf. GAL II, p. 231; Voorhoeve, p. 82. M. Smith in $E I^{2}$. The 'title page' (1a) shows various annotations, among them an owner's inscription with a seal, dated 1034 (16241625), of Muștafā b. Yūsuf, kāż̀̃ in Lesḳofça [Leskovac]; a note on the author and his work in Arabic; a kıt $a$ in Persian and Turkish in praise of the book; and a note in Turkish (5 lines), informing that the work comprises [data on] 145 different sciences ('ulüm) and that the molla had written 150 works. The MS is part of the Warner collection, described in Vol. 1, Chapter 3.

\section{Cod.Or. 954}

\section{A Turkish poem}

The manuscript contains an undated copied of an Persian mesnevī on mysticism, Asrārnāme, by Farīd ad-Dīn 'Aț̣āà (d. after 586/119o), cf. B. Reinert in Encyclopaedia Iranica; CCO 651 (II, p. 114). An incomplete Turkish müstezād (gazel with additions) rhymed in -ār görünür /-ndür is found on $\mathrm{f}$. 3 . The MS is part of the Warner collection, described in Vol. 1, Chapter 3.

\section{Cod.Or. 958}

\section{Turkish texts fragments}

The manuscript contains a great number of treatises and shorter texts in Arabic, mostly on philosophy. Among the authors are some Ottoman 
scholars: Molla Luții (d. 90o/1494, cf. 'OM II, pp. 11-12), represented with eight works; 'Abdurraḥmān b. Meḥmed el-Bisțāmī (d. 858/1454, cf. under Cod.Or. 947, above); Kemāl Paşazāde (d. 940/1533, cf. V.L. Ménage in $E I^{2}$ ), Meḥmed b. Hamza el-Fenārī (d. 834/1431) and Ḥasan Çelebi b. Meḥmed Şāh el-Fenārī (d. 886/1481). The texts were copied by a number of scribes; the volume, clearly compiled from at least three different manuscripts, contains a series of colophons, dated 925/1519 (21b, 35b, 55b), 926/1519-1520 (74b), 950/1543-1544 (302b), 953/1546-1547 (139a) and 954/1547-1548 (153b, 163a, 169b, 176b, 186b, 196b, 243b, 25ob). The name of the copyist, Hāmid b. 'Abdullāh b. Shaykh Dürūz, is mentioned on ff. 21b and 35b; he worked in the Beglerbegi medrese in Edirne (cf. f. 21b); a vakf inscription by the same, bequeathing the manuscript to his sons and grandsons, is found on f. 100a. There are some Turkish texts added in a minute şikeste hand: a prescription for reciting the sürat $\bar{A} l$ [Umrān] (2 lines) and advice on consultation (meşveret) ascribed to Ja far Şādiq (61b); a poem (müfred) on the legitimy of coffee-drinking ( 5 distichs, $86 a$ ), begins:

$$
\text { بر سوال ايلر سكا ارباب قهوه لطف ايدب *وير جواب باصواب اى مفتى عاليجناب }
$$

a prescription, headed havāṣṣ-i meşāyiḩ-i kibār, for reciting a sūrat-i tabārek for the benefit of a number of listed saints, whose names are all Ahmad, and a müfred; a distich and two medical prescriptions (88a); two distichs attributed to Necātī (100a); fetvās by [the şeyhülislām] Sacduddīn [d. 1008/ 1599] on the legality of having one's child given suck by a female slave and a digression by the same on the differing views by scholars, particularly in fetvās issued by Qāḍī Khān [d. 592/1196] (331b), followed by an anonymous letter, addressing a 'sulțān', on the same problem (332a). The MS is part of the Warner collection, described in Vol. 1, Chapter 3.

\section{Cod.Or. 977}

\section{Turkish text fragments}

The manuscript contains an undated copy of an Arabic commentary, alMüjiz al-Qānūn fì ț-ṭibb, by 'Alī b. Abì l-Ḥazm Ibn an-Nafìs (d. 687/1288), on a work on medicine, al-Qānūn fì ț-țibb, by Abū 'Alī al-Ḥusayn b. 'Abdallāh Ibn Sīnā (Avicenna, d. 428/1037), cf. GAL I, p. 493; Voorhoeve, p. 263. The endpapers contains a few Turkish text fragments; a recipe (4 lines) for a medicine, to be inhaled through the nose, is found on $\mathrm{f}$. 1a; various glosses (5 lines) in explanation of some medical terms, partly said to be of Greek origin (198a); and a quotation from a petition or a letter of appointment concerning a post of Koran reader (cüzhānn) at the Süleymānīye Mosque for 
4 akçe per day (2 lines and a tailed signature). The MS is part of the Warner collection, described in Vol. 1, Chapter 3.

\section{Cod.Or. 981}

A Turkish gloss

The manuscript contains a collection of, mostly, Arabic treatises, and a few Turkish works, see my description in Vol. I, pp. 364-369. It contains another Turkish text, hitherto overlooked, on f. $97 \mathrm{~b}$ : a gloss ( 5 lines) to an Arabic sentence quoted in the first line; it is signed by el-Hācc Üveys, kāiż at Üsküb (?). The MS is part of the Warner collection, described in Vol. 1, Chapter 3 .

\section{Cod.Or. 1025}

\section{A note and a distich in Turkish}

The manuscript contains a collection of (parts of) illustrated Arabic treatises on mathematics and astronomy, compiled from at least two different manuscripts. The dates Zī l-hicce 911 (April-May 1506, at Amasya) and end of Ramażān 829 (July-August 1426) are found in colophons on, respectively, pp. 15 and 42. The 'title page' (p. 1) contains a genealogy in red of Seyyid Mehmed - a note in Turkish, only partly legible, with the year 840 (1436-1437) and the place name of 'Ayntāb (Gaziantep) is found in the right margin. Annotations and text fragments in the handwriting of Muhammad b. 'Umar b. al-'Urḍi of Aleppo, an acquaintance of Jacob Golius and Levinus Warner, who helped them to acquire manuscripts from the Middle East (see Leiden, UB Cod.Or. 1122, Vol. 1, pp. 439-441, with plate), are found on pp. 1-3, 11 (left margin), 22, 24-25 and 26 (lower margin). The present manuscript had probably been in his possession. Among his inscriptions is a Turkish distich by Monlā Sürūri, followed by an Arabic translation (p. 9). The MS is part of the Warner collection, described in Vol. 1, Chapter 3 .

\section{Cod.Or. 1228}

\section{A letter in Turkish}

The manuscript, a miscellany, contains a collection of (numbered) original letters (mostly in Arabic and addressed or Erpenius and Golius), documents and parts taken from manuscripts. It had belonged to Johannes Heyman (1667-1737). See for more details, Vol. I, pp. 521-533. The manuscript 
contains an undated letter in Turkish, No. 35 of the miscellany, hitherto overlooked. It was sent by a certain Shaykh Cafer b. Mehmed, known as Kaàzìzāde; no addressee is mentioned. It concerns a request for the purchase of $15 \mathrm{okka}$ of pekmez (boiled grape-juice) and ten $o k k a$ of candy, at any price, to be paid for by 'Alì Çelebi. White paper, $155 \times 88 \mathrm{~mm}, 5$ lines, followed by a signature.

\section{Cod.Or. 1233}

Turkish annotations concerning the birth of sons

The manuscript contains an illustrated copy of an Arabic work on the magical use of a great number of Koran chapters, undocumented, by Abū l-'Abbās Aḥmad b. 'Alī b. Yūsuf al-Būnī al-Qurashī (d. 622/1225), cf. GAL I, p. 497, S I, p. 910; Voorhoeve, p. 374. The copy was completed by Ahmad b. 'Alī al-Anșāīi on 9 Receb 812 (17 November 1409), see colophon on p. 338. Two owner's inscriptions of Ḥāfiz Ebābekir b. el-Ḥācc Ḥasan el-Vā'ız at Bozok (Yozgat) with seals, one of which was a misprint, are found on the first original flyleaf, recto. A great many Turkish notes are found on the 'title page', almost all of them statements on the birth of sons: of Kaydāş b. Aḥmed b. Mevlānā Bahşsāş b. Luțfullāh b. Ḥāccī 'Abdullāh on 6 Żi l-ḳa'de 980 (10 March 1573) - he died on the same day, '10 March'; of Mușțafā b. Meḥmed on 22 March 982 (1575); of Fethī b. Ahmed b. Luṭullāh etc. on 27 Muharrem/8 May 983 (1575); of Ṭāhir b. Aḥmed b. Luṭfullāh etc. on 28 Ramażān 984 (9 December 1576); of Luțfullāh b. Ahmed b. Luțullāh etc. on 7 Żi l-ḥicce/17 Kānūn-i șānī 987 (January 1580); of Mes'ūd b. Mehmed b. Bayrām on 16 Cemāž l-āhir/May 996 (13 May 1588); and of Beşīr b. 'Abbās b. Aḥmed Faḳı b. Mevlānā'Aşlī (= 'Adlī?) Halīfe on 22 Zī l-ḥicce/Eylül 1000 (29 September 1592). The MS is part of the Schultens collection, described in Vol. 1 , Chapter 5 .

\section{Cod.Or. 1670, 1671}

\section{Various documents in Turkish and Dutch}

The Ottoman documents described in Vol. II, p. 207, at the time 'not available to readers', have meanwhile been recovered and put into a portfolio labeled Or. 1670. Apart from the two original documents, the letter of safeconduct (fermān of large format, headed by the tugra of Sultan Muștafā III, and the 'letter' (in fact a hüccet issued by the Molla (kāà $\bar{\imath})$ of Izmir, esSeyyid İbrāhīm eş-Şevḳi (?), upon the request of the first dragoman of the Dutch consulate, dated ${ }_{5}$ Cemãzi l-evvel 1187 / 24 August 1773; the name of the 
ship and the captain are mentioned but could not be identified), are accompanied by (draft) translations into Dutch. The portfolios also contains:

- A copybook, $245 \times 195 \mathrm{~mm}$, 11 folios, with parts of a draft transcription (in Western naskhi) and translation, partly interlinear, into French of a muhabbet-nāme (letter of friendship) from the Dey of Algiers, Hasan Paşa (in office 1791-1798), to the 'King of the Netherlands', emphasizing the need for friendship between the two nations (the Dey had declared war on the Dutch republic earlier, in January 1793; after lengthy negotiations peace was restored in 1794, cf. Gerard van Krieken, Kapers en kooplieden; de betrekkingen tussen Algiers en Nederland 1604-1830 (Amsterdam 1999), pp. 88-89); the letter was sent with the (Jewish) envoy, Miha Bū Bakrī, who should be given a letter in reply. The letter is dated mid Safer 1208 (end of September 1793). The paper cover of the copybook has a long title in Dutch:Afschrift van een Turkschen Brief, ontvangen door H.H. Hoogmogenden, op den 5 Octobr. 1793 nevens deselven Translaat in 't Hollandsch, door Ev. Scheidius. Everard Scheidius (1742-1794) was professor of Oriental languages in Harderberg (from 1765) and Leiden (from 1793).

- A letter in Dutch from the States-General in The Hague to Scheidius in Leiden (see above) with the request of a translation of an included 'official letter in Arabic' and their speedy return to The Hague; dated 8 November 1793 and signed by G.B. Emants.

\section{Cod.Or. 6292}

\section{A miscellany}

This volume, clearly used as a scrapbook, contains a great many, often brief, texts, prose and poetry, in Arabic, Persian and Turkish, and written in various hands (cf. Voorhoeve, pp. 421-422). A colophon, partly lost by trimming, with the date Thursday 10 (?) Rebíü l-ähir 1081 (27 August 1670) and the place name of Istanbul occurs in the lower margin of f. 134b. An owner's inscription of 'Abdulkāair b. el-Hācc İsmāīil with the year [1]249 (1833-1834) occurs on f. 1a. A note (in Arabic) on the birth of a daughter called Fāțima, on Sunday 22 Rebīü l-ähir 1176 (10 November 1762) is found on f. 135a. A seal with the name Hasan and the year 1155 (1742-1743) occurs on f. 136a. The 'title page' (1a) contains two Turkish text fragments: a verse from an ilāhi and four magic words with an instruction for their use, based on the authority of Shaykh Sa'duddīn el-Hamavì (9 lines). Two leaves with a description of the contents by P. Voorhoeve are included in the volume. There is one Turkish text of substantial length: 
(8) ff. $45 \mathrm{~b}-48 \mathrm{a}$

Hikāye-i 'acībe min Kuṭ̂tb es-Sürūr münādemetleri

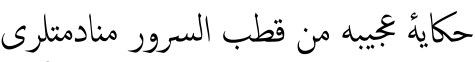

A series of anecdotes involving a number of Arab littérateurs of the 2nd/8th century, among whom Muțī‘ b. Iyās and Hakam al-Wādī, with quotations of their Arabic verses. The title is found in a heading preceding the text.

Begins (45b):

منقولدركه مشاهير ادبادن مطيع بن ايآس و يميى ابن زياد و حكم الوادى و حلاد الراويه ... متادى اولوب ... Ends (48a):

اول غلام حقنده سر كرفنه شد ديرلر يعنى باشى طوتيلوب روده كى استعال اولندى ديمكن كنايه ايدرلر

Bound in embossed dark red leather; a paper label with a title is found on the back; numbers on the bottom edge; glazed white and cream paper; 136 folios; $190 \times 118 \mathrm{~mm}$ and $(8) 170 \times 100 \mathrm{~mm}$, varying; (8) 23 lines; (8) without catchwords; small irregular nesih; see also above. Purchased from Friedrich \& Co., Cairo, through the firm of E.J. Brill, Leiden, in February 1931. (An invoice from Brill, dated 19 February 1931, is found in the volume.)

Cod.Or. 20.193

\section{Religious texts in Turkish}

The undated manuscript is a miscellany of a great many texts, mostly in Arabic, on paper and quires of varying format and written in various hands. The manuscript may have belonged to a preacher or imam. The Turkish texts are the following:

f. 2-3. A loose sheet of paper with a copy of a prayer to be said after a sermon, headed $D u^{\prime} a \bar{b} b a^{\prime} d e l-v a^{\prime} z$.

f. 3a. A sermon, headed Huṭbe-i Kürsī.

f. $3 \mathrm{~b}-4 \mathrm{a}$. A prayer, without heading.

f. 4a-b. A prayer to be said after a sermon, headed $D u^{\prime} \bar{a} b a^{\prime} d$ el-va'z (partly identical with the text found between f. 2 and f. 3 , see above).

f. 6b. A brief note in Arabic on Koranic matters, with a marginal gloss in Turkish. 
f. 28a. Five distichs in Persian, with glosses in Turkish.

f. 31-32. A loose sheet of paper with a note on tafsìr.

The manuscript was bought from E.J. Brill, booksellers, in November 1986 (and is described in their catalogue No. 55, under item 32 ).

Cod.Or. 26.264

\section{Mebhas -i ìmān}

An early 18th-century copy of a work on the principles of Islam by Hüdā'̄', whose name occurs in a number of poems found in the work (e.g. f. 7a:9). He may be identified by 'Azìz Mahmūd (d. 1038/1628), who, apart from the author of a Divān, also wrote a considerable number of Arabic and Turkish treatises, mostly on mystical subjects (cf. Hasan Kâmil Yılmaz in TDVIA), but is not known to have written this work. The title is mentioned seven times in the introductory mesnevi on the first page $(\mathrm{ib})$. The prose text, which does not show formal divisions and is alternated by a number of poems, is based on many Arabic and (seven) Turkish sources mentioned in the introduction $(4 a-5 b)$ and elsewhere. Among them - mentioned as the first in f. $4 \mathrm{~b}: 15$ - is the well-known Vaṣīyet-nāme by Birgili Mehmed Efendi. The work ends in a long series of questions (mes'ele, from f. 132a). A few marginal corrections and additions, and pencil notes by Barbara Flemming. (For another copy of the same text, see Cod.Or. 17.138.) The 'title page' (1a) contains an Arabic quotation from Ihyā al-'ulūm, followed by Arabic and Turkish jottings in a crude handwriting - these also occur on the inner front-board. The work is followed by a brief Turkish text, headed 'isḳâț-i șalātuñ beyānıdur, and probably in the hand of the copyist which is followed by some Turkish jottings.

Bound in a somewhat worn, brown leather cover with flap with blind tooled insets in Oriental style; glazed white paper; an illegible inscription is found on the bottom edge; $146+1$ folios; $215 \times 157 \mathrm{~mm}$ and $165 \times 100 \mathrm{~mm}$, varying; 15 lines; catchwords; vowelled nesih; rubrics in red; completed in 1115 (1703-1704); without the name of a copyist. Acquired from Barbara Flemming, 11 April 2003; her name and the numbers 1. and 1376, written in pencil, occur on $\mathrm{f}$. 1 a.

Begins (1b-2a, after an extended besmele): 


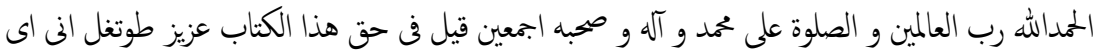

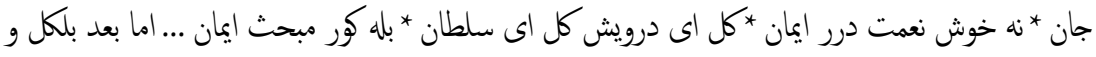

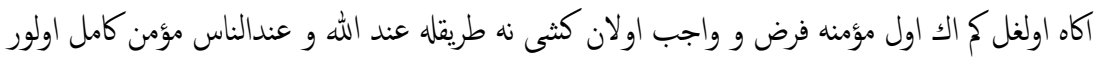
Ends (146a):

$$
\text { مسئل زيد عمرو بوزخانيه الوب كتمكه آتم اولورمى الجواب اولور ابو السعود }
$$

Colophon, with copyist's verses (ibidem):

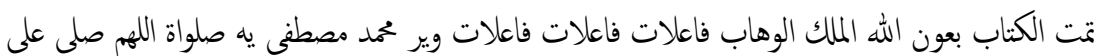

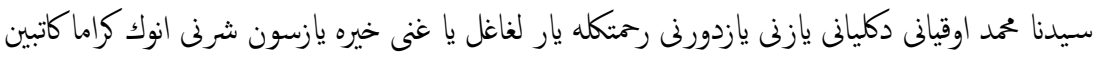

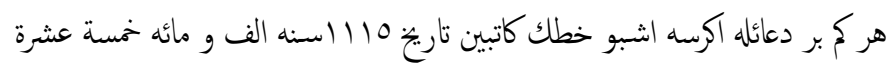

Catalogue entries: Karatay 126; TYTK (Antalya) 2778, 2779; TYTK (Isparta) 464; Yardım3259.

\section{Cod.Or. 26.265}

$D_{\bar{\imath}} \bar{a} \bar{n}$

ديوان

An undated collection of poems by Mehmed b. Süleymān who used the pen-name of Fużūlì (d. 963/1555-1556). The title, Dìvān-i Fu̇̇ūlì, is found in a title preceding the text on $\mathrm{f}$. $\mathrm{b}$. The collection only comprises the poet's gazel, 294 items, arranged in the usual Divann sequence. (For a copy of the first part of the preface, see Rotterdam, Wereldmuseum 70935, below.)

Bound in boards with dark brown leather back and edges; glazed cream paper with watermarks (bird with legend CFA); the title is written on the bottom edge; $1+70+1$ folios; $246 \times 177 \mathrm{~mm}$ and $155 \times 100 \mathrm{~mm}$, varying; 17 lines; catchwords; $r \iota k^{c} a$; title, rubrics and lines in red; without a date or name of a copyist; a seal of es-Seyyid Șālih Refik is printed over the title on f. 1 b. Acquired from Barbara Flemming, 11 April 2003.

$\operatorname{Begins}(\mathrm{lb})$ :

$$
\text { قد انار العشق للعشاق منهاج الهدا * سالك راه حقيقت عشقه ايلر اقتدا }
$$

Ends $(69 b)$ :

$$
\text { فقر و فنا سعادتى ويردك فضوليه *آنده اولن سعادت فقر و فنا حقى }
$$

Catalogue entries: Götz I, 335, and Sohrweide I, 228, where other MSS are mentioned; see also Fihris 1855-1865 (II, pp. 86-88); Karabulut 67; KIYK 56; TYTK (Antalya) 2025-2026; TYTK (Süleymaniye, Ali Nihat Tarlan) 205-207. 
Editions: Būlāq 1254; Tabrīz 1266, 1268; Istanbul, printed seven times between 1284 and 1328; Ali Nihad Tarlan, Fuzulî Divanı (Istanbul 1950); Abdülbâkî Gölpinarlı, Fuzulî Divanı (Istanbul 1961).

Literature: Abdullah Karahan in EI² and TDVIA.

\section{Cod.Or. 26.266}

A collection of traditions and stories

A late 16th-century copy, incomplete at the beginning, of a collection of traditions and anecdotes/stories (latîife, hikāyet) about Islam, the prophets and the early history of Islam, probably in translation of an Arabic workheadings are in that language. No title or name of an author are found in the manuscript. It seems to comprise only the last part of a second part $(\mathrm{k} \iota \mathrm{sm})$ and the third one (see heading on f. 44a) of a much larger work. The first heading in red (on f. 1 b) reads: Menāḳıb-i Fâțima. The last section (faṣl, from f. 55a) discusses prayers and how to use them in order to avoid calamities (fí l-hātimet fì d-du'äti d-def'ı l-belīyät).

Marginal corrections and additions. The last flyleaf (f. 66) contains various jottings in a crude hand, among them a talismanic formula, a preamble to a letter addressed to Mehmed Agga, a note signed by Mehmed Ag̉a (at Çorum) on the birth of a son called İbrāhīm—later changed into 'Alī -in the afternoon of Tuesday 26 Safer 1222 (5 May 1807), and an administrative note.

Bound in worn brown leather with flap and blind tooled insets in Oriental style; glazed cream paper, worn and partly restored in various places; tasselled cords in right margins; 66 folios; $195 \times 140 \mathrm{~mm}$ and $165 \times 95 \mathrm{~mm}$, varying; 15 lines; catchwords, partly lost by trimming; vowelled nesih, occasionally changing into ta lïk; headings, rubrics, and, occasionally, dots in red; completed by [...?] Bekir b. Makșūd b. İbrāhīm on the morning of a Monday at the end of Rebï̌ül-evvel 997 (? 7-16 February 1589). Acquired from Barbara Flemming, 11 April 2003.

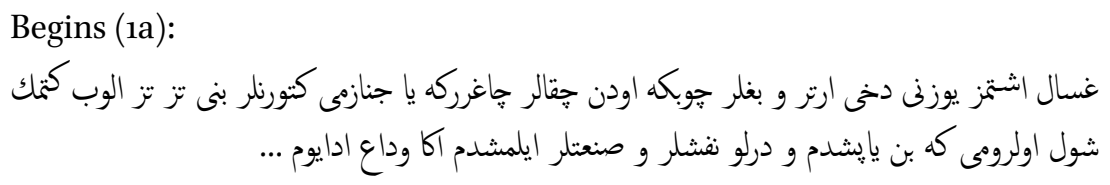


Ends (65b):

.... و السلام على المرسلين و الممد لله رب العالمين ... توفيقه وضع الله [؟] على سيدنا محمو اله و صحبه اجمعين

Colophon (ibidem):

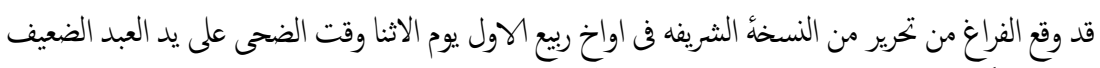

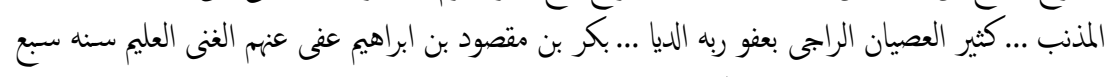

$$
\begin{aligned}
& \text { و تسعين [؟] و تسعائه من الهجرة النبوية ... }
\end{aligned}
$$

Cod.Or. 26.267

\section{Kitāb-i İmānīye}

$$
\text { كتاب ايمانيه }
$$

A late 16th-century copy of an anonymous work, incomplete at the beginning, containing prescriptions for the magical use of pious formulae. These are accompanied by historical anecdotes. The title is found in an epilogue by the (unnamed author), in which he in particular recommends the book to his readers and prays for a strong faith in himself and his readership (87a:7; see also the quotation below). Only one other copy of this work seems to be documented; it is mentioned in the union catalogue of the Islamic collections of (northern) Cyprus. Marginal additions in a different hand are found on ff. 22b and 87 b. Jottings in a bold hand occur on f. 88b. Two (parts of) pages, torn from an Ottoman printed book and a journal (Resimli mecmū'a neşrīyātından) are included in the manuscript.

Bound in boards with brown leather back and edges; somewhat coarse and worn cream glazed paper; 88 folios; $205 \times 145 \mathrm{~mm}$ and $145 \times 95 \mathrm{~mm}$, varying; 11 lines; catchwords; partly vowelled nesih; Arabic quotations and rubrics in red an green; red borders; completed by Yūsuf b. ... (illegible because of restored paper damage) in the province of Habeş (Ethiopia) on a Sunday of Rebï ül-evvel 982 (June-July 1574); two owners' seals are found in the margin of f. 3ob; an owner's inscription of Ḥāccī Bayrāmzāde Bekir Efendi with the year 1254 (1838-1839) occurs on f. 88b. Acquired from Barbara Flemming, 11 April 2003; the MS contains a slip of paper with the registration $4 .=1380$.

Begins (1a):

طاعت و عبادت قلوك در يس امدى بز قول لر او قرواشلر لازمدركى اول بزى ياوقدن وار ايلين افندمزه قوللوق ايدوز

From the authors's epilogue (87a-b): 
امدى اكتب صاحبى بو كتابى دايما اوقوياسز دخى بو فقير الحقيرى دعادن اونوتمسز الله ايمانله كندره ديسز

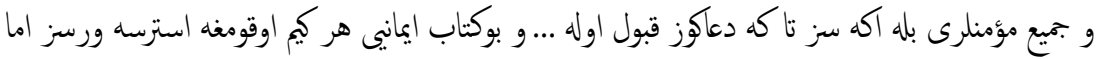

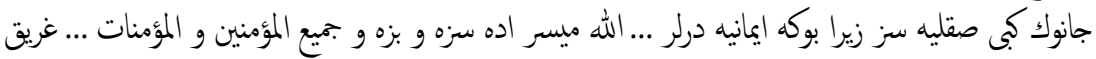
رمت ايليه آمين ...

Ends (87b):

$$
\text { و تمت كلمت ربك صدقا و عدلا لا مبدل الكلماته و هو السميع العليم و المدد الله رب العالمين }
$$

Colophon (ibidem):

قد فرغ هذه الكناب المباركه بين الصلوة يوم الاحد شهر ربيع الاول بولايت الحبش يوسف ابن ... سنه بمهو المد الله وحده فرهد

Copyist's verses (partly illegible, ibidem):

$$
\text { هر ككه بوكتابه نظر قلا * لطف ادب يازنى اجون دعا قلا }
$$

$$
\text { امتدن راضى اوله سون معين *رحت الله ... اجمعين * و الممد لله رب العالمين }
$$

Catalogue entry: KIYK 140.

Cod.Or. 26.268

Menāḳıb-içār yār

مناقب جار يار

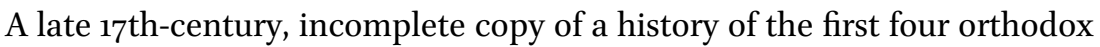
caliphs by Shaykh Şemsüddīn Sīvāsī (d. 1006/1587-1588) — a part of the text is missing between $\mathrm{f}$. 162 and f. 163. The title occurs in a heading preceding the text of $\mathrm{f} . \mathrm{lb}$; the name of the author is mentioned in $\mathrm{f} .1 \mathrm{~b}: 14$. The work is also known as Menāḳı-i hulefā-i rāşidīn. After a brief introduction (1b), twelve chapters $(b \bar{a} b)$ are dedicated to Abū Bakr (65 menāḳı, 2a-53b); 'Umar (81 menāḳıb, 53b-10ob); Abū Bakr and 'Umar (3 menāḳı, 10ob-102a); 'Uthmān (55 menāḳıb, 102a-127a); 'Alì (50 menāḳıb, 139a-164b and the final section in mesnevī rhyme of the 1ooth exploit); Abū Bakr, 'Umar, 'Uthmān and 'Alī (164b-205a, 46 menākıb - the 44th mostly in mesnevi rhyme); a münāzara (dispute) between Abū Bakr and 'Alī (205a-206b); the menākıb of the Ten Companions of the Prophet (206b-208b); the menākıb of the Ahl al-Bayt (17 sections, 208b-218b); the menâkıb of the Companions of the Prophet ( 7 sections, 218b-221b); and on the merits and qualities of the nation (umma, 221b-232a). Marginal additions and indications of content. (For other copies of the same work, see Codices Or. 12.354 and 14.410.) 
Bound in embossed boards with a brown leather back with gold ornamentation and title (Menākı ıb-içehāryārr) in Western (late-Ottoman) style; glazed white paper; $1+232+1$ folios; $197 \times 130 \mathrm{~mm}$ and $150 \times 95 \mathrm{~mm}$, varying; 23 lines; catchwords; small nesih; headings, rubrics, lines, and dots in red; completed by İbrāhīm b. 'Ömer on a Wednesday in Cemāzzì l-evvel 1106 (December 1694-January 1695). Acquired from Barbara Flemming, 11 April 2003.

Begins ( $\mathrm{lb}$, after a besmele):

حمد ير اجلال و ثناى بي اخلال اول قادر لايزاله سزاوار و لايقدر كه جهار اركان دين متينى جهار يار كزين

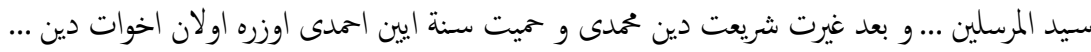
Ends (232a):

$$
\text { ربنا و اننا ما وعدتنا على رسلك و لا تخزنا يوم القيمة انك لا تخلف الميعاد }
$$

Colophon (ibidem):

قد وقع الفراغ من تحرير هذه المناقب الشريف على يد احقر العباد ابراهيم بن عمر فف يوم الاربع من شهر

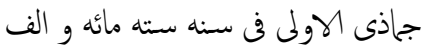

Catalogue entries: Fihris 4653-4655 (IV, pp. 146-147); Karatay 1159-1161, 3037 .

Edition: Istanbul 1258 (cf. GOW, p. 275n)

Literature: 'OM I, p. 95.

Cod.Or. 26.269

A miscellany

An undated collection of pious works in prose and poetry by, mostly, a man nicknamed Mollā 'Arab, not identified (see also under 3), and copied by, seemingly, one copyist. Additional text fragments are found on the endpapers, among them a prayer prescription and a calculation (1a), a talismanic diagram and square, and an Arabic prayer (99b). Crude marginal jottings in a large script, mostly consisting of the word vakf, are found throughout the volume.

\section{(1) ff. $1 \mathrm{~b}-12 \mathrm{~b}$}

A portion of scriptures and prayers to be recited daily (evrād) and recommended by the Prophet. It is preceded by a brief introduction ( $1 \mathrm{~b}-2 \mathrm{a})$. No title or author are indicated. A few marginal additions. 
Begins (1b, after a besmele):

الممد الله ذاكر الذاكين و زايد خيرات الشاكرين ... اى دين قرنداشى و اخرت يولاشى و فقك الله للحق و

Ends (12a-b):

... دكلو نماز قلسك عزم جلالم حقجون دنيا و اخرت مراد لرك ميسر ايليسم و كوكلوكى باى ايليسم

(2) ff. 12b-17b

el-Esmā’ el-ḥ̈̈snā

الاسماء الحسنى

A treatise on the beautiful names of God in the form of a prayer by Molla 'Arab. The title is found in a heading preceding the text; the name of the author in the concluding line.

Begins (12b, after a besmele):

تضرع ايدرم الله اومارم لطفكى سندن بكا تز و رانى رحن رحيم بير نوالكدن ملك قدوس جنابكدن سلام

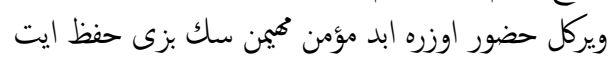

Ends $(17 \mathrm{a}-\mathrm{b})$ :

صلوتين سلامين بزى حلم ايت محددن اومر ملا عرب قلك حداعنوك صوين دايم بغشلا صوبمى و رب رحمت نوالكدن

(3) ff. 17b-39b

[Risāle] fì beyāni l-ed'iye

[رساله] فن بيان الادعيه

A treatise on prayers, possibly incomplete at the end, by Mehmed elMuhammedī, better known as Mollā 'Arab. The title is found in a heading preceding the text; the name of the author is mentioned in f. 18a:5. A few marginal additions.

Begins (17b-18a):

الممد الله الذى جعل الدعات الصالحات رسائل الواسائل بين المولى و عبيد ...

اما بو عبد فقير الى رحة ربه القدير محد نام المحمدى كه خلق ايجنده ملا عرب دمكله معلوم اولمشدر بعض دما

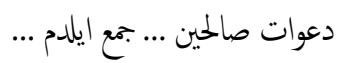

Ends (39b):

$$
\text { اردنجه يوز صلواة افسوندن صكره يازدروب بله كوتورلر اما خلايه كرميه لر }
$$


(4) ff. $40 \mathrm{a}-73 \mathrm{~b}$

A collection of religious poems and songs, mostly ilāhīs, by Mollā 'Arab. The caption Mollā 'Arab fermūd precedes most items. A few marginal additions.

Begins (40a):

$$
\text { صجوم جو قدر بلورק بن بو نقسك آه النذر آه زبون الدى الندن جان بو نقسك آه النذر آه }
$$

Ends (73b):

$$
\text { جمله اصحاب نسب احباب اتباع شيوخ *مؤمنين ختم بالايمان ايدب و يركل مدام }
$$

(5) ff. 73b-83b

An anonymous treatise, without title, on the magical use of the names of God. A few marginal corrections and additions.

Begins (73b, after a besmele):

$$
\text { صكنده يوز كز اقيه حق تع بو الهم كونده بيك كره اقسه حق تعالى اتى [اصل] يقيندن ايليه الرحمن هر كم بو اسم هرنمازك }
$$

Ends (83b):

$$
\text { الصبور هر كم رنجور اولسه و يا محنتى و يا باش اغرسى اولسه و يا خوذ ستمسى اولسه اوج بيك كز بو }
$$

(6) ff. $84 a-99 a$

A collection of, mostly, gazels by Zülālī (84a-b); Şāhidī (84b-85a); Harīmī (85b-86a, 94b-95b-a song with the maḳām Çārgāh); Halīfì (86a-b, 87a$88 \mathrm{~b}$ - a series of seven quatrains with a returning refrain in praise of Mollā'Arab-89a-b, 93b-94a); Nihānī (86b-87a, 96b-97b-a series of quatrains with returning refrain, $97 \mathrm{~b}-98 \mathrm{a}$ - a song with the makām Nühüft, 98a-99a); Süleymān (89b-90a); Halācog̀lı (90a-91a, 91a-93b-a series of quatrains with a returning refrain); ['Abdul]Vefā (94a-b); and Mollā'Arab (95b-96a). A few marginal corrections.

Bound in boards with flap and brown leather back and edges; glazed cream paper without watermarks, lightly stained and worn, particularly towards the end; $1+99+1$ folios; $147 \times 100 \mathrm{~mm}$ and $105 \times 60 \mathrm{~mm}$, varying; 8-11 lines; original quire numbering $1-10$ from $\mathrm{f} .5 \mathrm{a}$; catchwords, occasionally omitted 
or lost by trimming; vowelled nesih of calligraphic quality; headings, rubrics, lines and dots in red; without a date or name of a copyist. Acquired from Barbara Flemming, 11 April 2003.

Cod.Or. 26.270

\section{Hurşìd-nāme}

خرشيد نامه

An early 19th-century copy of a long poem in mesnevi rhyme describing the romance between Hurşīd and Ferahş̧̄ād by Şeyhoğlı Muṣțafā(flourished in the second half of the 8 th/14th century), incomplete both at the beginning and the end as well as erroneously bound. The work was completed in 789 (1387) and offered to Sultan Bāyezīd I. The full work comprises about 8000 distichs; the present version less than 2000. (See for another copy of the same text, Cod.Or. 14.446.)

The inner boards and the first flyleaf contain calculations, an Arabic quotation ascribed to the Imām Shāfí $\overline{1}$, and a statement (in Arabic, quoted below) by an owner that 'Ömer had copied the book but was afraid that he would come to him and buy it for a small amount of money, dated 29 Cemāz $\bar{\imath}$ l-evvel 1232 (16 April 1817).

Bound in boards with brown leather back and edges; glazed cream paper, stained and worn in many places; an illegible title is written on the bottom edge; $1+109$ folios; remants of original numbers 133 to 200 (80a) and 63 (92a) to 94 (108a); $193 \times 134 \mathrm{~mm}$ and $150 \times 100 \mathrm{~mm}$, varying; 15 lines; catchwords nearly all lost by trimming; vowelled nesih; headings in red; copied by 'Ömer in $123^{2}$ (1817), cf. above; an owner's inscription of Mehmed b. Hüseyn is found on the first flyleaf, recto. Acquired from Barbara Flemming, 11 April 2003 .

Copyist's inscription (first flyleaf, recto):

$$
\begin{aligned}
& \text { كنبت هذه المصحف الثريف بخط عمر و جهد كثير و عمر قصير اخاف من الاجل اذا جاءنى يباع بثمن }
\end{aligned}
$$

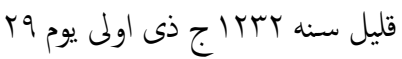

Begins (1a, as in Ayan's edition, p. 222:2525):

$$
\text { بنك استينه كجدى خيلى مدت * فرحشاد اتمشيدى صبر عادت }
$$

Ends (109b, as in Ayan's edition, p. 201:1939):

$$
\text { ججب سنى سولى بن نشا اولمدم دلشاد * مكر جفا كله اورلدى كوكلمه بنياد }
$$


Catalogue entries: Pertsch (Berlin) 365, where other MSS are mentioned; see also Ayan's edition, pp. 25-28.

Edition: by Hüseyin Ayan, in Latin script (Erzurum 1979).

Literature: Kathleen Burrill in $E I^{2}$.

\section{Cod.Or. 26.271}

\section{A miscellany}

A collection of texts related to Persian literature and lexicography, possibly copied by one copyist, Seyyid Ebūbekir Yazıcı, mentioned in a colophon on f. 53a with the year 1208 (1793-1794). The inner front-cover and the endpapers contain various jottings and notes, among them, mostly, preambles to letters (1a, 154b). The manuscript was endowed as a vakf to the library of the late 'Ayntābī Hāāccī Aḥmed Efendi at Uşak (inscription with a seal, dated 1283/1866-1867, on f. 2a).

$$
\text { (1) ff. 2b-53a }
$$

The Pand-nāma attributed to 'Ațțār with a Turkish translation

A late 18th-century copy of the Persian Pand-nāma, a didactic mesnevit, attributed to Farīd ad-Dīn 'Ațtār (d. after 586/109o, see B. Reinert in Encyclopaedia Iranica), with an anonymous interlinear Turkish translation. The heading Hāzza Kitāb Pend-i 'Atțār precedes the text on f. $2 \mathrm{~b}$. A few marginal corrections and additions. (For the existing Turkish translations and commentaries of this popular work, see Helmuth Ritter, "Attâr", in İA; for copies of other translations, see Codices Or. 12.431 and 12.448(5).)

Begins (2b, after a besmele):

$$
\begin{aligned}
& \text { حمد بي حد آن خداى باّك را *انك ايمان دادمشتى خاكـ را } \\
& \text { صايسيز شكر اول ياك خدايه *اويله تكرى كه بر آوج طبراغه ايمان و يردى }
\end{aligned}
$$

Ends (53a):

$$
\begin{aligned}
& \text { اين مبارك نامه جون كردى تمام * بعد از آن بنويس ديكر و السلام } \\
& \text { بومبارك نامه جون اولدى تمام * اندصكره بر غيرى سن ياز و السلام }
\end{aligned}
$$


Colophon (ibidem):

$$
\text { الخط المذنب سيد ابوبكر يازيجى ميانه سنه م• IT }
$$

(2) ff. 54b-105a

A rhymed Arabic/Persian-Turkish dictionary

The copy is undated and anonymous. The work consists of 30 chapters, consisting of poems of varying formats, mostly gazels and mesnevīs, and each dedicated to a special subject and conforming to a different metre. Prosodic indications in the form of red letters and numbers are found below the lines. A few marginal additions. The opening line, written upside down, is also found on f. $54 \mathrm{~b}$, together with a rhymed Arabic sentence.

Begins (54b):

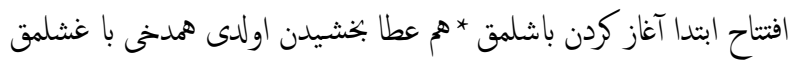

Ends (105a):

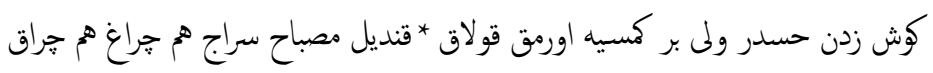

(3) f. 106a

A list of 22 Arabic verbal nouns with interlinear Turkish translations. Begins:

$$
\text { ابتدا [بشلمق] اقتندا [اويمق] اقتضا [استمك] }
$$

The sentence ka'r-i deryādan çıkmayınca dür bilinmez kıımatı is written in the left margin, as is the title of the following work (Lugat-i Vehbi Sünbülzāde).

(4) ff. 106b-153a

Tuhfe-i Vehbì

تحفة وهبى

An undated copy of a rhymed Persian-Turkish vocabulary by Sünbülzāde Mehmed, who used the pen-name of Vehbì (d. 1224/1809). The title and the name of the author are found in f. 109a:15 and in the concluding chronogram (153a). The work, clearly in imitation of the popular 16th-century Tühfe-i Şāhidi, was written in 1197 (1782-1783). The work is preceded by an introduction, in mesnevi rhyme (106b-10gb), in which the author informs us that it was the fruit of his mission to Persia (as envoy of Sultan 'Abdulhamìd to Karīm Khān Zand) and that he had written it for his son Luṭfullāh. It was dedicated to Grand Vizier Hamīd Halīl and his two sons (cf. Rieu, p. 144). It 
is followed by 58 chapters (kut tas) in gazellkașide format, a second meșnevī on a selection of expressions (ıștılāhât, 146b-153a), and a chronogram (153a). An additional verse is found in the margin of f. 12gb. (For other copies of the same text, see Leiden UB Codices Or. 11.989 and 18.692 [1])

Begins (106b, after a besmele):

$$
\text { حمد بى حد او كرم فرمايه *كه انك نعمتيدر بى غايه }
$$

Ends (153a):

$$
\text { هزاران شكر ايدوب حقه ديدم تاريخ اتمامن *بحمد لله بو زيبا تحفة وهبى تمام اولدى }
$$

Catalogue entries: Blaškoviçs 458; Fihris 569-573 (I, p. 145); Flügel 141; Kut 36o; Rieu, pp. 144-145; TYTK (Antalya) 1636.

Editions: at least 30 printed editions exist, cf. the article in $\dot{I A}$, among them Būlāq 1245, 1282; Istanbul 1213, 1241, 1263, 1267 and 1275. A modern edition is Numan Külekçi \& Turgut Karabey, Sünbülzade-Tuhfe (Erzurum 1990).

Literature: HOP IV, pp. 257-258; Ömer Faruk Akün in İA; W. Björkman \& Kathleen R.F. Burrill in $E I^{2}$. (See also Cod.Or. 1452.)

Bound in boards with dark brown leather back and edges; glazed cream paper; 154 folios; $205 \times 143 \mathrm{~mm}$ and $150 \times 90 \mathrm{~mm}$, varying; $11-16$ lines; catchwords; nesih, vowelled in (1); headings and rubrics in red; headings partly in black in (4); (1) completed by Seyyid Ebūbekir Yazıcı in the middle of 1208 (1793-1794). Acquired from Barbara Flemming, 11 April 2003.

Cod.Or. 26.272

Dìvān

ديوان

A late 17th-century copy of a collection of poems by the Halvetiiye Shaykh 'Abdulvehhāb of Elmalı who used more than one pen-name based on the root consonants of the second part of his name: $\operatorname{Vanhib}(\overline{\mathbf{l}})$, Vehhāb(ī) and Vāhib Ümmī (d. in 1004/1595-1596 or 1006/1597-1598). The poet does not seem to be mentioned in any of the known biographical dictionaries. There are at least six copies of this work preserved in Turkish libraries. The text in our volume is incomplete at the beginning where at least ten folios are missing. The collection consists of poems of the gazel/kașide format and not 
arranged in the usual $D \bar{\imath} v \bar{a} n$ sequence, and comprises poems both in 'arüż and syllabic metres. Marginal notes by an owner are found on f. $8 \mathrm{gb}$.

The (tattered) endpapers contain various jottings and notes, among them a $\dot{g}$ azel (3 distichs) and fragments, partly lost, of (an)other poem(s). A folded leaf, $160 \times 105 \mathrm{~mm}$, with an Arabic text is found between f. 158b and 159 .

Bound in boards attached to which is the remnant of a brown leather cover; glazed cream paper, stained and dicoloured, particularly towards the beginning and end; $170+1$ folios, with original numbers; $210 \times 147 \mathrm{~mm}$ and $145 \times 98 \mathrm{~mm} ; 15$ lines; catchords; nesih, partly vowelled, particularly up to f. 4ob; multiple red borders; completed by Ahmed Çelebi on the morning of Saturday 12 Cemāzi l-āhir 1093 (18 June 1682); an owner's inscription of Ḥāfiz Meḥmed Kāābil Efendi, halīfe of Şeyh Efendizāde es-Seyyid eş-Şeyh Ḩākān̄ī, with seal, is found on f. 17ob; a $v a k f$ inscription with the names of Mehmed Efendi and Ḥāccī Hüseyn occurs on the inner front-board. Acquired from Barbara Flemming, 11 April 2003.

Begins (11a):

$$
\text { غافل اولمه اج كوزك نكارى شيطان سنده در *لا دمه بو توحيده سهارى شيطان سنده در }
$$

Ends (170a):

$$
\text { واهب امى يوقلغنك و ارلغندن سوير سكا *وحيد بكا شاهد يتر كثف الله دن كلورزبيز }
$$

Colophon (ibidem):

تمت الكتاب بعون الله الملك الواب فى شهر جاذى الاخر فى وقت ضحى فى يوم السبت في با يوم سنه

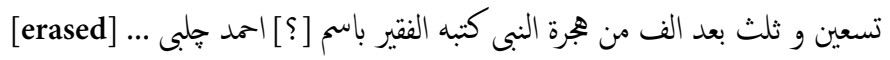

Copyist's verses (ibidem):

$$
\text { خير يازسن شرنى انك كراما كاتبين *كه دعايله اكلكسه اشبو رسمك كانبين }
$$

Edition: Ali Torun, Vâhib Ümmî: Dî̀ân (Yüksek Lisans tezi, Ankara 1987unpublished).

Literature: Cemâl Kurnaz \& Mustafa Tatcı, Türk Edebiyatında Hû Şiirleri (Ankara 1999), pp. 6o-64; Mustafa Tatcı, Elmalı'nın Canları (XVI-XVIII Asırlarda Elmalı Havzasında Yaşayan Halveti Erenleri. Hakkında Bir Araştirma), Istanbul 2008 (I am indebted to Edith Gülçin Ambros and Cemal Kurnaz for the aforementioned bio- and bibliographical information). 


\section{Cod.Or. 26.615}

A legal miscellany

The texts were copied by one copyist, Mehmed Reşīd b. İsmā̄îl, who was also the owner, in 1233 (1817-1818). A four-page survey of contents precedes the texts. The flyleaves contain a great number of additions, mostly fetvās, in Arabic and Turkish written in a different hand; some of these are signed: by Hāfiz İbrāhīm, müftı in Dirac (Durrës, on the 4th flyleaf, verso), and 'Abdurrahīm (next page). A diagram concerning the division of an estate is found on the first flyleaf, recto.

(1) fifth flyleaf, verso - f. 73a

Kānūn-nāme-i cedìd

قانون نامهُ جديد

A copy of a general law code of the Ottoman Empire, mostly consisting of fetvās issued by a number of shaykhulisläms, who were in function in the 16 th and early $17^{\text {th }}$ centuries, as well as separate laws (kānūn-nāmes) on specific subjects. The title is found on the first flyleaf, recto. The compilation of the law code was, according to the introductory part, initiated by Sultan Süleymān the Magnificent, conqueror of Hungary, after the vilāyet of Budin was founded [in 1541]. (For a detailed description of the contents, see in particular Götz II, pp. 112-114.) The copy was based on another copy made in Edirne in 1202/1787 (see the colophon, below). Marginal additions, often extensive. Schematic interlinear drawings in red are found on f. 63a. Purchased from the heirs of Robert Anhegger in 2003.

Begins ( 5 th flyleaf, verso, after a besmele):

المحد لله الذى له ملك السموات والارض و هو على كل شىء قدير جناب حاقان روى زمين و خليفهُ رسول رب العالمين

Ends (73a):

عشرلرين حكى ايدوب ... من بعد شرع شريفه قانون امر هايونمه مخالف و عناد ايتدرميه سن شويله بله سن

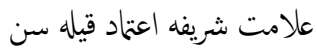

Colophon (ibidem):

تحريراً فن اواخر شهر رجب الفرد لسنه اثنين و مأتين و الف بمقام ادرنه المحروسه تمت الكتاب بعون الله الملك الوهاب

Owner's inscription (ibidem):

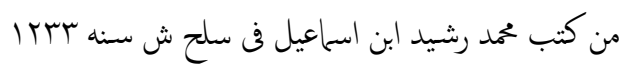


Catalogue entries: Flemming 352; Götz II, 110-112; Sohrweide I, 114, where other MSS are mentioned; see also Fihris 3764-3773 (III, pp. 222-223); Kut 41-49; TYTK (Antalya) 3457.

Literature: Ahmed Akgündüz, Osmanlı Kanunnâmeleri ve Hukukî Tahlilleri V (Istanbul 1992), pp. 266-269.

(2) ff. $73 b-86 b$

Ma'rüżàt

A copy of a collection of fetvās issued by the şeyhülislām, Ebūssu'ūd Meḥmed b. Meḥmed el-'̇mādī (d. 982/1574). The work begins, after a brief formula in praise of God and the Prophet in Arabic, with an introduction in the form of a petition $(73 \mathrm{~b})$ in which imams and müctehids (expounders of Islamic law) request clarification on a number of questions laid down in fetvās by the late Ebūssu'ūd. The work itself consists of a series of fetvās arranged in chapters (Kitāb) discussing a number of subjects, ranging from prayers to rent. Marginal additions, often extensive.

Begins (73b, after a besmele):

$$
\begin{aligned}
& \text { المحدلله رب العالمين و الصلوة و السلام على سيد المرسلين محمد خاتم النبيين ... اما بعد سعادتلو و سيادتلو } \\
& \text { و فضيلتلو و مروتلو سلطانم حضرتلرينه عرض داعى بـ ... اولدر كه ... }
\end{aligned}
$$

Ends (86b):

$$
\text { مسائل شتى ... بو شهادت ايله كنايس قديمه حالى اوزره قالمشدر كتبه ابو السعود }
$$

Colophon (ibidem):

$$
\text { و ثثلثين و الكناب بعون الله الملك المتعال محمد رشيد حرر في اليوم الثالث عشرين ذى القعدة الشريفه لسنه ثلث }
$$

Catalogue entries: Flemming 345-347, Götz II, 84, Sohrweide I, 108-109 and Sohrweide II, 101, where other MSS are mentioned; see also Fihris $4517-45^{23}$ (IV, pp. 109-111); Kut 50-54; Schmidt 89, 95(2).

Editions: in Millî tetebbu'lar mecmuası I (1331/1915), p. 337 ff.; Paul Horster, Zur Anwendung des Islamischen Rechts im 16. Jahrhundert (Stuttgart 1935), with a German translation; Ahmed Akgündüz, Osmanlı Kanunnâmeleri ve Hukukî Tahlilleri IV (Istanbul 1992), pp. ${ }^{2-75}$, with a transcription and a facsimile of the Selçuk University Theology Faculty Library MS 2671. 
Literature: cf. Flemming, p. 274; Sohrweide I, p. 85; Haim Gerber, State, Society, and Law in Islam, Ottoman Law in Comparative Perspective (New York 1994), p. $88 \mathrm{ff}$; Colin Imber, Ebu's-su'ud; the Islamic Legal Tradition (Edinburgh 1997).

$$
\text { (3) ff. 87a-90a }
$$

An appendix containing a series of fetvās by the şeyhülislām, Yahyā Efendi (three times in office between 1031/1622 and 1053/1644, cf. $S O^{2} \mathrm{~V}, \mathrm{p} .1674$ ). The text is headed:

$$
\text { فيا يتعلق بالقانون للمولى المرحوم يجيى افندى }
$$

The text is followed by a colophon (9oa):

$$
\begin{aligned}
& \text { تم الكتاب بعون الله الملك المتعال محد رشيد ابن اساعيل غقر الله لنا و لوالدينا حرره في اليوم الكامل عشر }
\end{aligned}
$$

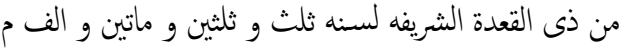

(4) ff. 90a-b

A series of comparisons in Arabic, headed Tarjịh al-bayān.

$$
\text { (5) ff. 90b-9la }
$$

Mesāiliül-müşkilāt

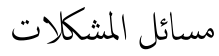

A brief treatise on the seven cases in which an oath is considered to be void. The source, mentioned at the end of the text, was a work entitled ad-Durar al-ghurar. An extensive marginal addition is found on $\mathrm{f}$. 91a. Begins:

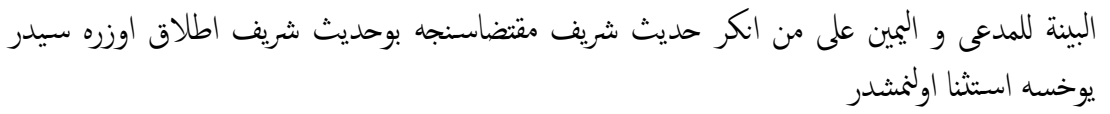

Bound in boards, covered in varicoloured marbled paper, with brown leather edges; glazedwhite paper; $5+91$ folios, with original numbers $1-90$ in red; $206 \times 124 \mathrm{~mm}$ and $150 \times 55 \mathrm{~mm}$, varying; 25 lines; without catchwords; small rık $a$; headings, rubrics and lines in red; completed by Meḥmed Reşīd b. İsmāīl on (2) 23 Z̄ı l-ḳa'de 1233 (24 September 1818) and (3) 10 Ž̄ l-ḳa'de 1233 (11 September 1818); an owner's inscription of the same, dated 29 Şa 'bān 1233 (4 July 1818), is found on f. 73a. Purchased from the heirs of Robert Anhegger in 2003 . 


\section{Cod.Or. 26.616}

Tuhfetül-küttāb

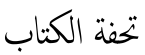

An early copy of a (rare) collection of legal documents by Mehmed b. 'Ubeydüllāh known as Mūsāzāde (d. 1197/1782-1783, cf. Fihris I, p. 139). The author is mentioned in p. 1:14; the title, which is mentioned in more complete versions of the text, has been omitted in the final part of the introduction on p. 2. The work is preceded by a brief introduction in Arabic (pp.1-2) in which the author explains that his late father, Mūsāzāde 'Ubeydüllāh Efendi was a $k \bar{a} \dot{z} \bar{l}$ and produced many drafts of legal documents; when he, the son, came into the service of Pirīzāde Meḥmed Ṣāḥib Efendi, a şeyhülislām [actually first imām of the sultan, 1193/1779-1195/1781; d. 1195/1781, cf. $S O^{2}$ VI, p. 1726], he collected the drafts as well as copies of 'fine letters' which his patron then corrected for him; these were sorted out and included in the present work. The collection contains the usual range of documents (statements issued by a $k \bar{a} \dot{z} \bar{l}$, hüccets, and letters authorized by the same), loosely arranged according to subject, from marriage contracts, declarations of divorce, wills, letters of manumission, to contracts of sales, appointments of attorneys, deeds of annulment, confessions of faith, death certificates, declarations of bankruptcy, settlements (in cases of injury and murder), vakfiyes and parts of them, bills of debt (temessük), various statements, such as confessions of guilt, perceptions of the crescent and petitions to the Porte. The original documents, partly 'depersonalized' (personal and place names changed to fulān) for the work, had nearly all, as far as indicated, been issued in Istanbul, Galata, and Üsküdar. Most dates are replaced by the formula Tārīh-i Kitāb. The work ends in a series of (parts of) model letters and documents of various type. Marginal corrections and additions, mostly fetvās (pp. 1, 2, ff. 221a-222a); two model petitions are found in the margin of f. 222b. (For another copy of the same text, see Leiden, UB Or. 12.032.)

The work is preceded by a 13-page survey of contents. The endpapers contain additional texts in a different hand: model petitions adressed to the sultan (first flyleaf, recto; second flyleaf, recto, 223 b, 224a), the last two dated 1238 (1822-1823) and signed el-Hācc Mehmed, müsellim of Kütahya; model signatures and episto-lary phrases in Arabic (first flyleaf, recto and verso); a table with numbers and their Arabic equivalents, followed by a signature of the manuscript owner, the ḳā̇̇̀ Hāfiz 'Alì Rıżā, dated 1238 (1822-1823, second flyleaf, recto); a model fetvā concerning the appointment of an functionary by the founder of a vakf (ninth flyleaf, recto); and two fetvās concerning financial transactions by [the şeyhülislām] Meḥmed 'Ārif Dürrīzāde (223a). 
Rebound in embossed dark brown leather; glazed white paper; $8+223+1$ folios, with original numbers $16-223$ in red-1-15 were removed and replaced by page numbers $1-28$ in black; $212 \times 145 \mathrm{~mm}$ and $153 \times 87 \mathrm{~mm} ; 22$ lines; catchwords; irregular small nesih; borders and headings, partly erased at the beginning, in red; multiple gold borders within black lines on pp. 1 and 2; a crude headpiece with floral motifs in gold on p. 1; completed by Ebābekir b. 'Ömer on a Sunday during the last days of Receb 1204 (6-15 April 1790). Purchased from the heirs of Robert Anhegger in 2003.

Begins (p. 1):

$$
\begin{aligned}
& \text { الحمد الله الذى شيد مبانى الدين القويم بقوائم اقلام البلغاء ... و بعد فيقول العبد الفقير المعترف بالعجز و }
\end{aligned}
$$

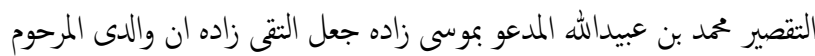

Ends (f. 222b):

$$
\text { امضاءو قضيه ... وانا الففير المحتاج الى شفاعت صاحب المعراج ابو بكر القاضى بمدينت فلان }
$$

Colophon (ibidem):

$$
\begin{aligned}
& \text { قد وقع الفراغ عن تحرير هذا الصك المرغوب عن يد عبدالمذنب ابوبكر بن عمر غقر لما و اليه في يوم بظر }
\end{aligned}
$$

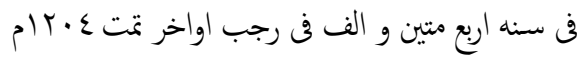

Catalogue entries: Fihris 544-546 (I, p. 139).

Cod.Or. 26.617

\section{Fetāvā-yi Aḳkermānī}

فنتاواى اقكرمانى

An undated copy of a collection of legal rulings (fetvās) by 'Alī 'Abdullāh el-Akkermānì (d. 1028/1618-1619). The title is found on the bottom edge. The work is also known as el-Vākı 'ät. The collection was compiled by Derviss Mehmed b. Hasan, who explains in the brief introduction preceding the text that he, languishing in poverty and confusion in the plain of Tepe-i Erba'in [this may refer either to a placename $=$ Kirklartepe (?) or to the low annual income of forty akçe, or perhaps both], made his way to the outpost of Akkerman in 1040 [1630-1631] to find employment and was so fortunate as to come across scattered papers containing the fetvās of the late 'Alī Efendi, which he thereupon decided to gather and order in the form of a book. The text is divided into 47 (unnumbered) chapters (Kitāb) treating subjects ranging from canonical ablutions (țahāre) to the division of estates (ferāyl $\dot{z}$, $227 \mathrm{~b}$ ). A few marginal additions, corrections and indications of content.

The endpapers contain some additional texts, partly in different hands: a quotation in Arabic on menstruation (first original flyleaf, recto); a series 
of calculations (first original flyleaf, verso); a survey of contents (second original flyleaf, recto); a series of titles of works on jurisprudence (second original flyleaf, verso, and two lines on the next page); a biographical note on 'Alī el-Aḳkermānī ('Atayi 639' added in pencil—the passage mentions 1030/1620-1621 as the year of his death, cf. above) and, in the margin, a fetva followed by a lengthy Arabic quotation, taken from the Fetāvā-yi Üskübī (see Cod.Or. 1276); and a fetvā by 'Abdurrahīm Efendi, dated ${ }_{15}$ Cemāż̄ l-āhir [1]234 (3 January 1828). A few notes in pencil and ballpoint are found on the inner front-board.

Bound in boards with flap and red leather back and edges; glazed cream paper; $(1)+3+235+(1)$ folios, with original numbers; $239 \times 148 \mathrm{~mm}$ and $196 \times$ $90 \mathrm{~mm}$; 29 lines; catchwords; small sü̈üs; headings rubrics and borders in red; double red borders on the first two pages of the main text; without a date or name of a copyist. Purchased from the heirs of Robert Anhegger, in 2003.

Begins (fourth flyleaf, verso, after an extended besmele):

$$
\begin{aligned}
& \text { الممد الله الذى ما سئل ال اجاب و ما داعى الاواجاب [=استجاب] و الصلوة و السلام على فاتحه ... اما }
\end{aligned}
$$

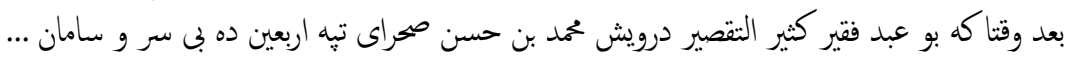

Ends (234b):

$$
\text { مسئله ذكيه دخى فوت اولوب ... الجواب التى سهمك برى هينده ايكيسى برابر زمينه ايله زمانه يه باقيسى : مهيل }
$$

Catalogue entries: Fihris 3031-3032 (III, pp. 159-16o); Karatay 303; Yardım 3334 .

\section{Cod.Or. 26.618}

\section{A miscellany}

A collection of texts copied by one scribe, 'Ömer b. Hüseyn Efendi (mentioned in a colophon on f. $283 \mathrm{a}$, cf. below). The first main text is preceded by a detailed nine-page survey of contents in red and black, written in a different, more casual, hand, and accompanied by interlinear and marginal additions, partly lost by trimming. A series of fetvās and quotations from works on jurisprudence are found on the fifth flyleaf, verso, and the following page; signatures of 'Abdullāh, with the year 1119 (1707-1708), and Ebū İshak İsmācill are added to two quotations. A quotation from a hüccet, partly lost by trimming, is found on f. 289a. Three fetvās and two Arabic quotations, 
again partly lost by trimming, occur on f. 290a. Administrative annotations in three columns, mentioning weekdays and amounts, are found on the last flyleaf, recto.

(1) sixth original flyleaf, verso-f. 283a

Fetāvā-yi 'Alì Efendi

فتناواى على افندى

An early 18th-century copy of a popular collection of legal rulings (fetvās) by the şeyhülistām, 'Alī Efendi of Çatalca (d. 1103/1691). The title is printed in gold on the back and occurs as 'Ali Efendi Fetāvāsı on the bottom edge. The text is accompanied in the margins by a plethora of additional texts in the same script, mostly fetvās in Arabic and Turkish taken from a great number of explicitly mentioned works. Two separate leaves with Arabic texts are found between ff. 154b-155a and 216b-217a.

Begins (sixth original flyleaf, recto, after a besmele):

الممد لله رب العالمين و الصلوة و السلام على خير خلقه محمد و آله التيبين الطاهرين عدد فتوى كتاب الطهارة Ends (283a):

زيدك برات ايله متصرف اولديغى ... زيدى بغير وجه [نرعى] منعه قادر اولورمى الجواب اولماز تمت الكناب

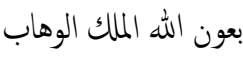

Colophon (ibidem):

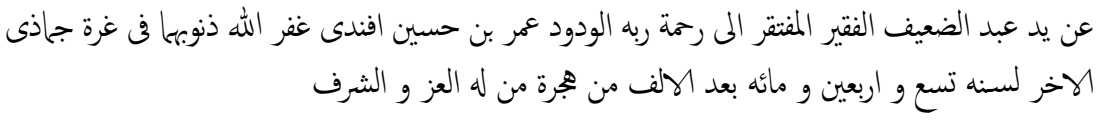

Catalogue entries: Götz II, 70, Sohrweide I, 110-111, Sohrweide II, 110, where other MSS are mentioned; see also: Fihris $3553^{-3574}$ (III, pp. 165-169); Karabulut 103; KIYK 22; Kut 21-22; TYTK (Antalya) 1210, 2955; TYTK (Türkiye Büyük Millet Meclisi) 69; Yardım 3343-3346.

Editions: Istanbul 1245; Būlāq 1257.

(2) ff. 283a-284a

A series of fetvās, headed باسمه سبحانه و تعالى

(3) ff. $284 \mathrm{a}-288 \mathrm{a}$

Hikāyet-i kāàż ma'e s-sārık

حكايت قاضى مع السارق

A copy of the story of the k $k \bar{a} \bar{z} \grave{l}$ and the learned thief, anonymous. A summary of the contents is found in Sohrweide II, p. 262 (Other versions of the 
story are found in Leiden, UB Codices Or. 12.112(13), 12.406(4), 12.407 and $12.424(2)$.)

Begins (284a):

حكايتده كتورمشلردر كه راى شهرنده بر قاضى وار ايدى انواع علم و زهد ايله اراسته و هراسته ايدى Ends (288a):

القصه جقاروب سكسان بش التونى دخى اوغرويه ويردى ... قصه دن مراد حصه در اولول [sic] البابدن

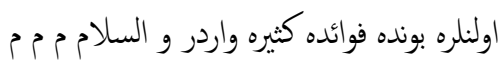

(4) ff. $288 \mathrm{a}-\mathrm{b}$

A quotation in Arabic from a work entitled Jāmi al-fatāwā. Various fetvās are found in the margins of f. $288 \mathrm{~b}$, partly lost by trimming.

Rebound in boards with an embossed light brown leather back with gold decoration and a title in Western style; white to brownish glazed paper, worn and blotted by moisture at the beginning and end; $(1)+6+291+(1)$ folios, with original numbers, mostly lost by trimming; $290 \times 160 \mathrm{~mm}$ and 195×70 mm, varying; 31 lines; catchwords; small ta lik $k$; headings, rubrics, lines and triple dots in red; (1) completed by 'Ömer b. Hüseyn Efendi on 1 Cemāzì l-āhir 1149 (7 October 1736). Purchased from the heirs of Robert Anhegger in 2003.

\section{Cod.Or. 26.619}

\section{A Turkish title and annotations}

This manuscript contains an undated copy of an Arabic commentary, al-

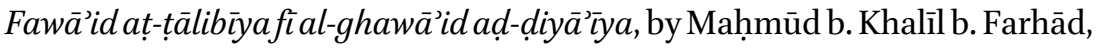
on, probably, a work on syntax, al-Küfı̀a, by Ibn Hājib (d. 646/1249), cf. GAL I, p. 303; S I, p. 531. A Turkish version of the title, Küfiye şerhi, is found on the first flyleaf, recto. The endpapers contain various annotations, among them in Turkish: administrative notes, a gloss and a price of 2 esedī $\dot{g} u r u s ̧, 35$ para (first original flyleaf, recto); the name of Civizāde and the numbers 2 and 25 (second original flyleaf, recto); and various Turkish glosses to Arabic expressions (written upside down, last original flyleaf, verso). Purchased from the heirs of Robert Anhegger, in 2003. 


\section{Cod.Or. 26.620}

A Turkish copyist's verse

This manuscript contains a copy of an Arabic commentary, Hall Asrār alakhyār , by Hüseyn b. Aḥmed, known as Zeynīzāde, on a work on grammar, Ižār al-asrārr, by Birgili Meḥmed Efendi (d. 929/1523), see GAL II, p. $5^{85}$ (No. 2o/c); S II, pp. 656-657. It was completed in 1197 (1782-1783), see the colophon on the last page. The colophon is accompanied by copyist's verses in Arabic and Turkish:

$$
\text { خيره يازسن شرنى آنك كراما كاتبين *كم دعائله اكارسه اشبو خطك كاتبين }
$$

Purchased from the heirs of Robert Anhegger in 2003.

Cod.Or. 26.621

The Anhegger archive

The archive contains the material remains of Anhegger's life, from school boy in Rotterdam to retired private scholar in Istanbul, spent on a wide range of activities and covering a period between the 1920 and his death in 2001. It is kept in units numbered 1 to 59 . They contain a wide variety of materials, among which papers, documents, bills, (draft) letters, (draft) articles, (off-prints from) journals, picture postcards, brochures, notebooks, copies of archival documents and other source materials, annotations, invitations to exhibitions, visiting cards, photographs, cassette-tapes and what not, mostly in a chaotic state. Most texts included in the archive, both printed and hand-written, are in German, Dutch and Turkish. In what follows, I present a summary survey of the contents, highlighting some of the more noteworthy items.

A survey of his life and work is found in two typed CVs, two lists of publications and a copy of a draft CV of his wife, Mualla Eyuboğlu (in Turkish) (in 4); a bibliography was made by Barbara Flemming (6 pp.), dated 18 May 2001 (in 7). More biographical materials on Anhegger and his wife, among them CV's in German and Turkish and papers documenting his acceptance of the Bundesverdienstkreuz (Cross of Merit) by the Federal Republic of Germany in 1985 are in 59. Materials on the Anhegger family, a family reunion in Lindau in 1956 and photographs of Anhegger are found in 38. Two photographs of the interior of Anhegger's house in Amsterdam, among them of his library, dated 1 May 2001, are found in 10. (See for Anhegger's biography, Gudrun Schubert, "Robert Anhegger, Notizen zu seinem Lebenslauf”, in Gudrun Schubert, ed., Türkische Miszellen, Festschrift Robert 
Anhegger (Varia Turcica IX), Istanbul 1987, pp. 1-4; "Robert Anhegger", in: Heymatlos, Exil in der Türkei 1933-1945 (Schriftenreihe des Vereins Aktives Museum, Vol. 8), Berlin 2000, pp. 52-53; and Tûbâ Çandar, Hitit Güneşi; Mualla Eyuboğlu Anhegger, Istanbul 2003, p. 107 ff.)

From Anhegger's early days date a small collection of letters, including bills, notes and other documents, typed and hand-written, addressed to him in Zurich and mostly related to his activities for the Swiss branch of the boy scouts called Schweizer Wandervogel, 1928-1932 (3, 13), and a typed list entitled Verzeichnis der Jugendgruppen im Kanton Zürich (January 1930, in 4).

Earlier biographical materials, mostly concerning Anhegger's political activities and his emigration to Turkey, are found in 13, among them letters (dated to 1928 to 2000 , both private and professional and received from his friend Andreas Tietze, the Turcologist Paul Wittek (1894-1978), and another friend and specialist in Karamanlı Turkish, Evangelia Balta, among others); a copy of Bulletin No. 2 of the Congrès mondial des jeunes contre la guerre et le fascisme, undated (6 pages); a two-page publication entitled der Kämpfer, undated, issued by the Communist Party of Switzerland in 1933; and a flyleaf headed Aufrufgegen den Krieg!/ Un appel contre la guerre by Romain Rolland, undated, with a blank list containing one signature; a schedule for a journey to Ticino (1928, one leaf); a separate file with papers concerning Anhegger's status as German immigrant in Switzerland 1932-1936 (Anhegger vainly tried to obtain Swiss citizenship despite the fact that he had been living there between 1923 and 1932 and his mother had the Swiss nationality; after he was accepted as a citizen in Zurich in 1934, it was again withdrawn later that year when it turned out he had omitted to declare that he was an 'active communist'); letters, mostly to his parents and his sister Gerda; an inventory and postcards by Anhegger documenting his move to and sojourn in Istanbul, 15 items, 1934-1942; a copy of a typed proclamation to German fellow-citizens, urging them to throw off the Hitler regime and conclude a honourable peace 'without collapse', March 1943 (4 pp.).

From his early days in Turkey, date (in 1) two photocopies of, probably, the first Anatolian journey undertaken by Anhegger and Andreas Tietze in 1936 (text about 80 pages), with copies of a Turkish-German vocabulary and some other papers; a carbon copy of an account in German of their second journey in Anatolia, 5 September to 3 October 1937, 78 numbered pages. (Photocopies of these texts are also found in the Amsterdam International Institute of Social History, see above.) A carbon copy of this text is found in 2. More copies of these texts are found in 59. (For details on the contents, 
see Erik-Jan Zürcher, "Two Young Ottomanists Discover Kemalist Turkey. The Travel Diaries of Robert Anhegger and Andreas Tietze", in Jan Schmidt, ed., Essays in Honour of Barbara Flemming II (Harvard University 2002), pp. 359-369).

More materials on Anhegger's early life are found in 11. It contains a German Ahnenpaß, printed at the Zentralverlag der NSDAP, Munich, with 27 entries on Anhegger and his ancestors, sealed and stamped by the Zivilstandamt, Zurich, 14 April 1942; a Meldungsbuch of the University of Vienna, with a photograph of Anhegger and entries dated 1932 (it contains a congratulatory telegram dated 1928, and a Zeugnis issued by the Deutsche Schule in Rotterdam, 1920); an exercise book with geological notes, entitled Exkursionsbericht, with a German text and drawings by Anhegger, undated; an exercise book with various annotations, among them diary entries dated 1926 and three photographs, among them of the German School in Rotterdam with pupils including Anhegger, 1921; nine school exercise books on various subjects; a Zeugnis issued to Anhegger by the Kantonsschule Zürich, with reports dated 1926-1931, with some attached documents; a typed essay written for the German Seminar [of Zurich University?] entitled Die Menschendarstellung bei Ibsen, 1 December 1933 (30 pp.); a copy of a letter concerning a family reunion, Kempten, 18 January 1994; an envelope containing three postcards and three copies of a letter with reviews in Turkish by five Swiss professors praising Anhegger's Alt- und Mittelhochdeutsches Lesebuch. Eski Almanca antolojisi, 800-1500 (Istanbul 1945), 1946. (Another copy is found in 14); a plastic folder containing nine postcards, with texts in Polish and German concerning the dispatch of food parcels, addressed to Dr. S. Lisie (Suria Gitla Lisie, Anhegger's first wife) in Istanbul and sent through the Jewish Council of Elders by family members in Sosnowitz, Gallicia, 1941-1942 (included is a typed note); a tenth postcard in French was sent from Buchara, 20 November 1941.

Anhegger's dissertation on the mining industry in the Ottoman Empire and his work on it is documented in 9. It contains a part of a typed draft copy of his Beiträge zur Geschichte des Bergbaus im Osmanischen Reich (2 Vols., published in the series Istanbuler Schriften, Nos. 2 and 14, Istanbul 1943 and 1944). In 16 there are two pages of the dissertation and a photocopy of an Ottoman document, headed Kānūn-i ma'ädin-i şehr ..., with a typed transcription. Photographs and transcriptions of Ottoman source texts used for his dissertation are also found in 35.42 contains fragmentary annotations; there is also some material related to Anhegger's work as teacher at the Yabancı Diller Okulu at Istanbul University (reports on progress of individual students); and a notebook with an entry for 1936 . 
Anhegger's interest in the fate of Turkish migrant workers in Germany and the Netherlands in the 1970 s and 1980 s is represented in 6, which contains a typed letter from the publisher C.H. Beck to the co-authors of a book, Gastarbeiterkinder aus der Türkei, Munich, 14 October 1982 and a copy of a presentation in Dutch on the occasion of an exhibition entitled 'Allochtone vrouwen informeren autochtone vrouwen' (undated, 3 pp.). Various papers, mostly in English, document a meeting on the subject 'Solidarity with Turkish Artists', organised by the Nederlands Turkije Komitee voor de Verdediging van Mensenrechten en Demokratie, Amsterdam 30 March 1983. In 7 we find a copy of the Turkish journal Tarih ve Toplum, 21 September 1985, which contains an article by Anhegger 'Almanların Türkiye'ye Göçü' (pp. 57-63) and a plastic folder containing a typed draft of 'Deutsche Auswanderer in die Türkei', and a brochure of the Türkisch-Deutsches Kulturinstitut (TürkAlman Kültür Merkezi), Istanbul 1987, with an article by Anhegger on the history of the institute. More materials on this topic are found in 12, which contains a collection of Dutch, German and Turkish journals, newspaper cuttings, reports, exhibition brochures, draft manuscripts, letters and notes, mostly on the Turkish community in the Netherlands and other countries of western Europe. Notable are also a typed copy of an essay by Anhegger: 'Çocuk ve Gençlik Kitaplıklarına düşen yeni görevler' (9 pp.); a carbon copy of a note by Renke Korn, 'Handlungsentwurf für die Reise des Engin Özkartal von Nevşehir nach Herne und zurück' (4 pp.), with a plastic folder containing papers on the same subject; various drafts of Turkish and translated poems; three copies of typed essays in Turkish by Özcan Öktem on problems regarding the education of Turkish children in Germany; a copy of a typed essay in Turkish by Oya Baydar on the history of the workers' movement in Turkey; a photograph of Nevzat Çelik and his mother (who, accused of murder, was jailed in a military prison in Metris, Istanbul - see also 13, 20, 27); and a copy of a typed note in German by Haldun Taner on Anhegger an the exhibition 'Kinder- und Jugendbücher der Türkei' in Munich (2 pp.). In 20 we find papers concerning a conference Kultur im Migrationsproze $\beta$ held in Bochum (1980-1981); copies of various brochures and journals, including Bizim Almanca. Unser Deutsch 19 (1986), with an article on Anhegger, pp. 14-16; copies of Dutch translations of poems by Nevzat Çelik and his mother, with a photograph and notes (see also above); and papers concerning a conference (Deutsch-türkische Tagung) held in Ankara in 1991. 22 contains a large collection of, mostly, autobiographical texts in, mostly, Turkish, both hand-written and typed by migrant workers residing in Germany, 1976. These texts were, it seems, written in response to a writing contest entitled Iş̧̧̧iler İ̧scilere, initiated by 
Radio Cologne. More materials on these matters are found in 31, 33 (in particular, on Turkish migrant workers in Germany and courses in the German language), 37 (documents on the Türk-Alman Kültür Merkezi, from 1959, a Wettbewerb concerning Turkish children in Germany and various other papers), 38 (various materials on the Türk-Alman Kültür Merkezi), 51, 54 and 57.

Related to this topic, was Anhegger's interest in Turkish (folk) poetry, theatre and (folk) music. 15 contains a copy of an inventory with titles of 'classic' Ottoman songs, with names of musicians and music groups, and an essay in Turkish on 'classic' Turkish music, both by Meliha Doğuduyal; various leaves with hand-written and typed copies of Turkish poems/songs and German translations, with a few accompanying documents; a green cardboard folder with miscellaneous papers: manuscripts, photocopies of articles, notes etc. on grammaphone records, and Turkish folk literature and street theatre, with texts in Turkish by Meddāḥ Sürūrī, and draft manuscripts by Anhegger for his presentation 'Die Frau von Karagöz will Advokatin werden. Alte Platten (Drehung 78 ) als Hilfsquellen für die Sozialgeschichte der Türkei', Istanbul 1989; a plastic folder with miscellaneous materials mostly transcribed texts and German versions of songs by migrant workers; a typed copy of a biography of the singer Ruhi Su (in German, 2 pp.). 18 contains a cardboard folder with a separate file with materials on the Turkish shadow theatre (Karagöz): photocopies, photographs, letters (regarding a lecture by Anhegger on the subject at the Toneelmuseum in Amsterdam, May 1973, and the manufacture of Karagöz puppets for the Museum voor Land- en Volkenkunde, the present Wereldmuseum (cf. above), in Rotterdam, 1981) and manuscripts; a transcript of a film with fragments of Turkish Karagöz dialogues and interviews held with Anhegger and Andreas Tietze on the subject, with accompanying letters from Manfred Blank Filmproduktion, Berlin, 1991. More on these matters is found in 20, which contains manuscripts, photocopies of texts in Dutch, German and Turkish, and annotations concerning migrant workers' poetry; notably also: a copy of 'Einige persönliche Bemerkungen zu Yunus Emre' by Anhegger (2 pp.); 27 contains materials related to, mostly, Turkish music and musicians: brochures, photocopies, newspaper cuttings, file cards, drafts of translations of songs, newspaper cuttings on Nevzat Çelik's hungerstrike in 1987 (see also above), photographs of grammophone records, journals (among them Tarih ve Toplum 86 and 87 (1991) — which include a serial contribution by Anhegger entitled 'SözlüTaş Plaklar'); a typed copy of a presentation by Anhegger, 'Kunstmusik und Volkslieder in der Türkei'; and a schematic survey of the development of grammaphone records and record companies in Turkey, 
1897-1931. Various manuscripts on Karagöz are found in 53. A collection of cassette tapes is in found in $\mathbf{5 8}$.

In the 1980s, Anhegger became interested in Karamanlıdika: books with Turkish texts written in the Greek alphabet produced by the Greek-Ortodox Turcophone communities in Anatolia and Istanbul from the 18th century onward. Anhegger collected Karamanlı books (these are now in the Leiden library - an inventory is found in Jan Schmidt, 'Robert Anhegger and his Bequest in the Leiden University Library', forthcoming), wrote articles on the subject and, together with Vedat Günyol, edited Evangelinos Misiailidis's long picaresque novel, Temaşa-i Dünya ve Cefakar u Cefakeş, ('The Theater of the World-Those Who Torture Themselves and Those Who Are Tortured by Others'). It appeared in Istanbul in 1986 under the more palatable title-palatable for modern Turks, that is—Seyreyle Dünyayı ('Look at the World'). A second, improved edition came out two years later. Materials on this topic are found in 21, which contains photocopies of draft manuscripts by Anhegger of articles about the Karamanlı language and literature and materials about the novel. 25 contains more materials on the edition of the novel. Various materials, such as parts of manuscripts, (offprints of) journals, photocopies, related to Karaman (Cappadocia) and its inhabitants are found in 47 .

In the 1990s Anhegger became interested in relations between the Ottomans and Protestant Europe in the early modern period. 10 contains newspaper articles, an off-print, correspondence and photocopies of texts, including an archival document, and hand-written notes concerning the life of Johann Jakob Redinger of Zurich (1619-1688), a linguist who undertook a mission to the Grand Vizier Aḥmed Köprülüat the Ottoman army headquarters at Uyvar (Újvár, Hungary), predicting the conversion of the Turks to Christianity, in 1664; and draft copies of an article, entitled 'Redinger bei den Türken'. In 19 this subject is elaborated. It contains, apart from a newspaper cutting, some letters and an off-print, notably, a photocopy of Extremos y Grandezas de Constantinopla by Rabi Moysen (Madrid 1638); photocopies of 17 th-century manuscripts with texts in Latin and German, among them letters by Amos Comenius and Jakob Redinger; a photocopy of a chapter on Comenius by Fr. Zollinger; and a copy of the journal Toplumsal Tarih 10 (1994).

During varying periods of his life, Anhegger was engaged with studies on yet other topics; these include: the history of the Balkans and Ottoman architecture found there $(14,31,44,50$ : contains correspondence with Wittek on inscriptions, 1972-1973); mystical orders such as those of the Mevlevi's and Bektaşı's $(\mathbf{2 8}, \mathbf{3 1}, \mathbf{4 9})$; the history of Ottoman architecture 
(32-40, 41 and 43) contain mostly black and white photographs with some negatives, and picture postcards, of, mostly, mosques, inscriptions and tomb stones, accompanied by annotations and drawings, arranged according to place-name but undated; indirect evidence points to the 1950s, when Anhegger published three articles on Ottoman architecture ('Beiträge zur (früh)osmanischen Baugeschichte') — a fourth was published in 1967-50: contains four folders with, mostly, photographs and picture postcards in no conspicuous order of, again, mostly mosques; there is also some personal material: a picture postcard sent to Anhegger by his father in May 1937 from Mostar and a photograph of a 'Gabelfrühstück mit Hasan' at Isparta with Çupi (nickname of Anhegger's first wife); there is also a hand-written list of Ottoman buildings found in the Balkans arranged according to placename, and referring to photographs, by Machiel Kiel; 51: contains drafts of publications on Ottoman architecture with drawings by Mualla, Anhegger's (second) wife; 56 : photographs and related materials as in 51 ; the Bursa Mint (39: various annotations, drafts of a publication and copies of Turkish texts, mostly archival documents, 48: a collection of photographs of archival documents); porcelain (44: concerns the collection in the Topkapı Palace). 7 contains a copy of a paper entitled 'Die Doğan-Appartements in IstanbulBeyoğlu [where Anhegger and his wife lived during the final decades of their life]. Ein Beitrag zur Stadtgeschichte Istanbuls', presented on 9 April 1992.

Of interest are also: various copies of the journal Teutonia dating from the 1950s (in 36); a part of a printed Ottoman tefsir in 46; and a collection of late Ottoman Zigarettenumschläge (cigarette paper booklets), accompanied with coloured slides and photographs, in 55 (the collection was described by Anhegger himself in 'Eski sarma sigara kağıdı kapakları', in Tarih ve Toplum 1 (1985), pp. 176-184; 248-255). 


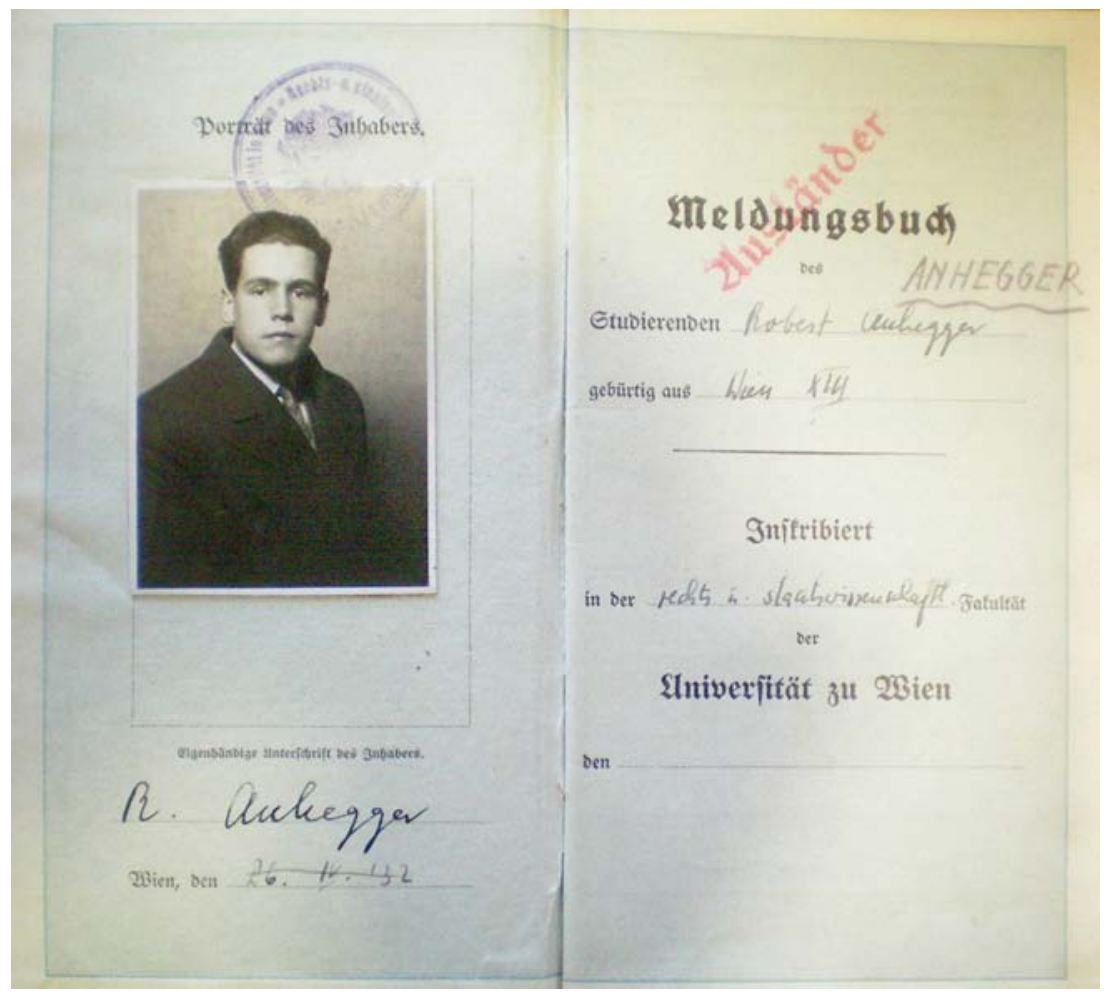

Figure 39. Leiden, UB Anhegger 7(11). Meldungsbuch (certificate of enrollment) issued by the University of Vienna in 1932, with photograph of Robert Anhegger. 


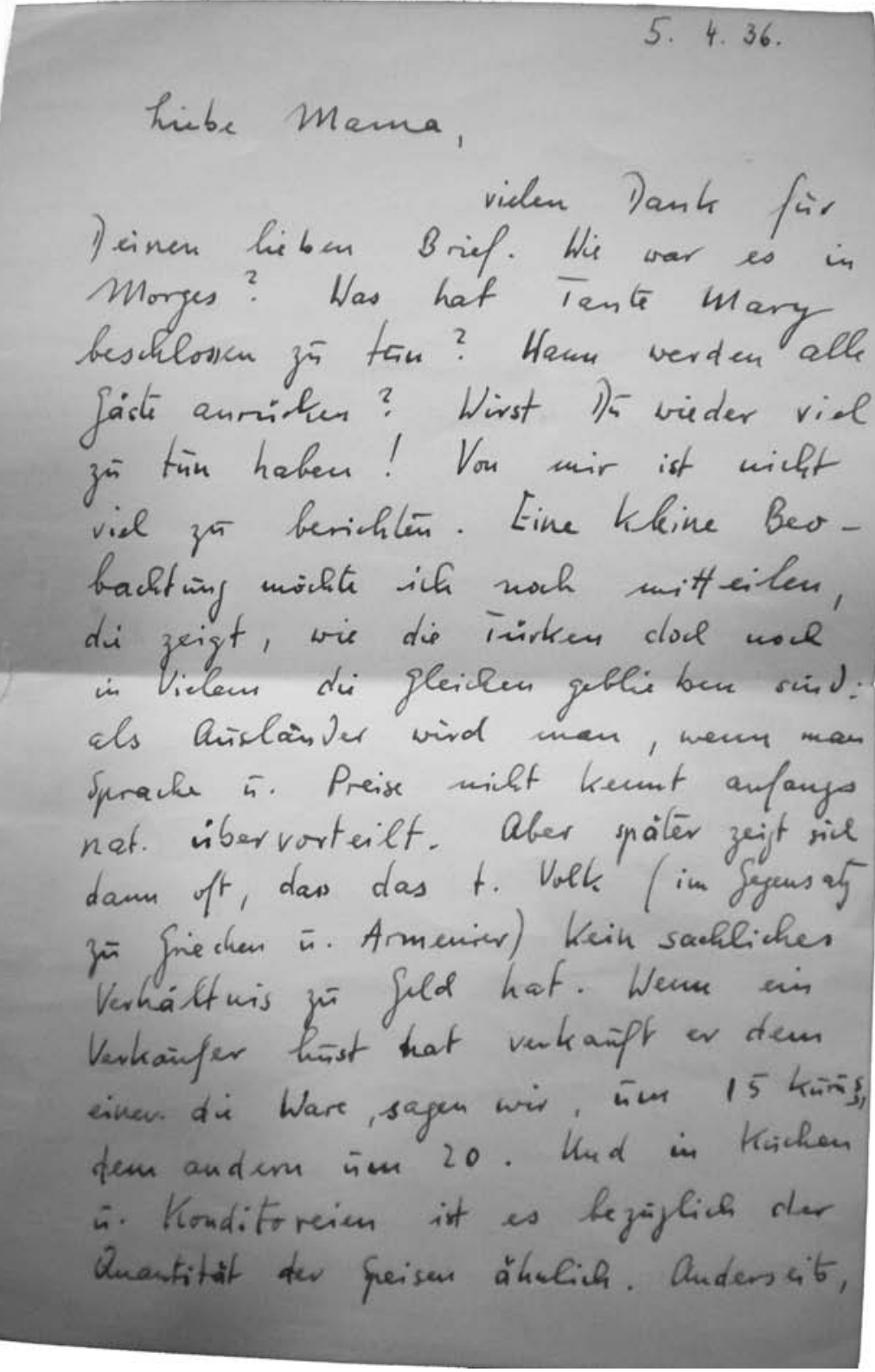

Figure 40. Leiden, UB Anhegger 7(13). First page of a letter from Robert Anhegger to his mother, dated 5 April 1936. 


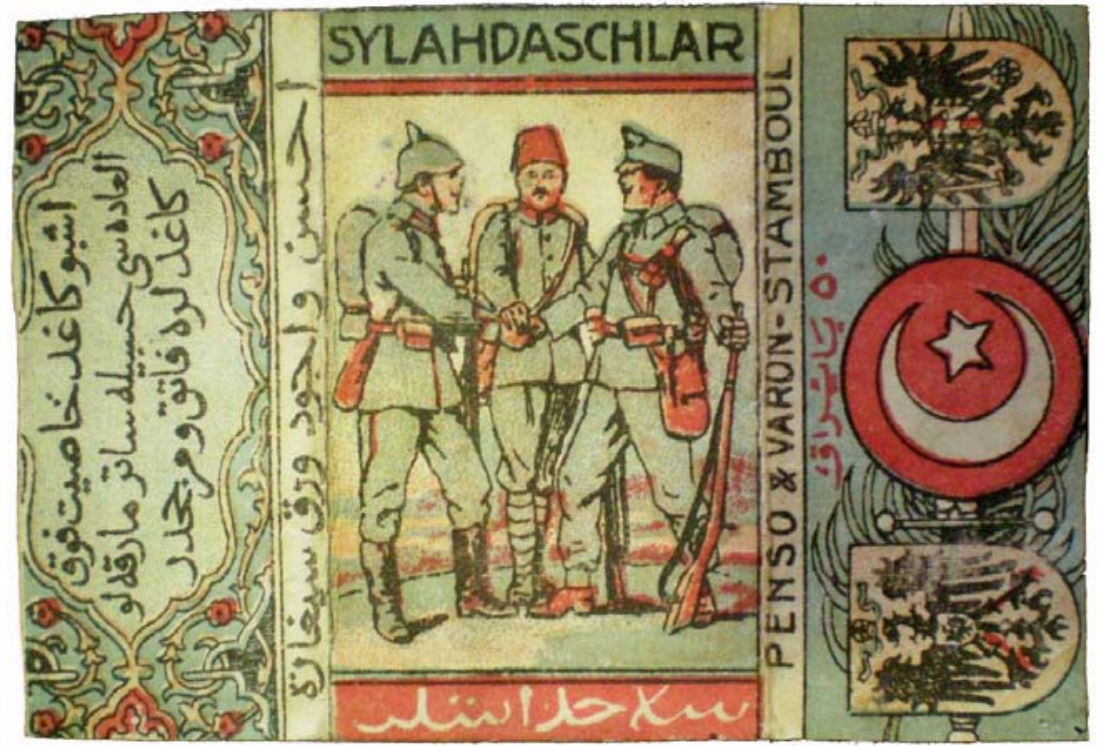

Figure 41a-e. Samples from the collection of late Ottoman cigarette paper booklets, depicting Nasruddin Hoca, a hare (Ch. Dragonis), 'brothers in arms' (silahdaşlar, Penso \& Varon), Hindenburg (Samir Sarrafoglu) and weightlifters.

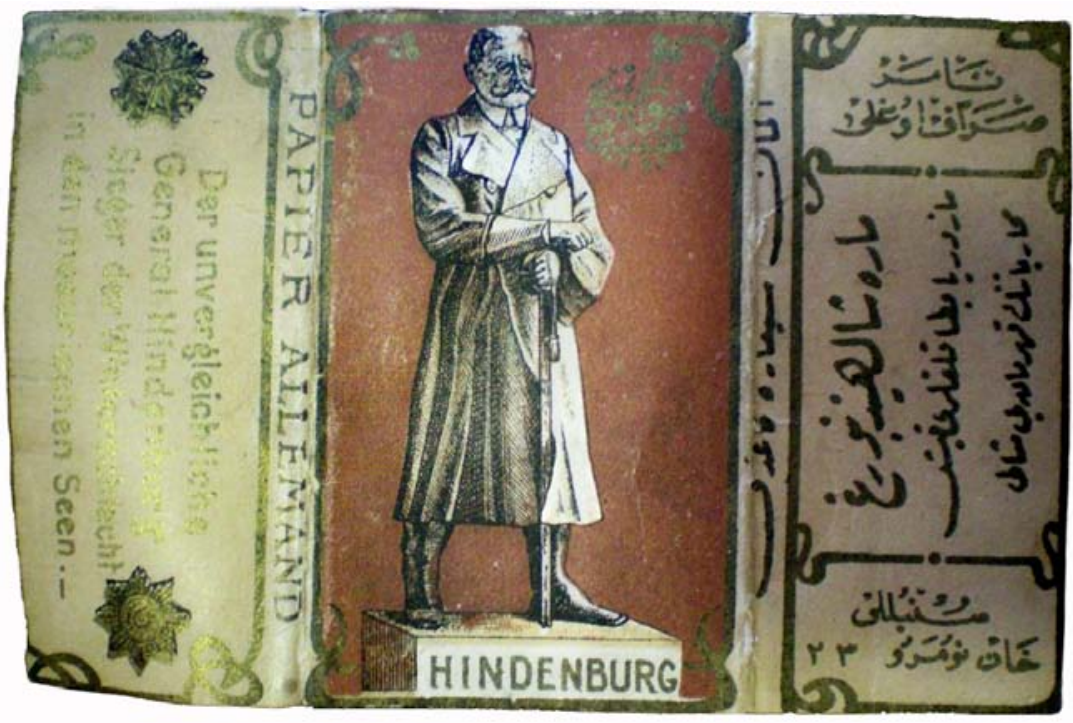

Figure $41 \mathrm{~b}$. 


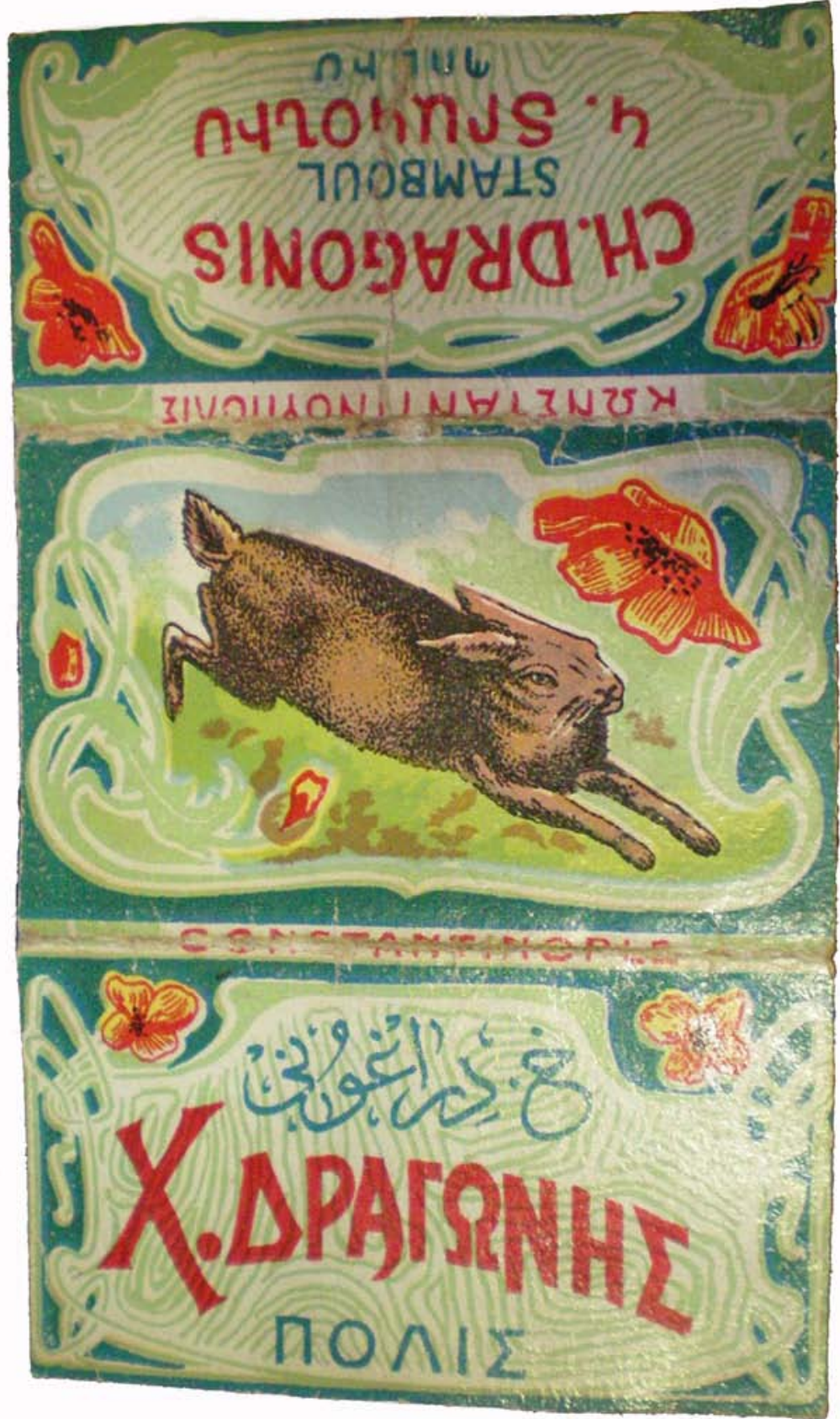

Figure 41c. 


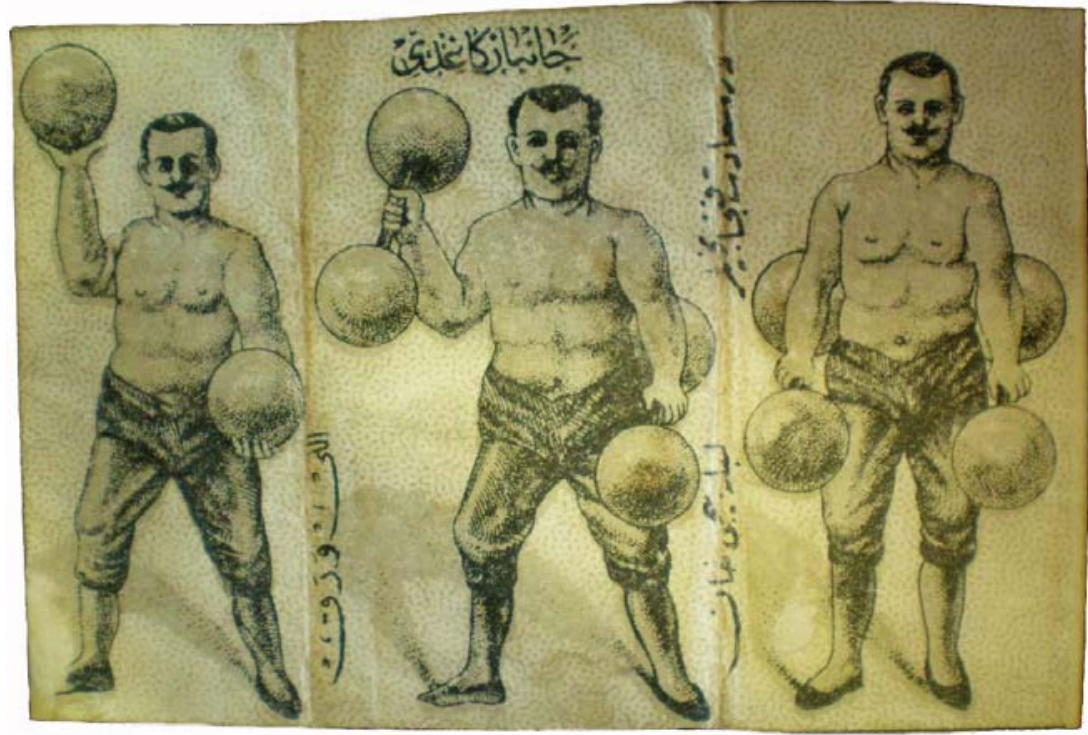

Figure 41d.

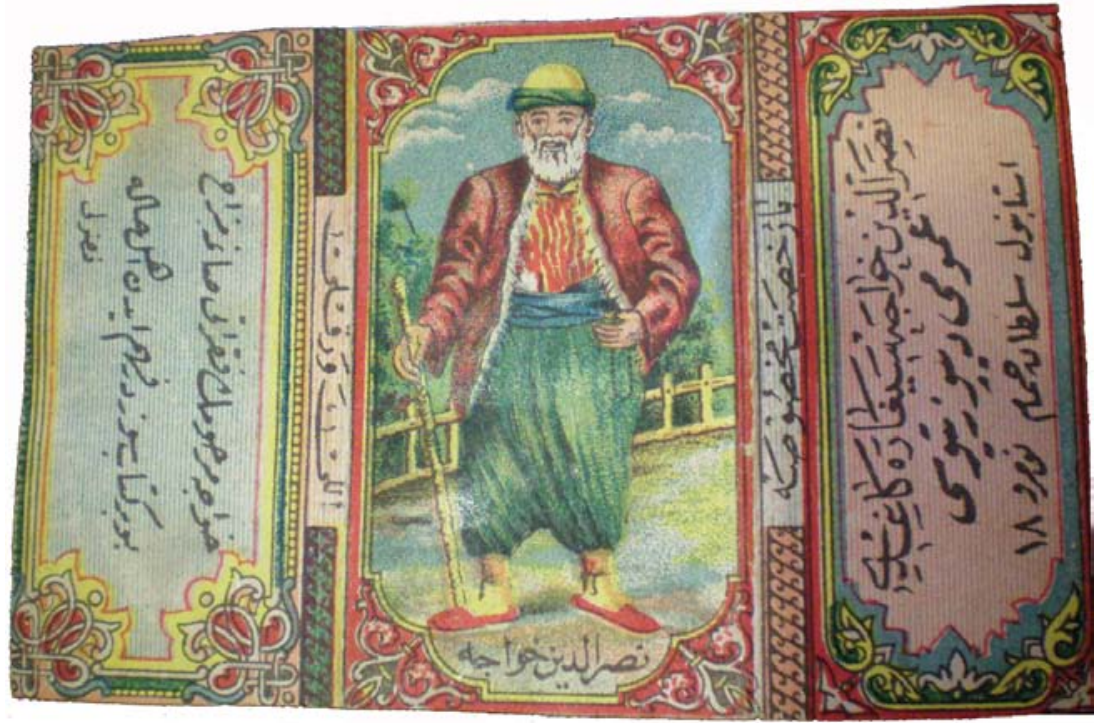

Figure 41e. 


\section{CHAPTER THIRTEEN}

\section{ROTTERDAM, MARITIEM MUSEUM \\ (MARITIME MUSEUM)}

\section{Address: Leuvehaven 1}

The museum had its origin in the collection of the Royal Dutch Yachting Club (Koninklijke Nederlandsche Yachtclub) in Rotterdam, to which was added a substantial private collection of objects related to navigation and shipping gathered by Prince Hendrik, son of King Willem II of the Netherlands and in function as navy officer in various ranks (1820-1879). In $185^{2}$ this collection, mostly consisting of ships' models and housed in the models room at the Willemskade in Rotterdam, was displayed in exhibition for members of the club. The collection, continually expanded since, became fully public in 1874 . It moved to a separate building, which it heretofore had shared with the Ethnographic Museum (see the introduction to the next chapter), in 1948. The Maritime Museum is the oldest of its kind in the Netherlands. Its collection includes a few documents and manuscripts connected to travel and navigation in the Ottoman Empire.

Literature: Schatkamer der scheepvaart. Honderd jaar Maritiem Museum 'Prins Hendrik' Rotterdam 15/2-10/6 1974 (Rotterdam 1974), pp. 7-64; Joh. Diepraam \& Onno Meeter, De bel luidt over 't water. Het Nationaal Scheepvaartmuseum in Antwerpen en het Maritiem Museum 'Prins Hendrik' te Rotterdam (Amsterdam 1988), pp. 51-61; Leo M. Akveld, Magnifiek Maritiem. Voorwerpen uit het Maritiem Museum 'Prins Hendrik' vertellen hun verhaal (Amsterdam 1992), pp. 8-12.

\section{H336(3)}

A passport

The passport consists of a sheet of white paper, $430 \times 270 \mathrm{~mm}$, with printed text in French on one side, to which data are added in handwriting. The document, on which a large Dutch coat of arms figures prominently, was issued to the navy officer Jean Anne Vening (1843-1893, cf. NNBWV, col. 998) at Leeuwarden on 23 May 1870 for a journey to the Ottoman Empire, Greece, Italy, the Papal States, Austria and elsewhere. To the pass are 


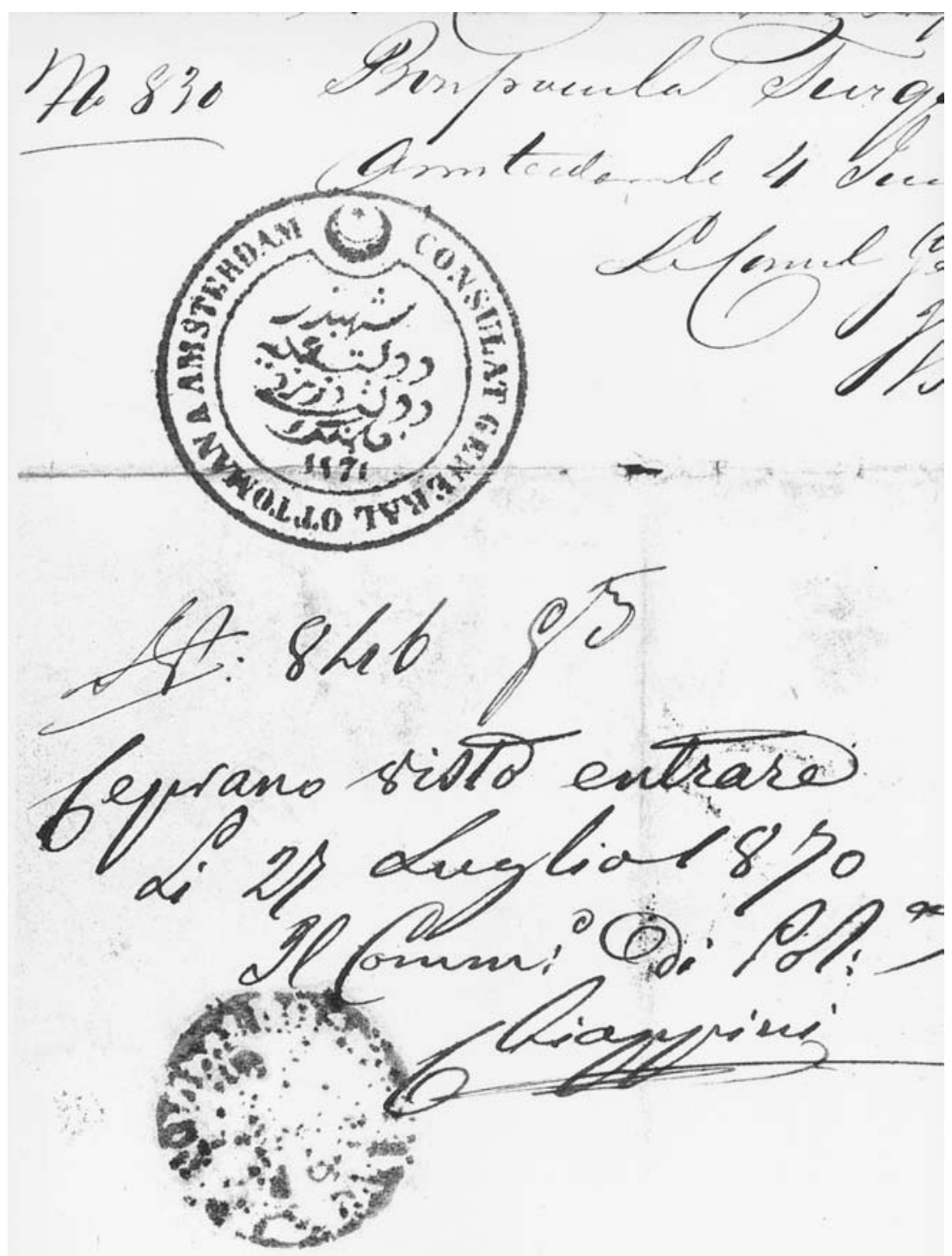

Figure 42. Rotterdam, Maritiem Museum H336(3). A visa with a stamp of the Ottoman Consulate in Amsterdam on a passport issued to a Dutch Navy officer, dated 4 June 1870 . 
added nine visas, handwritten in French and Italian, and furnished with stamps, granted in Amsterdam, Istanbul, Rome, Naples and Geneva. On the back, top right, is a visa issued by W. Pomo, Ottoman consul-general at Amsterdam, dated 4June 1870. A stamp with the Turkish text şehbender-i devlet-i 'aliye nezd-i devlet-i Felemenk and the year 1261 [1845] is added.

The passport is part of a small collection of private papers, eleven items dated 1869-1890, donated by Mrs. Kraaiveld, The Hague.

\section{H639}

\section{An Ottoman signal book}

The early 19th-century manual for signals used in the Ottoman Navy, designed and filled in by one scribe. It consists of four main parts: (1) a table with coloured pictures of flags with corresponding numbers (p. 11) and the year 1246 (1830-1831); (2) a list of ships, with indications of type and names, numbered 10 to 45 (pp. 12-13); (3) a survey (pp. 16-260) of the meaning of number codes, from 1 to 4885 , divided into sections according to subject as indicated both in Turkish, and, often, in French, beginning with the geographic directions (cihān erba'a rüzgārları gelmek gelinmek yol verüb ejglendirmek hușūṣı / vents principaux du partir et venir ainsi que de rester)-begins: 1. gel, 2. gelsün-and signals related to lying idle (kıyām hușūṣı / affaires de rester, de station — the first entry reads: 101. ḳalkmaġa hà żir ol) to warfare and the passing of islands (baćz-i cezireniñ üstünden ve altından yolverilmesi husūṣsı), followed by a table of the letters of the alphabet, numbered 1-20 (p. 26o); (4) a survey of the number codes of signals given by lighthouses, divided into chapters ( $b \bar{a} b)$; it begins: [fenār 'alāmet] 1. [fenūr işāret] 1/1. rūzgār üstünde olan gemi yāhud gemilerile kendünizi bildirin zī rātop atacaġım çabuk olun (pp. 338-369). The section ends with a survey of the signals particular for the subsequent ships, ending (p. 369) with 2/1 1/1 fırkateyn Şāğır Tunisī. Many pages have remained blank. An owner's inscription of Brusavizāde Hüseyn Hōoca is found on f. 1a. Annotations in Russian are found on p. 1. A few financial notes, one with the place-name of İskenderun, occur on the inner front-board and p. 1. A pencil note (Signal Book in Arabic) is found on p. 8.

Bound in boards, with red leather back; white glazed paper; 378 pages; $265 \times 192 \mathrm{~mm}$ and $223 \times 140 \mathrm{~mm}$; 20 lines; $r k^{\prime} a$; multiple black borders and lines; (Turkish) headings and numbers mostly in red; see also above. Origin unknown. 


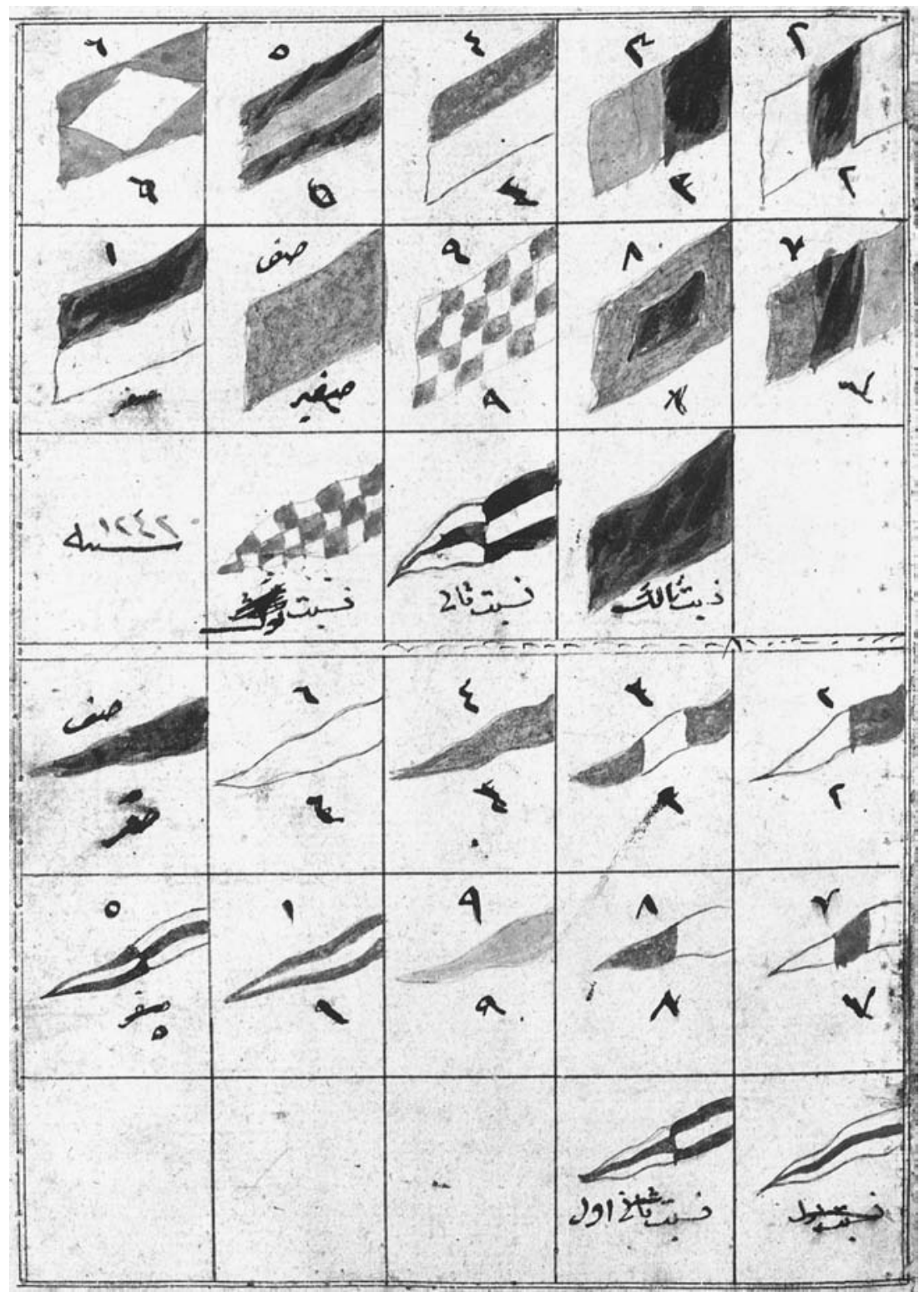

Figure 43. Rotterdam, Maritiem Museum H639, p. 11. Flags depicted in an Ottoman signal book, early 19th-century. 
262

CHAPTER THIRTEEN

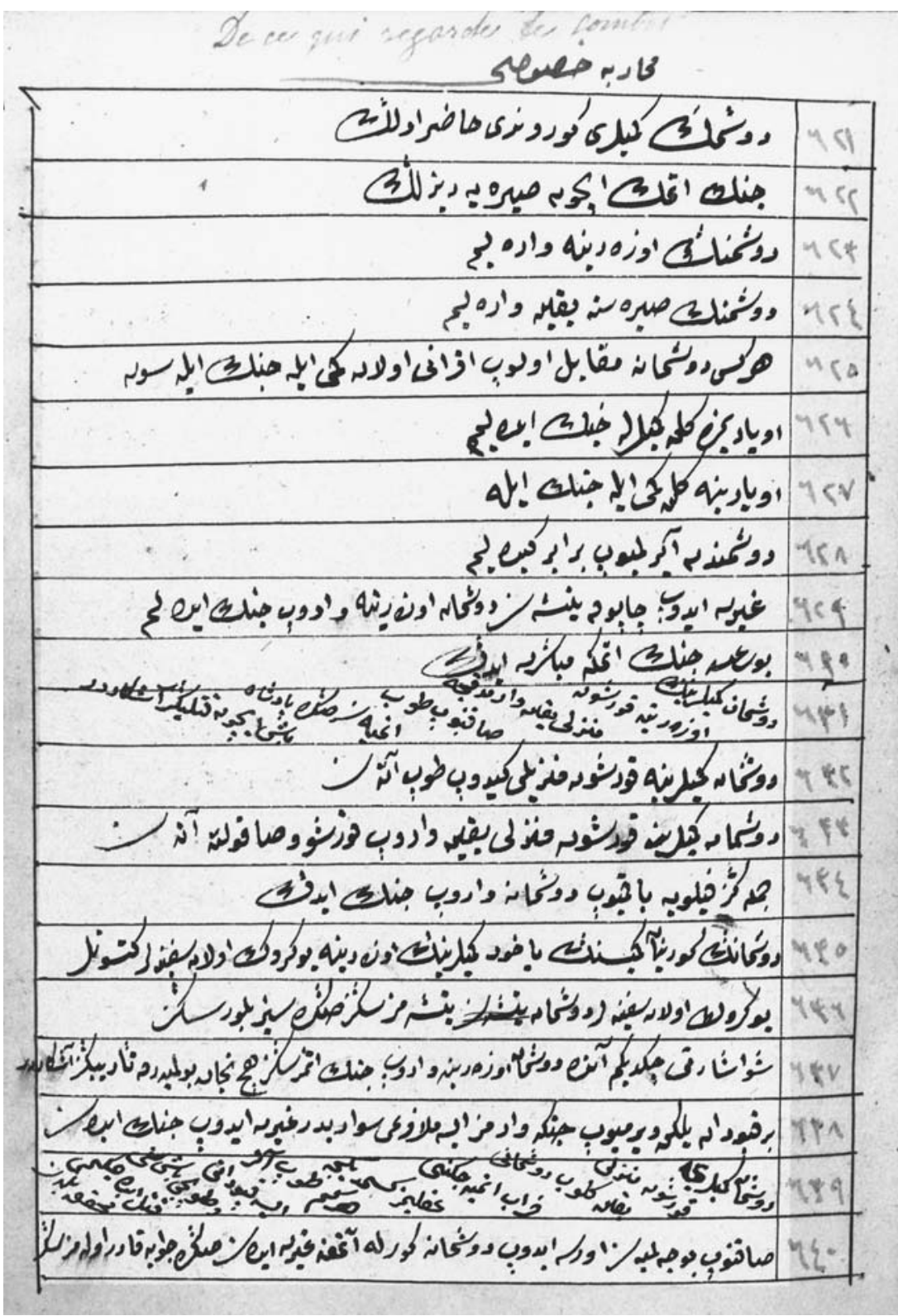

Figure 44. Rotterdam, Maritiem Museum H639, p. 47. A page of an Ottoman signal book with explanations of number codes, early 19th-century.

Jan Schmidt - 978-90-04-22191-8

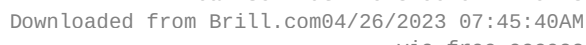

via free access 


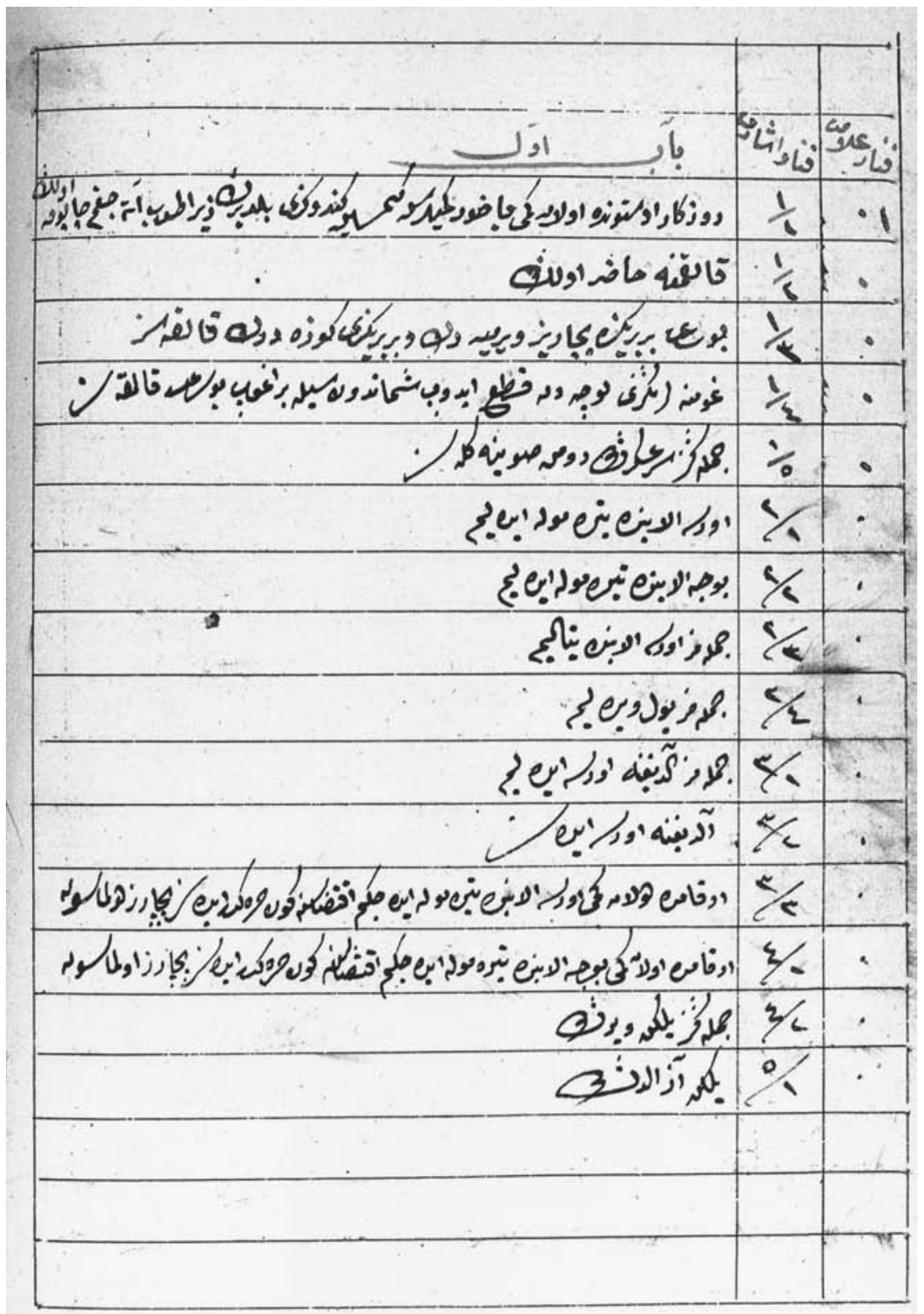

Figure 45. Rotterdam, Maritiem Museum H639, p. 338. Lighthouse codes with explanations found in an Ottoman signal book, early 19th-century. 


\section{P2316}

A passport

An original copy of a hükm-i şerīf (fermān), accompanied by a Dutch translation. The document was a letter of safe-conduct issued to Captain Metz, commander of the merchant steamer (tüccār vapur sefinesi), Fop Smit (see for a picture, Stoomvaart Maatschappij Rotterdamsche Lloyd 15 Juni 18831908, Rotterdam 1908), on request of the Dutch envoy to the Porte for a journey from Istanbul to the Black Sea; the captain was to pay a selamet resmi of 300 akçe on entering the Black Sea. It is dated 4 Rebïü l-ähir 1289 (11 June 1872). The text is headed by a tugra of Sultan 'Abdul'azìz (cf. Umur, pp. 302-305). Signatures are found below the text and on the back.

Worn cream paper which has undergone conservation treatment; $600 \times$ 480 mm; 3 lines; bold dìvānì. The Dutch translation: cream paper; $195^{\times}$ $135 \mathrm{~mm} ; 14$ lines.

Donated by H.H. Theunissen in 1926. 


\section{CHAPTER FOURTEEN}

\section{ROTTERDAM, WERELDMUSEUM \\ (WORLD MUSEUM)}

\section{Address: Willemskade 25}

The museum, until recently named Museum voor Volkenkunde, was founded in 1884 and housed in the Rotterdam Yachting Club (see the introduction to the previous chapter). The collection which consists mostly of objects of great variety, including photographs, was based on donations and loans of private collectors, among whom the merchant and consul, A.P.H. Hotz (see on him Leiden, UB Hotz collection, above). The collection has slowly expanded ever since and a separate Department of Islamic Culture was founded in 1966. The collection comprizes a few manuscipts with texts in Arabic and Turkish, among them a number of Korans, as well as some miniatures produced in various countries in Asia, among them also the Ottoman Empire. The Arabic manuscripts, apart from devotional works, comprise a small booklet demonstrating the use of the Arabic alphabet, of the type used in primary schools (No. 8648), and a collection of calligraphic examples, bound in a magnificent dark brown leather cover illuminated with floral motifs in gold (No. 64216), not further described here.

Literature: Schatten van het Museum voor Volkenkunde Rotterdam (Rotterdam 1987), pp. 9-11; A.F. Ros, "Opbouw en samenstelling van de collectie Islamitisch Cultuurgebied”, in: Dromen van het Paradijs, Islamitische kunst van het Museum voor Volkenkunde Rotterdam (Rotterdam 1993), pp. 17-27.

60948

\section{A miniature}

A leaf of glazed, cream paper, $220 \times 160 \mathrm{~mm}$, with a multicoloured miniature depicting the murder of the early Caliph 'Alī by Ibn Muljam, accompanied by two text fragments in Turkish. It was taken from a copy of the popular martyriology, Hadịkat es-su'adā, by Fużūlī (d. 963/1556), see for copies of this work, Leiden, UB Codices Or. 508, 12.437 and 14.367. It was possibly produced in Baghdad in the late 16th century. A coloured plate and a description is found in B.H. Flemming, "Turkse religieuze miniaturen en albumbladen", in Dromen van het Paradijs, pp. 86-95. Purchased in 1970. 


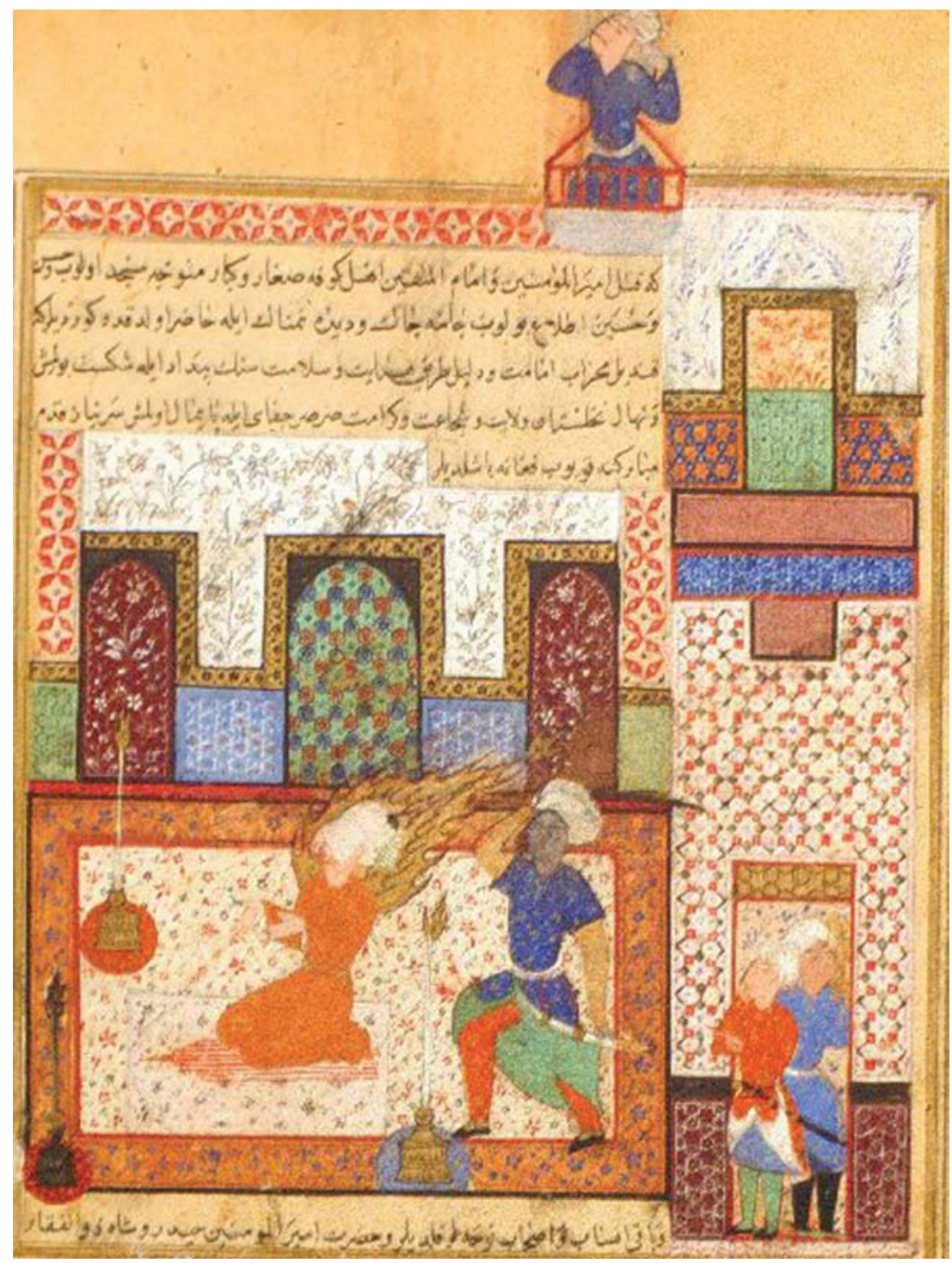

Figure 46. Rotterdam, Wereldmuseum 6o948. A miniature depicting the murder of 'Alī by Ibn Muljam, 16th century, taken from Fużūlì's Hadīkat es-su'adā. 
Two leaves of white paper, $425 \times 275 \mathrm{~mm}$, originally part of an album or larger collection, with multicoloured paintings of, respectively, a Kalenderī dervish and a șüfi. The figures are accompanied, at the bottom, by flowers. The words kalender and șüfi are written at the top; the names of the flowers are added too. They were produced by one artist, probably in the Ottoman Empire in the 18th century. Coloured plates and descriptions are found in B.H. Flemming, "Turkse religieuze minaturen en albumbladen", in Dromen van het Paradijs, pp. 86-95. Purchased in 1972 from an Iranian art dealer, Saeed Motamed.

\section{5}

\section{'Ahdnāme}

An original copy of a treaty granted by Sultan 'Osmān II to the Venetian Republic through her ambassador, Almoro Nani, in 1027 (1618), thereby reconfirming the earlier treaties of 1517 and 1603 . The text is preceded by a magnificent tugra illluminated with exuberant floral patterns in gold, red and blue.

Glazed white paper; $460 \times 303 \mathrm{~mm}$; dìvānī. Purchased in 1972 .

Catalogue entry: Schatten van het Museum voor Volkenkunde, pp. 121 and 155, with a coloured plate and a description by Alexander H. de Groot.

Literature: Gabriel Noradounghian, Receuil d'actes internationaux de l'Empire Ottoman I (Paris 1897), p. 43; Halil Inalcık, "Imtiyāzāt", in $E I^{2}$.

\section{6}

\section{Silsile-nāme}

A paper scroll with a pedigree of the Halvetīye shaykhs, Șāliḥ Efendi of Üsküdar and Meḥmed Efendi 'Āşı ̣a Paşalı, dated 1154 (1741-1742). It goes back to the Prophet Muhammad, 'Alī and the founder of the order, Sayyid Yahyā Shirwānī (d. in Baku in 1464), and ulimately to God and the angel Gabriel, whose names head the pedigree in separate circles. These are preceded by an introduction in Arabic, ending with the line der beyān-i ma'rifet-i silsileti ehl Allāh min zamān resūl Allāh ilā zamānināa; the word silsile-nāme is not expressly mentioned on the roll. The pedigree, mentioning a great many 


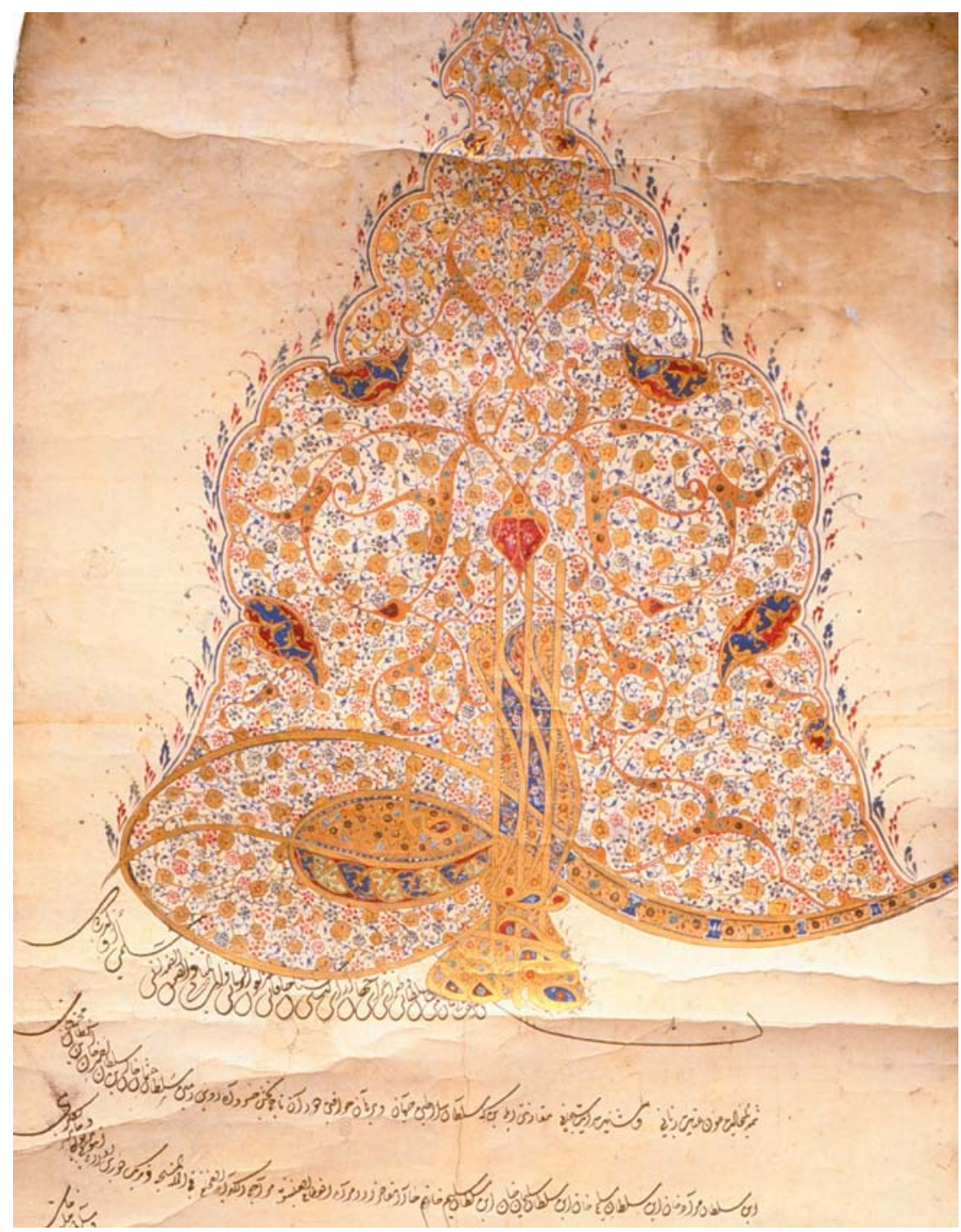

Figure 47. Rotterdam, Wereldmuseum 63215. The upper part of a copy of the 'ahdnāme of 1027/1618, granted to the Venetian Republic.

shaykhs, is accompanied by explicatory texts, often with biographical data, in Turkish. Additional notes in minute Turkish, in a less refined small script, have been added in some places since, at least until 1218 (1803-1804). The pedigree proper ends in an empty circle. Added at the bottom is a series of names in circles, headed Sultān Uways el-Qaranī [the popular saint and 
semi-legendary companion of the Prophet, cf. J. Baldick in $\left.E I^{2}\right]$. The roll lacks a colophon, so we do not know who designed the pedigree.

Glazed white paper, $7700 \times 280 \mathrm{~mm}$, text in various nashī hands; circles and lines in gold, red and black; a magnificent headpiece with floral motifs in, mostly, gold and blue. Purchased in 1982.

Catalogue entry: Schatten van het Museum voor Volkenkunde, pp. 123 and 156, with coloured plates.

Literature: Jan Schmidt, "Een Osmaanse silsila-nāmeh", in: Dromen van het Paradijs, pp. 80-83.

70935

Dìvān

An undated copy of the first pages of the collected Turkish poems of Meḥmed b. Süleymān who used the pen-name of Fużūlì (d. 963/1556). The text is preceded by a title page (1a) which presents a part of the first line of the introductory text in prose and verse which is found in complete copies, to which the words $\dot{g} a z e l \bar{y} y \bar{a} t$ and the name of the poet are added. (For a copy of the collected gazel, see Leiden, UB (Addenda) Or. 26.265, above.)

Two unbound quires of two folded leaves each; glazed cream paper; 8 folios; $270 \times 160 \mathrm{~mm}$ and $155 \times 90 \mathrm{~mm} ; 12$ lines; catchwords; calligraphic nesta lïk; a magnificently illuminated title page (1a), with a text in white against a golden background; text framed in gold with illuminations of multicoloured floral on ff. 1b-2a; rubrics and triple dots in red; occasional illuminations with multicoloured flower motifs between verses; multiple borders in blue, red, black, gold, green. Acquired in January 1990.

Text on the title page (1a, as in Gölpınarlı's edition, p. 1):

$$
\text { غزليات و الشعرا يتهم الغاوون مستغرق كرداب حرمان ايتشكن سلسلة استيثناء فضولى }
$$

It is followed by the remaining part of the first line (2a, as in Gölpınarlı's edition):

$$
\text { الا لذين آمنو برقوب شعراء اسلامى صحيح و سالم ساحل نجاته هكمش ... }
$$

Ends (8b, as in Gölpınarlı's edition, p. 12):

شعر ماتم حساد الكلام عظمت *صيرتهم محض الدلالتى [فى] الملا *تضيع و مراعات الصنايع بينهم [تسدد] 


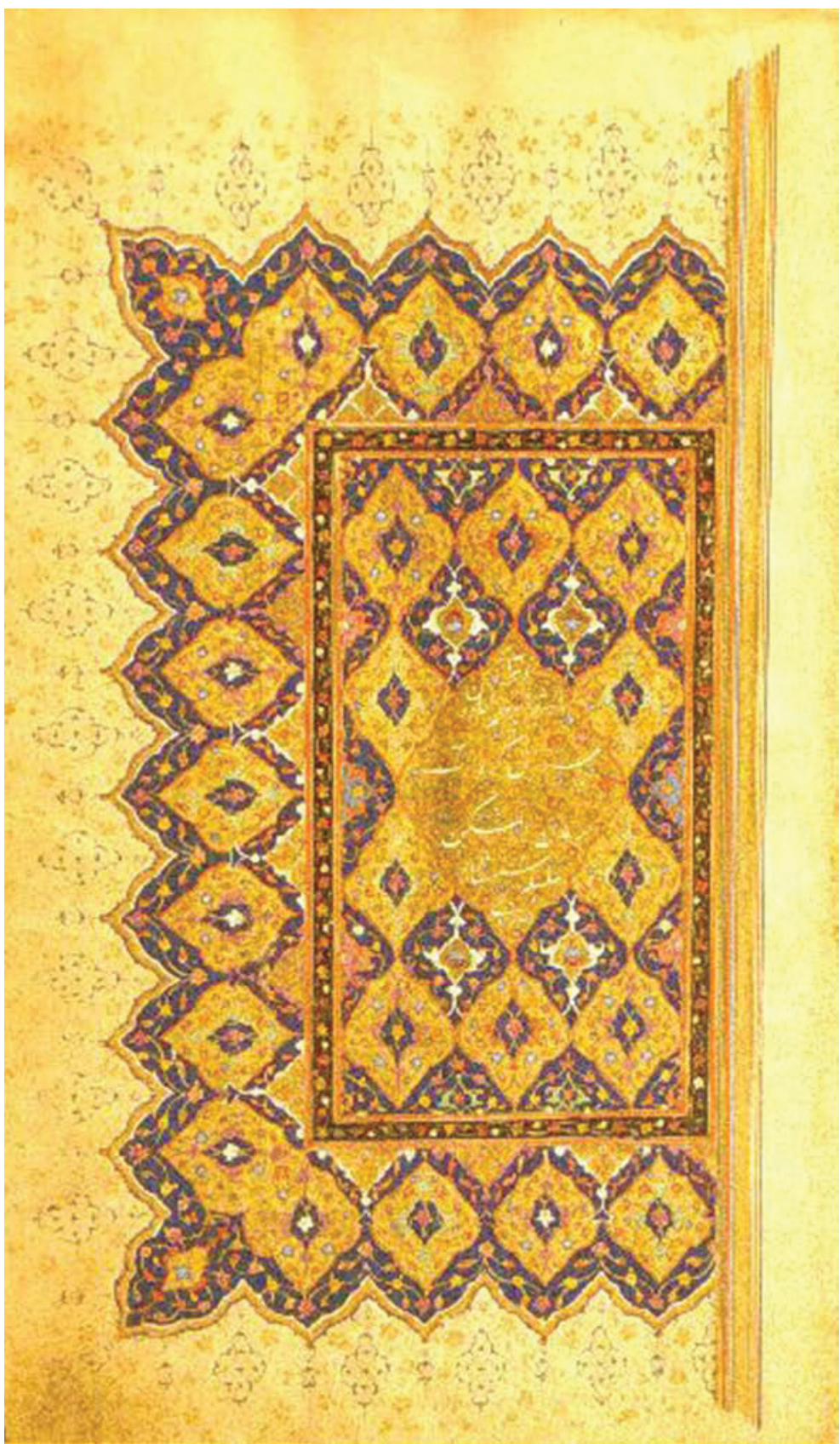

Figure 48. Rotterdam, Wereldmuseum 70935. The first page of a magnificently illuminated copy of Fużūlī's Dìvān, undated. 
Catalogue entries: Sohrweide I, 228, where other MSS are mentioned; see also Fihris 1855-1865 (II, pp. 86-88); Karabulut 67; KIYK 56; TYTK (Antalya) 2025-2026; TYTK (Süleymaniye, Ali Nihad Tarlan) 205-207; see also Gölpınarlı's edition, p. clvii, and Tarlan's edition, pp. viii-x.

Editions: Būlāq 1256; Tabrīz 1266, 1268; Istanbul, seven times from 1268; Abdülbâkî Gölpınarlı, Fuzûli Divanı (Istanbul 1948); Ali Nihad Tarlan, Fuzulî Divanı (Istanbul 1950, without the introduction).

Literature: Abdullah Karahan in $E I^{2}$ and TDVIA.

\section{3}

\section{Kitāb-i Usțuvānī Meḥmed Efendi}

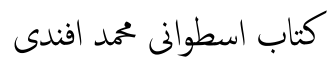

A late 18th-century copy of an anonymous treatise on the tenets of the Islamic faith, in particular on questions regarding public worship and praying, recorded by a student from the teachings of his master, Usțuvānī Meḥmed Efendi Dimışḳī (d. 1072/1661), who for a time was preacher in Istanbul. The work commences with a brief introduction ( $1 b-2 b)$. For descriptions of the content, the biography of the master and references, see Rieu, pp. 13-14; Rossi, p. 82. Copyist's verse in Arabic and Turkish occurs on f. 98b. A note in Arabic (4 lines) is found on the last flyleaf, recto. (For other copies of the same work, see Leiden, UB Codices Or. 17.121-122 and 17.136.)

Bound in boards with brown leather edges and back; glazed white paper; $(1)+98+4+(1)$ folios; $205 \times 135 \mathrm{~mm}$ and $142 \times 80 \mathrm{~mm}$; 13 lines; catchwords; vowelled, calligraphic nesih; headings, rubrics, borders and Arabic quotations in red; a fine headpiece with floral motifs in gold, red, pink and blue; gold borders and discs on ff. 1b-2a; completed in 1190 (1776-1777) by Meḥmed Rüşdī. Acquired from A. Touma, Syria, in 1995.

Begins (1b, after a besmele):

المحد الله الذى جعل العلماء ورثة الانياء و جعلهم بين عباد المقتداء ... و بعد بو عبد ضعيف [نقل ايدوب]

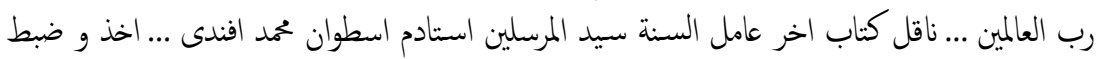

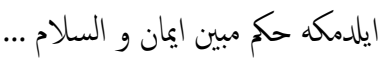

Ends (98b):

$$
\text { مسئله ... سجحده سهو ايدوب تحيات اوققتدر آبو الليث حزانه فقهنده يزار تمت الكتاب }
$$


Colophon (ibidem):

حرره اضعف المذنب الكتاب و خاك قدم استلحات محمد رشدى سنه • 119

Catalogue entries: Rieu, pp. 13-14; Rossi Vat. Turco 98, 362.

Edition: Kazan 1802 (in Tatar-Turkish). 


\section{CHAPTER FIFTEEN}

\section{UTRECHT, UNIVERSITEITSBIBLIOTHEEK (UB, UNIVERSITY LIBRARY)}

\section{Address: Heidelberglaan 3}

The Utrecht University Library has its origin in the municipal library, the founding of which was decided upon by the city council in 1581 . From 1640 onwards, the library was turned into an academic library, closely connected with the Illustrious School in the city, which later developed into the present university. The first oriental manuscripts, fourteen in all, with texts in Arabic, Persian, Turkish, and other languages came to the library in the form of a donation by the German Orientalist and part-time bookseller, Christianus Ravius (Christian Rau) 'Berlinatus' (1613-1677), in 1643 and 1644. Another two of his manuscripts came to the library through the hebraeist, Gerbrandt Anslo (1612-1643), whose library was purchased by the Illustrious School in 1643 (cf. $N N B W$ IX, cols. 26-27). As is clear from extensive inscriptions in Latin in his bold handwriting found in the manuscripts themselves, Ravius had been given, bought or borrowed-stolen according to one of the lenders, Şeyhzzāde Meḥmed Efendi (cf. Volume I, Cod.Or. 1228, No. 134, and Hs. 1 B 8, below) - the manuscripts in Istanbul in 1640. Five items of this sub-collection contain Turkish texts. The donation brought him a fee of f40o.- and the appointment as lecturer at the Illustrious School for a year (cf. Juynboll, Beoefenaars, pp. 217-220). A few manuscripts with Turkish text fragments followed later, particularly in 1860 as a gift from the widow of the orientalist, Jacobus Cornelis Swijghuisen Groenewoud (1784-1859), professor at the University of Utrecht from 1831 (cf. NNBW, VI, cols. 639-640). With the donation came a handwritten copy of the Turkish grammar (Hs. 1 F 9) by William Seaman (Grammatica lingae Turcicae, Oxford 1670), made in 1717 by Johann Eberhard Rau (Ravius, 1695-1770), professor at Herborn, whose son, Sebald Rau (1765-1807), later studied and taught at Utrecht University. The Turkish collection was more than doubled in the 1970 s with the purchase of a series of manuscripts from current sales catalogues initiated by the Turcologist and librarian, Henri Franciscus Hofman (1917-1998, see on him: Volume III, Cod.Or. 25.402). The old collection was described in CCO and in Catalogus Codicum Manu Scriptorum Bibliothecae Universitatis Rheno-Trajectinae (Utrecht \& The Hague 1887), p. 337 ff., which in turn, for the Islamic manuscripts, was based entirely on $\mathrm{CCO}$. 
Among the manuscripts obtained through Hofman, who had a special interest in archival documents and the history of science, there are quite a few outstanding items, in particular a magnificently produced copy of İbrāhīm Ḥaḳkī of Erzurum's Márifetnāme (Hs. 16 B 18), and a miscellany with original Ottoman documents (Hss. $16 \mathrm{C} 1$ and $16 \mathrm{C} 2$ ) which had been part of the library of 'Sir Wm Jones', which seems to point to the well-known Orientalist, William Jones (1746-1794), but this is quite impossible in view of the dating of some of the included documents and the year of binding (1849).

Literature: D. Grosheide, A.D.A. Monna \& P.N.G. Pesch, Vier eeuwen Universiteitsbibliotheek Utrecht (Utrecht 1986); Juynboll, pp. 217-222; see also Appendix I, below. I am also grateful to Dr. Hans Theunissen of Utrecht University for information on various aspects of the collection.

\section{Hs. 1 B 8}

Terceme-i el-Mevā'z ve l-itibār fiz żikri l-huțaț ve l-āsāarr

$$
\text { ترجمُ المواعظ و الاعتبار في ذكر الخطط و الاثار }
$$

An undated copy of an anonymous translation-the poetry was left as it was-of an Arabic work on the geography and history of Egypt, and in particular on the topography of Fusțāt and Cairo, by Taqī ad-Dīn Abū l-'Abbās Aḥmad b. 'Alī al-Maqrīzì (d. 845/1442), cf. GAL II, pp. 38-39 (No. 1); S II, p. 36. The title is written on the lower edge, as Terceme-i hutat-i Makriziz; the name of the author of the original is mentioned in f. 229a:2. The chapters on history begin on $\mathrm{f}$. 31a, section on the reigns of the Mamlūk sultans on f. ga. A postscript on the sultans who succeeded Sayf ad-Din Barsbay [ruled $825 / 1422-841 / 1437]$, which the translator 'saw ... at the end of the 3oth part $\left[c \ddot{u} z^{\prime}\right] \ldots$ in the margin of the manuscript he used' (2a:25-26), occurs on ff. $2 \mathrm{a}-\mathrm{b}$. A few marginal corrections and additions.

Four 'tailed signatures' are found on f. 225b, and a seal in the margin of f. 224a. Annotations in Latin by Christianus Ravius 'Berlinatus' are found on ff. 225 $\mathrm{b}$ and 224a, stating that he had been given the manuscript by its owner after he had promised him to produce an edition of the text, upon which he would give it back, Istanbul, 24 March 1640 [this never happened]; later, in 1643 or 1644 , he gave the manuscript to the library. Class numbers, among them the old number Or. No. 17, and a cutting from the catalo-gue of 1887 (cf. the Introduction to this chapter) are pasted on the inner back cover. 


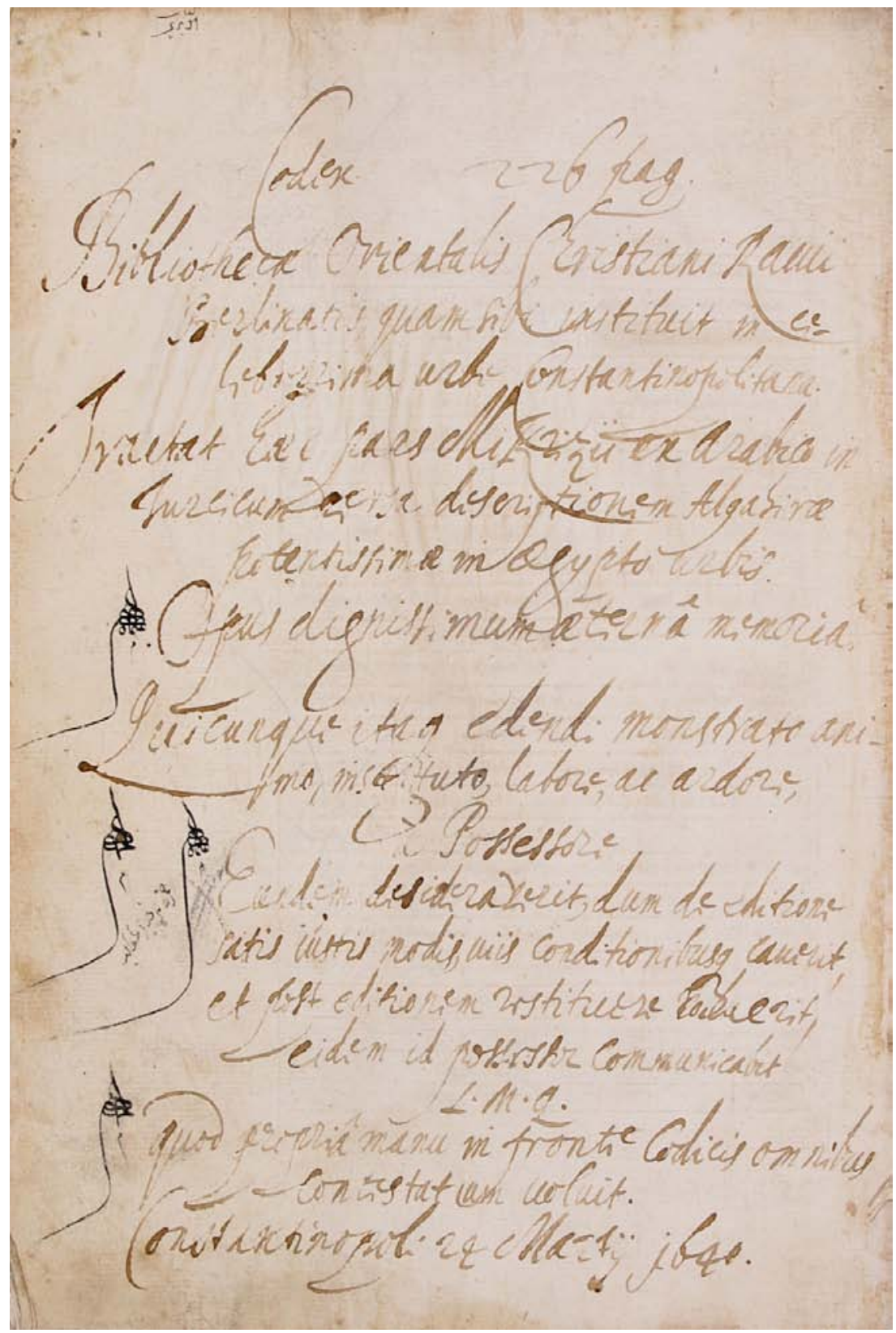

Figure 49. Utrecht, UB Hs. 1 B 8, f. 225 b. The first page of a manuscript with a translation of al-Maqrīzì's Khitaț, with tailed signatures and an explanation by Christianus Ravius that he had borrowed the book from an owner in Istanbul for an edition in 1640 . 


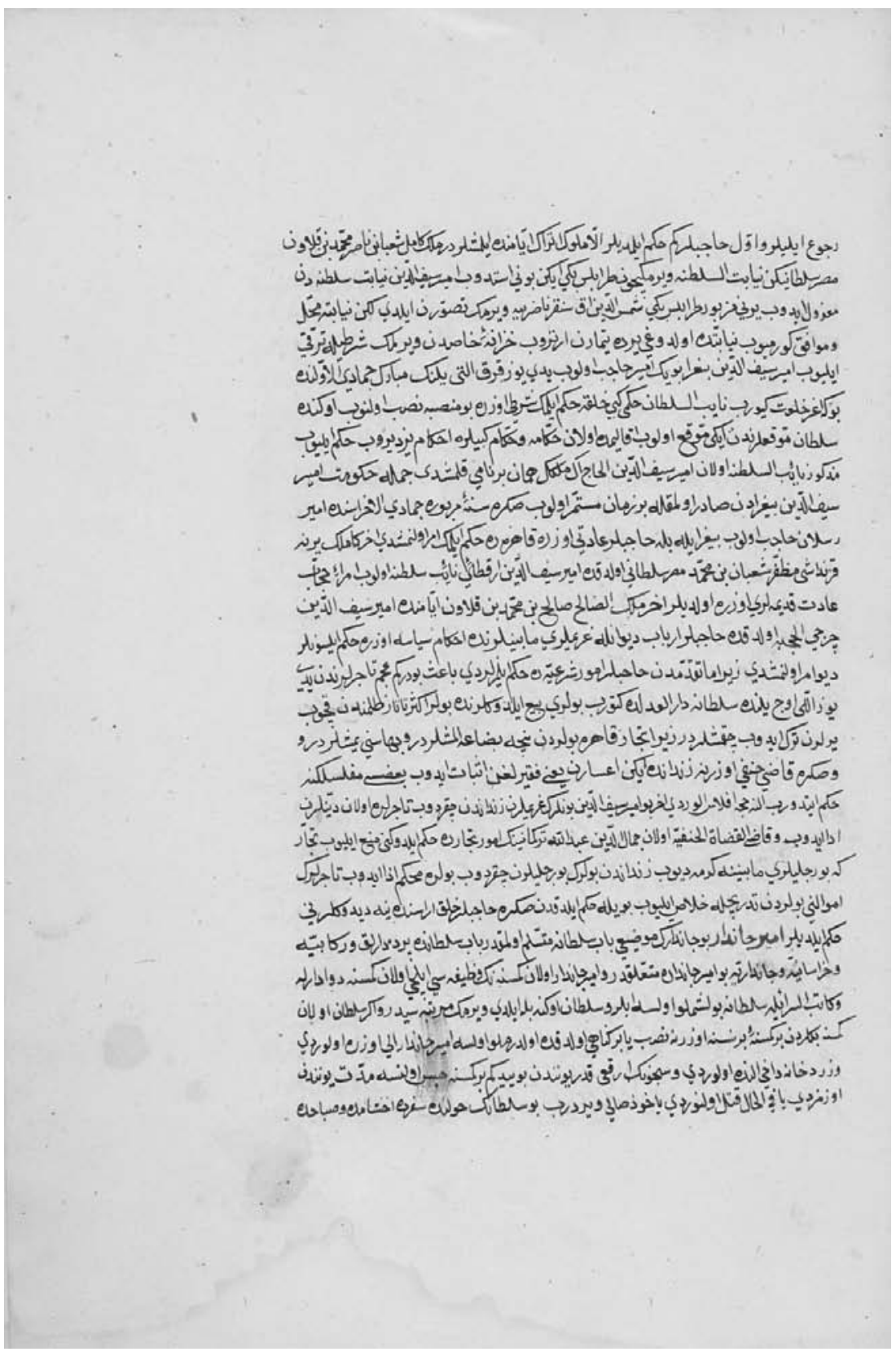

Figure 5oa-b. Utrecht, UB Hs. 1 B 8, ff. 24a-23b. Two pages from a translation of al-Maqrīzìs Khițat, showing the work of two different copyists; the catchword on the right suits the first word on the following page on the left. 


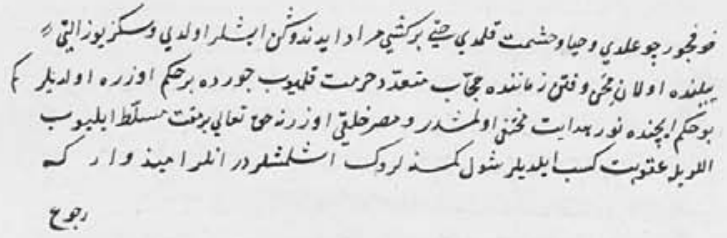

Figure 50a. 
Bound in embossed brown leather with flap and with blind tooled insets in Oriental style on the outer covers and flap; glazed white paper; $1+225$ folios (pencil numbers from left to right, in Western style); $302 \times 210 \mathrm{~mm}$ and $200 \times 120 \mathrm{~mm}$, varying; 27 lines; catchwords; small nesih and ta lïk by, clearly, more than one copyist; red rubrics and dots, omitted in some passages; ff. 93a, $84 \mathrm{~b}-\mathrm{a}, 29 \mathrm{a}, 24 \mathrm{a}$ have partly or completely remained blank owing to the fact that the book had been copied by more than one copyist; without a date or name of a copyist.

Begins (224a):

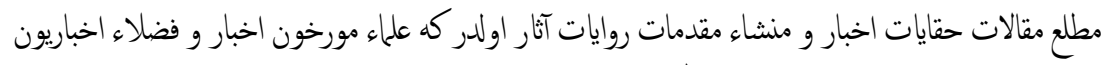

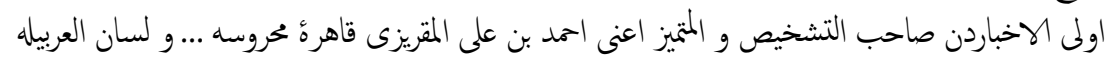

$$
\begin{aligned}
& \text { تسطير و تصنيف ايلدوكى اسلوب ل... }
\end{aligned}
$$

Ends ( $1 b)$ :

$$
\text { ملك اشرف قانصوه الغورى الاشرق قايتباى سنهُ مزبوره شوالنك غره سنده مصر سلطان اولدى تم }
$$

Catalogue entries: CCO 1680 (V, p. 266); Karatay 588-590.

\section{Hs. 1 E 17}

Turkish fetvās and a quotation from a treatise

The manuscript contains an undated copy of the first volume of an Arabic work on Hanafite jurisprudence, Anwār at-tanzīl wa'asrār at-ta'wül, by 'Abd Allāh b. 'Umar al-Bayḍawī (d. 716/1316?), cf. GAL I, p. 417. Owner's inscriptions of Ḥasan and Mușțafā ... occur on ff. 1a and 2a. Four fetvās in Turkish, copied from various sources, are found on $\mathrm{f}$. $2 \mathrm{a}$. A lengthy quotation from a Turkish treatise on the six classes of people of whom it is certain that they go straight to Hell, from the cruel tyrant down to the jealous 'âlim $(2 b-3 a)$. The text in small $t a$ lik $k$, which breaks off in the middle of a sentence, is preceded by an introduction in Arabic, Persian (verses) and Turkish (2b:1-11).

Begins ( $2 \mathrm{~b}$, after a besmele):

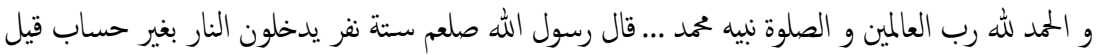

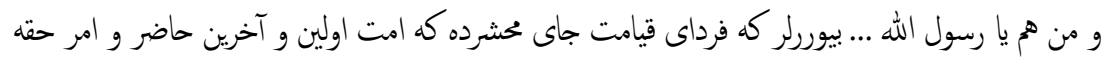

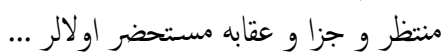

Ends (3a):

$$
\text { و درحت ميودار دايم ميل زمين سر تواضع نهاده در اما درحت بى بر مانند سبيدار [؟] سر بهوا اولوب : }
$$

Catalogue entries: $\mathrm{CCO}$ 2696; Voorhoeve, p. 16. 
Hs. 1 E 19

\section{Turkish text fragments}

The manuscript contains a copy on an Arabic work on Hanefite jurisprudence, Wiqāya ar-riwāya fi masā̇il al-Hidāya, a commentary on al-Marghinānī's al-Hidāya, by 'Ubayd Allāh b. Mas'ūd al-Maḥbūbī (7th/13th century, cf. GAL I, p. 377). The copy was completed by Ebū Bakr b. Walì on a Sunday in Şafer 1058 (February-March 1648) at the 'Ajamī madrasa in Aleppo, cf. the colophon on f. 255a. Provenance unknown.

The endpapers contain a few text fragments in Turkish: a fetvā by Behāyī [şeyhülislām, in office 1059/1649-1061/1651, cf. SO ${ }^{2}$ VI, p. 1759] (3 lines, 1a), a distich and an explanation (3 lines) referring to [the şeyhülislām] Ebūssu'ùd (256b).

Catalogue entries: $\mathrm{CCO}_{2698}$ (V, p. 271); Voorhoeve, p. $5^{2 .}$

\section{Hs. 1 F 12}

\section{Tevārīh-i āl-i 'Oșmān}

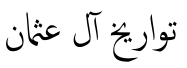

An undated, possibly early 16 th-century copy, incomplete after the first page where a few folios are missing (138a), of an anonymous early chronicle in prose and verse on the history of the Ottoman dynasty up to the year 896/1490-1491. The title, with the addition 'min evvelihì ve āhirih', is found on f. 139a. A few marginal additions and notes, partly in Latin, among these are indications of the incompleteness of the text (138a) and the missing of a catchword (4a).

The flyleaves contain a plethora of annotations on the contents and provenance of the MS, mostly in Latin, in small and bold script, mostly by Christianus Ravius 'Berlinatus'. He had obtained the MS in Istanbul on 18 May 1640 (note on f. 139b). In another extensive note (on the fist flyleaf, verso), Ravius mentions the Latin and German editions by Johannes 'Leunelatius' [= Leunclavius, Hans Lewenklau] of a comparable chronicle, a MS of which had been bought by Ieronimus Beck in istanbul in $155^{1}$ and had been offered to the Emperor Ferdinand (cf. Giese's article, p. 67). Notes in Arabic script are found on f. 139b, among them an owner's inscription of Meḥmed [b.] Aḥmed [?], known as Kâasimül-faḳ̄r [?] with the date ${ }_{15}$ Cemāzī l-evvel 1031 (28 March 1628). Class numbers, among them the old number Or. No. 20, and a cutting from the catalogue of 1887 (cf. the introduction to this chapter) are pasted on the inner back cover. 
Bound in embossed, dark brown leather with blind tooled insets in Oriental style on the outer covers; glazed white paper; various watermarks, possibly early 16th-century (communication from Hans Theunissen, Utrecht University); $1+139+1$ folios (pencil numbers from left to right, in Western style); $205 \times 145 \mathrm{~mm}$ and $170 \times 105 \mathrm{~mm}$, varying; 13 lines; catchwords; vowelled $n e s i h$; headings and rubrics in bolder script; without a date and the name of a copyist; acquired from Christianus Ravius on 24 November 1643 (notes in Latin on the inner front cover and the first flyleaf, verso).

Begins (138a, as in Giese's edition, p. 1):

$$
\text { بر نخا تاريخلر اومشدر عيان *كوكمه بر نسنه دشدى ناكهان }
$$

Breaks off (ibidem, cf. Giese's edition, p. 1:11):

$$
\text { اكلاوم اول بكلرى ک سرتسر* هم سلماندى اول هم دادكر [قامو] }
$$

Begins again (137b, cf. Giese's edition, p. 8:24-25):

$$
\text { وارب يلاق اواسنا اول كناره اسكله اورب بر كيجه جقاغه بشلادلر قره يره دكلدلر }
$$

Ends (1a, cf. Giese's edition, p. 151):

$$
\text { هجرتك سنه } 197 \text { يلنده محرمك اولندن سفر آينوك آخرنده قسطنطنيده قرار ايلدى تمت بامر الله تعالى }
$$

Catalogue entries: $\mathrm{CCO}_{2683}$ (V, p. 267); Flemming 124, where other MSS are mentioned.

Edition \& Translation: Friedrich Giese, Die altosmanischen anonymen Chroniken I \& II (Breslau \& Leipzig 1922 \& 1925).

Literature: Friedrich Giese, "Einleitung zu meiner Textausgabe der altosmanischen anonymen Chroniken tewārīhn-i āl-i 'oșmān”, in:Mitteilungenzur osmanischen Geschichte I (1921-1922), pp, 49-75; GOW, pp. 39-42; H. İnalclk, "The Rise of Ottoman Historiography", in B.L. Lewis and P.M. Holt, eds., Historians of the Middle East, pp. 152-167 (London 1962); V.L. Ménage, "The Beginnings of Ottoman Historiography", ibidem, pp. 168-179.

\section{Hs. 1 F 17}

\section{Turkish text fragments}

The manuscript contains an undated copy of a Persian work on the signs of prophethood, Shawāhid an-nubuwwa li-taqwiya yaqin ahl al-futuwwa, by 'Abd ar-Rahmmān Jāmī (d. 898/1492). The manuscript was bought by 
Christianus Ravius in Istanbul on 28 December 1640, and given to the library, probably in 1643 ( $\mathrm{cf}$. his notes on $\mathrm{ff} .1 \mathrm{~b}$ and $5 \mathrm{a}$ ).

The first flyleaves contain additional texts in a small hand, among them some in Turkish: prescriptions for reading certain passages of the Koran ( $3 \mathrm{~b})$, and various prescriptions for invoking certain names of God (4a).

Catalogue entry $\mathrm{CCO}_{2704}$ (V, p. 273).

\section{Hs. 1 F 18}

Turkish text fragments

The manuscript contains an undated copy of a Persian mathnawī, Silsilat adh-dhahab, by 'Abd ar-Raḥmān Jāmī (d. 898/1492, cf. Cl. Huart [H. Massé] in $\left.E I^{2}\right)$. Apart from a drawing of the seated figure of a writer, the 'title page' shows a number of owners' inscriptions: of Mehmed Serāser [?], el-münşī; of İbrāhīm, halīfe-i sarāy-i Ġalața; and of Meḥmed b. İlyās Vehbī, with a seal and dated 1 Muharrem 1066 (31 October 1655); a note: '[in] the handwriting of Monlā Fenāyì', is found on the same page. Received in 1860 from the widow of the orientalist, Jacobus Cornelis Swijghuisen Groenewoud (1784-1859), professor at the University of Utrecht from $183^{1}$ (cf. $N N B W$, VI, cols. 639-640).

Additional texts are found on the endpapers, among them some in Turkish: a g gazel by Luṭ̂i (Riyāżìzāde, 185a); prayer prescriptions (185b); and a prescription with a recipe for a medical $m a^{\prime} c \bar{u} n(187 \mathrm{a})$.

Catalogue entry: $C C O 2705$ (V, pp. 273-274).

\section{Hs. 1 G 24}

\section{A Turkish distich}

The manuscript contains an incomplete, undated copy of an Arabic work on Hanafite jurisprudence, Mukhtār li-l-fatwāa , by Abū l-Faḍl Majd ad-Dīn al-Mawșilī al-Buldajī (d. 683/1284), cf. GAL I, p. 382; S I, p. 657. An owner's inscription of Yūnus b. Hasan is found on $\mathrm{f}$. 1a; the same page contains a statement in Latin on the contents, with the addition that it had been left behind in 1685 by the Turks after they had given up their siege of Vienna. Received in 1860 from the widow of the orientalist, Jacobus Cornelis Swijghuisen Groenewoud (1784-1859), professor at the University of Utrecht from 1831 (cf. $N N B W \mathrm{VI}$, cols. 639-640). 
One Turkish distich was added on f. 285a: kadīmī āşinālardan hemān bir derd ü ġām ḳaldı/ ne yārān ḳaldı 'ālemde ne ol evvelki dem ḳaldi.

Catalogue entries: $C C O{ }_{2699}$ (V, pp. 271-272); Voorhoeve, p. 227.

\section{Hs. 1 G 26}

\section{Three distichs by Ḥāletī}

The manuscript contains an early and unique copy of a refutation of the Christian religion in Arabic, Jawāb Risālat li-ahl jazīrat Qubruș, by Muhammad b. Abū Ṭālib al-Anșārī aș-Ṣūì ad-Dimishqī (d. 727/1327), cf. GAL S II, p. 161. According to a colophon on f. 107b, the copy was completed on 25 Rebīü l-evvel 772 (17 October 1370). According to a note by Christianus Ravius (first flyleaf, recto), he had received the manuscript as the result of an exchange of gifts in Istanbul on 23 May 1640 (cf. Juynboll, Beoefenars, p. 161; see also Appendix I, below.)

Three rhymed distichs in Turkish by Ḥāletī are written on the first flyleaf, recto.

Catalogue entries: $\mathrm{CCO}_{2703}$ (V, p. 273); Voorhoeve, p. 96.

\section{Hs. 16 B 14}

A miscellany

A collection of religious parables ('balads', destān) in mesnevī rhyme, one of which was written by Kirdeci 'Alī, a follower of the Mawlānā [Jalāl ad-Dīn Rūmī, d. 672/1273] at Konya (cf. under 4, below) and another attributed to him (cf. under 2, below). The texts were copied by one, anonymous copyist, who may have added the last few almost identical beyts to each story which are sometimes also encountered as copyist's verses to colophons, and completed in 1222 (1807-1808, see colophon on f. 35b). An inscription declaring that the manuscript was turned into a vakf at the medrese of İzvornik [Zvornik] by Mahmūd Beg [b.?] 'Ömer Beg on 26 Receb [1] 306 [28 March 1889] occurs on f. 1a. Calculations and various, hardly legible annotations are found on the inner front- and back-board. The stories are the following — titles are found in the headings preceding the texts: 
(1) ff. 1b-7a

\section{Dāsitān-i Cimcime Sulțān}

$$
\text { داستان جمجمه سلطان }
$$

The anonymous story of the Prophet 'Īsā and Cimcime Sulțān. The prophet comes across the withered head of a man who had worshipped an idol and had subsequently suffered the tortures of Hell, begs God to revive him, assuring that he will worship God for ever if He does. His wish is granted, upon which the sultan lives for another 48 years. The text is identical with that in a manuscript, dated 1461, in the possession of Vasfi Mahir Kocatürk (cf. his Tarih, p. 157).

Begins (1b):

$$
\text { هر كم مراد اتديلر كه تكريه ايره * تكرينك ديزاروك [= ديدارنى] هز كوره }
$$

Ends (7a):

$$
\text { حق اكا رحت ايليه هم اكا ث־م يزانى فاتحه برله اكا }
$$

(2) ff. $7 \mathrm{a}-12 \mathrm{a}$

Dāsitān-i Kesik-baş

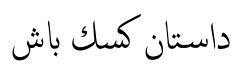

The story, attributed to Kirdeci 'Alī (cf. Kocatürk, Tarih, p. 142; the author's name occurs in his manuscript, dated 1461, cf. also under 1), of the Caliph 'Alì and the severed head. The story is sometimes found as an appendix to Süleymān Çelebī's popular Mevlid, cf. Neclâ Pekolcay's article, p. 63. The head, with weeping eyes, explains to 'Alī that he had lost his body as well as his wife and son, thrown into a pit, to a demon. He fights the demon in the pit with his sword, saves Kesik-baş, his wife and son, as well as another 500 Muslims. (Descriptions of the content is found in Kocatürk, Tarih, pp. 142-144, and Götz II, p. 463.)

Begins (7a, after a besmele):

$$
\text { باشلايالوم سوره بسم الله ايله *دوراشالوم دون كون اللهيله }
$$

Ends (12a):

$$
\text { حق تعالى رحت ايليه اكا× يزانى بر فاتحه برله اكا }
$$

Catalogue entry: Götz II, 493, where other MSS are mentioned.

Literature: Ahmed Yaġar Ocak, Türk folklorında Kesikbaş (Ankara 1992). 


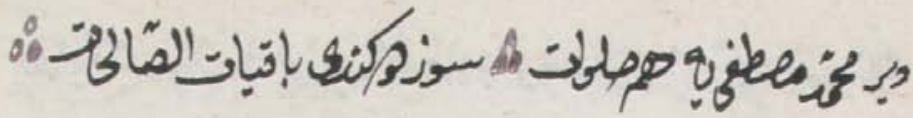

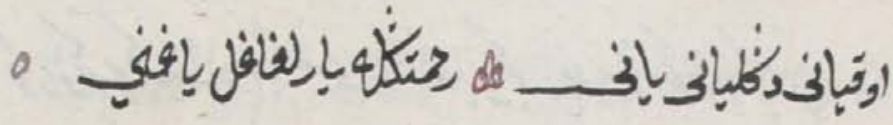

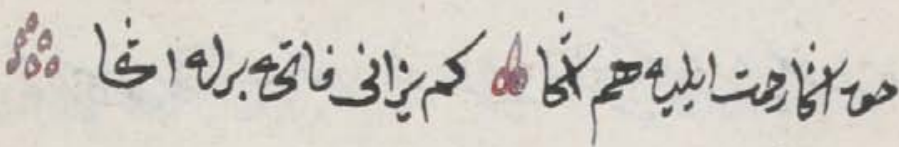

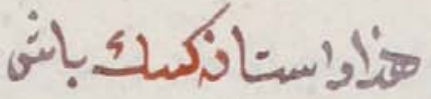 6.

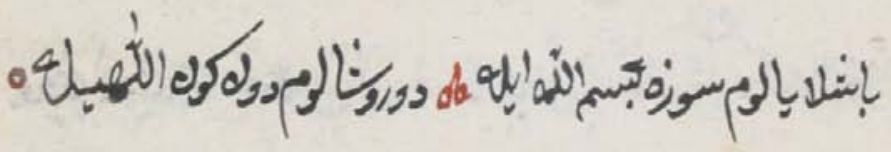

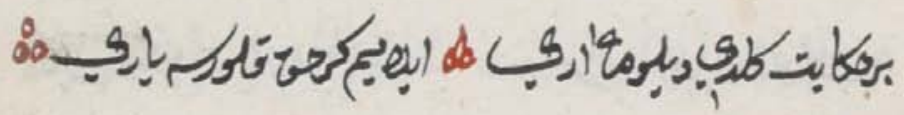

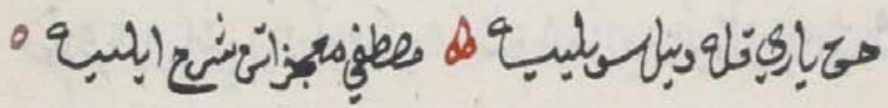

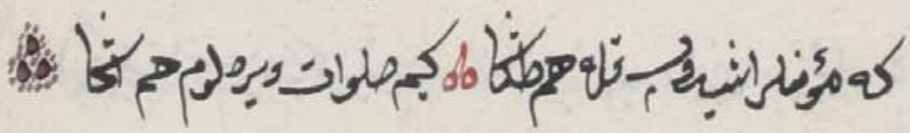

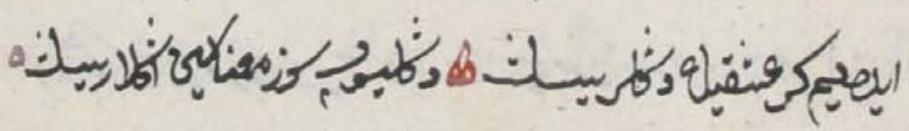

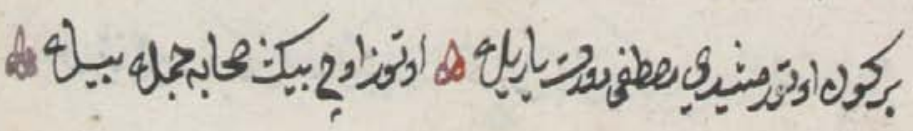

Figure 51. Utrecht, UB Hs. 16 B 14, f. 7 a. A page from a collection of religious parables, copied in 1222 (1807-1808), with a heading of the parable of Kesik-baş ('severed head'). 
(3) ff. $12 a-16 b$

Dāsitān-i Geyik

داستن كلك

The story of the Prophet Muhammad and the deer. The story is sometimes found as an appendix to Süleymān Çelebī's popular Mevlid, cf. Neclâ Pekolcay's article, p. 63. The Prophet, in the company of 'Umar and 'Alī, encounters a company of horsemen. Muhammad demonstrates his prophethood to the infidels by letting the deer, dragged along by the horsemen, bear witness to his identity. Eventually the horsemen are converted to Islam after the deer, left free, has been rescued by Gabriel from a trap set by the same horsemen. (Descriptions of the content are found in Kocatürk, Tarih, p. 157; Sohrweide I, p. 245.)

Begins (12a):

$$
\text { كر سورسك عشقيله محدى *وير صلوات يا محد امتى }
$$

Ends (16b):

$$
\text { تكرى رحت ايلسون اول جانيجون * هر كم دعا قيلوب بونى يارانه ايهون }
$$

Catalogue entries: Blochet A.F. 252, S 460, S 1389; Sohrweide I, 282.

$$
\text { (4) ff. 16b-2la }
$$

\section{Dāsitān-i Ejderhā}

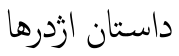

The story of the Caliph 'Alī and the dragon by Kirdeci 'Alī. (The author is mentioned in f. 21a:3). The prophet, attacking the Muslim-killing dragon with his sword, is nearly killed when, forgetting God, he only relies on his own force, but is rescued after he has repented. (A description of the content is found in Kocatürk, Tarih, p. 144.)

Begins (16b):

$$
\text { بر معجزات ادايم اكلار اسيك *جان قولاغن اجوبن دكلراسيك }
$$

Ends (21a):

$$
\begin{aligned}
& \text { بونى دييان ك داخى [=كرداجى] عالى درر * دنياده مولانانك هم قوليدرر } \\
& \text { اوقيانى دكليانى يازانى * رحتشكله يالغاغل يا غنى }
\end{aligned}
$$

Catalogue entry: Blochet A.F. 396. 
(5) ff. 21a-27a

Dāsitān-i Ana ile og̉ul

داستان انا ايله اوغل

The story of the mother and her son. It is also known as Hātūn destānı, and is sometimes found as an appendix to Süleymān Çelebī's popular Mevlid (cf. Kocatürk, Tarih, p. 145). A boy by accident puts out one of his widowed mother's eyes; enraged, the Caliph 'Alì throws him into a fire. Hasan and Husayn, pitying the boy, beg their grandfather, Muhammad, to save the boy. Eventually, the fire, into which the mother has also jumped, is extinguished by water carried by more than 100,000 birds, and mother and son are saved and healed. (For a descrption of the content, see Kocatürk, Tarih, pp. 145-146.)

Begins (21a):

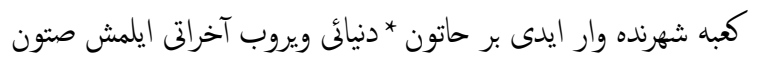

Ends (27a):

$$
\text { اوقيانى دكليانى يازانى * رحتكله يالغاغل يا غنى }
$$

(6) ff. $27 \mathrm{a}-35 \mathrm{~b}$

\section{Dāsitān-i Duhter-i miskīn}

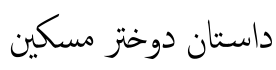

The story of the poor girl. The work is better known as Kız mevlüdu and under that title printed in Istanbul in 1339 (cf. plate in Kocatürk, p. 158; cf. Özege 10775), and as Kız Destanı (cf. Ersoylu's edition) - in two manuscripts, preserved in Istanbul, the title Hikāyet-i Kız ma'a cühūd is found (cf. Ersoylu's edition, p. iii, and below). A father, mother and daughter are starving in Damascus. Eventually the girl offers herself for sale and is bought by a rich young man with one blind eye. In a dream, the Prophet tells the man to set the girl free. This he does, his blind eye appears to be healed, and in gratitude he sends the girl back home with a hundred gold pieces. (For a description of the content, see Kocatürk, ibidem). The work is incomplete at the end, breaking off in a passage in which the man 'sees' the Prophet in his dream.

Begins (27a, as in Ersoylu's edition, p. 1):

$$
\text { هر كم اولور بو دنياده يوحسوللغه *صبر قلدى لايق اولدى قوللغه }
$$


Ends (35b, as in Ersoylu's edition, p. 14:191):

$$
\begin{aligned}
& \text { جالين كوردى اول بدر ايه بكزر * النده قاره قاشى هم يايه بكزر } \\
& \text { تا كي حتم بونده اولدى بو كتاب * مصطفى يه سن وير صلوات } \\
& \text { اوقيانى دكليانى يازانى * رمتكله يالغاغل يا غنى }
\end{aligned}
$$

Colophon (ibidem):

Catalogue entry: Karatay 2996 II.

Edition: Halil Ersoylu, Kız Destanı (Haża Hikikāyet-i Kıı ma'a Cühūd) (Ankara 1996), in Latin script with facsimiles of the Topkapı Sarayı Library MS $5^{20}$ and the Süleymaniye Library MS Haci Mahmud 4339.

Bound in tattered brown leather with flap; glazed white paper; 38 folios; $228 \times 157 \mathrm{~mm}$ and $185 \times 120 \mathrm{~mm}$, varying; 11 lines; catchwords; bold şikeste; headings and triple dots in red; completed in 1222 (1807-1808); without the name of a copyist.

Edition \& translation: Evelien Landman \& Cees Priem, "Six Turkish Religious Epics" (unpublished PhD thesis, University of Utrecht, 1994).

Literature: Vasfi Mahir Kocatürk, Türk Edebiyatı Tarihi (Ankara 1970), pp. 140-165; Neclâ Pekolcay, "Süleyman Çelebî Mevlidi metni ve menşei meselesi”, in Türk Dilive Edebiyatı dergisi VI (1954), pp. 39-64.

\section{Hs. 16 B 15}

Hedīyetül-müş̧āk fi şserh mesleki l-'uşşāk

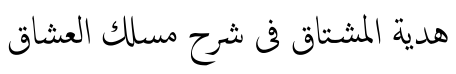

A mid 18th-century copy of a commentary on a kașide entitled Meslekül'uşşāk. The poem was written by Șarī 'Abdullāh Efendi (d. 1071/1660-1661); the commentary by his grandson, the Melāmìye shaykh, La lìzāde 'Abdulbākī Efendi (d. 1159/1746, cf. 'OM I, p. 159). The title is found in $2 \mathrm{~b}: 8$ and on the first flyleaf, recto; the kașide and its author are mentioned in f. 2a:12. Only one other copy, kept in the Cairo National Library (cf. below), seems to be documented. The work is preceded by an introduction $(1 b-2 b)$, in which 
the commentator explains that while he was suffering from an unmerited exile in the fortress of Limni [Limnos] his brother was able to give him a mecmū'a with mystical prose and ilāhìyât, compiled by their father [La'lā Shaykh Mehmed Efendi] when the latter had been sixteen years old. While he was busy reading the uplifting work for three months, on 1 Muharrem 1129 [16 december 1716] he came across the kașide written by his grandfather which directly addressed his soul. In the middle of the same month, he received a letter from his brother, asking him to write a commentary on the poem; this he did. The work itself consists of the subsequent distichs of the poem in red or gold, alternated by prose commentary, especially on the mystical content, to which the author here and there added verses composed by himself.

A few marginal corrections and additions by the copyist. Pencil notes with the price of $£_{35}$ as well as a label with a typed text in English describing the contents are found on the inner front-board.

Bound in embossed dark brown leather with simple gold decorations in Oriental style; glazed cream to brown paper; $(2)+40+(2)$ folios; $214 \times 113 \mathrm{~mm}$ and $160 \times 60 \mathrm{~mm}$; 23 lines; catchwords; small, calligraphic ta li $k$; quotations and lines in red and gold; borders in gold, within black lines on ff. $1 \mathrm{~b}-5 \mathrm{a}$; completed by Dervīş Hüseyn el-Ḥüseynī b. İbrāhīm Bürān [?] on ${ }_{15}$ Cemāż $\bar{\imath}$ $l-\bar{u} l \bar{a} 1186$ (14 August 1772, colophon in undotted script). Acquired in October 1977 .

Begins ( $(\mathrm{b}$, after a besmele):

$$
\begin{aligned}
& \text { سبحانك لا علم لنا الهما علمنا انك انت العليم الحكيم نصلى بامرك على سرولك الكريم ...و بعد ذرة ناهيز }
\end{aligned}
$$

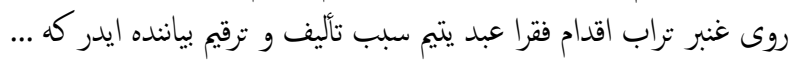

Ends (40a):

$$
\text { آمنا و صدقنا اللهم صلى على سيدنا محمد ... و آخر دعانا ان الممد لله رب العلمين }
$$

Colophon (ibidem):

$$
\begin{aligned}
& \text { قد وقع الفراغ من تخريره و تنميقه فى اليوم الخامس عشر من شهر جاذى الاولى سنه ست و ثمانين و مائه }
\end{aligned}
$$

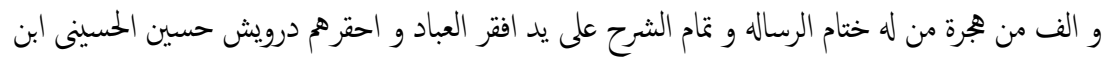

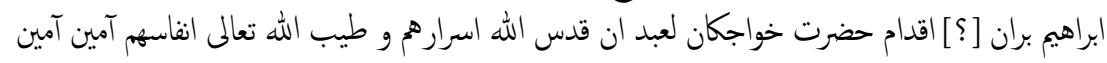

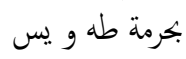

Catalogue entry: Fihris 5021 (IV, p. 245). 


\section{Hs. 16 B 16}

A miscellany

The collection contains undated copies of three works on science and law produced by a copyist called Bekir b. 'Abdurrahmān (see the colophon on p. 138). The endpapers and some of the margins along the text contain a plethora of annotations in a minute, almost illegible scribble, mostly in pencil, by an owner. These include calculations of various sorts, lengthy quotations in Arabic from manuals of jurisprudence, and magic diagrams (cf. pp. 2 and 196).

\section{(1) pp. 2-138}

\section{[Risāle-i] netāyicü l-fünūn}

$$
\text { [سالة ] نتايج الفنون }
$$

A copy of a concise encyclopaedia of the sciences in prose and poetry by Yahyā b. Pīr 'Alī b. Nașūh, who wrote under the pen-name of Nev'ì (d. 1007/1598-1599). Many manuscripts have survived. The title is mentioned in p. 5:16; the author's pen-name in p. 3:9. The work is also known under the longer title of Netāyicü l-fünūn ve mahạsinü l-mütūn. The work is preceded by a lengthy introduction (pp. 2-14), in which, among other things, the author discusses his sources and offers his work to Sultan Murād III (ruled 982/1574-1003/1595); it ends with the story of Cevān-i Fāżll (pp.11-14). The sciences treated in the book are: history (p. 14); philosophy (hikmet, p. 49); astronomy (p. 55) - the spaces where usually drawings are found have been left blank in this copy-theology (kelām, p. 63); jurisprudence (fikh, p. 71); the distinction between the law schools (hilaf beyne l-imāmin, p. 77); interpretation of the Koran (tefsïr, p. 82); mysticism (tașavvuf, p. 87); interpretation of dreams (p. 9o); magic, enchantment, and medicine (rukā ve efsūn ve țıbb, p. 97); exorcism ('azāyim, p. 97); medicine (p. 102); agriculture (filāhat, 106); astrology (p. 108); and augury and divination (fäl ve zecr, p. 115). The work concludes with the story of Beşīr and Şādān (p. 120). A few marginal corrections by the copyist. (For another copy of the same text, see UBL Cod.Or. 949(1).)

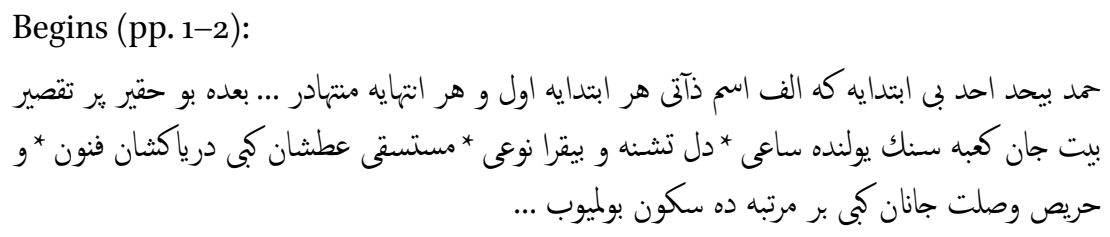


Ends (p. 138):

$$
\text { فاك راكاه جز تفريق مشمر * فك الصفو منها قد تكدر }
$$

Colophon (ibidem):

$$
\text { تم بعون الله الملكك الوهاب من يد اضعف العباد بكر بن عبد الرمن غفر الله له و لولديه }
$$

Catalogue entries: Flemming 372, Götz II, 3-6 and Sohrweide II, 169-170, where other MSS are mentioned; see also Fihris 4872-4886 (IV, pp. 203206); Sarajevo, 2865-2868; Schmidt 83; TIYK 108; TYTK (Süleymaniye, Ali Nihat Tarlan) $2-3$.

Literature: Abdülkadir Karahan, "Nevī”, in $\dot{I} A$.

(2) pp. 142-177

Risāle min 'ilm el-ferāyliz

$$
\text { رساله من علم الفرايض }
$$

A copy of a treatise on the division of inheritances by 'Abdulkerim b. 'Abdurrahmmān ez-Zīlī written in 1002 (1593-1594). Title, author and year of composition are mentioned in a heading preceding the text on p. 142. No references to this work or an author of that name have been found. The work is preceded by an introduction (pp. 142-149) with a detailed discussion of the relevant tefsir literature and fetva collections. The work itself is divided into unnumbered chapters $(b \bar{a} b)$ and sections ( $f a s ̧ l)$. Some lengthy marginal additions by the copyist (especially on pp. 160-161), partly consisting of diagrams (pp. 162, 167 and 174).

Begins (p. 142, after a besmele):

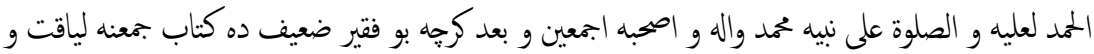

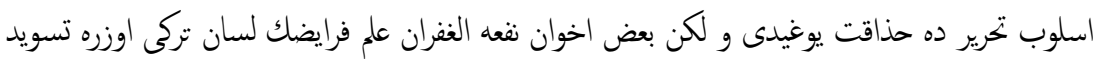

$$
\begin{aligned}
& \text { اولناسين طلب ايلمكين ... }
\end{aligned}
$$

Ends (p. 177):

$$
\text { ... قنغسى اول قنغسى صكه فوت اولدوغى مامعلوم اولدوغيجيون بزم ائمه مز قتنده مختار اولان بودر }
$$

Colophon (ibidem):

$$
\text { تمت بعون الله الملك الوهاب }
$$

(3) pp. 177-191

Mefhūm el-ferāyı̇ li-mezzheb el-Hanüfi

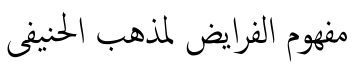


A copy of a succinct, anonymous treatise on the division of inheritances. The title is found in a heading preceding the text on p.177. The text is divided into sections beginning with [كلدك [امدى. Diagrams are found on pp. 179, 181, 182, 185 and 191 (șürat el-menāsaha, which concluded the treatise).

Begins (p. 177):

تنفيذ وصامز رمهم الله عليهم ديديلر كه تره كة ميته حقوق اربعة مرتبه تعلق ايدر اولا تجهيز تكفين قضاء ديون

Ends (p. 191):

اوج آلتون ويرن بنت بكرم اوج آلدى اول برسى هان اون دورت اقهه آلدى بمعا التمش اقهه اولدى و

Bound in embossed dark brown leather with flap and, originally, gold tooled but very worn insets in Oriental style; glazed cream paper, moisture stains in some places; 196 pages, with original numbers in pencil; $205 \times 152 \mathrm{~mm}$ and $140 \times 100 \mathrm{~mm}$, varying; 19 lines; catchwords; nesih; headings, rubrics, lines and dots in red; (1) completed by Bekir b. 'Abdurrahmān; without a date.

\section{Hs. 16 B 17}

A miscellany

A collection of two works, copied by one anonymous scribe, who completed his work, according to the last colophon (48b), on 20 Ramażān 1145 (6 March 1733). Two months later, in Şevvāl of the same year, the MS was, according to an inscription on the same page, acquired by İbrāhīm Efendi b. el-Hạccci Yūsuf. The 'title page' (1a) contains various notes, among them, in pencil, 'Jazici oglu' and the price of $£ 42$.

(1) ff. 1b-32a

\section{'Acāyibü l-mahlūkāt}

بجايب الخخلوقات

An undated copy of a popular cosmography by Yazıcıog̀lı Aḥmed Bīcān (d. in or after $870 / 1465^{-1466)}$. The title is mentioned on $\mathrm{f}$. 1a, in a heading preceding the text $(1 b)$ and in the final sentence (32a); the name of the author is found in f. $1 \mathrm{~b}: 3$ and in the final sentence (32a). The work is an abbreviated 
version of a work of the same title by Qazwīnì (d. 682/1283, cf. GAL S I, p. 882) and was written for Shaykh Ḥāccī Bayram in Gallipoli, mentioned in f. 2b:9, in 857/1453, the year in which Sultan Mehmed conquered Istanbul. A detailed description of the contents is found in Rieu, pp. 106-107. The chapter on mountains is preceded by a diagram of the seven 'climes' with their main geographical units (12b). The work ends in a section on the schorpion and a prayer for the author. Extensive marginal additions in various hands, partly lost by trimming, on ff. 6a-9b, 2oa and 23b. (For another copy of the same work, see UBL Cod.Or. 12.371(2).)

Begins ( $1 \mathrm{~b}$, after a besmele):

$$
\begin{aligned}
& \text { الممد لله رب العالمين و الصلوة ... اما بعد محب العلماء و خادم الفقرا يازجى اوغلى احمد بيجآن رحت الله } \\
& \text { عليها ايدر سبب تخرير كتآب اولدر كه ... }
\end{aligned}
$$

Ends (194b):

$$
\begin{aligned}
& \text { هنوز حقك قدرتى دكزندن بر قطره يازميه امدى حق تعالى رحمت ايلسون اول كثى يه كم بو يجايب }
\end{aligned}
$$

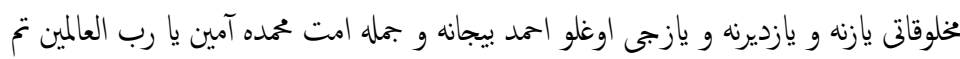

Catalogue entries: Götz II, 332, and Kut 394, where other MSS are mentioned; see also Karabulut 394; Sohrweide II, 159; Yardım 3804.

Edition: Kazan 1888.

Literature: Laban Kaptein, Eindtijd en Antichrist (ad-Dağğăl) in de Islam; Eschatologie bij Aḥmed Bīcān († ca. 1466) (Leiden 1997), p. 3o, where older literature is mentioned.

$$
\text { (2) ff. } 32 b-48 b
$$

A treatise on medicine

The anonymous treatise, without a title, consists of, mostly, a collection of medical prescriptions and recipes. It is possibly incomplete at the beginning. The central part (from f. 38a) contains a lengthy digression on medicine and its early practitioners, Abū 'Alī [Ibn] Sīnā (Avicenna), Galenus and Bukrāt (Hippocrates).

The margins and endpapers contain additional texts in various hands: a list of ingredients (in pencil, 33b); a prescription for curing coughs (46b); a recipe for ambergris (48b); an ilāhī (49a); a prayer prescription (49b); a list of ingredients for a mixture (terkīb, written up-side down, ibidem); idem, for a ma'cūn-i üsrüb (50a); a prescription for a 'zinc treatment' ('aml-i tūtiya $\overline{\text { ) }}$ 
attributed to Rāvī İbrāhīm Efendi, ibidem; and a prescription for removing warts (written up-side down, 5ob).

Begins ( $\mathrm{lb}$, after a besmele):

$$
\begin{aligned}
& \text { المحد لله رب العالمين و الصلوة ... اما بعد محب العلماء و خادم الفقرا يازجى اوغلى احمد بيجآن رحت الله } \\
& \text { عليها ايدر سبب تحرير كتآب اولدر كه ل.. }
\end{aligned}
$$

Ends (194b):

$$
\begin{aligned}
& \text { هنوز حقك قدرتى دكزندن بر قطره يازميه امدى حق تعالى رمت ايلسون اول كثى يه ك؟ بو بحايب }
\end{aligned}
$$

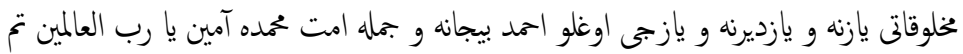

$$
\begin{aligned}
& \text { *** }
\end{aligned}
$$

Bound in somewhat tattered boards with flap and brown leather back and edges; white glazed paper; 50 folios (f. 2 occurs twice); $207 \times 135 \mathrm{~mm}$ and $160 \times 70 \mathrm{~mm}$, varying; 23 lines; catchwords; nesih; headings, rubrics and a colophon in blue; red lines; dots in red, blue and light brown; (2) completed in 1145 (1733), cf. above; without the name of a copyist. Acquired in October 1977 .

\section{Hs. 16 B 18}

\section{Márifetnāme}

معرفتنامه

A magnificently produced, lavishly illuminated and illustrated, early 19thcentury copy of a work in prose and verses of encyclopaedic scope on cosmology, human physiognomy and psychology, and mysticism by Shaykh es-Seyyid el-Ḥācc İsmāêil Ḥaḳkī Erżurumī (d. 1186/1772). The work was written for his son, es-Seyyid Ahmed Naīmī. The title is mentioned in headings on ff. 1b, 15b, 16a, in f. 16b:19, and in the colophon (348b). The name of the author occurs in f. 16a:1 and in the colophon (348b). The work consists of an introduction (15b-16b), a prologue (mukaddime, 16b-29a), three main chapters (fenn) subdivided into many chapters and sections, and a conclusion (hätime, on good manners [a $\bar{a} \bar{a} b]$ and the rules of behaviour towards friends and acquaintances, 346b-348b). It was completed in 1170/1756 (cf. the chronogram on f. $348 \mathrm{~b}$ ). (See for a succinct survey of the contents, Götz I, p. 6.)

The work is preceded by a detailed index, designed by Mehmed Zikrī Efendi ( $1 b-14 a)$. His name is mentioned in a colophon on f. 14a, which is followed by a quatrain by the same. The work is followed by a pious letter 
of advice in Arabic addressed to a 'brother', ending in some well-wishing lines in Turkish (349a-b). Multicoloured drawings with explanations in minute nesih are found on ff. 28b-29a (two drawings with the elements of the universe: Heaven, Hell and the earth in between, with the Kaba, the tombs of the prophets, the banner of Muhammad etc.); 33b (a circular diagram, däire-i vücüd, with the names of various concepts related to human existence, arranged in three concentric circles); 41b-42a (geometric forms and astronomical diagrams demonstrating, primarily, eclipses of the sun and moon); 46a (a circular diagram showing the spheres of heaven, efläk); 48a (two small circular diagrams showing the signs of the zodiac); $65 \mathrm{~b}$ (circular diagrams of the nine spheres of the sun, moon and stars); $67 \mathrm{a}-68 \mathrm{~b}$ (diagrams demonstrating the origin of the subsequent phases of the moon, followed by two tables on the position of the related to the stars, and the omens, ihtiyārät, related to the the same); $77 \mathrm{~b}-79 \mathrm{a}$ (calendars of various formats, covering the years 1161-1275/1748-1859); 84a-b (four circular diagrams showing compasses and geographical directions, cihāt); 91b-93a (diagrams and a table concerning the geography of the earth and its 'climes'); 98a-10ob (diagrams demonstrating longitude and latitude, followed by two tables with the geographical co-ordinates of various towns, and two Western-style maps of the globe of the earth, seen from four directions); 106a (three circular diagrams showing the relative positions of the earth and the signs of the zodiac); 110a (a circular diagram showing the eight human temperaments); 317b (a plan of the house of Shaykh İsmā̄il Tillovī [who was the author's mürşid at Siirt, cf. $S O^{2}$ III, p. 764 ]); and f. 349b (five pink flowers with green leaves set within a illuminated border).

Bound in embossed brown letter with flap and blind tooled insets in Oriental style; glazed white paper of high quality; $(1)+349+1(1)$ folios, original numbers in red 3-334; $249 \times 147 \mathrm{~mm}$ and $193 \times 98 \mathrm{~mm} ; 38$ lines, occasionally in two or three columns; catchwords; small nesih; headings in red and, occasionally, in white against a gold or red background; rubrics, lines and dots in red; multiple borders in gold within black and red lines; varicoloured headpieces and illuminated borders with floral motifs separating text surfaces; a lavishly illuminated index (1b-14a) and initial pages $(15 \mathrm{~b}-16 \mathrm{a})$ in various colours and floral motifs; completed by Ḥāiz Mușțafā b. Ḥasan el-Hạmidī in Erzurum in Ži l-ḥicce 1241 (July-August 1826). Acquired in October 1979 . 
Colophon to the index, with a following quatrain (14a):

كتبه محمد ذكرى افندى *كوكل حقى بلورسك و ترى سودى و ترى سوسنده * سون جانلرده مطلعدن

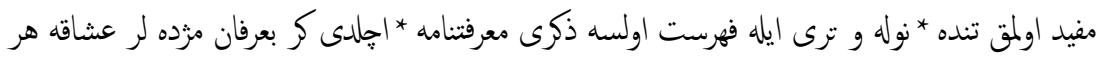

Begins (15b-16a, after a besmele):

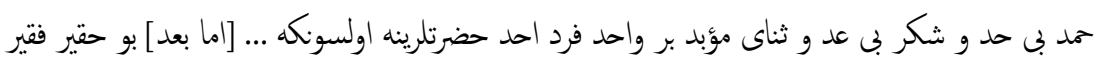

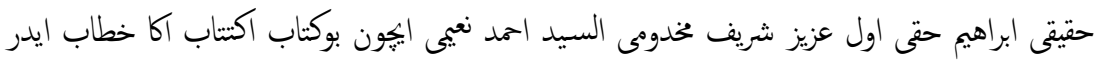

Ends (348b):

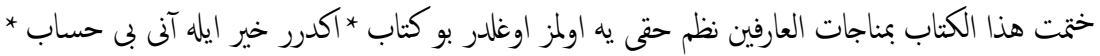

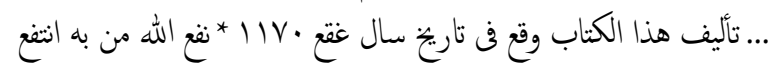

Colophon (ibidem):

قد تم تحرير هذا الكتاب المستطاب المقبول المرغوب ... المسىى بمعرفتنامه الذى فوائد كثرية للخلايق تمامتز

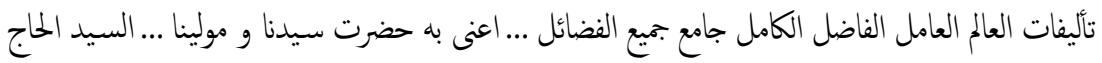

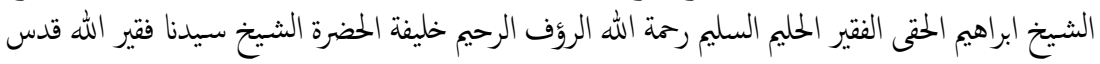

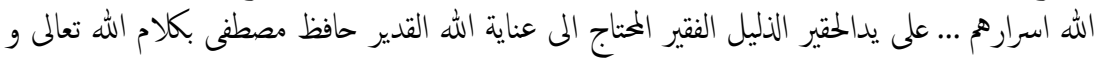

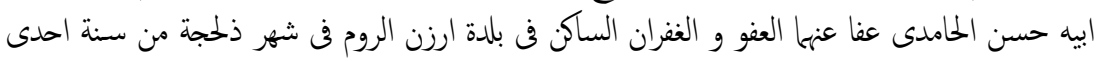

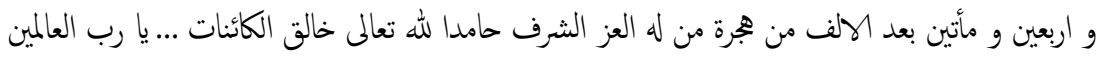

Catalogue entries: Götz I, 5 , where other MSS are mentioned; see also Fihris 4507-4515 (IV, pp. 107-109); TYTK (Isparta) 10.

Editions: Būlāq 1251, 1255, 1257, 1280; Istanbul 1284, 1294, 1310, 1330 (cf. Özege 12259); Kazan 1261 (incomplete); by Turgut Ulusoy (4 Vols. Hasankale 1979), in modern Turkish.

Literature: 'OM I, pp. 33-36; $S O$ III, p. 764.

\section{Hs. 16 B 19}

Tuhfe-i Şāhidī

تحفة شاهدى

A mid 18th-century copy of a rhymed Persian-Turkish dictionary by İbrāhīm Şāhidī, a Mevlevī dervish and poet (d. 957/1550). The name of the author and the title of the work occur in p. 9:2-3. The title Kitäb-i Şăhidi is found 


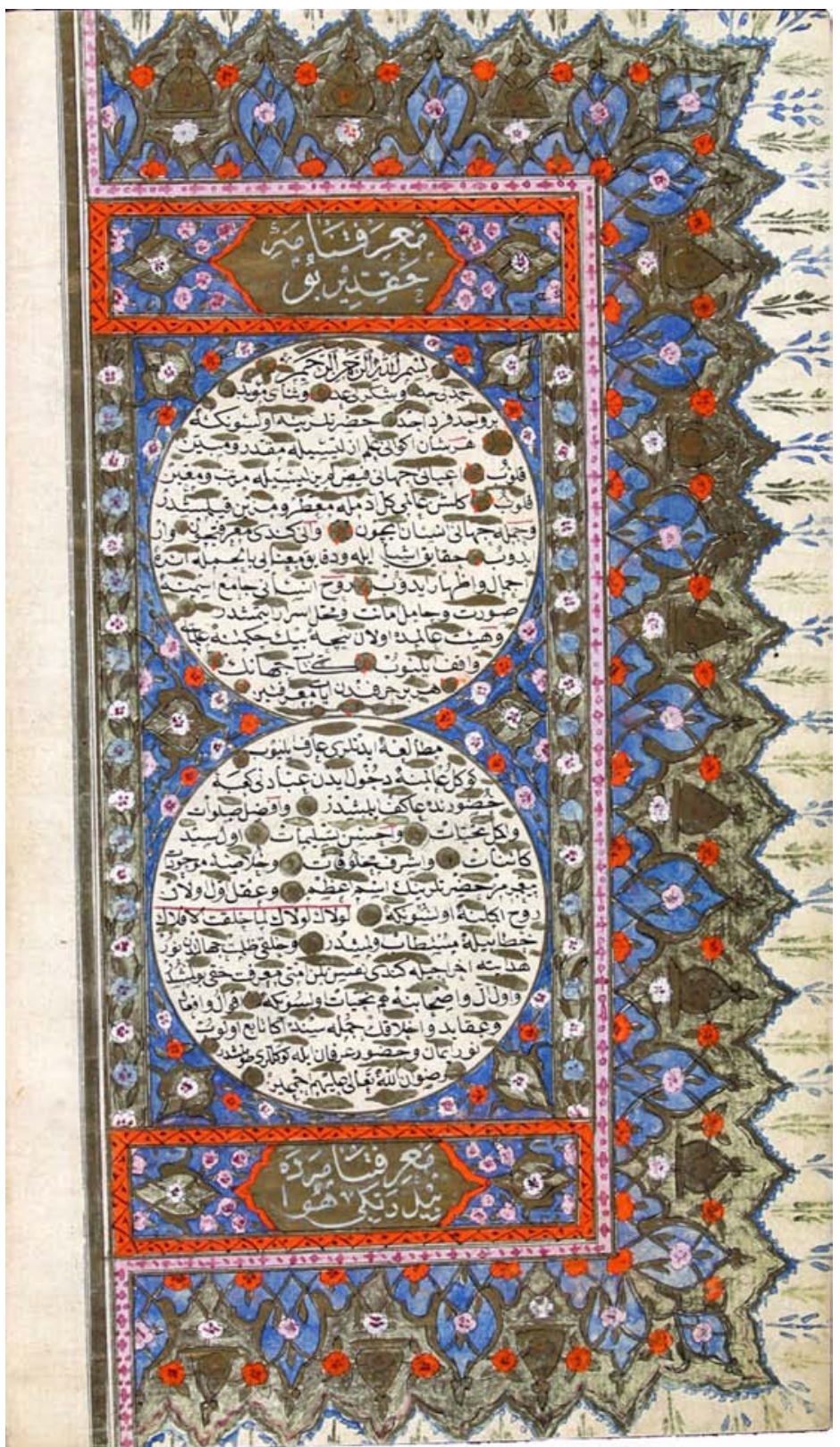

Figure 52. Utrecht, UB Hs. 16 B 18, f. 15b. The first page from a magnificently produced encyclopaedia of cosmic knowledge by İsmāīl Ḥaḳkī Erżurumī (d. 1186/1772), copied and designed in Erzurum in 1241/1826. 


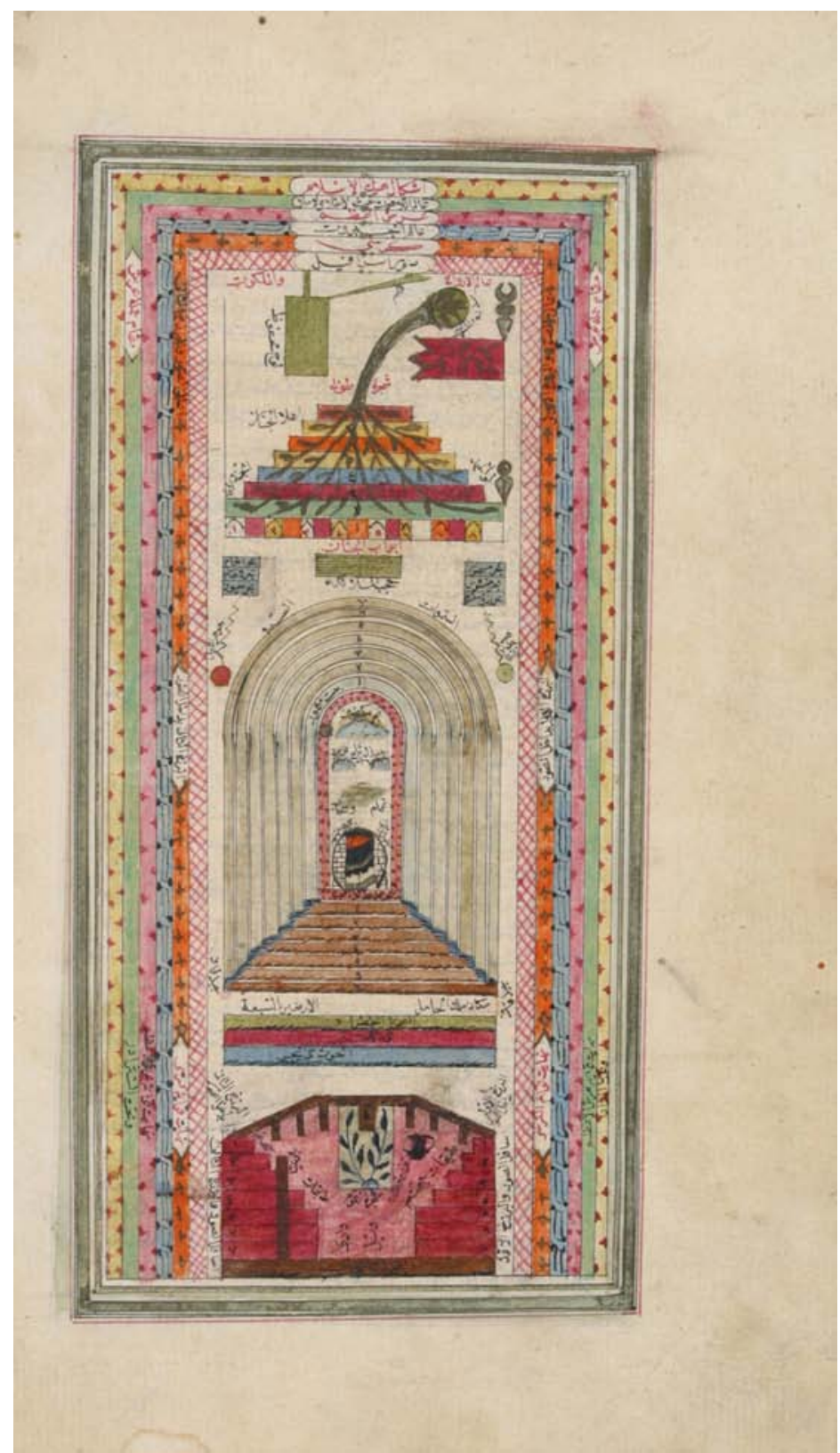

Figure 53. Utrecht, UB Hs. 16 B 18, f. 28 b. A page from a magnificently produced encyclopaedia of cosmic knowledge by İsmāêil Haḳḳi Erżurumī (d. 1186/1772), copied and designed in Erzurum in 1241/1826, with a schematic drawing of the universe centred on the Kaaba. 


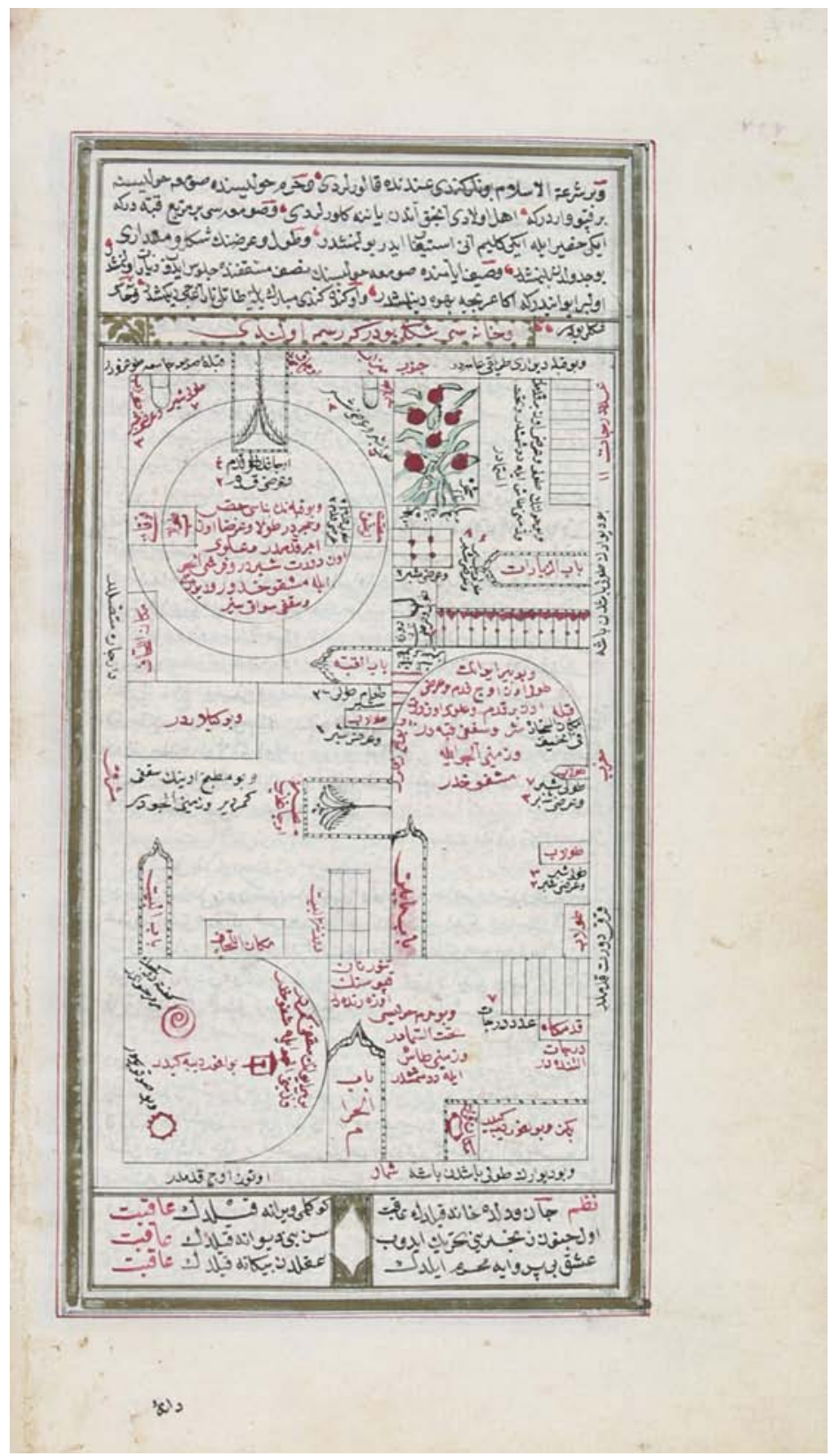

Figure 54. Utrecht, UB Hs. 16 B 18, f. 317b. A page from a magnificently produced encyclopaedia of cosmic knowledge by İsmāêl Haḳḳ̄ Erżurumī (d. 1186/1772), copied and designed in Erzurum in 1241/1826, with a plan of the house of the author's shaykh, İsmāî̀l Tillovì. 


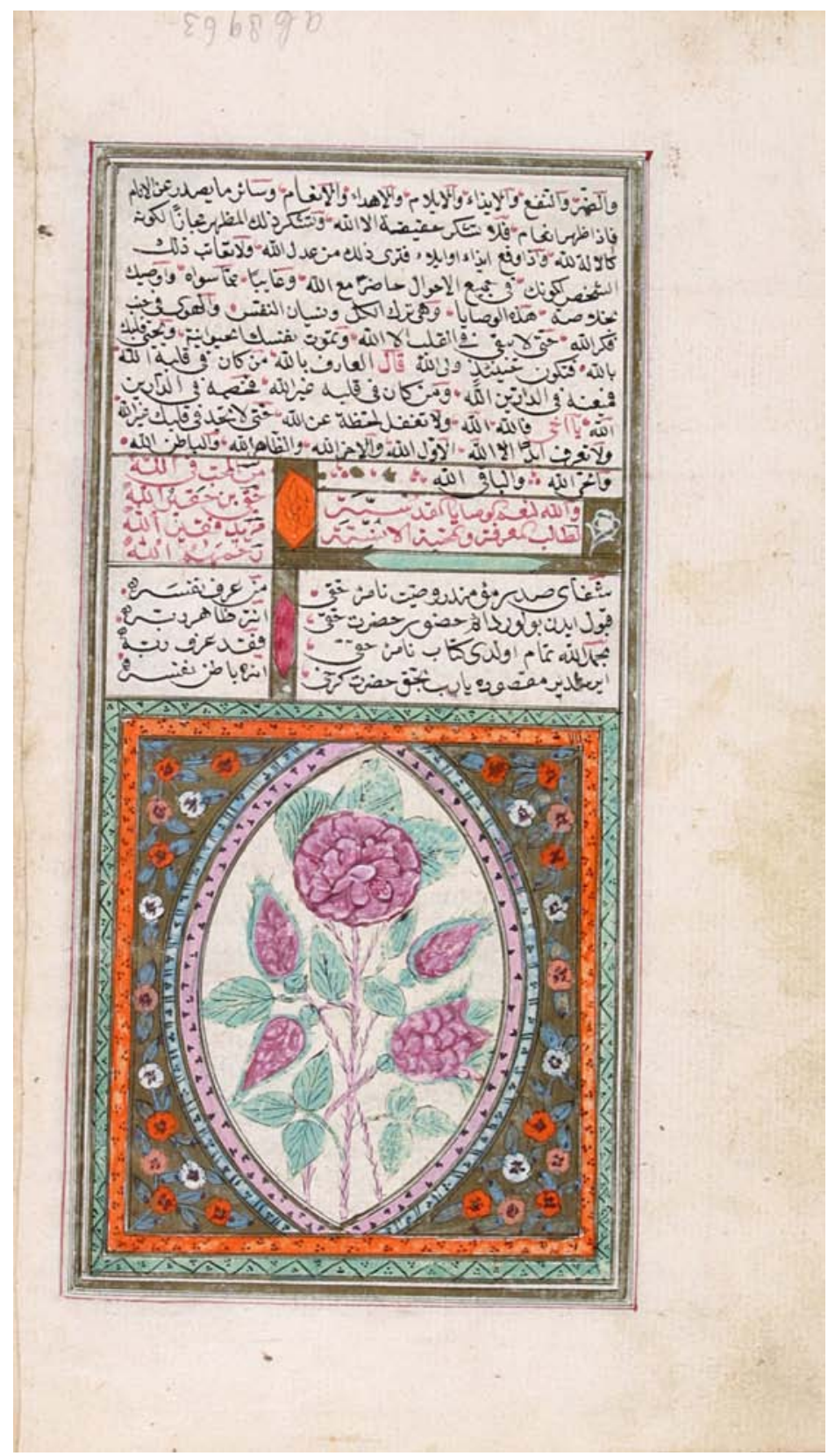

Figure 55. Utrecht, UB Hs. 16 B 18, f. 349 b. The final page of a letter of advice to a 'bother' appended to a magnificently produced encyclopaedia of cosmic knowledge İsmāēil Hakạkī Erżurumī (d. 1186/1772), copied and designed in Erzurum in 1241/1826. 
in a heading preceding the text on p. 1. Many copies of this work have survived. It commences with a quatrain not usually found in the text (cf. below), followed by an introductory mesnevi of 61 beyts in which, among other things, the author explains his life-long fascination for dictionaries and his decision to write a rhymed one as a nazire to the Tuhfe-i Husāmi (of 802/1399). He also expresses his hope that the work will be helpful to children in learning Persian and scanning verses. It is followed by $27 \mathrm{kut}$ ' as which discuss a vocabulary ranging from words for God to that for napkin. In the last section the author explains the numerical value of Arabic letters; it is followed by a table which shows the value of the letters in red (pp. 133-134). (For other copies of the text, see MSS Acad. 77 and 78, Hotz 2289, above; see also UBL Codices Or. 148, 1582, 1583, 5808, 6965, 6967, 8330, 11.117(2), 11.575(1), 12.428 and 25.760 .)

A few marginal pencil notes, partly in French; a handwritten label in French describing the MS is pasted on the inner back-board; pencil notes are added, among them the date ' 2 June 68 ' and the price of $£ 25$.

Bound in boards with light brown leather back and edges; glazed white paper; $1+134+1$ pages, with original numbers (folio-numbers $1-63$ in pencil have been added later); $217 \times 167 \mathrm{~mm}$ and $130 \times 75 \mathrm{~mm} ; 8$ lines 4 columns; catchwords; vowelled nesih; headings, rubrics and numbers in red; four lines erased on p. 15; completed by Ḧüseyn Efendi in 1166 (? 1752-1753). Acquired in November 1977.

Initial verses (p. 1, after a besmele):

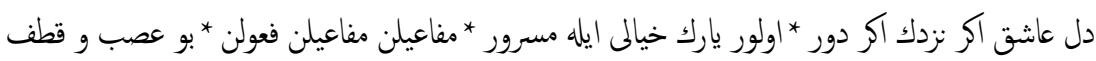
ايله وافر دراى حور عن أر تزد

Begins (ibidem, as in the printed edition of 1275):

$$
\text { بنام خالق و حى توانا *قديم و قادر و ببنا و دانا }
$$

Ends (p. 133, as in the printed edition of 1275, p. 23):

$$
\text { شاهدييه هر گ ا ايلرسه دعا * ايله محشرده شفاعت مصطفا }
$$

Colophon (ibidem, followed by a besmele):

$$
\text { بsic] } 1177 \text { بوكنابى او حسين افندى يظمش در سنى } 17 \text { see }
$$

Catalogue entries: Sohrweide II 199, where other references are found; see also Fihris 518-532 (I, pp. 133-136); Schmidt 34, 115, G 1500(1); Şeşen III 694/3; TIYK 55; TYTK (Antalya) 1633-1635; TYTK (Türkiye Büyük Millet Meclisi) 105 . 
Editions: Istanbul 1275; Antoinette C. Verburg, "The Tufe-i Şāhidī: a Sixteenth Century Persian-Ottoman Dictionary in Rhyme", in Archivum Ottomanicum 15 (1997), pp. $5^{-87}$ (in transcription, with translation and glossary).

Literature:Janos Eckmann, "Kāmūs" in $E I^{2}$; Storey III, pp. 66-67; see also the introduction to Verburg's edition.

Hs. 16 B 20

Ġāyetü l-beyān fì tedbìri bedeni l-insān

غايت البيان فى تدبير بدن الانسان

An early 18th-century copy of a handbook of medicine by Ṣālih b. Nașrullāh of Aleppo, also known as İbn Sellūm and chief physician (re'is el-ațtıba a $)$ at the court of Sultan Mehmed IV (d. 1080/1669-1670). As the introduction makes clear, the work was commissioned by the sultan; the author also expresses his intention to include descriptions of maladies and medicines, not yet mentioned in the traditional literature. The (incomplete) title is found in f. $3 \mathrm{~b}: 9$; the author's name in f. $3 \mathrm{a}: 5$. Although this is not mentioned in the introduction, the work clearly is a Turkish translation of the Arabic original by an anonymous translator-the author himself died when the original Arabic draft was hardly finished (cf. GAL II, p. 447; S II, p. 666; Kazancigl's study, p. 191, also mentions another translation of the same work). The handbook is preceded by an introduction ( $1 \mathrm{~b}-4 \mathrm{a})$ which consists of four main chapters (makāle), and ends with a conclusion (hātimetü l-kitāb, 17ob). See for a concise description of the contents, Sohrweide II, p. 173 .

Marginal corrections and additions, extensive on ff. 149b-151a, by the copyist; marginal indications of content in red. Additions by a later owner on ff. 4a (a recipe for a medical ointment), 167b (a description of the treatment of his nearly two-year-old daughter who had seriously burnt her right arm, dated 6 Rebīü l-evvel 1231/ 5 February 1816) and 172a (a recipe for a medicine against colds, menzu $\bar{u} l$ ). Jottings in bold script on ff. 1a and $172 \mathrm{~b}$.

Bound in embossed brown leather with blind tooled insets in Oriental style on the outer covers; glazed cream paper, torn and damaged in some parts; 172 folios, with original numbers; $239 \times 192 \mathrm{~mm}$ and $208 \times 121 \mathrm{~mm}$; 23 lines; catchwords; nesih; headings, rubrics, lines and double borders in red; gold borders within black lines on ff. 1b-2a; completed by the odabaşı İbrāhīm, known as kātib of the late kethüdā Parmakssı Ahmed, in Cairo on 20 Rebǐü l-ähir 1130 (23 March 1718). Acquired in October 1977. 
Begins ( $1 \mathrm{~b}-2 \mathrm{a}$, after an extended besmele):

$$
\text { جاقان اوان سواهر حمد و ثنا اول واجب الوجل اهود و مفيض الخير و الجود .... اما بعد مدح و ثنا سلطان محمدت }
$$

Ends (171b):

$$
\text { يلانك كززنى براكينه ايله إيليكه كجورب اوره بغلسه لر بالخاصه نافعدر اريدر كيده در }
$$

Colophon (ibidem):

قد وقع الفراغ على يد الفقير الحقير المعترف بالعجز و التقصير ابراهيم اوده باشى الشهير بكاتب المرحوم برمقسز

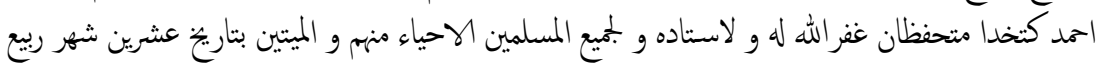

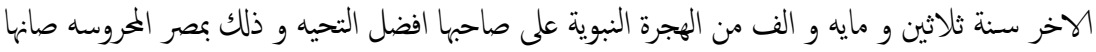

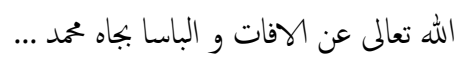

Catalogue entries: Sorhweide II, 188-189, where other MSS are mentioned; see also Fihris 3484-3490 (III, pp. 148-149); Karabulut 115; TYTK (Antalya) 1909, 3835; Medical Manuscripts pp. 48-52; TYTK (Balıkesir) 1119; Yardım 3784-3785.

Literature: 'OM III, p. 224; Aykut Kazancıgıl, Osmanlılarda Bilim ve Teknoloji (2nd impr. Istanbul 2000), pp. 191-192.

\section{Utrecht, Hs. 16 B 21}

Mā ḥażar

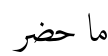

An undated copy of a treatise on medicine by Ebūbekir Nușret Efendi, librarian of the Nuruosmaniye Library at Istanbul (d. 1210/1795). The title is mentioned in f. 2b:2, the name of the author in f. 2a:1. The work is also known under the extended titles of Māhażar-i mu àlacāt-i tayyibe and Māhażare fì $t-t, t b b$. The work is preceded by an introduction $(1 \mathrm{~b}-5 \mathrm{a})$, and consists of two parts $(\mathrm{k} \iota \mathrm{sm})$, the former describing the working of talismans, magic squares in particular-drawings of these in black and red are found on $\mathrm{ff} .7 \mathrm{~b}, 9 \mathrm{~b}$, 10b, 15a, 16b, 20a and 21a; the latter (from f. 25a) consisting of a series of prescriptions and recipes. Marginal additions and indications of content. (For another copy of the same text, see Hs. 16 B 23, below.) The endpapers contain notes and jottings in pencil, among them a calculation (upside down, $75 \mathrm{~b}$ ) and series of letters of the alphabet, partly with diacritical marking (upside down, 81b).

Bound in worn dark brown leather: cream paper of low quality without watermarks; $1+81$ folios; $215 \times 170 \mathrm{~mm}$ and $155 \times 130 \mathrm{~mm}$, varying; 15 lines; 
catchwords; irregular nesih; rubrics, drawings (in part) and marginal indications of content in red; without a date and the name of a copyist. Acquired during the late 1970 .

Begins (1b-2a, after a besmele):

الممد الله الذى خلق الانسان و سخخره ماسواه و جعله مخدوما للكائنات ... اما بعد معلوم اوله كه بو مبتلاى

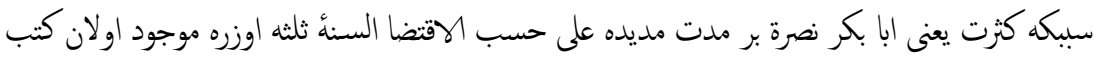

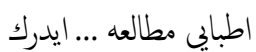

Ends (75a):

$$
\text { لقان روحى ... اوج دورت طملدوب اغر بيان ديمش اوزرينه وضع اولنسه اغرسينى تسكين ايدر م }
$$

Catalogue entries: Götz II, 417, where other MSS are mentioned; see also Fihris 4189 (IV, p. 18); Kut 343; Medical Manuscripts, pp. 119-121; Yardım 3787-3788.

Editions: printed 14 times in Istanbul between 1267 and 1331, cf. Özege 16969.

Hs. 16 B 22

\section{A manual for pilgrims}

The undated work in a mid 18th-century copy consists, according to the first lines (quoted below), of a description of the halting places (menzil) between Üsküdar, Damascus and the Holy Cities of Mecca and Medina. These are mentioned in headings in red together with the distances in hours of travel. The descriptions, often very brief, offer practical advice and name the obligatory sites, mostly mosques and tombs of saints, to be paid respect to by the passing pilgrim. More detailed descriptions are devoted to Damascus (10a-11a), Medina (17a-18a), Mecca (2ob-21b) and its surroundings (from 21b), including the pilgrimage rites to be performed there. These are followed by a description of the gates and other features of the Harem- $i$ şerif $(25 \mathrm{~b}-29 \mathrm{~b})$, and the places to be visited in Mecca and its surroundings $(29 b-33 a)$. The work concludes $(33 a-34 a)$ with the text of a fetva on the 14 historical appearances of comets (kuyruklı yıldı) and the catastrophic events by which they were accompanied, issued on request of a sultan by the şeyhülislām, [Yahyā] Minḳārīzāde [in office 1073/1662-1084/1674]. Annotations in tiny script in pencil, mostly in Arabic, are found on ff. 1a, 22b-23a, and $34 \mathrm{a}-\mathrm{b}$.

Without cover; glazed cream paper with moisture stains; 36 folios; $195^{\times}$ $125 \mathrm{~mm}$ and $130 \times 65 \mathrm{~mm}$, varying; 13 lines; catchwords, often omitted; ta lïk; 
headings and lines in red; completed in 1170 (1756-1757); without the name of a copyist. Acquired in the late 197os.

Begins (lb):

هو الخلاق الباق در ذكر منازل عن اسلامبول الم الشام و مدينه و مكه و جبل و عرفات شرفهم الله تعلى (1) Ends (34a):

شيخ الاسلام منقارى زاده اولان وجه ضروح اوزره ظاهر اولاجنى انجق الله تعالى حضرتلرى بلور كتبه الفقير

Colophon (ibidem):

سنd · 118

Utrecht, Hs. 16 B 23

Mā ḥażar

ماحضر

A mid 19th-century copy of a treatise on medicine by Ebūbekir Nușret Efendi, librarian of the Nuruosmaniye Library at Istanbul (d. 1210/1795). The title is mentioned in f. 2a:7, the name of the author in f. 1b:10. The title Kitäb-i Nușret Efendi is found in pencil in the upper margin of f. 1a. Drawings of magic squares are found on ff. $5 \mathrm{~b}, 6 \mathrm{a}, 7 \mathrm{~b}, 8 \mathrm{~b}, 13 \mathrm{a}, 14 \mathrm{a}, 14 \mathrm{~b}$ and 19a. Marginal additions, mostly indications of content in red. (See for another copy and further particulars Hs. 16 B 21, above.)

The endpapers, including f. 1a, contain a plethora of jottings and notes in pencil and ink, in various hands, among them a series of six different prescriptions, mostly of one line, for antidotes against poisons (66a); calculations (66b); various administrative notes $(67 \mathrm{a}-\mathrm{b})$; and a recipe with a list of ingredients, including opium $(67 \mathrm{~b})$.

Begins ( $1 \mathrm{~b}$, after a besmele):

المحد لله الذى خلق الانسان و سخرله ماسواه و جعله مخدوما للكائنات ... اما بعد معلوم اوله كه بو مبتلاء

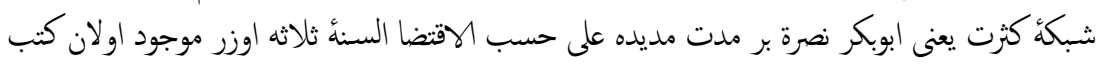
اطبايى مطالعه ... ايده رك بـ ابكر نصرة

Ends $(65 b)$ :

حاصلى بر درهى قولنجه امان و يرمز والسلاه اوله جق تبين [؟] يوقدر هر وقتده استعحال اولنور بر دنك يارم در هم 
Colophon (ibidem):

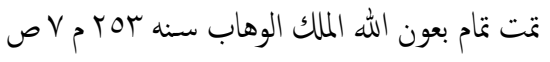

Bound but without cover; glazed white paper; 67 folios; $206 \times 147 \mathrm{~mm}$ and $150 \times 100 \mathrm{~mm}$, varying; 14 lines; catchwords; nesih and, mostly, $r$ k $k^{c} a$; marginal indications of content in red; completed on 7 Şafer [1]253 (13 May 1837); without the name of a copyist. Acquired during the late $1970 \mathrm{os}$.

Hs. 16 B 24

Revnāki -i bostān

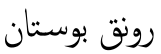

An early 18th-century copy of an anonymous treatise on agriculture and arboriculture. It was written in the 16th century or earlier; the, apparently, oldest manuscript, preserved in the Topkapı Sarayı Library, cf. Karatay 1755, is dated 985 (1577). The title is mentioned on f. 1b:9-10; the work consists of a brief introduction, four parts (faşl), a supplement (tetimme) and a conclusion (hätime, on fruits). Marginal indications of content in black and red. For a description of the contents, see Blochet S. 230.

The text is preceded by a three-page index. It is followed (35b) by a horticultural prescription and, upside down, a note on grammar in Arabic, both by the copyist. A fragment of a note (14 lines) on some inhabitants of Eyüb near Istanbul and another one (4 lines) on the repayment of a loan of 20 ğuruş by 'Abdurraḥmān Çelebi in 1129 (1717) are found on the last flyleaf, verso.

Bound in worn dark brown leather with flap and blind tooled insets in Oriental style; cream glazed paper; $2+35+2$ folios, with original numbers; $201 \times 135 \mathrm{~mm}$ and $148 \times 75 \mathrm{~mm}$; 17 lines; catchwords; ta lik ; borders, rubrics and indications of content (partly) in red; gold borders within black lines on the first to pages; completed by es-Seyyid Ḥüseyn b. es-Seyyid Mușțafā el-İrmenākī (sic, but probably referring to Ermenāk, present Ermenek) on a Thursday in the middle of Receb 1128 (1 or 8 July 1716). Acquired in the late 1970 .

Begins (second flyleaf, verso, after a besmele):

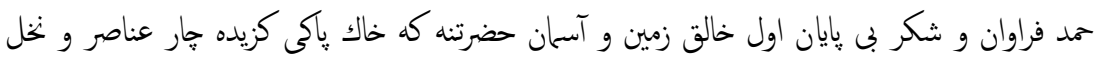

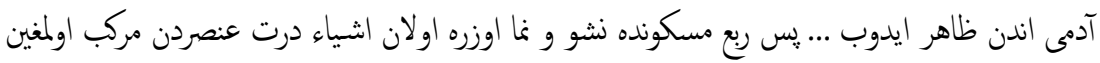

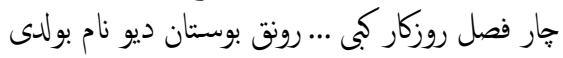


Ends (35b):

محكم بغليه بر زمان طوره ئ يايرغين بر طبقه دخى ديزوب ينه يبراق قويالر بو اوسلوب اوزره اغرينه وارنجه بعده

Colophon (ibidem):

تمت هذه الرساله اللطيفه عن يد العبد الضعيف الفتير اللى رحه ربه الجليل القدير السيد حسين بن السيد

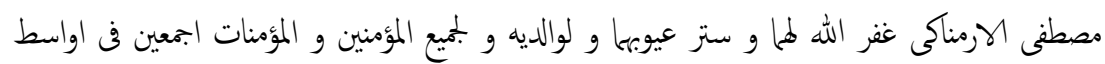

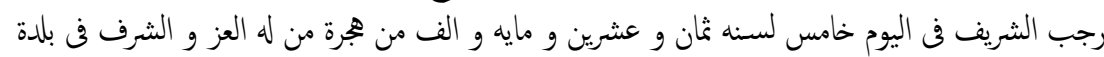

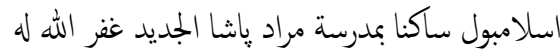

Catalogue entries: Sohrweide I, 331, where other MSS are mentioned; see also Fihris 2755 (II, p. 300); Kut 348; TYTK (Burdur) 1925.

Editions: Istanbul 126o; Konya 1285 (cf. Özege 16834).

\section{Hs. 16 B 25}

Turkish glosses

The manuscript contains a copy of a didactic Persian poem in mesnevi rhyme, Pand-nāma, attributed to Farīd ad-Dīn 'Atțār (d. after 586/119o), cf. B. Reinert in Encyclopaedia Iranica. The title Kitāb Pand-i 'Atțār is found in a heading preceding the text. According to a rhymed colophon on $\mathrm{f}$. 47a, the copy was completed by 'Oșmān in 1207 (1792-1793). The text is accompanied by interlinear glosses in Turkish in smaller script.

The endpapers contain a plethora of annotations and jottings in Arabic, Persian and Turkish, both in black ink and pencil—-the latter mostly lengthy quotations from pious treatises-among them the first six lines of the same poem, Pand-nāma, with the same interlinear glosses in Turkish (first unnumbered page); two identical colophons in imitation of the colophon on the same page (47a, quoted below) with the name of Süleymān and the year $1210\left(1795^{-1796)}\right.$; a repeated mention of the year $1263(1846-1847)$ in plene Turkish (written upside down, 47b); an ebced table (upside down, 48a); pious phrases and aphorisms in Arabic and Turkish, often repeated (last unnumbered page).

Begins (first unnumbered folio, verso):

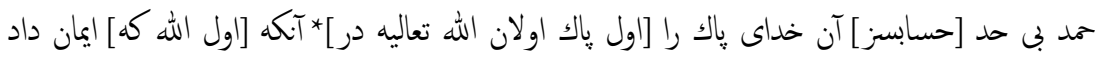

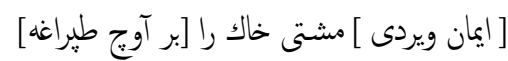


Ends (47a):

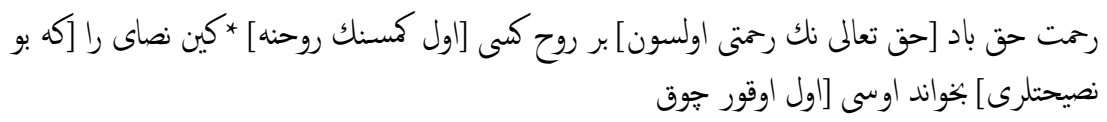

Colophon (ibidem):

جون نوشت عثمان پِند يادكار * هفت دو صد تاريخى با هزار

Hs. 16 C 1

A miscellany

The volume is a collection of separately hinged, original copies of official Ottoman documents and related correspondence, in varying formats, with texts in $r k^{\prime} a$, div $\bar{a} n \bar{\imath}$, siya âkat and other scripts, mostly dating from the late 18th century. Most of these papers, as is clear from annotations on the documents themselves, seem to have once belonged to the archive of the Mevkūfāt ḳalemi, 'Bureau of Retained Revenues', in the Finance Department of the Porte in Istanbul which, among other tasks, was responsible for the maintenance of military depots on the Ottoman frontiers and the provisioning of soldiers and their animals involved in military campaigns (cf. F. Müge Göçek, "Mewkūūātčı", in $E I^{2}$ ). The collection was shortly after its production acquired by 'Sir Wm Jones', whose name appears in gold on the back of the bound volume (who could not have been the famous 'Oriental Jones' in view of the dates on some of the manuscripts; the volumes were only bound in 1849). How he, whoever he may have been, obtained these documents is a mystery-quite a few of the documents, in view of their content, may have been captured in the Balkans during the last year of Austro-Ottoman war of 1788-1791. The papers may also have been gathered by an Ottoman official, who afterwards sold them on the market. A second volume (in fact the first), of the same format and clearly of the same origin, is found in MS $16 \mathrm{C}_{2}$, described below. Modern pagination in pencil is found on the documents.

Many texts - the exceptions are outlined below - are (extracts or parts of) reports (takrīr, i'lām) written by Palace officials sent on purchasing missions, copied in a neat $r \iota k^{c} a$ hand, obviously by a clerk of the aforementioned Mevkūfät ḳalemi. A few original letters and documents related to the reports are added. In a second stage the sheets on which these copies had been made, were used for further bureaucratic processing and, finally, archiving, by other clerks: we find on most sheets notes in bold dīvāni addressing the defterdār, and sometimes other officials, indicating, for instance, which fermāns were to be issued, notes by financial experts (in 
siya kat script) calculating the financial consequences, and so forth. These texts, many of which are signed and stamped with seals, and brief notes are often preceded by headings in small $r k^{\prime} a$ on the content and provenance of the documentation found on the page, always mentioning the Palace offcials charged with the purchases and a date. There are also original copies of letters and draft fermāns (in careless dīvāni with erasures and corrections) on the same subjects on separate leaves. Most documents in this volume date from the year 1205 (1790-1791), a minority from the years 1202, 1203 and 1204 (1787-179o); exceptional are 1191/1777 (p. 85), 1206/1791-1792 (p. 39), 1208/1793-1794 (p. 89), 1211/1796-1797 (p. 109), 1217/1802-1803 (p. 111), and 1221/1806 (p. 99).

The collection is preceded, pp. 1-3, by a copy of a fermān with additional notes which is concerned with the conclusion of a truce (mütäreke-i hāayrìye) and the abolition of wartime measures related to the levying of taxes and acquisition of provisions in the provinces between Edirne and Kırḳilise on the one side, and the military headquarters (ordu-yı hümāyūn) in the Balkans on the other, in Cemāzi l-evvel 1205 (January 1791); the relevant defters should be closed. A note in bold dīvānī instructs the defterdār to consign these documents to the archives (bațtälda hıfž eylesiz deyü), upper margin, p. 3 .

Provisions, to be transported either to the military headquarters in the field or to the Palace, Arsenal, or, in one case, the soupkitchen ['imäret] of the Süleymānīye Mosque (cf. p. 31) in Istanbul, were, mostly, grain (wheat and barley) — to be delivered from the Morea [Peleponnese], cf. pp. 13, 55; from the aerea of Tekfurḍagì [Tekirdağ], pp. 29, 141, 152; Silistre, p. 33; Salonica, p. 35; Yeñişehir [Larissa], p. 35; Sīrōz [Serres], p. 51; Athens, p. 57; Candarlı, p. 61; Kuşadası, p. 61; İbrā̄îl [Braila], p. 71; Sofia, pp. 79, 81; Karīnābād [Karnobat], p. 85; Varna, p. 87; Çatalca and surroundings, p. 91; Yeñibāzār [Novi Pazar] and surroundings, p. 101; from the storehouse in Edirne, p. 123; from İhtimān, pp. 135, 137; peksimet (biscuit) (from the area of Bursa, pp. 15, 125, 127, 153, 155; Lefkoşe [Nicosia], p. 65; Sīrōz [Serre], p. 73; Salonica, pp. 103-104; the Mora [Peleponnese], p. 147); firewood (from Sofia, p. 77); and straw (from Karīnābād [Karnobat], p. 85; from the Çatalca area, p. 91) - a bill concerning the delivery and payment of various loads of grain in the port of Ruscuk (Ruse), handed in and signed by İsmācil Aga, is found on p. 63 .

Saltpetre (gühercile) was to be mined in the aera of Üsküb and transported (on camels) to the gunpowder-mill (bārüthāne) in Gallipoli (cf. pp. 21, 23, 41, 48, 105, 107, 129, 157). Copper was ordered from the mine at Gümüşhane; the purchase was to be financed from the poll tax (cizye) levied 
in Diyārbekir (p. 97). Many documents discuss transport of the collected provisions, and the way in which the necessary beasts of burden and carts are to be purchased or hired, and ships to be chartered. Camels were ordered from Central and East Anatolia (a report from the kạ̄ż̀ of Çekmece-i șagīir (Küçük Çekmece) reported that ten out of 385 camels which had been passing through his district from Çorum, Nig̈de and other places, had died, p. 19, cf. also p. 45); from Denizli (p. 93); Menteşe (p. 95); Tire (pp. 119, 121). Buffaloes $(c \bar{a} m \bar{u} s)$ were obtained from Thessaly and Thrace (p. 39). Horses were ordered from Tire (pp. 53, 119, 121). Ships were chartered in various ports (iskele): Ǵolos (Volos, p. 17), Ṭalande (Atalandi, p. 17), Tekfurḍagīi (Tekirdağ, pp. 17, 113), Silistre (on the Danube, p. 33), Bandırma (pp. 43, 69). Ox carts were ordered from Filibe (Plovdiv) (p. 65).

One report discusses the absence of kilns for baking bread in the military stations between Edirne and İsakçi (Isaccea); a fermān ordering the digging of enough kilns was to be dispatched (p. 59).

Some reports document in a lively fashion how the provisioning sometimes was sabotaged by agents or local producers, or how logistics occassionally broke down. Of an ordered amount of $27,584 \mathrm{kil}$ of wheat from the Morea, fifteen months later 11,625 had yet to be sent; the governor of the peninsula, Ebūbekr Paşa, was to be sent a fermān to take care that the whole load were delivered; the defterdār is accordingly instructed on 23 Şevvāl 1205 in the usual marginal annotation (25 June 1791, p. 55). The Molla, es-Seyyid el-Ḥācc Aḥmed, of Lefkoşa (Nicosia) complained on 9 Şevvāl 1205 (11 June 1791) that he was unable to ship the ordered ammount of 10,000 kanțār of peksimet to Istanbul because of the presence of a part of the Russian fleet off the coast of the island, blocking the arrival of the chartered Venetian transport (p. 67). An employee (gediklï) of the Porte, Ahmed Aga, sent on a mission to buy buffaloes, reportedly disappeared with the money (mîri akçe) entrusted to him-the defterdār is instructed to dispatch another agent (p. 117). The Venetian ambassador sent a report, confirmed by letters from the gümrük emini of Istanbul, Hasan, and the k kāż̀ of Limni, Mehmed Efendi, on the shipwreck of a Venetian vessel, which had been sailing from Golos(Volos) with 59 sacks of flour for the Porte, on the rocks of Limni [Limnos] (pp. 131-133).

Some documents are concerned with the levying of taxes (p. 75, from the provinces of Aydın, Teke and Menteşe; p. 83, from the Vidin area, where problems had arisen owing to the Austrian Campaign, 6 Şa $b \bar{a} n$ 1202/12 May 1788; and from the provinces of Hamīd, p. 146, and Kütahya, p. 149).

Documents which do not seem to be (directly) related to provisioning, the levying of taxes or the war-effort are: an undated report concerning 
the clearance of debts incurred by the murdered voyvoda of Wallachia, Alexander Ipsilanti, form his estate. A note in the upper margin instructs the defterdār to keep the report for the time being in the muhallefāt [halîfeligi] kalemi (p. 9); a promissory note on a loan of 1000 gurus from a häce of the Porte, Ḥasan Efendi, signed by Mușțafā, ser-i bevvābinn-i dergāh-i 'Ālī (p. 110); a statement, unsigned, on a outstanding debt owed by a muhäfiz of İnebahtı [Navpaktos] — a marginal note addressing the defterdār is dated 17 Cemāzī l-evvel [1]217 (15 September 1802, p. 111); and a report ('arïza) from an agent to a patron concerning the inspection of ships passing through the ports of the Black Sea near Bafra; goods belonging to the mother of Țayyār [Mehmed] Paşa [the rebellious governor of Canik and Samsun] had been confiscated from a kayı ; her agent, Emīr Mehmed, and the captain had been interrogated, and the goods had been sent to Istanbul, dated 11 Rebī ï l-ähir [1]221 (28 June 1806; see for the same affair also under MS 16 $\mathrm{C} 2$, below).

The office also received petitions-some original copies are found in the volume-with further administrative annotations in the collection: a request for the allocation of a daily portion of half an okka of rice from a mukāta'a in Filibe (Plovdiv), used for provisioning the kìlār-i 'ammire, formerly granted to his two (deceased) brothers, and signed by Seyyid Muștafā Morī (p. 11); a request for tax exemption from a mütevellī, İbrāhīm Hāāzāde 'Abdurraḥmān, on behalf of the suffering villagers of Burgozoz employed by his $v a k f$ (p. 49); a petition from a leading merchant (tüccār kalfası), Manuel, son of Ḳosțațin, of Țațavla (Galata), concerning a conflict on the repair of a building on vakf land near the quay of Davud Paşa, with a legal statement (p. 89); and a request on the replacement of an absentee mültezim stationed at the fortress of Cisr-i kebīr (Klis) (p. 143).

Bound in boards with green leather backing and edges; the legends 'SIR WM JONES MSS' and 'VOL 2 ' are stamped in gold on the back; white glazed paper; $(2)+158+(2)$ pages; $380 \times 270 \mathrm{~mm}$, varying; original documents with texts in various formats and scripts; occasional rubrics in red; seals, see also above. Acquired from Ad Orientem (St. Leonard's on Sea, Sussex, England) on 3 October 1975 . 


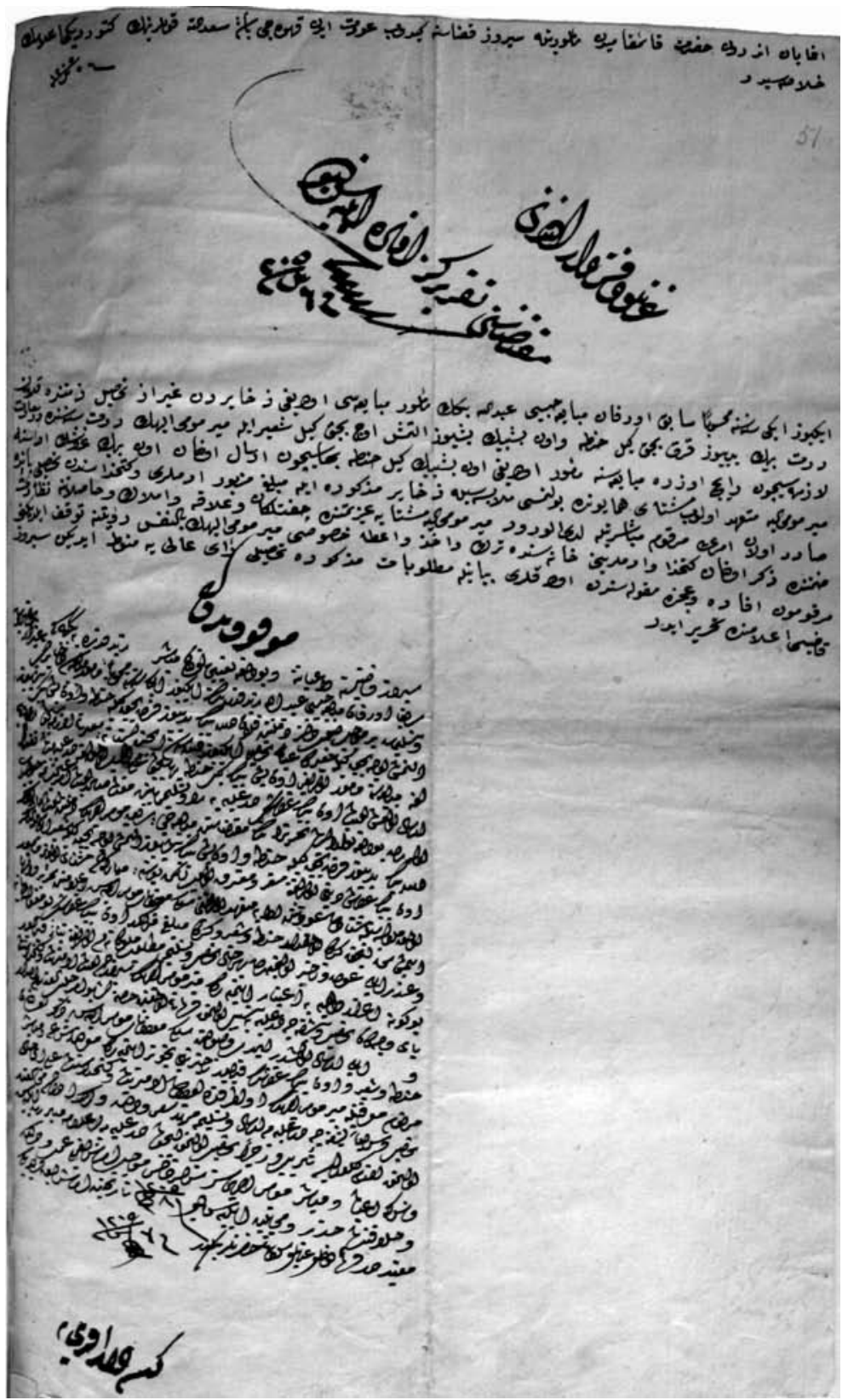

Figure 56. Utrecht, UB Hs. 16 C 1, p. 51. A page from a collection of original letters and documents, showing a report (by the kahvecibaşı of the Palace, Sa'dullāh) and a hüküm concerning the purchase of wheat and barley in Sīrūz (Serre), with bureaucratic annotations, dated 1205/1791. 


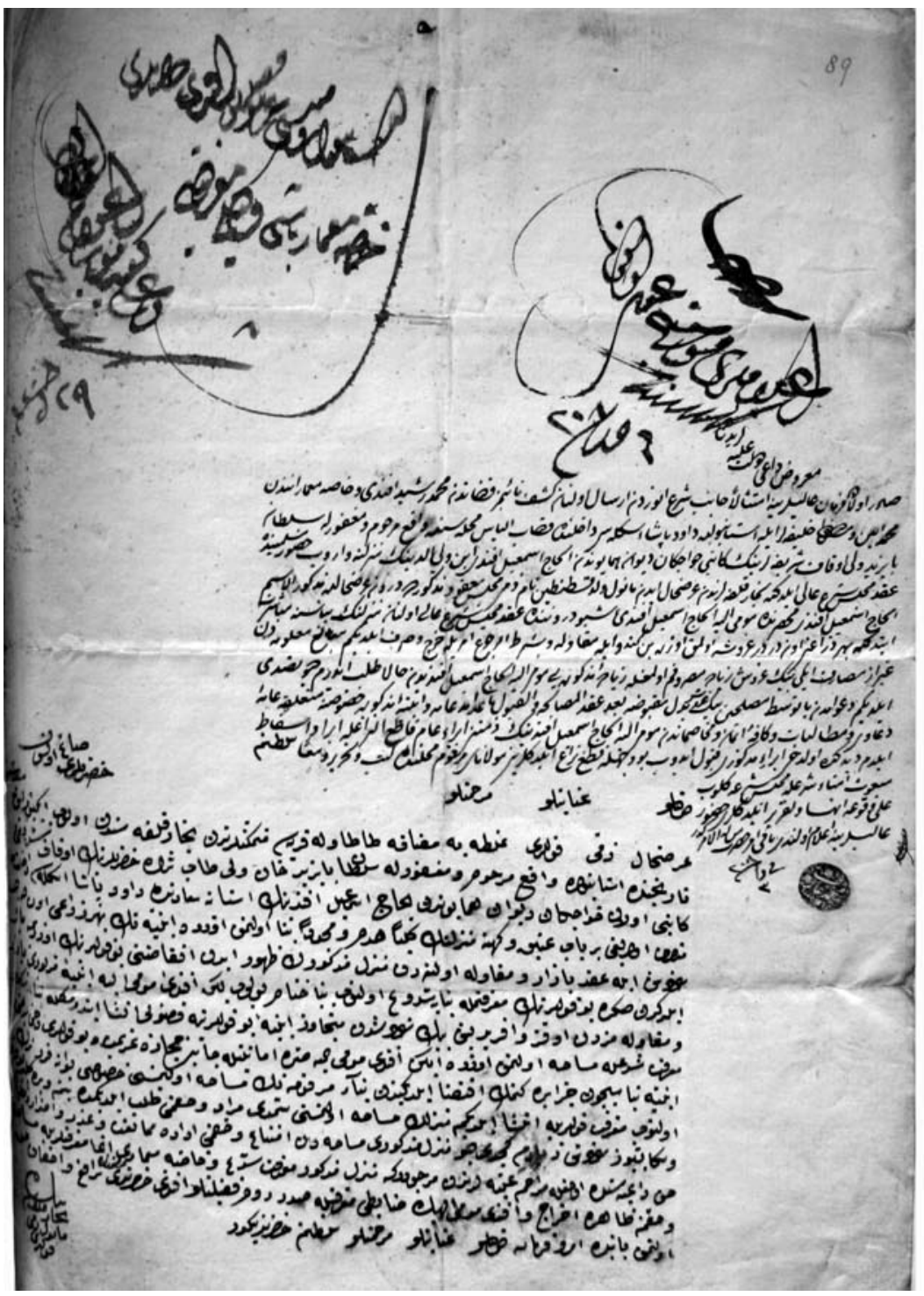

Figure 57. Utrecht, UB Hs. 16 C 1, p. 89. A page from a collection of original letters and documents, showing a petition and a legal report concerning a conflict about the repair of a building near the quay of Davudpaşa, Istanbul, preceded by bureaucratic annotations, dated 1208 (1793-1794). 


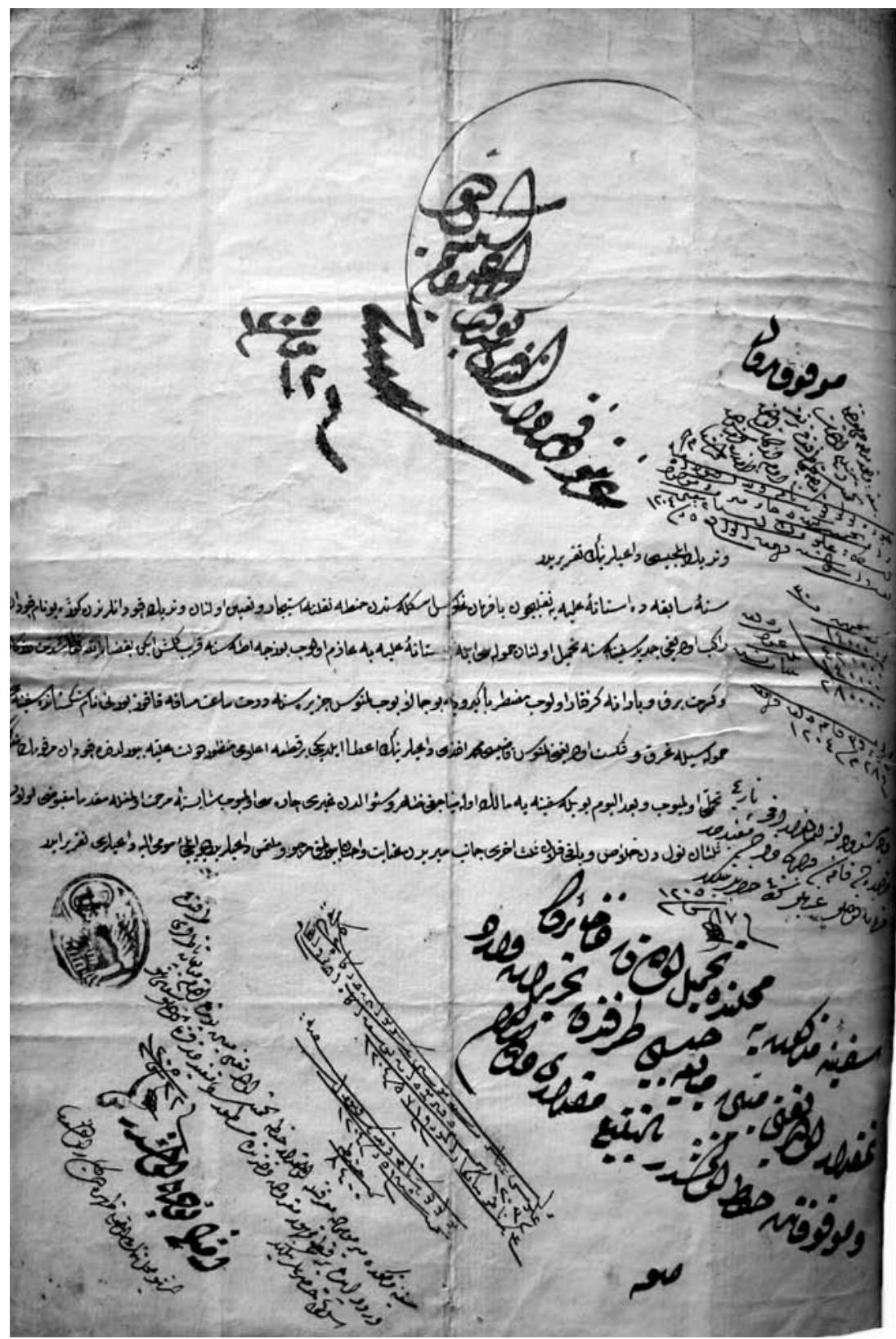

Figure 58. Utrecht, UB Hs. 16 C 1, p. 132. A page from a collection of original letters and documents, showing a statement of the Venetian ambassador, surrounded by bureaucratic annotations, on the shipwreck of a Venetian vessel off Limnos which had been on its way to Istanbul with grain, dated $1205 / 1791$. 


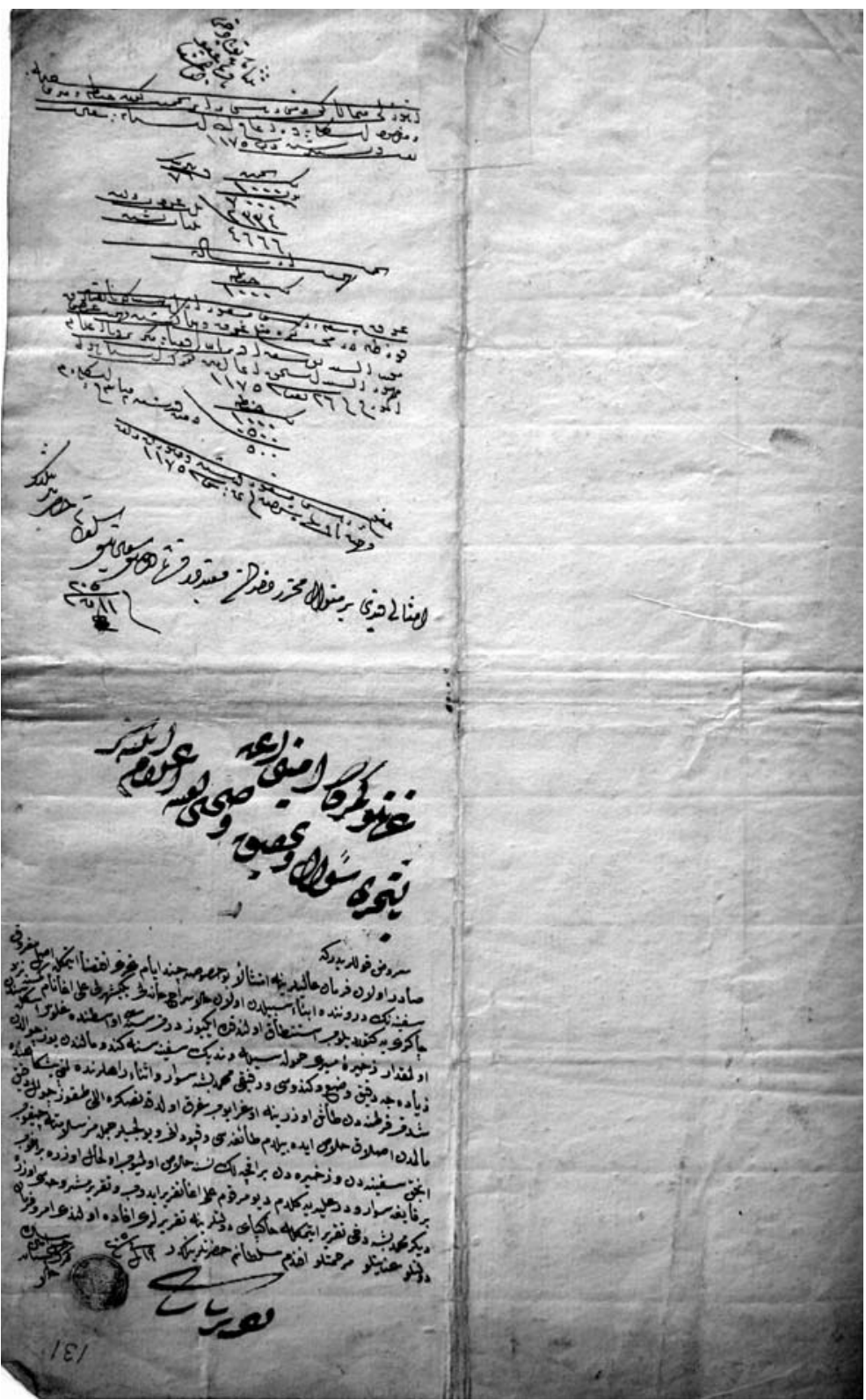

Figure 59. Utrecht, UB Hs. $16 \mathrm{C}$ 1, p. 131. The verso side of the previous document, with a copy of a report of the gümrük emini of Istanbul on the same affair, dated 1205/1791. 


\section{Hs. 16 C 2}

\section{A miscellany}

The volume is a collection of separately hinged, original copies of official Ottoman documents and related correspondence of varying formats, of the same type as found in MS $16 \mathrm{C}$, described above. Modern pagination in pencil occurs on the documents.

Most documents, as in the collection described above, concern provisioning and are dated with the year 1205 (1790-1791), but we also find the years $1202 / 1787-1788$ (pp. 19, 27, 33, 47), 1203/1788-1789 (pp. 50-51), 1210/1795-1796 (p. 7), 1218/1803-1804 (p. 21) and 1221/1806-1807 (cf. below)

Goods ordered are: peksimet (from Bursa, pp. 2-3 [with a draft note in French, signed 'Jean au convent du S. George Galata', p. 1]; Sīrōz[Serre], p. 11; and Salonica, pp. 23, 55); horses (from Tire, pp. 5, 50, 53); grain (from Athens, pp. 5; from the Arsenal for the 'imāret of the Süleymāniye Mosque in Istanbul, p. 5o); oil (rügan, from Manastir, p. 2o); wheat (p. 36); carts, camels and horses (from Aydos, p. 45). Unspecified provisions were to be shipped through the port of Bandirma (p. 31). Reports by various local authorities on the shipment of provisions between Golos (Volos) and the Morea (Peleponnese) are found on pp. 37, 39, 41, 43, and 45. A few documents concern the conscription of troops (from the $k \bar{a} \dot{z} \bar{\imath}$ of Ṭulyān [Doljane], p. 27) and the disarray and reorganisation of military stations near Edirne in accordance with the rules of the mevkūfät [kalemi] (p. 33-the verso side, p, 34, contains a administrative note with titles of manuscripts and printed books with prices in $\dot{g} u r u s ̧)$.

Problems with the provisioning are found in documents on pp. 17-18: a letter to the Porte from Ahmed, $k \bar{a} \dot{z} \bar{\imath}$ at Anabolı [Navplio], concerning the shipment of 5000 kil of wheat on a Sicilian vessel, to be transported from Tarabolı (Morea) to the Arsenal; it is accompanied by a statement (ilàm) from Hasan, gümrük emini, about the shipwreck of the same ship in the Dardanelles (p. 17). A copy of a hüküm addressed tp the authorities in Salonica, Yeñişehir (Larissa), Tirhạala [Trikala] and other towns in Thessaly forbids the obstruction, robbing or embezzlement of agents charged with the purchase of provisions (p. 51).

The collection also contains copies, partly original, of petitions: from a mütevellī, Mușțafāel-Hilmī, requesting protection against scoundrels living in the village of Duraḳlı (Bursa), part of the vakf of the late vālide-sultān, Gülrūh, dated ${ }_{3}$ Cemāzī l-ähir 1210 (15 December 1795, p. 9); from a müderris, es-Seyyid Ahmed, concerning the repayment of a debt of $2625 \dot{g} u r u s ̧$ (p. 21); from a certain Simeon, concerning a debt owed by the former voyvoda of 
Wallachia, Constantin Ipsilanti (p. 25). An unsigned draft petition with a request for re-employment as hammālbaşı at the Arsenal is found on p. 14. A hüccet confirming the duties of Ahmed Halīfe, who is paid as soldier from the miri coffers and is also a salaried reader in the mosque of Amasya occurs on p. 51 .

There are also a few private letters, all dated 1221 (1806-1807). Two almost identical copies (pp. 7,13 ), signed ... vālide hanım efendi, were from a woman called Fāțima-her seals are found on the back - probably identical with the mother of Țayyār Paşa (cf. under MS 16 C 1, above), addressing a brother, with whom her son was staying; both are dated 5 Şafer (24 April 1806). The letters discuss the whereabouts and military activities of a number of common acquaintances: Yūsuf Paşa and Ḥazinedāroğlı Süleymān Ag̉a had been involved in some fighting; Kavaḳlı Selīm had moved with a thousand horsemen towards Șulu Ot, but no hostilities had taken place yet; Tunḳalog̉ı Ḥāccī Süleymān Bölükbaşı was requested in Ḳavak but was waiting for orders from 'our Pasha', who had not yet appeared, and taken Laçin with 450 soldiers. Canik was still unoccupied. The second copy (p. 13) contains marginal additions in a different hand, on the loss of papers and the difficulty of rewriting the letter, and the handing over of the household linen (çamaşurlar) sent to her brother. A letter from el-Hācc 'Oșmān on the confiscation of goods and linen sent to her son at Şohūm (Sokhumi) by the mother of Țayyār Paşa, a resident of Bafra, with her agent, Emīr Mehmed, by the mütesellim, Selìm Ag̀a, is found on p. 15 (see also under MS 16 C 1, above).

Bound in boards with green leather backing and edges; the legends 'SIR WM JONES MSS' and 'VOL 1 ' are stamped in gold on the back; white glazed paper; $(2)+55^{+}(2)$ pages (pp. 49-52 are part of a folded leaf); $380 \times 270 \mathrm{~mm}$, varying; original documents with texts in various formats and scripts; occasional rubrics in red; seals, see also above. Acquired from Ad Orientem (St. Leonard's on Sea, Sussex, England) on 3 October 1975. 


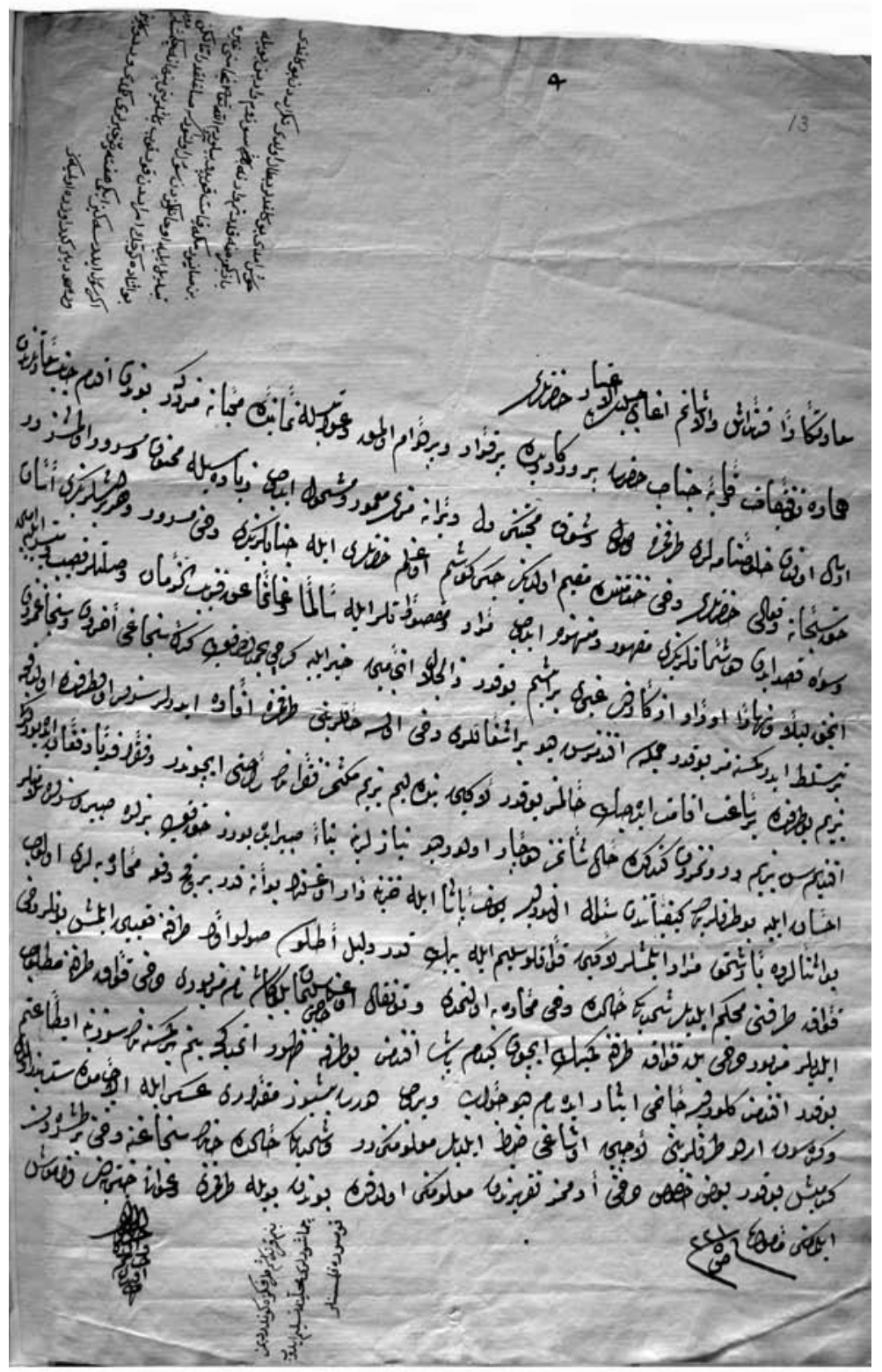

Figure 6o. Utrecht, UB Hs. 16 C 2, p. 13. A page from a collection of original letters and documents, showing a copy of a private letter from the mother of the Ottoman rebel Ṭayyār Paşa to her brother, dated 1221/1806. 


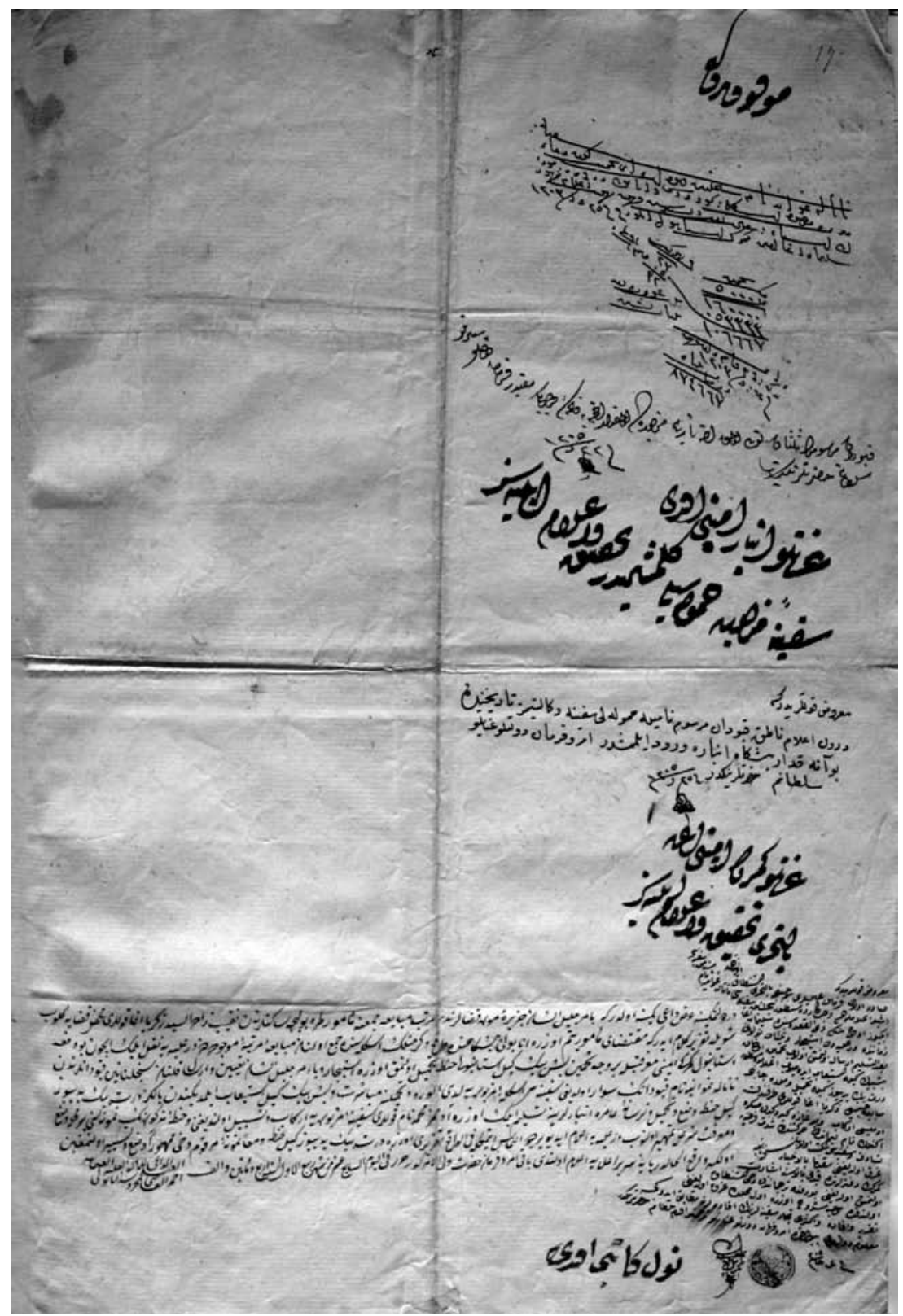

Figure 61. Utrecht, UB Hs. 16 C 2, p. 17. A page from a collection of original letters and documents, showing a report on the purchase, shipment and eventual loss of a load of grain sent from the Mora (Peloponnese) to Istanbul, preceded by bureaucratic annotations, dated 1204-1205 (1789-1791). 


\title{
EPILOGUE
}

\begin{abstract}
Turkish Manuscripts in Public Collections in the Netherlands: a Treasure Trove for the History of Turkish Literary Culture and a Source for Scholarly Contacts between West and East
\end{abstract}

During the years 1998 to 2003 I have been busy compiling this catalogue of the Turkish manuscripts preserved in Dutch collections, the fourth and last volume of which you are presently reading. With Turkish manuscripts are meant handwritten Turkish texts, of whatever size, available for scrutiny in public institutions - private collections have therefore been excluded. For practical reasons, materials preserved in archives, private or public, have also been excluded. An exception has, to a limited extent, been made for the Amsterdam International Institute of Social History, in itself exceptional among archives, the relevant sub-collections of which are listed in the second chapter, above. To get an idea of the riches of, among others, Turkish texts to be found in (regular) Dutch archives, in particular in the National Archive in The Hague, there is a good survey in Alexander H. de Groot's, 'Source Materials for the History of the Middle East in the National Archives (NA) of the Netherlands at The Hague', in Manuscripts of the Middle East 1 (1986), pp. 8-14; a selection of documents in facsimile (colour photographs) giving an idea of the features of some of the Turkish archival material available is found in Zeki Çelikkol, Alexander de Groot \& Ben Slot, ... It Began with the Tulip. The History of Four Centuries of Relationship between Turkey and the Netherlands in Pictures (Ankara 2000).

Before putting my pen down, however, I wish to sum up some aspects of the texts which passed through my hands during the cataloguing work and try to answer some basic questions about the national collection as a whole. These, first of all, concern the number of texts involved, the language, the genre and subjects encountered in them, the dating of the individual items as far as that is possible, and the provenance of the items. The latter aspects are related to the question of purchase policies. The manuscripts, after all, could only have reached Dutch collections because keepers of local libraries and museums must have been interested to accept them as gifts or have taken the trouble to buy them. The same was true for earlier stages in the acquisition line; many manuscripts had, before they reached their final 
destination, been in the private possession of scholars and other collectors. Which motives, if detectable, contributed to the choice, if there was any, to collect the manuscripts? Other questions to be touched upon: what is their documentary value for, firstly, aspects of the historical Turkish culture and for the relations, political, commercial and intellectual, between West and East, in particular between the Netherlands and the Islamic world. Finally, I will try to assess to what extent the collection as a whole has so far been used for scholarly purposes and what potential the collection still has for future research. My introductions to the consecutive chapters of this catalogue already give some answers to these questions, but a summing up and elaboration of these facts may be useful at this point. In the following sections, I will, firstly, outline the growth, contents and provenance of the collections in three periods: (1) c. 1600 to 1800 ; (2) the 19th century; and (3) after 1900.

\section{Manuscripts Obtained before 1800}

The materials obtained by Dutch institutions before the 19th century had exclusively been collected by Western, mostly Dutch, scholars, in particular professors of Leiden University, either directly for the Leiden University Library — only by Jacob Golius_-or for their own libraries. Only exceptionally are we informed about the origin of their manuscripts, but sources included, interestingly, the Istanbul market and local scribes. Sometimes manuscripts had been war-booty. The five sub-collections obtained by the Leiden University Library between $c .1600$ and 1781 , were those of:

1. Joseph Justus Scaliger (1540-16o9)

2. Jacob Golius (1596-1667)

3. Levinus Warner (1619-1665)

4. Henricus Dibbets (1660-1740)

5. Jan Jacob Schultens $(1716-1778)$

The early 17 th century also saw, apart from the Leiden University, the founding of Academies/Universities in other towns: Amsterdam, Groningen and Utrecht. The local academic libraries connected with these learned institutions began to acquire their own manuscripts, albeit on a much smaller scale than the Leiden Academy. Before 180o, they were drawn from the libraries of the following scholars (see for details the introductions to the consecutive chapters in this volume): 
- Amsterdam:

1. Thomas Vieroot (1698-1780)

- Groningen:

1. Jakob Christmann (1554-1613)

2. Leonhard Offerhaus (1699-1779)

3. Gerard Kuijpers (1722-1798)

4. Everard Scheidius (1742-1794)

5. Nicolaus Wilhelm Schroeder (Steinmetz) (1721-1798)

- Utrecht:

1. Christiaan Ravius (1613-1677)

Although all men mentioned so far were scholars, they were not all professors: Warner died as diplomat, albeit a diplomat with a strong scholarly penchant, in Istanbul, and Dibbets, who had studied at the Leiden university, ended his career as a protestant minister in that city. Vieroot was a pastor of Amsterdam. Ravius was, temporarily, lecturer in Utrecht. Only Golius, Warner and Ravius had travelled and sojourned in the Near East, and had extensive contacts with local men, scholars and scribes. By far the largest contribution to the Leiden collection was made by Golius and Warner, who also co-operated in the acquisition of manuscripts from the Middle East, Istanbul in particular. This 'core collection', then, gave rise to the official name of the Leiden collection: Legatum Warnerianum. Most manuscripts which came to Golius' private collection were scattered at an auction in 1696, but some of these items later returned to their base, so to say, until well into the 19th century. A few others surfaced in the library of Joannes Willmet, on whom more below, in the early 1800 s, and consequently in the collection of the Academy of Arts and Sciences, at present on loan in the Leiden library.

What can we say about the quantity and contents of the manuscripts of these early sub-collections? After some counting, one could say that-to restrict ourselves first to the Leiden University Library collection:

(1) the total number of individually numbered items (including some described under 'addenda' in this volume) - Turkish texts in them varying from one line to one or more individual works-: 278 .

(2) the numbers as distributed over the five sub-collections: Scaliger: 9; Golius: 24 (of which one, Or. 1280, came through Schultens); Warner: 218 
(one item, Or. 1068, dates from the 18th century and cannot have belonged to the original collection); Dibbets: 1; Schultens: 27 (including the one originally owned by Golius).

(3) language: although almost all Turkish texts are written in the language used in the Ottoman Empire, there are a few texts in Chagatay (literary Eastern Turkish): six items, all related to the poetry of 'Alī Şīr Nevầì, and Kipchak Turkish: one item (Or. 517).

(4) genres/subjects of the main Turkish, including mixed Arabic-Turkish and Persian-Turkish, works (some of the genres overlap):

1. dictionaries: 36

2. history (universal, Seljuq and Ottoman): 19

3. personal scrapbooks with various texts (including those compiled by Warner): 19

4. letters/manuals on letter-writing (inşa $\bar{a}): 13$

5. Bible in translation: 12

6. commentaries on Arabic and Persian literary works: 10

7. ethics/religious dogma: 9

8. Ottoman legislation (kānūn $): 8$

9. lyrical poetry/songs: 8

10. divination/magic (fälnāmes, ta bürnāmes, señirnāmes): 8

11. narrative/religious poetry (mesnevīs): 6

12. jurisprudence $(f i k h, f e t v \bar{a} s): 5$

13. calendars/almanacs: 5

14. cosmology/geography: 5

15. stories/fables/anecdotes: 5

16. mysticism/mystical orders: 5

17. grammars/phrasebooks: 4

18. prayers/commentary on Arabic prayers: 4

19. advice/'mirrors for princes': 4

20. biography/biographical dictionaries: 4

21. prosody ('arū $\dot{z}): 3$

22. proverbs: 3

23. martyriology (on the death of Husayn): 2

24. satirical verse: 2

25. medicine: 2

26. horsemanship: 2

27. tradition (hadīs): 2 
28. description of circumcision festivities (sūrnāme): 1

29. refutation of Christianity: 1

30. encyclopaedia: 1

31. Koran interpretation (tefsir $): 1$

32. description of religious sects: 1

33. capitulations ('ahdnāme): 1

34. musicology: 1

(5) dating/origin: of the total of 278 items, 130 are explicitely dated in, mostly, colophons. Autographs are Or. 164 (not certain), 432 and 801. Of other MSS it is possible to establish an approximate date of production from circumstantial evidence such as the lifetime of the author of the original text or owners' inscriptions. Restricting myself to manuscripts with main Turkish works and not including works compiled by or written (translated) for Warner, we get the following picture for the MSS collected up to the166os:

14th century: 1

in or before before the 16 th century: 1

1500-1550: 10

1550-1600: 25

17th century: 18

1600-1643: 20

A few texts in the Golius-Warner collections, apart from the notebooks compiled by Warner himself or the Bible translation made under his supervision during the same period, were written/copied during the period Warner sojourned in Istanbul:

1644: 1

1645: 1

1659-1660: 2

1662: 1

For the MSS acquired between 1670 and 1782, we get the following figures:

1550-1600: 1

17th century: 3

1600-1675: 4

1675-1700: 4

1700-1750: 1

Place names mentioned in colophons include: Istanbul (7 items), Çorlu (2 items), Izmir, Edirne, Aḳhiṣār, Konya, Kütahya, Amasya, 'Ādilcevāz, Cyprus, Sofia, Nikbolı, Sarajevo and Şeki (Azerbeijan). One manuscript was copied 
in Leiden by Shahin Kandi, an Armenian employed by Golius, in 1662 (Or. 1183) - one page in Or. 148 was also copied by him.

(6) earlier owners: In a number of manuscripts Ottoman owners, often members of the learned and official classes, including imāms, k kàżis, $k \hat{a} \bar{z} \bar{\imath}$ 'askers, and defterdārs, noted their names, sometimes accompanied by seals and, rarely, further data. Some of these owners were high-ranking intellectuals and writers like the historian and şeyhülislām, Hōoca Sa'duddīn, and the courtier and patron of the arts, Gażanfer Aga (see for more details, Vol. I, p. 44). Of one earlier owner (of Or. 1025), it is known that he was a correspondent of Warner and a source of manuscripts: Muhammad al-'Urḍi of Aleppo (see Or. 1122, containing autograph copies of his letters). A few manuscripts were obtained in the aftermath of military confrontations in south-eastern Europe: Or. 222 (at Lepanto in 1571) and Or. 242 (found in a fortress in Hungary in 1566). Of the last collection acquired in the 18th century, that of Jan Jacob Schultens, who did not travel in the Islamic world, a relatively greater number of MSS had belonged to Dutch orientalists of an earlier generation: Jacob Rhenferd, professor at Franeker University between 1682 and 1712 (Or. 1224), Johannes Heyman, Protestant minister in Izmir and later, from 1710 to 1737, professor in Leiden (Or. 1228, 1267-via Herman van der Horst, Heyman's successor in Izmir - and Or. 1276), and Albert Schultens, Jan Jacob's father, professor in Franeker and Leiden from 1713 to $175^{\circ}$ (Or. 1246, 1249, 1285-1286, 1295). These last manuscripts had their origin in Hungary and were probably, at least in part-Or. 1246 had originally been bought in Istanbul - war-booty obtained after the Ottomans had withdrawn in the Balkans after the débacle of Vienna in 1683 (cf. Vol. I, p. 515). Or. 1301 had belonged to an unidentified man called D.G. Wassarschein.

If we apply the same statistics for the smaller collections in Amsterdam, Groningen and Utrecht, we find that before 1800,

(1) the total number of items with Turkish texts collected was: 26

(2) numbers acquired from individual scholars: Vieroot: 1; Christmann: 7; Offerhaus: 1; Kuijpers: 1; Scheidius: 1; Schroeder: 8; Ravius: 4. Of another 3 items belonging to the older collections the origin is not clear.

(3) language: only the Groningen Hs. 474 contains texts in Eastern Turkish; all others are Ottoman in origin. 
(4) genres/subjects of the main Turkish texts:

1. prayers/commentaries on Arabic prayers: 7

2. ethics/religious dogma: 4

3. lyrical poetry/songs: 4

4. divination/magic: 3

5. Bible in translation: 2

6. tradition (hadīs): 2

7. narrative/religious poetry (mesnevīs): 2

8. letter: 1

9. calligraphic samples: 1

10. stories/anecdotes: 1

11. sexuology: 1

12. history/geography (of Egypt): 1

13. history (Ottoman): 1

(5) dating/origin: of the total number, only 3 are explicitely dated. Autographs are: Groningen, UB Hss. 485 (by Christmann), 486 and 489. Global dating of the main Turkish texts gives the following:

14th century: 1

1550-1600: 1

16th-17th century: 3

1600-1650: 1

1650-1700: 1

(6) earlier owners: In a few manuscripts Ottoman owners have left their inscriptions and seals, as did some Western colleagues. The latter are not always indentifiable. So much is certain that Schroeder obtained two volumes from the Swiss scholar Johann Heinrich Hottinger (1647-1692), who in turn obtained them from a certain 'H.R.W.'- the initials are in both cases dated 1625 . The Groningen collection comprises some items which had their origin as booty in south-eastern Europe: Hs. 486 (probably found in the Buda area, after 995/1587), Hs. 489 (found at Buda before 1695) and Hs. 491 (found by a German-speaking soldier sometime after 1044/1634). Ravius obtained his manuscripts in Istanbul in 1640-one of them, Utrecht, UB Hs. 1 B 8, seems to have been 'borrowed' from a local scholar, but clearly not returned.

\section{Manuscripts Obtained between 1800 and 1900}

After the 18th century, the picture gets more complex. Two manuscripts, Or. 2019 and 3100, had clearly already been acquired in the 17th century, but 
were only registered into the Legatum in 1871 and 1888 respectively. They belonged to the Scaliger (Greek) and Warner collections. The more substantial contributions to the Leiden University Library in the 19th century were made by:

1. Johannes Heyman (1667-1737)

2. Hendrik Albert Schultens (1749-1793)

3. Hendrik Arent Hamaker (1795-1835)

4. Gaspard Testa (1770-1847) or one of his sons

5. Johannes Henricus van der Palm (1763-1840)

6. Dirk Cornelis (1752-1833) \& Jan Jacob van Voorst (1791-1869)

7. S.J.E. Rau (1801-1807)

With the exception of (the unidentified) Testa, member of a large family of diplomats residing in the Ottoman Empire, the Van Voorsts, Protestant ministers of Amsterdam, and S.J.E. Rau, a jurist who had inherited manuscripts from his father, the Leiden theologian and orientalist, S.F.J. Rau $\left(1765^{-1807}\right)$, all these men were again professors, mostly in Leiden. Most of the manuscripts which had been produced or collected by Heyman and Schultens only came to the Library via sons or colleagues-orientalists of later generations: most of the Hamaker manuscripts were state documents translated for the States-General by Albert, Jan Jacob, Hendrik Albert Schultens and himself in the course of the 18th century (Or. 1380-1387). The Van der Palm collection had first belonged to H.A. Schultens, and most items in it had earlier belonged to Heyman and/or his father, Jan Jacob Schultens. At least two items in the Rau collection, Or. 3080 and 3083 , donated in 1888, had belonged to Golius. (This pattern of multiple ownership one sees often repeated in the older collections - one could perhaps make a case for maintaining that most of our 'pre-modern' Turkish manuscripts had belonged to one basic collection which time and again changed scholarly hands through 'borrowing', bequests and auctions.) Among the lesser figures, who were not (primarily) orientalists but had often either been professor or studied at Leiden University and/or were pastors, we find:

8. Louis-Gérôme Gohier (1746-1830)

9. Johannes Dresselhuis (1789-1861)

10. Lodewijk Adolf Schroeder (Steinmetz) (1808-1837)

11. Nicole Ernest Chauguion (1803-1881)

12. Johann Hermann Gerhard Wolters (1777-1840)

13. Pierre Josué Louis Huet (1799-1846)

14. Abraham Constatin Mouradgea d'Ohsson (1779-1851) 
15. Willem Pleyte (1836-1903)

16. Hendrik Christiaan Millies (1810-1868)

17. Rinse Koopmans van Boekeren (1832-1896)

18. Antonie Rutgers (1804-1884)

The first, exceptionally, was a French politician without connection with the Netherlands-his collection was bought at an auction in Paris in 1831; d'Ohsson was a diplomat married to a Dutch wife. L.A. Schroeder was a son of Nicolaus Wilhelm, professor at Marburg and Groningen, part of whose library came to the Groningen University Library (cf. above). Multiple ownership is again recognizable here: a manuscript acquired from Huet in 1849, Or. 1628, had earlier belonged to at least four Western owners from the second half of the 16th century onwards: the poet, Justus Raphelengius, Golius, Reland and Bergius, a German scholar who flourished around 1800. The first acquisition purchased directly from a bookseller, Belinfante in The Hague, took place in $185^{1}$ (Or. 1634) - the manuscript originally had belonged to Reland - to be followed by many more purchases from both well-known international book traders like Köhler in Leipzig, Brill in Leiden, and more obscure local Dutch antiquarians - but much of this was still in the future. The 19th century saw only three such purchases in all. Due to a specialisation in the contents of national collections, some manuscripts were transferred from other Dutch collections to the Leiden Library; I mention here the Rijks Japansch Museum in Leiden which handed over one item, Or. 1686, which had belonged to Heyman, in 186o. The so-called Rijks-Instelling, an academy for East-Indian civil servants and the Ethnographic Museum in Leiden, did the same with, respectively, two (Or. 2233 and 2242 II) and another two items (Or. 3070b and 3071) in the 1870 and 1880 s.

Apart from the Legatum in the Leiden library, the minor collections in the Netherlands also saw an expansion. In 1837 a substantial collection was donated to the Royal Academy of Arts and Sciences (as it is called at present) in Amsterdam; it is on permanent loan in the Leiden library. The collection had been owed by the orientalist, Joannes Willmet (1750-1835), professor at the academies/universities of Harderwijk and Amsterdam. Many of these manuscripts, in turn, had belonged to scholars of earlier generations, among them Golius, Heyman, Reland, and J.J. Schultens, encountered earlier. For the other academic libraries - the Groningen library did not acquire further Turkish items - the following picture arises:

- Amsterdam:

1. Pieter Arnold Diederichs (1804-1874) 
- Utrecht

1. Jacobus Cornelis Swijghuisen Groenewoud (1784-1859)

Some other collections, not primarily focused on collecting orientalia, which nevertheless began to obtain Turkish items, often by chance, were the Royal Library in The Hague (from 1798) — their Oriental manuscripts, of which one, Or. 2081, acquired in 1816, had once belonged to Heyman, onother, Or. 2067, to the Jesuite Collège Louis-le-Grand in Paris up to 1762, were turned over to the Leiden library in 1873-; the MeermannoWestreenianum collection in the same city (from 1848); the Leiden Ethnographic Museum (1837) — some Oriental items, one of which, Or. 3071, had possibly been compiled by Warner, were transferred to the Library in 1887 (cf. above)—; and the Rotterdam Maritime Museum, founded in 1852.

If we turn again to statistics in the same way as in the previous section, we find the following data-I restrict myself first to the Leiden University Library Legatum collection (described in Vol. II):

(1) total number of items: 89

(2) numbers distributed over collectors (previous Western owners): Scaliger: 1; Warner: 1; Heyman: 1; H.A. Schultens: 1; Hamaker: 10; Gohier: 1; Chauguion: 3; Dresselhuis: 1; Testa: 28; Schroeder: 1; Wolters: 1; Van der Palm: 8; Huet: 1; Belinfante (bookseller): 1; d'Ohsson: 1; Van Voorst: 7; Rijks Japansch Museum: 1; Köhler (bookseller): 1; Pleyte 1; Millies: 1; Koopmans van Boekeren: 1; Royal Library: 4; Rijksinstelling: 2; Brill (bookseller): 1; Rutgers: 1; Leiden Ethnographic Museum: 2; and Rau: 5. Of two items (Or. 1311 and 1355), the provenance is unknown; the first item, Or. 1311, was owned by Ottomans until 1162/1748-1749.

(3) language: only one item contains texts in Kipchak Turkish: Or. 1553.

(4) genres/subjects of the main Turkish texts-not mentioned are translations into Western languages:

1. letters/documents/epistolary manuals (inşā $): 21$

2. dictionaries/glossaries: 13

3. ethics/religious dogma: 8

4. stories/fables/anecdotes: 5

5. biography: 4

6. personal scrapbooks with various texts: 4 
7. lyrical poetry/songs: 4

8. narrative poems (mesnevis) in various genres: 4

9. calendars/almanacs: 4

10. divination/magic (Tábìrnāmes/ihtilālnāmes): 4

11. grammars/phrasebooks: 3

12. life/miracles of Muhammad: 3

13. eschatology: 2

14. description of an embassy (sefāretnāme): 2

15. translations of Arabic and Persian literary works: 2

16. prayers/commentaries on Arabic prayers

17. commentary on a dictionary: 1

18. history (Ottoman): 1

19. history (non-Ottoman): 1

20. history-cum-autobiography (Ottoman): 1

21. medicine/human biology: 1

22. book of advice: 1

23. encyclopaedia: 1

24. jurisprudence: 1

25. sexuology: 1

26. mysticism: 1

27. logbook: 1

28. prosody ('arū $\dot{z}): 1$

29. cosmology: 1

30. capitulations ('ahdnāme): 1

31. Bible translation: 1

32. historical pedigree: 1

(5) dating/origin: of the total 89 items, 38 are explicitely dated. Autographs are: Or. 1310 (by Heyman) and 1563. Global dating of the main Turkish texts, gives the following:

15th-16th century: 1

16th century, or earlier: 1

1500-1550: 1

1550-1650: 4

16th-17th century: 1

1600-1650: 7

1650-1700: 13

18th century: 1

18th-19th century: 1

1700-1750: 9 


$$
\begin{aligned}
& \text { 1750-1800: } 13 \\
& \text { 1750-1850: } 5 \\
& \text { 1800-1850: } 7
\end{aligned}
$$

Only of very few manuscripts the place of origin is indicated; exceptional are Or. 1548, produced in the Crimea; Or. 1940, copied in Aleppo. Or. 1553, with Kipchak-Turkish texts, was probably copied/compiled in Cairo. Some manuscripts were compiled or copied by scholars or dragomans: Or. 2019 (copied by Scaliger), Or. 1310 (by Heyman), 1408 (copied by Hamakers), 1589 (copied by Denis-Dominique Cardonne, French dragoman in Syria), 1598 (copied/compiled by Heyman). A French translation by a certain 'LaRoque', probably identical with the jeune de langues, Thomas Roque, is found in Or. 1599. Or. 3083 was copied by the aforementioned Shahin Kandi, a copyist in Golius' service. A few manuscripts, originally in the possession of Heyman, were copied in Izmir, most probably by a consular clerk, during the time he was pastor in that city: Or. 1591, 1686, and 2081.

(6) earlier owners: There are only eleven manuscripts acquired in this period that contain explicit mention of earlier Ottoman owners-none of them are known from literature. One manuscript, Or. 1634, had been turned into a $v a k f$ in 106o/1650. Another manuscript, Or. 1362, was probably acquired as war-booty from the Escorial Library in Madrid in the early 1800 s. Of only a few Western owners do we know that they had, most probably, acquired the manuscripts directly in the Middle East, namely: Heyman, Testa and d'Ohsson - they all sojourned for longer or shorter periods in the region.

If we turn to the Academy collection (described in this volume), we get the following picture:

(1) total number of items with Turkish texts: 54

(2) language: exclusively Ottoman Turkish

(3) genres/subjects of the main Turkish tetxs:

1. dictionaries/glossaries: 23

2. letters/documents/epistolary manuals (inşā): 13

3. grammar/phrasebooks: 9

4. prayers/commentaries on Arabic prayers: 7

5. traditions (hadīs $): 7$

6. history of the early prophets: 5 
7. ethics/religious dogma: 4

8. calendars/almanacs: 4

9. divination/magic (fälnāmes): 2

10. astronomy (use of the quadrant): 2

11. calligraphic samples: 2

12. Bible translation: 1

13. Koran interpretation (tefsìr): 1

14. commentaries on Arabic and Persian literary works: 1

15. prosody ('arü $\dot{z}): 1$

16. advice: 1

17. narrative poetry (mesnevī): 1

18. pilgrimage manual: 1

19. historical pedigree: 1

20. stories: 1

21. capitulations ('ahdnāme): 1

22. mysticism: 1

(4) dating/origin: of the total number of 54 items, 23 are explicitly dated. Apart from some of the items in the Schulz \& Woltersdorf collection (cf. below), there are no autographs. Global dating results in the following picture:

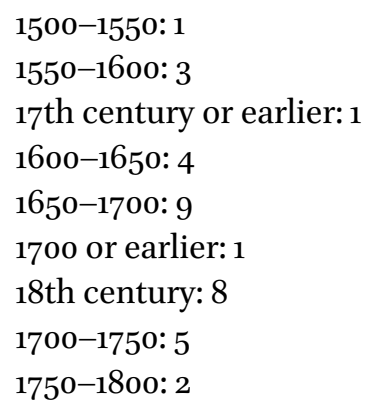

Place names mentioned in colophons include: Muş, Izmir, Cairo, Algiers and Jerusalem. The manuscripts produced in Izmir all had belonged to Heyman and were copied by the same, aforementioned, consular clerk, during the 1690 s and 1700 (Acad. 76, 80 and 87). A few manuscripts were copied by Shahin Kandi: Acad. 22, 182 and 197; these must have once been owned by Golius. Some items had belonged and had, mostly, been compiled and copied by Stephan Schulz (1714-1776) and Albert Friedrich Woltersdorf (d. 1755) who had travelled as missionaries in the Middle East between $175^{2}$ and 1756 (Acad. 77, 79 [?], 82, 92, 95, 205, 210 and 222 [?]). 
(5) earlier owners: Only in seven manuscripts, (an) earlier Ottoman owner(s) left their markings, none of them of any note. Acad. 59 was turned into a vakf in 1708. The manuscripts were all acquired by Willmet in the Netherlands, mostly through auctions; years of acquisition mentioned by him in the manuscripts are: 1773, 1779, 1780, 1800, 1804 and 1821 . Most of them had earlier belonged to one or more Dutch scholars. Among them werenumbers refer to the quantity of items originally owned by each scholar:

1. Jacob Golius (1596-1667): 4

2. Cornelis Uythage: 1

3. Jacques Bernard (1658-1718): 1

4. Adrianus Reland $(1676-1718): 3$

5. Johannes Heyman (1667-1737): 3

6. Jacob Meier (1679-1741): 1

7. Gerardus Johannes Lette (1724-1760): 1

8. Herman van der Horst (1692-1765): 1

9. Jan Jacob Schultens (1716-1778): 14

10. Jacob Willemsen (1698-1780): 8

11. Joseph-Hippolyte Ghesquière (1731-1802): 2

12. Diedericus Adrianus Walraven (1732-1804): 6

13. V.D.M. Timmermans Hubert: 1

Among these men, only a few were not professors at one of the Dutch academies/ universities: Cornelis Uythage, a student of theology in Leiden and publicist, who bought one MS, Acad. 38, in Leiden in 1680; Ghesquière, an abbot-historian, who had found two MSS (Acad. 45 and 46) in a 'box belonging to one of the grand viziers' - what he meant by that remains enigmatic; Lette, Protestant minister and student of Albert Schultens; Herman van der Horst, Protestant minister in Izmir; and Timmermans Hubert, a Potestant minister about whom nothing seems to be further known.

Of the other minor collections, only the university libraries of Amsterdam and Utrecht saw their Turkish collection increase, but not much. The Amsterdam library obtained (in 1892) 12 items, all letters/documents or small collections of letters/documents in original copies which had their origin in the Ottoman Empire between 1616 and 1850. The Utrecht library obtained two manuscripts with Arabic and Persian texts, with some Turkish additions, in 1860. One of these, Hs. 1 G 24, was war-booty from the Vienna area, found in 1685. Furthermore, the Museum Meermanno-Westreenianum obtained a Koran with Turkish recipes in 1848 ; it had originally been found in Hungary in 1687 , where it had been abandoned by retreating Ottoman troops. The Ethnographic Museum in Leiden obtained an official letter, 
which may have belonged to Heyman, and two scrolls, from the Royal Museum of Curiosities (Zeldzaamheden) in The Hague in 1883-Or. 1686 in the Legatum had also once been part of the same collection, before it came to the 'Japanese Museum' in Leiden —; and, finally, there was an Ottoman Navy signal book of 1246/1830-1831 or somewhat earlier, which came to the Rotterdam Maritime Museum in 1852, probably from the 'core' collection which had belonged to Prince Hendrik, a naval officer, who in turn may have acquired it during a journey in the Middle East. These data result in the following statistics:

(1) total number: 19

(2) language: Ottoman Turkish (most letters in the Amsterdam collection contain texts in Western languages).

(3) genre/subjects of the main Turkish texts:

1. letters/documents: 6

2. calendar/almanac: 2

3. navy signals: 1

(4) dating/origin:

1700-1750: 1

1800-1850: 5

Of the six letters, four consists of fermāns issued directly to Western travellers; one was addressed to a Western general (Hs. Diederichs $136 \mathrm{~N}$ ), one was written by a consular clerk in Izmir (and perhaps never sent-Leiden, Ethnographic Museum 36-9550). The signal book (Rotterdam, Maritime Museum H639) has an Ottoman owner's inscription of 1246/1830-1831.

\section{Manuscripts Obtained after 1900}

If we, again, first direct our attention to the Leiden University Library (Legatum) collection, we get the following picture (for more details see Vols. II \& III). Between 1888 and 1913 no manuscripts with Turkish texts enriched the shelves of the library. Acquisitions began to regularly trickle in again from 1913 onwards, only to acquire torrential proportions in the 1960s and 1970s. Whereas between 1913 and 1965 only 67 such items reached the library shelves, the years 1965-1970 saw a spectacular growth of another 204 
items with regular purchases from the Leiden-based merchant Fatatri, and this trend was more or less sustained during the following decades.

(1) The total number of items with Turkish texts registered between 1913 and December 2002 is: 645. An additional nine were acquired in April 2003.

(2) Substantial providers of our manuscripts in the category of scholars were during this period-the names are followed by the number of items provided:

1. F.G. Kramp (in 1913): 6

2. Johannes Hendrik Kramers (1871-1951): 13

3. E. von Scherling: 6

4. Cornelis van Arendonk (d. 1946): 12

5. Christiaan Snouck Hurgronje (1857-1936): 5

6. Dr Qāsim Sāmarāīi (partly through Mrs. J.H. Pels Rijcken): 10

7. Franz Taeschner (1888-1967) (through Brill): 109

8. P.Sj. van Koningsveld: 1

9. R.B.C. Huygens: 1

10. Wāșif 'Abd ar-Raḥmān Shāhid: 2

11. F. de Jong: 10

12. Salih Hajibegović Alić: 64

13. Hendrik Kraemer (1888-1965): 1

14. Nico van den Boogert: 2

15. Menno Hekker: 28

16. Barbara Flemming: 9

Among the men, mentioned above, Kramers, Van Arendonk, Snouck Hurgronje and Van Koningsveld had been keepers of the Legatum. Most of the others were, at least for some time, either in the employ of Leiden University or residents of Leiden. Exceptions are De Jong, who was professor in Utrecht, and Hajibegović, who was a Bosnian scholar working in California. (Von Scherling was a antiquarian book-seller but one of profound scholarly inclinations.)

More incidentally, Turkish items were obtained through donations or purchased on the base of sales' catalogues from auctioneers and booktraders; among the providers were- the names are again followed by the number of items:

16. E.H. Stieltjes: 1

17. Luzac \& Co. (London): 1 
18. E.J. Brill (Leiden/London): 20

19. A. Visser: 1

20. Dr Riza Nur: 3

21. Adrien Maisonneuve (Paris): 1

22. A. Spakler: 1

23. J.C. Jute: 1

24. Burgersdijk \& Niermans: 3

25. A.L. van Ghent (Blaricum): 2

26. G. Rueter (Sloterdijk): 1

27. Bakker (Amsterdam): 1

28. Accolade: 1

29. P. Valkema Blouw (Amsterdam): 1

3o. Thornton \& Son (Oxford): 9

31. M. Akkut (Istanbul): 4

32. Menno Herzberger \& Co. (Amsterdam): 1

33. A.A. Fatatri (Leiden): 204

34. Der Bücherwurm (Berlin): 1

35. Otto Harrassowitz (Wiesbaden): 2

36. Kegan Paul (London): 1

37. Ad Orientem (St. Leonhards): 3

38. De Sfinx (The Hague): 1

39. Mrs. Pierik: 1

40. Adab Books (Winterburn): 1

41. W. van Gestel (Tilburg): 1

42. David Loman (London): 7

43. Bonte Oudheden (Leiden): 1

44. Sotheby's (London): 8

45. Jan Willem van Meeuwen (The Hague): 3

46. Thomas Leeuwenberg (Tilburg): 5

47. McBlain (Des Moines): 5

48. Hellmut Schumann (Zurich): 2

49. A.L. van Gendt \& Co. (Amsterdam): 1

50. Christie's (London): 2

51. Dimitri Stamoulis (Grenoble): 6

52. Th.G. Appelboom (Groningen): 2

53. De Graaf (Nieuwkoop): 1

56. Tjerk de Boei (Utrecht): 1

57. Goetheanum (Dornach): 5

58. Mrs. I. Acker-Van Eijk (Leiden): 22

59. G.J.O. Bouwman (The Hague): 31

6o. N.W.J. van Duykeren (Doesburg): 1 
The origin of some items is unclear: Or. 6887 and 6890 were both registered in 1946 but no source was given. Or. 10.978 was bought in Britain in 1964; the source is unknown.

(3) language: almost all texts are in Ottoman Turkish; exceptions are: Or. 6269, 8481, 14.304 and 26.26o, with texts in Chagatay Turkish, and Or. 8798, 11.050, 12.398 and 25.734, with texts in Azerī Turkish. Or. 12.315 contains annotations in Uzbek Turkish. A few manuscripts contain texts in both Albanian, Turkish and, sometimes, also Arabic: Or. 14.636, 14.646, 17.910 and 17.913. Or. 17.067 contains a description of the Ottoman Empire in Italian.

(4) genres/subjects of the main Turkish texts:

1. ethics/religious dogma: 80

2. mysticism/șüfı̈ rituals: 69

3. letters/documents/epistolary manuals $($ inş $\bar{a}): 59$

4. lyrical poetry/songs: $5^{2}$

5 . jurisprudence (including fatwas): 42

6. narrative poems (mesnevīs) in various genres: 39

7. prayers/commentaries on Arabic prayers: 35

8. dictionaries/glossaries: 33

9. personal scrapbooks with various texts: 29

10. magic/divination (including $f a ̈ l$, reml, talismans): 29

11. translations/commentaries on Arabic and Persian literary works: 27

12. biography of the Prophet (including the Mevlid by Süleymān Çelebi): 25

13. stories/fables/anecdotes: 22

14. astronomy/use of astrolabe and quadrant: 19

15. history (Ottoman): 18

16. pilgrimage/haij manuals: 18

17. tradition (hadīs): 17

18. cosmology/geography/ethnography: 16

19. medicine/pharmacology/surgery: 14

20. dream interpretation (including Ta'bīrnāmes): 13

21. interpretation/recitation of the Koran: 12

22. history (non-Ottoman): 11

23. Arabic grammar: 10

24. advice/'mirrors for princes': 9

25. biography: 9

26. calendars/almanacs: 6 
27. futuwwa/guilds: 6

28. biographical dictionaries: 5

29. (interpretation of) the 'beautiful names' of God: 5

30. epic (prose): 4

31. Persian grammar: 4

32. arithmetic: 4

33. martyriology: 4

34. metaphysics: 3

35. physiognomy/chiromancy/señirnāmes: 3

36. Ottoman legislation (kānūn $): 3$

37. history of the prophets: 3

38. political programme: 2

39. pedagogy: 2

40. sermon: 2

41. philosophy/logic: 2

42. maps: 2

43. eschatology: 2

44. alchemy: 2

45. satirical verse: 2

46. riddles: 1

47. opera libretto: 1

48. memoirs: 1

49. theology (kelām): 1

50. manual for judges: 1

51. prosody ('arūiz): 1

52 . commentary on Turkish poetry: 1

53. political apology: 1

54. memorandum on negotiations: 1

55. description of Istanbul: 1

56. musicology: 1

57. bowmanship: 1

58. collection of treatises on various subjects: 1

59. proverbs: 1

6o. stage play: 1

61. album with seal imprints: 1

62. refutation of Judaism: 1

63. horsemanship: 1

Of special note are items which have the character of small archives and do not fit in ith the categories lined out here. These are: the Snouck Hurgronje 
Papers which contain letters in Turkish (Or. 8952); the Kramers Papers with notebooks, letters, newspapers and documents of varying type (Or. 1421-8, 18.096 and 18.100); a small collection originating in the Bektashi tekke of Cairo, with ledgers, notebooks and various papers (Or. 14.385); and the Hofman bequest mostly consisting of reference files (Or. 25.402).

(5) dating/origin: of the total 654 items, 305 are explicitely dated. Autographs, or possible autographs, are Or. 11.584, 11.950, 12.033(2), 12.352-353, 12.380, 12.829, 20.404(1), 23.659, 23.661, 23.671, 25.730, and 26.046. One MS, Or. 6255, was copied from an autograph. One copyist is identifiable as the poet Sālim (flourished in the second half of the 18th century, Or. 12.055); he added his own verses to the MS. Global dating of the main Turkish texts, results in the following table:

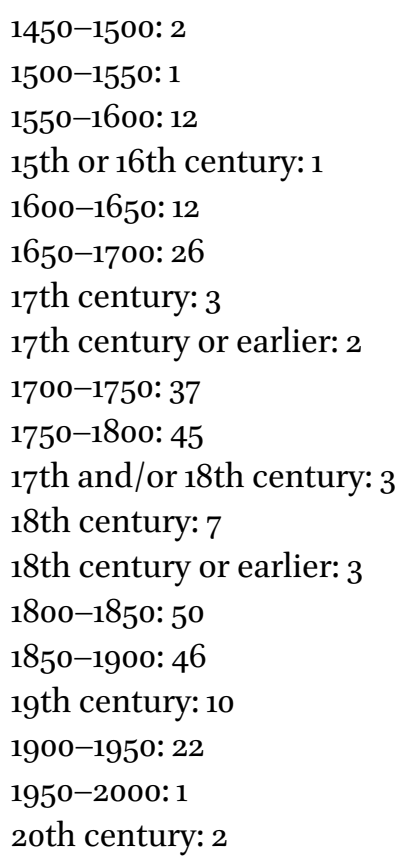

Place names mentioned in colophons are: Istanbul (6 items), Ankara (2 items), Bursa (2 items), Sivas (2 items), Erzurum (2 items), Kars (2 items), Cairo (2 items), Aleppo, Yanya (Ioannina), Niksar, Payas, Köprü, İsbedin, Üsküdar, Siroz, Trabzon, Amasya, Rusye, Kula, Delvina, Paşa, Erzincan, Tekirdağ, Soma, Suvarı (?), Algiers, Edirne, Benkovac, Medina, Damascus, Ayntab, Izmir, Kastamonu, Belina, Katerini, Farsala, Foca, Ujiçe, Aydonat and Midilli. 
(6) earlier owners: Some manuscripts contain marks of earlier Ottoman owners, quite a few of them of high rank; we find şeyhülislāms, defterdārs, court physicians and a minister (Or. 12.047). Or. 6255 may even have belonged to a sultan. In some manuscripts inscriptions of earlier Western owners are found; among them were the orientalists Muchlinski (Or. 5804-5805) and De Sacy (Or. 5807-5808), and the Armenian missionary Awetarian (Or. 6269). Or. 8330 and 18.259, as Or. 2067 mentioned above, originally belonged to the library of the Jesuite Collège Louis-le-Grand in Paris; the former came into the possession of a jeune de langues in 1780. Another MS, Or. 12.335, had belonged to the library of a Bavarian monastery before coming into the possession of French and English collectors. Although some MSS had been turned into vakfs by their Ottoman owners, they all the same found their way to the market: Or. 8483, 10.851, 11.541, 11.590, 11.700. $12.093,12.307,12.370,14.584,17.105,25.578$, and 25.730 . Of a large part of the Taeschner collection, it is known that they were bought in Istanbul from the bookseller Nașrullāh Tebrīzī between 1913 and 1930. A few others were acquired by Taeschner from German booksellers and colleagues, among them Georg Jacob and Franz Babinger. Three MSS had been bought by him in Cairo in 1931, another (Or. 12.440) had been copied there for him in the same year. Many other MSS had also been directly bought in the Ottoman Empire and their successor states, in particular those originally acquired by Fatatri, Salih Hajibegović Alić, Mrs. Acker-Van Eijk and Robert Cornelis Hekker (whose son Menno donated his MSS to the Leiden library). Or. 23.663, from the collection of Mrs. Acker-Van Eijk, had previously belonged to the Ottoman book-collector 'Alī Emīīi. Alić acquired his manuscrips in Yugoslavia. Both Mrs. Acker-Van Eijk and Hekker seem to have bought all their MSS in Istanbul. Flemming acquired her MSS in Istanbul and Damascus. A few MSS, mostly notebooks dating from the late 19th and early 2oth centuries, also containing Albanian texts, had their origin in the library of a Bektashī tekke in Farsala: Or. 14.646, 17.910 and $17 \cdot 913$.

If we again turn to the minor collections - I do not include here the archives acquired by the Amsterdam International Institute of Social History - we see again that of the university libraries, only those of Amsterdam and Utrecht saw some increase of their collections during the 2oth century. The Amsterdam library obtained one manuscript - offered for sale in 1923, Hs. Cn 12-and more letters of interest for the history of the Ottoman Empire: 12 further items were bought at auctions in the 1920s, but only two contain Turkish texts. During the 1970s the orientalist and librarian, Hofman, 
took the initiative to have 11 manuscripts, chosen from sales' catalogues, purchased by the Utrecht library. The Amsterdam Historical Museum, openend to the public in 1926, houses the library of Abraham Willet, who acquired one Turkish manuscript in the 19th century. The Maritime Museum in Amsterdam acquired three Ottoman passes which originally had been sold at an auction in 1868. Its sister institute in Rotterdam acquired another two. The Royal Library in The Hague lay the foundation to an extensive collection of alba amicorum, one of which, Hs. $135 \mathrm{~K}$ 4, contains Turkish texts. It was bought at an auction in Munich in 1973. The Leiden University Library acquired the library of A.P.H. Hotz in 1935, which comprizes one Turkish manuscript, and the archive of the assyriologist, Fritz Rudolf Kraus, with a large collection of letters, in the 199os-both are kept in separate collections in the library. The Rotterdam Wereldmuseum (Ethnographic Museum), finally acquired six items with Turkish texts or originating in the Ottoman Empire between 1970 and 1995.

(1) total number of items with Turkish texts: 33

(2) language: Ottoman Turkish (most letters in the Amsterdam collection contain texts in Western languages).

(3) genre/subjects of the main Turkish texts:

1. letters/documents: 10

2. minatures: 3

3. medicine/medical recipes: 4

4. calendars/alamanacs: 3

4. dictionaries: 2

5. encyclopaedias: 2

6. jurisprudence: 2

7. narrative poetry $($ mesnevi $\bar{l}): 1$

8. divination/magic: 1

9. calligraphic samples: 1

10. capitulations ('ahdnāme): 1

11. pedigree (silsile-nāme): 1

12. lyrical poetry $\left(D_{\bar{\imath}} \bar{\alpha} \bar{a}\right): 1$

13. dogma/ethics: 1

14. commentary on an Arabic work of literature: 1

15. ballads (destāns): 1

16. cosmography: 1 
17. manual for pilgrims: 1

18. agriculture/arboriculture: 1

(4) dating/origin:

$$
\begin{aligned}
& \text { 1550-1600: } 1 \\
& \text { 1600-1650: } 2 \\
& \text { 1650-1700: } 1 \\
& \text { 1700-1750: } 3 \\
& \text { 1750-1800: } 10 \\
& \text { 1800-1850: } 8 \\
& \text { 1850-1900: } 11
\end{aligned}
$$

The manuscript in the Willet Library in the Amsterdam Historical Museum had been in possession of Ottomans until at least the early 19th century. The three passes issued to Flemish sea captains and Dutch officers in the Amsterdam Maritime Museum collection had formerly belonged to Jacob Baart de la Faille whose grand-father had been owner of two of the ships involved. Two other passes in the Rotterdam Maritime Museum had also been issued to Dutch officers. Most of the letters acquired by the Amsterdam University library in the 1920s had their origing in the private papers of the diplomat, Anton Prokesch von Osten, and his family. The two calendar/almanacs in the same collection were purchased by J.A. Dortmond, possibly in the Middle East. The album amicorum in the Royal Library collection, had formerly belonged to Joannes Willmet, original owner of the Academy collection (cf. above). The collections acquired by the Rotterdam Ethnographic Museum and the Utrecht Unversity Library were all purchased from booktraders or at auctions.

\section{Evaluation}

To sum up: the total number of manuscripts, ranging from a single document to collections of more than forty treatises, described on these pages is 1162. Many of these manuscripts contain main Arabic and/or, more rarely, Persian texts, with added fragments in Turkish, ranging from annotations of a personal or commercial type to medical recipes and talismanic formulae: in all 302 in number. Almost all manuscripts had their origin (were written, compiled and copied) in the Ottoman Empire, including NorthAfrica. The great extent of the intermixture of the three languages: Arabic, Persian and Turkish, in collections as a whole but also within single manuscripts, emphasizes the three-lingual aspect of the dominant (Islamic) 
literary culture of the Empire. Nearly all texts, apart from transcriptions and some very modern (2oth-century) ones, are written in variations of the Arabic script. An exception is Or. $1129(G)$, written in Hebrew script. The libraries and earlier collectors, mentioned here, tended to buy manuscripts containing texts in all three languages, and could hardly avoid, even if they wanted, acquiring texts in more than one language, even if they specialized in one language (which perhaps only Franz Taeschner did to some extent: of the 128 manuscripts he obtained, 106 contain main Turkish texts.) As we saw, a few manuscripts contain texts in Chagatay, Azerī, Kipchak or Uzbek Turkish; most of the texts in Chagatay Turkish are (part of) works by the poet Nevā'i of Herat, or works related to his work. The Ottomans considered the poet's oeuvre as belonging to their literary canon, and the texts were probably mostly produced within the Empire. This is probably not the case for texts in the other Turkic languages: Or. 6269 is clearly of (Central-) Asian origin, the same may be true of Groningen, UB Hs. 474; Or. 8798, with poems in Azerī Turkish, was probably produced in Tabrīz; Or. 12.398 may have been originated in Azerbeijan; Or. 25.734 certainly was. Or. 12.315, with Uzbek notes, probably also had its origin in Asia outside the Ottoman border.

So much for numbers and languages. Subjects and genres found in the main Turkish texts, as is clear from the tables given above, varied greatly and may be said to reflect the interests of a broad reading public in the Ottoman Empire, from high-ranking scholars and courtiers to medrese students, soldiers and dervishes. Exceptional are the afore-mentioned compilations and scholarly notes made or special projects initated by the collectororientalists themselves, such as the 17 th-century Bible translation in which Golius and Warner were involved, or the translation work undertaken by generations of Leiden orientalists on behest of the States-General in The Hague (which also enriched the Leiden library with a extensive collection of what were clearly archival documents). The same is true for private papers and archives bequeathed by scholars to the Leiden library. They all document aspects of contacts and trans-cultural interests between East and West. Apart from these exceptional materials, randomness of the changing market conditions through the centuries must have been a dominant selective factor shaping the Dutch collections as a whole, as must have been the limited means of most buyers, including the restricted budgets of modern libraries. That is not to say that predilection here and there of the individual collector/buyer did not leave any imprint: the 17th-century collection of the Legatum is relatively rich in lexicographic and historiographic texts: both were essential for the development of orientalistic scholarship in the 
early Republic, relatively new to the knowledge of Turkish and the history of the Middle East and beyond. Works on religion and Islamic ethics are richly represented in almost all sub-collections. This may reflect both the highly theological interest of the pre-modern Dutch universities - many of the early orientalists were also theologians - and the relative abundance of such works on Ottoman book-markets for the benefit of 'ulemā, imāms and medrese students. The considerable number of letters, documents and epistolary manuals in all sub-collections, may also partly be caused by the availability of original documents issued by Ottoman authorities to Dutch subjects, and the importance of samples and epistolary hand-books for Ottoman officialdom. The relative high quantity of works on history, geography, the pilgrimage and the the futuwwa brotherhoods and guilds in the 2oth century is largely due to the special interests of Franz Taeschner who published on these matters (and, being a rich man, could aford to indulge in specialised purchases). The abundance of works on Hanafi jursiprudence, religion, mysticism and the sūfi orders may have been influenced by the extensive availability of such works after the closure of medreses and tekkes in the 1920 in Turkey (of which in particular the locally-buying Fatatri seems to have profited). Genres far less well or hardly at all represented in the Dutch collections are works on musicology, sexuology, horsemanship, bowmanship, agriculture and arboriculture, and records/manuals for sea captains such as logbooks and signalbooks. Works on mathematics, zoology and veterinary science, technology (such as architecture or mechanics), and mineralogy are completely lacking. This may again reflect the lack of importance attached to such works in traditional Ottoman culture as well as the limited readership/use for such works. Selectivity in the purchase policies of public institutions, if they existed at all, are rarely documented: an exception is Amsterdam UB, Hs. Cn 12, which is accompanied by letters which clearly show that in the early 1920 s the Leiden University Library was not interested in acquiring manuscripts 'of insufficient importance', meaning perhaps not containing complete texts or good-looking manuscripts or famous, or on the other hand rare, works of literature, even if the costs involved were negligeable. (During the 1920s only six manuscripts were apparently found important enough by the Leiden interpres and worthwile acquiring; two of these were bought from from book-sellers.) Financial means of public institutions were limited at all times, with the exception perhaps of the 1960 s and early 1970s, when the Leiden University library did not encounter much trouble in raising government funding for the purchase of the so-called 'Sultan's Library' (from Mrs Akkut in Istanbul) and the Taeschner collection. 
As regards the age of the manuscripts: most items with main Turkish texts had their origin in the 17th, 18th and 19th centuries. The oldest (datable) manuscripts are Or. 517, and Groningen, UB Hs. 474, both dating from the 14th century, and both of non-Ottoman origin. Manuscripts with Arabic and Persian main texts, to which Turkish fragments were added later, often were older: four date from the $13^{\text {th }}$, five from the $14^{\text {th }}$, and 25 from the $15^{\text {th }}$ century. Interesting is also the other extremity of the time-line: manuscripts continued to be produced well into the 2oth century-handwritten texts have perhaps only become rarer with the introduction of personal computers on a massive scale also in the Middle East-but no longer for the book-market but rather for private use as teaching material or copybooks. Some texts in this late category seem to have been copied from printed books, the first of which had already appeared in the Ottoman Empire in the 18th century. Printed books were, at least before the end of the 19th century, not less expensive than hand-written texts, and this may have contributed to the long continuation of copying by hand. The category of late texts includes, interestingly, autograph neat copies made for printers (but apparently not always accepted by them-an example may be Or. 26.046, a late 19th-century autograph of a mesnevi on the martyrdom of Husayn). Another interesting category is manuscripts produced shortly before acquisition. This allows us insight into the state of the book-trade at various specific periods, in particular into the types of works available during such periods. Quite a few of these works have become rare or were never seen again. Examples of such rare/unique works are Mülhimì’s Şehinşāhnāme (Or. 730), a rhymed work on the reign of Sultan Murād IV (ruled 1612-1640), dedicated to the sultan and written a year or two before the dedicatee died-this may have caused a drop in sales and threfore in copies (our copy dates from 1639-1640). It was bought by Warner in, probably, Istanbul one or two decades later. Another striking example is the chronicle/autobiography by Kabudlı Vașfí Efendi (Or. 1551), written in 1249/1834, and already in Leiden five years later.

A not unimportant aspect of manuscripts is their outward aspect. A fairly number of the manuscripts in our collections are preserved in their original bindings, sometimes richly tooled and decorated with gilt motifs. A few texts are provided with tables, diagrams, and (rarely) maps, an even smaller number are illuminated and/or illustrated. The existence of such items in collections could reflect the taste/choice of original collectors: the university libraries, as were the scholars-collectors who were the source of many of their acquisitions, particularly before $c$. 1850, seem to have always been more interested in the texts themselves rather than the visible 
aspect and art-historical quality of the items involved. Private collectors such as Hotz and Willet may have decided to buy Turkish manuscripts for this reason only-their libraries comprise one item each and both have miniatures of high artistic quality. The same undoubtedly is true for museums which like to display manuscripts rather than lend them to readers for perusing texts: examples are the Ethnographic Museums of Leiden and Rotterdam which purchased small collections of miniatures and richly illuminated texts.

The Dutch collections as a whole, then, represent a plethora of works in a plethora of genres and formats, and produced during during six centuries. The three works best represented are (1) Tuhfe-i Şāhidī, a rhymed Persian-Turkish dictionary for schoolboys; (2) the Vașiyyet-nāme by Birgili Mehmed Efendi, a succinct Turkish version in simple language of his (Arabic) manual on Islamic dogma and the duties of Muslims; and (3) the Mevlid by Süleymān Çelebi, a rhymed work on the birth and in celebration of the life of the Prophet. Of the former work, 24 copies are kept in our collections, as are two commentaries on the work. Of the Vașìnet-nāme 21 copies are preserved together with four commentaries and one rhymed version. Of the Mevlid 16 copies are preserved as well as one commentary on it. This probably, again, reflects the popularity of the three works in historical days. The Mevlid indeed is still widely recited in Turkey today. On the other side of the scale: our collections contain a surprising number of rare and unique - at least hitherto undocumented (but not necessarily also revelatory or startlingly original) — works - I have touched upon some examples above. These occur in all collections, both old and modern. Even a recent collection, that gathered by Mrs Acker-Van Eijk in Istanbul from 1951 onwards, and acquired by the Leiden University Library in 1996, comprises autograph works on a, seemingly undocumented, Istanbul tekke written in the first decade of the 2oth century (Or. 23.659 and 23.661) as well as an equally undocumented rhymed grammar in an autograph written in 1175/1761-1762 (Or. 23.671). Documentation is a keyword here: the bibliography of Turkish literature in its widest sense produced during the manuscript age is far from complete and cataloguing of large manuscript collections such as those kept in the Süleymaniye Library in Istanbul or the University Library of Cairo, to mention only two, is fragmentary (in the former case) or non-existent (in the latter). This catalogue - it goes without saying — strives to contribute to such a bibliography. 


\section{Readership and Use, Past and Future}

The materials here described, as said above, are available to the reading public for perusal. To what extent does the reading public make use of that possibility? From early days there has been the recurring idea that not so much the public should come to the reading rooms and read, or look at displays, as that it was a special task of the librarians to do something with the acquired texts, and preferably edit and translate these texts and make them accessible to a scholarly, perhaps in a few cases also wider readership. When the function of interpres was created in he Leiden library in the early 18th century it seems that, in fact, one of his main tasks was to publish as many texts as possible represented in the manuscripts of the Legatum, if not, indeed, all of them. This idea was rather far-fetched and seems to have paralyzed the consecutive interpretes almost completely. Nothing much happened after Golius had begun to take his task as editor/translator seriously in the 17th century. Only from the late 19th century new editions, facsimiles and/or translations of texts in Dutch collections were published: examples are Or. 419 (by A.Th. Houtsma in 1902), Or. 894 (Buğra Atsız in 1977), Or. 917(1) (Joseph Matuz in 1968), Or. 1551 (translation by Jan Schmidt in 2002), Or. 1553 (F.N. Uzluk in 1954), Groningen UB, Hs. 488(1) (K.R.F. Burrill in 1970), or were Dutch manuscripts used for editions or scholarly articles and monographs. There was a clear preference here for rare/unique works. Only recently, in 1997, on the other hand, was the popular Tuhfe-i Şăhidī edited (on the basis of Or. 148) and thoroughly analysed, despite its importance for the language education in the Ottoman Empire from the 16th century onwards. Much remains to be done, both in the way of editions/translations of texts, and the exploration of them in the study of the historical Turcophone culture, particularly that of the Ottoman Empire. An important and hardly explored source is the personal scrapbooks (mecmü'as) which are richly represented in the Leiden University Library collection. These in a unique way connect historical individuals with their historical milieu, their work and intellectual interests and activities. For the contacts between East and West, furthermore, the aforementioned papers and archives bequeathed by Dutch orientalists as well as official letters collected in inşāworks or preserved in original copies, either sent to The Hague or issued to Dutch travellers, wait to be further examined. But there is much more: materials for historical, linguistic, literary, calligraphic, and other studies abound, as is shown in the tables above. This catalogue hopes to be useful as a key for locating and identifying the sources necessary for future scholarly activities of whatever kind. 


\section{POSTSCRIPTUM}

After I wrote the Epilogue, the Leiden University Library obtained two manuscripts collections: one from the private library of Barbara Flemming (nine manuscripts described under Or. 26.264 to 26.272 ) and another who had belonged to Robert Anhegger (six manuscripts, Or. 26.615 to 26.620). The latter also left his, mostly, scholarly archive to the Leiden library (Or. 26.621).

The manuscrips of both collections had all, probably, their origin in Turkey and mostly contain texts in Turkish. The manuscripts that belonged to Flemming are various in genre: five are mainly concerned with Islamic religion, magic and the history of the first four caliphs; three contain poetry, among them two divans (one of which is a rare copy of the poems of the 16thcentury poet 'Abdulvehhāb of Elmalı) and a romance in mesnevi rhyme. One manuscript contains a copy of the popular Pandnāma attributed to 'Ațtāar with a Turkish translation and Persian-Turkish vocabularies. Four of the nine manuscripts are miscellanies that contain more than one main text. In a way, this collection combines some main trends by which Ottoman Schrifttum is characterized: a dominance of multi-text volumes and a dominance of texts on religion, of poetry and of a lively interest in Persian literature among Ottoman literati. The manuscripts were, as far as we can see, mostly produced in the late 17 th- to early 18 th centuries; one was copied in the 16th and another in the 17th century. A few manuscripts show traces of 19th-century Ottoman owners.

Of the manuscripts that belonged to Anhegger, four are of a legal nature. They contain a code of law (kānūn), collections of fetvās and a collection of legal documents for the use of kiàziss. A fifth manuscript, a copy of an Arabic work on grammar, has only one line, a copyist's verse, in Turkish. Two of the manuscripts are, again, collective volumes. Three manuscrips were copied in the 18th and early 19 th centuries. These manuscripts in a small way are a further contribution to our knowledge of Ottoman-Turkish literary culture and-and this is in particular true for the Anhegger archive- to scholarly contacts between West and East; Anhegger spent most of his life in Turkey, was married first to a woman of Jewish-Gallician origin, and, later to a Turkish woman, adopted the Turkish nationality, taught German to Turks, and did research into various aspects of Ottoman history. These aspects are documented in detail in his archive. 
Jan Schmidt - 978-90-04-22191-8

Downloaded from Brill.com04/26/2023 07:45:40AM via free access 


\section{INDEX}

\section{General Index}

Numbers indicate press marks in various collections, alphabetically arranged under the cities in which these are housed and the names of the institutes respectively; 'Introduction', refers to the introductions of the consecutive chapters devoted to these institutes; further abbreviations used are: 'Acad.' (Koninklijke Academie van Wetenschappen, 'Royal Academy of Arts and Sciences'); 'AHM' (Amsterdams Historisch Museum, at present the Amsterdam Museum); 'BPL' (Bibliotheca Publica Latina); 'IISH' (International Institute of Social History); 'KB' (Koninlijke Bibliotheek, 'Royal Library'); 'MM' (Maritiem Museum, Maritime Museum); 'MMW' (Museum Meermanno-Westreenianum); 'NS' (Nederlands Scheepvaartmuseum, 'Netherlands Maritime Museum'); 'MV' (Museum Volkenkunde, 'Museum of Ethnology'); 'UB' (universiteitsbibliotheek, 'University Library') — 'Amsterdam, UB', refers to the University Library of the University of Amsterdam, not to that of the 'Free University' in the same city- 'WM' (Wereldmuseum). Manuscripts marked 'Leiden, UB Or.' with number, are found in the chapter on the Legatum Warnerianum (in the Leiden University Library), Addenda. Numbers printed in bold indicate titles or content descriptions, or genre of works contained in MSS of the collections as well as authors of such works.

'Abdul'azīz, Sultan: Rotterdam, MM P2316

'Abdulbāḳi Efendi, La līzāde: Utrecht, UB Hs. 16 B 15

'Abdulesīm Aḳ 'Abalı b. Hüseyn (copyist): Leiden, UB Acad. 49

'Abdulhamīd I, Sultan: Amsterdam, NS A.4898(14-15)

'Abdulkạdir b. el-Hācc İ̀mā̄̄il (MS owner): Leiden, UB Or. 6292

'Abdulkerīm b. 'Abdurraḥmān ez-Zilī: Utrecht, UB Hs. 16 B 16(2)

'Abdulkerīm b. Nu'mān (copyist): Leiden, UB Acad. 152

'Abdullāh Çelebi (calligrapher): The Hague, KB Hs. 135 K 4(3)

'Abdullāh Efendi, Șarı: Utrecht, UB hs. 16 B 15

'Abdullāh Hulīfe (MS owner): Leiden, UB Acad. 27

'Abdullāh eș-Ṣimavī el-İlāhì: Leiden, UB Or. 919

'Abdulkāāir el-Mollā: Leiden, UB Acad. 75

'Abdulmecīd I, Sultan: Amsterdam, UB Hs. Diederichs 136 F 1,2, 136 G 1,2, 136 I

'Abdulvefā (poet): Leiden, UB Or. 26.269(6)

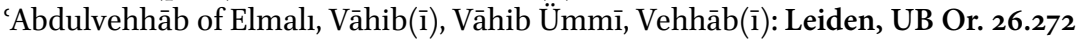

'Abdurrahīm (muftī), Leiden, UB Or. 26.615, 26.617 
'Abdurrahīm b. Ahmed, Kāżìi: Leiden, UB Acad. 42(2), 178(1)

'Abdurraḥmān, İbrāhīm Huānzāde (mütevellī): Utrecht, UB Hs. 16 C 1

'Abdurraḥmān b. Meḥmed el-Bisțāmī: Leiden, UB Or. 947, $95^{8}$

'Abdurraḥmān Çelebi: Utrecht, UB Hs. 16 B 24

'Abd ar-Raḥmān al-Qazwīnī Khațīb Dimashq: Leiden, UB Or. 211

Abessynian: Leiden, UB Acad. 210

Abū l-'Abbās Aḥmad b. 'Alī b. Yūsuf al-Būnī al-Qurashī: Leiden, UB Or. 1233

Abū Bakr b. Walī (copyist): Utrecht, UB Hs. 1 E 19

Abū l-Faḍl Majd ad-Dīn al-Mawșilī al-Buldajī: Utrecht, UB Hs. 1 G 24

Abū Hanīfa: Leiden, UB Acad. 34(1)

Abū Mikhāyīl b. Balāzmuz b. Jurjī Kharrāj (? MS owner): Leiden, UB Acad. 153

Abū Ṭāhir Mūsā Ṭarțūsī: Leiden, UB Acad. 183

Abudacnus, Josephus see Yūsuf b. Abū Daqan

Abūlḥasan Bakrī Muḥammad b. Isḥāq: Leiden, UB Acad. 8(2)

'Acāyibü l-mahlūkāt: Utrecht, UB Hs. 16 B 17(1)

Ad Orientem (booksellers): Utrecht, UB Hs. 16 C 1-2

Adam: Leiden, UB Acad. 182, 211(4)

Adana: Leiden, UB BPL 3273

agriculture: Leiden, UB Hs. 16 B 16(1); Utrecht, UB Hs. 16 B 24

'ahdnāme: Leiden, UB Acad. 39, 87(3); Rotterdam, WM 63215

'ahdnāme-i hümāyūn (of 1634): Leiden, UB Acad. 197

Ahı Paşa: Leiden, UB Acad. 210

Ahızāde Efendi: Amsterdam, UB Hs. Cn 12(2)

Aḥmad b. 'Alī al-Anșāiñ (copyist): Leiden, UB Or. 1233

Ahmed $(k \bar{a} \dot{z} \bar{\imath}):$ Utrecht, UB Hs. 16 C 2

Ahmed, Șağır (levend): Leiden, UB Acad. 87(3)

Ahmed, es-Seyyid (müderris): Utrecht, UB Hs. 16 C 2

Aḥmed, es-Seyyid el-Hācc: Utrecht, UB Hs. 16 C 1

Aḥmed III, Sultan: Leiden, UB Acad. 182

Aḥmed Agga: Leiden, UB Acad. 87(3); Utrecht, UB Hs. 16 C 1

Aḥmed Ag̀a, Ṭırmānī (copyist): The Hague, KB Hs. 135 K 4

Aḥmed b. Maḥmūd Yüknekī, Edīb: Groningen, UB Hs. 474(2)

Aḥmed b. Meḥmed b. İbrāhīm (copyist/compiler): Leiden, UB Acad. 84

Aḥmed Beg b. Dāvud Paşa of Rumelia (MS owner): Leiden, UB Acad. 35

Ahmed Efendi ( $k \bar{a} \bar{z} \dot{\imath}$ of Izmir): Leiden, UB Acad. 87(3)

Aḥmed Efendi, 'Ayntābī Hạaccī (MS owner): Leiden, UB Or. 26.271

Ahmed Halife: Utrecht, UB Hs. 16 C 2

Aḥmed Na'īmī, es-Seyyid: Utrecht, UB Hs. 16 B 18

Aḥmed Paşa: Groningen, UB Hs. 490; Leiden, UB Acad. 46(1)

Ahmed Paşa, Köprülü(grand vizier): Leiden, UB Or. 26.621

Ahmed Vâlâ Nûruddin (Vâ-Nû): Amsterdam, IISH

'Ajamī madrasa (Aleppo): Utrecht, UB Hs. 1 E 19

Akbulut, Nurettin: Leiden, UB BPL 3273

Akkerman: Leiden, UB Or. 26.617

Alaca Huyük: Leiden, UB BPL 3273

Albania: Amsterdam, UB Hs. Diederichs 136 J; Leiden, UB BPL 3273

album amicorum: The Hague, KB Introduction 
album amicorum (Ernst Brinck): The Hague, KB, Hs. 135 K 4

album amicorum (Johannes Fredericus Gronovius): The Hague, KB Introduction

album amicorum (Johan Philip Mulhausen/Mulheuser): The Hague, KB Introduction

album amicorum (Laurentius van Santen): The Hague, KB Introduction

album amicorum (Joannes Willmet): The Hague, KB Introduction

Aleppo: Amsterdam, UB Hs. Diederichs 9 U; Leiden, UB Acad. 97(3,6,7,11,12), 149

Alexander, see İskender

Alexandretta, see İskenderun

Alexandria: Amsterdam, UB Hs. Cq 45; Leiden, UB Acad. 97(3,8-11)

Algeria(n): Leiden, UB Acad. 87(3)

Algiers: Leiden, UB Acad. 178; Or. 1670-1671

'Ālī: Leiden, UB Acad. 210

'Alī (caliph): Rotterdam, WM 6o948, 68276; Utrecht, UB Hs. 16 B 14(2-5)

'Alī (caliph), seal of: Groningen, UB Hs. 471

'Alī (cavass): Amsterdam, NS A.4898(16)

'Alī (copyist): Leiden, UB Acad. 179

'Alī 'Adullāh el-Aḳkermānī: Leiden, UB Or. 26.617

'Alī Ag̀a: Amsterdam, UB Hs. Diederichs $136 \mathrm{~N}$

'Alī Akbar Khițāīi: Leiden, UB Or. 854

'Alī b. Yūsuf b. Mü'min (copyist): Groningen, UB Hs. 462(2)

'Alī Başe: Leiden, UB Acad. 97(2), 205

'Alī Cān (MS owner): Leiden, UB Acad. 179

'Alī Çelebi: Leiden, UB Or. 1228

'Alī Çelebi (müftì): Amsterdam, UB Hs. Cn 12(2)

'Alī Efendi (of Çatalca, müftì): Leiden, UB Or. 26.618

'Alī Hōōa Edirnevī, Adamcıl (copyist): Leiden, UB Acad. 42

'Alī Meḥmed Emīn Paşa: Amsterdam, UB Hs. Cq 42

'Alī Paşa, Tepedelenli: Amsterdam, UB Hs. Diederichs 136 J

'Alī Riża, Hāfiż (ḳāżĭ, MS owner): Leiden, UB Or. 26.616

'Alī Ufkī (Wojcieh Bobowski, Albertus Bobovius): Amsterdam, UB Hs. VI H 2

Ālihī: Leiden, UB Acad. 212

Alkım, Bahadur: Leiden, UB BPL 3273

almanac: Amsterdam, UB Hs. Dortmond 56, 291; Leiden, MK 36o-9545, 360-9546;

Leiden, UB Acad. 35(4), 45(2), 46

Amasya: Groningen, UB Hs. 488(2); Leiden, UB Or. 1025; Utrecht, UB Hs. 16 C 2

Amos, the Book of: Amsterdam, UB Hs. VI H 2, p

Amsterdam: Amsterdam, UB Hs. Diederichs 136 M; Rotterdam, MM H336(3)

al-amthila al-mukhtalifa: Leiden, UB Acad. $5^{8}$

Anabolı (Navplio): Utrecht, UB Hs. 16 C 2

Anastasiadis, Chariklia: Leiden, UB BPL 3273

Anatolia: Amsterdam, UB Hs. Diederichs 136 G 1; Leiden, UB BPL 3273; Utrecht, UB Hs. $16 \mathrm{C} 1$

Anatolia Club (Ankara): Leiden, UB BPL 3273

Anatolian journey (of Anhegger and Tietze): Leiden, UB Or. 26.621

anecdote(s): Amsterdam, UB Hs. Cn 12(1); Groningen, UB Hs. 488(1,2); Leiden, UB

Acad. 205, 211(1,5); Or. 6292(8), Or. 26.266, 26.267 
Anhegger, Robert (also MS owner): Amsterdam, IISH; Leiden, UB BPL 3273; Or. $26.615^{-621}$

Ankara: Leiden, UB BPL 3273

Anslo, Gerbrandt: Utrecht, UB Introduction

Antwerp: Amsterdam, NS A.4898(14-16)

Anwār at-tanzīl wa'asrār at-ta'wül: Utrecht, UB Hs. $1 \mathrm{E} 17$

aphorism: Leiden, UB Acad. 63, 152; Or. 858; Utrecht, UB Hs. 16 B 25

Arar, İsmail H.: Amsterdam, IISH

arboriculture: Utrecht, UB Hs. 16 B 24

Archeological Museum (Istanbul): Leiden, UB BPL 3273

Architecture, Ottoman (photographs of): Leiden, UB Or. 26.621

Archive, the Anhegger: Leiden, UB Or. 26.621

'Ārifì, see Yūsuf 'Ārifì

'Ārifì Aḥmed Paşa: Amsterdam, UB Hs Cq 43

Ariştus (Aristotle): Amsterdam, UB Hs. Cn 12(1)

'arïza: Utrecht, UB Hs. $16 \mathrm{C} 1$

Armenian: Amsterdam, UB Hs. VI H 2; Cq 48

Armenian (language): Leiden, UB Acad. 204

Armenian Church: Leiden, UB BPL 3273

Arnavutköy: Amsterdam, UB Hs. Cq 53 b

Arsca (fortress of): The Hague, MMW Hs. 10 E 30

Arsenal (Ottoman Navy): Utrecht, UB Hs. 16 C 1,2

Arslan Meḥmed Paşa: Amsterdam, UB Hs. Diederichs F 1,2

Arslan Süleymān Paşa: Amsterdam, UB Hs. Diederichs 136 F 1,2

'arü $\dot{z}$, see prosody

'ar $\dot{z}-i$ hăl, see petition

astrolabe, treatises on the use of: Leiden, UB Acad. 49

astrology (-gical): Amsterdam, UB Hs. Cn 12(1,2); Leiden, UB Acad. 35(4), 45(2), 46(2); Utrecht, UB Hs. 16 B 16(1)

astronomy (-mical): Leiden, UB Acad. 46(2); Or. 1025; Utrecht, UB Hs. 16 B 18

At meydānı, see Hippodrome

'Atebetül-ḥakāayık: Groningen, UB Hs. 474(2)

Atalandi, see Talande

Atatürk (Mustafa Kemal): Leiden, UB BPL 3273

Athens: Amsterdam, UB Hs. Diederichs G 1-4; Utrecht, UB Hs. 16 C 1,2

'Atțāar, Farīd ad-Dīn: Leiden, UB Acad. 147; Or. 954, 26.271(1); Utrecht, UB Hs. 16 B 25

Auerbach, Erich: Leiden, UB BPL 3273

Augsburg: Leiden, UB Acad. 97(11)

augury: Utrecht, UB Hs. 16 B 16(1)

Austria(n): Amsterdam, NS A. 4898(14-15); UB Hs. Diederichs H 1; Leiden, UB BPL 3273; Rotterdam, MM H336(3)

Austrian Campaign (1788): Utrecht, UB Hs. 16 C 1

Austrian Mediterranean Fleet: Amsterdam, UB Hs. Cq. 45

autograph: Groningen, UB Hs. 485, 489

Avicenna, see Ibn Sīnā

Avāmil-i Türkīye, [Kitāb-i]: Leiden, UB Acad. 64(3) 
Awāmil al-mi'a: Leiden, UB Acad. 64(1)

Aya Sofya Mosque: Leiden, UB Acad. 156

Āyat Abū Bakr aṣ-Șiddīq: Groningen, UB Hs. 491(3)

Āyat 'Umar al-Fārūq: Groningen, UB Hs. 491(3)

Aydın: Leiden, UB Acad. 87(1); Utrecht, UB Hs. 16 C 1

Aydos: Utrecht, UB Hs. $16 \mathrm{C}_{2}$

'Ayntab (Gaziantep): Leiden, UB Acad. 153; Or. 1025

Azerbaijan: Amsterdam, IISH

Baart de la Faille, Jacob (MS owner): Amsterdam, NS A.4898(14-16)

Badouacius, Isaacus (MS owner): Groningen, UB Introduction, Hs. 493

Bafra: Utrecht, UB Hs. 16 C 1,2

Baghdad: Leiden, UB Or. 878; Rotterdam, WM 60948

Bahadinli, Yusuf Ziya: Amsterdam, IISH

Bahā'î: The Hague, KB Hs. 135 K 4

Bahr el-ma'ārif: Leiden, UB Acad. 152

Bālī b. 'Alī (ḳā̇ì $):$ Leiden, UB Acad. 197

Balkan, Kemal: Leiden, UB BPL 3273

Balkans: Leiden, UB BPL 3273; Or 62.621; Urecht, UB Hs. 16 C 1

Balta, Evangelia: Leiden, UB Or. 26.621

Bandırma: Utrecht, UB Hs. 16 C 1,2

Bär, Rudolf: Leiden, UB BPL 3273

Barbatus, see Abudacnus

Bauer, Theo: Leiden, UB BPL 3273

Baydar, Oya: Leiden, UB Or. 26621

al-Bayḍawī, 'Abd Allāh b. 'Umar: Utrecht, UB Hs. 1 E 17

Bāyezīd, Shaykh: Groningen, UB Hs. 49o(3)

Bāyezīd I, Sultan: Leiden, UB Or. 26.270

Bayrām, Shaykh Hāācī: Utrecht, UB Hs. 16 B 17(1)

Bayrām er-Rūmī (copyist): Leiden, UB Acad. 45

Beck, Ieronimus: Utrecht, UB Hs. 1 F 12

Begpazarı (Beypazarı): Leiden, UB Acad. 205

Beglerbegi medrese (Edirne): Leiden, UB Or. $95^{8}$

Behāyī (şeyhülislām): Utrecht, UB Hs. 1 E 19

Beirut: Amsterdam UB, Hs. Diederichs 136 G 1-4

Bekir b. İbrāhīm (copyist): Utrecht, UB Hs. 16 B 16

Bekir b. Makșūd b. İbrāhīm (copyist): Leiden, UB Or. 26.266

Bekir Efemdi, Ḥāccī Bayrāmzāde (MS owner): Leiden, UB Or. 26.267

Belgrade: Leiden, UB BPL 3273

Bender (Tighina, in Moldavia): Leiden, UB Acad. 205

berāt: Leiden, UB Acad. 46(3), 87(3), 97(1), 205

Berlin: Leiden, UB BPL 3273

Bernard, Jacques (MS owner): Leiden, UB Introduction, Acad. 22

Bernfeld, Mr.: Leiden, UB BPL 3273

Berthier, César (general): Amsterdam, UB Hs. Diederichs $136 \mathrm{~J}$

Beschrijvinge vande salarissen, soldien, en vande incoemen, die den Turcxschen keijser geeft ...: The Hague, KB Introduction 
Beşir and Şādān, story of: Utrecht, UB Hs. 16 B 16(1)

Beşīr Ag̀a, Hāccī: Leiden, UB Acad. 205

Beşīr b. 'Abbās b. Aḥmed Faḳı b. Mevlānā'Aşlī (?) Hualīfe: Leiden, UB Or. 1233

Bethlen Gabor: Amsterdam, UB Hs. Diederichs $9 \mathrm{U}$

Beyān el-ed'iye, [Risāle] fi: Leiden, UB Or. 26.269(3)

Beyān-i su'āl-i cevāb ve cevāb be-su'āl: Groningen, UB Hs. 491(4)

Beyatll, see Yahya Kemal

Beyoğlu (Istanbul): Leiden, UB BPL 3273

Bible: Amsterdam, UB Hs. VI H 2; Leiden, UB Acad. 1, 34, 97(7)

Bidard, Mr. le: Amsterdam, UB Hs. Cq 44

Bilderdijk, Willem: The Hague, KB Introduction

Bilgiç, Emin: Leiden, UB BPL 3273

bill of exchange, see poliçe

biographical sources (on the life of Anhegger): Leiden, UB Or.26.621

birds of Africa, description of: Leiden, UB Acad. 97(3)

Birgili Meḥmed Efendi, see Meḥmed b. Pīr 'Alī Birgivī

Bisson Bey, Vice-admiral: Amsterdam, UB Hs. Diederichs 136 Bp

el-Bisțāmī, see 'Abdurraḥmān b. Meḥmed

Bitola, see Manastir

Black Sea: Leiden, UB BPL 3273; Rotterdam, MM P2316; Utrecht, UB Hs. 16 C 1

Bobovius, Albertus, see 'Alī Ufkī

Boġazhișārı: Leiden, UB Acad. 97(4)

Boghos Yūsuf Beg: Amsterdam, UB Cq 45

Boldue, de (magistrat): Amsterdam, UB Hs. Diederichs $136 \mathrm{M}$

Bolu, Amsterdam, IISH

Bosch, Clemens (Emin): Leiden, UB BPL 3273

Bosnia: Amsterdam, UB Hs. Diederichs 136 F 1,2, 136 N

Bosphorus: Leiden, UB BPL 3273

Bossert, Hellmuth: Leiden, UB BPL 3273

Bostānzāde Efendi: Amsterdam, UB Hs. Cn 12(2)

Bozok (Yozgat): Leiden, UB Or. 1233

Braila, see İbrā̄il

Brandenburg, Karl August, Count of: The Hague, MMW Hs. 10 E 30

Brill, E.J. (booksellers, Leiden): Leiden, UB Or. 6292

Brinck, Ernst (MS compiler): The Hague, KB Hs. 135 K 4

Britain (-tish): Amsterdam, UB Hs. Diederichs 136 I, 136 J

Browne, Mr., Francis: Leiden, UB Acad. 97(10)

Bruin, J.J. de (MS owner) Leiden, UB Acad. 27, 30, 34-35, 152, 182, 211

Brussels: Amsterdam, UB Hs. Diederichs $136 \mathrm{M}$

Bucharest: Amsterdam, UB Hs. Diederichs $136 \mathrm{H} 1$

Büchner, Dr (orientalist): Amsterdam, UB Hs. Cn 12

Budin (Buda): Groningen, UB Hs. 486, 489

buffaloes: Utrecht, UB Hs. 16 C 1

Buhtal (Počitelj): Amsterdam, UB Hs. Diederichs $136 \mathrm{~N}$

Buḳrāt, see Hippocrates

Burgoz: Utrecht, UB Hs. 16 C 1

Bursa: Groningen, UB Hs. 491(2); Leiden, UB Acad. 46(3); BPL 3273; Utrecht, UB Hs. $16 \mathrm{C} 1,2^{2}$ 
Bustān: Leiden, UB Acad. 142; Or. 896

Büyük Ada: Leiden, UB BPL 3273

Bystram, Baron Adolf von: Amsterdam, UB Hs. Diederichs 136 G 1-4

Ca'fer b. Meḥmed, 'Kāàżīzāde': Leiden, UB Or. 1228

Çag̉alazāde, see Çig̉alazāde

Cairo: Amsterdam, UB Hs. Diederichs 136 G 1-4; Leiden, UB Acad. 59, 95, 97(3,8-11); Utrecht, UB Hs. 1 B 8, 16 B 20

calendar: Amsterdam, UB Hs. Cn 12(1), Dortmond 56, 291; Leiden, MK 360-9545, 360-9546; Leiden, UB Acad. 45(2), 46

Caliphs, the early: Leiden, UB Acad. 156; Or. 26.268

Callenberg, Johann Heinrich: Leiden, UB Acad. Introduction

Callenberg, T.H.: Leiden, UB Acad. 97(7)

calligraphy (-phic samples): Groningen, UB Hs. 487; The Hague, KB 135 K 4(3);

Leiden, UB Acad. 204, 209; Rotterdam, WM Introduction

camels: Utrecht, UB Hs. 16 C 1,2

Cāmi ü l-luġāt: Leiden, UB Acad. 74(1)

Camlıca: Amsterdam, UB Hs. Cq 49

Cān Beg: Groningen, UB Hs. 486

Candarlı: Utrecht, UB Hs. $16 \mathrm{C} 1$

Canik: Utrecht, UB Hs. 16 C 2

capitulations, see 'ahdnāme

Çarşıkapı (Istanbul): Leiden, UB BPL 3273

Çatalca: Utrecht, UB Hs. $16 \mathrm{C} 1$

Cefr-i Hażret-i İmām 'Alī: Amsterdam, UB Hs. Cn 12(2)

Çekmece-i șagīir (Küçük Çekmece): Utrecht, UB Hs. 16 C 1

Çelik, Nevzat: Leiden, UB Or. 26.621

censor(ship): Leiden, UB BPL 3273

Cevān-i Fāżll, story of: Utrecht, UB Hs. 16 B 16(1)

China, description of: Leiden, UB Or. 854

Chinese (language): Groningen, UB Hs. 479

Christmann, Jakob (MS owner): Groningen, UB Introduction, Hs. 465, 479, 485, 486, 487,492

Chronicles, the Book of: Amsterdam, UB Hs. VI H 2, g

chronogram: Amsterdam, AHM Hs. LA 2047; UB, Hs. Cn 12; Leiden, UB Acad. 46(1), 74(2), 152, 153; Or. 26.271(4)

Ciax, Mr. le docteur: Amsterdam, UB Hs. Diederichs 136 I

Cicala, Scipione: Amsterdam, UB Hs. Diederichs $136 \mathrm{M}$

Çı̆̆, Muazzez: Leiden, UB BPL 3273

Cigala, Bassa; Amsterdam, UB Hs. Diederichs 136 M

Çig̉alazāde family: Amsterdam, UB Hs. Diederichs $136 \mathrm{M}$

Cihangir (Istanbul): Leiden, UB BPL 3273

cigarette paper booklets, Ottoman (collection of): Leiden: UB Or. 26.621

Cimcime Sulțān: Utrecht, UB Hs. 16 B 14(1)

Circīs (prophet): Leiden, UB Acad. 211(3)

Cisr-i kebīr (Klis): Utrecht, Hs. UB 16 C 1

Civizāde: Leiden UB, Or. 26.619 
cizye: Leiden, UB Acad. 87(3); Utrecht, UB Hs. 16 C 1

Clermont, Collège (Paris): The Hague, MMW Introduction

Clodius, Johannes Christianus: Leiden, UB Acad. 95

cloth: Leiden, UB Acad. 87(3)

Coccolini, Mr.: Leiden, UB Acad. 97(11)

coffee: Leiden, UB BPL 3273; Or. $95^{8}$

coffee houses: Leiden, UB BPL 3273

Cohen \& Fratelli: Leiden, UB Acad. 97(11)

Cold War: Leiden, UB BPL 3273

collection of dictionaries: Leiden, UB Acad. 74, 79, 222

collection of documents and letters: Utrecht, UB Hs. 167 C 1-2

collection of forty traditions (hadīth): Leiden, UB Acad. 35(3)

collection of (model) letters: Leiden, UB Acad. 84-87, 97, 205, 210; BPL Introduction

collection of pious and magical texts: Groningen, UB Hs. 471, 473, 484; Leiden, UB

Acad. 38

collection of religious parables (destān): Utrecht, UB Hs. 16 B 14

collection of religious poems and songs: Leiden, UB Or. $26.269(4,6)$

collection of quatrains: Groningen, UB Hs. 474(3)

collection of stories/anecdotes: Groningen, UB Hs. 488(1); Leiden, UB Or. 26.266

collection of traditions (hadith): Leiden, UB Acad. 42(2); Or. 26.266

colloquial phrases, Turkish(-Italian): Leiden, UB Acad. 8o(2)

Colyer, Giacomo (Jacob, envoy): Leiden, UB Acad. 87(3)

Comenius: Leiden, UB Or. 26.621

comet: Utrecht, UB Hs. 16 B 22

Comintern: Amsterdam, IISH

Communist Party (of Switzerland): Leiden, UB Or. 26.621

Companions (of the Prophet): Leiden, UB Or. 26.268

Corfu: Amsterdam, UB Hs. Diederichs 136 I

Çorum: Leiden, UB Or. 26.266; Utrecht, UB Hs. 16 C 1

cosmography: Leiden, UB Acad. 211(4), Utrecht, UB Hs. 16 B 17(1)

cosmology: Amsterdam, UB Hs. Cn 12(1); Utrecht, UB Hs. 16 B 18

Cossacks: Amsterdam, UB Hs. Diederichs 9 U

Cottbus: Leiden, UB BPL 3273

cotton: Leiden, UB Acad. 87(3)

Croix, Mr. de: Leiden, UB Acad. 97(10)

'Crystal Night': Leiden, UB BPL 3273

çuhadār, miniature of: Leiden, MV Introduction

Curet, Mr.: Leiden, UB Acad. 97(8)

customs (officer): Leiden, UB Acad. 87(3)

Cyprus: Amsterdam, IISH; UB Hs. Diederichs 136 G 1-4

Czechoslovakia: Leiden, UB BPL 3273

Dād Sipehsālār Beg: Groningen, UB Hs. 474(2)

Dādiyān (dynasty): Leiden, UB Acad. 182

Dakāayikü l-ahbār: Leiden, UB Acad. 42(2), 178(1)

dā'ire-i ricāl-i gayb: Leiden, UB Acad. 35(1)

Dalmatian Army, French: Amsterdam, UB Hs. Diederichs $136 \mathrm{~N}$ 
Damascus: Amsterdam UB, Hs. Diederichs 136 G 1-4; Leiden, UB Acad. 151; Utrecht, UB Hs. 16 B 14(6), 16 B 22

Dame Catherine, la (ship): Amsterdam, NS A.4898(15)

Damietta: Leiden, UB Acad. 97(11)

Daniel, the Book of: Amsterdam, UB Hs. VI H 2, o

Dānisten, [Risāle-i]: Leiden, UB Acad. 74(6), 79(1)

Dānistan, Kitāb-i: Leiden, UB Or. 896

Danti, Hendrick (Henrico, MS owner): Groningen, UB Hs. 479

Dardanelles: Utrecht, UB Hs. 16 C 2

Dāsitān-i Ana ile og̀ul: Utrecht, UB Hs. 16 B 14(5)

Dāsitān-i Cimcime Sulțān: Utrecht, UB Hs. 16 B 14(1)

Dāsitān-i Duhter-i miskīn: Utrecht, UB Hs. 16 B 14(6)

Dāsitān-i Ejderhā: Utrecht, UB Hs. 16 B 14(4)

Dāsitān-i Kesik-baş: Utrecht, UB 16 B 14(2)

Dāsitān-i Geyik: Utrecht, UB Hs. 16 B 14(3)

Dauchez, Charles (MS owner): The Hague, MMW Introduction

David, Martin: Leiden, UB BPL 3273

Dāvud (prophet): Leiden, UB Acad. 211(4)

Dāvud b. Maḥmūd el-Kayserī: Leiden, UB Or. 858(2)

Dāvud Paşa (minister): Amsterdam, UB Hs. Cq 48

Dāvudpaşa (Istanbul): Utrecht, UB Hs. 16 C 1

Deli Birāder, see Meḥmed Ġazālī

Denizli: Utrecht, UB Hs. 16 C 1

Derviş, Etem: Amsterdam, IISH

destāns, collection of: Utrecht, UB Hs. 16 B 14

Devil: Leiden, UB Acad. 8(2), 42(2)

dialogues, Turkish: Leiden, UB Acad. 92, 95, 96

Diary (by Stephan Schultz): Leiden, UB Acad. Introduction

dictionary, Arabic: Groningen, UB Hs. 462(2)

dictionary, Arabic-Italian/German: Leiden, UB Acad. 204

dictionary: Arabic/Persian-Turkish: Leiden, UB Or. 26.271(2)

dictionary, Arabic-Persian-Turkish: Leiden, UB Acad. 87(4); Or. 836

dictionary, Arabic-Turkish: Leiden, UB Acad. 74(1,2,3,4,5,7), 75(1), 76, 79(2); Or. 26.271(3)

dictionary, Italian-Turkish: Leiden, UB Acad. 222

dictionary, Persian-Turkish: Leiden, UB Acad. 74(6,8), 77, 78, 79(1); Hotz 2289; Or. 896

dictionary, Turkish-Persian-Arabic-Aramaic: Leiden, UB Acad. 222

dictionary, Turkish(-Italian): Leiden, UB Acad. 8o(1)

dictionary and phrasebook, Turkish-French: Leiden, UB Acad. 82

Didier, Mr.: Leiden, UB Acad. 97(11)

Diederichs, Pieter Arnold (MS owner): Amsterdam, UB Introduction

Dikerdem, Mahmut: Amsterdam IIHS

Dirac (Durrës): Leiden, UB Or. 26.615

Dìvān ('Abdulvehhāb): Leiden, UB $\mathbf{2 6 . 2 7 2}$

Dìvān (Fużūlì): Leiden, UB Or. 26.265; Rotterdam, WM 70935

Dìvān (Kemāl Ümmī): Groningen, UB Hs. 491(6) 
Dìvān (Ușūlī): Groningen, UB Hs. 490

division of inheritances, see ferāyı $\dot{z}$

Dìwān (Saqqā): Leiden, UB Acad. 151

Dìwān (Ṭālib Âmulī): Leiden, UB Acad. 149

divination (-natory): Groningen, UB Hs. 471; Leiden, UB Acad. 45, 46; Utrecht, UB Hs. 16 B 16(1)

Diyarbakır: Leiden, UB BPL 3273; Utrecht, UB Hs. 16 C 1

Doğan appartments (in Beyoğlu): Leiden, UB Or. 26.621

dogma, see religious dogma

Doğuduyal, Meliha: Leiden, UB Or. 26.621

Dolmabahçe Palace: Leiden, UB BPL 3273

Doljane, see Țulyān

Dortmond, J.A. (MS owner): Amsterdam, UB Introduction

Dračevo: Amsterdam, UB Hs. Diederichs $136 \mathrm{~N}$

drawing(s): Leiden, UB Acad. 35(1), 45(2), 49; Utrecht, Hs. 1 F 18; Utrecht, UB Hs. 16 B 18

dreams, interpretation of: Utrecht, UB Hs. 16 B 16(1)

Dresdner Bank: Leiden, UB BPL 3273

du'ānāme: Leiden, UB Acad. 87(3)

Dubrovnik, see Ragusa

Duda, Herbert Wilhelm: Leiden, UB BPL 3273

Duraḳlı (Bursa): Utrecht, UB Hs. 16 C 2

Durar al-ghurar: Leiden, UB Or. 26.615

Durrës, see Dirac

Dürrīzāde, see Meḥmed ‘Ārif

Dutch Republic: Leiden, MV 36-9550; UB, Acad. 197

earthquake: Leiden, UB Acad. 87(3); BPL 3273

Ebū 'Abdullāh Meḥmed b. Selāmetḳużā'̄i: Leiden, UB Acad. 42(2), 178(1)

Ebūbekir b. el-Hācc Ḥasan el-Vāćz, Ḥāfız (MS owner): Leiden, UB Or. 1233

Ebūbekir b. 'Ömer (copyist): Leiden, UB Or. 26.616

Ebūbekir Nușret Efendi: Utrecht, UB Hs. 16 B 21

Ebūbekir Paşa: Utrecht, UB Hs. 16 C 1

Ebūbekir Yazıcı, Seyyid (copyist): Leiden, UB Or. 26.271

Ebūlhayr (b. Yūsuf Nābī): Leiden, UB Acad. 154

Ebūssu'ūd Meḥmed b. Meḥmed el-'̇̉mādī (şeyhülislām): Amsterdam, UB Hs. C 12(2);

Leiden, UB Or. 26.615(2) Utrecht, UB Hs. 1 E 19

Ecclesiastes, the Book of: Amsterdam, UB Hs. VI H 2, c

Eendragt (ship): Leiden, MV 36-9550

Edirne: Amsterdam, UB Hs. Diederichs 136 G 1; Leiden, UB Acad. 87(3), 205; Or. 958; Utrecht, UB Hs. 16 C 1,2

Egypt: Amsterdam, UB Hs. Diederichs 136 G 2; Leiden, UB Acad. 97(11); Utrecht, UB Hs. 1 B 8

Egyptian fleet: Amsterdam, UB Hs. Diederichs 136 Bp

Ehelolf, Hans: Leiden, UB BPL 3273

Embassy, Ottoman (London): Amsterdam, UB Hs. Diederichs $136 \mathrm{~K}$

Embassy, Swedish (Istanbul): Leiden, UB Acad. 97 $(5,6)$ 
Emīr b. Mehmed (copyist): Leiden, UB Acad. 8

Emrī: Leiden, UB Acad. 156

encyclopaedia of sciences: Leiden, UB Or. 947; Utrecht, UB Hs. 16 B 16(1)

Ephesus: Leiden, UB BPL Introduction Eraud, Mr.: Leiden, UB Acad. 97(10,11)

Erçog̉dı (?) b. Ḩōca, Imam Hāācī (copyist): Leiden, UB Acad. 74(1)

Ermenāk (Ermenek): Utrecht, UB Hs. 16 B 24

Erpenius (Thomas van Erpe): Leiden, UB Or. 1228

Erzurum: Amsterdam, UB Hs. Cq 55c

Erzurumī, see İsmāêil Ḥaḳkī

Escher, B.G. (navy officer): Amsterdam, NS A.4898(16)

el-Esmā' el-hü̈nā: Leiden, UB Or. 26.269(2)

Esther, the Book of: Amsterdam, UB Hs. VI H 2, b

Ethiopia, see Habeş

evrād: Leiden, UB Or. 26.269(1)

Evrenos Beg, Ġāzi: Leiden, UB Acad. 46(3)

Exercitationes linguae Turcicae: Groningen, UB Hs. 485

Extremos y Grandezas de Constantinopla: Leiden, UB Or. 26.621

Eyüb (Istanbul): Utrecht, UB Hs. 16 B 24

Eyuboğlu, Mualla (second wife of Anhegger): Leiden, UB Or. 26.621

Ezekiel, the Book of: Amsterdam, UB Hs. VI H 2, n

Ezra, the Book of: Amsterdam, Hs. VI H 2, h

Fāl-i Cafer Șādık, Risāle-i: Leiden, UB Acad. 45(1)

fälnāme: Leiden, UB Acad. 45(1), 74

Faḳīrī: Groningen, UB Hs. 491(1)

Fāțima: Groningen, UB Hs. 484; Leiden, UB Acad. 178; Or. 6292, 26.266; Utrecht, UB Hs. $16 \mathrm{C} 2$

Fawā'id aț-țālibì ya fi al-ghawā’id ad-diyā'̄ya: Leiden UB, Or. 26.619

Fawā'ih al-miskìya fì 'l-fawātih al-Makkīya: Leiden, UB Or. 947

Fāyıżì Efendi: Amsterdam, UB Hs. Cn 12(2)

Fażāyl-i şehr-i Ramażān: Leiden, UB Or. 933

Fażlullāh b. Muștafā(copyist): Leiden, UB Or. 919

Fedāyī, see Meḥmed b. 'Alī b. Aḥmed

Fegan, Fuat: Amsterdam, IISH

Fegan, Latife: Amsterdam, IISH

Fenārī, see Meḥmed b. Hamza

Fenāȳi, Monlā: Utrecht, UB Hs. 1 F 18

ferāyız: Utrecht, UB Hs. 16 B 16(2,3)

Ferdinand, Habsburg Emperor: Utrecht, UB Hs, 1 F 12

Feriköy (Istanbul): Leiden, UB BPL 3273

fermān: Amsterdam, NS A.4898(14-16); UB Hs. Diederichs 136 G 1,2, 136 H 1,2, 136

I; Leiden, UB Acad. 97(3); Or. 1670-1671; Rotterdam, MM P2316; Utrecht, UB Hs. $16 \mathrm{C}_{1}$

Ferro (consul): Leiden, UB Acad. 97(11)

Fetāvā-yi Aḳkermānī: Leiden, UB Or. 26.617

Fetāvāa-y I 'Al̄̄ Efendi: Leiden, UB Or. 26.618(1)

Fetāvā-yi Üskübī: Leiden, UB Or. 26.617 
Fetḥī b. Aḥmed b. Mevlānā Bahş̧āş b. Luṭfullāh b. Ḥāccī 'Abdullāh: Leiden, UB Or. 1233

fetvā: Leiden, UB Acad. 58, 75; Or. 958. 26.615, 26.616, 26.618; Utrecht, UB Hs. 1 E 17, 1 E 19, 16 B 16(2), 16 B 22

fetvās, collection of: Leiden, UB Or. 26.615(2, 3), 26.617, 26.618(1-2)

Feyrerin, Anna: Groningen, UB Hs. 472

Feyrerin, D.: Groningen, UB Hs. 472

Feżä'il-i Mekke ve l-Medine ve l-Kuds ve l-Halīl: Leiden, UB Acad. 179

Fig̀ānī: Leiden, UB Acad. 156

figs: Leiden, UB Acad. $87(3)$

Filibe (Plovdiv): Utrecht, UB Hs. 16 C 1

Firişteog̀lı, see 'İzzüddīn 'Abdullațîf

Flemming, Barbara (also MS owner): Leiden, UB Or. 26.264-272, 26.621

Foça: Leiden, UB Acad. 87(3)

Fop Smit (ship): Rotterdam, MM P2316

France: Amsterdam, IISH; UB Hs. Diederichs 136 J; Leiden, UB BPL 3273

Franco, Elsa: Leiden, UB BPL 3273

Frank(ish): Groningen, UB Hs. 486

Frankish quarter (Izmir): Leiden, UB Acad. 87(3), 97(3)

Friedrich, Johannes: Leiden, UB BPL 3273

Friedrich \& Co. (booksellers, Cairo): Leiden, UB Or. 6292

Fu'ād Meḥmed Paşa, Keçecizāde: Amsterdam, UB Hs. Cq 49

Fuchshofern (officer, MS owner): The Hague, MMW Hs. 10 E 30

Fusțāt: Utrecht, UB Hs. 1 B 8

Fużūlī, see Meḥmed b. Süleymān

Gabriel, see Jabrā’īl

Galata (Istanbul): Leiden, UB BPL 3273; Utrecht, UB Hs. 16 C 1,2

Galen(us): Utrecht, UB Hs. 16 B 17(2)

Gallipoli (Gelibolu): Utrecht, UB Hs. 16 B 17(1), 16 C 1

Gautier, Jean-Joseph (general): Amsterdam, UB Hs. Diederichs $136 \mathrm{~N}$

Gautié (?), M.: Amsterdam, UB Hs. Diederichs 136 Bp

Ġāyetü l-beyān fì tedbīri bedeni l-insān: Utrecht, UB Hs. 16 B 20

Gazālī, see Meḥmed Ġazālī

gazel: Groningen, UB Hs. 465, 490, 491; Leiden, UB Acad. 34, 74(2), 142, 149, 152, 156, 212; Or. 26.265, 26.269(6), 26.272; Utrecht, UB Hs. 1 F 18

Gaziantep, see 'Ayntab

Geer, Laurens de (merchant): Amsterdam, UB Hs. VI H 2

Gelibolu, see Gallipoli

Geneva: Rotterdam, MM H336(3)

geography: Utrecht, UB Hs. 16 B 18

geography (of Egypt): Utrecht, UB Hs. 1 B 8

German Democratic Republic: Leiden, UB BPL 3273

German Hospital (Istanbul): Leiden, UB BPL 3273

Germany: Leiden, UB BPL 3273

al-Ghazālī: Leiden, UB Acad. 42(1)

Ghesquière, Joseph-Hippolyte (MS owner): Leiden, UB Acad. 45, 46 
Ghunyat al-mutamalli: Leiden, UB Acad. 30

Gidionsz, Jan (captain): Amsterdam, UB Hs. VI H 2

glossary, see dictionary

Golius, Jacob (orientalist, MS owner): Amsterdam, UB Hs. VI H 2; Groningen, UB Introduction; The Hague, KB Introduction; Leiden, UB Acad. Introduction, 22, 152, 156, 182, 197; BPL Introduction; Or. 211, 1025; Or. 1228

Ǵolos (Volos): Utrecht, UB Hs. 16 C 1,2

Gospels, the Four: Leiden, UB Acad. 1

Gossmann, Frederike: Amsterdam, UB Cq. 48

Grammaire turque, ou méthode courte \& facile pour apprendre la langue turque etc.: Leiden, Acad. 82, 92

grammar (Arabic): Groningen, UB Hs. 479; Leiden, UB Acad. 58, 63, 64(1,3); Or. 26.619, 26.620; Utrecht, UB Hs. 16 B 24

grammar (Persian): Leiden, UB Acad, 140(2)

grammar (Turkish): Leiden, UB Acad. 59, 6o; Utrecht, UB Introduction

Grammatica linguae Turcicae: Utrecht, UB Introduction

Grammatica Turcica ... difficultates illustrans, ac aliquot colloquiis et sententiis Turcicis aucta: Leiden, UB Acad. 95

Greece: Amsterdam, UB Hs. Cq 45, 53a; Rotterdam, MM H336(3)

Greek (language): Leiden, UB Acad. 95, 182

Greek inscriptions: Leiden, UB Acad. 97(11)

Gröning (consul): Leiden, UB Acad. 97(8)

Grünfeld (family): Leiden, UB BPL 3273

Guignard, François Wmmanuel, comte de St. Priest: The Hague, KB Introduction

Gül, Turan: Amsterdam IIHS

Gulistān: Leiden, UB Acad. 140(1)

Gülrūh (vālide sulțān): Utrecht, UB Hs. 16 C 2

Gülşenì, Shaykh: Groningen, UB Hs. 490

gümrük mukāța'ası: Leiden, UB Acad. 97(1), 205

Gümülcine (Komotini): Leiden, UB Acad. 46(3)

Gümüşhāne: Utrecht, UB Hs. 16 C 1

gunpowder-mill: Utrecht, UB Hs. 16 C 1

gurre-nāme: Groningen, UB Hs. 471, 491(3); Leiden, UB Acad. 46(1), 152

Güterbock, Hans Gustav: Leiden, UB BPL 3273

Haanwinckel, Hendrik (consul): Leiden, UB Acad. 97(6)

Habakkuk, the Book of: Amsterdam, UB Hs. VI H 2, p

Habeş (Ethiopia): Leiden, UB Or. 26.267

Habsburg (dynasty): Amsterdam, UB Hs. Diederichs 9 U

Hadīkat es-su'adā: Rotterdam, WM 60948

hadith: Groningen, UB Hs. 474(1), 484, 490; Leiden, UB Acad. 8(2,3), Acad. 22, Acad. $35(3), 42(1,2), 178(1,3,4), 211(1)$

Hāfiz: The Hague, KB Introduction

Haga, Cornelis (Dutch envoy): Amsterdam, UB Hs. Diederichs 9 U; The Hague, KB

Hs. 135 K 4; Leiden, UB BPL Introduction

Haggai, the Book of: Amsterdam, UB VI H 2, p

Hagia Sophia, see Aya Sofya 
Hahn-Hahn, Countess Ida: Amsterdam, UB Hs. Diederichs 136 G 1-4

Hakam al-Wādī: Leiden, UB Or. 6292(8)

Ḩāḳānī, Şeyh Efendizāde es-Seyyid eş- Şeyh̆: Leiden, UB Or. 26.272

Hakverdi, see 'Abdulhaqq, Sayyid

Hālet Meḥmed Sa'̄ì Efendi (nişāncı): Amsterdam, UB Hs. Cq 50

Hâletî: Utrecht, UB Hs. 1 G 26

Halīfi: Leiden, UB Or. 26.269(6)

Halīl b. 'Abdī (MS owner): Groningen, UB Hs. 465

Halīl Paşa (kapudan): The Hague, KB Hs. 135 K 4(1)

Hālim: Leiden, UB Acad. 156

Hall Asrār al-akhyār: Leiden, UB Or. 26.620

Halle: Leiden, UB Acad. 97(7)

Hālvetīye shayks, pedigree of: Rotterdam, WM 68276

Hamaker, Hendrik Arent: The Hague, KB Introduction

Hamdī (see also Mehmed Ḥamdullāh): Leiden, UB Acad. 142

Hamīd (province): Utrecht, UB Hs. 16 C 1

Ḥāmid b. 'Abdullāh b. Shaykh Dürūz (copyist): Leiden, UB Or. $95^{8}$

Hamīd Halīl (grand vizier): Leiden, UB Or. 26.271(4)

Hamse: Leiden, UB Acad. 156

Harem-i şerīf: Utrecht, UB Hs. 16 B 22

Harīmī: Leiden, UB Or. 26.269(6)

Harsányi, Nagy Jakab: Leiden, UB Acad. 95

Hasan (gümrük emīni): Utrecht, UB Hs. 16 C 1,2

Hasan (son of 'Alī): Utrecht, UB Hs. 16 B 14(5)

Hasan (MS owner): Utrecht, UB Hs. 1 E 17

Hasan, Uzun (Akkoyunlu): Leiden, UB Acad. 183

Hasan Aġa: Leiden, UB Acad. 205

Ḩasan b. Bayrām, Mollā (copyist): Leiden, UB Acad. 74(2,7)

Ḥasan Çelebi b. el-Hāacc Çelebi b. el- Ḥācc 'Abdulkạādir el-Çelebi (copyist): Leiden,

UB Acad. 153

Hasan Efendi (hāce): Utrecht, UB Hs. 16 C 1

Ḥasan İbrāhīm: Leiden, UB Acad. 205

Hasan Paşa (Dey): Leiden, UB Or. 1670-1671

Ḥasan es-Sürūrī (designer/calligrapher): Leiden, MK 36o-9545

Hāşimī Efendi: Amsterdam, UB Hs. Cn 12(2)

Hasselt, J.A.K. van (navy officer): Amsterdam, NS A.4898(16)

Hatun Destānı: Utrecht, UB Hs. 16 B 14(5)

Hayālī: Leiden, UB Acad. 78, 156

Haydarpaşa Station (Istanbul): Leiden, UB BPL 3273

Hayrīye: Leiden, Acad. 154

Hayrullāh b. 'Alī: Leiden, UB Acad. 97(13)

Heaven: Utrecht, UB Hs. 16 B 18

Hebron: Leiden, UB Acad. 179

Hedīyetül-müştāk fì şerh mesleki l- uşşāạ: Utrecht, UB Hs. 16 B 15

Heijder Veijdt \& Co., de: Amsterdam, NS A.4898(14-15)

Hell: Groningen, UB Hs. 491(3); Utrecht, UB Hs. 1 E 17, Hs. 16 B 14(1), 16 B 18

'Hella' (pension, Istanbul): Leiden, UB BPL 3273 
Herbert Freiherr von Rathkeal, Peter Philipp (internuntius): Amsterdam, NS A.4898 (14-15)

Hersch (landlord): Leiden, UB BPL 3273

Heyman, Johannes (MS owner): Leiden, UB Acad. Introduction, 76, 8o, 87, 96; Or. 1228

al-Hidāya: Utrecht, UB Hs. $1 \mathrm{E} 19$

Hikāyet-i kā̄̇̀̄ ma'e s-sārık: Leiden, UB Or. 26.618(3)

Himmetì: Leiden, UB Acad. 156

Hikāyāt min 'Acāyibi l-mahlūḳāt: Leiden, UB Acad. 211(4)

Hikāye-i 'acībe min Kuṭb es-Sürūr münādemetleri: Leiden, UB Or. 6292(8)

Ḥilmī, see Meḥmed Emīn Ḥilmī

Himmler, Heinrich: Leiden, UB BPL 3273

Hippocrates (Bukrāaț): Utrecht, UB Hs. 16 B 17(2)

Hippodrome (At meydānı): Leiden, UB Acad. 156

history (of Egypt): Utrecht, UB Hs. 1 B 8

history (of the Ottoman dynasty): Utrecht, UB Hs. 1 F 12

Hitler, Adolf: Leiden, UB BPL 3273

Ḩıżır Şāh Efendi: Leiden, UB Or. 933

Hıżır-İlyās, seal of: Groningen, UB Hs. 471

Hochepied, Daniel (Alexander), baron de (consul): Leiden, MV 36-9550; UB, Acad. $87(3)$

Hocker, Mr. (physician): Leiden, UB Acad. 97(10)

Hofman, Henri Franciscus: Utrecht, UB Introduction

Hoier, Hans (captain): Amsterdam, NS A.4898(15)

Holdermann S.J., Jean-Baptiste: Leiden, UB Acad. 82, 92

horses: Utrecht, UB Hs. 16 C 1,2

Horst, Herman van der (MS owner): Leiden, UB Acad. 86; BPL Introduction

Hosea, the Book of: Amsterdam, UB Hs. VI H 2, p

Hottinger, Johann Heinrich (MS owner): Groningen, UB Introduction, Hs. 484, 488

Hotz, A.P.H. (MS owner): Leiden, UB Hotz Introduction; Rotterdam, WM Introduction

hü̈cet: Leiden, UB Acad. 87(3); Or. 1670-1671. Or. 26.618; Utrecht, UB Hs. 16 C 2

Hüdā'̄ ('Azīz Maḥmūd): Leiden, UB Or. 26.264

hükm-i hümāyūn: Leiden, UB Acad. 87(3); Utrecht, UB Hs. 16 C 2

hükm-i şerīf: Amsterdam, UB Hs. Diederichs 136 G 1, 136 H 1; Leiden, UB Acad. 87(3);

Rotterdam, MM P2316

Hungary: Amsterdam, UB Hs. Diederichs 9 U

Hungarian campaign: Groningen, UB Hs. 486

Huurşīd and Ferāḥşād, story of: Leiden, UB Or. 26.270

Hurşīd-nāme: Leiden, UB Or. 26.270

Ḥusāmzāde: Leiden, UB Or. 933

Husayn (son of 'Alī): Utrecht, UB Hs. 16 B 14(5)

Ḥusayn Khān, Mīrzā(envoy): Amsterdam, UB Hs. Cq 55

Ḧüseyn: Leiden, UB Acad. 147

Hüseyn (MS owner): Leiden, UB Acad. 27

Ḥüseyn, Ḥāccī (MS owner): Leiden, UB Or. 26.272

Ḥüseyn, Ḥarşdār (? MS owner): Leiden, UB Acad. 183 
Hüseyn Ag̀a (mütevellī): Leiden, UB Acad. 205

Hüseyn b. 'Abdulkerīm el-İskilibī (copyist): Leiden, UB Acad. 77

Hüüseyn b. Aḥmed, Zeynīzāde: Leiden, UB Or. 26.620

Ḥüseyn b. es-Seyyid Mușțafā el-İrmenākī, es-Seyyid (copyist): Utrecht, UB Hs. 16 B 24

Hüseyn Hōca, Brusavīzāde (MS owner): Rotterdam, MM H639

Hüseyn el-Hüseynī b. İbrāhīm Bürān (?) (copyist): Utrecht, UB Hs. 16 B 15

Hüusnī: Leiden, UB Acad. 156

Husrev, Monlā: Amsterdam, UB Hs. Cn 12(2)

Huszár, Valentin von (orientalist): Amsterdam, UB Hs. Cq 54

Huṭbe-i Kürsī: Leiden, UB Or. 20.193

Ibn Ḥājib: Leiden, UB Or. 26.619

İbn Kāàżīi Șimavna: Leiden, UB Or. 919

İbn-i Kemāl, see Kemāl Paşazāde

Ibn Muhammad Șāliḥ: Leiden, UB Acad. 59, 60

Ibn Muljam: Rotterdam, WM 60948

Ibn an-Nafìs, 'Alī b. Abīl-Hazm: Leiden, UB Or. 977

İbn Sellūm, see Șālih b. Nașrullāh

Ibn Sīnā, Abū 'Alī al-Husayn b. 'Abd Allāh (Avicenna): Leiden, UB Acad. 35(1); Or.

977; Utrecht, UB Hs. 16 B 17(2)

Ibn Wāfid, Abū l-Muțarrif 'Abd ar-Raḥmān: Groningen, UB Hs. 465

İbrāhīm (odabaşı, copyist): Utrecht, UB Hs. 16 B 20

İbrāhīm (MS owner): Leiden, UB Acad. 78

İbrāhīm (MS reader): Leiden, UB Acad. 179

İbrāhīm, el-Hạācc: Leiden, UB Acad. 97(13)

İbrāhīm, Ḥāfıż (muftī in Dirac): Leiden, UB Or. 26.615

İbrāhīm, halīfe-i sarāy-i Ġalața (MS owner): Utrecht, UB Hs. 1 F 18

İbrāhīm, Karamanog̉lı: Leiden, UB Acad. 205

İbrāhīm Ag̀a (Janissary officer): Leiden, UB Acad. 210

İbrāhīm Ag̀a (MS owner): Amsterdam, AHM Hs. LA 2047

İbrāhīm b. Meḥmed b. Ḥasan, el-Ḥācc (copyist): Leiden, UB Acad. 63

Ibrāhīm b. Muḥammad al-Halabī: Leiden, UB Acad. 30

İbrāhīm Efendi b. el-Hāccī Yūsuf (MS owner): Utrecht, UB Hs. 16 B 17

İbrāhīm Paşa (ḳapudan): The Hague, MMW Introduction; Leiden, UB Acad. 87(3)

Ibrāhīm Pasha: Amsterdam, UB Hs. Diederichs F 1,2

İbrāhīm Şāhidī: Leiden, UB Acad. 77, 78; Hotz 2289

İbrā̄̄l (Braila): Utrecht, UB Hs. 16 C 1

Idrīs (prophet): Leiden, UB Acad. 211(2)

İhtimān: Utrecht, UB Hs. 16 C 1

Ihyā' ulūm ad-dìn: Leiden, UB Acad. 42(1); Or. 26.264

ilāhī: Groningen, UB Hs. 491(6); Leiden, UB Or. 6292, 26.269(4); Utrecht, UB Hs. 16

$\mathrm{B} 17(2)$

ilām: Utrecht, UB Hs. 16 C 1,2

'ilāmet-i şerīfe: Leiden, UB Acad. 205

illumination: Rotterdam, WM 70935; Utrecht, UB Hs. 16 B 18

İlyās b. Hü̈seyn (copyist): Leiden, UB Acad. 178 
Imāms, the Twelve: Groningen, UB Hs. 484

İmānīye, Kitāa-i: Leiden, UB Or. 26.267

İnebahtı (Navpaktos): Utrecht, UB Hs. 16 C 1

İnşā, Kitāb-i: Leiden, UB Acad. 84, 85, 87(1)

İnşā-i pür-belāgat u fașāhat: Leiden, UB Acad. 87(2)

Institutum Judaicum (Halle): Leiden, UB Acad. Introduction

Ioannina (Janina): Amsterdam, UB Hs. Diederichs $136 \mathrm{~J}$

Ipsilanti, Alexander (voyvoda): Utrecht, UB Hs. 16 C 1

Ipsilanti, Constantin (voyvoda): Utrecht, UB Hs. 16 C 2

'İsā (prophet): Groningen, UB Hs. 491(3); Leiden, UB Acad. 34; Utrecht, UB Hs. 16 B 14(1)

İsakç̧i (Isaccea): Utrecht, UB Hs. 16 C 1

Isaiah, the Book of: Amsterdam, UB Hs VI H 2, 1

İshạ,, Mevlānā: Leiden, UB Acad. $15^{2}$

İsḥak Ag̀a (gümrük emīni): Leiden, UB Acad. 205;

İskāț-i șalātuň beyānı: Leiden, UB Or. 26.264

İskender (zü l-karneyn): Amsterdam, UB Hs, Cn 12(1) Leiden, UB Acad. 45(2)

İskender Paşa: Amsterdam, UB Hs. Diederichs $9 \mathrm{U}$

İskenderun (Alexandretta): Leiden, UB Acad. 97(11-13); Rotterdam, MM H639

Islamic faith/religion, see religious dogma

İsmāēill ( $D \bar{v} v \bar{a} n$ secretary; copyist/ calligrapher): Groningen, UB Hs. 487

İsmā'īl Ag̉a: Utrecht, UB Hs. 16 C 1

İsmā̄il Anḳaravì: Leiden, UB Or. 942

İsmāêil Haḳḳ̄ Erzurumī: Utrecht, UB Hs. 16 B 18

İsmāêil Kapudan: Amsterdam, UB Hs. Diederichs $136 \mathrm{~N}$

İsmā̄îl Tillovī, Shaykh: Utrecht, UB Hs. 16 B 18

Istanbul: Amsterdam, NS A.4898(16); UB Hs. VI H 2, Cq 46, 53, 54; Diederichs 9U, 136 F 1,2, 136 G 1-4, 136 H 1; Dortmond 56; Groningen, UB Hs. 485; Leiden, UB Acad. 97(1,4,11), 156, 197, 205, 210; BPL Introduction; UB, Or. 26.621, 26.621; Rotterdam, MM H336(3), P2316; WM 72963; Utrecht, UB Hs. 1 B 8, 1 F 12, 1 F 17, 1 G 26, 16 C 1 İsmen, Fatma Hikmet: Amsterdam IIHS

Istanbul University: Leiden, UB BPL 3273

İstanköy (Stanchio, Kos): Leiden, UB Acad. 97(11)

Italy: Rotterdam, $\mathrm{MM} \mathrm{H} 336(3)$

'itıknāme: Leiden, UB Acad. 210

Izhār al-asrār: Leiden, UB Or. 26.620

izin tezkiresi: Leiden, UB Acad. 87(3)

Izmir: Amsterdam, NS A.4898(16); UB Hs. Cq. 53a; Diederichs 136 G 1,2; Leiden, MV 36-9550; Leiden, UB Acad. 76, 8o, 86, 87, 96, 97(3-6,11); BPL, Introduction;

Or. $1670-1671$

'İzzüddīn 'Abdullațîf b. Melek, Firişteoġlı: Leiden, UB Acad. 74(2)

İzvornik (Zvornik), medrese of: Utrecht, UB Hs. 16 B 14

Jabrā'īl (Gabriel): Leiden, UB Acad. 140; Rotterdam, WM 68276; Utrecht, UB Hs. 16 B 14(3)

Ja'far aș-Ṣādiq: Leiden, UB Acad. 45(1), 74; Or. $95^{8}$

Jaffa: Leiden, UB Acad. 97(3) 
Jāmī: The Hague, KB Hs. 135 K 4

Jāmī, 'Abd ar-Raḥmān: Utrecht, UB Hs. 1 F 17,1 F 18

Jāmi`al-fatāwā: Leiden, UB Or. 26.618(4)

Janina, see Ioannina

Jannisary (-ries): Leiden, UB Acad. 87(3), 97(10)

Jawāb Risālat li-ahl jazīrat Qubruṣ: Utrecht, UB Hs. 1 G 26

al-Jawharī, Ismāēil b. Hammād: Groningen, UB Hs. 462(2)

Jeremiah, the Book of: Amsterdam, UB Hs. VI H 2, $m$

Jerusalem: Amsterdam, UB Hs. Diederichs 136 G 1-4; Leiden, UB Acad. 97(3,11), 179

Jesuit fathers: Leiden, UB Acad. 97(11)

Jew(ish): Leiden, UB BPL 3273; Or. 1670-1671

Joachimsthal: Leiden, UB BPL 3273

Job, the Book of: Amsterdam, UB Hs. VI H 2, j,k

Joel, the Book of: Amsterdam, UB Hs. VI H 2, p

Jonah, the Book of: Amsterdam, UB VI H 2, p

Jones, Sir William: Utrecht, UB Hs. 16 C 1-2

Joshua, the Book of: Amsterdam, UB Hs. VI H 2, a

Judges, the Book of: Amsterdam, UB Hs. VI H 2, 1

jurisprudence: Leiden, UB Or. 919; Utrecht, UB Hs. 1 E 17, 1 E 19, 16 B 16

al-Jurjānī, 'Abd al-Qāhir b. 'Abd ar-Raḥmān: Leiden, UB Acad. 64(1,3)

Kab al-Aḥbār: Leiden, UB Acad. 211(6)

Ka'ba: Leiden, UB Acad. 34(1); Utrecht, UB Hs. 16 B 18

Kadirī: Groningen, UB Hs. 491

(al-)Käfìya: Leiden, UB Or. 26.619

Kä’ide-i İnşā: Leiden, UB Acad. 86

Kalaç, Mustafa: Leiden, UB BPL 3273

Kalenderī (dervish): Rotterdam, WM 63213

Kandi, Shahin (copyist): Amsterdam, UB Hs. VI H 2; Leiden, UB Acad. 22, 182, 197

Kānūn-nāme-i cedìd: Leiden, UB Or. 26.615(1)

Kara Oglan: Leiden, UB Acad. 34

Karagöz (shadow theatre): Leiden, UB Or. 26.621

Karamanlı Turkish, books: Leiden, UB Or. 26.621

Karatepe: Leiden, UB BPL 3273

Karfetānzāde (? MS owner): Groningen, UB Hs. 489

Karīnābād (Karnobat): Utrecht, UB Hs. 16 C 1

Kashf al-Wāridāt li-țâlib al-kamālāt: Leiden, UB Or. 919

ḳașide: Groningen, UB Hs. 490, 491(1,6); Leiden, UB Acad. 74(2); Or. 26.272; Utrecht, UB Hs. 16 B 15

Kavak: Utrecht, UB Hs. 16 C 2

Kaydāş b. Aḥmed b. Mevlānā Bahş̧āş b. Luṭullāh b. Ḥāccī 'Abdullāh: Leiden, UB Or. 1233

$k \bar{a} \dot{z} \bar{\imath}$ and the learned thief, story of: Leiden, UB Or. 26.618(3)

Kāżìzāde, see Ca'fer b. Mehmed

Kelimāt-i Türkīye: Leiden, UB Acad. 8o(1)

Kemāl Paşazāde: Amsterdam, UB Hs. Cn 12(2); Leiden, UB Acad. 156; Or. $95^{8}$

Kemāl Ümmī (İsmāēl of Karaman): Groningen, UB Hs. 491(6)

Kemphaan (navy brig): Amsterdam, NS A.4898(16) 
Ken`ān 'Abdullāh: Leiden, UB Acad. 205

Kesik-baş: Utrecht, UB Hs. 16 B 14(2)

el-Keşşăf: Leiden, UB Acad. 27

al-Khamrīya, qașidat: Leiden, UB Or. 858(2)

Kiel, Machiel: Leiden, UB Or. 26.621

Kifāyetül-vaḳt li-márifeti d-dā'ire ve fá̀luh ve s-semt: Leiden, UB Acad. 49(2)

Kings, the Book of: Amsterdam, UB Hs. VI H 2, e,f

Kirān el-Habeşī [hikāyeti]: Leiden, UB Acad. 183

Kirdeci 'Alī: Utrecht, UB Hs. 16 B 14(2,4)

Kurkkkilise: Utrecht, UB Hs. 16 C 1

kıt ‘a: Groningen, UB Hs. 490; Leiden, UB Acad. 74(2), 76, 77, 152; Or. 947

Kıvılcıml, Dr Hikmet: Amsterdam, IISH

Kiyāsī: Leiden, UB Acad. 156

Kız Mevlūdu: Utrecht, UB Hs. 16 B 14(6)

Kızılyay, Hatice: Leiden, UB BPL 3273

Kızlcahamam: Leiden, UB BPL 3273

Klis, see Cisr-i kebīr

Komotini, see Gümülcine

Konya: Groningen, UB Hs. 491(1); Leiden, UB Acad. 205; Leiden, UB BPL 3273

Koran: Groningen, UB Hs. 471, 472, 473, 483; The Hague, MMW Introduction, Hs.

10 E 30; Leiden, UB Acad. 22, 34(1), 42(1), 45(1), 74(2); BPL 3273; Or. 1233, 20.193;

Rotterdam, WM Introduction; Utrecht, UB Hs. 16 B 16(1)

Koran recitation: Groningen, UB Hs. 491(5); Leiden, UB Acad. 27; Or. 958, 977

Koran recitation, prescription for: Utrecht, UB Hs. 1 F 17

Korkud, Prince: Groningen, UB Hs. 488(2)

Kos, see İstanköy

Koşay, Dr Hamid Zübeyr: Leiden, UB BPL 3273

Koschaker, Paul: Leiden, UB BPL 3273

Kraaiveld, Mrs. (MS owner): Rotterdam, MM H336(3)

Kramers, Jan hendrik: Amsterdam IISH

Kraus, Fritz Rudolf: Leiden, UB BPL 3273

Kraus, Siegfried: Leiden, UB BPL 3273

Kraus, Werner: Leiden, UB BPL 3273

Kraus \& Co.: Leiden, UB BPL 3273

Kraus-Karge, Ilse: Leiden, UB BPL 3273

Kubād (King): Leiden, UB Acad. 183

Küçük, Celâl: Amsterdam, IISH

Küçük Çekmece, see Çekmece-i șagīir

Kuijpers, Gerardus (MS owner): Groningen, UB Introduction, Hs. 479

Kurds: Leiden, UB BPL 3273

Kuşadası: Utrecht, UB Hs. 16 C 1

Kütahya: Leiden, UB Acad. 205; Utrecht, UB Hs. 16 C 1

Lac, le: Amsterdam, UB Hs. 48a

Laçin: Utrecht, UB Hs. 16 C 2

La lī, see Meḥmed Efendi

La'līzāde, see 'Abdulbāḳī Efendi 
Lamartine, Alphonse de: Amsterdam, UB Hs. Cq 48a

Lamentations, the Book of: Amsterdam, UB Hs, VI H 2, b

Lāmi'ī, see Maḥmūd b. 'Oșmān

Landsberger, Benno: Leiden, UB BPL 3273

Larissa, see Yeñişehir

Larkiani, Mr.: Leiden, UB Acad. 97(11)

Lastik Işs: Amsterdam, IISH

lațīfe, see anecdote

Latin: Amsterdam, UB Hs. Diederichs 136 F 1,2; Leiden, UB Acad. 22, 30, 95, 97(3,7), 182, 205; Utrecht, UB Hs. 1 B 8, 1 F 12, 1 G 24

Latin inscriptions: Leiden, UB Acad. $97(11)$

Lauerman, Sirick (captain): Amsterdam, NS A.4898(14)

law code: Leiden, UB Or. 26.615(1)

Lawrence of Arabia: Leiden, UB BPL 3273

Lecoy, Chevalier de (Prussian envoy): Amsterdam, UB Hs, Diederichs $136 \mathrm{G} 2$

Lefḳoşa (Nicosia): Leiden, UB Acad. 97(3), 205; Utrecht, UB Hs. 16 C 1

Legal documents, collection of: Leiden, UB Or. 26.616

Leipzig: Leiden, UB BPL 3273

Lennep, Jacob van (consul): Amsterdam, NS A.4898(16)

Lesḳofça (Leskovac): Leiden, UB Or. 947

Lette, G.J. (MS owner): Leiden, UB Acad. 156

letter(s): Amsterdam, UB Hs. Cq 42-46, 49, 50, 53-55; Diederichs 9 U, 136 Bp, 136 F 1,2, 136 J, 136 K, 136 M, 136 N, 136 O; Groningen, UB Hs. 465; Leiden, MV 36-9550; UB Acad. 42, 46(3), 75, 84-87, 97(1,2,4-13), 204, 205, 210; BPL Introduction, 3273; Or. 977, 1228, 26.621; Utrecht, UB Hs. 16 B 18, 16 C 1-2 letter of friendship: Leiden, Or. 1670-1671

letter of manumission, see 'itıknāme

letter of safe-conduct, see passport

Leunclavius (Lewenklau), Hans: Utrecht, UB Hs. 1 F 12

levend: Leiden, UB Acad. 87(3)

Levoča (Leutschau): Amsterdam, UB Hs. Diederichs 136 F 1,2

Limni (Limnos): Utrecht, UB Hs. 16 B 15, 16 C 1

linen: Leiden, UB Acad. 97(10,11)

Lipova: Groningen, UB Hs. 489

Lisie, Suria Gitla (first wife of Anhegger): Leiden, UB Or. 26.621

Ljubinje, see Lūbīn

Lodz: Leiden, UB BPL 3273

London: Amsterdam, UB Hs. Cq $53 \mathrm{C}$

Longy, Louis (consul): Leiden, UB Acad. 97(12,13)

Lūbīn (Ljubinje): Amsterdam, UB Hs. Diederichs $136 \mathrm{~N}$

Lubin, Francesco (Franz, merchant): Amsterdam, UB Hs. Diederichs $136 \mathrm{H} 1$

Lucaris, Cyrillus (patriarch): Leiden, UB BPL Introduction

Luġat-i Firişteog lı: Leiden, UB Acad. 74(2)

Luġat-i müşkilāt-i inşā: Leiden, UB Acad. 87(4)

al-Lugha aṣ-Ṣaghīra: Leiden, UB Acad. 74(3)

Lutfí, Molla: Leiden, UB Or. $95^{8}$

Luṭ̂i Riyāżīzāde: Utrecht, UB Hs. 1 F 18 
Luṭfullāh b. Aḥmed b. Mevlānā Bahş̧āş b. Luṭfullāh b. Ḥāccī 'Abdullāh: Leiden, UB Or. 1233

Luṭfullāh b. Vehbī: Leiden, UB Or. 26.271(4)

Mā ḥażar (-i mu'ālacāt-i țayyibe): Utrecht, UB Hs. 16 B 21, 16 B 23

Mā hażare fi ț-țıb: Utrecht, UB Hs. 16 B 21, 16 B 23

ma'cūn: Utrecht, UB Hs. 1 F 18, 16 B 17(2)

magic(al): Groningen, UB Hs. 471, 472, 473, 483, 484, 491(3); Leiden, UB Acad. 38 ; Or. 1233, 6292, 26.267, 26.269(5); Utrecht, UB Hs. 16 B 16, 16 B 21, 16 B 23

Maġnisa (Manisa): Leiden, UB Acad. 97(2), 205

al-Mạ̣būbī, 'Ubayd Allāh b. Mas'ūd: Utrecht, UB Hs. 1 E 19

Mahdī Khān (consul): Amsterdam, UB Hs. Cq 55a

Maḥmūd: Leiden, UB Acad. 74(2)

Maḥmūd II, Sultan: Amsterdam, UB Cq 45; Diederichs $136 \mathrm{H} 1$

Maḥmūd b. 'Abd ar-Raḥmān al-Iṣfahānī: Leiden, UB Or. 933

Mahmūd b. Khalīl b. Farhād: Leiden, UB Or. 26.619

Maḥmūd b. 'Oșmān, Lāmi'î: Leiden, UB Acad. 140(1)

Maḥmūd Beg (b.?) 'Ömer Beg (MS owner): Utrecht, UB Hs. 16 B 14

Maḥmūd Paşa, Çiğalazāde: Amsterdam, UB Hs. Diederichs 136 M

Maḥmūdīye, [Kitäb-i]: Leiden, UB Acad. 74(2)

maḳām (musical mode): Amsterdam, UB Hs. Dortmond 56; Leiden, UB Or. 26.269

(6)

Malachi, the Book of: Amsterdam, UB Hs. VI H 2, p

Malatya: Leiden, UB BPL 3273

Mamlūk sultans: Utrecht, UB Hs. 1 B 8

Manastir (Bitola): Leiden, UB Acad. 46(3); Utrecht, UB Hs. 16 C 2

Mandaic script: Leiden, UB Acad. 222

Manisa, see Maġnisa

Mann, Johann Frederik (chancellor): Leiden, UB Acad. 97(11)

Manuel, son of Kosțațin (merchant): Utrecht, UB Hs. 16 C 1

al-Maqrīzì, Taqī ad-Dīn Abūl-'Abbās Aḥmad b. 'Alī: Utrecht, UB Hs. 1 B 8

Marcquis, Willem (merchant): Leiden, UB Acad. 87(3)

al-Marghinānī: Utrecht, UB Hs. 1 E 19

Ma'rifetnāme: Utrecht, UB Hs. 16 B 18

Ma'rüżät: Leiden, UB Or. 26.615(2)

Masnad: Leiden, UB Acad. 42(1)

Mediterranean Sea: Amsterdam, NS A.4898(14-15)

Mațāli‘ al-anzāer: Leiden, UB Or. 933

mathematics: Leiden, UB Or. 1025

Matthieu, Mr.: Leiden, UB Acad. 97(10)

Mebhas -i ìmān: Leiden, UB Or. 26.264

Mecca: Leiden, UB Acad. 179; Utrecht, UB Hs. 16 B 22

medicine: Leiden, UB Or. 977; UB Hs. 16 B 16(1), 16 B 17(2), 16 B 20, 16 B 21

Medina: Leiden, UB Acad. 179; Utrecht, UB Hs. 16 B 22

Meerman, Johan (MS owner): The Hague, KB Introduction

Mefhūm el-ferāyı ż li-mezheb el-Hanîfi: Utrecht, UB Hs. 16 B 16(3)

Mehmed, Sultan: Amsterdam, UB Hs. Cn 12(2) 
Meḥmed $(k \bar{a} \dot{z} \bar{\imath}):$ Leiden, UB Acad. 205

Meḥmed, Emīr (agent): Utrecht, UB Hs. 16 C 1,2

Meḥmed, Mevlānā $(k \bar{a} \bar{z} \bar{\imath})$ : Leiden, UB Acad. 205

Mehmed, Seyyid: Leiden, UB Or. 1025

Mehmed IV, Sultan: Amsterdam, UB Hs. VI H 2; Utrecht, UB Hs. 16 B 20

Meḥmed 'Abbās: Leiden, UB Acad. 97(13)

Mehmed Ağa: Leiden, UB Acad. 205; Or. 26.266

Meḥmed 'Alī Paşa (ḳapudan): Amsterdam, UB Hs, Cq 44

Meḥmed 'Arif Dürrīzāde (şeyhülislām): Leiden, UB Or. 26.616

Meḥmed b. 'Alī b. Aḥmed, Fedāyī (copyist): Amsterdam, UB Hs. Cn 12

Meḥmed b. Aḥmed (?), Kāsimül-faḳīr (?) (MS owner): Leiden, UB Hs. 1 F 12

Meḥmed b. Ḥasan, Derviş: Leiden, UB Or. 26.617

Mehmed b. Hüseyn (MS owmer): Leiden, UB Or. 26.270

Meḥmed b. İlyās Vehbī (MS owner): Utrecht, UB Hs. 1 F 18

Meḥmed b. Hamza el-Fenārī: Leiden, UB Or. $95^{8}$

Meḥmed b. Pīr 'Alī Birgivī (Birgili Meḥmed Efendi): Leiden, UB Acad. 27, 46(1); Or. $26.264,26.620$

Mehmed b. Ramażān (copyist): Amsterdam, AHM Hs. LA 2047;

Meḥmed b. Süleymān, Fużūlī: Amsterdam, UB Hs. C 12(1); Leiden, UB Or. 26.265; Rotterdam, WM 60948, 70935

Meḥmed b. 'Ubeydüllah, Mūsāzāde: Leiden, UB Or. 26.616

Meḥmed Çelebi (mütevellī): Leiden, UB Acad. 97(2), 205

Meḥmed Efendi $(k \bar{a} \dot{z} \bar{\imath})$ : Utrecht, UB 16 C 1

Mehmed Efendi (MS owner): Leiden, UB Or. 26.272

Meḥmed Efendi, Kör, Pīr: App, II

Meḥmed Efendi, La lī, Shaykh: Utrecht, UB Hs. 16 B 15

Mehmed Efendi, Şeyhzāde: Utrecht, UB Introduction

Meḥmed Efendi ‘'̄sşılḳ Paşalı (shaykh): Rotterdam, WM 68276

Meḥmed Emīn Hilmì (designer/ calligrapher): Leiden MMV 36o-9546

Meḥmed Ġazālī, Deli Birāder: Groningen, UB Hs. 488(2)

Meḥmed Ḥamdullāh, Hamdī: Amsterdam, AHM Hs. LA 2047

Meḥmed Ḳābil Efendi, Ḥāfız (MS owner): Leiden, UB Or. 26.272

Meḥmed Meḥmed Kāàżiāde: Leiden, UB Acad. 97(1), 205

Meḥmed el-Muḥammedī, Molla 'Arab: Leiden, UB Or. 26.269

Meḥmed Nāilīi: Amsterdam, Hs. Dortmond 56

Meḥmed Paşa: Leiden, UB Acad. 87(3), 142

Meḥmed Paşa, Kabūlī (minister, ambassador): Amsterdam, UB Hs. Cq 46; Diederichs $136 \mathrm{~K}$

Meḥmed Paşa, Kara (vizier): Amsterdam, UB Hs. Diederichs 9 U

Meḥmed Paşa, Țayyār: Utrecht, UB Hs. 16 C 1,2

Meḥmed Serāser (?), el-münşī (MS owner): Utrecht, UB Hs. 1 F 18

Meḥmed Reşīd b. İsmāīll (copyist): Leiden, UB Or. 26.615

Meḥmed Rüşdī (copyist): Rotterdam, WM 72963

Meḥmed el-Yemen̄i, Shayh: Leiden, UB Acad. 179

Meḥmed Zikrī Efendi (designer/copyist): Utrecht, UB Hs. 16 B 18

Meier, Jacob (MS owner): Leiden, UB Acad. Introduction, 30

Melāmīye (shaykh): Utrecht, UB Hs. 16 B 15 
Meletius, see Eftimiyos

Mémoire sur les turcs: The Hague, KB Introduction

Menāḳıb-i çār yār: Leiden, UB Or. 26.268

Menāḳıb-i ḩulefā-i rāşidīn: Leiden, UB Or. 26.268

Menāḳıb-i Nașruddīn Hōca: Groningen, UB Hs. 488(1)

Menteşe: Utrecht, UB Hs. 16 C 1

mersīye: Groningen, UB Hs. 490

Mesā’ilü l-müşkilāt: Leiden, UB Or. 26.615(5)

Meşāmī: Leiden, UB Acad. 156

Meslekül-'aşşāk: Utrecht, UB Hs. 16 B 15

messnevī: Amsterdam, AHM Hs. LA 2047; Groningen, UB Hs. 486, 489, 490, 491(2,6);

Leiden, UB Acad. 45(1), 64(3), 74(2), 77, 154, 156, 212; Or. 896, 954, 26.268, 26.270,

26.271(4); Utrecht, UB 1 F 18, 16 B 14, 16 B 25

Mesopotamia: Leiden, UB BPL 3273

Mes'ūd b. Meḥmed b. Bayrām: Leiden, UB Or. 1233

metaphysics: Leiden, UB Or. 933

metereology (-gical): Leiden, UB Acad. 46(1)

Metkovik (Metković): Amsterdam, UB Hs. Diederichs $136 \mathrm{~N}$

Metz, Captain: Rotterdam, MM P2316

Mevkūfāt ḳalemi: Utrecht, UB Hs. 16 C 1-2

Mevlid (Mevlüd): Groningen, UB Hs. 491(2); Utrecht, UB Hs. 16 B 14(2,3,5)

meyhāane: Leiden, UB Acad. 87(3)

Micah, the Book of: Amsterdam, UB Hs. VI H 2, p

Michaelis, Johannes, see Yuḥanā b. Mikā'īl b. 'Ațāyā

Michaelis, Moses, see Mūsā b. Mikā'īl b. 'Ațāyā

Michelsohn, Kurt: Leiden, UB BPL 3273

Michelsohn, Max: Leiden, UB BPL 3273

Michelsohn \& Ascher: Leiden, UB BPL 3273

Midilli (Mytilene): Leiden, UB Acad. 87(3)

Miftāh al-'ulūm: Leiden, UB Or. 211

migrant workers, Turkish (in Germany, the Netherlands): Leiden, UB Or. 26.621

Miha Bū Baḳrī (envoy): Leiden, UB Or. 1670-1671

Millies, H.C.: Leiden, UB Acad. 222

Miloch, Prince: Amsterdam, UB Hs, Cq 43

miniatures: Amsterdam, AHM Hs. LA 2047; Leiden, MV Introduction; UB Hotz 2289;

Rotterdam, WM Introduction, 60948, 63213-214

Minḳārīzāde, see Yaḥyā Minḳāīzāde

mining industry, Ottoman: Leiden, UB Or. 26.621

Mint, Ottoman (at Bursa): Leiden, UB Or. 26.621

mírāc: Groningen, UB Hs. 491(2)

mi'rācīye: Groningen, UB Hs. 490

miracles of the Prophet: Groningen, UB Hs. 491(2); Leiden, UB Acad. 27

Misailidis, Evangelinos: Leiden, UB Or. 26.621

miscellany: Amsterdam, UB Hs. Cn 12; Cq 48; Groningen, UB Hs. 471, 472, 473, 474, 483, 484, 488, 491; Leiden, UB Acad. 8, 34, 35, 38, 42, 45, 46, 64, 75, 87, 97, 140, 178, 211; Or. 6292, 20.193, 26.269, 26.271, 26.615, 26.618; Utrecht, UB Hs. 16 B 14, 16

B 16, 16 B 17, 16 C 1-2 
Mische, Henricus (Heinrich, MS owner): Groningen, UB Hs. 489

Mohila, Constantinus: Amsterdam, UB Hs. Diederichs 9 U

Moldavia: Amsterdam, UB Hs. Diederichs 9 U

Molla 'Arab, see Meḥmed el- Muhammedī

Moltke, Helmuth von: Leiden, UB BPL 3273

Mor(e)a (Peleponnese): Utrecht, UB Hs. 16 C 1,2

Mostar: Amsterdam, UB Hs. Diederichs 136 N; Leiden, UB Or. 26.621

mosques, Ottoman (photographs of): Leiden, UB Or. 26.621

Motamed, Saeed (art dealer): Rotterdam, WM 63213-214

Moyesen, Rabi: Leiden, UB Or 26.621

mu'aşşer: Groningen, UB Hs. 490

Müfì dül-müstefidīn: Leiden, UB Acad. 76

müfred: Amsterdam, Hs. Cn 12(2); Leiden, UB Acad. 75, 152; Or. 958

muhallefät (halîfeligi ḳalemi): Utrecht, UB Hs. 16 C 1

Muhammad (the Prophet): Groningen, UB Hs. 471, 490, 491(2); Leiden, Acad. 8(2),

27, 34, 38, 140, 178; Or. 933; Rotterdam, WM 68276; Utrecht, UB Hs. 16 B 14(3,5,6)

Muhammad, banner of: Utrecht, Hs. 16 B 18

Muhammad, seal of: Groningen, UB Hs. 471

Muḥammad 'Alī Pasha: Amsterdam, UB Hs. Cq 45, Diederichs 136 Bp, 136 F 1,2

Muhạmmad b. Abī Ṭālib al-Anșārī aṣ-Ṣūfì ad-Dimishqī: Utrecht, UB Hs. 1 G 26

Muḥammad b. As'ad ad-Dawwānī: Leiden, UB Or. 878

Muḥammad b. Mas'ūd b. Aḥmad (copyist): Leiden, UB Or. 211

Muḥammad b. Hājjī Ilyās: Leiden, UB Acad. 74(6), 79(1)

Muḥammad b. 'Umar al-'Urụī al-Ḥalabī (also MS owner): Leiden, UB Or. 1025

Muḥammad Samarqandī, Hajjī (copyist): Leiden, UB Acad. $15^{1}$

hammes: Groningen, UB Hs. 490

Muhibbī: Leiden, UB Acad. 156

al-Müjiz al-Qānūn fì t-țibb: Leiden, UB Or. 977

Mukanțarāt, Risāle-i: Leiden, UB Acad. 49(1)

Mukhtār li-l-fatwā: Utrecht, UB Hs. 1 G 24

Muntehab [fí 'ilmi l-lugat]: Leiden, UB Acad. 74(1), 75(1)

Munich: Leiden, UB BPL 3273

mürabba': Groningen, UB Hs. 490

Murād, Sultan (miniature of): Leiden, MV Introduction

Murād I, Sultan: Leiden, UB Acad. 46(3)

Murād III, Sultan: Leiden, UB Acad. 182; Or. 878; Utrecht, UB Hs. 16 B 16(1)

Murād IV, Sultan: Leiden, UB Acad. 197

Muş: Leiden, UB Acad. 74(1)

Mūsā (prophet): Leiden, UB Acad. 211(4)

Mūsā er-Riżā, Imām: Groningen, UB Hs. 490

Mūsāzāde, see Meḥmed b. 'Ubeydüllāh

music (Ottoman, Turkish folk): Leiden, UB Or. 26.621

müseddes: Groningen, UB Hs. 490

Müşkilāt-i inşā: Leiden, UB Acad. 74(4)

Muṣlihüddīn Mușțafāb. Şa bān, Sürūrī: Leiden, UB Acad. 152

Muștafā (copyist): Leiden, UB Or. 896

Mușțafā ... (MS owner): Utrecht, UB Hs. 1 E 17 
Mușțafā (ser-i bevvābīn): Utrecht, UB Hs. 16 C 1

Mușțafā (ser-țopçı): Leiden, UB Acad. 205

Mușțafā, Prince: Leiden, UB Acad. 152

Mușțafā, Shaykh (MS owner): Leiden, UB Or. 854

Mușțafā b. Aḥmed (MS owner): Leiden, UB Acad. 147

Mușțafā b. 'Alī (MS owner): Leiden, UB Acad. 75

Mușțafā b. 'Alī Selīmī (muvaḳkıt): Leiden, UB Acad. 49 (1,2)

Mușțafā b. Ḥasan el-Ḥāmidi, Ḥāfız (copyist): Utrecht, UB Hs. 16 B 18

Muștafā b. Mehmed: Leiden, UB Or. 1233

Mușțafā b. Mollā Riḍwānal-Baghdādī (copyist): Leiden, UB Acad. 149

Mușțafā b. Yūsuf (ḳàżĭ, MS owner): Leiden, UB Or. 947

Mușțafā Babazāde Diyārbekrī, Seyyid (MS owner): Leiden, UB Acad. 74

Mușțafā Beg (servant): Leiden, UB Acad. 97(13)

Mușțafā Efendi, Shaykh: Leiden, UB Acad. 205

Muștafā el-Ḥilmī (mütevellī): Utrecht, UB Hs. 16 C 2

Mușțafā Kātibzāde (copyist): Leiden, UB Acad. 78

Mușțafā Morī, Seyyid: Utrecht, UB Hs. 16 C 1

Mușțafā Paşa (kapudan): Leiden, UB Acad. 87(3)

Mușțafā Reşīd Paşa (ambassador): Amsterdam, UB Hs. Cq 54; Diederichs 136 O

müstezād: Leiden, UB Or. 954

Musurus Paşa, Kostaki: Amsterdam, UB Hs. 53

Müteferriḳa, İbrāhīm: Leiden, UB Acad. 82, 92

Muțī b. Iyās: Leiden, UB Or. 6292(8)

Müzehher Vâ-Nû: Amsterdam, IISH

mysticism: Leiden, UB Acad. 212; Or. 954; Utrecht, UB Hs. 16 B 16(1), 16 B 18

Mytilene, see Midilli

Nābī, see Yūsuf Nābī

Nahum, the Book of: Amsterdam, UB Hs. VI H 2, p

Nā'ilī, see Meḥmed Nāiilī

$\mathrm{Na}$ 'ìmì, see Aḥmed $\mathrm{Na}$ 'ìmī

Nani, Almoro (ambassador): Rotterdam, WM 63215

Naples: Amsterdam, UB Hs. Diederichs 136 I; Rotterdam, MM H336(3)

Napoleon I, Emperor: Amsterdam, UB Hs. Diederichs 136 J

Nașị̂atnāme: Leiden, UB Acad. 8(2)

Naşruddīn Hōōca: Groningen, UB Hs. 488(1); Leiden, UB Acad. 205

Nașūḥ Paşa (grand vizier): Amsterdam, UB Hs. Diederichs 9 U

Navplio (see also Anabolı): Amsterdam, UB Cq 53e

Navy, Ottoman: Rotterdam, MM H639

navy flags/signals, Ottoman: Rotterdam, MM H639

Nawābigh al-kalim: Leiden, UB Or. 858

Nazi (Party): Leiden, UB BPL 3273

Nâzım Hikmet (Ran): Amsterdam, IISH

nazīre: Leiden, UB Acad. 77, 156

Necātī: Leiden, UB Or. $95^{8}$

Negroni, Andrea (Austrian envoy): The Hague, KB Hs. 135 K 4(2)

Nehemia, the Book of: Amsterdam, UB Hs. VI H 2, i 
Nensén, Petrus (pastor): Leiden, UB Acad. 97(6)

Nesīmī: Groningen, UB Hs. 490; Leiden, UB Acad. 78

Netāyicül-fünūn (ve mahāāinül-mütūn), (Risāle-i): Utrecht, UB Hs. 16 B 16(1)

Nev'ī (see also Yahyāb. Pīr 'Alī): Amsterdam, UB Hs. Cn 12(1,2)

Nicosia, see Lefkoşa

Nigde: Utrecht, UB Hs. 16 C 1

Nihānī: Leiden, UB Or. 26.269(6)

Niksārīzāde Efendi: Leiden, UB Hs. C 12(2)

Nile: Amsterdam, UB Hs. Diederichs 136 G 1-4

Nippur: Leiden, UB BPL 3273

Niş (Niš): Leiden, UB Acad. 87(3)

Nıșāb-i șıbyān-i 'Arabì ma'e Fārsī ma'e Türkì: Leiden, UB Acad. 74(7)

Notgemeinschaft Deutscher Wissenschaftler im Ausland Leiden, UB BPL 3273

Novi Pazar, see Yen̄ibāzār

Nuremberg: Leiden, UB Acad. 97(11)

Obadiah, the Book of: Amsterdam, UB Hs. VI H 2, p

Offerhaus, Leonard (MS owner): Groningen, Introduction UB Hs. 489

Ogan, Ahmed Aziz: Leiden, UB BPL 3273

Olcay, Osman: Amsterdam IISH

Öktem, Özcan: Leiden, UB Or. 26.621

'Ömer (copyist): Leiden, UB Or. 26.270

'Ömer (poet): Leiden, UB Acad. 78

'Ömer Ag̉a: Amsterdam, UB Hs. Diederichs 136 N

'Ömer b. Hüseyn Efendi (copyist): Leiden, UB Or. 26.618

'Ömer Luṭfí (nāzirir-i ịttisāb): Amsterdam, NS A.4898(16)

opium: Utrecht, UB Hs. 16 B 23

ordu-yı hümāyūn: Utrecht, UB Hs. 16 C 1

'Ossmān, el-Hāàc: Utrecht, UB Hs. 16 C 2

'Oșmān II, Sultan: Rotterdam, WM 63215

'Oșmān Ag̉a: Leiden, UB Acad. 97(13)

Ottenfeld, Baron von (Austrian envoy): Amsterdam, UB Hs. Diederichs $136 \mathrm{H} 1$

Otto, King: Amsterdam, UB Hs. Cq 45

Ottoman dynasty: Leiden, UB Acad. 182

ox carts: Utrecht, UB Hs. 16 C 1,2

Özkartal, Engin: Leiden, UB Or. 26.621

Pagel \& Kraus: Leiden, UB BPL 3273

painting, see illumination, miniature

Palestine: Leiden, UB BPL 3273

Pamukçu, Sina: Amsterdam, IISH

Pand-nāma: Leiden, UB Acad. 147; Or. 26.271(1); Utrecht, UB Hs. 16 B 25

Papal States: Rotterdam, MM H336(3)

Papen, Franz von (ambassador): Leiden, UB BPL 3273

Paradise: Leiden, UB Acad. 178(1)

Parga: Amsterdam, UB Hs. Diederichs $136 \mathrm{~J}$

Paris: Amsterdam, UB Hs. Diederichs 136 O 
Parmaksız Ahmed: Utrecht, UB Hs. 16 B 20

passport: Amsterdam, NS A.4898(14-16); UB Hs. Diederichs 136 G 2, 136 H 1, 136

I; The Hague, KB Hs. 135 K 4(1); Leiden, MV Introduction; UB Or. 1670-1671;

Rotterdam, MM H336(3), P2316

pedigree: Leiden, UB Acad. 182

peksimet: Utrecht, UB Hs. 16 C 1,2

Peleponnese, see Mor(e)a

Pentateuch: Leiden, UB Acad. 34

Persia(n): Amsterdam, UB Hs. Cq 55; Diederichs 9 U

Persian dynasties: Leiden, UB Acad. 182

Perzische Handelsvereeniging J.C.P. Hotz \& Zoon: Leiden, Hotz Introduction

petition: Amsterdam, UB Hs, Diederichs F 1,2; Groningen, UB Hs. 479, 487; Leiden,

UB Acad. 85, 210; BPL 3273; Or. 977; Utrecht, UB Hs. 16 C 1,2

philosophy: Leiden, UB Or. 958; Utrecht, UB Hs. 16 B 16(1)

photograph(s): Amsterdam, UB Hs. Cq 48; Leiden, UB Or. 26.621

physiognomy: Utrecht, UB Hs. 16 B 18

pilgrims, manual for: Utrecht, UB Hs. 16 B 22

pilgrimage ceremonies: Leiden, UB Acad. 179; Utrecht, UB Hs. 16 B 22

Pirizāde Meḥmed Șāḥib Efendi (şeyhülislām): Leiden, UB Or. 26.616

Piyāle Beg: Groningen, UB Hs. 488(2)

plague: Leiden, UB Acad. 97(11)

Plovdiv, see Filibe

poem(s): Amsterdam, AHM Hs. LA 2047; Groningen, UB Hs. 462(2), 465, 474(2,3),

486, 487, 488(2), 489, 490, 491(1,2,6); The Hague, KB Hs. 135 K 4(2); Leiden, UB

Acad. 22, 34-35, 45(1), 46(1), 64(3), 74(2), 75, 76-78, 84, 87(1,2), 142, 149, 151, 152, 153,

154, 156, 212; Hotz 2289; Or. 919, 954, 958, 26.269(4,6), 26.271(2,4), 26.272, 26.620.

26.621; Rotterdam, WM 70935, 72963; Utrecht, UB Hs. 1 B 8, 1 E 17, 1 E 19, 1 F 18, 1

G 24, 1 G 26, 16 B 14, 16 B 15, 16 B 18, 16 B 25

poems, French: Amsterdam, UB Hs. Cq 48

Poland: Amsterdam, UB Hs. Diederichs 9 U

poliçe: Leiden, UB Acad. 210

Polonezköy: Leiden, UB BPL 3273

Pomo, W. (consul): Rotterdam, MM H336(3)

porcelain (in Topkapı Palace): Leiden, UB Or. 26.621

Porte, Sublime: Amsterdam, UB Cq 42, 49, 55; Diederichs 9 U; Leiden, MV 36-9550;

UB Acad. 87(1,3), 250; Utrecht, UB Hs. 16 C 1,2

Prague: Leiden, UB BPL 3273

prayer(s): Groningen, UB Hs. 471, 472, 473, 484, 491, 492; Leiden, UB Acad. 8, 27,

$34(2), 35(2), 38,45(1,2), 46(1), 64(2), 178(2), 179$; Or. 933, 20.193, 26.266, 26.269(3);

Utrecht, UB Hs. 16 B $17(1)$

prayer prescription: Groningen, UB Hs. 471, 472, 473, 483, 484, 491(5), 492; Leiden,

UB Acad. 38, 45(1), 75; Or. 933, 26.269; Utrecht, UB Hs. 1 F 18, 16 B 17 (2)

praying: Leiden, UB Hs. Acad. 30, 34(1), 178(2,4); Rotterdam, WM 72963

prescription, see recipe

prognostic, see divination

Prokesch von Osten, Anton Graf (ambassador): Amsterdam, UB Introduction, Hs.

Cq 42-46, 49, 53, 55 
Prokesch von Osten, née Kiesewetter von Wiesenbrunn, Irene: Amsterdam, UB Cq 53

Prophet, the, see Muhammad

prophets, tombs of the: Utrecht, UB Hs. 16 B 18

prosody, compendium of: Leiden, UB Acad. 152

proverbs: Leiden, UB Or. 858(1)

Proverbs, the Book of: Amsterdam, UB Hs. VI H 2, c

Prussia(n): Amsterdam, UB Hs. Diederichs 136 G 2

Psalms: Amsterdam, UB Hs. VI H 2, 1; Groningen, UB Hs. 479

psychology: Utrecht, UB Hs. 16 B 18

Qāọī Khān: Leiden, UB Or. 958

al-Qānūn fì țțibb: Leiden, UB Or. 977

quarantine: Amsterdam, UB Hs. Cq 55a; Leiden, UB Acad. 97(11)

quatrain: Groningen, UB Hs, 474(2,3), 491(6); Leiden, UB Acad. 46(1), 142, 149; Or. 919, 26.269(6); Utrecht, UB Hs. 16 B 18

Qazwīnī: Utrecht, UB Hs. 16 B 17(1)

Radio Istanbul: Leiden, UB BPL 3273

Ragusa (Dubrovnik): Amsterdam, UB Hs. Diederichs $136 \mathrm{~N}$

Rāhat el-ḳuūb: Leiden, Acad. 8(1)

Ranspek (?), Sebastiano (MS owner): Groningen, UB Hs. 473

Rappard, Frans Alexander (MS owner): The Hague, KB Hs. 135 K 4

Rāshid (Rosetta): Leiden, UB Acad. 97(10)

Rath, Ernst-Eduard vom: Leiden, UB BPL 3273

Rau, Christian, see Ravius

Rau, Johann Eberhard: Utrecht, UB Introduction

Rau, Sebald: Utrecht, UB Introduction

Rāvī İbrāhīm Efendi: Utrecht, UB Hs. 16 B 17(2)

Ravius 'Berlinatus', Christianus (Christian Rau, MS owner): Amsterdam, UB Introduction; Utrecht, UB Introduction, Hs. 1 B 8, 1 F 12, 1 F 17, 1 G 26

Receb Müste'idd (copyist): Leiden, UB Or. 858(2)

recipe: The Hague, MMW Hs. 10 E 30; Leiden, UB Acad. 30, 34, 75, 209; Or. 854, 878, 933, 958, 977; Utrecht, UB Hs. 1 F 18, 16 B 17(2), 16 B 20, 16 B 21, 16 B 23

Reland, Adrianus (MS owner): Leiden, UB Acad. Introduction, 152, 182, 197, 211

religious dogma: Groningen, UB Hs. 485, 491(4), 493; Leiden, UB Acad. 8, 27, 178(2),

211, 212; Or. 26.264; Rotterdam, WM 72963; Utrecht, UB Hs. 16 B 16(1)

Resimli Ay (periodical): Amsterdam, IISH

Revnāk-i bostān: Utrecht, UB Hs. 16 B 24

rhetoric: Leiden, UB Or. 211

Rhodes: Amsterdam, UB Hs. Diederichs 136 G 1-4; Leiden, UB Acad. 97(11)

ricāl-i gayb, dā'ire-i: Leiden, UB Acad. 42(2)

rice: Leiden, UB Acad. 97(13); Utrecht, UB Hs. 16 C 1

Risāla fì ithbāt al-wājib: Leiden, UB Or. 878

Risāle-i Fāl-i Cáfer Șādık: Leiden, UB Acad. 45(1)

Risāle min 'ilm el-ferāyıż: Utrecht, UB Hs. 16 B 16(2)

Ritter, Hellmut: Leiden, UB BPL 3273 
Rivet, André: Leiden, UB BPL Introduction

Rescher, Oskar: Leiden, UB BPL 3273

Redinger, Johann Jakob: Leiden, UB Or. 26.621

Rolland, Romain: Leiden, UB Or. 26.621

Rome: Leiden, UB BPL 3273; Rotterdam, MM H336(3)

Rosenberg, Hans: Leiden, UB BPL 3273

Rossi, Dr. Charles (inspecteur sanitaire): Amsterdam, UB Hs. Cq 55a

Rossmann, Johan (MS owner): The Hague, MMW 10 E 30

Ruhi Su: Leiden, UB Or. 26.621

Rumeli(a): Leiden, UB Acad. 46(3)

Ruscuk (Ruse): Utrecht, UB Hs. 16 C 1

Rüşdī, see Meḥmed Rüşdī

Russia(ns): Leiden, UB BPL 3273

Russian (language): Rotterdam, MM H639

Russian fleet: Utrecht, UB Hs. 16 C 1

Ruth, the Book of: Amsterdam, UB Hs. VI H 2, b

rūznāme, see almanac

Rūznāme-i istihrāc-i şemsīye: Leiden, UB Acad. 46(2)

Rüznāme-i nev: Leiden, UB Acad. 46(2)

Rydel(ius Agha) (Swedish consul): Leiden, UB Acad. 97(4)

Sab'ìyāt: Leiden, UB Acad. 211(5)

Sa'dī: Leiden, UB Acad. 140(1), 142; Or. 896

Sa'duddīn el-Hamavī, shaykh: Leiden, UB Or. 6292

Șādiq, Mollā (merchant): Amsterdam, UB Hs. Cq 55a

Sa'duddīn (şeyhülislām): Leiden, UB Or. $95^{8}$

Şāh u gedā: Leiden, UB Acad. 156

aș-Ṣaḥāh: Groningen, UB Hs. 462(2)

Şāhidī (see also İbrāhīm Şāhidī): Leiden, UB Or. 26.269(6)

Sa'ìd Muḥammad Beg: Amsterdam, UB Hs. Diederichs 136 Bp

Șālih Ag̀a, Bursalı (MS owner): Amsterdam, AHM Hs. LA 2047

Șāliḥ b. Nașrullāh of Aleppo, İbn Sellūm: Utrecht, UB Hs. 16 B 20

Șāliḥ Efendi of Üsküdar (shaykh): Rotterdam, WM 68276

Șālih Refik, es-Seyyid (MS owner): Leiden, UB Or. 26.265

Salonica (Thessaloniki): Leiden, UB Acad. 46(3); Utrecht, UB Hs. 16 C 1,2

salpetre: Utrecht, UB Hs. 16 C 1

Samos: Amsterdam, UB Hs. Cq 53 a

Samuel, the Book of: Amsterdam, UB Hs. VI H 2, c,d

Saqqā: Leiden, UB Acad. 151

Sayda (Sidon): Amsterdam, UB Hs. Diederichs 9 U; Leiden, UB Acad. 97(3)

Sayf ad-Dīn Barsbay, Sultan: Utrecht, UB Hs. 1 B 8

Schachten, Baron de: Amsterdam, UB Hs. Diederichs 1360

Scheidius, Everard (MS owner): Groningen, UB Introduction, Hs. 462(2); Leiden, UB

Acad. Introduction; UB Or. 1670-1671

Scherling, E. von (MS owner): Leiden, MK Introduction

Schlottwitz: Leiden, UB BPL 3273

Schmitz, Johann (MS owner): Groningen, UB Hs. 489 
Schreiber, Mr.: Leiden, UB BPL 3273

Schroeder (Steinmetz), Nicolaus Wilhelm (MS owner): Groningen, UB Introduction, Hs. 471-474, 483, 484, 488, 490, 491

Schultens, Hendrik Albert: The Hague, KB Introduction

Schultens, Jan Jacob (MS owner): The Hague, KB Introduction; Leiden, UB Acad. Introduction, 58, 6o, 64, 74, 76, 80, 86, 87, 96, 140, 142, 151, 178, 183; BPL Introduction; Or. 1233

Schultz, Stephan (author/copyist/MS owner): Leiden, UB Acad. Introduction, 77, $82,92,95,97,209,210$

Schwartz, Philipp: Leiden, UB BPL 3273

sciences: Utrecht, UB Hs. 16 B 16(1)

Seaman, William: Utrecht, UB Introduction

Şehr-engìz der Yeñiçe: Groningen, UB Hs. 490

selāmet(lik) resmi: Leiden, UB Acad. 87(3); Rotterdam, MM P2316

Selīm, Kavaḳlı: Utrecht, UB Hs. 16 C 2

Selīm, Sultan: Amsterdam, UB Hs. Cn 12(2)

Selīm I, Sultan: Leiden, UB Or. 854

Selīm Aga (mütesellim): Utrecht, UB Hs. 16 C 2

Selim Bey: Leiden, UB BPL 3273

Selīmī, see Mușțafāb. 'Alī

Selīmīye Mosque (Istanbul): Groningen, UB Hs. 487; Leiden, UB Acad. 49(1)

Sellem (ser-kätib): Leiden, UB Acad. 97 $(5,6)$

Şema'hāne (Istanbul): Leiden, UB Acad. 205

Şemī: Leiden, UB Acad. 147

Şemsüddīn Sīvāsī, Shaykh: Leiden, UB Or. 26.268

Şerh-i dībāce-i Gülistān: Leiden, UB Acad. 140(1)

Şerh-i esmā'i l-hüsnā: Leiden, UB Acad. 38

Şerh-i fäl-i Kur'āan: Groningen, UB Hs. 471

Şerh-i tekrär-nāme: Groningen, UB Hs. 471

Şerh-i sefer-nāme: Groningen, UB Hs. 471

Serre, see Sīrōz

Sertel, Sabiha: Amsterdam, IISH

Sertel, Zekeriya: Amsterdam, IISH

Seyir-nāme: Groningen, UB Hs. 484

Seydiköy: Leiden, UB Acad. 97(11)

Şeyhoğlı Mușțafā: Leiden, UB Or. 26.270

Seyyid: Groningen, UB Hs. 490

sex, treatise on the practice of: Groningen, UB Hs. 488(2)

Shāfi'ì, Imām: Leiden, UB Or. 26.270

Shāhin b. Qandī, see Kandi, Shahin

Shawāhid an-nubuwwa li-taqwiya yaqin ahl al-futuwwa: Utrecht, UB Hs. 1 F 17 ash-

Shudhūr adh-dhahabì ya wa l-qita' al-Ahmmadì ya fì l-lughat at-Turkī ya: Leiden,

UB Acad. 59, 60

Skopje, see Üsküb

Sicily (-lian): Amsterdam, UB Hs. Diederichs 136 I; Utrecht, UB Hs. 16 C 2

Sidon, see Sayda

signal book, Ottoman: Rotterdam, MM H639 
Sijms, Cornelis: Amsterdam, UB Hs. Diederichs 9 U

Siklós, Battle of: The Hague, MMW Hs. 10 E 30

Silier, Orhan: Amsterdam, IISH

Silistre: Utrecht, UB Hs. 16 C 1

Silsilat adh-dhahab: Utrecht, UB Hs. 1 F 18

Silsile-nāme: Rotterdam, WM 68276

Simeon: Utrecht, UB Hs 16 C 2

Sinān Paşa, Frenk: Groningen, UB Hs. 486

Sinān Paşa, Koca (grand vizier): Leiden, UB Or. 878

Sinān Yūsuf Paşa, Çığalazāde: Amsterdam, UB Hs. Diederichs 136 M

Sinop: Amsterdam, UB Hs. Diederichs $9 \mathrm{U}$

Sīōz (Serre): Utrecht, UB Hs. 16 C 1,2

Sivas: Leiden, UB BPL 3273

Siyāhī: Leiden, UB Acad. 156

slave: Leiden, UB Acad. 87(3), 183, 210

Sofia: Leiden, UB Acad. 205; Utrecht, UB Hs. 16 C 1

Șohūm (Sokhumi): Utrecht, UB Hs. 16 C 2

Song of Songs, the: Amsterdam, UB Hs. VI H 2, b

songs: Leiden, UB Acad. 156; Or. 26.269 $(4,6)$

Spindelmühle (Bohemia): Leiden, UB BPL 3273

Spremberg: Leiden, UB BPL 3273

Spruyt, W.J. (MS owner): Leiden, MV Introduction

St. George, see Circīs

St. Priest, see Guignard

Stad Lier, de (ship): Amsterdam, NS A.4898(14)

Stamm, Johann Jakob: Leiden, UB BPL 3273

stirrup: Leiden, UB Acad. 210

Stockholm: Leiden, UB Acad. 97(6)

story: Leiden, UB Acad. 183; Or. 26.266

Strasbourg: Leiden, UB BPL 3273

Stürmer, Bartholomäus Graf von (internuntius): Amsterdam, UB Hs. Cq 54

Subhatu l-ahbār: Leiden, UB Acad. 182

Suhl: Leiden, UB BPL 3273

Sulaymān (prophet): Leiden, UB Acad. 211(6)

Süleymān: Groningen, UB Hs. 479

Süleymān (copyist): Utrecht, UB Hs. 16 B 25

Süleymān (prophet), seal of: Groningen, UB Hs. 471

Süleymān (poet): Leiden, UB Or. 26.269(6)

Süleymān (voyvoda): Leiden, UB Acad. 210

Süleymān (the Magnificent), Sultan: Leiden, UB Acad. 156, 182; Or. 26.615(1)

Süleymān, el-Hācc (muteșarrıf): Leiden, UB Acad. 205

Süleymān Ag̀a: Leiden, UB Acad. 210

Süleymān Ag̉a, Hazīnedāroġlı: Utrecht, UB Hs. 16 C 2

Süleymān el-'Ārif (MS reader): Leiden, UB Acad. 179

Süleymān Bölükbaşı, Tunḳalog̉lı Hācci: Utrecht, UB Hs. 16 C 2

Süleymān Çelebi: Groningen, UB Hs. 491(2); Utrecht, UB Hs. 16 B 14(2,3,5)

Süleymān Paşa, see also Arslan Süleymān Paşa 
Süleymān Paşa (ambassador): Amsterdam, UB Hs. Diederichs 136 O

Süleymānīye Mosque: Leiden, UB Or. 977; Utrecht, UB Hs. 16 C 1

Sülker, Zekeriya: Amsterdam, IISH

Șulu Ot: Utrecht, UB Hs. 16 C 2

Sünbül 'Alī: Amsterdam, UB Hs. Cn 12(2)

Sünbülzāde Meḥmed, Vehbī: Leiden, UB Or. 26.271(4)

Șun'ullāh Efendi: Amsterdam, UB Hs. Cn 12(2)

Sürūrī, see Ḥasan es-Sürūrī; Muṣlihüddīn Mușțafāb. Şacbān

Sürūrī, Meddāḥ: Leiden, UB Or. 26.621

Sürūrī, Monlā: Leiden, UB Or. 1025

story (-ries): Groningen, UB Hs. 488(1); Leiden, UB Acad. 22; Or. 26.618(3)

Șun'ī: Leiden, UB Acad. 156

Swijghuisen Groenewoud, Jacobus Cornelis (MS owner): Utrecht, UB Introduction,

Hs. 1 F 18 , 1 G 24

Tācirī: Leiden, UB Acad. 156

at-Tadhkira: Groningen, UB Hs. 465

tafsir, see tefsìr

at-Taftāzānī, Mas'ūd b. 'Umar: Leiden, UB Or. 858(1)

Ṭāhir b. Aḥmed b. Mevlānā Bahşāas b. Luṭfullāh b. Ḥāccī 'Abdullāh: Leiden, UB Or.

1233

tailed signature: Leiden, UB Acad. 78

takrìr: Utrecht, UB Hs. 16 C 1

Taksim (Istanbul): Leiden, UB BPL 3273

Talande (Atalandi): Utrecht, UB Hs. 16 C 1

Ṭālib Āmulī: Leiden, UB Acad. 149

talisman(ic): Groningen, UB Hs. 471, 483, 4912; Leiden, UB Acad. 34(2), 38, 74, 152;

Or. 878, 26.266, 26.269; Utrecht, UB Hs. 16 B 21

Talkhiss al-Miftāh: Leiden, UB Or. 211

Tan (newspaper): Amsterdam, IISH

Taner, Haldun: Leiden, UB Or. 26.621

tanzimāt-i hayrīye: Amsterdam, UB Hs. Diederichs 136 G 1

Tanzuğ, Kadriye: Leiden, UB BPL 3273

Țarabolı: Utrecht, UB Hs. 16 C 2

tārīh, see chronogram

Tārīkh-i Khițāy u Khuțan: Leiden, UB Or. 854

Tarjīh al-bayān: Leiden, UB Or.26.615(4)

Tatars: Amsterdam, UB Hs. Diederichs 9 U; Leiden, UB Acad. 35(4)

Țațavla (Galata): Utrecht, UB Hs. 16 C 1

Taurus Express: Leiden, UB BPL 3273

Țawāli al-anwār min Mațāli al-anzārr: Leiden, UB Or. 933

tax (see also varlık vergisi): Leiden, UB Acad. 87(3), 210; Utrecht, UB Hs. 16 C 1;

Leiden, UB Or. 20.193

tefsir: Utrecht, UB Hs. 16 B 16(1,2); Leiden, UB Or. 26.621

Teke: Utrecht, UB Hs. 16 C 1

Tekfurdağ (Tekirdağ): Utrecht, UB Hs. 16 C 1

Temaşa-i Dünya ve Cefakar u Cefakeş: Leiden, UB Or. 26.621 
temessük: Leiden, UB Acad. 84, 205, 210

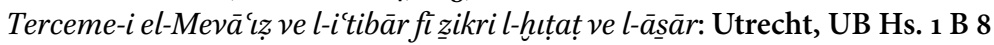

tercī-i bend: Leiden, UB Acad. 156

Tercümān-i Șaḥhāḥ: Leiden, UB Acad. 74(5)

Testa, Caspard (envoy): Amsterdam, NS A.4898(16)

Testament, the New: Leiden, UB Acad. 1

Teutonia (journal): Leiden, UB Or. 26.621

Tevārīh-i āl-i 'Oșmān: Utrecht, UB Hs. 1 F 12

tevhìd: Groningen, UB Hs. 490

Tevrāt, see Pentateuch

tezkire: Leiden, UB Acad. 85

theology, see religious dogma

Thessaloniki, see Salonica

Thessaly: Utrecht, UB Hs. 16 C 1,2

Theunissen, H.H. (MS owner): Rotterdam, MM P2316

Thrace: Utrecht, UB Hs. 16 C 1

Tietze, Andreas: Amsterdam, IISH; Leiden, UB BPL 3273; Or. 26.621

Tighina, see Bender

tìmār: Leiden, UB Acad. 210

Timmermans Hubert, V.D.M (MS owner): Leiden, UB Acad. 42

Tire: Utrecht, UB Hs. 16 C 1

Tirḥala (Trikala): Utrecht, UB Hs. $16 \mathrm{C}_{2}$

tobacco: Leiden, UB Acad. 212

Tokat: Leiden, UB Acad. 210

Tomsza, Stefanus: Amsterdam, UB Hs. Diederichs 9 U

Torley Duwel, C.L.: The Hague, KB Introduction

Tosun, Mebrure: Leiden, UB BPL 3273

Touma, A. (MS owner): Rotterdam, WM 72963

Țrablūs, see Tripoli

Trabzon: Amsterdam, UB Hs. Diederichs 9 U

translation: Amsterdam, UB Hs. VI H 2, Diederichs 136 G 3,4, $136 \mathrm{H} \mathrm{2,136} \mathrm{N}$;

Groningen, UB Hs. 479, 485; Leiden, UB Acad. 1, 58, 59, 92, 97(3), 183, 205; Or.

26.271(1); Utrecht, UB Hs. 1 B 8

Transylvania: Amsterdam, UB Hs. Diederichs 9 U

Travnik: Amsterdam, UB Hs. Diederichs $136 \mathrm{~N}$

treaty, see 'ahdnāme

Trieste: Amsterdam, UB Hs. Cq 53e; Diederichs G 1-4; Leiden, UB Acad. 97(11)

Trikala, see Tirhala

Tripoli: Leiden, UB Acad. 153

Tripoli (Syria): Leiden, UB Acad. 97(3) tug்: Amsterdam, NS A.4898(16); The Hague, KB Hs. 135 K 4(1); Leiden, UB Acad. 210

tugira: Amsterdam, NS A.4898(14-15); UB Hs. Diederichs 136 G 1,2, 136 H 1, 136 I;

Leiden, UB Acad. 78; Rotterdam, MM P2316

Tuhfat al-Hādīya: Leiden, UB Acad. 74(6), 79(1)

Tuhfe-i Fedāyyi: Leiden, UB Acad. 153

Tuhfe-i Husāmī: Leiden, UB Acad. 77

Tuhfe-i Şāhidī: Leiden, UB Acad. 77, 78, 153; Hotz 2289; Or. 26.271(4) 
Tuhfe-i Vehbī: Leiden, UB Or. 26.271(4)

Tuhfetül-'āşıḳin: Leiden, UB Acad. 179

Tuhfetül-küttāb: Leiden, UB Or. 26.616

Ṭulyān (Doljane): Utrecht, UB Hs. 16 C 2

Tünel (Galata, Istanbul): Leiden, UB BPL 3273

Tunisia(n): Leiden, UB Acad. 87(3)

Türk-Alman Kültür Merkezi: Leiden, UB Or. 26.621

Türk Tarih Kurumu: Leiden, UB BPL 3273

Türkçe tekellümāt: Leiden, UB Acad. 96

Turkey: Leiden, UB BPL 3273

Turkish, eastern (language): Groningen, UB Hs. 474

Turkish, learning of: Leiden, UB BPL 3273

Turkish, reform of: Leiden, UB BPL 3273

Türkiye Devrimci İşçi Sendikaları Konfederasyonu (DISK): Amsterdam, IISH

Türkiye İş̧i Partisi (TIP): Amsterdam, IISH

Türkiye Komünist Partisi (TPK): Amsterdam, IISH

Türkiye Yazarları Sendikası: Amsterdam, IISH

Turks: Leiden, UB Acad. 35(4)

typhus epidemic: Leiden, UB BPL 3273

'Ubaydullāh, Mevlānā: Leiden, UB Acad. 75

Üftāde, Hōoca (MS owner): Groningen, UB Hs. 490

'Umar (caliph): Utrecht, UB Hs. 16 B 14(3)

Ulus (newspaper): Leiden, UB BPL 3273

Ümmì Kemāl, see Kemāl Ümmī

al-'Urụī, see Muḥammad b. 'Umar

'Urfi: The Hague, KB Hs. 135 K 4

USA: Leiden, UB BPL 3273

Uşak: Leiden, UB Or. 26.271

Üsküb (Skopje): Leiden, UB Or. 977; Utrecht, UB Hs. 16 C 1

Üsküdar: Amsterdam, UB Hs. Diederichs 136 G 1; Utrecht, UB Hs. 16 B 22

Ustuvānī Meḥmed Efendi, Kitāb-i: Rotterdam, WM 72963

Usțuvānī Meḥmed Efendi Dimışḳi (preacher): Rotterdam, WM 72963

Ușūì: Groningen, UB Hs. 490

Üveys, el-Hācc $(k \bar{a} \dot{z} \grave{\imath}):$ Leiden, UB Or. 981

Uways al-Qaranī, Sulțān: Rotterdam, WM 68276

Uythage, Cornelis (MS owner): Leiden, UB Acad. 38

Uzun Ḥasan, see Hasan

Vāhib(ī), see 'Abdulvehhāb

Vāhib Ümmī, see 'Abdulvehhāb

vakf (evkāf): The Hague, MMW Introduction; Leiden, UB Acad. 46(3), 59, 210; Or.

958, 26.269, 26.271, 26.272; Utrecht, UB Hs. 16 B 14, 16 C 1,2

(el-)Vāḳı'āt, see Fetāvā-yi Aḳkermānī

Vâ-Nû, see Ahmed Vâlâ Nûruddin; Müzehher Vâ-Nû

Vefā (poet), see 'Abdulvefā

Vefā, Shaykh: Leiden, UB Acad. 46(1,2) 
Vehhāb(ī), see 'Abdulvehhāb

Vehbī, see Sünbülzāde Meḥmed

Venetian (Republic): Rotterdam, WM 63215; Utrecht, UB Hs. 16 C 1

Vening, Jean Anne (navy officer): Rotterdam, MM H336(3)

Vesīletün-necāt fì mevlūdin-nebì 'aleyhī ș-șalāt: Groningen, UB Hs. 491(2)

varlık vergisi: Leiden, UB BPL 3273

Varna: Utrecht, UB Hs. 16 C 1

Vașiyet [-name]: Leiden, UB Acad. 27; Or. 26.264

Vașìyet-nāme-i resūl Allāh: Leiden, UB Acad. 8(2)

Vatan Partisi: Amsterdam, IISH

Venice: Amsterdam, UB Hs. Diederichs 136 J; Leiden, UB Acad. 97(11)

verse, see poem

Veijdt, Ambroise (MS owner): Amsterdam, NS A.4898(14-16)

Vezīr Hān (Istanbul): Leiden, UB Acad. 210

Vidin: Utrecht, UB Hs. 16 C 1

Vienna: Amsterdam, UB Hs. Cq 53e; Diederichs 136 G 1-4, 136 M; Leiden, UB BPL 3273; UB Or. 26.621;

Vienna, siege of (1684): Utrecht, UB Hs. 1 G 24

Vieroot, Thomas (MS owner): Amsterdam, Introduction, UB Hs. VI H 2

Villotte, Jaques (MS owner): The Hague, MMW Introduction

vocabulary, see dictionary

Vogoridis Bey, Stafanaki: Amsterdam, UB Hs. Cq 53a

Volos, see Ġolos

Vougasso (captain): Leiden, UB Acad. 97(11)

Vries, L.A. (MS owner): Amsterdam, UB Hs. Cn 12

Wādī Khalfa: Amsterdam, UB Hs. Diederichs 136 G 1-4

Wallachia: Amsterdam, UB Cq 5o; Utrecht, UB Hs. 16 C 1,2

Walraven, Didericus Adrianus (MS owner): Leiden, UB Acad. Introduction, 38, 63, 79, 197, 212, 222

Wandervogel: Leiden, UB Or. 26.621

al-Wāridāt: Leiden, UB Or. 919

Warner(us), Levinus (Lieven, MS owner): Amsterdam, UB Hs. VI H 2; Leiden, UB Or.

$836,854,858,896,919,933,942,947,954,958,977,1025$

Westreenen van Tiellandt, W.H.J. baron van (MS owner): The Hague, MMW Introduction, Hs. 10 E 30

wheat: Utrecht, UB 16 C 1,2

Widmer of Basel, Daniel (MS owner): Groningen, UB Introduction, Hs. 490

Willemsen, Jacob (MS owner): Leiden, UB Acad. Introduction, 27, 30, 34-35, 152, 182, 197, 211

Willet, Abraham (MS owner): Amsterdam, AHM Introduction, Hs. LA 2047

Willmet, Joannes (manuscript owner): Amsterdam, UB Introduction; The Hague,

KB Introduction, Hs. 135 K 4; Leiden, UB Acad. Introduction, 1, 8, 22, 27, 30, 34, $35,38,42,45,46,49,58-60,63,64,74-79,80,82,84,85-87,92,95,96,140,142,147$, $15^{-154}, 156,178,179,182,183,197,204,205,209-212,222$; BPL Introduction

wine: Leiden, UB Acad. 87(3); BPL 3273

Wiqāya ar-riwāya fı̀ masā il al-Hidāya: Utrecht, UB Hs. 1 E 19 
Wird-i sharīf: Groningen, UB Hs. 491(3)

Wittek, Paul: Leiden, UB Or. 26.621

Woltersdorf, Albert Friedrich (copyist, compiler, MS owner): Leiden, UB Acad.

Introduction, 79, 82, 97, 204, 205, 209, 210, 222

wonders, book of: Leiden, UB Acad. 97(3)

wool: Leiden, UB Acad. 87(3)

Woolley, Charles Leonard: Leiden, UB BPL 3273

World War, Second: Leiden, UB BPL 3273

Yabancı Diller Okulu (of Istanul University): Leiden, UB Or. 26.621

Yahyā: Groningen, UB Hs. 465

Yaḥyāb. Pīr 'Alī b. Nașūḥ, Nevīi: Utrecht, UB Hs. 16 B 16(1)

Yaḥyā Beg Dukakinzāde: Leiden, UB Acad. 156

Yahyā Efendi (şeyhülislām): Leiden, UB Or. 26.615(3)

Yaḥyā Efendi b. Zekeriyā Efendi: Amsterdam, UB Hs. C 12(2)

Yahya Kemal (Beyatlı): Amsterdam, IISH

Yahyā Minḳārīzāde (şeyhülislām): Utrecht, UB Hs. 16 B 22

Yanaki (dragoman): Leiden, UB Acad. 205

Yāsinn, sūra, commentary on: Leiden, UB Acad. 22

Yazıcı, see Ebūbekir Yazıcı

Yazıcıoğlı Aḥmed Bīcān: Utrecht, UB Hs. 16 B 17(1)

Yen̄ibāzār (Novi Pazar): Utrecht, UB Hs. 16 C 1

Yen̄işehir (Larissa): Utrecht, UB Hs. 16 C 1,2

Yıldız Park (Istanbul): Leiden, UB BPL 3273

yol emri: Amsterdam, UB Hs. Diederichs $136 \mathrm{H} 1$

Yozgat, see Bozok

Yūnus b. Hasan (MS owner): Utrecht, UB Hs. 1 G 24

Yunus Emre: Leiden, UB Or. 26.621

Yūsuf (prophet): Leiden, UB Acad. 211(5)

Yūsuf (MS owner): Leiden, UB Acad. 84

Yūsuf (prophet), seal of: Groningen, UB Hs. 471

Yūsuf, el-Hācc(ī): Leiden, UB Acad. 97(13)

Yūsuf 'Ārifĩ: Leiden, UB Acad. 97(13)

Yūsuf b. 'Abdullațîf: Leiden, UB Acad. 182

Yūsuf b. Abī Bakr aṣ-Ṣakkāḳī: Leiden, UB Or. 211

Yūsuf Nābī: Leiden, UB Acad. 154

Yūsuf Paşa: Utrecht, UB Hs. 16 C 2

Yūsufu Züleyhăa: Amsterdam, AHM Hs. LA 2047; Groningen, UB Hs. 489

Zachariah, the Book of: Amsterdam, UB Hs. VI H 2, p

Zahrī: Leiden, UB Or. 933

az-Zamkhsharī, Mahmūd b. 'Umar: Leiden, UB Or. 858(1)

ze $e^{\complement} \bar{m} m e t$ : Leiden, UB Acad. 210

Zephaniah, the Book of: Amsterdam, UB Hs. VI H 2, p

Zeynīzāde, see Hüseyn b. Aḥmed

Zihnī Efendi: Groningen, UB Hs. 489

zikr: Leiden, UB Acad. $5^{8}$ 
Zülālī: Leiden, UB Or. 26.269(6)

Zvornik, see İzvornik

\section{Titles in Arabic Script}

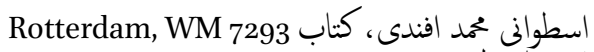

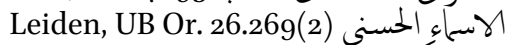

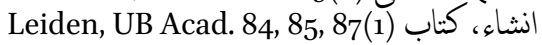

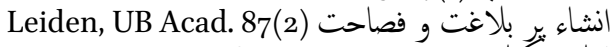
ايمانيه، كتاب Leiden, UB Or. 26.267

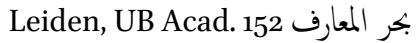
بيان الادعيه، [رساله] في (3) Leiden, UB Or. 26.269

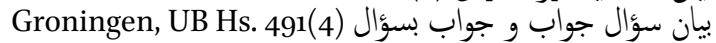

تحفهُ شاهدى Leiden, UB Acad. تحفة العاشقين 179 تحفة فئة الكباى 153 تحفة الكتاب في

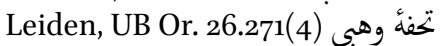

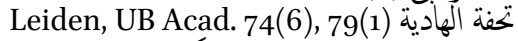

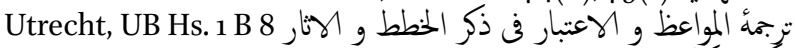
تركجه تكلمات 96 تواريخ آل عثمان 12 ت 12

Leiden, UB Acad. 211(4) حكايات من عجايب المخلوقات

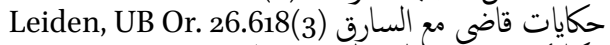

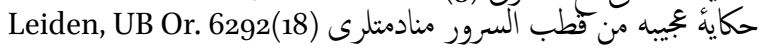

خرشيدنامه خيريه 154

داستان ازدرها (4) Utrecht, UB Hs. 16 B

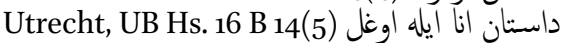

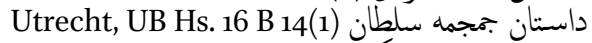

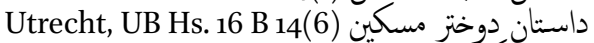

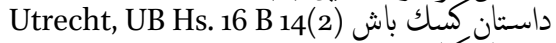

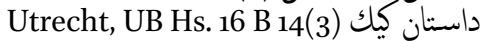

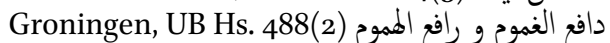

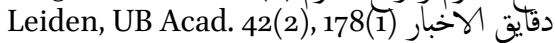
ديوان(اصولى) Groningen, UB Hs. 490 Leiden, UB Or. 26.272 ديوان (عبدالواني) (فضول) Leiden, UB Or. 26.265; Rotterdam, WM 70935 ديوان (فضولى) (عكلون) (6)

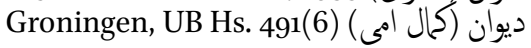


راحت القلوب (1) القابض

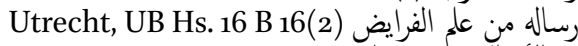

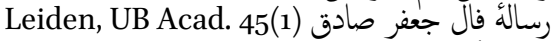

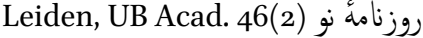
رونت بوستنان Utrecht, UB Hs. 16 B 24

سبحت الاخبار 182 Leiden, UB Acad. سلسله نامه 68276 Rotterdam, WM 68 سنبح سير نامه 484 نسله 484

شاه و كدا 154 شاه شرح اسهاء الحسنى 38 Leiden, UB Acad.

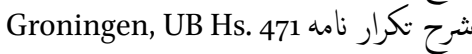

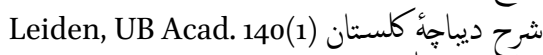

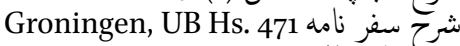

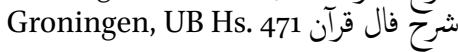

Groningen, UB Hs. 474)عتبت الحقايق (2)

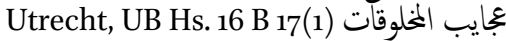

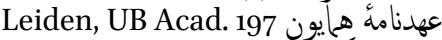

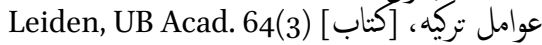

غtrecht, UB Hs. 16 B 20 غايت البيان فى تدبير بدن الانسان

فتناواى اقكرمانى فناواى على افندى (1) Leiden, UB Or. 26.618

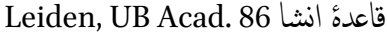

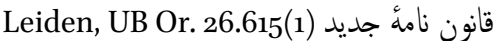
قرآن الحبشى [حكايتى] 183

كفايت الوقت لمعرفة الدائرة و فضله و السمت (2) Leiden, UB Acad. 49 كلماته كلمات تركيه (1)(1)

Leiden, UB Acad. 87(4) لغات مشكلات انشا اللغة الصغيرة (3) Leiden, UB Acad.

ما حضر Utrecht, UB Hs. 16 B 21, 16 B 23 مبحث مبحث ايمان 26.264 موديه

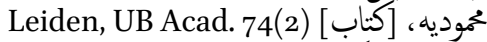
مسائل المشكلات (5) مشكابت (2)

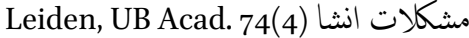

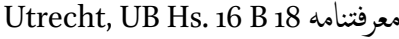
معروضات (2) معرفنام (26.615

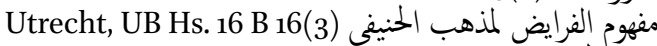
مفيد المستفدين المرايض 76 
مقنطرات، رساله (1) مناف

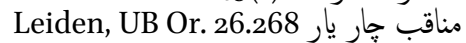

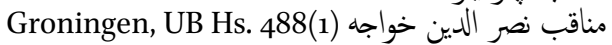

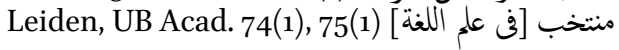

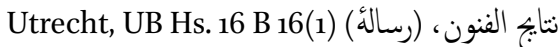
Leiden, UB Acad. 74)(7) نصاب صبيان عربى مع فارسى مع تركيل) (1) وصيت [نامه] 27 وصن وصيت نامهُ رسول الله (2) 8eiden, UB Acad. وصئ هtrecht, UB Hs. 16 B 15 هدية المشتاق فى شرح مسلك العشاق Amsterdam, AHM LA 2047; Groningen, UB Hs. 489 يوسف و زليخا 


\section{GENERAL INDEX (VOLS. I-IV)}

This index presents the titles and the names of authors of the main Turkish works described in all four volumes of this catalogue. For more more detailed references one should consult the indices to the individual volumes. Abbreviations used here are explained in the index to this volume, above.

\section{Titles in Transcription}

el-'Acāyib ve l-ġarāyıb: Leiden, UB Or. 14.408

'Acāyibül-mahlūḳāt: Leiden, UB Or. 12.371(2); Utrecht, UB Hs. 16 B 17(1)

Afät-i 'adem-i ta'dīl el-erkān: Leiden, UB Or. 14.264(7b)

Ahlāku l-'alāyī: Leiden, UB Or. 6804

Ahvālül-erbāīn: Leiden, UB Or. 11.80o(2)

Ahvāl-i kiyāmet: Leiden, UB Or. 14.349

'Aḳāyid-i ìmān-i ehl-i sünnet ve l-cemā'at: Leiden, UB Or. 12.339(4)

'Aḳāyidün̄ nev'in beyān: Leiden, UB Or. 12.339(10)

'Akāayidün şerḥi: Leiden, UB Or. 12.339(5)

Akṣā el-ereb fì tercemet-i Mukaddimet el-edeb: Leiden, UB Or. 6801

el-Akvā̄ el-müselleme fı́ gazavāt el-Mesleme: Leiden, UB Or. ${ }_{11.536} 6$

'Amelīyāt-i cerrāhìye: Leiden, UB Or. 20.402

al-Amthilat al-jadīda fi bayāni l-lughat l-jayyida: Leiden, UB Or. 11.766(21)

Amthila Farsi: Leiden, UB Or. 11.766(22)

Āṣaf-nāme: Leiden, UB Or. 923(1), 1278(2), 25.757(1)

Ās̄āru l-imāmìye: Leiden, UB Or. 6269

Āșāru l-Müştāḳ esrāru l-’uşşāḳ: Leiden, UB Or. 23.658

Așl el-cevāb: Leiden, UB Or. 109o(2)

'Atebetül-hakāâlk: Groningen, UB Hs. 474(2)

'Avāmil el-mi'e: Leiden, UB Or. 11.538(8), 11.980(3), 20.400(5)

'Avāmil-i Türkìye: Leiden, UB Acad. 64(3)

'Ayn el-müftì li-hayrāti l-müsteftī: Leiden, UB Or. 11.589(1)

Bahr el-ġarāi ib: Leiden, UB Or. 663,823

Baḥr el-ma'ārif: Leiden, UB Acad. 152; Or. 451(1), 2082(1)

Bedāyı'u ș-ṣukūk: Leiden, UB Or. 11.059

Behcetül-fetāvā: Leiden, UB Or. 11.794

Behcetül-lugàat: Leiden, UB Or. 14.092

Beyān el-ed'iye, [Risāle] fi: Leiden, UB (Addenda) 26.269(3)

Beyān-i șıāt Allāh ta'àlā: Leiden, UB Or. 14.264(7a)

Beyān-i su'āl-i cevāb ve cevāb be-su'āl: Groningen, UB Hs. 491(4) 
Beyān-i su'āl-i tāc: Leiden, UB Or. 14.637(7)

Beyān-i țarīḳat-i 'Alìye’nin̄ bināsı: Leiden, UB Or. 17.110(4)

Beyānu t-tevhīd: Leiden, UB Or. 12.339(12)

Beyān-i tevhīd-i şerīf: Leiden, UB Or. 17.110(3)

Bināve menba'-i Nakşbendīye: Leiden, UB Or. 17.110(2)

Biżā'atu l-hükkām fì ị̂kāmi l-aḥkām: Leiden, UB Or. 11.525

Burhān el-'ārifin: Leiden, UB Or. 11.040

Cāmesb-nāme: Leiden, UB Or. $155^{8}$

Cāmi' el-Fārisíf fì 'ilmel-luga: Leiden, UB Or. 498

Cāmi ü l-hikāààt: Leiden, UB Or. 12.398

Cāmi ü l-luġāt: Leiden, UB Acad. 74(1), 75(1); Or. 2745

Cāmi ü l-meknūnāt: Leiden, UB Or. 1448(1)

Celādet-i Hüseynìye: Leiden, UB Or. 26.046

Celālüddīn $H^{v}$ ärezmşah: Leiden, UB Or. 14.509

Cem-nümā fi fenn-i cog̀rafya: Leiden, UB Or. 12.366

Cenāḥu n-necāḥ̂ fi cünūḥi l-cenāḥ: Leiden, UB Or. 1206(2)

el-Cerīde: Leiden, UB Or. 11.752(4-5), 11.796(3-4)

Cerìde min el-ferā $\iota \dot{z}$ : Leiden, UB Or. 12.495

Cevāb-i Münker ü Nekīr: Leiden, UB Or. 12.339(15)

Cevāhir el-İslām: Leiden, UB Or. 1573

Cevāhirül-kelimāt: Leiden, UB Or. 2081

Cevāhir et-Tevārīh: Leiden, UB Or. 1225

Cihādnāme-i Hasan Paşa: Leiden, UB Or. 14.435(1)

Cihān-nümā: Leiden, UB Or. 1109, 12.363

Dāfíu l-gumūm ve rāfíu l-hümūm: Groningen, UB Hs. 488(2)

Dakāyikül-ahbār: Leiden, UB Acad. 42(2), 178(1); Or. 12.386

Daḳä iḳ el-hakāi ik: Leiden, UB Or. 860(1), 962(1), 12.040(1)

Dārüs-selām-i Bà̉dāduñ başına gelen ahvvālleri Leiden, UB Or. 1278(1)

Dāsitān-i Ana ile og̀ul: Utrecht, UB Hs. 16 B 14(5)

Dāsitān-i Cimcime Sulțān: Utrecht, UB Hs. 16 B 14(1)

Dāsitān-i Duhter-i miskīn: Utrecht, UB Hs. 16 B 14(6)

Dāsitān-i Ejderhā: Utrecht, UB Hs. 16 B 14(4)

Dāsitān-i Kesik-baş: Utrecht, UB 16 B 14(2)

Dāsitān-i Geyik: Utrecht, UB Hs. 16 B 14(3)

Dāsitān-i Varḳa vu Gülşāh: Leiden, UB Or. 17.104

Delāyil-i nübüvvet-i Muhammedī ve şemāyil-i fütüvvet-i Aḥmedī: Leiden, UB Or. $14.250(2)$

Dìvān ('Abdulvehhāb): Leiden, UB (Addenda) 26.272

Dìvān ('Ažbī): Leiden, UB Or. 12.465(1)

Dìvān (Bāḳ̂̀): Leiden, UB Or. 837(1), 1285

Dìvān (Eşref): Leiden, UB Or. 25.719

Dìvān (Fițnat): Leiden, UB Or. 12.388, 14.591(1)

Dìvān (Fużūlī): Leiden, UB (Addenda) 26.265; Rotterdam, WM 70935

Dìvān (Hāletī): Leiden, UB Or. 1280, 23.649(2)

Dìvān (Hamdī): Leiden, UB Or. 6964 
Dìvān (Kemāl Ümmī): Groningen, UB Hs. 491(6)

Dìvān (Lāmi'î̀): Leiden, UB Or. 12.391

Dìvān (Meczūūb): Leiden, UB Or. 8798

Dìvān (Münīf): Leiden, UB Or. 12.385(2), 12.387(4)

Dìvān (Nāiilī): Leiden, UB Or. 1454

Dìvān (Naḳşī): Leiden, UB Or. 6887

Dìvān (Nedīm): Leiden, UB Or. 11.071

Dìvān (Nesīmī): Leiden, UB Or. 1503

Dìvān (Nūrī): Leiden, UB Or. 12.394

Dìvān (Rāğıb): Leiden, UB Or. 12.389

Dìvān (Riyāżī): Leiden, UB Or. 12.392(1)

Dìvān (Sābit): Leiden, UB Or. 17.098

Dìvān (Şeyhūi): Leiden, UB Or. 1017(1)

Dìvān (Tevfik): Leiden, UB Or. 12.466

Dìvān (Ușūì): Groningen, UB Hs. 490

Dìvān (Yahyāa): Leiden, UB Or. 879, 12.467, 23.649(1)

Dìvān (Zarîfi): Leiden, UB Or. 1286(3)

Dìvān-i esrār: Leiden, UB Or. 23.638(4)

Dìvān-i hezelīyāt: Leiden, UB Or. 23.653, 25.171

Dìvān-i ilāhīyāt: Leiden, UB Or. 12.441(2), 14.518

Dīwān (Ṣāib): Leiden, UB Or. 11.050

Dürr-i manzūum: Leiden, UB Or. 1086(2)

Dürr-i meknūn: Leiden, UB Or. 1301, 12.370, 12.371(1)

Dürretüt-tāc: Leiden, UB Or. 6805

Düstūr el-'amel: Leiden, UB Or. 752(1), 1134

Düstūr eț-țīb fí 'amel mīzān et-terkīb: Leiden, UB Or. 14.407(2)

Düstūr el-vüzerā: Leiden, UB Or. 12.414

Ebū Mị̣cān ḥikāyeti: Leiden, UB Or. 1559(6)

Ecdād-i peyg்amber șallā Allāhu ta'ālā'aleyhi ve sellem: Leiden, UB Or. 12.339(7)

Edirne mu'āhedesi: Leiden, UB Or. 26.248

Edvār: Leiden, UB Or. 1175

Edvār yahud Hayātu l-ervāh: Leiden, UB Or. 12.416

Efāl el-lùga Cärullāh el-'Allāme: Leiden, UB Or. 841(1)

Emsāal: Leiden, UB Or. 1589(1)

Enīsül-'ärifin: Leiden, UB Or. 895

Envār el-'āşıḳin: Leiden, UB Or. 1554

Es'ile ve ecvibe-i mutașavvifāne: Leiden, UB Or. 8236(6), 12.055(3)

el-Esmā u l-hü̈nā: Leiden, UB Or. 12.339(6), 14.264(5), (Addenda) 26.269(2)

Evvelīyāt: Leiden, UB Or. 5807

Fāl-i Kur 'ān: Leiden, UB Or. 1205(2), 1259(1)

Fālnàme: Leiden, UB Or. 12.029(7,8), 12.441(5), 18.175(3)

Fālnāme-i Caffer Șādık: Leiden, UB Acad. 45(1); Or. 1259(2,3)

Fażāil: Leiden, UB Or. 14.562(2)

Fażāi il el-cihād: Leiden, UB Or. 12.438

Fażlet-nāme: Leiden, UB Or. 12.435 
Ferā ${ }^{i} \dot{z}$ : Leiden, UB Or. 11.752(3), 17.135, 17.140

el-Ferec ba'd eş-şidde: Leiden, UB Or. 12.406(6), 12.407

Ferhād u Şïrin: Leiden, UB Or. 11.054(2)

Ferrācīye: Leiden, UB Or. 23.665

Fetāvā-yi 'Abdurraḥim Efendi: Leiden, UB Or. 14.654

Fetāvā-yi Akkermānī: Leiden, UB (Addenda) Or. 26.617

Fetāvā-yi 'Ali Efendi: Leiden, UB (Addenda) Or. 26.618 (1)

Fetāvā-yi Hākimī Efendi: Leiden, UB Or. 11.581(5)

Fetāvā-yi Kemāl Paşazāde: Leiden, UB Or. 866

Fetāvā-yi Kör Müftī: Leiden, UB Or. 1276

Fetāvā-yi Rıżā: Leiden, UB Or. 11.614

Fetāvā-yi Yahyā Efendi: Leiden, UB Or. 6803

Fethnāme-i Kıbrıs: Leiden, UB Or. 12.356

Fevāid-i gazā: Leiden, UB Or. 765, 835, 25·757(2)

Fuṣūl-i hall u 'aḳd ve uṣūl-i harc u naḳd: Leiden, UB Or. 923(2)

Futūhāt-i 'Aynīye: Leiden, UB Or. 942(4)

el-Fütüvvet: Leiden, UB Or. 12.429(3)

Fütüvvetnāme: Leiden, UB Or. 12.427(2)

Fütüvvetnāme-i kebīr: Leiden, UB Or. 12.348, 12.427(1)

Ġălib-i mag̀lūb risālesi: Leiden, UB Or. 18.175(10)

Ġarīb-nāme: Leiden, UB Or. 6197

Ġāyetül-beyān fì tedbīri bedeni l-insān: Utrecht, UB Hs. 16 B 20

Ǵazavāt-i Sulțān Seyyid Bațtāl Ġāzì: Leiden, UB Or. 10.852, 14.643

Gazavāt-nāme-i Hasan Paşa: Leiden, UB Or. 14.435(2)

Gencīne-i rāz: Leiden, UB Or. 12.384

Ġıd̄-yi rūḥ-efzā: Leiden, UB Or. 1068(1)

Gülistān bi t-Turkī: Leiden, UB Or. 1553

Gülşen-i 'aşk: Leiden, UB Or. 12.383

Gülşen-i mülūk: Leiden, UB Or. 923(3)

Gülşen-i rāz: Leiden, UB Or. 1017(2)

Gülzār: Leiden, UB Or. 981(21)

Ġurre-nāme: Leiden, UB Or. 12.122(4), 12.113

Hadīka-i endīye der țarīka-i Naḳşbendīye ve behce-i Hāalidīye: Leiden, UB Or. 17.108

Hadīkat es-su'adā: Leiden, UB Or. 508, 12.437, 14.367, 14.636

Hadīkat-nāme: Leiden, UB Or. 1903(2)

Hall-i tahkị̂āt: Leiden, UB Or. 5805(ii), 12.033(2)

Hamìdīye: Leiden, UB Or. 20.404(1)

Harìdet fì ilmel-ferāylż: Leiden, UB Or. 11.068

Hātime-i kașīde-i Burdatu l-maqām: Leiden, UB Or. 11.911(6)

Havāṣṣ el-Kur'ān: Leiden, UB Or. 997(11)

Hayāt ve hătıratım: Leiden, UB Or. 6694c

Hayāt-i ebedī: Leiden, UB Or. 14.264(4)

Hayātu l-ervāh, see Edvār

Hayretül-ebrär: Leiden, UB Or. 11.054(1) 
Hayrīye: Leiden, UB Acad. 154; Or. 25.724, 25.758(1)

Hedīyetül-hüccāc: Leiden, UB Or. 12.380

Hedīyetül-müştākf fi şerh mesleki l-’uşşāḳ: Utrecht, UB Hs. 16 B 15

Hicret-i Resūl Allāh: Leiden, UB Or. 12.439(4)

Hidāyetüs-sālikīn ve behcetül-'āşıkìn: Leiden, UB Or. 8236(4)

Hikāyāt min 'Acāyibi l-mahlūkăt: Leiden, UB Acad. 211

Hikāyāt-i Esepos: Leiden, UB Or. 1289

Hikāyāt-i garībe: Leiden, UB Or. 12.406(1)

Hikāye: Leiden, UB Or. 14.591(2)

Hikāye-i 'acībe min Kuṭb es-Sürūr münādemetleri: Leiden, UB (Addenda) Or. 6292

(8)

Hikāyet-i 'acāyib ügarāyib: Leiden, UB Or. 1087

Hikāyet-i Arżu ile Kanber: Leiden, UB Or. 6967c, 12.406(3), 12.406(3)

Hikāyet-i kā̇̇̇ ma'e s-sarı: Leiden, UB (Addenda) Or. 26.618(3)

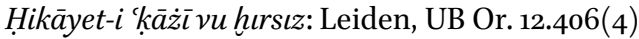

Hikāyet-i Mihr ile Vefā: Leiden, UB Or. 12.406(5)

Hikmetnāme: Leiden, UB Or. 644(26), 697

Hilye-i çehār yār-i güzīn: Leiden, UB Or. 25.729(2)

Hilye-i Huạkānī: Leiden, UB Or. 12.003, 25.729(1)

Hilye-i peyġamberān-i kirām: Leiden, UB Or. 25·729(3)

Hilye-i şerīf-i enbiyā: Leiden, UB Or. 1557(2)

Hulāșat aț-țıbb: Leiden, UB Or. 20.398

Hulvīyāt: Leiden, UB Or. 8483

Hümāyūn-nāme: Leiden, UB Or. 448, 1246, 17.958

Hurşīd-nāme: Leiden, UB Or. 14.466, (Addenda) 26.270

Hüsn ü Dil: Leiden, UB Or. 1300, 11.053, 14.510

Husrev ü Şììn: Leiden, UB Or. 982, 12.382, 14.560

Hutbet el-beyān: Leiden, UB Or. 23.645

Huṭbe-i nikạh: Leiden, UB Or. 14.556(1)

İbret-nāme: Leiden, UB Or. 3086

İbret-nümā: Leiden, UB Or. 8763, 25.758(11)

İhtilāc: Leiden, UB Or. 1628(2)

İhtiyārāt: Leiden, UB Or. $6813(8)$

İksir-i devlet: Leiden, UB Or. 25.763

İlāhīyāt, see Dìvān-i ilāhīyāt

İlm-i hạal: Leiden, UB Or. 1559(1), 11.544

İmād el-isslām: Leiden, UB Or. 14.622

İmānìye, Kitāb-i: Leiden, UB (Addenda) 26.267

İnşa $\bar{a}$ : Leiden, UB Acad. 84, 85, 87(1); Or. 898, 1560, 3084

İnşā-i $\dot{G} ı n \bar{a} y \bar{\imath} z \bar{a} d e$ : Leiden, UB Or. 1302

İnşā-i merḡūb: Leiden, UB Or. 1506, 23.633

el-İnşāc el-merğūb: Leiden, UB Or. 11.584

İnşā́ci pür-belāgat u fașāḥat: Leiden, UB Acad. 87(2)

İtihāa et-Tevārīh: Leiden, UB Or. 1234

İşci defteri: Leiden, UB Or. 26.246

İskender-nāme: Leiden, UB Or. $14.55^{8}$ 
Kāfiye-i manzūme: Leiden, UB Or. 23.671

Kă 'ide fí 'ilmi l-ḳıā'at: Leiden, UB Or. 23.669

Kă ide-i İnşā́ : Leiden, UB Acad. 86

Kānūn-i cedìd: Leiden, UB Or. 322(1)

Kānūn-i livā-i Kayșarīye: Leiden, UB Or. 305 (4)

Kānūn-nāme: Leiden, UB Or. 25·757(5)

Kānūn-nāme-i cedìd: Leiden, UB (Addenda) Or. 26.615 (1)

Kānūn-nāme-i cedìd-i vilāyet-i Karaman: Leiden, UB Or. 305(2)

Kāanūn-nāme-i cedìd-i pādişāhī: Leiden, UB Or. 327(3)

Kānūn-nāme-i hümāyūn: Leiden, UB Or. 25.757(4)

Kānūn-nāme-i kadìm-i vilāyet-i Karaman: Leiden, UB Or. 305(1)

Kānūn-nāme-i livā-i Silistre: Leiden, UB Or. 327(4)

Känūn-nāme-i 'Oșmānī: Leiden, UB Or. 327(2), 865(1)

Kānūn-nāme-i Tevārīh-i pādişāhān-i Çìn ü Hıțāy: Leiden, UB Or. 12.365(1)

Kānūn-nāme-i vilāyet-i Karaman: Leiden, UB Or. 305(6)

Kavā id: Leiden, UB Or. 17.159

Kavs-nāme: Leiden, UB Or. 12.417

Kayșar-i Rūm'uñ Mu'àviye bin Ebì Sufyān'dan etdigi su'āller: Leiden, UB Or. 23.652

Kăż̀̇ ile bilen ḥarāmı ḥikāyesi: Leiden, UB Or. 12.424(2)

Kelimāt-i Türkīye: Leiden, UB Acad. 8o(1); Or. 1686

Kenzül-fütūḥ: Leiden, UB Or. 23.668

Kenzül-ma'ārif: Leiden, UB Or. 20.405

Kerāmät-i Ahı Evren: Leiden, UB Or. 12.429(4)

Keşfül-esrār fi remzi t-tehevvüd: Leiden, UB Or. $25 \cdot 756$

Kifāyetül-vakt li-ma'rifeti d-dāire ve fażluh ve s-semt: Leiden, UB Acad. 49(2); Or. 12.058(4), 17.167, 20.400(1)

Kırān el-Habeşi ḥikāyeti: Leiden, UB Acad. 183

Kırk su'äl: Leiden, UB Or. 1559(5), 11.935, 12.371(3), 17.163(1)

Kırk Vezīr hikāyesi: Leiden, UB Or. 1552(2)

Kıșșat 'Anter bin Şeddād: Leiden, UB Or. 12.433

Kitāb-i Cafer Șādık: Leiden, UB Or. 1205(3)

Kitāb aș-ṣalāt: Leiden, UB Or. 12.339(19)

Kitāb-i Țaşkendī: Leiden, UB Or. $75^{2(2)}$

Kitāb-i Usțuānī Meḥmed Efendi: Leiden, UB Or. 17.121, 17.122, 17.136; Rotterdam, WM 72963

Kiyāfetnāme-i insānīye: Leiden, UB Or. 12.415

Kudūrī-i şerîf tercemesi: Leiden, UB Or. 20.404(2)

Künhül-ahbār: Leiden, UB Or. 288

Lețāyif-i Naṣruddīn Hōoca: Leiden, UB Or. 1132, 2067

Leylā vü Mecnūn: Leiden, UB Or. 10.978, 11.054(3)

Luġat Ahterī Kebìr: Leiden, UB Or. 461, 1435

Luġat-i Firişteog்: Leiden, UB Or. 25.760(1)

Lugāt-i müşkilāt-i inşā: Leiden, UB Acad. 87(4)

Luġat-i Nevā $\bar{\imath}$ : Leiden, UB Or. 703, 841(4), 1100(3), 1135

Luġat-i Ni'metullāh: Leiden, UB Or. 164, 227, 684(1), 925

Luġat-i Vașșāf: Leiden, UB Or. $5^{809}$ 
al-Lugha aṣ-ṣaghïra: Leiden, UB Or. 74(3)

Lutfiye: Leiden, UB Or. 1452(1), $25 \cdot 731$

Mā ḥażar: Utrecht, UB Hs. 16 B 21, 16 B 23

Mă'-i ma'nī: Leiden, UB Or. 8236(10)

Ma'ālimü l-yakìn fì sìret seyyidi l-mürsilīn: Leiden, UB Or. 12.342

Ma'ānì-i şerîf-i esmā el-hüsnā: Leiden, UB Or. 12.095(3)

Mahbūb el-kulūb: Leiden, UB Or. 14.304

Maḥmūdīye: Leiden, UB Acad. 74(2); Or. 857

Majmū' tarjumān Turkī wa-'Ajamī wa-Mughal wa-Fārsī: Leiden, UB Or. 517

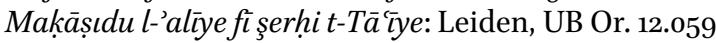

Maḳtel-i Hüseyn: Leiden, UB Or. 1263

Manzūme-i mirāàcìye: Leiden, UB Or. 11.052(1)

Ma'rifetnāme: Utrecht, UB Hs. 16 B 18

Ma'rūzāt: Leiden UB (Addenda) Or. 26.615(2)

Mebde' ü me'ād: Leiden, UB Or. 942(7)

Mebhas

Mecma'u l-kavāid ve menba'u l-fevāyid: Leiden, UB Or. 1566

Mecma' el-lețāyif: Leiden, UB Or. 1552(1)

Mecmū'a: Leiden, UB Or. 12.829

Mecmū'atu t-tevārīhi l-Mevlevīye: Leiden, UB Or. 12.430

Medḥ-i dōlāb: Leiden, UB Or. 12.396(3)

Mefhūm el-ferāyıż li-mezheb el-Hanefi: Utrecht, UB Hs. 16 B 16(3)

Menāhic el-vusūul: Leiden, UB Or. 11.052(2)

Menāḳıb-i çehār yār-i güzīn: Leiden, UB Or. 14.410, (Addenda) 26.268

Menāḳıb el-cevāhir li-h̆aḳ Emìr Sulțān: Leiden, UB Or. 775(1)

Menākıb-ı hulefā'ı rāşsidīn: Leiden, UB Or. 12.354

Menāḳıb-ı Nașruddīn Hōca: Groningen, UB Hs. 488(1)

Menāḳıb-i şerīf: Leiden, UB Or. 1555

Menāsik-i hacc-i şerīf: Leiden, UB Or. 12.376, 12.377, 12.379

Menāsik el-hacc: Leiden, UB Or. 12.373, 12.375, 12.378, 17.120

Menāsik el-hacc 'an el-ġayr: Leiden, UB Or. 11.549(10), 12.374

Menāzil: Leiden, UB Or. $155^{\circ}$

Merāsim-i ușūl-i iḳrār u ilbās-i țarīkat-i 'Alīye-i Nakş̧bendīye el-Kāāirīye-i Zenbūrīye:

Leiden UB Or. 23.661

Mesāilü l-müşkilāt: Leiden, UB. Or. 26.615 (5)

Mesā il-i şettā: Leiden, UB Or. 11.752(6)

Mesālik-i memālik: Leiden, UB Or. 602

Mevākib: Leiden, UB Or. 11.058

Mevlidü n-nebī: Leiden, UB Or. 12.439(2)

Mevlūd-i İmām Hasan u İmām Hüüseyn: Leiden, UB Or. 26.249(1)

Mevlüd-i Keşfi: Leiden, UB Or. 12.396(1)

Mevlūd-i Şāhidī: Leiden, UB Or. 12.396(2)

Miftāḥu l-cenne: Leiden, UB Or. 12.019(6), 14.409

Miftāhu l-edeb: Leiden, UB Or. 18.691(2)

Miftāhu l-luġa: Leiden, UB Or. 969(2), 18.691(1)

Miftạḥ müşkilātı l-'ālimīn ve ādāb țarīkatı l-vāṣılīn: Leiden, UB Or. 8531 
Miftāḥ es-sa'āde Leiden, UB Or. 11.115

Mihr ü Māh: Leiden, UB Or. 1286(2)

Minhāc el-fuḳarā: Leiden, UB Or. 12.033(1)

Mírācu n-nebī: Leiden, UB Or. 12.395(2), 12.434(2), 12.439(3)

Mir'ātül-'avālim: Leiden, UB Or. 12.369

Mir'ātü ș-ṣafāfı́ ạ̣vāli l-enbiyā: Leiden, UB Or. 14.519

Mirḳāt el-luġa: Leiden, UB Or. 237

Miskinlik kitābı: Leiden, UB Or. 1279(1)

Mīzānü l-hakk fı ihtiyārı l-hakk: Leiden, UB Or. 17.124

Mìzānül-'ukelàli-temyìzi l-fużalā: Leiden, UB Or. 17.110(7)

Mu'ayyid al-fuḍalā: Leiden, UB Or. 1674

Mücerrebāt: Leiden, UB Or. 17.102

Müfidü l-müstefidin: Leiden, UB Acad. 76

Muhtașar fì beyān maḳālāt ehl el-'âlem ve l-mezāhib el-muhtelife li-țavāif el-ümem:

Leiden, UB Or. $1129(\mathrm{G})$

Mukaddimetü t-tevcīd fı̀ kelāmi l-mecìd: Leiden, UB Or. 12.002

Münācāt-i Ahı Evren fütüvvet ve l-müruvvet, der: Leiden, UB Or. 12.429(7)

Münācāt-i Fãțima ez-Zahrī: Leiden, UB Or. 14.556(8)

Münşe'āt-i merğübe-i Ebūbekir Kānī Efendi: Leiden, UB Or. 12.409

Münşe'āt-i Nābì: Leiden, UB Or. 12.408(1)

Münşe'āt-i Nergisī: Leiden, UB Or. 1564, 25.761(3)

Münşe'àt-i selāțīn: Leiden, UB Or. 277, 12.351

Müntehab [fi 'ilmi l-lugat], see Cāmi ü l-luḡāt

Mürşid-i kāmil: Leiden, UB Or. 8236(9)

Mürşidül-muhtār fi 'ilmi l-esrār: Leiden, UB Or. 17.956

Mürşidül-vārișin fì şerh aḥvāli l-'arba'īn: Leiden, UB Or. 17.139

Mușārrihat al-asmā': Leiden, UB Or. 500(1)

Müşkilāt-i inşā: Leiden, UB Or. 74(4)

al-Muthallath: Leiden, UB Or. 500 $(2,5)$

Namāz niyetleri: Leiden, UB Or. 14.556(3)

Namāzlık: Leiden, UB Or. 17.159(1)

Nașịhat el-mülūk terg்i ben li-ḥüsni s-sülūk: Leiden, UB Or. 625

Nazm el-äl: Leiden, UB Or. 23.666

Nazm-i Kä̇̇̇̇zāde: Leiden, UB Or. 12.339(13)

Nazm-i Kemāl Paşazāde: Leiden, UB Or. 14.264(9a)

Necātül-ġarịk: Leiden, UB Or. 14.555

Nehcüs-sülūkfi siyāseti l-mülūk: Leiden, UB Or. 12.413

Neșrün-nāzirìn ve maḳbülül-hātirìn: Leiden, UB Or. 801

Netāyicül-fünūn: Leiden, UB Or. 949(1); Utrecht, UB Hs. 16 B 16(1)

Netīcetül-fetāvā: Leiden, UB Or. 11.798

Nevādirü l-hikem: Leiden, UB Or. 12.419(1)

Nișāb aṣ-ṣıbyān: Leiden, UB Or. 5803(2)

Niṣāb aș-șıbyān ma'e 'Arabì ma'e Fārsī ma'e Türkī: Leiden, UB Acad. 74(7)

Noḳtatül-beyān: Leiden, UB Or. 23.662(2)

Nuhbe-i Pendnāme: Leiden, UB Or. 1563

Nuṣh u pend: Leiden, UB Or. 25.758(8) 
Rāhatu l-ervāḥ: Leiden, UB Or. 1286(1)

Rạḥatu l-ervāḥ ve mūnisi l-eşbāḥ: Leiden, UB Or. 12.429(5)

Rāhatu l-ḳulūb: Leiden, UB Acad. 8(1)

Ravżat el-envār: Leiden, UB 451(2)

Rāz-nāme: Leiden, UB Or. 12.405

Reml-i Peyjamber 'aleyhī s-selām: Leiden, UB Or. 12.029(26)

Resāil ül-müsşı̀ye fi l-emrażi l-müşkile: Leiden, UB Or. 25·770(2)

Revnāk-i bostān: Utrecht, UB Hs. 16 B 24

Risāle-i Ādāb-i sālikīn der țarīḳat-i Nakşbendīye: Leiden, UB Or. 17.110(1)

Risāle fì āhirü z-zamān: Leiden, UB Or. 17.124

Risāle-i 'arūż: Leiden, UB Or. 11.735

Risāle-i ațvār-i seb'a: Leiden, UB Or. 8236(1)

Risālet Bedel-i hacc: Leiden, UB Or. 12.374

Risāletü l-bey’ve ş-şirā': Leiden, UB Or. 1556(2), 11.547(4)

Risāle-i ceyb-i äfākẹi: Leiden, UB Or. 20.400(3)

Risāle-i deste-gül fì keyfı̀yet halkatı l-cenìn ve tevlī dihī: Leiden, UB Or. 1390

Risāle-i Ebū l-Meşrıḳi: Leiden, UB Or. 12.441(6)

Risāle-i evșāf-i İstanbul: Leiden, UB Or. 12.362

Risāle-i Fàl-i Ca'fer Șādık, see Fālnāme-i Cafer Șādık

Risāle-i feyż̄ ye fi luġāti l-müfredāti t-țbbìye: Leiden, UB Or. 14.407(1)

Risāle-i fütüvvet-i tarịkat: Leiden, UB Or. 11.041(1)

Risāle bi-hakk-i kisve: Leiden, UB Or. 14.637(6)

Risāle der hakk-i devr: Leiden, UB Or. 23.647(3)

Risāle fi hakkki ș-șādık ve l-ḳäżi: Leiden, UB Or. 12.112(13)

Risāle fi hakk şeyh 'Abdulkādir el-Gülānī: Leiden, UB Or. 12.057

Risāle-i Hüseynīye: Leiden, UB Or. 23.647(1)

Risāle fì 'ilmi l-ahlāk: Leiden, UB Or. 25.730

Risāle min 'ilm el-ferāyıż: Utrecht, UB Hs. 16 B 16(2)

Risāle-i 'ilm-i hal ü tevḥid: Leiden, UB Or. 12.339(16)

Risāle-i 'ilm-i hesāb: Leiden, UB Or. 20.401

Risāle-i irāde-i cüz'̄̄ye: Leiden, UB Or. 12.425, 17.124

Risāle fi ilmi t-tașavvuf: Leiden, UB Or. 1294(6)

Risāle-i i’tikâadīye ve redd-i i’tikāadu l-bātilì̄ye: Leiden, UB Or. 26.247

Risāle-i Käşif Efendi: Leiden, UB Or. 23.638(3)

Risāle fì kavā'id el-Kur'ān: Leiden, UB Or. 11.689(2)

Risāle-i Kā̇̇̇̇zāde Efendi: Leiden, UB Or. 12.339(3), 14.264(8)

Risāle-i Lubb el-hakāyyk: Leiden, UB Or. 12.030(3)

Risāle-i Lubb-i haḳikat: Leiden, UB Or. 12.030(2)

Risāle-i Mahmūùd Paşa: Leiden, UB Or. 1559(3), 12.406(2)

Risāle-i Mehmed 'Amīkī: Leiden, UB Or. 23.638

er-Risālet el-mensūbe ilā ş-Şeyh Mehmed Murād el-Ma’șūmī el-Buhārī en-Nakşbendī:

Leiden, UB Or. 12.338

Risāle fì mefhūmi l-ferā ‘̇ż: Leiden, UB Or. 11.786

er-Risālet el-Muhammedīye: Leiden, UB Or. 6802, 10.853, 14.192

Risāle-i mukanțarāt: Leiden, UB Acad. 49(1); Or. 20.400(2)

Risāle-i Naḳşbendī el-Kadirū -yi Zenbūrīye: Leiden, UB Or. 23.659

Risāle-i Pōr Erzincānī: Leiden, UB Or. 1264(1) 
Risāle-i Rūmī: Leiden, UB Or. 12.043(3)

Risāle-i Rūmī Aḥmed Efendi: Leiden, UB Or. 12.043(2), 12.339(2)

er-Risālet es-semā ‘̀ye el-mülzime li'-münkirinn: Leiden, UB Or. 11.985

er-Risāletüş-şemsīye: Leiden, UB Or. 6813(4)

Risālet eş-Şeyh 'Abdulahad en-Nūrī: Leiden, UB Or. 11.985(1)

Risāle-i țabāyi'-i bürūcāt: Leiden, UB Or. 23.637(3)

Risāle-i Tábìrnāme: Leiden, UB Or. 1634(2)

Risāle-i Teshïlül-mīkāt: Leiden, UB Or. 12.058(3)

Risāle-i Tursunzāde 'Abdullāh Efendi: Leiden, UB Or. 25.572(2)

Risāle der usțurlāb: Leiden, UB Or. 12.104(7)

Risāle-i usțurlāb: Leiden, UB Or. 12.058(5)

Risāle-i Vaḥid Efendi: Leiden, UB Or. $12.35^{8}$

Risāle-i vāridātül-hakk: Leiden, UB Or. 11.041(2)

Risāle-i Vìrānī Baba: Leiden, UB Or. 12.465(2), 14.637(3), 23.662(1)

Risāle-i vücūd: Leiden, UB Or. 12.030(1)

Risāle-i ya'ı̄ye: Leiden, UB Or. 86o(2), 962(2), 981(22), 12.040(2)

Risāle fìzātu l-kürsì: Leiden, UB Or. 12.058(2)

Riyā̇̇u ş-şu'arā: Leiden, UB Or. 12.360

Rusya develeti cānibine verilen 'ahdnāme-i hümāyūn: Leiden, UB Or. 12.422(1)

Rūznāme: Amsterdam, UB Hs. Dortmond 56, 291; Leiden, MV 36o-9545, 36o-9546;

UB Or. 1568

Rūznāme-i cedìd: Leiden, UB Or. 6238

Rüznāme-i istihrac-i şemsīye: Leiden, UB Or. 1259(7)

Rüznāme-i nev: Leiden, UB Acad. 46(2)

Rūznāme-i Türkī: Leiden, UB Or. 1270

Sa'ādetnāme: Leiden, UB Or. 721, 12.047, 14.508(2), 14.511

Sā'at-nāme: Leiden, UB Or. 12.343, 12.845, 14.610, 25.767

Șad kelime-i çehār yār-i güzīn: Leiden, UB Or. 829

Şāh u gedā: Leiden, UB Acad. 156; Or. 3047, 10.851

aṣ-Ṣaḥạh al-'Ajamīya: Leiden, UB Or. 781, 863, 1100(1)

aș-Ṣaḥăh al-mukhtașar: Leiden, UB Or. 500(3)

Sāḳ̂-nāme: Leiden, UB Or. 12.392(2)

Seb'a-ı seyyār: Leiden, UB Or. 11.054(4)

Secde-i sehve lāzim gelen șüratlar: Leiden, UB Or. 12.421(1)

Şecere-i semere: Leiden, UB Or. 20.405(1)

Sedd-i İskenderī: Leiden, UB Or. 8481, 11.054(5)

Şedd-nāme: Leiden, UB Or. 12.429(1)

Sefāret-nāme-i Fransa: Leiden, UB Or. 1589(2), 1940

Şehinşāh-nāme: Leiden, UB Or. 730

Şemsīye: Leiden, UB Or. 1448(2), 14.673, 17.103

Señirnāme: Leiden, UB Or. 1259(5), 18.175(1); Groningen, UB Hs. 484

Şerā' $\iota$ ți İsläm: Leiden, UB Or. 14.264(6b)

Şerhü l-aḥādīsi l-erba'īn: Leiden, UB Or. 942(5)

Şerh-i Behāristān: Leiden, UB Or. 827

Şerh-i Bustān: Leiden, UB Or. 839(1), 12.448(4)

Şerḥ-i Cezìre-i Mesnnevī: Leiden, UB Or. 5805(2) 
Şerh-i dībāce-i Gülistān: Leiden, UB Acad. 140(1)

Şerh-i Dìvān-i Häfız: Leiden, UB Or. 11.051

Şerh-i Dìvān-i Şāhì: Leiden, UB Or. 724

Şerḥ-i esmāu l-hüsnā: Leiden, UB Or. 8236(7), 12.339(8)

Şerh-ifäl-i Kur'än: Groningen, UB Hs. 471

Şerh-i kașide-i Burda: Leiden, UB Or. 11.579

Şerh-i kașide-i Hamrīye: Leiden, UB Or. 1140

Şerhü l-kebā ir: Leiden, UB Or. 6813(1)

Şerh-i Lugat-i Firişteog்l: Leiden, UB Or. ${ }^{661}$

Şerh-i Mevlüd: Leiden, UB Or. $25 \cdot 769$

Şerh-i Mülteḳa l-ebhur: Leiden, UB Or. $85^{28}$

Şerḥ-i Rüznāme-i hażret-i Şeyh Vefā: Leiden, UB Or. 1259(6)

Şerh-i Şebistān-i hayāl: Leiden, UB Or. 659

Şerh-i sefer-nāme: Groningen, UB Hs. 471

Şerh-i şu'abu l-imāan: Leiden, UB Or. 6813(6)

Şerh-i tekrār-nāme: Groningen, UB Hs. 471

Şerh-i Tuhfe-i Şāhidì: Leiden, UB Or. 1449, 18.155

Şerh-i Tuhfetü l-ahrrār: Leiden, UB Or.738

Şerh-i Vașīyet-i Birgivī: Leiden, UB Or. 11.774, 17.129, 23.650(2)

Şevk-engiz: Leiden, UB Or. 1452(2)

Shāmil al-lugha: Leiden, UB Or. 18.693

Shudhūr adh-dhahabìya wa 'l-qița' al-Ahmadīya fì l-lughat at-Turkīya: Leiden, UB

Acad. 59, 6o; Or. 3087

Sihām-i każā: Leiden, UB Or. 662, 870

Silsile-nāme: Rotterdam, WM 68276

Şirlerim ve nesir maḳālelerimden bir ḳaçı: Leiden, UB Or. 6694b

Siyāhatnāme: Leiden, UB Or. 644(24)

Subḥatu l-ahbārrve tuhfatu l-ahyārr: Leiden, UB Acad. 182; Or. 3080

Subhatu l-'uşşāk: Leiden, UB Or. 11.598(9)

Sübḥe-i șıbyān: Leiden, UB Or. 11.117(1), 25.760(2)

Süleymān-nāme: Leiden, UB Or. 17.130

Sülük-i ḳavìm ve șırāt-i Müstaḳim: Leiden, UB Or. 20.40o(6)

Sūra-i Żuhā tercemesi: Leiden, UB Or. 12.029(2)

Sūrnāme-i hümāyūn: Leiden, UB Or. 309

Şifāel-kulūb ve l-Fu'ād li-ḥażret es-sulțān Murād: Leiden, UB Or. 727

Şurūt-i İslāmìye: Leiden, UB Or. 14.264(10)

Ta'bir: Leiden, UB Or. 1628(1)

Ta bïrnāme: Leiden, UB Or. 1259(4), 11.706, 14.515, 14.556(10), 18.175(5,6), 25.728(3,4,8)

Ta'bìrnāme-i hażret-i Yūsuf: Leiden, UB Or. 25.728(1)

Ta'bìrnāme-i muhtașar: Leiden, UB Or. 18.175(4)

Tabșıra: Leiden, UB Or. 12.357

Tāc et-Tevārîh: Leiden, UB Or. 519, 1183(1)

Tafșil-i vilāyet-i Karaman: Leiden, UB Or. 305(3)

Tafż̀̈lül-ìmān: Leiden, UB Or. 11.766(20)

Tahmīs-i ḳașìde-i Burda: Leiden, UB Or. 11.911(3)

Takvìmüt-Tevārĭh: Leiden, UB Or. 290 
Tandır başı: Leiden, UB Or. 8235

Tārīh-i Hind-i garbì: Leiden, UB Or. 12.365(3)

Tārihh-i Kamaniçe: Leiden, UB Or. 12.355, 25.761(1)

Tārīh-i Lutfi: Leiden, UB Or. 12.352, 12.353

Tārîh-i Müneccimbaşı tercümesi: Leiden, UB Or. 8799

Tārīh-i Na'īmā: Leiden, UB Or. 12.350(1)

Tärīh-i Nişancı: Leiden, UB Or. 672, 838, 10.861

Tārīh-i Peçevī: Leiden, UB Or. 1311

Tārīh-i Răşsid: Leiden, UB Or. 8517

Tārīh-i Vecīhī: Leiden, UB Or. 894

Tavā'if-i 'aşere: Leiden, UB Or. 665, 1076

Tayyibetül-ezkār fì medīneti l-envār: Leiden, UB Or. 12.421(2)

Tecvīd-i cedìd-i manzūum: Leiden, UB Or. 11.944(1)

Tefä ül-nāme: Leiden, UB Or. 8414a, 23.646

Tefsìr-i sūre-i Fätiḥa-i kerīme: Leiden, UB Or. 14.264(6c)

Tenbīhü l-ġabífi rüyeti n-nebi: Leiden, UB Or. 8236(8)

Terbiye-i etfāl: Leiden, UB Or. 11.122

Terceme-i Akrābādīn-i cedìd: Leiden, UB Or. 25.770(3)

Tercemet bābu l-ah̄ir li’l-Fütūhāti l-Mekkīye: Leiden, UB Or. 12.345

Terceme-i Cog̈räfya: Leiden, UB Or. 12.364

Terceme-i Emr el-muhkem el-merbūt fi māyelzem li-ehl țarị̂ Allāh min eş-şürūṭ:

Leiden, UB Or. 23.638(1)

Terceme-i Eyyühä l-veled: Leiden, UB Or. 12.339(11)

Terceme-i kașìde-i Burda: Leiden, UB Or. 11.111(1), 11.752(2), 11.967(4)

Terceme-i Kìmiyā s-sa'ādet: Leiden, UB Or. 11.043, 12.055(1), 12.346

Tercemet el-Kudūrī: Leiden, UB Or. 11.753

Terceme-i el-Mevā' $z$ v ve l-i'tibār fizikri l-hıțaț ve l-āsāär: Utrecht, UB Hs. 1 B 8

Terceme-i Mi'yāru ț-țarīkat: Leiden, UB Or. 12.344

Terceme-i Muḳaddime-i İbn Haldūn: Leiden, UB Or. 17.106

Terceme-i Pendnāme-i şeyh 'Atțār: Leiden, UB Or. 12.431, 12.448(5), (Addenda) 26.271

(1)

Terceme-i Risāle-i Hüsnīye: Leiden, UB Or. 14.639

Terceme-i Risāle-i sī faṣl: Leiden, UB Or. 20.399(1), 23.637(2)

Terceme-i Şevāhidü n-nübǜve: Leiden UB Or. 14.250(1)

Terceme-i Seyr ve sülūk ilā melik el-mülūk: Leiden, UB Or. 23.638(5)

Terceme-i Siyāset şer'īye: Leiden, UB Or. 12.371

Terceme-i Zahīret el-mülük: Leiden, UB Or. 694

Tercümān eṣ-Ṣahāḥ: Leiden, UB Or. 716

[et-]Teressül [ fı ] ḳavā'idi l-inşā́: Leiden, UB Or. 12.335(1,2)

Teshīr-i ekber: Leiden, UB Or. 8371(3)

Tevārĭh: Leiden, UB Or. 1551

Tevārīh-i āl-i 'Oșmān: Leiden, UB Or. 12.440, 12.594; Utrecht, UB Hs. 1 F 12

Tevārīh-i àl-i Selçuk: Leiden, UB Or. 419

Tevārīh-i fethnnāme-i Bag̀dād: Leiden, UB Or. 1183(2)

Tevārīh-i Mahmūd Pasa: Leiden, UB Or. 1559(3), 12.406(2)

Tevārīh-i Seyyid Batțāl Ġāzī: Leiden, UB Or. 14.516

Tevārīh-i Sulțān Selīm Hāan: Leiden, UB Or. 333 
Tevārīh-i Tiryākī Hasan Paşa: Leiden, UB Or. 12.349

Tezkiretü l-evliyā tercemesi: Leiden, UB Or. 815, 14.338

Tezkire-i şu'arā: Leiden, UB Or. 12.390

Tezkiretü ş-şu'arā: Leiden, UB Or. 855, 6255, 12.361

Tuhfat al-Hādīya: Leiden, UB Acad. 74(6), 79(1); Or. 167, 1028, 18.694

Tuhfe-i Fedāy ì: Leiden, UB Acad. 153

Tuhfe-i Hamdī: Leiden, UB Or. 12.341

Tuhfe-i Şāhidī: Leiden, UB Acad. 77, 78; Hotz 2289; Or. 148, 1575, 1582, 1583, 5808, $6965,6967,8330,11.117(2), 11.575(1), 12.428,25.760(3)$; Utrecht, UB Hs. 16 B 19

Tuhfe-i Vehbi: Leiden, UB Or. 11.989, 18.692(1), (Addenda) 26.271(4)

Tuhfetū l-'asşıḳin: Leiden, UB Acad. 179; Or. 23.654

Tuhfetül-esrār fì r-redd 'alān-nașārāmin farḳı l-küffār: Leiden, UB Or. 432

Tuhfetül-Haremeyn: Leiden, UB Or. 14.653

Tuhfetül-kibār fi esfāri l-bihạar: Leiden, UB Or. 825, 1599

Tuhfetül-küttāb: Leiden, UB Or. 12.032, (Addenda) 26.616

Tuhfetül-’uşşāḳve turfetül-müştāḳve zübdetül-esrārve haḳ̂̄ ḳatu l-ahbar: Leiden, UB Or. $23.638(6)$

Türkçe tekellümāt: Leiden, UB Acad. 96

Türkiye’niñ yeñi başdan ihyası ve fırḳa proġramı: Leiden, UB Or. 6694a, 10.805

Unmūzece ațțıbb: Leiden, UB Or. 11.606

el-Ușül el-kebìr: Leiden, UB Or. 12.048

Ușūl-i muhāākemāt-i cezā'̄ye: Leiden, UB Or. 26.253

'Uyūnül-hidāye: Leiden, UB Or. 12.436, 14.637(4), 25.718

Vā'ız-i mev'ıza kitābı: Leiden, UB Or. 1559(4)

Vāḳı'a-nāme: Leien, UB Or. 12.419(2), 25.759(1)

Vāmık u 'Azrāa: Leiden, UB Or. 566

Vāridāt: Leiden, UB Or. 12.347

Vāridāt-i menșūre ve Dìvān-i manzūme: Leiden, UB Or. 8529, 11.039, 12.393

Vaṣiyet: Leiden, UB Acad. 27; Or. 96o, 1288, 1562, 11.042, 11.111(2), 12.339(1), 14.264(2), 17.123, 17.128, 17.134, 23.650(1)

Vașìyet-i Mevlānā Husrev: Leiden, UB Or. 11.538(10)

Vașīyet-nāme-i beyān-i şirk-i ekber: Leiden, UB Or. 14.264(6a)

Vașìyet-nāme-i resūl Allāh: Leiden, UB Acad. 8(2)

Vesī letül-ıtḳān fı̀ şerh Rüsūh el-lisān fì ḥurūfel-Kur'ān: Leiden, UB Or. 792

Vesī letün-necāt fì mevlūdi n-nebī 'aleyhi ș-șalàt: Groningen, UB Hs. 491(2); Leiden,

UB Or. 1205(4), 12.395(1), 12.397(2), 12.441(1), 14.556(5), 26.237-245, 26.249(2)

Vücūdnāme-i elīf-i ḥurūfāt: Leiden, UB Or. 14.637(8)

Vuṣlat es-Sālikìn: Leiden, UB Or. 12.055(6)

Yūsuf ḳıșșası: Leiden, UB Or. 6240

Yūsufu Züleyhā: Amsterdam, AHM LA 2047; Groningen, UB Hs. 486; Leiden, UB Or. 14.561

Zafernāme: Leiden, UB Or. 12.385(1), 12.387(2)

Zeyl-i Siyer-i nebevi: Leiden, UB Or. 8876 
Żurūb-i emsāal: Leiden, UB Or. 14.456 (1)

Zübdetül-ḩaḳāik: Leiden, UB Or. 17.127

Zübdetül-müntahab: Leiden, UB Or. 17.105

Zübdetün-nașāyih: Leiden, UB Or. 17.153(2)

\section{Authors}

'Abdī, see Șarı 'Abdullāh

'Abdulaḥad Nūrī Efendi: Leiden, UB Or. 11.985(1,2)

'Abdul'azīz Efendi, Kara Çelebizāde: Leiden, UB Or. 14.519

'Abdulbāḳ̄ 'Ārif Efendi: Leiden, UB Or. 11.052

'Abdulbāḳī b. el-Mevlā Ṭursun b. eş-Şeyh Murād: Leiden, UB Or. 1557(2)

'Abdulbāḳī La līzāde: Leiden, UB Or. 1068(1); Utrecht, UB Hs. 16 B 15

'Abdulcelīl Çelebi, Levnī: Leiden, UB Or. 12.424(3)

'Abdulfettāḥ Şevḳat: Leiden, UB Or. 12.390

'Abdulkerīm b. 'Abdurraḥmān ez-Zīlī: Utrecht, UB 16 B 16(2)

'Abdulkerīm b. Şeyh Ahmed, 'Āciz(ī): Leiden, UB Or. 12.398

'Abdullāh b. Rıżvān, müteferriḳa: Leiden, UB Or. 1234

'Abdullāh b. Șāliḥ b. İsmā̄̄il Eyübī, el-Hācc: Leiden, UB Or. 12.380

'Abdullātīif Çelebi, Lațîfi: Leiden, UB Or. 855, 11.598(9), 12.361, 12.362

'Abdulvehhāb of Elmalı, Vāhib(ī), Vāhib Ümmī, Vehhāb(ī): Leiden, UB (Addenda) 26.272

'Abdurrahīm b. Ahmed, Kāżīi: Leiden, UB Or. 12.386

'Abdurraḥ̄m Efendi, Menteşīzāde: Leiden, UB Acad. 42(2), 178(1); Or. 14.654

'Abdurraḥmān b. Yūsuf Akssarāyī: Leiden, UB Or. 14.622

Abū Nașr al-Farāhī: Leiden, UB Or. $5^{803(2)}$

'Āciz(ī), see 'Abdulkerīm b. Şeyh Aḥmed

Āhī, see Ben̄lü Hasan

Aḥmed, Seyyid: Leiden, UB Or. 11.798

Aḥmed Aḳhiṣārī Ṣaruhānī, Rūmī: Leiden, UB 12.043(2), 12.339(2)

Aḥmed b. Huayruddīn el-Güzelḥıșārī, İsḥāk Hōcası Aḥmed Efendi: Leiden, UB Or. 6801

Aḥmed b. Mușțafā, Seyyid, Lālī: Leiden, UB Or. 1566, 11.579

Aḥmed b. 'Oșmān b. Sֵānī: Leiden, UB Or. 14.435(2)

Aḥmed Çarbīn: Leiden, UB Or. 23.666

Aḥmed-i Dāî̀: Leiden, UB Or. 20.399(1), 23.637(1)

Aḥmed Dede, Seyyid-i șaḥị̣: Leiden, UB Or. 12.430

Ahmed Ḳonevī: Leiden, UB Or. 11.944

Aḥmed Luțî: Leiden, UB Or. 12.352, 12.353

Aḥmed-i Mıșrī: Leiden, UB Or. 1552(2)

Aḥmed Nādīde, Ḥāfız: Leiden UB Or. 1449, 18.155

Aḥmed Nedīm: Leiden, UB Or. 8799, 11.071

Aḥmed Şikārīzāde, Dervīş: Leiden, UB Or. 12.421(2)

Ahmed Vāmıḳ, el-Hāācc: Leiden, UB Or. 1563

Ahterī, see Muștafā b. Şemsüddīn

'Ākif Meḥmed Paşa: Leiden, UB Or. 12.357 
'Alāùddīn 'Alī, 'Āşş̣ Paşa: Leiden UB Or. 6197

'Alā'uddīn 'Alī b. Emrüllāh b. el-Ḥınnā’'ì, Ḳınalızāde 'Alī Çelebi: Leiden, UB Or. 6804

'Ālī, see Mușțafā b. Aḥmed

'Alī, Ak, of Foca: Leiden, UB Or. 14.562(2)

'Alī, Seyyid Emīr, Hāşimī: Leiden, UB (Addenda) Or. 12.03o(3)

'Alī 'Abdullāh el-Aḳkermānī: Leiden, UB Or. 26.617

'Alī Akbar Khițāīi: Leiden, UB Or. 12.365(1)

'Alī Aḳkermānī, Naksşī: Leiden, UB Or. 6887

'Alī 'Azīz Efendi Giridī: Leiden, UB Or. 12.347

'Alī b. Birrī b. Yūsuf: Leiden, UB Or. 14.556(4)

'Alī b. Ḥasan el-Amasī: Leiden, UB Or. 11.735(3)

'Alī b. Hüseyn, Seydī 'Alī Rè̄ìs, Kātib-i Rūmì: Leiden, UB Or. 12.058(2)

'Alī b. Șāliḥ, 'Alī Çelebi, Vāsi' 'Alīsi: Leiden, UB Or. 448, 1246, 17.958

'Alī Cemālī Efendi, Zenbilli: Leiden, UB Or. 11.985(3)

'Alī Çelebi, see 'Alī b. Șāliḥ

'Alī Efendi (müftī): Leiden, UB (Addenda) Or. 26.618 (1)

'Alī Efendi, Mü'ezzzinzāde ('Ayn-i 'Alī): Leiden, UB Or. 25.757(5)

'Alī eș-Ṣadrī el-Konevī: Leiden, UB Or. 11.774, 17.129, 23.650(2)

'Alī Șaḥhạā, es-Seyyid: Leiden, UB Or. 23.644

'Alì Şīr Nevāīì, Mīr: Leiden, UB Or. 8481, 11.054, 14.304

'Ālihī: Leiden, UB Acad. 212

Altı Parmak, see Meḥmed b. Meḥmed

'Amīḳī, see Meḥmed 'Amīḳī

'Āşık Paşa, see 'Alā'uddīn ‘Alī

'Āşıł Paşazāde, Dervīş Aḥmed: Leiden, UB Or. 12.440, 12.594

'Ayn-i 'Alī, see 'Alī Efendi

'Ažbī Mușțafā Efendi: Leiden, UB Or. 12.465(1)

'Azīz Maḥmūd, Hüdā'ī: Leiden, UB Or. 12.441(2), 14.518, 14.555, (Addenda) 26.264

'Azmī, see Pīr Meḥmed b. Pīr Aḥmed

'Azmīzāde Muṣțafā Efendi, Ḥāletī: Leiden, UB Or. 128o, 23.649(2)

Bāḳ̄i, see Maḥmūd 'Abdulbāḳ̄

Baronian, Petros: Leiden, UB Or. 12.366

Ben̄lü Hasan, Āhī: Leiden, UB Or. 1300, 11.053

Birgili Meḥmed Efendi, see Meḥmed b. Pīr 'Alī Birgivī

Ca'fer 'İyānī b. Ḥasan: Leiden, UB Or. 14.435(1)

Ca'fer Vecdī: Leiden, UB Or. 1087

Cām, Dervisş: Leiden, UB Or. 12.429(5)

Cevrī, see İbrāhīm Çelebi

Dāīì, see Aḥmed-i Dāî̀

Deli Birāder, see Meḥmed Ǵazālì

ed-Dervāzī, see Meḥmed b. Yūnus

Ebū 'Abdullāh Meḥmed b. Selāmetḳużā'î: Leiden, UB Acad. 42(2); Or. 12.386

Ebūbekir Kānī: Leiden, UB Or. 12.409 
Ebūbekir Nușret Efendi: Utrecht, UB Hs. 16 B 21, 16 B 23

Ebūlfażl (defterdār): Leiden, UB Or. 305(6)

Ebūlfażl 'Abdullāh el-Yeñişehrī: Leiden, UB Or. 11.794

Ebūlḥasan İsmācīl b. İbrāhīm b. İsfendiyār, İsmā̄īl Beg İsfendiyārog̉lı: Leiden, UB Or. 8483

Ebū l-Meşrıḳ̄: Leiden, UB Or. 12.441(6)

Ebū Saīd Hasan Hamdī: Leiden, UB Or. 12.341

Ebū s-su'ūd Efendi: Leiden, UB (Addenda) Or. 26.615 (2)

Edīb Aḥmed b. Maḥmūd of Yüknek: Groningen, UB Hs. 474(2)

Enverī Nūruddīn: Leiden, UB Or. 8530

Emīr Çelebi, see Mehmed Ṭabīb

Emrī: Leiden, UB Or. 12.431, 12.448(5)

Es`ad Efendi, Kāşifì (Kāşifül'esrār): Leiden, UB Or. 23.638 $(3,4)$

Eşref, Seyyid: Leiden, UB Or. $25 \cdot 719$

Faḳı, Dervīş (see also Süle Faḳı): Leiden, UB Or. 14.556(6)

Fażlī: Leiden, UB Or. 8236(9)

Fedāyī, see Meḥmed Fedāȳ̄

Fehmī, see Hasan Fehmī

Ferīdūn Aḥmed Beg: Leiden, UB Or. 277, 12.019(6), 12.351

Feyżī (see also Mușțafā Feyżī, Ṭursunzāde 'Abdullāh): Leiden, UB Or. 644(24), 1560

Firdevsī-i Rūmī, Uzun: Leiden, UB Or. 1903(2), 17.130

Firākì, see Furātī

Firişteog̉lı, see 'İzzüddīn'Abdullaṭif

Fițnat, see Zübeyde Hanım

Furātī (Firāḳ̂̄), Mevlānā: Leiden, UB Or. 1559(5), 11.935, 12.371(3), 17.163(1)

Fużūlī, see Meḥmed b. Süleymān

Ġināyīzāde: Leiden, UB Or. 1302

Gülşehrī: Leiden, UB Or. 12.429(4)

Hāāccī Efendizāde Aḳsarāyī, see Ḥasan b. el-Ḥāccī ‘Abdurraḥmān

Ḥāccī Hualīfa, see Mușțafā b. 'Abdullāh

Hācibzāde, see Meḥmed b. Mușțafā b. Maḥmūd

Hākānī Meḥmed Beg: Leiden, UB Or. 12.003, 25.729(1)

Ḥākimī Efendi, see Meḥmed b. Muṣlīhüddīn

Hāletī, see 'Azmīzāde Muștafā Efendi

Halīmī, see Luṭfullāh b. Ebī Yūsuf

Halīmī Efendi, Ahızāde: Leiden, UB Or. 14.25o(1)

Ḥamdī (see also Ebū Sa'īd Ḥasan, Hamdullāh b. Hayruddīn): Leiden, UB Or. 6964

Hamdī 'Ošmān: Leiden, UB Or. 23.671

Hamdullāh b. Hayruddīn, Hamdī: Leiden, UB Or. 792

Hamza Efendi: Leiden, UB Or. 1556(2), 11.547(4)

Hasan Ag̉a, mühürdār: Leiden, UB Or. 1225

Ḥasan b. el-Ḥāccī 'Abdurraḥmān, Hāāccī Efendizāde Aḳsarāyī: Leiden, UB Or. 11.115

Ḥasan b. Hüseyn el-Ḳarahișārī: Leiden, UB Or. 18.693

Ḥasan Çelebi, Ḳınalızāde: Leiden, UB Or. 6255 
Hasan Fehmī İsmā‘̄il: Leiden, UB Or. 26.246

Hasan Vecīhī: Leiden, UB Or. 894

Hāşimī, see 'Alī, Seyyid Emīr

Ḥayātīzāde, see Mușțafā Feyżì

Hayātīzāde Damadı, see Süleymān Efendi

Hayyāṭ Vehbī el-Erzincānī: Leiden, UB Or. 23.668

Hevā'ì, see 'Oșmān Sürūrī

Hibetüllāh Çavuş b. İbrāhīm: Leiden, UB Or. 12.343, 12.845, 14.610, 25.767

Hüdā'ì (see also ‘Azīz Maḥmūd, Meḥmed el-Üsküdārī): Leiden, UB Or. 17.138

Hüseyn b. el-Hāàcc Ḥasan el-Edirnevī: Leiden, UB Or. 12.057

Hüseyn b. es-Seyyid Gaybī, Seyyid: Leiden, UB Or. 23.645

Hüseyn Efendi, Nazmīzāde: Leiden, UB Or. $5^{809}$

Hüseyn-i Kefevī: Leiden, UB Or. 12.405

Hüseyn Șı1ḳī: Leiden, UB Or. 20.404(1)

Husrev, Molla: Leiden, UB Or. 11.538(10)

İbn ‘̄̄sā Aḳhiṣārī, see İlyās b. ‘̄̃sā

Ibn Muhammad Ṣāliḥ: Leiden, UB Acad. 59, 6o; Or. 3087

İbn Sellūm, see Șālih b. Nașrullāh

İbn aț-Ṭabbāh, see İbrāhīm, Dervīş

İbrāhīm, Mücellidzāde Şeyh el-Hāạc: Leiden, UB Or. 12.381(5)

İbrāhīm, Dervīş, İbn aț-Ṭabbāḥ: Leiden, UB Or. 11.589(1)

İbrāhīm b. Bālī: Leiden, UB Or. 697

İbrāhīm Çelebi, Cevrī: Leiden, UB Or. 5805(ii), 12.033(2), 25.729(2)

İbrāhīm Peçevī (Peçuyī): Leiden, UB Or. 1311

İbrāhīm Şāhidī: Leiden UB, Acad. 77, 78; Hotz 2289; Or. 148, 1575, 1582, 1583, 5808, $6965,6967,8330,11.117(2), 11.575(1), 12.428,25.760(3)$; Utrecht, UB Hs. 16 B 19

'İlmī Dede, Dervīş: Leiden, UB Or. $5^{805}(2)$

İlyās b. 'Īsā Șaruhanī, İbn 'Īsā Aḳhiṣārī: Leiden, UB Or. 8371(3)

'İmāduddīn, Seyyid, Nesīmī: Leiden, UB Or. 1503

'Īsā, Mevlānā: Leiden, UB Or. 1448(1)

İsfendiyārog̉ll, see Ebūlhạasan İsmāc̄ill b. İbrāhīm

İshāḳ Hōcası Ahmed Efendi, see Aḥmed b. Hayruddīn

İsmā̄ill Beg İsfendiyārog̉lı, see Ebūlhasan İsmāc̄ill b. İbrāhīm

İsmāî̀ Dede Anḳaravī, Rüsūhī: Leiden, UB Or. 942, 1140, 12.033(1), 12.059

İsmāêil Ferruh Efendi: Leiden, UB Or. $11.05^{8}$

İsmācil Hakkī of Bursa: Leiden, UB Or. 6813

İsmāî̀l Ḥaḳkī Erżurumī, es-Seyyid el-Hācc: Utrecht, UB Hs. 16 B 18

'İzzüddīn'Abdullaṭif b. Melik, Firişteoğlı: Leiden, UB Or. 25.76o(1)

Kāmī: Leiden, UB Or. 11.043, 12.055

Kānī, see Ebūbekir Kān̄̄

Kara Çelebizāde, see 'Abdul'azīz Efendi

Kāşifì (Kāş̧ifül'esrār), see Es'ad Efendi

Kāsım Paşa, Cerrāḥ: Leiden, UB Or. 17.102

Kātib Çelebi, see Mușțafā b. 'Abdullāh

Kātibzāde Çelebi: Leiden, UB Or. 898 
Kāẓım, see Uz

Kaà̇īīāde Meḥmed b. Muṣtafâ: Leiden, UB Or. 12.043(4), 12.339(3,13), 14.264(8)

Keçecizāde, see Meḥmed '̇̇zzet Molla

Kemāl Paşazāde, see Şemsüddīn Aḥmed

Kemāl Ümmī: Groningen, UB Hs. 491(6); Leiden, UB Or. 12.396(3)

Keşfi: Leiden, UB Or. 12.396

Ķınalızāde Hasan Çelebi, see Hasan Çelebi

Ḳınalızāde 'Alī Çelebi, see 'Alā'uddīn 'Alī b. Emrüllāh

Kirdeci 'Alī: Utrecht, UB Hs. 16 B 14 $(2,4)$

Kurd b. 'Alī el-Kașșāb el-Pirlepevī: Leiden, UB Or. 12.346

Kurd Meḥmed Efendi: Leiden, UB Or. 11.753

Lālī, see Aḥmed b. Mușṭafā

Lațîfî, see 'Abdullațîf Çelebi

Lāmi'î, see Maḥmūd b. 'Oșmān

Levnī, see 'Abdulcelīl Çelebi

Luṭfì, see Aḥmed Luṭfì

Luṭī Paşa b. 'Abdulmu'īn: Leiden, UB Or. 923(1), 1278(2), 14.264(4), 25.757(1)

Luṭfullāh b. Ebī Yūsuf, Ḥalīmī: Leiden, UB Or. 500(1), 663, 823

Maḥmūd 'Abdulbāḳī, Bāḳī: Leiden, UB Or. 837(1), 1285, 12.342, 12.438

Maḥmūd b. Edhem of Amasya: Leiden, UB Or. 969(2), 18.691(1)

Mạ̣mūd b. 'Oșmān, Lāmi'î: Leiden, UB Acad. 140(1); Or. 566, 3o86, 8763, 12.391, 14.510

Maḥmūd b. es-Seyyid Meḥmed Şeker (Şükür): Leiden, UB Or. $11.5^{84}$

Maḥmūd Ḳudsī b. Şeyh Fahruddīn: Leiden, UB Or. 1206(2)

Mecīdī: Leiden, UB Or. 981(21)

Meczūb-i 'Acemī: Leiden, UB Or. 8798

Meḥmed, Hāfızog̀lı Dervīş, Yemīnī: Leiden, UB Or. 12.435

Meḥmed 'Amīḳi: Leiden, UB Or. 23.638(2)

Meḥmed b. 'Abdulḥalīm Brusavī: Leiden, UB Or. 6803

Meḥmed b. Ahmed: Leiden, UB Or. 11.041(2), 26.247

Meḥmed b. 'Alī, Sipāhīzāde: Leiden, UB Or. 602

Meḥmed b. Bisțām el-Huuşşābī el-Vānī el-Vanḳulī: Leiden, UB Or. 12.104(7)

Mehmed b. Halīl: Leiden, UB Or. 11.111(1), 11.967(4)

Mehmmed b. Mehmmed, Altı Parmak: Leiden, UB Or. 14.250(2)

Meḥmed b. Muṣlīhüddīn, Hākimī Efendi: Leiden, UB Or. 11.581(5)

Meḥmed b. Mușțafā, Riyāżì: Leiden, UB Or. 752(1), 1134, 12.360, 12.392

Meḥmed b. Mușțafā el-Akkkermānī: Leiden, UB Or. 12.425, 17.105, 17.124

Meḥmed b. Mușțafā b. Maḥmūd el-İstanbulī, Ḥācibzāde: Leiden, UB Or. 11.525

Meḥmed b. Nergis Aḥmed, Nergisī: Leiden, UB Or. 1564, 11.536, 25.761(3), 25.763

Meḥmed b. Pīr 'Alī Birgivī, Birgili Meḥmed Efendi: Leiden, UB Acad. 27; Or. 96o, $1288,1562,11.042,11.111(2), 12.339(1), 14.264(2), 17.128,17.134,23.650(1)$

Meḥmed b. Şa çān: Leiden, UB Or. $43^{2}$

Meḥmed b. Șāliḥ Yazıcı, Yazıcıoġı Meḥmed: Leiden, UB Or. 6802, 10.853, 14.192

Meḥmed b. es-Seyyid 'Alā'uddīn el-Hüseynī er-Rażavī, es-Seyyid: Leiden, UB Or. $12.348,12.427(1)$ 
Meḥmed b. Süleymān, Fużūlī: Leiden, UB Or. 508, 10.978, 12.437, 14.367, 14.636, (Addenda) 26.265; Rotterdam, WM 70935

Meḥmed b. 'Ubeydüllāh, Mūsāzāde: Leiden, UB Or. 12.032, (Addenda) 26.616

Meḥmed b. Yūnus ed-Dervāzī: Leiden, UB Or. 12.417

Meḥmed Behā'üddīn Erzincānī, Pīr: Leiden, UB Or. 1264(1)

Meḥmed Efendi b. Hasan Efendi, Pīr, Kör: Leiden, UB Or. 1276

Meḥmed Emīn, Nahịfi: Leiden, UB Or. 12.413

Meḥmed Emīn b. Șadruddīn Şīrvānī: Leiden, UB Or. 1129(G)

Mehmed Emīn Vahīd Efendi: Leiden, UB Or. 12.358

Mehmed Es`ad Efendi: Leiden, UB Or. 14.092

Meḥmed Fahruddīn b. Ṭabīb Aḥmed Bosnavī: Leiden, UB Or. 23.665

Meḥmed Fedāyī: Leiden, UB Acad. 153

Meḥmed Ġazālī, Deli Birāder: Groningen, UB Hs. 488(2)

Meḥmed Ḥamdullāh, Ḥamdī: Amsterdam, AHM LA 2047; Leiden, UB Or. 14.561

Meḥmed Hāşim Efendi, Emīrzāde Seyyid: Leiden, UB Or. 12.829

Mehmed 'İzzet Molla Efendi, Keçecizāde: Leiden, UB Or. 12.383

Meḥmed Mekkī: Leiden, UB Or. 17.139

Meḥmed Mevḳūātī: Leiden, UB Or. $85^{28}$

Meḥmed Mıṣrī, Niyāzī: Leiden, UB Or 8236(6,7), 12.055(3), 23.638(6), 23.647

Meḥmed Muḥyīddīn Brusevī, Üftāde: Leiden, UB Or. 11.985(4)

Meḥmed Nüzhet: Leiden, UB Or. 20.401(2)

Meḥmed Rāşid: Leiden, UB Or. 8517

Meḥmed Rāşid, Seyyid: Leiden, UB Or. $25 \cdot 73^{\circ}$

Meḥmed Riżā, es-Seyyid: Leiden, UB Or. 11.614

Meḥmed Șādıḳ, Şānīzāde: Leiden, UB Or. 11.059

Meḥmed Ṣāhịib, Pīrīzāde: Leiden, UB Or. 17.106

Mehmed Sirrī: Leiden, UB Or. 12.372

Meḥmed Țabīb, Seyyid, Emīr Çelebi: Leiden, UB Or. 11.606

Mehmed Tevfik: Leiden, UB Or. 8235

Meḥmed el-Üsküdārī, Hüdā’̄ì: Leiden, UB Or. 12.339(12)

Meḥmed el-Veffāḳ en-Naķşbendī el-Üsküdārī: Leiden, UB Or. 1555

Meḥmed Vuṣūlī: Leiden, UB Or. 333

Meḥmed el-Yemenī: Leiden, UB Acad. 179; Or. 23.654

Mīrek Meḥmed Naksşbendī -i Ţaşkendī: Leiden, UB Or. 752(2)

Mizrāḳlı Efendi (Ușūī Efendi): Leiden, UB Or. 14.409

Mücellidzāde, see İbrāhīm

Muhammad 'Alī of Tabrīz, Mīrzā, Șā’ib: Leiden, UB Or. 11.050

Muḥammad b. Lād Dihlawī: Leiden, UB Or. 1674

Muḥammad b. Ḥajjī Ilyās: Leiden, UB Acad. 74(6), 79(1); Or. 167, 1028, 18.694

Muḥammad b. Muḥammad Rị̣ā of Tabrīz: Leiden, UB Or.8798

Muhammad Timur, Molla: Leiden, UB Or. 6269

Muḥyīddīn Vildān, Mevlānā: Leiden, UB Or. 305(1)

Münīf, see Muștafā Münīf

Murād Çelebi (defterdār): Leiden, UB Or. 305(2)

Muṣlihüddīn Mușțafā b. Şa bān, Sürūrī: Leiden, UB Acad. 152; Or. 451(1), 659, 694, 2082(1), 11.051, 14.408

Mūsāzāde, see Meḥmed b. 'Ubeydüllāh 
Mușțafā Ag̉a el-Müteferriḳa, Kapu Ag̉ası Kulı: Leiden, UB Or. 765, 835, 25.757(2)

Mușțafā b. 'Abdullāh, Kātib Çelebi (Hâ̄ccī Hualīfa): Leiden, UB Or. 825, 1109, 1599, $12.363,17.124$

Mușțafā b. Aḥmed b. 'Abdullāh, 'Ālī: Leiden, UB Or. 288, 923(2), 12.419(1)

Mușțafā b. 'Alī, Selīmī: Leiden, UB Acad. 49(1,2); Or. 12.058(3,4,5), 17.167, 20.400(1,2,3)

Mușțafā b. Mehmmed of Kastamonu: Leiden, UB Or. 829

Mușțafā b. Meḥmed b. Aḥmed eț-Ṭabīb: Leiden, UB Or. 14.407

Mușțafā b. Mollā Riżvān el-Bag̉dādī, Meddāḥ 'ammi r-rüsūl: Leiden, UB Or. 1183(2)

Mușțafā b. Şemsüddīn Ḳarahịịārī, Ahterī: Leiden, UB Or. 461, 1435

Mușțafā Feyżì, Hayātīzāde: Leiden, UB Or. 25.770(2)

Mușțafā Hāşim el-Üsküdārī el-Celvetī: Leiden, UB Or. 8529, 11.039, 12.393

Mușțafā Münīf: Leiden, UB Or. 12.385, 12.387

Mușțafā Müstakīm, Niyāzī: Leiden, UB Or. 20.400(6)

Muștafā Na'īmā: Leiden, UB Or. 12.350(1)

Mușțafā Vașfì Efendi of Kābūd, el-Hāaccī: Leiden, UB Or. 1551

Mușțafā Şem'ī: Leiden, UB Or. 721, 724, 738, 827, 839(1), 12.047, 12.448(4), 14.508(2), 14.511

Müştāḳ-i Dīdār, Muṣṭafā: Leiden, UB Or. 23.658

Naḥīfi, see Meḥmed Emīn, Süleymān b. 'Abdurraḥmān

Nābī, see Yūsuf Nābī

Nāìīi, see Pīrīzāde (Yen̄izāde)

$\mathrm{Na}$ īmā, see Mușțafā Na'īmā

Naḳşī, see 'Alī Aḳkermānī

Nāmıḳ Kemāl, Meḥmed: Leiden, UB Or. 14.509

Naẓmīzāde, see Hüseyn Beg

Nawā'ì, see 'Alì Şīr Nevā'ì

Nedīm, see Aḥmed Nedīm

Nef'̄ì, see 'Ömer Efendi

Nergisī, see Meḥmed b. Nergis Aḥmed

Neşāțī Aḥmed Dede: Leiden, UB Or. 25·729(3)

Nesīmī, see 'İmāduddīn

Nevā'ì, see 'Alī Şīr Nevā'̀̄

Nev'ì, see Yahyā b. Pīr 'Alī

Nidā'î: Leiden, UB Or. 1086(2)

Ni`metullāh b. Aḥmed b. Ḳāżī Mübārek er-Rūmī, Hualīl Ṣūfì: Leiden, UB Or. 164, 227, 684(1), 925

Niyāzī, see Meḥmed Mıṣrī, Mușṭafā Müstaḳimm

Nur, see Riza Nur

Nūrī: Leiden, UB Or. 12.394

Nūruddīn (see also Enverī): Leiden, UB Or. 12.344

Nüzhet, see Meḥmed Nüzhet

'Ömer Dede Rūşenī: Leiden, UB Or. 1279(1)

'Ömer Efendi, Nef'ī: Leiden, UB Or. 662, 870

'Ömer Şifā'ī, Dervīş: Leiden, UB Or. 17.956

'Ossmān b. 'Abdulmennān: Leiden, UB Or. 12.364 
'Ossmān b. Dervīş: Leiden, UB Or. 917(2)

'Oșmān Beg, Duḳakinzāde: Leiden, UB Or. $5^{807}$

'Oșmān Dede: Leiden, UB Or. 12.395(2), 12.434(2)

'Oșmān 'İșmet Nūrīzāde: Leiden, UB Or. 12.338

'Ossmān Sürūrī, Seyyid, Hevā'ī: Leiden, UB Or. 23.653, 25.171

'Ossmān Zennānī (Zennātī): Leiden, UB Or. 20.405(3)

Pertev: Leiden, UB Or. 12.414

Pīr Çelebi Naḳkāş: Leiden, UB Or. 703, 1100(3), 1135

Pīr Meḥmed b. Evrenos b. Nūruddīn b. Fāris, eż-Ża'ī fī er-Rūmī: Leiden, UB Or. 923(3)

Pīr Meḥmed b. Pīr Aḥmed b. Halīl, 'Azmī: Leiden, UB Or. 895

Pīrīzāde (Yeñizāde) Mușțafā Çelebi, Nā’ilī: Leiden, UB Or. 1454

Rāġıb Meḥmed Paşa: Leiden, UB Or. 12.389

Ramanżānzāde Meḥmed Paşa, Küçük Nişāncı: Leiden, UB Or. 672, 838, 10.861

Rāşid, see Meḥmed Rāşid

er-Rażavī, see Mehmed b. es-Seyyid 'Alācuddīn

Resmī 'Alī Baba: Leiden, UB Or. 12.436, 14.637(4), 25.718

Revnakīi: Leiden, UB Or. 12.030(1)

Riza Nur: Leiden, UB Or. 6694, 10.805

Riyāżī, see Meḥmed b. Mușțafā

Rūmī Aḥmed Efendi, see Aḥmed Aḳhị̣ārī Șaruhānī

Rüşdī, see Yemezzāde Süleymān

Sābit 'Alā'uddīn Efendi: Leiden, UB Or. 12.439(1), 17.098

Sa'duddīn b. Maḥmūd b. Aḥmedüddīn b. Meḥmed eş-Şehīd eş-Şirvānī eş-Şekivānī ed-Dehnevī: Leiden, UB Or. 801

Sa`duddīn Meḥmed b. Ḥasan Cān, Hōoca Efendi Leiden: UB Or. 519, 1183(1)

Şāhidī (see also İbrāhīm Şāhidī): Leiden, UB Or. 12.396(2)

Sā'ì: Leiden, UB Or. 644(26)

Șā'ib, see Muhammad 'Alī

Sakffi: Leiden, UB Or. 26.046

Șāliḥ b. 'Abdullāh: Leiden, UB Or. 12.495

Șāliḥ b. Nașrullāh, İbn Sellūm: Utrecht, UB Hs. 16 B 20

Şānīzāde, see Meḥmed Șādık

Șarı 'Abdullāh b. Meḥmed el-Bayrāmī, 'Abdī: Leiden, UB Or. 625

Selīm Baba Dīvāne el-Üsküdārī: Leiden, UB Or. 8531, 11.040

Selīmī, see Mușțafā b. 'Alī

Şefḳat, see 'Abdulfettāh Şefḳat

Şem'ī, see Mușțafā Şem'ì

Şemsī: Leiden, UB Or. 2081

Şemsüddīn Ahmed es-Sivasî: Leiden, UB Or. 12.354, 14.410, (Addenda) 26.268

Şemsüddīn Aḥmed b. Süleymān b. Kemāl, Kemāl Paşazāde: Leiden, UB Or. 305(3),

86o(1,2), 866, 962(1,2), 981(22), 12.040, 14.264(9a), 17.124

Seydī 'Alī Re'īs, see 'Alī b. Hüseyn

Seyf-i Sarāyī: Leiden, UB Or. 1553 
Seyfi: Leiden, UB Or. 917(1)

Şeyhīi, see Yūsuf Sinān

Şeyhoğlı: Leiden, UB Or. 1278(1)

Şeyhoğlı Mușțafā: Leiden, UB Or. 14.466, (Addenda) 26.270

Şeyḩzāde Muḥyīddīn Meḥmed b. Muṣlīḥuddīn Muṣțafā: Leiden, UB Or. 23.662(2)

Seyyidī: Leiden, UB Or. 14.264(3)

Șıdḳī, see Hüseyn Ṣıdḳī

Şifā'ì, see 'Ömer Şifā'ī

Sinānuddīn Yūsuf b. 'Abdullāh el-Amasī er-Rūmī, Sinān Efendi: Leiden, UB Or. $11.549(10), 12.373,12.374,12.375,17.120$

Sinānuddīn Yūsuf b. Orḩan: Leiden, UB Or. 1294(6)

Sipāhīzāde, see Meḥmed b. 'Alī

Sırrī, see Meḥmed Sırrī

es-Sivasī, see Şemsüddīn Aḥmed

Şükrī, see Vāmıḳ Şükrī

Süle Faḳı: Leiden, UB Or. 6240

Süleymān b. 'Abdurraḥmān, Naḥîfi: Leiden, UB Or. 11.911(3), 12.439(2,3,4)

Süleymān Çelebi: Groningen, UB Hs. 491(2); Leiden, UB Or. 1205(4), 12.395(1), 12.397 (2), 12.441(1), 14.556(5), 26.237-245, 26.249(2)

Süleymān Efendi, Ḥayātīzāde Damadı: Leiden, UB Or. 25·770(3)

Sünbülī Yūsuf Sinān Efendi, see Yūsuf b. Ya ḳūb

Sünbülzāde Meḥmed, Vehbī: Leiden, UB Or. 1452, 11.989, 18.692(1), 25·731, (Addenda) 26.271(4)

Sürūrī, see Muṣlihüuddīn Mușțafā, 'Ossmān Sürūrī

Ṭaşkendī, see Mīrek Meḥmed Nakşsbendī

Tevfik, Seyyid: Leiden, UB Or. 12.466

Ṭursunzāde 'Abdullāh Efendi, Feyżī: Leiden, UB Or. 25·572(2)

Üftāde, see Meḥmed Muhyīiddīn Brusevī

Ümmī, see Kemāl Ümmī

Ușūlī: Groningen, UB Hs. 490

Ușūlī Efendi, see Mizrāḳlı Efendi

Üveys b. Meḥmed, Veysī: Leiden, UB Or. 6805, 8876, 12.419(2), 25.759(1)

Üveys Efendi, Üveysî: Leiden, UB Or. 25.758(8)

Uz, A. Kaẓım: Leiden, UB Or. 12.416

Vāhib(ī), see 'Abdulvehhāb

Vāhib Ümmī, see 'Abdulvehhāb

Vahīd Efendi, see Mehmed Emīn

Vāḥidī: Leiden, UB Or. 665, 1076

Vāmıḳ, see Aḥmed Vāmık

Vāmıḳ Şükrī: Leiden, UB Or. 17.110(7)

Vankulīi see Meḥmed b. Bisțām

Vașfī, see Muștafā Vaṣfī

Vāsic 'Alīsi, see 'Alī b. Șālih 
Vecdī, see Ca'fer Vecdī

Vecīhī, see Ḥasan Vecīhị

Vehhāb(ī), see 'Abdulvehhāb

Vehbī, see Hayyāṭ Vehbī, Sünbülzāde Meḥmed

Veysī, see Üveys b. Mehmed

Vīrānī Baba: Leiden, UB Or. 12.465(2), 14.637(3). 23.662(1)

Vuṣūlī, see Meḥmed Vuṣūlī

Yaḥyā Āgāh b. Șāliḥ, İstanbulī: Leiden, UB Or. 23.659, 23.661

Yahyā b. Bahşî: Leiden, UB Or. 775(1)

Yahyyā b. Halīl el-Burḡāzì: Leiden, UB Or. 12.427(2), 12.429(3)

Yahyā b. Nașūḥ b. İsrācîl: Leiden, UB Or. ${ }^{661}$

Yahyyā b. Pīr 'Alī, Nev'ī: Leiden, UB Or. 949(1); Utrecht, UB Hs. 16 B 16(1)

Yahyā Beg Duḳakinzāde: Leiden, UB Acad. 156; Or. 3047, 10.851, 12.384

Yahyyā Efendi b. Zekeriyā Efendi: Leiden, UB Or. 879, 12.467, 23.649(1)

Yazıcı Șalāḥuddīn: Leiden, UB Or. 1448(2), 14.673, 17.103

Yazıcıog̀lı Ahmed Bīcān: Leiden, UB Or. 1301, 1554, 12.370, 12.371(1,2); Utrecht, UB Hs. 16 B $17(1)$

Yazıcıog̀lı 'Alī: Leiden, UB Or. 417

Yazıcıog̉l Meḥmed, see Meḥmed b. Șāliḥ Yazıcı

Yemezzāde Süleymān Rüşdī: Leiden, UB Or. 23.638(1)

Yemīnī, see Meḥmed, Ḥāfıẓoğlı

Yūsuf b. 'Abdullațîf: Leiden, UB Acad. 182; Or. 3080

Yūsuf b. Ebī 'Abduddeyyān: Leiden, UB Or. 25.756

Yūsuf b. Ya ḳūb el-Hualvetī, Sünbülī Yūsuf Sinān Efendi: Leiden, UB Or. 8236(8)

Yūsuf Balıkesrī, Devletog̉lı: Leiden, UB Or. 12.432

Yūsuf Nābī: Leiden, UB Acad. 154; Or. 12.355, 12.408(1), 14.653, 25.724, 25.758(1), $25 \cdot 761(1)$

Yūsuf Sinān Germiyānī, Şeyhī: Leiden, UB Or. 982, 1017(1), 12.382, 14.560

Yūsufì (meddāḥ): Leiden, UB Or. 17.104

Ża'îîi, see Pīr Meḥmed b. Evrenos

Zarīî̀ of Çorlu: Leiden, UB Or. 1286

Zennānī (Zennātī), see 'Oșmān Zennānī

Zeynül'ābidīn b. Hualīl: Leiden, UB Or. 727

Zihnī Efendi: Groningen, UB Hs. 489

ez-Zīlī, see 'Abdulkerīm b. 'Abdurraḥmān

Zīrek: Leiden, UB Or. 12.356

Zübeyde Hanım, Fıțnat: Leiden, UB Or. 12.388, 14.591

Zühdī: Leiden, UB Or. 11.752(2) 